Tesis doctoral

\title{
Inversión Directa y Comercio en México Yukari TSUSHIMA
}

\section{Doctorado en Estudios Latinoamericanos}

Dirección:

Dr. Miguel Carrera Troyano

Dr. Fernando Rueda-Junquera 



\section{Agradecimientos}

A mi familia en Japón, mi padre, mi madre y mi hermana, por animarme siempre a seguir estudiar.

A mis profesores, Dr. Miguel Carrera y Dr. Fernando Rueda-Junquera, por no abandonarme nunca en estos diez años.

A todos mis amigos y profesores que he conocido en el instituto de Iberoamérica de la Universidad de Salamanca

A la Dra. Flavia Freidenberg, por decidir mandarme al Colegio de la Frontera Norte en Tijuana.

A mis amigos y profesores en el Colegio de la Frontera Norte de Tijuana, por darme oportunidades para conocer la situación en el Norte de México.

A Blanca, Belén, Lucas, Marce y Mari José, por tratarme como un miembro de su familia en Salamanca.

A Manuel, de la Librería Fonseca III, por su ayuda al fotocopiar e imprimir mis montones de papeles durante diez años.

A mis muchísimos “amigos” en el mundo del ciclismo ¡Mi otra pasión!

Por último,, a Ángel, mi novio eterno: gracias por guiarme y protegerme siempre desde el cielo. 


\section{Índice}

RESUMEN

Introducción 19

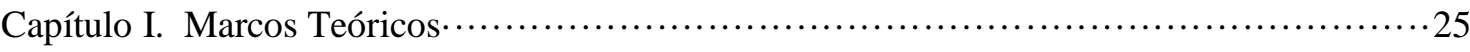

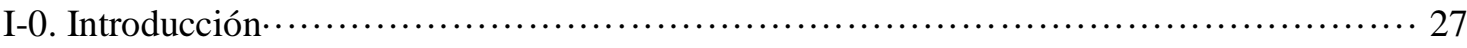

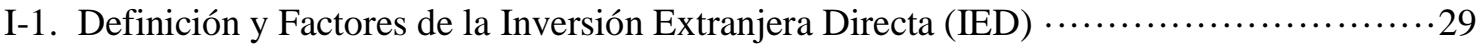

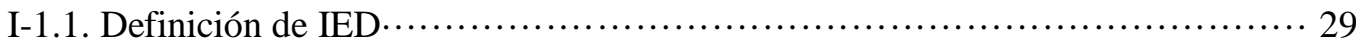

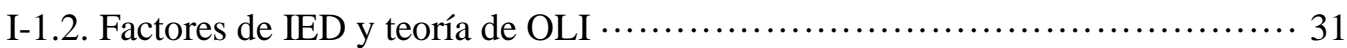

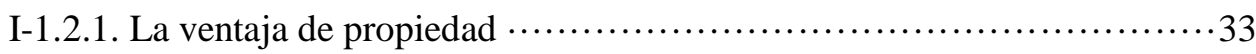

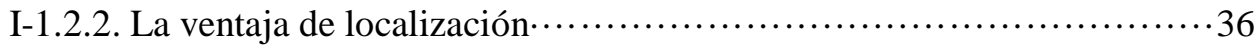

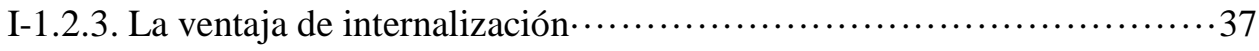

I-1.3. Breve Historia de las dos Teorías importantes de IED: Hymer, Vernon y

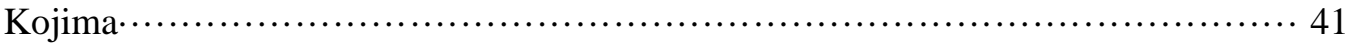

I-1.3.1. La teoría de Hymer.......................................... 42

I-1.3.2. La teoría del ciclo de Vida del producto de Vernon …...............44

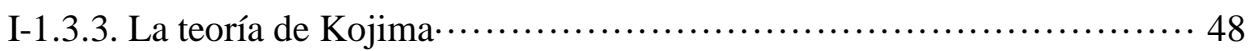

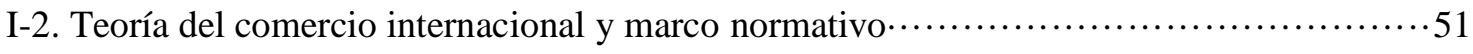

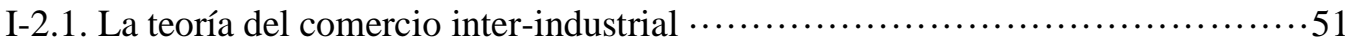

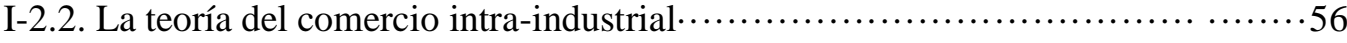

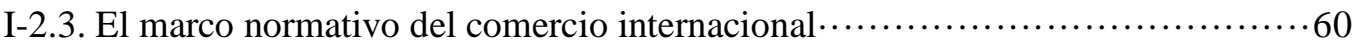

I-2.3.1. Marco normativo multilateral: la Organización Mundial de Comercio

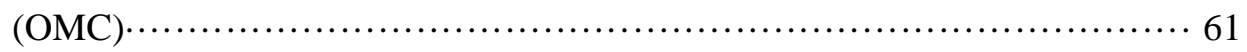

I-2.3.2. Marco normativo plurilateral: el TLCAN y el AAE $\cdots \cdots \ldots \ldots \ldots \ldots \ldots 6$

I-2.3.2.1. El Tratado Libre Comercio de América del Norte (TLCAN) $\cdots 66$

I-2.3.2.2. El Acuerdo de Asociación Económica México-Japón (AAE) $\cdots 70$

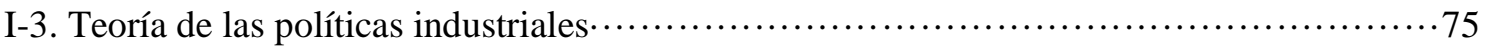

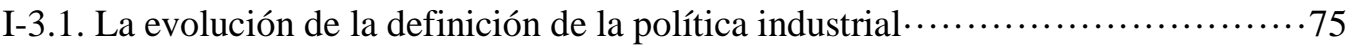

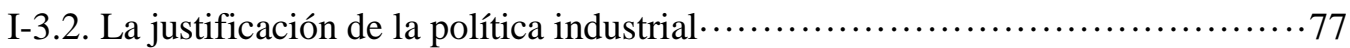

I-3.3. Tipos de políticas industriales para la atracción de la inversión extranjera $\cdots . . .79$

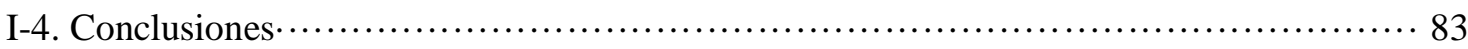

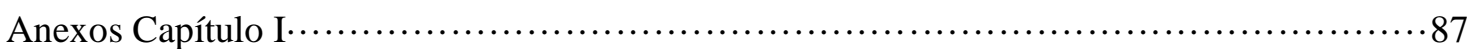




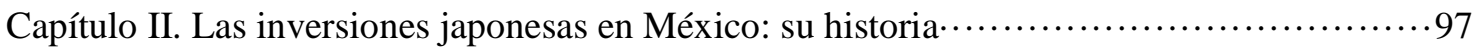

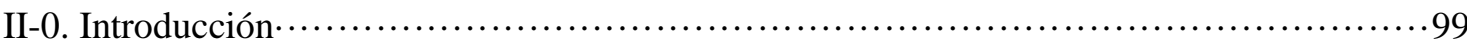

II-1. Antecedentes de las inversiones japonesas en México: Inversiones en Estados Unidos • 100

II-2. Tímido pero firme comienzo de las inversiones japonesas en México: los años 1960 y

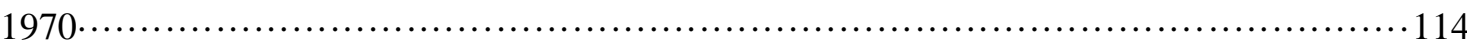

II-3. Cambios en el marco legal y llegada de las PYMEs japonesas a México: los años

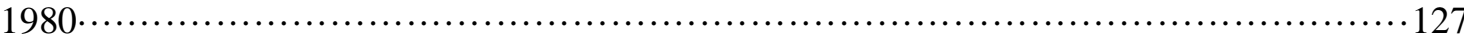

II-4. Inversiones japonesas en México tras el Tratado de Libre Comercio de América del Norte:

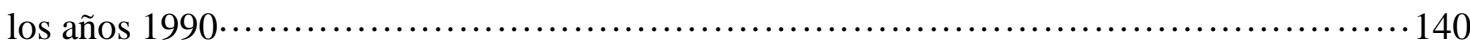

II-5. Surgimiento de la economía china y cambio de las tendencias de las inversiones japonesas

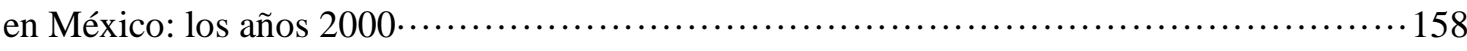

II-6. Cambio de destino de la inversión japonesa en México: del norte hacia El Bajío $\cdots \cdots \cdots \cdot 183$

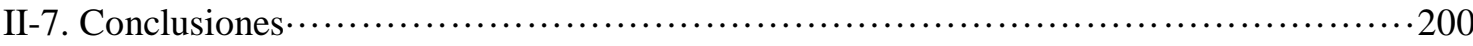

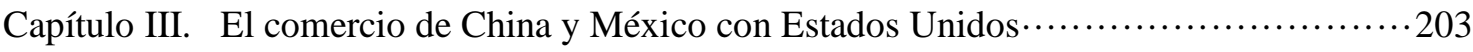

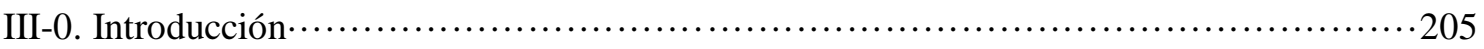

III-1. China y México: Exportaciones e importaciones a Estados Unidos $\cdots \ldots \ldots \ldots \ldots \ldots \ldots \ldots \ldots \ldots$

III-1.1. El Comercio de México ….............................................209

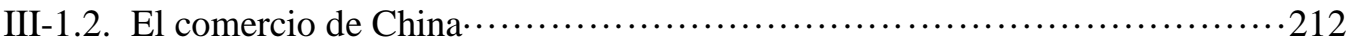

III-1.3. Las diferencias de los comercios de ambos países con Estados Unidos $\cdots \cdots \cdot 215$

III-2. Comercio Inter-industrial de China y México con Estados Unidos: Ventajas Comparativas

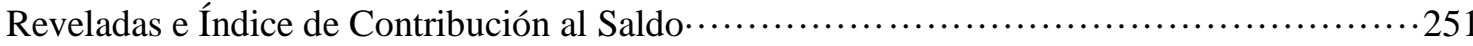

III-2.1. Comercio Inter-industrial en el comercio de China y México con Estados

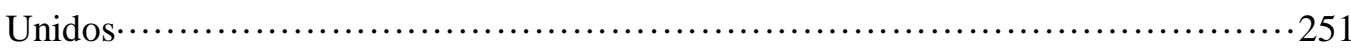

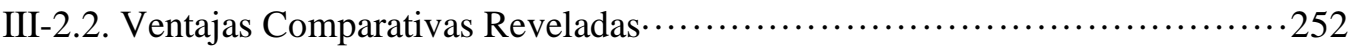

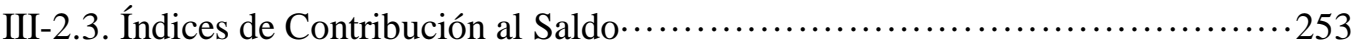

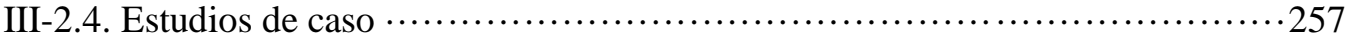

III-2.4.1. Comercio de Sistema Armonizado en la Partida 8528: Receptores de

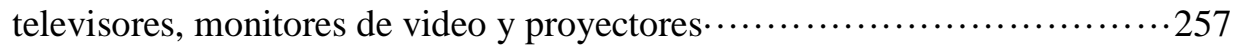

III-2.4.2. Comercio de Sistema Armonizado en la Partida 6104: traje, vestido y falda etc. de punto o ganchillo, para mujeres y chicas......................265

III-3. Comercio Intra-Industrial en el comercio de México y China con Estados Unidos ….272

III-3.1. Situación general del Comercio Intra-industrial de China y México con Estados

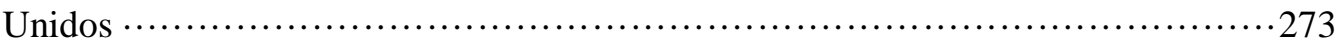

III-3.2. Comercio Intra-industrial de China y México con Estados Unidos. Estudios de caso 
III-3.2.2 Comercio Intra-industrial en el Capítulo 87: Vehículos automóviles, tractores, motos y demás vehículos terrestres, sus partes y accesorios.........284

III-3.2.3. Comercio Intra-industrial en la Partida 8528: Aparatos receptores de televisión, incluyendo con aparato receptor de radiodifusión o de grabación o reproducción de sonido o imagen incorporada; video-monitores y teleproyectores.

III-3.3. Comercio Intra-industrial de México y de China con Estados Unidos: ¿qué factores deciden el CII? ...................................................292

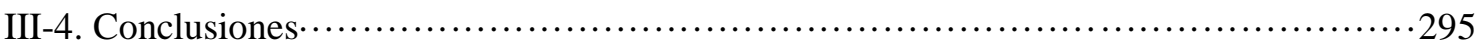

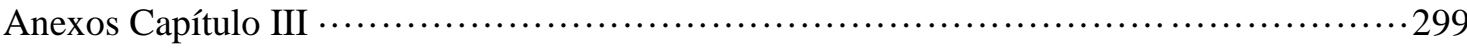

Capítulo IV. Políticas industriales como instrumentos para atraer inversiones extranjeras

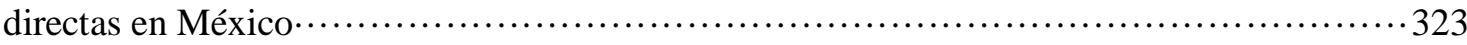

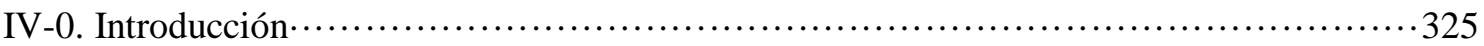

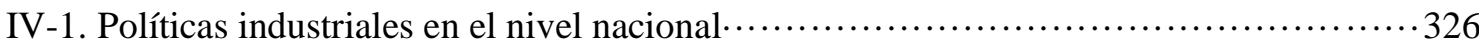

IV-1. 1. Políticas industriales en la zona franca de exportación: Programa de la Maquiladora y Programa para la Industria Manufacturera, Maquiladora y de Servicios

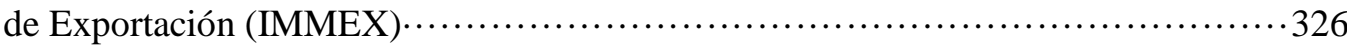

IV-1. 2. Participaciones de los capitales extranjeros desde el 49\% hasta el 100\%: cambio de la Ley de Inversión Extranjera.......................................3 334

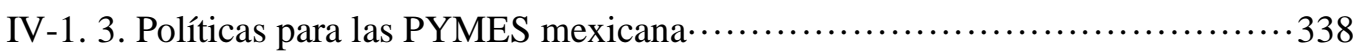

IV-1. 3. 1. Sistema para la Subcontratación Industrial (SSI) …..............339

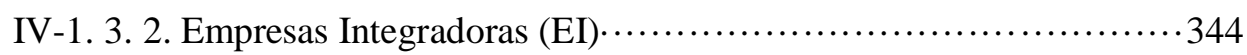

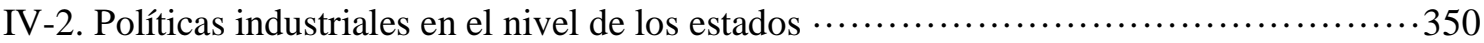

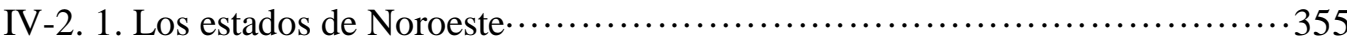

IV-2. 2. Los estados de Noreste............................................... 356

IV-2. 3. Los estados de la zona Central Occidente …...............................357

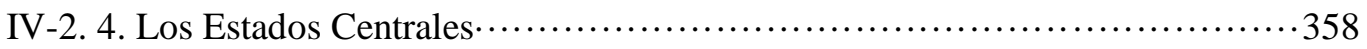

IV-2. 5. Los estados de Sur …............................................ 359

IV-2. 6. Políticas fiscales de atracción de IED y problema de gastos tributarios en

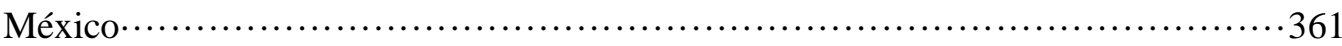

IV-3. Políticas para atraer IED en el nivel municipio: El caso de Tijuana, Baja California $\cdots 365$

IV-3. 1. Programa desarrollo de la ciudad de Tijuana, Baja California $\cdots \ldots \ldots \ldots \ldots . . . \cdots 365$

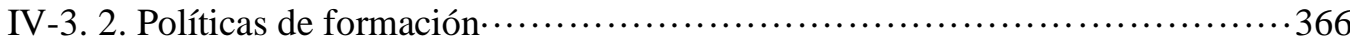

IV-3. 2. 1. Antecedentes históricos: Educación Superior y Formación en

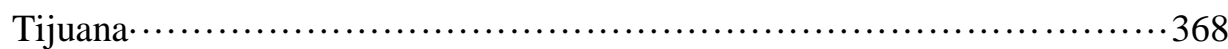


IV-3. 2. 2. Formaciones de técnicas e ingenieros en Tijuana $. \cdots \ldots \ldots \ldots \ldots . \ldots . \ldots . \ldots 9$

IV-3. 2. 2. 1. Formación de técnicos …......................... 369

IV-3. 2. 2. 2 Formación de ingenieros............................3 373

IV-4. La relación entre las industrias y las políticas industriales para atraer IED en México: el

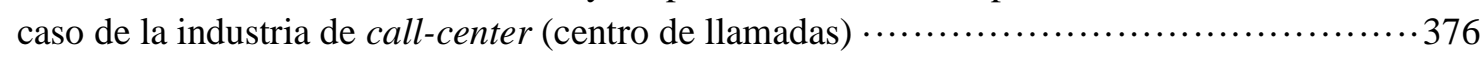

IV-4. 1. Industria de call-center: definición y principales características..............376

IV-4. 2. Historia de la industria de call-center.................................. 378

IV-4. 3. Desarrollo del clúster de Call-center en Baja California......................387

IV-4. 3. 1. Situación del clúster de call-centers: entrevista al Presidente de la industria de call-center en Baja California ................................389

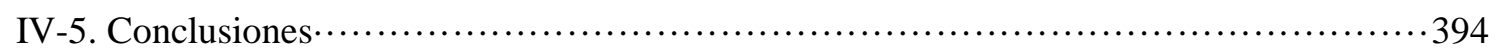

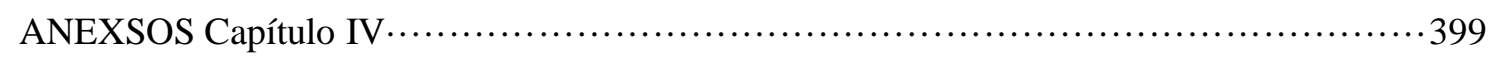

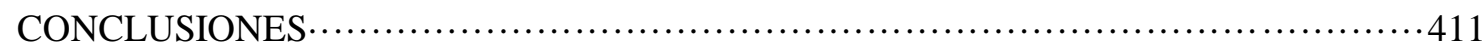

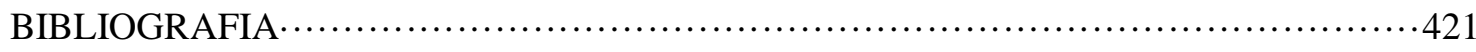




\section{Índice de Tablas}

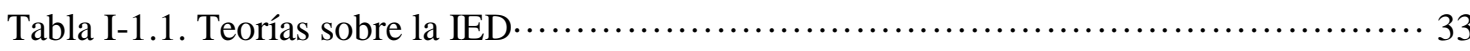

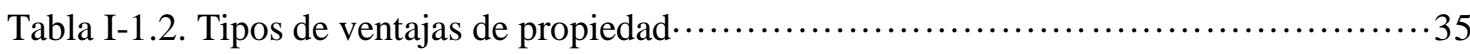

Tabla I-1.3. Las actividades de las empresas en otros países y el grado de

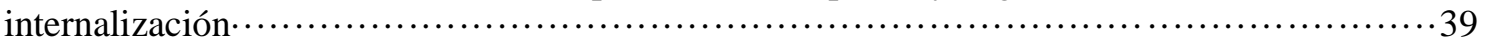

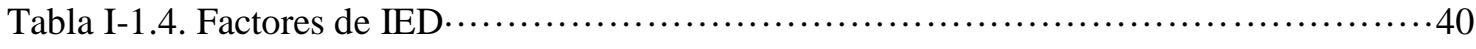

Tabla II-1.1. Números de posiciones de productos electrodomésticas y coches por cada 1000

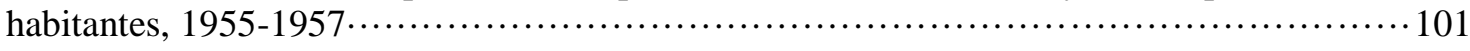

Tabla II-1. 2. Números de automóviles que los japoneses tenían en Japón $\cdots \cdots \ldots \ldots \ldots \ldots \ldots \ldots \ldots \ldots \ldots$

Tabla II-2.1. Cinco principales motivos de las inversiones japonesas en América Latina,

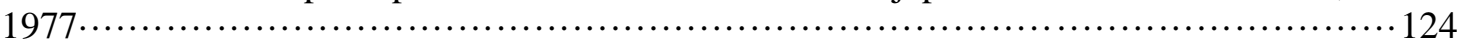

Tabla II-2. 2. Cuatro principales motivos de las inversiones japonesas en América Latina por

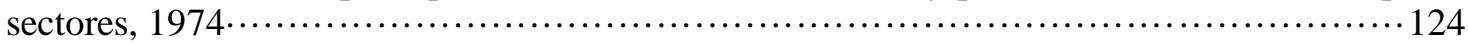

Tabla II-2. 3. Cuatro principales motivos de las inversiones japonesas en América Latina por

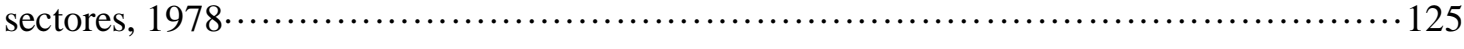

Tablas II-4. 1. Problemas y obstáculos de las empresas japonesas en América Latina,

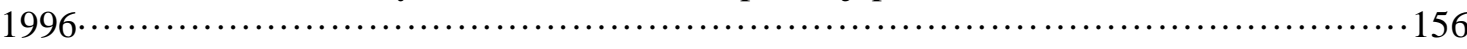

Tablas II-5. 1. Costes en México y China, 2012 …............................... 162-163

Tablas II-5. 2. Localizaciones de las empresas japonesas en México por entidad federativa de destino, 1999-2014 (En millones de dólares) ….................................177-179

Tablas II-5. 3. Localizaciones de las empresas japonesas en México por grupos de zonas de

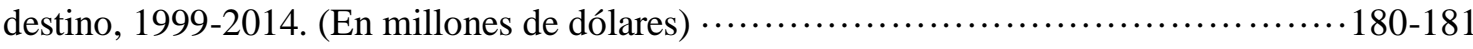

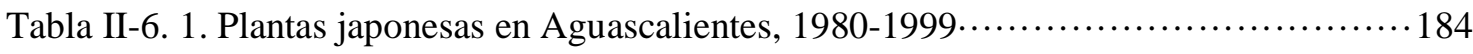

Tabla II-6. 2. Costos en El Bajío vs Frontera Norte (diciembre de 2014- enero de 2016)

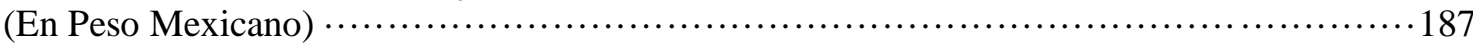

Tabla II-6. 3. Las Diferencias de Costos en El Bajío verus Frontera Norte (diciembre de 2014-

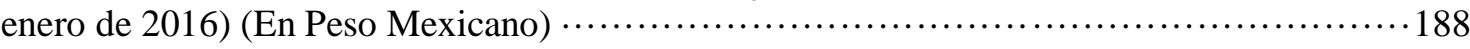

Tabla III-1.1. China: principales destinos de las exportaciones, 1995-2014 (Países con >5\%)

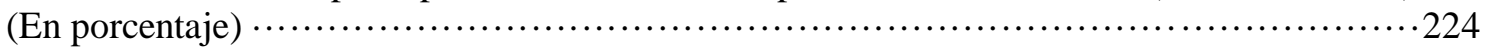

Tabla III-1.2. México: principales destinos de las exportaciones, 1995-2014 (Países con >5\%)

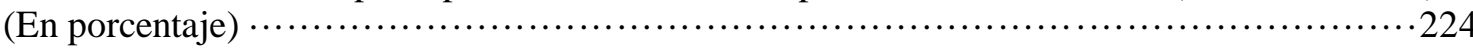

Tabla III-1.3. China: principales productos exportados al mercado mundial ( $>5 \%)$

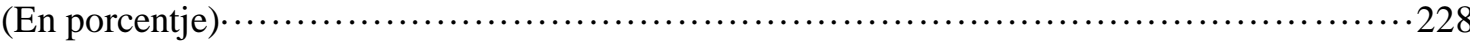

Tabla III-1.4. México: principales productos exportados al mercado mundial (>5\%)

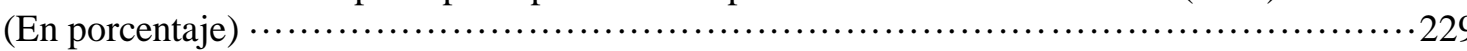

Tabla III-1.5. China: principales productos de exportación a Estados Unidos, 1995-2014(>5\%)

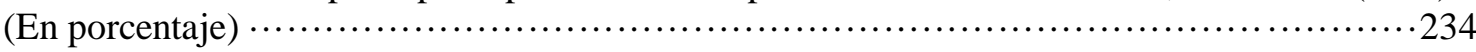

Tabla III-1.6. México: principales productos de exportación a Estados Unidos, 1995-2014

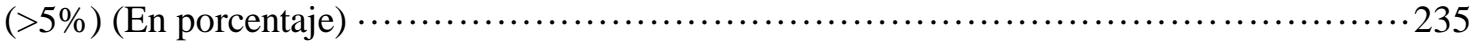

Tabla III-1.7. China: principales orígenes de las importaciones (>5\%)

(En porcentaje) 
Tabla III-1.8. México: principales orígenes de las importaciones (>5\%)

(En porcentaje)

Tabla III-1.9. China: principales productos importados desde el resto del mundo (>5\%)

(En porcentaje)

Tabla III-1.10. México: principales productos importados desde el resto del mundo ( $>5 \%)$

(En porcentaje)

Tabla III-1.11. China: principales productos importados desde Estados Unidos (>5\%)

(En porcentaje)

Tabla III-1.12. México: principales productos importados desde Estados Unidos (>5\%)

(En porcentaje)

Tabla III-3.1. Secciones del Sistema Armonizado ….....................................2 278

Tabla III-3.2. Productos en el Capítulo 61 del Sistema Armonizado $\ldots \ldots \ldots \ldots \ldots \ldots \ldots \ldots \ldots \ldots \ldots \ldots \ldots \ldots \ldots$

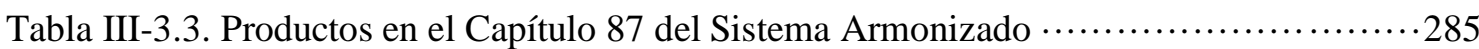

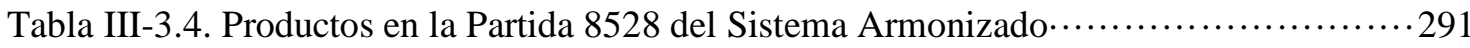

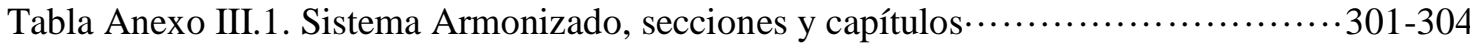

Tabla Anexo III.2. Ventajas Comparativas Reveladas de China en el comercio con Estados

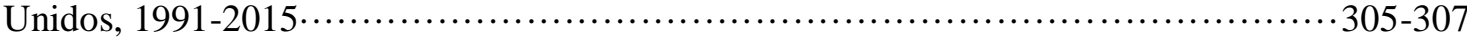

Tabla Anexo III.3. Ventajas Comparativas Reveladas de México en el comercio con Estados

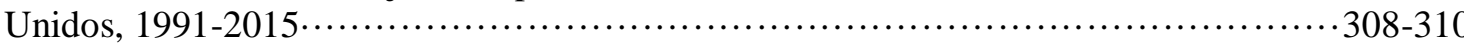

Tabla Anexo III.4. Índices de Contribución al Saldo de China en el comercio con Estados Unidos, 1991-2015. 311-313

Tabla Anexo III.5. Índices de Contribución al Saldo de México en el comercio con Estados

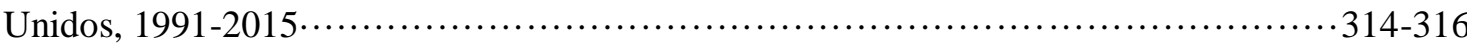

Tabla Anexo III.6. CII en el comercio de China con Estados Unidos, por Secciones, 1991-

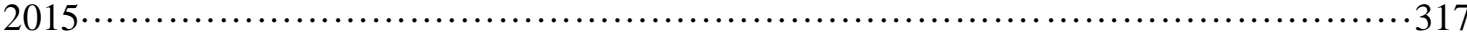

Tabla Anexo III.7. CII en el comercio de México con Estados Unidos, por Secciones, 1991 -

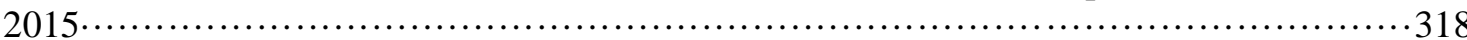

Tabla Anexo III.8. CII en el comercio de China con Estados Unidos, Capítulo 61, 1991 2015

Tabla Anexo III.9. CII en el comercio de México con Estados Unidos, Capítulo 61, 1991 -

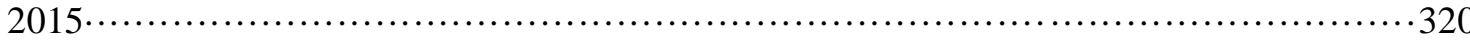

Tabla Anexo III.10. CII en el comercio de China con Estados Unidos, Capítulo 87, 1991 -

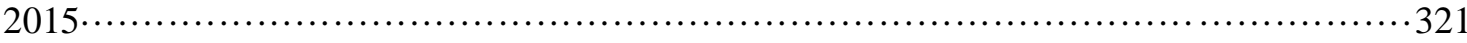

Tabla Anexo III.11. CII en el comercio de México con Estados Unidos, Capítulo 87, 1991-

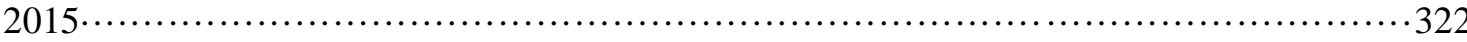

Tablas IV-1.1. Localizaciones: Las empresas mexicanas registradas para subcontratar en el SSI, 2015 .

Tabla IV-1. 2. Actividades de las empresas registradas en el SSI, 2015.

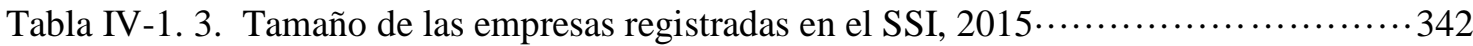

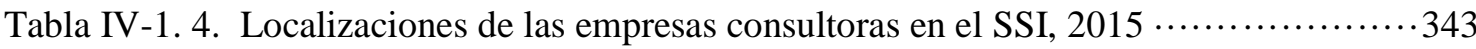

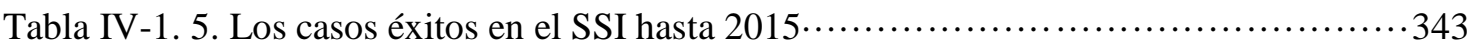

Tabla IV-1. 6. Empresas Integradoras y Números de Socios en los Estados. 1993-2000 ….347

Tabla IV-1.7. Empresas Integradoras y Números de Socios en los Estados, 2000-2014 …....349 
Tabla IV-2. 1a. Clasificaciones de las políticas fiscales en cada estado en México: Parte 1‥351

Tabla IV-2. 1b. Clasificaciones de las políticas fiscales en cada estado en México: Parte $2 \cdots 352$

Tabla IV-2. 2. Los TOP 5 estados. Números de ámbitos de políticas fiscales................. 353

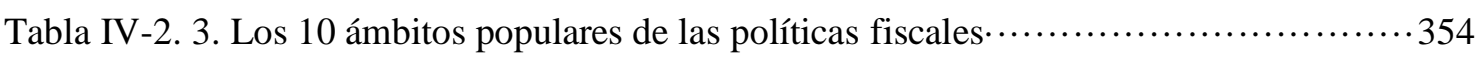

Tabla IV-2. 4. Los 5 ámbitos menos comunes de las políticas filicales.......................354

Tabla IV-2. 5. Los Estados de Noroeste. Políticas más comunes............................ 356

Tabla IV-2. 6. Los Estados de Noreste. Políticas más comunes.............................. 357

Tabla IV-2. 7. Los Estados de la zona Central Occidente. Políticas más comunes ……...... 358

Tabla IV-2. 8. Los estados de centrales. Políticas más comunes.............................359

Tabla IV-2. 9. Los estados de Sur. Políticas más comunes …........................... 360

Tabla IV-4. 1. Call-centers en México, 1973-2008....................................... 384

Tabla IV-4. 2. Lista de preguntas al Sr. Jorge Oros, presidente del cluster de call-center en Baja

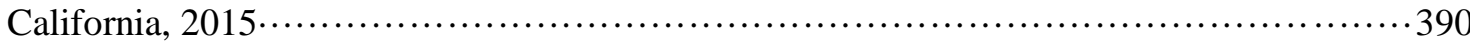

Tabla Anexo IV-1. Los institutos tecnológicos en Tijuana, 2015…................ 401-402

Tabla Anexo IV-2. Carreras en las Universidades públicas de Tijuana 2015: Licenciaturas e

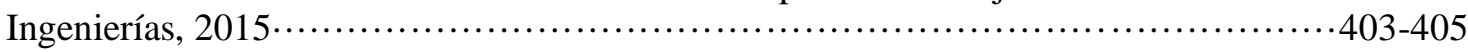

Tabla Anexo IV-3. Carreras en las Universidades privadas de Tijuana 2015: Licenciaturas e

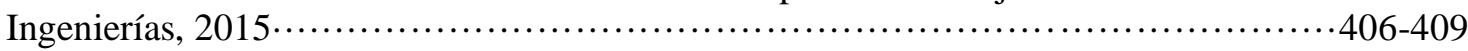

\section{Índice de gráficos}

Gráfico II-1. 1. Tasa de natalidad en Estados Unidos, 1940-2008

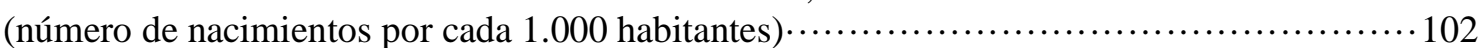

Gráfico II-1. 2. Producción de automóviles en Japón, 1950-1975

(En unidades)

Gráfico II-1. 3. Aumento de PIB (real) de Japón. 1955-1985

(En porcentaje)

Gráficos II-1. 4. Exportaciones a Estados Unidos: Automóviles y electrodomésticos japoneses, 1970-1979

Gráfico II-1. 5. Inversiones japonesas en Estados Unidos. 1951-1979

(En millones dólares)

Gráfico II-2. 1. Inversiones japonesas en México: en los años 1960

(En miles de dólares de Estados Unidos)

Gráfico II-2. 2. México: Producto Interno Bruto por habitante. 1960-1969

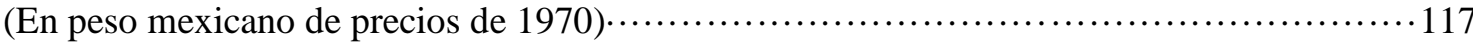

Gráfico II-2. 3. Producción de televisores y radios en México, 1965-1984

(Unidades)

Gráfico II-2. 4. Las inversiones japonesas en México, 1970-1979.

(En millones dólares de Estados Unidos)

Gráfico II-2.5. Número de casos de las inversiones japonesas en México, 1970-1979......... 120 
Gráfico II-2. 6. Crecimiento de PIB per cápita, 1969-1980

(En porcentaje)

Gráfico II-3. 1. Inversiones japonesas en todo el mundo 1975-1996 e inversiones japonesas en

México, 1980-1993 (En millones de dólares de Estados Unidos)

Gráfico II-3. 2. PIB Per Cápita de Japón, 1975-1989

(En Dólares de Estados Unidos. Precios y el tipo de cambio actuales) $\cdot 128$

Gráfico II-3. 3. Saldo de la Balanza por cuenta corriente de Japón, 1980-1990

(En millones de Dólares de Estados Unidos)

Gráficos II-3. 4. Tamaño de las empresas japonesas que invierten a América Latina, 1980 y 1984

Gráfico II-3. 5. Tipo de cambo de yen-dólares de Estados Unidos. 1980-1990

(Yen)

Gráfico II-4. 1. Inversiones japonesas en México, 1990-1998

(En millones de dólares)

Gráfico II-4. 2. Actividad productiva de las empresas japonesas en México: principales productos exportados, 1990-1999. (En porcentaje)

Gráfico II-4. 3. Actividad productiva de las empresas japonesas en México: contenidos locales

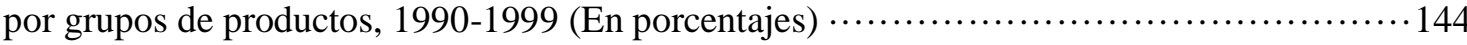

Gráfico II-4. 4. Actividad productiva de las empresas japonesas en México: contenidos importados por grupos de productos, 1990-1999 (En porcentajes)

Gráfico II-4. 5. Actividad productiva de las empresas japonesas en México: contenidos importados desde Japón por grupos de productos, 1990-1999 (En porcentajes)

Gráfico II-4. 6. Actividad productiva de las empresas japonesas en México: contenidos importados desde los terceros países por grupos de productos, 1990-1999 (En porcentajes)

Gráficos II-4. 7. Actividad productiva de las empresas japonesas en México: Orígenes de los

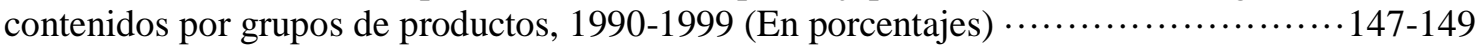

Gráficos II-4. 8. Actividad productiva de las empresas japonesas en México: Ventas locales y exportaciones por grupos de productos, 1990-1999 (En porcentajes) $\cdots \ldots \ldots \ldots \ldots \ldots \ldots \ldots \ldots \ldots \ldots \ldots \ldots 151-154$

Gráfico II-5. 1. Flujos de inversiones japonesas en México, 2000-2013

(En millones de dólares)

Gráfico II-5. 2. Inversiones japonesas a México y China, 1985-2012

(En millones de dólares)

Gráfico II-5. 3. Importaciones de Estados Unidos desde China y México, 1990-2011

(En miles de dólares) 164

Gráficos II-5. 4. Importaciones de Estados Unidos desde China y México por grupos de productos, 1990-2011 (En miles de dólares)

165-169

Gráficos II-5. 5. Inversiones japonesas en el mundo, Flujo, 1995-2012

(En Millones dólares)

Gráfico II-5. 6. Número de los flujos de inversión extranjera directa planeados hacia México por

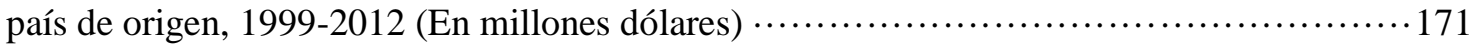

Gráficos II-5. 7. Ventas de las empresas japonesas en México por grupos de productos, 1997-

2012 (En millones de dólares) $172-174$

Gráfico II-5. 8. Números de Trabajadores en las empresas japonesas en México, 20002012 
Gráfico II-5. 9. Números de empresas japonesas en México y números de empresas japonesas retiradas de sus actividades en América Latina, 1999 - 2012 …........................... 176

Gráfico II-6.1. Porcentaje de aumento de salarios

(En porcentajes)

Gráfico II-6.2. Costes de Transporte

(En peso mexicano)

Gráficos II-6.3. Transporte desde México a Estados Unidos: Comercios totales, 1995-

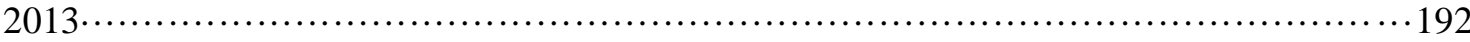

Gráficos II-6. 4. Transporte desde México a Estados Unidos: exportaciones, 1995-2013 …193

Gráficos II-6. 5. Transporte desde Estados Unidos a México: Importaciones, 1995-2013 ….. 194

Gráfico III-0.1. Importaciones de Estados Unidos, 1995-2014

(En trillones de dólares corrientes)

Gráfico III-0.2. Distribución de las importaciones de Estados Unidos por países, 2014

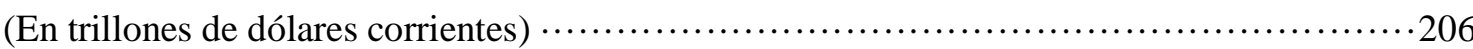

Gráfico III-0.3. Distribución de las importaciones de Estados Unidos por países, 1995

(En billones de dólares corrientes)

Gráfico III-0.4. Distribución de las exportaciones de China por países, 1995-2014

(En trillones de dólares corrientes)....

Gráfico III-1.1. Comercio de México, 1984-2014

(En miles de millones de Dólares)

Gráfico III-1.2. Saldos del comercio de México y China con Estados Unidos, 1984-2014

(En miles de millones de dólares)

Gráfico III-1.3. Peso de Estados Unidos en el comercio de México, 1984-2014

(En porcentaje)

Gráfico III-1.4. Distribución por países de las exportaciones de México, 2014

(En billones de dólares).

Gráfico III-1.5. Comercio de China, 1984-2014

(En dólares de Estados Unidos)...

Gráfico III-I.6. Peso de Estados Unidos en el comercio de China, 1984-2014

(En porcentaje).....

Gráfico III-1.7. Evolución de las exportaciones totales de México y China, 1984-2014

(En miles de millones de dólares).

Gráfico. III-1.8. Peso de Estados Unidos en las exportaciones de México y China, 1984-2014

(En porcentaje)

Gráfico III-1.9. Distribución por regiones de las exportaciones de China, 2014

(En trillones de dólares).

Gráfico III-1.10. Exportaciones a Estados Unidos de México y China, 1984-2014

(En miles de millones de dólares)

Gráfico III-1.11. China y México: tipo de cambio frente al dólar estadounidense, 1990-2015

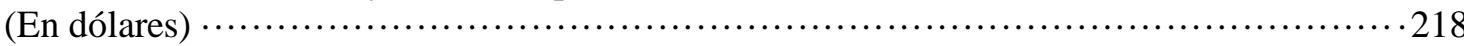

Gráfico III-1.12a. Tipo de cambio efectivo real para China, 1994-2016 …................219

Gráfico III.1.12b. Tipo de cambio efectivo real para México, 1994-2016…................219 
Gráfico III-1.13. China y México: importaciones desde todo el mundo, 1984-2014

(En miles de millones de dólares).

Gráfico III-1.14. China y México: importaciones desde Estados Unidos, 1984-2014

(En miles de millones de dólares)

Gráfico III-1.15. Destinos de las exportaciones chinas, 1995-2014

(En porcentaje)

Gráfico III-1.16. Destinos de las exportaciones mexicanas, 1995-2014

(En porcentaje)

Gráfico III-1.17. Composición de las exportaciones chinas, 1995-2014

(En porcentaje)

Gráfico III-1.18. Composición de las exportaciones mexicanas, 1995-2014

(En porcentaje)

Gráfico III-1.19. Composición de las exportaciones chinas a Estados Unidos, 1995-2014

(En porcentaje)

Gráfico III-1.20. Composición de las exportaciones mexicanas a Estados Unidos, 1995-2014

(Enporcentaje)

Gráfico III-1.21. Origen de las importaciones chinas, 1995-2014

(En porcentaje)

Gráfico III-1.22. Origen de las importaciones mexicanas, 1995-2014

(En porcentaje)

Gráfico III-1.23. Composición de las importaciones chinas, 1995-2014

(En porcentaje)

Gráfico III-1.24. Composición de las importaciones mexicanas, 1995-2014

(En porcentaje)

Gráfico III-1.25. Composición de las importaciones chinas desde Estados Unidos, 1995-2014

(En porcentaje) 248

Gráfico III-1.26. Composición de las importaciones mexicanas desde Estados Unidos, 1995-

2014 (En porcentaje)

Gráfico III-2.1. Ventaja Comparativa Revelada en el comercio de China y México con Estados

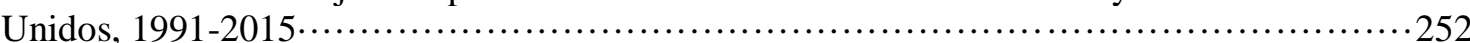

Gráfico III-2.2. Ventajas Comparativas Reveladas de China en su comercio con Estados Unidos,

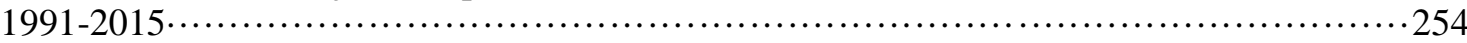

Gráfico III-2.3. Ventajas Comparativas Reveladas de México en su comercio con Estados

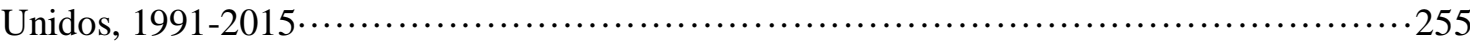

Gráfico III-2.4. Índice de Contribución al Saldo de China en su comercio con Estados Unidos,

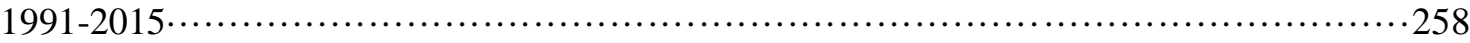

Gráfico III-2.5. Índice de Contribución al Saldo de México en su comercio con Estados Unidos, $1991-2015$ .259

Gráfico III-2.6. Exportaciones de México y China a Estados Unidos, capítulo 85. 1991-2015

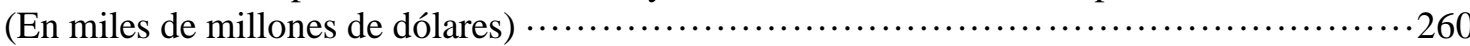

Gráfico III-2.7. Saldo Comercial Relativo de México y China con Estados Unidos, capítulo 85,

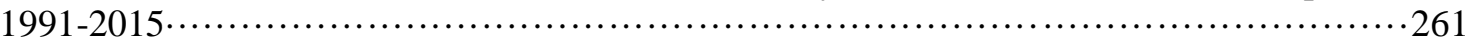

Gráfico III-2.8. Índice de Contribución al Saldo en el comercio de México y China con Estados Unidos, capítulo 85, 1991-2015 $\cdot 261$ 
Gráfico III-2.9. China: comercio con Estados Unidos, Partida 8528, 1992-2014

(En miles de millones de dólares).

Gráfico III-2.10. México: comercio con Estados Unidos, Partida 8528, 1992-2014

(En miles de millones de dólares) 262

Gráfico III-2.11 Ventaja Comparativa Revelada de Estados Unidos con China y México, Partida 8528, 1992-2015. .264

Gráfico III-2.12. Exportaciones de México y China a Estados Unidos, capítulo 61, 1991 2015 265

Gráfico III-2.13. Saldo Comercial Relativo de México y China con Estados Unidos, capítulo 85, $1991-2015$ 266

Gráfico III-2.14. Índice de Contribución al Saldo en el comercio de México y China con Estados Unidos, capítulo 61, 1991-2015

Gráfico III-2.15. China: comercio con Estados Unidos, Partida 6104, 1992-2014

(En miles de millones) 268

Gráfico III-2.16. México: comercio con Estados Unidos, Partida 6104, 1992-2014

(En miles de millones) 268

Gráfico III-2.17. Saldo de Estados Unidos con China y México, Partida 6104, 1991-2014

(En millones de dólares) 269

Gráfico III-2.18. Ventaja Comparativa Relevada de Estados Unidos con México y China, Partida 6104, 1993-2015 270

Gráfico III-3.1. CII de China y México con Estados Unidos, 1991-2015 274

Gráfico III-3.2. CII en el comercio de China con Estados Unidos por Secciones del Sistema Armonizado, 1991-2015. 276

Gráfico III-3.3. CII en el comercio de México con Estados Unidos por Secciones del Sistema Armonizado, 1991-2015. 277

Gráfico III-3.4. CII en el comercio de México con Estados Unidos en la Sección XI, 1991-2015 280

Gráfico III-3.5. CII en el Comercio de China con Estados Unidos, Capítulo 61, 1991-

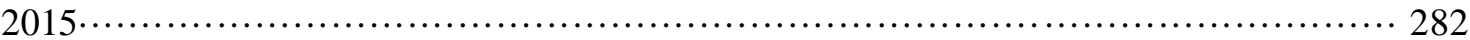

Gráfico III-3.6. CII en el Comercio de México con Estados Unidos, Capítulo 61, 19912015 .

Gráfico III-3.7. CII en el comercio de México con Estados Unidos en la Sección XVII, 1991-

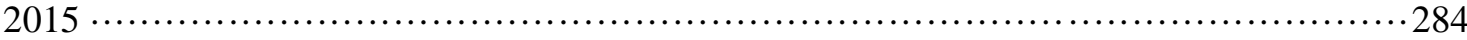

Gráfico III-3.8. CII en el comercio de China con Estados Unidos, Capítulo 87, 1991-

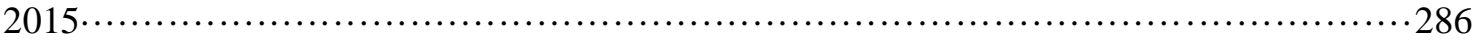

Gráfico III-3.9. CII en el comercio de México con Estados Unidos, Capítulo 87, 19912015 .

Gráfico III-3.10. CII en el comercio de México con Estados Unidos en la Sección XVI, 1991 2015 289

Gráfico III-3.11. Comercio de China y México con Estados Unidos, Partida 8528, 1991-2015

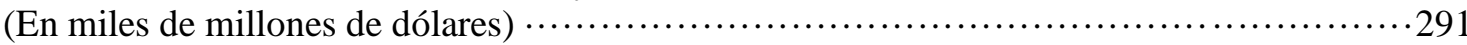

Gráfico III-3.12. CII de China y México con Estados Unidos, Partida 8528, 1991-2015 …...292

Grafico IV-1. 1. México: Estructura de las exportaciones según programas. 1993-2001

(En millones de dólares) 
Grafico IV-4. 1. Hispanos en Estados Unidos. Nacido dentro o fuera de Estados Unidos. 19602014 (En millones)

Grafico IV-4. 2. Porcentaje de los hispanos en Estados Unidos. 1960-2014.

(En porcentaje)

Grafico IV-4. 3. Porcentaje de los hispanos en Estados Unidos. Orígenes Mexicanos y non-

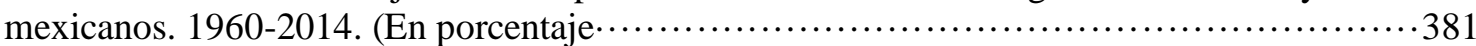

Grafico IV-4. 4. Números de estaciones de los call-centers en México, 1973-2008. 385

\section{Índice de ilustraciones}

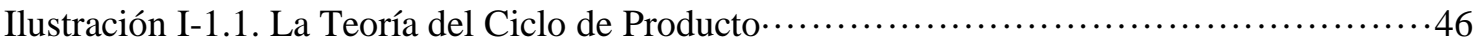

Ilustración I-2.1. La diferencia entre Inter-industrial y dos tipos de Comercio Intra-

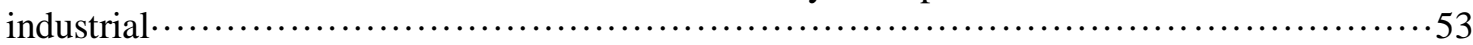

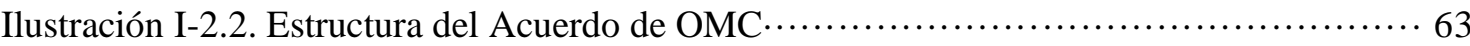

Ilustración II-3. 1. Ejemplo de jerarquía de empresas japonesas en la industria de

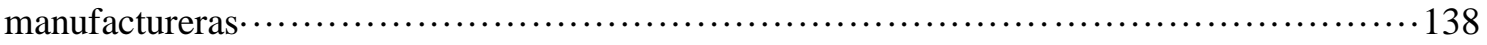

Ilustración II-4. 1. Redes de las empresas televisores japonesas en México $\cdots \cdots \ldots \ldots \ldots \ldots \ldots \ldots \ldots \ldots \ldots \ldots$

Ilustración II-6. 1. Ferrocarriles en Bajío: Kansas City Southern México, con conexión con

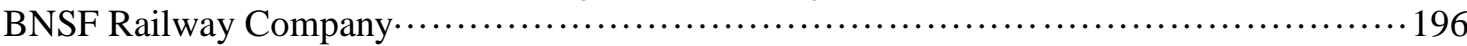

Ilustración II-6. 2. Ferrocarriles en Bajío: Red de FERROMEX…........................ 196

Ilustración II-6. 3. Parques Industriales en México ….................................. 198

Ilustración II-7. 1. Factores decisivos de las inversiones japonesas en México …..............202

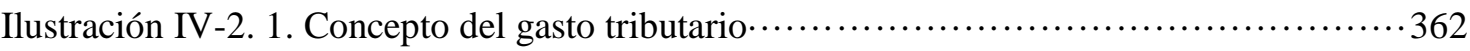

Ilustración IV-4. 1. Relaciones entre las empresas de call-centers y sus clientes................386 


\section{RESUMEN}

Desde las reformas de los años 80, la proximidad con Estados Unidos y el bajo coste de la mano de obra han sido dos motivos principales para atraer inversiones directas extranjeras (IDE) a México. Empresas estadounidenses, asiáticas y europeas han invertido en México para aprovechar estas ventajas. México se ha convertido, de esta manera, en un lugar donde fabricar y exportar a Estados, siguiendo una estrategia favorecida por el gobierno de México, que ha desarrollado políticas para atraer más IDE y aprovechar estas inversiones para su desarrollo económico.

Además de un capítulo dedicado a la teoría de la IDE y el comercio, en esta tesis, se analiza en el capítulo segundo la evolución de las inversiones japonesas en México, comenzando con las realizadas durante el periodo de Industrialización por Sustitución de Importaciones y las realizadas por las empresas japonesas en Estados Unidos, hasta analizar las últimas tendencias espaciales de localización de esta inversión en El Bajío.

En el tercer capítulo se analiza empíricamente el comercio de China y México con Estados Unidos. Tras el TLCAN México tenía una cuota mayor en dicho mercado, pero desde la entrada de China en la OMC, esa situación ha cambiado. Desde entonces los productos chinos han desplazado, en buena medida, a los mexicanos en el mercado de Estados Unidos. El análisis muestra diferencias importantes en el Comercio IntraIndustrial de ambos países, siendo mucho mayor en el caso de México.

El cuarto y último capítulo presta atención a las políticas para atraer la inversión directa en los tres niveles (federal, estatal y municipal), destacando los diferentes roles de las tres niveles administrativos y la evolución de las políticas a lo largo del tiempo. Se ilustra la importancia de estas políticas en el caso del sector de Call Centers en Tijuana (Baja California).

Palabras clave: Inversión Directa Extranjera, México, Japón; Estados Unidos, China, Comercio. 
Introducción 
El origen de esta tesis se encuentra en la tesis doctoral que esta doctoranda realizó en la Universidad de Toyo en Japón en el año 2004 y que generó el deseo de aprender más sobre América Latina, por lo que vine a Salamanca en el año 2007 para cursar el Máster de Estudios Latinoamericanos en los cursos 2007-2008 y 2008-2009. Para completar mis estudios de Máster realicé un TFM bajo la dirección del profesor Fernando Rueda sobre "Comercio de Servicios y Desarrollo Económico. El Caso de la industria de Call-center en México" en el que se prestaba, de nuevo, una especial atención a México. Por todo esto, me decidí en el curso 2009 a comenzar mis estudios de doctorado en el Programa de Doctorado en Estudios Latinoamericanos poniendo una especial atención a las relaciones entre Japón y México. No obstante, en el curso de estos estudios de doctorado se hizo evidente que estas relaciones sólo se podían estudiar teniendo en cuenta otros dos países (China y Estados Unidos), hasta llegar a la estructura actual del trabajo. En el proceso tuve la ocasión de viajar a Tijuana con una beca de la Universidad de Salamanca para realizar una estancia de dos meses en el Colegio de la Frontera Norte, donde tuve ocasión de conocer de primera mano la realidad de la frontera y de la producción de las empresas japonesas allí instaladas.

La inversión extranjera directa (IED) es una actividad económica internacional, en la que intervienen empresas que quieren invertir en otros países y al mismo tiempo, se necesitan países que estén dispuestos a recibirlas. Para las empresas, la IED es una manera de aumentar las oportunidades de sus negocios y de ampliar sus beneficios. Para los países que reciben la IED, ésta tiene varios significados, ya que supone la posibilidad de recibir nuevos capitales, de incorporar nuevas tecnologías y aprender nuevas formas de producción y comercialización, de generar empleos y de diversificar y aumentar las exportaciones, entre otras (DUNNING, 1995). Todas estas posibilidades pueden inducir el desarrollo económico y social en los países destino de la IED.

Para México, la IED significa todo lo que se acaba de mencionar. Sin embargo, una característica de la IED en México es que, su principal objetivo ha sido, desde las políticas de liberalización y apertura de los años ochenta, la exportación a Estados Unidos. Aunque las nacionalidades de las empresas son distintas (japonesas, europeas, coreanas y estadounidenses), la mayor parte de estas empresas que han invertido en México tras el final del proceso de Industrialización por Sustitución de Importaciones, han buscado principalmente exportar sus productos a Estados Unidos. 
Esta posición de México, como un receptor de IED, viene de dos factores propios de atracción. El primero es su condición geográfica, es decir, su proximidad a Estados Unidos. El segundo factor es su bajo coste de la mano de obra, especialmente, comparado con el coste laboral en Estados Unidos. Estas dos condiciones de partida son muy atractivas para las empresas que quieren fabricar productos para exportar al mercado estadounidense. El gobierno de México aprovechó estas dos ventajas para atraer IED.

En los años 80, tras la crisis de la deuda externa de 1982, México cierra su etapa de industrialización por sustitución de importaciones y va realizando las así llamadas "reformas del Consenso de Washington", que impulsaron la liberalización comercial y de los flujos de capitales en México. Dentro de esta estrategia de apertura y de búsqueda de un crecimiento guiado por las exportaciones, México firmó con Estados Unidos y Canadá en 1992 el Tratado de Libre Comercio de América del Norte (TLCAN), lo que permitió a las empresas instaladas en México un acceso sin aranceles al mercado estadounidense. Esta estrategia de atracción de la IED, basada en el aprovechamiento de la ventaja de localización y del bajo coste de la mano de obra, pareció funcionar muy bien hasta el año 2000. Como vamos a analizar en los capítulos posteriores, la IED en México aumentó, la exportación a Estados Unidos se incrementó, y la cuota de mercado en Estados Unidos, también, se expandió. Sin embargo, al empezar el nuevo siglo, esta situación de México empezó a cambiar. Su cuota del mercado estadounidense y sus exportaciones a Estados Unidos se redujeron. Uno de los principales motivos de este cambio fue el surgimiento de la economía china como la "fábrica del mundo" (DUSSEL PETERS, 2015a) tras su incorporación a la Organización Mundial del Comercio (OMC). Desde ese momento, se puede decir que México se está enfrentado a la necesidad de un cambio en sus estrategias de atracción de la IED. Aunque no se ha alterado la ventaja de su localización, no ha ocurrido lo mismo con el coste de su mano de obra, ya que el precio de la mano de obra en China y de otros países emergentes es más barato que en México. Por ello, se necesita reconsiderar los motivos de la IED en México nuevamente. Aunque su ventaja de localización no ha cambiado, su efecto a la hora de tomar la decisión de invertir ha variado, México no puede competir solo con su coste, sino que necesita competir con otros factores que mejoren la productividad e incorporen valor a los productos.

El objetivo de esta tesis es reconsiderar el papel de la IED en México y buscar sus nuevas significaciones. Se analiza la IED en México desde tres puntos de vista: el de la evolución de las inversiones japonesas en México, el de la evidencia empírica de los flujos 
de comercio que surgen a partir de las inversiones recibidas por México y, finalmente, el de las políticas públicas de atracción de IED desarrolladas por el sector público de este país federal en sus diferentes niveles.

En su diseño original, el objetivo de la tesis estaba concentrado en las inversiones japonesas en México. Sin embargo, el curso posterior de la investigación nos ha llevado a añadir dos elementos básicos: por un lado, una consideración muy detenida de los flujos comerciales (que son la razón básica de la IED en México); y por otro lado, una atención muy especial tanto a Estados Unidos, que es el mercado principal de destino de las exportaciones, como a China que compite con México en dicho mercado. Así se ha llegado a la estructura actual.

Las hipótesis de las que parte la tesis son las tres siguientes:

a) La evolución de la IED japonesa en México se ajusta a la teoría ecléctica de Dunning ya que en su evolución tienen importancia tanto las ventajas de las empresas japonesas (sus ventajas de propiedad), como las ventajas de localización de México y las necesidades de las empresas japonesas de internalizar estas ventajas.

b) La evolución de las exportaciones de México a Estados Unidos es fruto de los flujos de IED recibidos por este país, pero se ha visto afectada por los cambios en las políticas comerciales de México y Estados Unidos y por los cambios en la regulación internacional del comercio.

c) Las políticas públicas tienen un papel clave para explicar la evolución de los flujos de IED en México, aunque otros factores externos, propios de los países de origen de la IED, de la evolución de la competencia internacional en el sector de las manufacturas y de la coyuntura económica y política del país de destino de las exportaciones que debe generar dicha IED, son también relevantes.

Así, para alcanzar el objetivo citado y contrastar las hipótesis indicadas, la tesis se ha articulado en cuatro capítulos a los que se suma uno de conclusiones. Después de esta introducción, en el capítulo I, se analizan las teorías que sirven para entender los flujos de IED y comercio de México, además de prestar una atención especial a la evolución del marco normativo en el que se ha desarrollado el comercio internacional en las últimas décadas. En el aspecto metodológico, este capítulo está basado en una revisión crítica de la literatura. 
En el capítulo II, se analiza la evolución histórica de la IED japonesa en México y es el capítulo que está más directamente relacionado con la tesis doctoral que defendí en la Universidad de Toyo, aunque todo el texto ha sido debidamente actualizado, ya que se han producido importantes cambios en los últimos años que no estaban contemplados en mi anterior tesis doctoral. A través de este análisis histórico, se pueden identificar los principales factores que han influido en el flujo de inversiones extranjeras hacia México. Este capítulo está basado en un análisis histórico de la inversión de Japón en México a partir de una revisión de la literatura.

En el Capítulo III, se analiza el comercio de México y China con Estados Unidos. Como se ha indicado antes, la mayor parte del objetivo de la IED en México que ha llegado a partir de los años 80 es la exportación a Estados Unidos. Por eso, analizar el comercio de México con Estados Unidos es importante para entender las tendencias y características de las empresas que hacen IED en México. Asimismo, por medio de la comparación con el comercio chino con Estados Unidos, se pueden entender más claramente sus características. En esta parte, la metodología es el análisis empírico a partir de los indicadores de comercio inter e intra-industrial.

En el Capítulo IV, se analizan las políticas públicas de México para atraer IED. Además, en el caso de México que es un país federal, dependiendo del nivel del gobierno (gobierno central, gobierno de los estados y gobierno municipal), sus papeles son distintos. Por eso, es clave entender los papeles de cada nivel del gobierno. En este capítulo se presta una especial atención al sector de los call-centers que es un sector que estudié anteriormente en mi Trabajo de Fin de Máster (TFM) y que sirve para ilustrar el efecto de las políticas públicas para la atracción de IED. En este capítulo, además de una revisión crítica de la literatura son también importantes, en términos metodológicos, las entrevistas que tuve la oportunidad de hacer durante la estancia en el Colegio de la Frontera Norte con personas relevantes de Tijuana relacionadas con las inversiones internacionales directas.

Por último, la tesis se cierra con las conclusiones en las que se recogen los principales resultados de la investigación desarrollada. 


\section{Capítulo I}

Marco teórico 


\section{I-0. Introducción}

En este capítulo se presentan los marcos teóricos utilizados en esta tesis. En concreto, se examina la teoría de la inversión extranjera directa (IED), la teoría del comercio internacional (inter-industrial e intra-industrial) y la teoría de las políticas industriales para la atracción de IED.

En la primera sección, se analizan las definiciones de IED y los motivos por los que tiene lugar la IED. En la segunda sección, se presenta la evolución histórica de las teorías que tratan de explicar los flujos comerciales inter-industriales e intra-industriales. Asimismo, en esta segunda sección se analizan los principales marcos normativos que regulan el comercio internacional y que son relevantes para el objeto de estudio de la tesis: concretamente, la Organización Mundial del Comercio (OMC), el Tratado de Libre Comercio de América del Norte (TLCAN) y el Acuerdo de Asociación Económica México-Japón (AAE). Para México, estas instituciones y tratados son vías para facilitar su inserción comercial y aumentar su presencia en el mundo internacional. Se investiga cómo estas instituciones han afectado a las actividades comerciales de México y a la relación de China con el sistema de comercio mundial. A diferencia de México, China es un país que ha tardado más en incorporarse plenamente al sistema mundial de regulación del comercio.

Por último, en la tercera sección se analiza la teoría de la política industrial, concebida como una política de atracción de la IED. Para aumentar la IED y aprovecharla al máximo posible, se necesita el desarrollo de una política industrial. En el caso de México, el Programa de Maquiladora es una de las claves de su éxito en la década de los noventa. Se examina la justificación de las intervenciones gubernamentales para atraer IED en México, así como su eficacia.

Estos tres marcos teóricos ayudan a entender mejor la IED en México. El principal motivo de la IED en México es su proximidad al mercado de Estados Unidos porque para la mayor parte de las empresas extranjeras instaladas en México, su objetivo principal es vender sus productos a Estados Unidos. En otras palabras, el comercio con Estados Unidos es el primer objetivo de la IED en México. Desde el punto de la vista del gobierno mexicano, la IED es una oportunidad y, por ello, tiene que adoptar políticas industriales de atracción de la IED. 
En suma, los marcos teóricos de la IED, el comercio internacional y la política industrial se vinculan entre sí para examinar el objeto de estudio de la tesis. En el caso de México, estos tres marcos teóricos tienen una relación muy fuerte con la actividad económica, en general y con la IED en México, en particular. Por eso, en este capítulo, mientras se analizan los marcos teóricos y la evolución histórica de cada teoría, se tiene en cuenta simultáneamente su influencia en la explicación de los flujos de IED de México y en las actividades del gobierno mexicano para atraer dicha IED. 


\section{I-1. Definición y factores de la Inversión Extranjera Directa (IED)}

\section{I-1.1. Definición de la IED}

En esta parte, se empieza con una pregunta fundamental: ¿qué es la Inversión Extranjera Directa (IED)? Contestar a esta pregunta no es una tarea sencilla, ya que hay que tener en cuenta varios factores. Por ejemplo, hay que considerar la diferencia entre la inversión extranjera directa y la inversión extranjera indirecta o de cartera.

Lo primero a destacar es que no hay una única definición de IED, sino varias teorías y definiciones de IED. Además, hasta 1960, la diferencia entre IED e inversión de cartera no era tan clara. Se consideraba que la inversión extranjera era inversión de cartera (BUCKLEY, 2011). A partir de 1960, ambos conceptos comenzaron a diferenciarse más claramente, gracias al debate académico y a los cambios percibidos en la dinámica de los negocios internacionales.

Por lo tanto, se tardó casi 50 años en comenzar a establecer la definición de IED. Es muy normal que haya varias definiciones, dependiendo de las diferentes escuelas de economistas. Sin embargo, podemos encontrar algunos puntos comunes en esas definiciones. A continuación, vamos a examinar las definiciones de IED para buscar sus perspectivas comunes.

DUNNING (1995, pp.3-4) define IED como "la inversión que se realiza fuera del país de origen de la empresa que invierte, pero dentro de la empresa que invierte. El control sobre el uso de los recursos transferidos permanece en manos del inversor. Los recursos pueden consistir en un "paquete" de activos y productos intermedios, tales como capital, tecnología, capacidad de gestión, acceso a mercados y emprendimiento ${ }^{1 /}$.

Según esta definición, la IED tiene dos condiciones importantes. Primero, la IED es una forma de transferir algunos "recursos" de las empresas, que pueden ser desde dinero hasta tecnología y experiencia de gestión. Cuando la empresa quiere mover su "recurso" a otro mercado, se necesita la IED. Segundo, la propiedad de estos recursos se queda en manos de las empresas que hacen la inversión; es decir, la empresa que hace la IED tiene que mantener su poder de decisión sobre sus actividades.

\footnotetext{
${ }^{1}$ Esta cita ha sido traducida del inglés por la doctoranda.
} 
Si nos preguntamos "qué no es IED," podemos entender esta perspectiva. Para DUNNING (1995, p.5), la transferencia de recursos en el caso de la inversión indirecta conlleva que "los activos específicos y bienes intermedios por separado se transfieran entre dos agentes económicos independientes a través del mercado, pasando el control sobre los recursos del vendedor al comprador ${ }^{2 \%}$.

Como se muestra después, Dunning es el impulsor del paradigma OLI (Ownership, Location and Internalization $)^{3}$ en la teoría de la IED. Él da una especial importancia a la propiedad (ownership). En su teoría, la ventaja de la propiedad es la que impulsa realmente la IED, aunque su definición de propiedad es muy amplia.

Otra definición anterior de IED, es la de LEWIS (1948 ) que señaló que la IED englobaba los siguientes cuatro componentes: “(1) las ramas filiales extranjeras y otras propiedades extranjeras que empresas nacionales controlan y tienen; (2) las compañías controladas por nacionales, pero que están organizadas para operar exclusivamente en el extranjero, tanto si estas empresas están registradas en el país o en el extranjero; (3) las participaciones por personas y grupos de individuos que tienen importantes intereses comunes en empresas extranjeras; y (4) los bienes raíces propiedad de nacionales del país, tales como minas, plantaciones y tierras de madera ${ }^{4}$ ". Esta definición delimita mucho más el contenido de la IED y es la que se usaba en los documentos del Departamento de Comercio de Estados Unidos.

Después de presentar estas definiciones de IED, se puede notar que hay algunos puntos comunes. El más importante es que, las empresas matrices que hacen IED tienen que mantener el "control" de sus filiales en los países en los que se establecen. Como se muestra en el próximo epígrafe, la primera diferencia entre IED e inversión de cartera es si la empresa puede o no mantener su "control". Las empresas que hacen IED tienen que controlar varias cosas de sus subsidiarias extranjeras, por ejemplo, la nacionalidad de las filiales, la estrategia, la investigación y tecnología, los recursos humanos, etc. Los costes de control de todo ello son muy elevados y por ello, es normal que la mayor parte de las empresas multinacionales sean empresas grandes.

\footnotetext{
${ }^{2}$ Esta cita ha sido traducida del inglés por la doctoranda.

${ }^{3}$ OLI significa Propiedad (Ownership), Locación (Location) e Internalización (Internalization).

${ }^{4}$ Esta cita ha sido traducida del inglés por la doctoranda.
} 


\section{I-1.2. Factores de IED y teoría de OLI}

En esta parte, se analizan algunos factores explicativos de la IED; es decir, se busca entender el porqué de los flujos de IED. Para considerar este tema, tenemos que analizarlo desde dos puntos de vista: el de los países que hacen la IED (los países inversores) y el de los países que reciben dicha IED, (los países receptores). En la literatura que analiza los motivos de la IED, hay teorías que se centran en los motivos de los receptores de IED y otras que lo hacen en los motivos los países inversores. Asimismo, hay teorías que ponen su atención en algunas diferencias entre los dos tipos de países.

$\mathrm{Al}$ igual que ocurre con las definiciones de IED, existen diversas teorías sobre los factores explicativos de la IED. Por ejemplo, desde el punto de vista de un especialista en finanzas internacionales, la diferencia de tipos de interés entre dos países es un motivo de la IED y ello se refleja en las relaciones entre los países que hacen y reciben IED (HYMER, 1976). Desde el punto de vista de un especialista en política económica, la existencia de políticas adecuadas para atraer la IED es un factor clave (DUNNING, 1995, p. 66) y, por lo tanto, este enfoque se centra en las condiciones que ofrecen los países que reciben IED. Asimismo, en ensayos de antropología, sociología y economía se insiste en la importancia de otras variables sociales como, por ejemplo, el nivel de la educación, las instituciones y las infraestructuras como factores determinantes de la capacidad de un país para recibir inversiones (DUNNING, 1995, pp. 67-68).

Históricamente, la primera teoría de IED está basada en las diferencias de los tipos de interés, porque, como vamos a comentar en la próxima sección, no había una clasificación clara entre IED e inversión de cartera. Sin embargo, después de la clasificación de Hymer, hay más teorías para analizar los motivos de la IED. HYMER (1976, p. 1) intentó delimitar las diferencias entre IED e inversión de cartera o portafolio, señalando que "si los inversores controlan directamente a las empresas extranjeras, su inversión se llama inversión directa; y si no las controlan, esta inversión es la inversión de portafolio"

Otra cuestión interesante en la teoría de Hymer es que él intentó sacar alguna lección desde la inversión de cartera para explicar mejor la IED (HYMER, 1976, pp. 6-

\footnotetext{
${ }^{5}$ Esta cita ha sido traducida del inglés por la doctoranda.
} 
23). La clasificación de Hymer es una contribución importante para la economía, pero su teoría está basada en la teoría de las inversiones de cartera. Ahora, tenemos que avanzar hacia el análisis de las teorías de los factores explicativos de las inversiones.

En la Tabla I-1.1 se presentan los principales motivos de la IED según las aportaciones realizadas por la literatura hasta los años 70. En la primera parte de la década de 1950, se consideraba que la IED era una parte de las inversiones de cartera. Sin embargo, en la segunda mitad de la misma década, empezaron a considerar que debía haber alguna característica en el país de destino de inversión que produce beneficio a las empresas para que haya IED. En la década de 1960, los análisis de IED se enfocaron a los productos que las empresas fabricaban. Por ejemplo, (VERNON, 1966) explicó que si hay diferencias en la demanda de productos entre dos países que comercian, puede ocurrir la IED. En la década de 1970, los análisis de la IED se enfocaron en factores intangibles que producen diferencias de productos. Las empresas que hacen IED, tienen dos problemas: cómo controlar este factor intangible en otros países y cómo transferir este factor intangible a sus filiales en otros países. Las teorías de la internalización y el paradigma eclético son para explicar estos problemas.

Ahora, vamos a comenzar examinando la teoría de OLI (Ownership, Location and Internalization). Dunning es el primer creador de esta teoría, que analiza la IED desde tres puntos de vista: propiedad, localización e internalización. Una empresa que quiere invertir en otros países tiene que poseer estas tres ventajas. Ahora, vamos a analizar dichas ventajas. 
Tabla I-1.1. Teorías sobre la IED

\begin{tabular}{|l|l|l|}
\hline \multicolumn{1}{|c|}{ Años } & \multicolumn{1}{|c|}{ Motivos de IED } & \multicolumn{1}{c|}{ Puntos Importantes } \\
\hline-1950 & Cartera de valores (Portfolio) & Diferencia de las tasas de interés entre dos países \\
\hline & Localización & Para obtener recursos o vender productos \\
\hline 1960 & Integración & $\begin{array}{l}\text { Beneficio a través de integración horizontal o } \\
\text { vertical }\end{array}$ \\
\hline & $\begin{array}{l}\text { Control de factores para } \\
\text { producir valor agregado }\end{array}$ & $\begin{array}{l}\text { IED concebida como transferencia de paquetes } \\
\text { de recursos }\end{array}$ \\
\hline 1970 & Ciclo de vida del producto & $\begin{array}{l}\text { Relación entre el grado de perfeccionamiento del } \\
\text { producto y su comercialización }\end{array}$ \\
\hline & Transferir recursos intangibles & $\begin{array}{l}\text { Para localizar algunos recursos intangibles en } \\
\text { empresa, se necesita inversión a otros países }\end{array}$ \\
\hline & Internalización & $\begin{array}{l}\text { Internalización de transacciones dentro de la } \\
\text { cadena de la empresa }\end{array}$ \\
\hline & Ecléctico (OLI) & Propiedad + Localización + Internalización \\
\hline
\end{tabular}

Fuente. Elaboración propia a partir de DUNNING (1995), Multinational Enterprises and the Global Economy, Addison-Wesly Publishing Company: Massachusetts, pp. 66-90.

\section{I-1.2.1. La ventaja de propiedad}

La primera ventaja es la ventaja de propiedad (ownership-specific advantages). Esta ventaja se deriva de lo que tienen las empresas que hacen IED. Al compararse con otras empresas, la empresa que hace (o quiere hacer) IED tiene que poseer algunas características excelentes de partida dentro de su estructura; por ejemplo, tecnologías de vanguardia, capacidades de investigación y desarrollo, capacidad de mercadotecnia o marketing, programas adecuados de formación y de recursos humanos, etc. Estas ventajas de propiedad son el origen de la competitividad de la empresa y lo que da valor añadido a sus productos (DUNNING, 1995, p. 79-81).

Por supuesto, esta ventaja de propiedad es importante en el mercado doméstico para competir con otras empresas. Sin embargo, cuando una empresa quiere instalarse en otros países, esta ventaja es un factor clave para decidir cómo invertir en dichos países. Dunning analiza dos tipos de ventajas de propiedad (DUNNING y LUNDAN, 2008). El primer tipo es el que produce beneficio si las empresas la aprovechan tanto dentro como fuera de su cadena de producción; por ejemplo, las empresas pueden generar su beneficio a través de sus patentes y de sus técnicas de gestión y marketing. El otro tipo de ventaja de propiedad es la que puede producir ganancia si las empresas la usan sólo dentro de su cadena de producción; por ejemplo, la integración de productos y procesos, la expansión de las capacidades de gestión y de tecnología de productos, la reducción de costes de 
transacción, etc. Es decir, este tipo de ventaja es la que no se puede vender a otras empresas.

En las últimas décadas, este segundo tipo de ventaja de propiedad (esa característica especial de las empresas que no se vende) es muy importante. Por ejemplo, todo lo que tiene que ver con los gastos en investigación y desarrollo (I+D) en la industria de manufacturas serían del primer tipo. Los frutos de esta I+D se pueden vender a otras empresas en el mercado, a través de las patentes. Sin embargo, la manera en la que estos frutos se incorporan dentro de los procesos de producción no se vende, ni las otras empresas lo pueden comprar, porque las situaciones de los procesos de producción son distintas, dependiendo de las empresas (GONZALES y DEL CANTO, 1998). Cada empresa tiene situaciones de producción específicas y, por ello, ellas tienen que elegir la mejor manera de aprovechar los frutos de la I+D. Este tipo de experiencias de aprendizaje es una "propiedad" intangible, que no se vende en los mercados. Sin embargo, desde el punto de vista del desarrollo económico, esta experiencia de aprendizaje es un factor clave y por ello, este segundo tipo de ventaja de propiedad es muy importante.

Además, Dunning y Lundan distinguen tres tipos de ventajas de propiedad (véase la Tabla I-1.2). En primer lugar, hay una ventaja de propiedad que producen las instituciones de la empresa $(O i)$. El segundo tipo es una ventaja de propiedad que producen los activos de la empresa $(\mathrm{Oa})$. El tercer y último tipo es la ventaja de propiedad que producen las transacciones $(O t)$. Sus características se reflejan a continuación (DUNNING y LUNDAN, 2008, pp. 581-582):

a) La $\mathrm{Oi}$ tiene que ver con la influencia de normas y valores en los mecanismos formales e informales que organizan los procesos de producción. Por ejemplo, las formas escritas de $O i$ son reglas, normas de empresas y disciplina de mercado. También se incluye "la cultura de empresa" como Oi informal. Por ejemplo, dentro y fuera de la empresa ¿qué tipo de valores existen?, ¿qué tipo de acción tiene la más alta valoración? Se puede resumir que O $i$ es un factor para definir la valoración de las conductas de las empresas y las industriales. La empresa que posea este tipo de ventaja tendría un factor para obtener la confianza de los consumidores y sobre todo para producir legitimidad de la empresa entre sus trabajadores.

b) La $O a$ es una ventaja de propiedad "tradicional," por ejemplo, la capacidad de I+D, la forma de contratación y formación de los trabajadores, la innovación de productos 
y procesos, etc. La mayor parte de los estudios sobre las ventajas de propiedad se han centrado en la $\mathrm{Oa}$.

c) La Ot es una ventaja que está basada en la disminución de los costes de transacción. También, según LUNDAN (2010), ésta es una ventaja de gobernanza común. Esta ventaja corresponde a las economías de escala y gama de las empresas multi-fábrica. Esta $O t$ es además una parte de los motivos de Internalización que forma parte del paradigma OLI.

Ahora, tenemos que pensar: ¿cómo se relacionan estos tres tipos de ventajas de propiedad? Primero, las ventajas de $O i$ tienen influencias en $O t$ y $O a$ (LUNDAN, 2010, pp. 57-59). O sea, si las ventajas institucionales son fuertes, las ventajas de los activos y de la gobernanza común van a ser fuertes también. En la teoría de OLI, la ventaja de propiedad es el origen de la competitividad de los productos de la empresa en el mercado. Entonces, se puede decir que las ventajas de $O i$ son el origen básico de las ventajas de propiedad, esto significa que, de alguna manera, las ventajas de $O i$ son el origen de la competitividad de los productos.

Tabla I-1.2 Tipos de ventajas de propiedad

\begin{tabular}{|l|l|l|}
\hline $\begin{array}{l}\text { Tipos de ventaja de } \\
\text { propiedad }\end{array}$ & Contenidos & Resultados \\
\hline $\begin{array}{l}\text { Ventaja institucional } \\
\text { (Oi) }\end{array}$ & $\begin{array}{l}\text { Instituciones formales e informales que organizan } \\
\text { procesos para agregar valores dentro de la empresa y } \\
\text { entre empresas y partes interesadas. Por ejemplo, } \\
\text { normas, reglas y cultura de empresa; sistema de } \\
\text { incentivos y evaluación; diversidad de liderazgo y } \\
\text { gestión. }\end{array}$ & $\begin{array}{l}\text { Legitimidad y } \\
\text { confianza }\end{array}$ \\
\hline $\begin{array}{l}\text { Ventaja de derechos } \\
\text { de propiedad y/o } \\
\text { activos intangibles } \\
\text { (Oa) }\end{array}$ & $\begin{array}{l}\text { Innovación de productos, gestión de producción, } \\
\text { organización y sistema de marketing, conocimiento no- } \\
\text { codificable, acumulaciones de experiencias de } \\
\text { marketing y financiación etc. Capacidad para reducir } \\
\text { costes. }\end{array}$ & $\begin{array}{l}\text { Eficacia en } \\
\text { mercado }\end{array}$ \\
\hline $\begin{array}{l}\text { Ventaja de } \\
\text { gobernanza común } \\
\text { (Ot) }\end{array}$ & $\begin{array}{l}\text { Ventaja de economía de escala y gama en la multi- } \\
\text { producción. Ventajas especiales de la multi- } \\
\text { nacionalidad. }\end{array}$ & $\begin{array}{l}\text { Eficacia } \\
\text { organizacional }\end{array}$ \\
\hline
\end{tabular}

Fuente. LUNDAN. (2010). "What are Ownership Advantages?", Multinational Business Review, 18 (1), pp. 51-70.

https://www.researchgate.net/profile/Sarianna_Lundan/publication/228118954_What_are_Ownershi p_Advantages/links/566835dd08ae34c89a05b521.pdf, fecha de consulta: 26/0/2014. 


\section{I-1.2.2. La ventaja de localización}

Ahora, se analiza la ventaja de la localización (location-specific advantages). Esta ventaja está relacionada con la zona geográfica en la que las empresas realizan sus IED y recoge la influencia de los factores espaciales (DUNNING y LUNDUN, 2008, p. 24). Por ejemplo, una empresa que hace IED en un lugar donde vive gran cantidad de consumidores, tiene una ventaja de localización, ya que la proximidad al mercado induce la reducción de los costes de transporte de su producto. También, una empresa que hace IED en un lugar donde hay algún recurso natural importante (por ejemplo, petróleo), puede obtener una ventaja de localización gracias a la seguridad de abastecimiento de los recursos. Estos tipos de ventaja de localización provienen de condiciones geográficas naturales (DUNNING, 1995, pp. 82-83).

Sin embargo, hay otro tipo de ventaja de localización. Por ejemplo, si hay un país que tiene políticas para promover la IED desde otros países -como la exención de impuestos a empresas y la concesión de subvenciones-, hay posibilidades de aumentar la IED. Además, si el gobierno construye mejores infraestructuras (puertos, ferrocarriles, autopistas, etc.) en comparación con otros países, las empresas tienen más incentivos para invertir en dicho país. Este tipo de ventaja de localización procede de las políticas de los gobiernos del país de destino (DUNNING, 1980).

Otros tipos de ventaja de localización tienen su origen en las condiciones sociales y culturales. Por ejemplo, si hay un país en el que el precio de la mano de obra es barato, esto es un atractivo para la llegada de IED, puesto que la empresa puede reducir sus costes de producción en dicho país (DUNNING, 1995, p. 81). En otras ocasiones, al pensar en los trabajadores en el país de destino, hay algunas empresas que prefieren invertir en los países con un nivel de educación alto, aunque el coste de la mano de obra sea más caro; porque así pueden garantizar la calidad de sus productos y los trabajadores pueden tener una mayor productividad. También, un país que tiene un nivel de seguridad pública alto, es más favorable como país de destino de la IED. Además, si hay algunas afinidades culturales entre el país origen y el país destino de la IED, esto puede ser un motivo suficiente para hacer inversión, ya que los costes de adaptación de los productos serán menores. Todas las ventajas que hemos visto hasta aquí dependen de las condiciones del destino de la IED (DUNNING, 1998). 
KRUGMAN (1992) hace hincapié en la localización de las empresas, desde el punto de vista de los costes de transporte. Este autor sostiene que "la reducción de los costes de transporte tiene dos efectos. Facilita el que la producción se realice en el lugar en que los costes son menores; pero también, hace más fácil que la producción se concentre en un solo lugar, para aprovechar las economías de escala." Asimismo, considera que "la naturaleza de las externalidades proviene de los efectos del tamaño del mercado frente a los costes de transporte -de la existencia de nexos hacia adelante y hacia atrás, que incita a los productores a concentrarse en las proximidades de los grandes mercados-."

En suma, las empresas que hacen sus negocios en otros países, tienen que tener en cuenta las ventajas de propiedad y de localización. Hay varias formas de hacer negocios en el extranjero: licencia, exportación e IED. La próxima ventaja -la de internalizaciónes un elemento clave para elegir la forma más adecuada de hacer negocios internacionales.

\section{I-1.2.3. La ventaja de internalización}

En esta parte, tenemos que empezar con la explicación de lo que es la internalización. Ésta se refiere a las transacciones transfronterizas de bienes intermedios organizadas dentro de las estructuras de las empresas y no dentro del mercado normal (DUNNING, 1995, p. 75). La "internalización" es una manera de transacción de la empresa (especialmente de empresas transnacionales), cuando se encuentra algún problema en el mercado normal.

Desde el punto de vista de la teoría económica, todas las transacciones se deben hacer en el mercado. En este mercado, hay un vendedor y un comprador. Ellos tienen sus limitaciones de presupuesto e información. Después de la "negociación," el precio de los bienes se establece. Esto es el negocio dentro del mercado de competencia perfecta.

Sin embargo, algunas veces, no se puede mantener esta condición en el mercado. En el mundo real, es imposible que el vendedor y el comprador tengan información perfecta del otro, esto es, hay asimetría de información. Al menos, el vendedor conoce su producto, pero el comprador, no conoce toda la información sobre el producto. Además, en el mercado hay monopolios y oligopolios. Estos hechos son motivos para bloquear las transacciones normales en el mercado (RUGMAN, 1980). Entonces, para las empresas, 
la "internalización" es una manera de que el negocio se haga dentro de su cadena de producción, como un mercado "doméstico" dentro de la jerarquía de la empresa (RUGMAN, 1985).

La internalización tiene varias ventajas para las empresas multinacionales. La primera es la protección de informaciones importantes para las empresas. Es necesario supervisar y controlar la confidencialidad de la información relevante para la empresa. Además, como hemos visto antes, este tipo de información es el origen de la competitividad de las empresas, o sea, el origen de la ventaja de propiedad. Entonces, es normal que las empresas quieran controlar dicha información y para ello, necesitan que sus grados de internalización sean muy altos (RUGMAN y VERBEKE, 2003).

Además, algunas informaciones que son el origen de la competitividad de los productos no son visibles. Este tipo de "información tácita o confidencial” se aprende de la experiencia, a través del trabajo diario, y por ello, es imposible venderla y comprarla en el mercado normal. Sin embargo, las empresas dentro de la misma cadena de la producción pueden obtener oportunidades de transmitir esta "información confidencial". Entonces, aquí podemos encontrar otra ventaja de la internalización: la oportunidad de transmitir informaciones a través del aprendizaje (DUNNING, 2000).

La otra ventaja de la internalización es la reducción de los costes de transacción. La empresa internaliza ciertas transacciones para hacer frente a las imperfecciones de los mercados de bienes y factores. La definición de "coste" en este contexto es muy amplia, incluyendo los denominados "costes hundidos" o "costes irrecuperables" (sunk costs). ${ }^{6}$ " Estos costes son necesarios cuando alguna empresa decide hacer o no contratos con otras empresas. Como se ha indicado antes, al negociar hay asimetría de información y como consecuencia de ello, el vendedor y el comprador siempre asumen riesgos en los productos y negocios. Sin embargo, cuando se trata de dos empresas dentro de la cadena de producción, se tienen menos riesgos al negociar, porque ellos ya tienen algunas informaciones sobre los productos y las condiciones de producción, como, por ejemplo, la capacidad de entrega del producto, la calidad de los productos, etc. Esta ventaja es

\footnotetext{
${ }^{6}$ El "coste hundido" o "coste irrecuperable" (sunk cost) es un coste inicial, que no se puede recuperar. Por ejemplo, cuando una empresa estudia hacer o no IED en otro país, tiene que investigar. Entonces, tiene que gastar dinero para, por ejemplo, viajar al país de destino y examinar la situación de su mercado. Este coste es necesario para la toma de decisiones y si la empresa decide no hacer la IED, no puede recuperar dicho coste.
} 
importante para controlar la producción, ya que propicia la reducción de costes (RUGMAN y VERBEKE, 2003, pp. 130-135).

Como se ha indicado al final de la anterior sección, hay diversas maneras de desarrollar la actividad económica en otros países, por ejemplo, a través de la exportación, las licencias, las joint-venture y la IED. Estas diferentes formas de hacer actividades en otros países dependen de las diferencias de los grados de internalización. Las empresas multinacionales eligen entre estas distintas formas, en función de sus condiciones específicas. La Tabla I-1.3 muestra las relaciones entre las actividades de las empresas transnacionales en otros países y su grado de internalización (RUGMAN, 1985, p. 573).

Tabla I-1.3. Las actividades de las empresas en otros países y el grado de internalización

\begin{tabular}{|c|c|}
\hline ACTIVIDADES & Grado de Internalización \\
\hline Exportación & \\
\hline IDE (100\% control) & \\
\hline Joint-venture & \\
\hline Licencia & \\
\hline
\end{tabular}

Fuente. Elaboración propia a partir de RUGMAN. (1985). "Internalization is still a general theory of foreign direct investment”, Weltwirtschaftliches Archiv, 121(3), pp. 570-575.

La exportación tiene el grado de internalización más alto, mientras que la licencia tiene el grado más bajo. Esta diferencia del grado de internalización significa que, para las empresas matrices, la exportación es la forma más fácil de controlar los factores de sus filiales (por ejemplo, la calidad de los productos, la formación de los recursos humanos, el acceso a los proveedores y a la información sobre los productos, etc.) y la licencia es la más difícil de controlarlos.

Asimismo, las empresas matrices se enfrentan a un trade-off entre los grados de internalización y los costes de controlar sus filiales. La exportación es la mejor manera de controlar, pero al mismo tiempo, el coste del negocio es el más caro porque principalmente, la empresa tiene que hacer todo por sí misma (por ejemplo, investigar el mercado, buscar los intermediarios, etc.). Por el contrario, la licencia es el más difícil de controlar, pero los costes del negocio son los más baratos. Las empresas que quieren hacer negocios internacionales, tienen que considerar este trade-off entre la internalización y el coste de los negocios. Por supuesto, la internalización no es el único factor que decide la manera de desarrollar el negocio en el extranjero. También hay que considerar el factor 
de la localización. Por ejemplo, en las relaciones económicas entre España y los países América Latina, para las empresas españolas será más fácil encontrar los países destino de la actividad empresarial en dicha región, dado que el obstáculo del idioma es menor. La Tabla I-1.4 recoge los tres factores de ventajas tenidas en cuenta para hacer la IED, basadas en la teoría de OLI.

Tabla I-1.4. Factores de IED

\begin{tabular}{|c|c|c|}
\hline Factores & Funciones & Ejemplos \\
\hline $\begin{array}{c}\text { Propiedad } \\
\text { (Ownership) }\end{array}$ & $\begin{array}{l}\text { Capacidades para producir } \\
\text { valor que otras empresas no } \\
\text { puedan imitar. } \\
\text { Orígenes de competitividad } \\
\text { de empresas }\end{array}$ & $\begin{array}{l}\text { - Investigación y desarrollo } \\
\text { - } \text { Patentes } \\
\text { - Formación de recursos humanos } \\
\text { - } \text { Marketing } \\
\text { - Experiencias de administración }\end{array}$ \\
\hline $\begin{array}{l}\text { Locación } \\
\text { (Location) }\end{array}$ & $\begin{array}{l}\text { - Beneficios que ofrecen los } \\
\text { destinos geográficos de la } \\
\text { IED }\end{array}$ & $\begin{array}{ll}\text { - } & \text { Bajos costes (salarios, transportes, } \\
& \text { etc.) } \\
\text { - } & \text { Situación de las infraestructuras } \\
\text { - Nivel de educación / formación } \\
\text { - Simplicidad del sistema de } \\
\text { impuestos }\end{array}$ \\
\hline $\begin{array}{l}\text { Internalización } \\
\text { (Internalization) }\end{array}$ & $\begin{array}{l}\text { - Transacciones fronterizas de } \\
\text { bienes intermedios } \\
\text { organizadas dentro de la } \\
\text { cadena de producción de las } \\
\text { mismas empresas }\end{array}$ & $\begin{array}{ll}\text { - } & \text { Subcontrataciones } \\
\text { - } & \text { Keiretsu }\end{array}$ \\
\hline
\end{tabular}

Fuente. Elaboración propia.

En resumen, para hacer IED, la empresa necesita tener la ventaja de propiedad, que es el origen de la competitividad. Ésta es la primera condición para la IED. Luego tiene que pensar dónde se invierte, o sea, en qué país. La empresa tiene que considerar qué tipo de beneficio puede aprovechar la IED en ese país. Este "beneficio" es diferente, dependiendo de los sectores y de los objetivos de la IED. Por último, la empresa tiene que pensar cómo internaliza sus transacciones dentro de la cadena de producción. Esto

\footnotetext{
${ }^{7}$ Según McGUIRE y DOW (2009), el Keiretsu es una estructura de relaciones verticales y horizontales entre las empresas japonesas. Su relación vertical es la relación entre empresas de proveedores- productos finales. En esta relación, los proveedores pueden vender sus productos a largo plazo y las empresas de productos finales pueden asegurar calidades de sus productos finales, a través de dar una oportunidad de aprendizaje de nuevas tecnologías a sus proveedores. Su relación horizontal se refiere a un grupo de empresas que los bancos tienen poder de gobernar. En el marco de esta relación horizontal, las empresas pueden extender sus actividades a otras industrias, por ejemplo. Dentro de las relaciones horizontales y verticales de las empresas japonesas, hay alianzas y contratos para conocer la tecnología y el know-how nuevos. MCGUIRE, Jean y DOW, Sandra. (2009). "Japanese keiretsu: Past, present, future.”, Asia Pacific journal of management, 2009, vol. 26, no 2, pp. 333-351. Disponible en Internet. http://link.springer.com/article/10.1007/s10490-008-9104-5
} 
significa que tiene que tener en cuenta la relación con sus filiales y las posibilidades ofrecidas por la subcontratación.

\section{I-1.3. Breve historia de las teorías más importantes de IED: Hymer, Vernon y Kojima}

En esta parte, se analiza la historia de las teorías más importantes de IED. A través del análisis de la historia de estas teorías, podemos encontrar las tendencias de las actividades de las empresas multinacionales.

Cuando pensamos en la historia de la teoría de la IED, el año de 1960 es muy importante. En este año, dos grandes teorías se presentaron. La primera es la de Stephen Hymer: La Operación Internacional de las Empresas Nacionales (The Internacional operations of national Firms), que fue su tesis doctoral en la Universidad de Cambridge. La segunda es la de Vernon: El ciclo del producto (Product Cycle). La teoría de Vernon es para explicar cómo desarrollan las empresas sus productos, principalmente. Sin embargo, considera las razones para invertir en otros países, se trata, por tanto, también de una teoría de la IED. Entonces, por estas dos teorías, podemos decir que desde el año 1960, empezaron los estudios modernos sobre la IED (DUNNING, 1995, pp. 68-69).

Antes de Hymer y Vernon, había algunos estudios sobre IED. Sin embargo, en esas teorías de antes del año 1960 no hubo una clasificación clara entre la IED y la inversión en cartera y tampoco hubo una clasificación clara entre la propiedad (internalización) y la no-propiedad en los modelos de negocios internacionales, ni formas distintas de operación extranjera (filiales, subsidiarios y licencias) (BUCKLEY, 2011, p. 67). Además, se había considerado que IED era una manera arbitrada de inversión y transferencia de riesgo de capital (TEECE, 2006). No habían considerado cómo operan sus funciones las empresas en los países extranjeros. Lo que era importante era ganar dinero a través de los movimientos de los capitales desde los países de origen a los países de destino. Los países de "destino" no eran para producir ni para vender productos.

Sin embargo, en la misma época, en el mundo de la economía industrial se presentó otro punto de vista sobre la IED. Éste estaba basado en algunos estudios con la perspectiva de la estructura industrial, como tamaño de empresa, condiciones de entrada a nuevos mercados extranjeros, integración vertical y diversificación (BUCKLEY, 2011, 
p. 70). Originalmente, la economía industrial se enfocaba en analizar cómo es la situación de mercado, por ejemplo, monopolio y oligopolio. Entonces, ¿por qué se habían usado para explicar las actividades en economías de otros países? Para contestar esta pregunta, se tiene que considerar la situación de economía internacional en la época anterior a 1960.

En 1945 terminó la Segunda Guerra Mundial. En la mayor parte de los países que habían participado en esta guerra, su economía había sufrido muchos daños. No tenían capacidad ni para producir ni para vender productos. Sin embargo, Estados Unidos era una excepción. La mayor parte de su estructura de producción se había mantenido intacta. Entonces, automáticamente, Estados Unidos se convirtió en exportador de productos y capital. Esta situación fue evidente en casi todas las industrias. Así que la economía industrial era la principal manera de analizar la IED en los años 1950. Además, esta visión tiene gran influencia en la tesis de Hymer en el año 1960.

En el periodo pre-Hymer, los estudios de IED desde la perspectiva de la competitividad internacional también se habían estado desarrollando (BUCKLEY, 2011, p. 65). La idea original de la competitividad internacional se remonta al mercantilismo. Entonces, esta teoría era para explicar el comercio internacional. Sin embargo, en esta época, como hemos visto antes, consideraron que la IED era fundamentalmente un tipo de exportación de capital. En esta situación, era normal que hubiera autores que intentaran analizar la IED desde el mismo punto de vista de los flujos de mercancías. Según un ensayo de Williamson en el año 1894, se consideró que el movimiento de capital a los otros países era un motivo para evitar a los aranceles (BUCKLEY, 2011, p. 64). Esta idea viene de un pensamiento que consideró la IED desde la perspectiva de los flujos de mercancías.

Basándose en estas teorías y en la situación mundial, en los años sesenta se establecieron dos teorías importantes para las actividades de las empresas multinacionales e IED. La primera es de la teoría de Stephen Hymer, y la otra es de la teoría del ciclo del producto (product cycle) de Vernon.

\section{I-1.3.1. La teoría de Hymer}

La teoría de Hymer analiza los motivos de la IED de las empresas multinacionales. Como se ha mencionado anteriormente, la primera contribución de la tesis doctoral de 
Hymer es que distingue entre IED e inversión en cartera. En su tesis, la clave para distinguir entre estos dos tipos de inversión es el "control". HYMER (1976, p. 1) señala que "si el inversor directamente controla a la empresa extranjera, esta inversión se llama inversión directa; si no la controla, su inversión es inversión de cartera ${ }^{8}$." También, HYMER (1976, p. 20) señala que "no toda la inversión extranjera o la entrada de flujos de capital de exterior da lugar al control: la compra de bonos o de obligaciones son ejemplos de este último caso. La inversión extranjera directa se refiere a todos aquellos casos en el que el inversor extranjero exporta capital, adquiere de hecho el control y mantiene la capacidad de decisión."

Ahora, podemos entender que la relación entre inversor y "control" es una clave para distinguir los dos tipos de inversiones extranjeras. Sin embargo, tenemos que delimitar la definición de "control" de la empresa. En su tesis, Hymer considera que la mejor manera de medir el "control" es por medio de la proporción del capital que poseen las empresas. Este punto de vista es un ejemplo de que Hymer recibió la influencia de la economía industrial. Además, en la tesis de Hymer, la empresa que quiere hacer IED, debería tener una experiencia de exportación antes de la IED. HYMER (1976, p. 81) apunta a que "la operación internacional, frecuentemente se establece para remplazar exportaciones o para producir importaciones". Él insiste en la importancia de una historia previa de experiencia de exportación hacia otro país. Esta idea de Hymer es un ejemplo muy realista de la inversión en otros países. La experiencia de exportación y el conocimiento derivado de esta experiencia se convertirán en una ventaja de propiedad para las empresas que hacen IED.

Tenemos que enfocarnos también en otra cosa en el estudio de Hymer: insiste en la necesidad de controlar la IED. La regulación de la IED por parte del gobierno del país de destino es necesaria. En su opinión, las autoridades canadienses (Hymer es canadiense) deberían considerar la utilidad de las siguientes medidas (HYMER y ROMERO, 1982):

a) Utilizar el registro anti-monopolista para asegurar un comportamiento competitivo de las empresas extranjeras.

b) Cooperar con otras naciones en el registro de los oligopolios internacionales.

\footnotetext{
${ }^{8}$ Esta cita ha sido traducida del inglés por la doctoranda.
} 
c) Utilizar la política fiscal para maximizar la participación canadiense en los impuestos pagados por las empresas internacionales que tengan operaciones en el país.

d) Emplear la legislación de la propiedad industrial y otros medios para fomentar la entrada de tecnología extranjera en Canadá.

e) Utilizar las restricciones sobre la inversión directa en vez de los aranceles para estimular la industria canadiense y el desarrollo de una capacidad empresarial interior.

Estas condiciones son muy normales como una recomendación de política económica de atracción de la IED. Además, éstas reflejan la situación de la economía de Canadá en los años 1960-1970. Las grandes empresas multinacionales estadounidenses eran las que hacían IED en Canadá. Para aprovechar esa IED, Hymer pensaba que eran necesarias las condiciones señaladas anteriormente.

En general, Hymer consideraba que el objeto de IED era obtener el "control" de las empresas en otros países. También, un motivo de la IED era la existencia de imperfecciones en el mercado doméstico del país de origen. En este sentido, la economía industrial tuvo influencia en su teoría. Según el estudio de BUCKLEY (2006, p. 146) sobre los ensayos de Hymer, la condición necesaria para la IED es que la empresa multinacional posea la ventaja de la propiedad, mientras que la condición suficiente para la IED es que la empresa pueda obtener ganancias a través de la exportación de su ventaja internamente, más que por medio de licencias. Generalmente, los estudios de Hymer se concentron en la importancia de la ventaja de la propiedad para hacer IED. Sin embargo, también pusieron de manifiesto la importancia de la experiencia previa de exportación para realizar la IED.

\section{I-1.3.2. La teoría del ciclo de vida del producto de Vernon}

Por otro lado, en los años 1960, está la teoría de VERNON (1966, pp.190-200): la teoría del ciclo de vida del producto (Product Life Cycle). En su trabajo International Investment and International Trade in the Product Cycle, Vernon explica que la decisión de las empresas de realizar IED se deriva del proceso de maduración de sus productos y de la situación del mercado doméstico. Vamos a ver estas etapas y situaciones de IED. 
Normalmente, las empresas en el país avanzado empiezan a producir nuevos productos respondiendo a nuevas necesidades. Cuando empiezan a producir el nuevo producto en el país, que llamamos País A, las empresas del País A establecen sus fábricas en su país y venden sus productos dentro de su país (VERNON, 1966, p. 193). A partir de ahí, la empresa puede exportar a otros países, por ejemplo, el país B. En este momento, el país B es el país destino de exportación. A medida que pasa el tiempo, el producto se va estandarizando y crece su demanda. Esta situación es muy beneficiosa para la empresa. Pero para poder responder a esta creciente demanda, tiene que plantear una nueva manera de hacer aumentar su oferta. En ese momento en el que el producto se ha hecho más estandarizado, va a decidir hacer IED en otro país donde los costes son menores y establecer filiales en dicho país. En este caso, las empresas del país A establecen sus filiales en el país B. Desde las filiales de este país destino, la empresa puede ofertar su producto a los consumidores en su país A. Entonces, el país B, ahora, se convierte en el país destino de la IED (VERNON, 1966, pp. 203-205). ${ }^{9}$ Ahora, vamos a pensar en la situación del país destino de la IED, el país B. En esta situación, el país B es menos desarrollado que el país A. Antes, el país B era un país destino de la exportación. Esto significaba que había demanda del producto desde el principio, pero había poca oferta. $\mathrm{O}$ sea, había más demanda que oferta y por eso, tenían que importar. Ahora, gracias a la IED, el país B puede producir dentro de su país. Entonces, algún día en el futuro, la producción excederá la demanda y el país B podrá exportar el producto. Pero, ¿a dónde exportará? Podrá exportar a otro país C que es menos desarrollado que el país B. En el país C, podremos encontrar casi la misma historia que la descrita para el país $\mathrm{B}$ (VERNON, 1966, p. 197). La Ilustración I-1.1 muestra su teoría por medio de tres gráficos. Las historias de los países B y C son casi iguales. Sin embargo, desde la perspectiva de la madurez de los productos, podemos encontrar una diferencia importante: desde el país A se exportan los productos no estandarizados, esto es, los productos nuevos o innovadores; mientras que desde los países B y C se exportan los productos maduros o estandarizados (VERNON, 1966, p. 198)

\footnotetext{
${ }^{9}$ Según de la teoría de Hymer, la IDE es una sustitución de la exportación.
} 


\section{Ilustración I-1.1. La Teoría del Ciclo de Vida del Producto}

País A

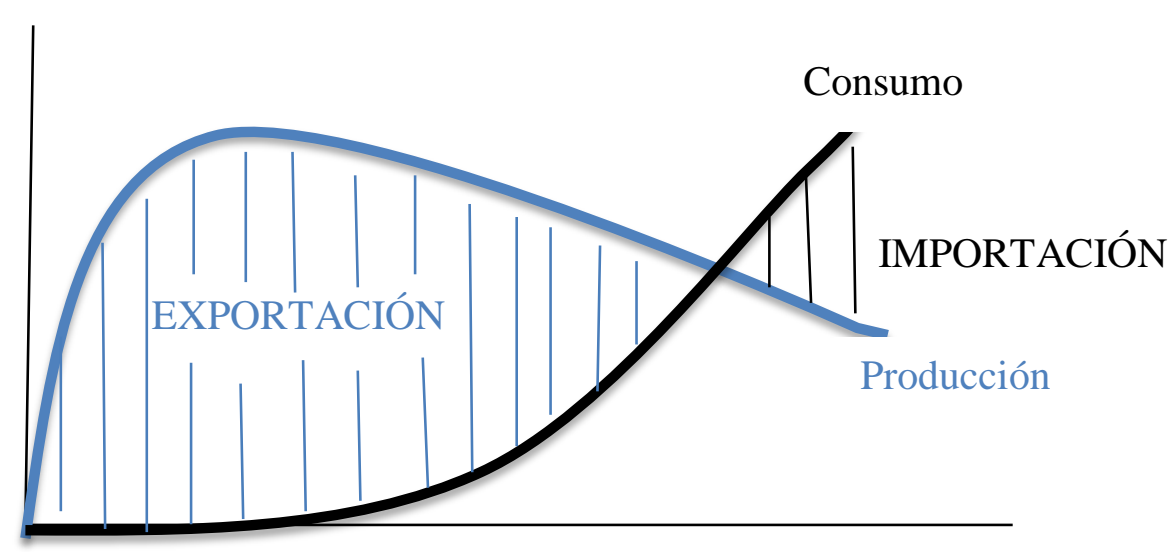

Grado de Avances

País A > País B > País C

Producción
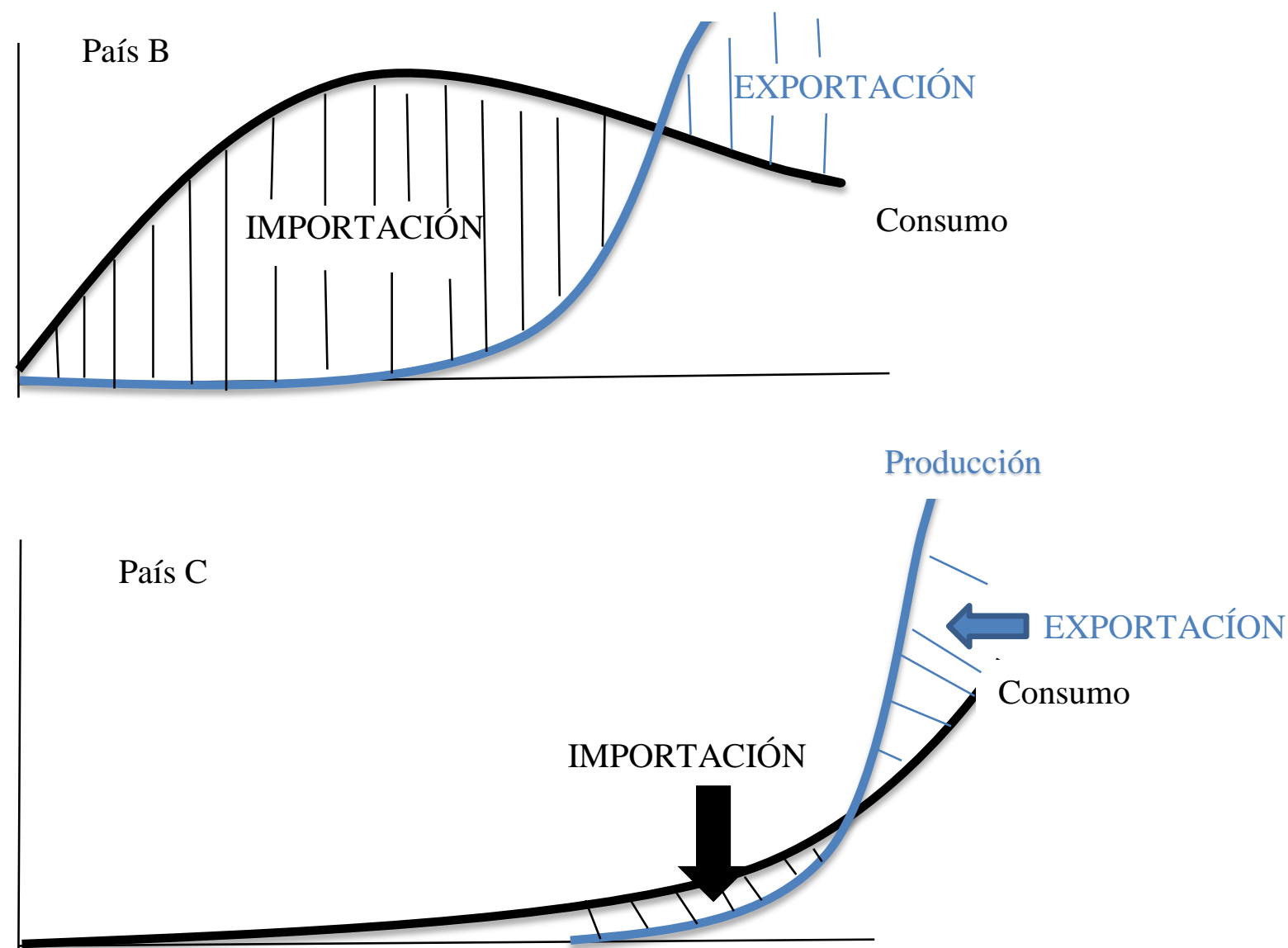

Fuente. VERNON. (1966). "International investment and international trade in the product cycle", The quarterly journal of economics, 80(2), p. 199. Disponible en http://s3.amazonaws.com/academia.edu.documents/27784550/vernon.pdf?AWSAccessKeyId=AKIA J56TQJRTWSMTNPEA\&Expires=1485023424\&Signature=TwxaKyt55M3qysXVgpp5E7k9KoU\% 3D\&response-content-

disposition=inline\%3B\%20filename\%3DInternational_investment_and_internation.pdf 
En resumen, en la teoría del ciclo de vida del producto, se explican las relaciones entre las etapas de la IED y el proceso de maduración de los productos. Esta teoría está basada en la perspectiva de la microeconomía. Una contribución de Vernon es que se puede usar su teoría para ilustrar la importancia de la innovación de los productos. Pero la mejor contribución ha sido la de explicar la relación entre los negocios internacionales y la producción en un país extranjero (DUNNING, 1995, p. 71). En la teoría de Hymer, aunque se dice que la IED es una sustitución de la exportación (HYMER, 1976, p. 80), no hay una explicación sobre cómo se relacionan los negocios internacionales y la producción en países extranjeros. Por el contrario, en la teoría de Vernon, se explica cómo cambian desde la exportación a la IED, desde el punto de vista de la innovación de los productos.

Podemos encontrar algunas ventajas de esta teoría del ciclo de vida del producto. Primero, en esta teoría se analizan las relaciones entre la IED y la madurez de los productos. O sea, es una teoría dinámica. Las empresas tienen que cambiar algunas de sus actividades para mantener sus ganancias. Entonces, la teoría del ciclo de vida del producto está más cerca de la actividad de las empresas en el mundo real. Segundo, se considera la posibilidad de innovación de productos. El punto de vista de la "innovación" es muy importante, para las empresas que producen, por ejemplo, televisores. La teoría del ciclo de vida del producto es una explicación del proceso de cómo las empresas multinacionales trasladan la tecnología más avanzada a través de la IED.

Además, la teoría de Vernon da una gran importancia a las producciones en otros países ya que son una estrategia para aumentar los beneficios de las empresas matrices en el país de origen (CARRILLO y GERBER, 2006). Como hemos visto, cuando un país de destino de exportación (como el País B) se convierte en un país de producción, la empresa tiene motivos para hacer la IED y para producir en ese país. Esta producción inducirá la posterior exportación a otros países (como el País C). Los beneficios a través de estas producciones en los países extranjeros son para la empresa matriz.

Históricamente, la definición de la IED es una movilización de recursos de las empresas, tales como las tecnologías avanzadas y las capacidades de innovación. Además, dependiendo de la industria, estos dos recursos son vitales para sus actividades. En la teoría de Vernon, se analiza este elemento como el más importante para las ctaividades de IED de las empresas. 


\section{I-1.3.3. La teoría de Kojima}

Como hemos visto, en los años 1960, hay dos teorías principales sobre la IED. Estas teorías tienen una influencia muy grande y desde los años 1970, la mayor parte de los expertos de IED tienen que trabajar para justificar las dos grandes teorías.

Además, la situación de la economía mundial cambió drásticamente desde los años 1970. Por ejemplo, después de su "milagro de desarrollo económico" en la segunda mitad de 1960, las empresas japonesas empezaron a exportar sus productos a otros países y hacer IED para construir las fábricas en otros países (TAKEDA, 1983). Es decir, Japón empezó a aparecer con fuerza en el mundo económico. Por otro lado, la mayor parte de los países “desarrollados” avanzó en sus procesos de industrialización. Basándose en estos hechos, los economistas expertos en las teorías de IED comenzaron a aparecer por todo el mundo. Además, ellos estudiaron varios países relacionados con la IED: por ejemplo, Japón, los países orientales y los países latinoamericanos.

En el mundo académico, podemos encontrar esta misma tendencia. Se puede decir que hubo una gran diversidad de expertos de distintos países en el análisis de la IED. Por, ejemplo, en el año 1971 el economista japonés, Kiyoshi Kojima clasificó dos tipos de IED: la estadounidense y la japonesa. La IED japonesa estaría "orientada al comercio" (trade-oriented)", mientras que la IED estadounidense no lo estaría (anti-trade-oriented)" (KOJIMA, 1973). En el caso de la inversión japonesa se dirigía a países con abundancia de materias primas y bajos precios de la mano de obra y era una inversión que creaba comercio, ya fueran exportaciones de materias primas hacia Japón o productos manufacturados para el mercado japonés o para mercados de terceros países. En el caso opuesto, la inversión estadounidense se dirigía a la producción de bienes manufacturados con destino a los propios mercados de los países de destino, como los mercados cerrados de América Latina.

En resumen, Kojima analiza que la forma de la IED de Japón produce exportaciones desde el país de destino y contribuye al desarrollo de la economía. Esta perspectiva es muy interesante y podemos encontrar alguna lección de IED en América Latina.

En la mitad de 1970, hubo IED de las pequeñas y medianas empresas japonesas hacia otros países, porque sus destinos eran los países asiáticos que estaban muy cerca de 
Japón (SUGITANI, 1991). En este sentido, la teoría de Kojima parece adecuada. Sin embargo, en la década de 1980, los protagonistas de la IED japonesa eran las grandes empresas japonesas, porque éstas tenían como destino principal, el mercado de Estados Unidos, que estaba más lejos de Japón. Las pequeñas y medianas empresas japonesas no tenían capacidad para hacer IED en Estados Unidos por sí mismas, pero sí para participar en los procesos de las grandes empresas. Por eso, desde ese momento, la mayor parte de los inversores eran grandes empresas japonesas. Ellas traían sus proveedores japoneses (empresas pequeñas y medianas) a los países destino de la IED. Entonces, aunque tenían actividad en los otros países, mantenían relación con sus proveedores japoneses en los otros países y las empresas locales no pudieron entrar en esta relación (SUGITANI, 1991, pp. 22-30). En esta situación, aunque la exportación desde los países de destino aumentó, es muy complicado asegurar que las empresas japonesas contribuyeran al desarrollo económico de esos países.

Antes de 1970, la mayor parte de los protagonistas de los estudios sobre IED habían sido las empresas estadounidenses. Sin embargo, desde los años 1970, los economistas, como Kojima, comenzaron a estudir la IED de otros países. Esto significa que más países se convirtieron en países de origen de la IED.

Además, desde los años 1970, la teoría de OLI de Dunning comenzó a tener una gran influencia en los estudios sobre la IED. Como hemos visto anteriormente, esta teoría se centra en tres factores de la IED: propiedad, localización e internalización. Especialmente, Dunning pone énfasis en la importancia de la ventaja de la propiedad, porque esta ventaja es uno de los principales orígenes de la competitividad de las empresas. Si no tienen esta ventaja de la propiedad, no pueden hacer IED. Además, uno de motivos de la internalización es guardar la ventaja de la propiedad. Aunque él proponga la teoría ecléctica de la IED, la parte principal de la teoría de Dunning es la importancia de la ventaja de propiedad.

Se puede decir que las teorías modernas de la IED son seguidoras de la teoría de OLI. Dependiendo del economista, hay diferencias respecto a qué factor es el más importante, pero casi todos analizan la IED desde el punto de vista de la teoría de OLI. Así que podemos decir que la contribución de Dunning ha sido muy importante.

Entonces, ¿cuáles son las ventajas de la teoría de OLI para explicar la IED? La primera ventaja es que podemos analizar la IED desde tres perspectivas: propiedad, 
localización e internalización y entender las relaciones entre los tres factores. Antes de la teoría de OLI, cada factor se había analizado independientemente. Sin embargo, a través de la teoría de OLI, podemos analizar la IED en esas tres dimensiones. La segunda ventaja es que con la teoría de OLI podemos analizar la actividad de la IED desde el punto de vista de las empresas que la hacen. Por ejemplo, la teoría de Vernon lo hacía desde el punto de vista del lugar (o sea el país).

En definitiva, las teorías analizadas de Hymer, Vernon, Kojima y OLI se han convertido en referencias básicas para los estudios de la IED. Estas teorías recogen bastante bien la esencia de las empresas que llevan a cabo la IED. 


\section{I-2. Teoría del comercio internacional y marco normativo}

En esta sección se presentan las principales teorías del comercio internacional que son relevantes para los análisis del comercio que se realizan en esta tesis doctoral, desde tres puntos de vista: comercio inter-industrial, comercio intra-industrial y marco normativo del comercio internacional.

Entendemos como comercio internacional el intercambio de bienes y/o servicios entre dos países. Hay varios tipos de comercio internacional y vamos a fijarnos en dos, en función del tipo de productos que se intercambian: comercio inter-industrial y comercio intra-industrial, donde la expresión industria se refiere a un sector de la industria, por lo que podría traducirse como comercio inter-sectorial y comercio intra-sectorial. Históricamente, el comercio inter-industrial ha sido dominante. Es el tipo de comercio que responde a los ejemplos de especialización que ofrecen Adam Smith o David Ricardo, donde un país se especializa en aquellos bienes que produce de manera más eficiente e importa aquellos otros donde es relativamente ineficiente. También es el tipo de especialización que surge del teorema de Heckscher-Ohlin. Sin embargo, en los últimos cincuenta años, se ha hecho evidente que los porcentajes de comercio intra-industrial han aumentado (BALASSA, 1966). En esta sección se analizan las teorías del comercio interindustrial e intra-industrial para comparar sus diferencias y los motivos del aumento del comercio intra-industrial.

Tras ello, en la segunda parte de la sección se examina el marco normativo del comercio internacional. Actualmente, los países tienen muchos socios comerciales y en este contexto, se necesitan instituciones internacionales que regulen las relaciones comerciales. Por esta razón, se analizan las normas del comercio internacional, prestando especial atención a las implicaciones de la entrada de China a la OMC.

\section{I-2.1. La teoría del comercio inter-industrial}

El comercio inter-industrial es el comercio de bienes de sectores distintos. Si, por ejemplo, hay dos países -País A y País B- y el País A exporta productos agrícolas al País B, mientras que el País B exporta productos manufacturados al País A, este comercio es inter-industrial. Como se ha indicado antes, éste es el tipo de comercio congruente con las teorías de Ricardo o Heckscher-Ohlin (BUITELAAR y PADILLA, 1996). 
Otro tipo de comercio internacional es el comercio intra-industrial; esto es el comercio de productos en la misma categoría de la industria. Por ejemplo, el País A exporta un producto manufacturado al País B y éste exporta el mismo producto manufacturado al País A (DUSSEL PETERS y CÁRDENAS CASTRO, 2011). En el comercio intra-industrial, hay dos tipos de comercio: el vertical y el horizontal. Por ejemplo, si el País A exporta motores de automóviles al País B, mientras que el País B exporta automóviles que usan los motores importados de País A, éste sería el caso de un comercio intra-industrial vertical. Si ambos países exportan e importan automóviles entre sí, sería el caso de un comercio intra-industrial horizontal (VALDERRAMA SANTIBÁÑEZ y NEME CASTILLO, 2011; MARTIN y RÍOS, 1996). La Ilustración I2.1 sirve para explicar la definición del comercio inter-industrial e intra-industrial. 
Ilustración I-2.1. La diferencia entre comercio inter-industrial y los dos tipos de comercio intra-industrial

\section{Comercio INTER-industrial}

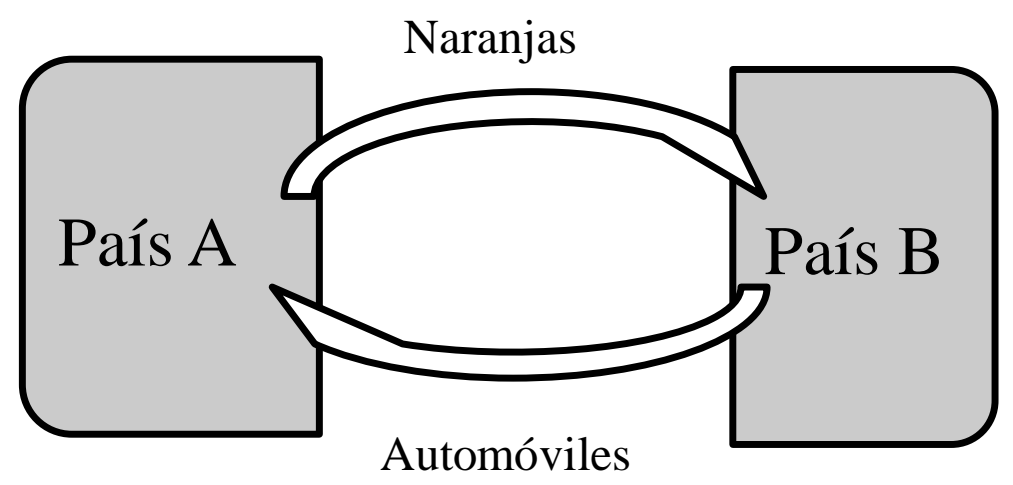

2. Comercio INTRA-industrial horizontal

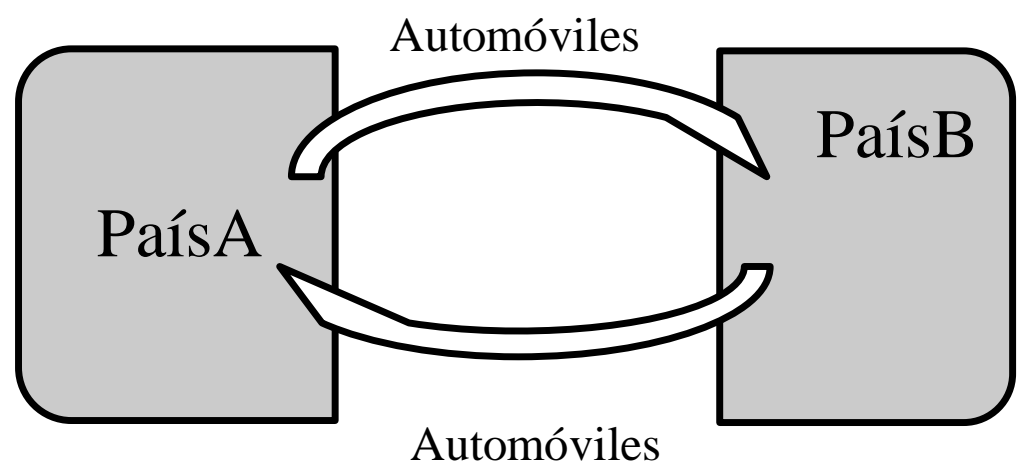

3. Comercio INTRA-industrial vertical

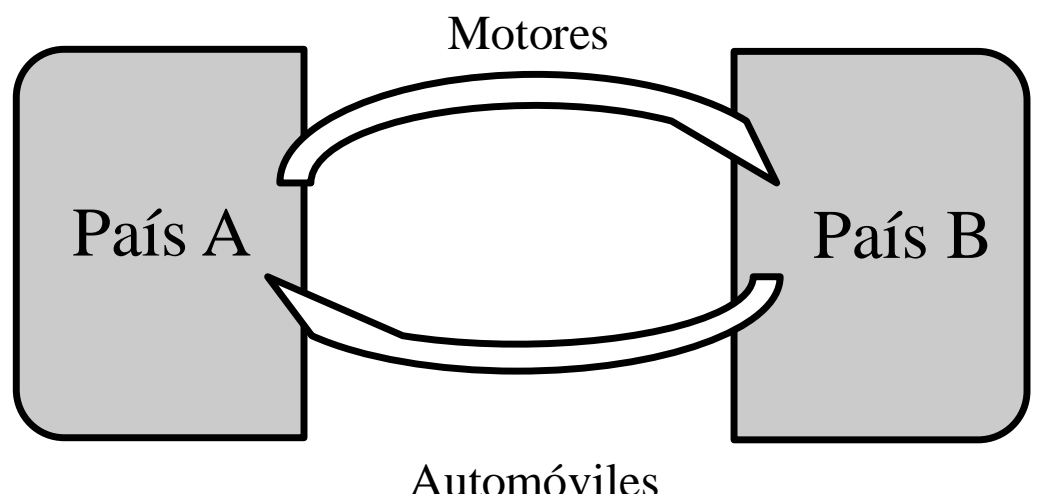

Fuente. Tomado desde MARTíN y RÍOS. (1996). "Naturaleza y causas del comercio intraindustrial”, Ekonomiaz: Revista vasca de economía, (36), pp.78-101.Disponible en https://dialnet.unirioja.es/descarga/articulo/274415.pdf 
La pregunta de por qué ocurre el comercio internacional es una pregunta clásica en el mundo de la economía internacional, desde el siglo XVIII, pues está ya presente en la obra de Adam Smith, que plantea la teoría de la ventaja absoluta (SMITH, 1776).

En la década de 1800, David Ricardo propone la teoría de la ventaja comparativa y demuestra que si cada país se especializa y exporta los bienes en los que tiene comparativamente menores costes de oportunidad, el comercio internacional genera beneficios a todos los países y a todos los individuos (POSADA y VÉLEZ, 2009). Las teorías que explican el comercio inter-industrial se basan en la teoría de Ricardo y se centran en la existencia de ventajas comparativas en cada país.

Cuando hay dos países y dos factores de producción (capital y trabajo), cada país posee ventaja comparativa en la fabricación de los bienes que utilizan de manera intensiva su factor de producción abundante. Si cada país se concentra en aprovechar sus ventajas comparativas, al fabricar sus productos y exportarlos, mientras que importa los productos que produce el otro país, los dos países puedan disfrutar de una mayor eficiencia económica. Éste es el resumen de la teoría de Heckscher-Ohlin (AGUIRRE et al., 2012; BALASSA, 1986). Además, en esta teoría, debido a la relación entre los precios de los factores y los precios de los bienes, el bien intensivo en trabajo es necesariamente más barato antes del comercio en el país donde el trabajo es relativamente abundante, es decir, en el país que tiene ventaja comparativa en el bien intensivo en trabajo (CHACHOLIADES, 1992).

Hay otro elemento clásico en la teoría del comercio inter-industrial: el teorema de Stolper-Samuelson. Este teorema está basado en la teoría de Heckscher-Ohlin y postula que la exportación del producto que utiliza en su producción de manera intensiva grandes cantidades del factor abundante y relativamente barato hace que este factor sea algo más escaso en el mercado nacional. Por tanto, el aumento de la demanda por el factor abundante resulta en un aumento en su precio y en un aumento en su remuneración. Al mismo tiempo, la remuneración del factor utilizado de forma intensiva en el producto que compite con las importaciones disminuye al tiempo que su demanda cae. El aumento en la remuneración del factor abundante de cada país viene acompañado de una caída de la remuneración del factor escaso (CARBAUGH, 2004; STOLPER y SAMUELSON, 1941). Es decir, cuando sube el precio relativo de los bienes, sube, también, el ingreso de los factores que se usan intensivamente en su producción. 
Lo que es importante en las teorías del comercio inter-industrial es que son teorías basadas en la ventaja comparativa y que este comercio genera efectos redistributivos al interior de los países, haciendo que unos agentes ganen y otros pierdan, aunque el saldo global sea positivo (POSADA y VÉLEZ, 2009, p303).

Por otro lado, las teorías del comercio inter-industrial tienen estos supuestos importantes y problemáticos (KRUGMAN, 1979):

1. Entre dos países, hay una diferencia clara de sus ventajas comparativas. En términos de la teoría de Heckscher-Ohlin, estas ventajas vienen dadas por las dotaciones de factores, así que un país tiene una abundancia relativa de capital, mientras que el otro país tiene una abundancia relativa de mano de obra. En el marco de Heckscher-Ohlin con dos países, dos productos y dos factores de producción, cada país solo tiene una ventaja comparativa en un producto.

2. Además, su ventaja comparativa es solo de un tipo en cada país: no hay variedades de su ventaja comparativa (por ejemplo, respecto a la mano de obra no se distingue entre mano de obra cualificada y no-cualificada). Generalmente, la mano de obra cualificada tiene capacidad de fabricar productos con alto valor añadido. En las teorías clásicas del comercio inter-industrial, no hay diferencias de variedades dentro de una ventaja comparativa.

3. Estos modelos proponen la especialización del país. Es decir, dentro de cada país, solo hay unas industrias que disfrutan de la ventaja comparativa y el comercio va a generar una especialización en ese tipo de industrias, mientras que otras industrias que no pueden aprovechar su ventaja comparativa, tenderían a desaparecer.

A partir de estas ideas propuestas por las teorías del comercio inter-industrial, tenemos que analizar qué significan estas teorías desde el punto de la vista de México. Las ventajas comparativas en el marco de Heckscher-Ohlin vienen dadas por la abundancia relativa de los factores de producción; por eso, en la mayoría de las teorías para explicar el comercio de inter-industrial, se considera el capital y el trabajo.

Un país como México tiene abundancia relativa de mano de obra y escasez relativa de capital respecto a Estados Unidos, y de ahí surgirían sus ventajas comparativas. Basándose en estas teorías, el mejor proyecto para el desarrollo de su economía es que, en condiciones de libre comercio, el país debía concentrarse en la fabricación de productos que utilicen de manera relativamente intensiva su mano de obra abundante y 
exportar estos productos a Estados Unidos. Según el teorema de Stolper-Samuelson, las industrias de México intensivas en capital que habían estado protegidas reducirían sus actividades, mientras que las industrias que utilizaban instensivamente su mano de obra abundante se desarrollarían más. Además, según la misma teoría, la ventaja comparativa de cada país se va a fortalecer a través del libre comercio y, por lo tanto, no va a haber oportunidades para cambiar sus ventajas comparativas.

Estas teorías son útiles para explicar parte de la exportación de México y, sobre todo, su comercio con Estados Unidos, que es un país que tiene una dotación de factores de producción muy distinta a la de México, con abundancia relativa de capital. Sin embargo, actualmente, las industrias mexicanas que exportan son muy variadas. Entre sus exportaciones hay productos manufacturados que necesitan altas concentraciones de capitales y tecnologías (como automóviles, fármacos y productos aeronáuticos). Aunque en México hay exportación de productos que necesitan una alta concentración de mano de obra, esto no significa que desaparezca la industria que necesita alta concentración de capital. Esta realidad no coincide con lo que pronostican las teorías del comercio interindustrial.

Debe señalarse, que esta situación también se puede encontrar fuera de México. El desarrollo económico de los países asiáticos que fueron llamados los cuatro dragones (Corea de Sur, Singapur, Taiwán y Hong Kong) es también un motivo, para desarrollar otro punto de vista para analizar el comercio internacional. Partiendo de esta idea de insuficiencia del planteamiento de la teoría de las ventajas comparativas para explicar el comercio, analizaremos a continuación la teoría del comercio intra-industrial.

\section{I-2.2. La teoría del comercio intra-industrial}

Como hemos visto, una característica de las teorías del comercio inter-industrial es que está basada en la existencia de ventajas comparativas y que estas ventajas comparativas se profundizan con el comercio. Sin embargo, en el siglo XX, varios economistas insistieron en que estas teorías no reflejan correctamente la situación de la economía internacional.

En la economía mundial las actividades de las empresas multinacionales son cada vez más importantes (KRUGMAN y OBSTFELD, 2006). Estas empresas buscan 
mercados y/o consumos intermedios fuera de sus países de origen. Tienen sus cadenas de producción y venta dentro de su grupo de empresas. Un factor que facilita la expansión de las empresas multinacionales es el desarrollo y abaratamiento de los transportes. Barcos y aviones aumentaron su tamaño y su capacidad de llevar más cargas con costes menores y, a menudo, con velocidades más altas. Al mismo tiempo, las tecnologías de la información y las comunicaciones han permitido que sea cada vez más fácil dividir un proceso productivo entre diferentes localizaciones, con lo que el proceso de fabricación de un producto se corresponde cada vez menos con las ventajas de un único país (KRUGMAN y OBSTFELD, 2006, pp. 168-173).

Además, el desarrollo económico de algunos países asiáticos en las décadas de 1970 y 1980 (especialmente de Corea del Sur, Taiwán, Singapur y Hong Kong, y posteriormente, China) es otro factor del desarrollo de comercio internacional (SEN, 1988). Al aumentar el número de actores relevantes en el comercio internacional, éste se complica más que antes. Las exportaciones de estos países, con un componente muy importante de manufacturas, no responden a los esquemas interpretativos propuestos por Heckscher-Ohlin.

Después de la Segunda Guerra Mundial, el comercio entre los países desarrollados se vio favorecido por la firma de los acuerdos de liberalización comercial de las sucesivas rondas de negociación del Acuerdo General sobre Aranceles y Comercio. De esta manera, el comercio entre países desarrollados era una manera dominante del comercio internacional en la segunda mitad del siglo XX (BALASSA, 1963; KRUGMAN, 1992, p. 145).

Como hemos visto anteriormente, en la teoría del comercio inter-industrial, cuando hay diferencias de ventajas comparativas, hay comercio internacional. Es decir, cuando hay diferencias en la dotación relativa de factores de producción entre dos países (por ejemplo, cuando un país tiene una dotación relativamente abundante de capital y el otro país de mano de obra), hay comercio internacional entre ellos.

Sin embargo, en el comercio entre dos países desarrollados, ambos tienen una fuerte dotación de capital, por lo que ninguno de los dos países debería tener ventaja comparativa en los bienes intensivos en capital y los dos deberían tener el mismo tipo de ventaja comparativa (KRUGMAN, 1992, p. 140). Según la teoría del comercio interindustrial, estos dos países no podrían exportar e importar los productos en la misma 
industria. En la teoría inter-industrial, no se puede explicar esta situación. Por eso, hay una necesidad de una teoría para explicar el comercio intra-sectorial. BALASSA (1966, p. 470) es el primero en dar cuenta del fenómeno del comercio intra-industrial y en proponer las primeras aproximaciones a su medición.

A partir de su trabajo surge una literatura creciente sobre el comercio intra-industrial. Un hito importante en la literatura es el trabajo de GRUBEL y LLOYD (1975). Estos autores muestran la importancia del comercio intra-industrial y utilizan el concepto de economías de escala como una fuerza dominante para explicar el comercio internacional. Es decir, si los costos medios decrecen a medida que aumenta el volumen de producción, entonces, bajo del supuesto de que se demandan distintas variedades del mismo bien, se pueden tener ganancias de eficiencia si se divide la producción de tal forma que los países se especialicen en diferentes variedades del mismo producto.

En esta aproximación de GRUBEL y LLOYD (1975, pp. 647-648), se necesitan dos elementos para la existencia de comercio intra-industrial: economías de escala y diferenciación de productos por parte de los consumidores. Si la base de la teoría del comercio inter-industrial es la teoría de las ventajas comparativas, la base de la teoría del comercio intra-industrial se centra en las economías de escala y la diferenciación de productos.

Partiendo de este planteamiento, KRUGMAN (1981) y HELPMAN (1981) empezaron a profundizar en el estudio del comercio intra-industrial. Ambos autores analizaron la especialización del comercio intra-industrial y alcanzaron las siguientes conclusiones:

a) La mayor parte del comercio internacional se hace entre países que tienen factores de producción muy similares.

b) La mayor parte del comercio entre dos países desarrollados similares es comercio intra-industrial.

c) El aumento del comercio de tipo intra-industrial no ha producido problemas serios de distribución de ingresos.

Según sus análisis, KRUGMAN (1981, p. 959) indica que hay un creciente comercio internacional entre países que tienen similares factores de producción. En la teoría del comercio inter-industrial, las ventajas comparativas son la causa del comercio 
internacional. Sin embargo, este autor hace notar que la mayor parte del comercio internacional se hace entre países que tienen ventajas comparativas muy similares. Además, dice que donde hay más similitud de las ventajas comparativas, hay más comercio intra-industrial (KRUGMAN, 1981, pp. 969-971). Es precisamente en esa situación, donde las empresas quieren fabricar un producto en un país y venderlo en varios países para aprovechar las economías de escala.

Una contribución de HELPMAN (1981, p. 307) a la teoría del comercio intraindustrial fue el poner el foco en los consumidores. En efecto, las teorías del comercio inter-industrial son, en buena medida, teorías generadas desde el punto de vista de los fabricantes, es decir, enfocadas en cómo se genera la ventaja comparativa a partir de distintos usos de los factores de producción. Sin embargo, HELPMAN (1981, pp. 308311) asume que los consumidores conocen la existencia de nuevas variedades de un bien a medida que van estando disponibles en el mercado, bajo el supuesto restrictivo de que a cada una de estas variedades se le asocia el mismo precio. Serían los bienes diferenciados horizontalmente, con el mismo precio y con las mismas características, pero con elementos que hacen que los consumidores los perciban como bienes diferenciados. Además, para el productor, se considera que existen rendimientos crecientes dentro de la cadena de producción y que ningún productor tiene poder de mercado (HELPMAN, 1981, pp. 311-316).

KRUGMAN (1992, pp. 90-96) ha analizado la relación entre las economías de escala y el coste de transporte. Ésta es una de sus contribuciones en el ámbito de la geografía económica. Él analiza que si los costes de transportes son muy altos, las economías de escala son poco importantes y el porcentaje de demanda que está vinculado forzosamente a una localización determinada es pequeño, la producción industrial puede estar distributiva de forma homogénea entre distintas regiones (KRUGMAN, 1992, p. 94). Al contrario, si los costes de transportes son bajos y existen importantes economías de escala, el resultado será la formación de un único centro de producción industrial para cada una de las variedades (KRUGMAN, 1992, p. 96).

Es decir, cuando los costes de transportes son más bajos, las economías de escala tienen más importancia, dando como resultado que los lugares de producción de cada una de las variedades están concentrados en un lugar, desde donde se exportan al resto del 
mundo, dando lugar al comercio intra-industrial. Entonces, en este caso, se puede decir que cuando hay comercio intra-industrial, hay concentración de los lugares de producción.

El surgimiento de la teoría del comercio intra-industrial ocurre debido al cambio de la situación de la economía internacional. Esto significa que, en el último medio siglo, los cambios más importantes en la economía mundial vendrían dados por el aprovechamiento de las economías de escala, el abaratamiento del coste del transporte sumado al desarrollo de las tecnologías de la información y las comunicaciones y el aprovechamiento de las economías de escala por parte de las empresas. Al mismo tiempo, la existencia de consumidores cada vez más ricos con una creciente preferencia por la diversidad permite explicar el desarrollo del comercio intra-industrial, que va a ser en su mayor parte entre países con un nivel de desarrollo alto.

\section{I-2.3. El marco normativo del comercio internacional}

En esta sección se analiza el marco normativo del comercio internacional. Actualmente, casi todos países en el mundo comercian con otros países; es decir, un país tiene relaciones comerciales con muchos países a la vez. En este contexto, se necesitarán instituciones para controlar las relaciones comerciales. Además, el aumento del número de países que participan en esas relaciones significa que hay más posibilidades de encontrar problemas en el mundo del comercio internacional. Cuando hay problemas en este ámbito, se necesitará un sistema internacional para resolverlos.

En el comercio internacional actual, el papel de este tipo de instituciones es muy importante. Por eso, analizar el marco normativo de las instituciones que regulan el comercio internacional es una ayuda para entender la situación actual del comercio internacional. Además, en un país como México, que está desarrollando su economía, su actuación en las organizaciones internacionales es un factor importante para decidir los planes de futuro de las empresas que son las que realizan las exportaciones e importaciones. Por eso, es útil analizar los marcos normativos que afectan a su comercio internacional.

A continuación, se analizan dos tipos de marcos normativos sobre comercio internacional en los que participa México: los de carácter multilateral y los de carácter plurilateral. En el nivel multilateral, analizamos el marco normativo de la Organización 
Mundial de Comercio (OMC); mientras que, en el marco plurilateral, examinamos el Tratado Libre Comercio América del Norte (TLCAN) y el Acuerdo de Asociación Económica México-Japón (AAE).

\section{I-2.3.1. Marco normativo multilateral: la Organización Mundial de Comercio (OMC)}

En comparación con otras organizaciones internacionales, la historia de la OMC es muy corta. Se estableció en 1995, como resultado de negociaciones de la Ronda Uruguay (1986-94). En agosto de 2016 había 164 países de miembros. ${ }^{10}$

El motivo del establecimiento de la OMC está ligado a las negociaciones comerciales multilaterales de la Ronda Uruguay, que se celebraron en el marco del Acuerdo General sobre Aranceles Aduaneros y Comercio (GATT). Dicha Ronda tenía 15 temas iniciales de negociación ${ }^{11}$ :

a) Productos obtenidos de la explotación de recursos naturales

b) Aranceles

c) Obstáculos no arancelarios

d) Textiles y vestido

e) Agricultura

f) Productos tropicales

g) Artículos del GATT

h) Códigos de la Ronda de Tokio

i) Antidumping

j) Subvenciones

k) Propiedad intelectual

1) Medidas en materia de inversiones

m) Solución de diferencias

n) El sistema del GATT

o) Servicios

\footnotetext{
${ }^{10}$ Según informaciones de Organización Mundial de Comercio, disponible en https://www.wto.org/spanish/thewto_s/whatis_s/who_we_are_s.htm, fecha de consulta: 12/12/ 2015. ${ }^{11}$ Según informaciones de Organización Mundial de Comercio, disponible en https://www.wto.org/spanish/thewto_s/whatis_s/who_we_are_s.htm, fecha de consulta: 12/12/ 2015.
} 
Algunos de estos temas eran nuevos: por ejemplo, los servicios, los obstáculos no arancelarios y la propiedad intelectual. Estos temas han ganado importancia en las últimas décadas, así que, se puede entender la necesidad de establecer nuevos reglamentos. Los cambios que se están produciendo en el mundo, tales como el progreso técnico (microelectrónica, bioquímica, tecnologías de la información y las comunicaciones,), el desarrollo de la industria de servicios, el aumento de la IED o la globalización de la producción son factores que hacen necesaria la existencia de la OMC (ALPERSTAIN, 2008).

Asimismo, la OMC se ha creado para asegurar que sus países miembros se comprometan, entre otras cosas, a lo siguiente (LARA, 2002):

a) Que no establezcan discriminaciones entre sus socios comerciales.

b) Que otorguen un trato igualitario a empresas y a inversionistas tanto nacionales como extranjeros.

c) Que establezcan políticas comerciales previsibles de tal manera que los inversionistas nacionales y extranjeros puedan tener una panorámica más clara de sus oportunidades para incrementar el comercio.

d) Que eliminen la competencia desleal

e) Que se especialicen en la producción de aquellos bienes que saben hacer mejor o a un costo relativo más bajo.

f) Que dispongan, en el caso de los países en desarrollo, de plazos más largos para aplicar completamente los acuerdos de la OMC con el propósito de reducir las desigualdades entre las partes.

Se nota que las cosas que la OMC quiere asegurar son: primero, la eliminación de la discriminación en el comercio internacional; segundo, el aumento de las oportunidades para los inversionistas; y tercero, el establecimiento de un plan especial de aplicación de los Acuerdos de la OMC para los países en desarrollo.

Actualmente, la OMC tiene tres temas principales de negociación: el comercio internacional de bienes, el comercio internacional de servicios y la propiedad intelectual en el comercio internacional. En estos temas existen ya principios generales regulados en la OMC a través de acuerdos firmados (véase la Ilustración I-2.2): en el comercio de bienes, el Acuerdo General sobre Aranceles Aduaneros y Comercio (GATT); en el comercio de servicios, el Acuerdo General sobre el Comercio de Servicios (AGCS); y en 
la propiedad intelectual, el Acuerdo sobre los Aspectos de los Derechos de Propiedad Intelectual relacionados con el Comercio (ADPIC).

Ilustración I-2.2. Estructura del Acuerdo de OMC

\begin{tabular}{|c|c|c|c|}
\hline & BIENES & SERVICIOS & $\begin{array}{c}\text { PROPIEDAD } \\
\text { INTELECTUAL }\end{array}$ \\
\hline $\begin{array}{l}\text { Acuerdo de } \\
\text { constitución }\end{array}$ & \multicolumn{3}{|c|}{ Acuerdo por el que se establece la OMC } \\
\hline $\begin{array}{l}\text { Acuerdos } \\
\text { generales }\end{array}$ & $\begin{array}{l}\text { Acuerdo General sobre } \\
\text { Aranceles Aduaneros y } \\
\text { Comercio (GATT) }\end{array}$ & $\begin{array}{l}\text { Acuerdo General sobre el } \\
\text { Comercio de Servicios } \\
\text { (AGCS) }\end{array}$ & $\begin{array}{l}\text { Acuerdo sobre los } \\
\text { Aspectos de los } \\
\text { Derechos de Propiedad } \\
\text { Intelectual } \\
\text { relacionados con el } \\
\text { Comercio (ADPIC) }\end{array}$ \\
\hline $\begin{array}{l}\text { Regulaciones } \\
\text { adicionales }\end{array}$ & $\begin{array}{l}\text { Otros acuerdos sobre } \\
\text { bienes y sus anexos }\end{array}$ & Anexos sobre servicios & \\
\hline $\begin{array}{l}\text { Compromisos } \\
\text { en accesos a } \\
\text { mercados }\end{array}$ & $\begin{array}{l}\text { Listas de compromisos } \\
\text { de los países }\end{array}$ & $\begin{array}{l}\text { Listas de compromisos de } \\
\text { los países (Extensiones de la } \\
\text { cláusula NMF) }\end{array}$ & \\
\hline
\end{tabular}

Fuente. Tomado desde Web de OMC, disponible en

https://www.wto.org/spanish/thewto_s/whatis_s/tif_s/agrm1_s.htm, fecha de consulta 14/2/2016

En el caso del comercio de bienes, hay 12 acuerdos concretos ${ }^{12}$ :
a) Agricultura
b) Aplicación de Medidas Sanitarias y Fitosanitarias
c) Textiles y el Vestido
d) Obstáculos Técnicos al Comercio
e) Medidas en Materia de Inversiones Relacionadas con el Comercio
f) Aplicación del Artículo VI (sobre anti-dumping)
g) Aplicación del Artículo VII (sobre aduana)
h) Inspección Previa a la Expedición
i) Normas de Origen
j) Procedimientos para el Trámite de Licencias de Importación
k) Subvenciones y Medidas Compensatorias
1) Salvaguardias

\footnotetext{
${ }^{12}$ Según Informaciones de SICE (Informaciones de Sistema de Información Sobre Comercio Exterior), disponible en http://www.sice.oas.org/Trade/ronda_ur/25.asp, fecha de consulta: 12/12/2015.
} 
Estos acuerdos sobre el comercio de bienes están basados en el GATT. Por eso, los productos que engloban los acuerdos de la OMC son productos clásicos, como, por ejemplo, los agrícolas y los textiles y de confección. Además, se nota que estas industrias son las principales industrias en los países subdesarrollados.

En el comercio de servicios, hay acuerdos en $5 \operatorname{sectores}^{13}$ :

a) Movimiento de personas físicas

b) Transporte aéreo

c) Servicios financieros

d) Transporte marítimo

e) Telecomunicaciones

Como hemos visto, el motivo de la fundación de OMC es establecer nuevas reglas para las industrias de servicios que se han desarrollado mucho en las últimas décadas. Sin embargo, al contrario de los acuerdos sobre el comercio de bienes, los países donde las industrias de servicios son activas son los países desarrollados.

Hasta el momento, se han analizado temas relacionados directamente con el comercio, especialmente, las regulaciones que afectan a las exportaciones e importaciones. Sin embargo, hay otros ámbitos relacionados indirectamente con el comercio que no se deben olvidar, como es el caso de las inversiones. Sobre éstas, la OMC tiene dos regulaciones principales: los tratados bilaterales de inversiones (TBI) y los Acuerdos de integración regional (AIR). Asimismo, la OMC incide sobre cuatro ámbitos relevantes de las inversiones (SUAVE, 2009): la protección de las inversiones, la liberalización de las inversiones, las distorsiones de la inversión y la buena gobernanza. En el caso del segundo tema (la liberalización de las inversiones) la OMC desarrolla una actividad más firme.

Una cuestión importante en el marco multilateral del comercio ha sido la entrada de China en la OMC. Las reformas económicas de China en los años ochenta y su rápida integración en el mercado mundial son factores importantes para su admisión en la OMC en 2001. Su entrada requirió 15 años de negociaciones. El motivo de esta larga negociación fue el cambio del modelo chino de desarrollo económico. Basándose en las

\footnotetext{
${ }^{13}$ Según Informaciones de SICE (Informaciones de Sistema de Información Sobre Comercio Exterior), disponible en http://www.sice.oas.org/Agreemts/WTO_s.asp fecha de consulta: 12/12/2015
} 
diferencias ideológicas, China había tenido intención de alejarse de las instituciones internacionales "capitalistas". Sin embargo, después del cambio de su política de desarrollo económico en 1980, el gobierno chino promovió un acercamiento a estas instituciones (DUSSEL PETERS, 2015b).

Para entrar en la OMC, China tenía un objetivo: mejorar su inserción internacional en el comercio para aprovechar las ganancias derivadas del proceso de globalización (GITLI y ARCE, 2001). Sin embargo, un factor también muy importante fue que en 1999 China suscribió un acuerdo bilateral con Estados Unidos para facilitar su acceso a este organismo, lo que dio un importante impulso a sus negociaciones de ingreso (GITLI y ARCE, 2001, p. 87). Antes de ratificar este acuerdo, el gobierno estadounidense ya había impulsado varios acuerdos económicos con China. Así, en 1992, ambos países firmaron un acuerdo sobre derechos de propiedad intelectual y acceso a mercados; en 1998, suscribieron varios acuerdos sobre exportación de alta tecnología, desarrollo de infraestructura, aplicaciones de internet y políticas de estándares laborales; en 1999, firmaron un acuerdo sobre agricultura y, finalmente, el 15 de noviembre de ese mismo año, promovieron otro acuerdo sobre los términos de acceso de China a la OMC (GONZÁLEZ, 2000). Desde el punto de vista de política internacional, estos acuerdos bilaterales con Estado Unidos fueron un importante apoyo para la entrada de China en la OMC.

Cuando se empezó a negociar la entrada de China, los países miembros de la OMC aprovecharon esta oportunidad para mejorar las condiciones de sus relaciones comerciales con la economía china. Por ejemplo, en el sector de los servicios, China era un destino de inversiones extranjeras muy atractivo. Sin embargo, en China este sector estaba sujeto a múltiples restricciones y obstáculos que impedían el avance de las empresas extranjeras, especialmente las de los países desarrollados. Obtener un mejor acceso a la industria de servicios era su objetivo y por eso, los países desarrollados miembros de la OMC querían la entrada de China (COLLADO, 2002).

Desde el punto de vista de la economía mexicana, ¿qué significó la entrada de China en la OMC? Ante todo, supuso que China y México tendrían que competir en el mercado internacional en las mismas condiciones (DUSSEL PETERS, 2005). Entrar en la OMC significa que los países miembros tienen que aceptar la cláusula de la Nación Más Favorecida (HERNÁNDEZ, 2006). 
Mientras China negociaba con Estados Unidos su entrada en la OMC, México acabó de implementar la entrada en vigor del TLCAN con Estados Unidos. En este contexto, México disfrutaba de reglas de origen en TLCAN y un acceso en mejores condiciones que otros países y fue capaz de aumentar sus exportaciones a Estados Unidos. Sin embargo, después de la entrada de China a la OMC, esta ventaja de acceso de México se redujo porque los aranceles a los que se enfrentaban los productos chinos también era relativamente bajos. Por eso, como se analizará en el Capítulo II, un motivo de la reducción de las importaciones en Estados Unidos desde México en la década de 2000 fue la entrada de China en la OMC.

El ingreso de China a la OMC facilitó sus exportaciones al mercado estadounidense y lanzó una importante señal a México en el sentido de que, si aparecían productos chinos en el mercado de Estados Unidos que fueran más baratos que los mexicanos, tendrían que competir con ellos. Esto significaba que las empresas localizadas en México tenían que cambiar sus estrategias para exportar a su vecino del Norte: no se podía depender únicamente de sus precios baratos, sino que se necesitaba añadir otros elementos atractivos a sus productos exportados. La entrada de China a la OMC indujo el cambio de la estrategia de las empresas exportadoras ubicadas en México, que tuvieron que adaptarse a esta creciente competencia para mantener sus cuotas de mercado en Estados Unidos.

\section{I-2.3.2. Marco normativo plurilateral: el TLCAN y el AAE}

\section{I-2.3.2.1. El Tratado Libre Comercio de América del Norte (TLCAN)}

Comparado con la OMC, el TLCAN es distinto. Primero, este Tratado no es multilateral, sus miembros son solo tres países: Estados Unidos, Canadá y México. Segundo, no es un acuerdo mundial, sino que es un acuerdo de integración que está restringido a tres países que están en el continente de América del Norte, esto es, son países vecinos. Estas condiciones inducen las características del marco normativo del TLCAN.

Los tres países firmaron el TLCAN en diciembre de 1992 y entró en vigor en enero de 1994. Es importante examinar algunos acuerdos bilaterales que fueron los antecedentes del TLCAN. 
Como antecedente de tratados para fomentar las relaciones entre México y Estados Unidos podemos citar el Programa Mexicano-Estadounidense de Prestación de Mano de Obra, conocido como "Plan Bracero" en el periodo 1942-1964 (PALACIOS, 2013). Este programa era para buscar trabajadores mexicanos que fueran a trabajar al campo de manera temporal y/o a la construcción del ferrocarril en Estados Unidos. Después de la finalización del Programa en 1964, los trabajadores mexicanos perdieron sus trabajos y se quedaron en la frontera. Posteriormente, cuando se promovió el Programa de Maquiladoras en México, uno de sus objetivos fue dar trabajo a estos mexicanos que habían usado el Plan Bracero en la frontera entre México y Estados Unidos.

Para Estados Unidos, el Programa de Maquiladoras fue una forma de importar productos intensivos en mano de obra a precios más bajos dando oportunidades a las empresas de Estados Unidos para producir con costes menores. Tener un tratado con México significaba que las importaciones eran más fáciles. En este contexto, las vinculaciones entre México y Estados Unidos se fortalecieron y al final, se logró el TLCAN.

A continuación, se analiza la normativa del TLCAN. Este Tratado tiene 22 capítulos, 297 artículos y 8 anexos (véase el Anexo I-1). Según el texto del TLCAN, sus objetivos principales "expresados en sus principios y reglas, son principalmente los de trato nacional, trato de nación más favorecida y transparencia."14

Como primera característica, se nota que el comercio e inversión en la industria de automóviles tiene una sección independiente. Esta industria es la principal exportación desde México, sin embargo, sus fabricantes son empresas extranjeras. Establecer reglamentos claros es una ayuda para desarrollar esta industria.

El TLCAN es un acuerdo entre socios asimétricos. La diferencia económica entre México y sus dos vecinos del Norte es muy grande. Por ejemplo, México tenía más barreras para las actividades económicas, especialmente en la regulación de las inversiones extranjeras y en la protección de la industria nacional. Cada miembro del TLCAN tuvo que planear la liberalización de su mercado de forma distinta, ya que las

\footnotetext{
${ }^{14}$ Según informaciones de h de SICE (Informaciones de Sistema de Información Sobre Comercio Exterior), disponible en http://www.sice.oas.org/Trade/nafta_s/CAP01.asp\#Cap.I, fecha de consulta: 12/12/2015.
} 
condiciones de partida eran diferentes. En el caso de México, se establecieron algunas excepciones y se necesitó más tiempo para la liberalización.

Dada su relevancia, merecen una especial atención los Capítulo XI (Inversión) y IV (Reglas de Origen) del TLCAN. El Capítulo XI sobre Inversión, Servicios y Asuntos Relacionados ya tenía un antecedente en el Acuerdo de Libre Comercio Canadá-Estados Unidos. Este acuerdo fue firmado en 1987, y en ese momento, este capítulo no constituyó ningún problema, debido a la similitud de los sistemas económico y jurídico de los dos países signatarios. Sin embargo, al añadir México al Acuerdo, este capítulo fue más complicado y se necesitó un cambio, así como incluir un artículo de excepciones (GUTIÉRREZ HACES, 2004).

Por ejemplo, en el artículo del TLCAN, hay una sección de industrias de telecomunicaciones y de servicios financieros. Estas dos industrias son muy importantes para invertir en otros países desde Canadá y Estados Unidos. Sin embargo, las dos industrias en México estaban protegidas. Por eso, se necesitó un artículo para aclarar cómo el gobierno mexicano iba a abrir estas industrias a los capitales extranjeros.

Sobre el Capítulo IV de las Reglas de Origen, el TLCAN es un tratado de libre comercio y por eso, la definición de los productos "fabricados en América del Norte" es muy importante. Para las empresas que tienen sus fábricas en los países miembros y quieren exportar a los otros países miembros, este artículo de reglas de origen es muy importante.

Cada producto tiene su porcentaje de "contenido regional." Si no se puede satisfacer esta condición, los gobiernos de los países miembros imponen aranceles al importar. El cálculo del contenido regional se realiza por medio de dos métodos: usando el valor de transacción del bien y usando el costo neto del bien. En el TLCAN, utilizando el primer método, los contenidos regionales tienen que superar el 60\%, mientras que con el segundo médodo los, contenidos regionales tienen que superar el 50\%. ${ }^{15}$ Cada producto tiene su regulación de contenido regional.

Método $1 . \mathrm{VCR}=[(\mathrm{VT}-\mathrm{VMN}) / \mathrm{VT}] \times 100$

\footnotetext{
${ }^{15}$ Según informaciones de h de SICE (Informaciones de Sistema de Información Sobre Comercio Exterior), disponible en http://www.sice.oas.org/Trade/nafta_s/Indice1.asp\#top, fecha de consulta: $12 / 12 / 2015$.
} 
Método 2. $\mathrm{VCR}=[(\mathrm{CN}-\mathrm{VMN}) / \mathrm{CN}] \times 100$

donde:

VCR: valor de contenido regional expresado como porcentaje

VT: valor de transacción del bien, ajustado sobre la base L.A.B (Libre A Bordo).

VMN: Valor de los materiales no originarios utilizados por el productor en la producción del bien

$\mathrm{CN}$ : costo neto del bien.

En general, los fabricantes o exportadores pueden elegir el método de cálculo que quieran usar. No obstante, para la industria de automóviles se obliga a usar el método del coste neto.

Basándose en estas condiciones, es importante examinar si los requisitos de contenidos regionales ayudan o no al desarrollo de la industria manufacturera de México. En otra parte de este capítulo, analizamos el comercio intra-industrial entre México y Estados Unidos. En esa parte, consideramos que las reglas de origen tienen un vínculo importante con el comercio intra-industrial de México.

Por otra parte, en el TLCAN, hay algunas industrias "sensibles" para las que se han establecido artículos propios: la industria de textiles, la industria de automóviles, el sector agropecuario, la industria de energía y la petroquímica básica. Se observa que éstas son las principales industrias para las exportaciones desde México, excepto en los casos de la industria de la energía y la petroquímica básica. Esto significa que en la negociación del TLCAN, el tratamiento de las industrias mexicanas era un factor clave para el éxito de las negociaciones.

Lo que se debe examinar con especial atención es la situación de México después de la entrada en vigor del TLCAN. Como se ha comentado anteriormente, en la década 2000, en el mercado de Estados Unidos, los productos chinos avanzaron y compitieron con los productos mexicanos. Después de la entrada de China en la OMC, su avance en el mercado de Estados Unidos se aceleró. Por eso, algunas industrias mexicanas perdieron cuota de mercado y vieron reducidas sus ganancias en Estados Unidos. Basada en esta experiencia, surge una pregunta: ¿hasta qué punto el TLCAN ha ayudado al comercio de México? Esta cuestión se analizará en el capítulo III. 


\section{I-2.3.2.2. El Acuerdo de Asociación Económica México-Japón (AAE)}

Un dato interesante es que, para Japón, México fue el segundo país con el que tuvo un acuerdo bilateral. ${ }^{16}$ Mientras Japón solo tenía una experiencia de negociación de este tipo de acuerdos, México ya había tenido más experiencias de negociaciones de acuerdos económicos.

Este acuerdo AAE fue firmado en septiembre de 2004 y entró en vigor en 2005. Sin embargo, antes de la firma, los gobiernos de Japón y México tuvieron que enfrentar una crisis que puso en peligro la firma del acuerdo. México pidió a Japón la eliminación de los aranceles de los productos de carne de cerdo, pollos y ternera, zumo y fruta de naranjas. Por su parte, el gobierno de Japón pidió a México la reducción de aranceles en la industria de automóviles y de hierro. En estas dos industrias, agrícolas y manufactureras, no se pudieron concretar acuerdos entre los dos países ${ }^{17}$. Al final, México decidió reducir los aranceles de algunos productos que se usan en la industria de automóviles, mientras que Japón decidió conceder un contingente arancelario ${ }^{18}$ a los cinco productos agrícolas. De esta manera se permitió la firma del acuerdo. Para el gobierno mexicano, el AAE con su contraparte japonesa reafirmaba la estrategia de apertura económica regulada por acuerdos intergubernamentales y practicada desde inicios de los años noventa, cuando la administración de Carlos Salinas de Gortari (1988-1994) emprendió las negociaciones del TLCAN y del Tratado de Libre Comercio con Costa Rica (RAMÍREZ BONILLA, 2104).

Ahora, se analiza brevemente el texto de este acuerdo. En el AAE, hay 18 capítulos, 177 artículos y 18 anexos (véase el Anexo I-2). Se nota que la lista del acuerdo AAE es muy larga: más larga que la del TLCAN. Esta larga lista indica que la negociación del AAE entre ambos países fue muy complicada. La estructura del AAE ha descansado sobre tres pilares: el del comercio, el de la inversión y el de la cooperación (FALCK REYES y DE LA VEGA SHIOTA, 2014).

En este acuerdo, hay un capítulo que no se suele encontrar en los acuerdos económicos: el de la Cooperación Bilateral (Capítulo 14). El AAE es un acuerdo de libre

\footnotetext{
${ }^{16}$ El primer país con el que Japón tuvo un acuerdo económico fue Singapur.

${ }^{17}$ Según informaciones de Japan Customs, disponible en http://www.customs.go.jp/tetsuzuki/canswer/keizairenkei/4004_jr.htm, fecha de consulta:24/3/2016.

${ }^{18}$ El contingente arancelario es una manera de controlar los aranceles y el volumen de importación.

Cuando el volumen de importación excede cierta cantidad, se reimponen los aranceles altos.
} 
comercio, pero al mismo tiempo, tiene otro aspecto, el de la cooperación entre ambos países. Es cierto que los temas que se tratan en el capítulo 14 son muy diversos: pequeñas y medianas empresas (PYMEs), promoción de comercio e inversión, ciencia y tecnología, educación y capacitación laboral, turismo, agricultura, propiedad intelectual, medio ambiente y mejora del ambiente de negocios. En el caso de México, mejorar estos aspectos, por ejemplo, sus PYMES y su educación y formación, es de una gran ayuda para el desarrollo económico. Especialmente, el artículo 139 (promoción del comercio y la inversión) es muy importante. Se dice que Japón y México intercambiarán sus expertos e informaciones de negocios internacionales y fomentarán seminarios y mesas de trabajo para empresas privadas de las Partes interesadas en establecer vínculos de negocio. ${ }^{19}$ En suma, el capítulo 14 pone de manifiesto que el gobierno de México considera que Japón es un país de inversión extranjero muy importante y tener vinculación con este país es una buena vía para lograr su desarrollo económico (OKABE, 2004).

Además, esto significa que México a través del AAE no sólo quiere conseguir un éxito económico, sino que también quiere obtener una oportunidad para el aprendizaje desde la experiencia de Japón. Por eso, en el capítulo 14, hay artículos de Cooperación en Materia de PYMES (Artículo 141) y de Cooperación en Materia de Educación Técnica y Vocacional y Capacitación (Artículo 143).

Por ejemplo, en Tijuana las empresas japonesas han ayudado a que un instituto practicara la actividad de $5 \mathrm{~S}^{20}$. Esta actividad es habitual en las fábricas japonesas para mejorar sus condiciones laborales. El gobierno mexicano esperaba que los estudiantes en el instituto aprendieran este sistema de mejora de la condición laboral y que más estudiantes trabajaran en las fábricas japonesas instaladas en México. El gobierno mexicano quiere que este tipo de experiencias ayuden a aumentar su presencia en la economía mundial.

Estas temáticas del Acuerdo significan que ambos gobiernos esperan que el AAE sea una base para fortalecer la vinculación entre México y Japón, no solo económicamente, sino también social y diplomáticamente.

\footnotetext{
${ }^{19}$ Según informaciones de h de SICE (Informaciones de Sistema de Información Sobre Comercio Exterior), disponible en http://www.sice.oas.org/Trade/MEX_JPN_s/JPN_MEX_s.asp\#Cap\%C3\%ADtulo_1, fecha de consulta: 12/12/2015.

${ }^{20}$ La actividad de 5S se explica en el Capítulo II.
} 
Respecto a las reglas de origen, vienen establecidas en el Capítulo 4 del AAE. Las formas de calcular los contenidos locales son iguales que las empleadas en el TLCAN para México. La definición de "fabricado en México" y "fabricado en Japón” es muy clara. En el AAE, principalmente hay tres tipos de la definición ${ }^{21}$ :

a) Que el bien sea obtenido en su totalidad o producido enteramente en el Área de una o ambas Partes, según la definición del artículo 38;

b) Que el bien se produzca enteramente en el Área de una o ambas Partes, a partir exclusivamente de materiales originarios;

c) Que el bien cumple con los requisitos establecidos en el anexo 4, así como con todas las demás disposiciones aplicables de este capítulo, cuando el bien se produzca enteramente en el Área de una o ambas Partes, utilizando materiales no originarios,

d) Excepto para un bien comprendido en los Capítulos 61 al 63 del Sistema Armonizado, que el bien sea producido enteramente en el Área de una o ambas Partes, pero uno o más de los materiales no originarios utilizados en la producción del bien no cumpla un cambio de clasificación arancelaria aplicable debido a que:

(i) el bien se ha importado a una Parte sin ensamblar o desensamblado, pero se ha clasificado como un bien ensamblado de conformidad con la Regla 2a de las Reglas Generales de Interpretación del Sistema Armonizado; o

(ii) la partida para el bien sea la misma tanto para el bien como para sus partes y los describa específicamente y esa partida no se divida en subpartidas, o la subpartida sea la misma tanto para el bien como para sus partes y los describa específicamente; siempre que el valor de contenido regional del bien, determinado de conformidad con el artículo 23, no sea inferior al 50 por ciento, a menos que se establezca otra cosa en el anexo 4, y el bien cumpla con las demás disposiciones aplicables de este capítulo.

\footnotetext{
${ }^{21}$ Según informaciones de h de SICE (Informaciones de Sistema de Información Sobre Comercio Exterior), disponible en http://www.sice.oas.org/Trade/MEX_JPN_s/JPN_MEX_s.asp\#Cap\%C3\%ADtulo_4, fecha de consulta: $12 / 12 / 2015$.
} 
En resumen, las definiciones de "fabricado en México" y "fabricado en Japón” son las siguientes ${ }^{22}$ :

a) Los bienes que se producen totalmente en el territorio de Japón o México

b) Los productos que usan ingredientes de Japón y México y se producen en México o Japón.

c) Los productos que usan ingredientes, pero, no son de Japón y/o México y se producen en México o Japón. Sin embargo, hay algunas condiciones en este caso:

(i). Si alcanzan más de ciertos porcentajes de valor añadido en productos finales (dependiendo de los productos, los porcentajes son distintos), se puede definir como "fabricado en México o Japón”.

(ii). Si hay cambio de número del Sistema Armonizado entre productos importados y productos exportados, se puede definir como "fabricado en México o Japón”.

(iii). Si hay algunos procesos importantes de fabricación en Japón o México, este producto se puede definir como "fabricado en México o Japón."

Vamos a analizar las condiciones (i), (ii) y (iii). La (i) es una cuestión de contenidos locales. Cada producto tiene sus porcentajes de contenidos locales. La (ii) significa que si, por ejemplo, Japón importa naranjas desde Brasil para fabricar zumo de naranja en Japón que luego exporta a México, este producto se considera "fabricado en Japón.” La (iii) es una cuestión relacionada con el proceso de fabricación. Por ejemplo, en la industria textil, la definición en el AAE de "fabricado en México o Japón" de ropas, es el de cortar y coser en territorio de Japón y México.

Usar las condiciones de los contenidos locales y el cambio de números del Sistema Armonizado es muy habitual para decidir el origen de los productos. Lo más importante en el AAE es que se usa el concepto de procesos de fabricación para decidir el origen de los productos. En la fabricación de los productos, "el proceso importante" alude a los procesos que producen el mayor valor añadido y/o los procesos destinados a diferenciarse de otros productos. En el AAE, a través de subrayar este proceso importante, se intenta desarrollar las industrias manufactureras de México y Japón. La mayor parte de las

\footnotetext{
${ }^{22}$ Según informaciones de Japan External Trade Organization, disponible en https://www.jetro.go.jp/world/qa/04E-080308.html, fecha de consulta: 12/12/2015.
} 
inversiones japonesas en México son en la industria manufacturera y esto es un motivo para enfocar los procesos de fabricación como una definición de las reglas de origen. El AAE tiene otra característica, especialmente desde el punto de la vista del gobierno de Japón (KOBAYASHI, 2007). La mayor parte de los Acuerdos de Asociación Económica japoneses tiene una explicación clara de la relación con otras instituciones, tratados y acuerdos internacionales, como la OMC. Sin embargo, no hay explicaciones claras sobre la relación entre el AAE México-Japón y otros tratados y/o instituciones internacionales. Esta característica indica que, para México, cuando hay algún problema económico con Japón en el marco del AAE, tiene que negociar directamente con Japón y no puede hacerlo a través de la OMC.

El AAE entre México y Japón está basado en la historia de las inversiones japonesas en México y en la cooperación bilateral entre ambos países. Para México, fortalecer esta relación con Japón y aprovechar su ayuda para desarrollarse económica y socialmente son los motivos para haber promovido el AAE. Para Japón, los principales objetivos del AAE son aumentar la influencia económica en México y asegurar la actividad de las empresas japonesas en dicho país. En la situación económica actual, la buena relación económica complementaria entre Japón y México es muy importante para ambos países.

El resultado de este acuerdo es muy claro: entre 2003 y 2013, el número de empresas japonesas en el país se incrementó en casi 2'5 veces, al pasar de 281 a 679 siendo las empresas automovilísticas como Nissan, Toyota y Mazda, las que principalmente han invertido y se han instalado en estados como Aguascalientes, Querétaro y Guanajuato en la región Bajío-Centro Occidente del país (GARCÍA, 2014). Al mismo tiempo, bajo el AAE se ha profundizado el déficit comercial de México con Japón. La dinámica del comercio entre ambos países ha respondido más al aumento de las importaciones realizadas por México que a sus exportaciones (DE LEÓN P, 2010). 


\section{I-3. Teoría de las políticas industriales}

\section{I-3.1. La evolución de la definición de la política industrial}

En esta sección se va a conceptualizar lo que se entiende por "política industrial". Como se mostrará, su definición ha ido evolucionando a lo largo del tiempo.

Tradicionalmente, en el mundo académico se define la política industrial como una intervención del gobierno en actividades en las que hay algún fallo de mercado. Se trata de guiar el proceso de intervención, dada la presencia de externalidades y economías de escala. Se hace necesaria la intervención del gobierno, porque al existir fallos de mercado, éste no funciona bien y no hay eficiencia en el mismo (KOSACOFF y RAMOS, 1999). Esta definición también indica que la intervención del gobierno es muy pasiva: si no hay fallo de mercado, el gobierno no necesitará intervenir en él.

Según ROSALES (1994), en América Latina durante el periodo de Industrialización por Sustitución de Importaciones (ISI) "la política industrial ha estado asociada a la idea de intervención pública directa en la estructura productiva, de conformidad con determinadas visiones de futuro. En virtud de ella, se ha intentado identificar y promover sectores y a veces empresas específicas, con mayor potencial de crecimiento." Esta definición indica que la intervención del gobierno en el mercado se justifica por un motivo de crecimiento económico. En otras palabras, una acción del gobierno para intentar hacer crecer su economía es concebida como una política industrial. En la definición de la política desarrollista, lo más importante es su motivo: el crecimiento de la economía por medio de una intervención pública en sectores o empresas. Comparada con la definición tradicional de política industrial, la moderna la concibe como una intervención más activa del gobierno.

No obstante, tras la crisis de la deuda externa de 1982 y la llegada de las políticas del Consenso de Washington a América Latina, se empezó a cuestionar la validez de los principios que habían inspirado la política industrial de los gobiernos durante el periodo de la ISI (PERES NÚÑEZ, 1993). Durante este periodo de predominio de las doctrinas monetaristas y neoclásicas se ha llegado a decir que la mejor política industrial es la que no existe y que hay que dejar que sea el mercado el que asigne los recursos con una mínima intervención estatal. 
Últimamente, se ha vuelto a poner interés en la necesidad de las políticas industriales. Así, la "Nueva Economía Institucional" sugiere que, a diferencia de la visión neoclásica, es necesario promover la eficacia de la coordinación del mercado sobre la base de precios correctos, como la principal estrategia para el desarrollo (GONZÁLEZ GARCÍA y MEZA ROLA, 2008).

Como se ha mostrado, la diferencia entre las definiciones de la política industrial se encuentra en sus objetivos: en la definición tradicional y en la del periodo del Consenso de Washington, el objetivo principal es modificar los fallos de mercado, mientras que en la definición del periodo de la ISI y de las propuestas postdesarrollistas es promover el crecimiento económico. Uno de los motivos de este cambio de la definición de la política industrial es la influencia de los cambios de las condiciones económicas mundiales y la evolución de las ideas económicas dominantes.

En los ochenta, hubo varios cambios en la economía mundial originados, entre otros, por factores como la crisis de la deuda externa en México y Brasil, la llegada de las políticas del Consenso de Washington, la recesión de Estados Unidos, el boom económico de Japón y el surgimiento económico de los “tigres asiáticos” (Corea del Sur, Hong Kong, Taiwán y Singapur) (ROS, 2001). Al analizar estos factores, se observan cambios en la forma en la que se producen las intervenciones públicas. Por ejemplo, los gobiernos de los países asiáticos (incluyendo Japón) impulsaron su desarrollo por medio de la promoción de sus exportaciones. Algo similar hicieron algunos gobiernos latinoamericanos como el de México, que comenzó a fomentar sus exportaciones, tras aceptar las recetas de política económica del Consenso de Washington, quitando el énfasis en el mercado interior (KOSACOFF y RAMOS, 1999, pp. 50-51).

Esta promoción de las exportaciones fue impulsada y dirigida por sus respectivos gobiernos, no con el objetivo de corregir los fallos de mercado, sino de hacer crecer sus economías. Se trataba de aprovechar las ventajas de la abundancia de la mano de obra que, asociada a la inversión directa extranjera, podría generar producción y exportaciones.

En los países asiáticos, donde sus gobiernos ya tenían algunas intervenciones públicas en las actividades de producción y exportación, pudieron aumentar sus exportaciones. A su vez, esta expansión de sus exportaciones hizo mejorar las condiciones económicas internas, especialmente por medio del aumento de los salarios y el empleo, lo que se tradujo en un incremento del consumo (ROS, 2001, p. 135). 
En este contexto, la definición de la política industrial ha comenzado a cambiar en los últimos años otra vez. Se considera que el gobierno tiene que presentar políticas para mejorar las condiciones económicas del país, impulsando las capacidades de las empresas y los sectores nacionales, pero no a través del control de sus actividades, sino por medio de la promoción de dichas actividades.

\section{I-3.2. La justificación de la política industrial}

Según la teoría económica clásica y neoclásica, todas las actividades económicas se hacen en el mercado. En él, todos los vendedores y compradores tienen suficiente información para hacer la transacción económica. En esta situación, el punto de coincidencia del precio que vendedores y compradores quiere, produce la máxima eficacia en la economía. Desde esta perspectiva, todas las actividades se pueden explicar cómo actividades desarrolladas en los mercados.

No obstante, a veces se pueden encontrar problemas que no se pueden solucionar con esta teoría. Además, cuando no funciona correctamente este mecanismo del mercado, hay una razón de ser para las políticas industriales, ya que éstas aparecen cuando no funciona el mecanismo del mercado (ROSALES, 1994, pp. 61-62).

En la teoría económica clásica y neoclásica, todas las transacciones se deben hacer en el mercado porque gracias a la "mano invisible", las transacciones se hacen correctamente y son eficaces. Esto significa que el gobierno no tiene necesidad de intervenir en las actividades del mercado. Sin embargo, en algunas ocasiones, este mecanismo no funciona correctamente. En este caso, el gobierno tiene que intervenir en las actividades económicas del mercado. Cuando el mercado pierde su eficiencia, el gobierno organiza la intervención en el mercado. Concretamente, hay tres situaciones en las que se justifican las intervenciones del gobierno: bienes públicos, mercados no competitivos y externalidades (KOSACOFF y RAMOS, 1999, pp. 37-38). A continuación, se examinan dichas situaciones

1) Bienes públicos (KOSACOFF y RAMOS, 1997):

En la teoría de los intercambios en el mercado, sólo los compradores que aceptan los precios que el vendedor ofrece, tienen el derecho a consumir bienes o a usar servicios. 
Sin embargo, en algunas situaciones, es muy complicado distinguir quién puede recibir los beneficios de dicho derecho y quién no puede. Por ejemplo, si hay un sistema de alumbrado en una calle, no se puede elegir que unas personas reciban alumbrado y otras no y es muy difícil obligar a alguien a pagar por usarlo. Generalmente, se denominan "bienes públicos" a aquellos bienes en los que no se pueden elegir fácilmente a las personas que tienen o no derecho a usarlos, ya que su disfrute se puede llevar a cabo por cualquiera de ellas. En este tipo de bienes es casi imposible que una persona privada pueda controlarlos y por eso, el gobierno tiene que intervenir para aplicar impuestos o precios públicos. Es decir, para mantener un servicio eficaz, el gobierno tiene que intervenir. En teoría, en el mercado se puede elegir quién ofrece los bienes y servicios y quién recibe dichos bienes y servicios. Sin embargo, en la realidad, hay casos de bienes públicos en los que las personas que no aceptan los precios de los bienes, reciben los beneficios de los mismos. La persona que hace este tipo de "trampa" se llama "free rider". Para corregir esta situación, el gobierno tiene una justificación para intervenir en el mercado.

2) Mercados no competitivos (KOSACOFF y RAMOS, 1997, pp. 3-4):

Si hay un mercado en el que existen economías de escala, este mercado tiene posibilidad de convertirse en un mercado de monopolios u oligopolios. Cuando ocurre esto, el precio va a estar controlado por un reducido número de empresas y además, va a existir asimetrías en el acceso a la información. En la teoría de la economía de mercado, los vendedores y compradores tienen suficiente información para decidir sus preferencias. Sin embargo, en el mercado de monopolios u oligopolios, los vendedores tienen más información sobre los precios de los bienes que los compradores. En estas situaciones, los consumidores no pueden recibir el mejor beneficio en la transacción en el mercado normal, porque las empresas tienden a establecer el precio más alto. Esta situación es un tipo de "fallo de mercado." Para arreglar este fallo, el gobierno interviene en el mercado para bajar los precios y mejorar los beneficios de los consumidores.

\section{3) Externalidades (KOSACOFF y RAMOS, 1997, p. 3):}

Pueden ser positivas y negativas y hacen referencia a las consecuencias no buscadas de la actividad económica que tienen impactos positivos o negativos, respectivamente, para el conjunto de la sociedad. Un ejemplo de externalidad positiva se deriva de la educación, cuando hay personas más educadas en una sociedad es más fácil 
la innovación, las instituciones funcionan mejor y hay más cohesión social. Un ejemplo de externalidad negativa es la contaminación causada por determinadas actividades económicas. Para gestionar adecuadamente estas externalidades en el mercado, ha de intervenir el gobierno.

Estos tres casos son los motivos originales que justifican la necesidad de la política industrial. Sin embargo, STIGLITZ (1993) considera que últimamente, además de los tres motivos mencionados, hay siete situaciones -especialmente en el mercado financieroque justifican la intervención del gobierno en el mercado, en concreto: los problemas de "bien público" en materia de supervisión financiera, las externalidades de supervisión financiera en la concesión de préstamos, las externalidades de las turbulencias financieras, los mercados imperfectos, la competencia imperfecta, los mercados no competitivos y las inversiones realizadas con información limitada.

\section{I-3.3. Tipos de políticas industriales para la atracción de la inversión extranjera}

Tras analizar los motivos que justifican la existencia de políticas industriales, esta sección se dedica a examinar las tres principales políticas industriales de atracción de la IED: políticas pasivas, políticas activas y políticas integradas (GLIGO, 2007).

Las políticas pasivas hacen referencia a la ausencia de medidas específicas para la atracción de IED. (GLIGO, 2007, pp. 21-22). Cuando un país tiene ventajas comparativas muy altas o unas buenas condiciones macroeconómicas, tiende a elegir este tipo de políticas. Por ejemplo, el país que tiene algún recurso natural especial (por ejemplo, el petróleo), puede elegir este tipo de políticas. También, el país que tiene una inflación baja tiene más posibilidades de atraer IED que el país que tiene una inflación muy alta. ${ }^{23}$ Sin embargo, en el mundo real, es casi imposible encontrar países que tengan políticas pasivas hacia la IED. Cada país tiene alguna política para atraer la IED y los países que tienen recursos naturales especiales no son una excepción a esta tendencia.

Las políticas activas conllevan una intervención más proactiva por parte del gobierno para establecer las condiciones necesarias de atracción de la IED, más allá de la

\footnotetext{
${ }^{23}$ Las empresas reciben los beneficios de su IED en el futuro (dentro de uno o cinco años). La existencia de alta inflación significa que sus futuros beneficios se van a devaluar y por eso, prefieren el país que tenga baja inflación.
} 
existencia de recursos naturales en el país o de un cuadro macroeconómico favorable. En este caso, el gobierno define el plan para atraer la IED: qué tipo de inversión es la más favorable para el país, de qué países ha de ser originaria la IED, etc. GLIGO (2007, pp. 23-32) señala que el país que tiene políticas activas tiende a elaborar planes para la atracción de la IED con los siguientes elementos:

1) Establecimiento de una agencia de promoción de inversiones.

2) Adopción de incentivos fiscales (por ejemplo, rebajas o eliminaciones temporales o permanentes de impuestos de distinta índole) e incentivos financieros (por ejemplo, subsidios directos para rebajar el costo de la puesta en marcha de la inversión)

3) Políticas selectivas para mejorar el clima de inversión (por ejemplo, la formación de recursos humanos en la industria en la que el gobierno quiere aumentar la IED).

Si se analizan estos tres elementos para el objeto de estudio de la investigación esto es, México-, se observa que, en cuanto al primero, hay una agencia de promoción de la IED denominada ProMéxico, que se estableció en 2007. Esta agencia es "el organismo del gobierno federal encargado de coordinar las estrategias dirigidas al fortalecimiento de la participación de México en la economía internacional, apoyando el proceso exportador de empresas establecidas en el país y coordinando acciones encaminadas a la atracción de inversión extranjera." 24 Normalmente, los países que quieren atraer IED establecen este tipo de agencias (MORTIMORE, VERGARA y KATZ, 2001). En cuanto a los otros dos elementos, se puede decir que la industria maquiladora es un ejemplo. Los programas para el desarrollo de esta industria parten de la creación de una zona franca donde la IED disfruta de importantes ventajas fiscales y financieras, de este modo se intenta captar IED y mejorar la industria manufacturera de México (MARTÍNEZ PIVA, 2015).

Por último, las políticas integradas conllevan una articulación de las políticas de atracción de la IED con las políticas de desarrollo del país (GLIGO, 2007, p. 25). Cuando ambas están integradas y coordinadas, permiten, por una parte, generar condiciones en el país que lo hagan atractivo para los inversionistas y, por otra, aprovechar al máximo los beneficios potenciales de la IED. Según GLIGO (2007, p. 26), entre los elementos más importantes para definir las políticas integradas, está el de la vinculación de las

\footnotetext{
${ }^{24}$ Según informaciones de ProMexico, disponible en http://www.promexico.mx/, fecha de consulta: $15 / 12 / 2015$.
} 
actividades de las empresas extranjeras con la economía local, de tal forma que se logre elevar la competitividad de las empresas locales.

Las políticas integradas de atracción de la IED deben vincularse con otras políticas nacionales de desarrollo, tales como políticas educativas, fiscales y de promoción de PYMEs. Esta vinculación con otras políticas es fundamental para mejorar la situación de las empresas locales (ESQUIVEL y LARRAÍN, 2001). En el caso de los países latinoamericanos, ocurre que en muchas ocasiones hay un aumento de las cifras de las variables macroeconómicas (exportaciones, importaciones, PIB etc.) tras la llegada de la IED, pero la vida de la mayoría de los ciudadanos no mejora. Se puede decir que en estos casos, la vinculación entre las políticas para atraer la IED y otras políticas es débil. Por eso, el tercer elemento (las políticas selectivas para mejorar el clima de inversión) es muy importante.

Tras presentar los tres modelos de políticas industriales para atraer la IED, el siguiente paso es identificar qué modelo se ajusta mejor al caso de las políticas industriales de México. Como se mostrará con más detalle en el capítulo IV, el gobierno federal de México ha pasado de una política activa a una política integrada, mientras que los gobiernos de cada estado siguen teniendo políticas activas.

Las políticas del gobierno nacional estaban más cerca de las políticas activas, pero ahora, se han vuelto más integradas. En los primeros momentos, el gobierno mexicano había basado su programa de atracción de la IED en la maquiladora. Sin embargo, en los últimos años, ha convertido el Programa de Maquiladora en el Programa para la Industria Manufacturera, Maquiladora y de Servicios de Exportación (IMMEX) con el objetivo de integrar el programa de atracción de IED con las economías locales (GAMBRILL, 2008).

En el caso de las políticas de los estados de México, su principal forma de atraer la IED ha sido el recurso a las políticas fiscales. Los estados han tenido potestad para conceder algunos incentivos fiscales a las empresas extranjeras instaladas en ellos, desde los años 70 (ROS, 1990). Por eso, su forma de atraer IED está más cercana a las políticas activas. Sin embargo, al mismo tiempo, cada estado ha intentado establecer programas para aumentar la competitividad de las empresas locales y así poder aprovechar mejor la IED. Por eso, este tipo de programas intentan paulatinamente configurarlas como políticas integradas. En suma, en la actualidad, los gobiernos de México, tanto el central 
como el de cada estado, están intentando de una u otra forma integrar la actividad de la IED con la de la economía local.

Como se ha analizado, hay tres tipos de políticas industriales para atraer la IED. En el caso de México, en la actualidad coexisten conjuntamente dos tipos: las activas y las integradas. Como se examinará en el Capítulo IV, las políticas para atraer IED en México han ido cambiando. Esta evolución desde las políticas activas hacia las políticas integradas significa que ha habido cambios en los países originarios de la IED, en el contexto económico mundial (especialmente, en la situación económica de los Estados Unidos) y en las condiciones de las empresas que llevan a cabo la IED en México. 


\section{I-4. Conclusiones}

Tras examinar los tres marcos teóricos de la investigación, en esta sección se analizan las principales relaciones entre dichos marcos y el objeto de estudio de la investigación, la economía mexicana.

Para las empresas extranjeras que hacen (o quieren hacer) inversiones en México, una ventaja importante del país es su proximidad geográfica a Estados Unidos. Esta ventaja no cambiará en el futuro, pero lo importante es considerar qué significa esta ventaja. Su principal industria de exportación a Estados Unidos es la industria manufacturera. Para esta industria, la ventaja de proximidad permite reducir el coste de transporte al mercado estadounidense. Esto no es una idea nueva y, además, esta condición geográfica no va cambiar en el futuro.

Sin embargo, para dar una nueva perspectiva a la teoría de la localización, se puede considerar cómo esta ventaja geográfica afecta a los factores de la internalización y de la propiedad dentro del marco teórico de OLI. Por ejemplo, como se verá en el Capítulo IV, en el caso de la industria de call-centers, la ventaja geográfica de México ofrece dos ventajas a sus actividades: la primera es la oportunidad de dar servicio al mercado estadounidense y la segunda es la alta posibilidad de encontrar recursos humanos mexicanos que conozcan la cultura y vida cotidiana de los Estados Unidos. Para las empresas de call-center, los recursos humanos adecuados son una de las mayores ventajas derivadas de la proximidad a Estados Unidos. Para las empresas, tener la capacidad de emplear a personal bilingüe que conozca la situación actual de Estados Unidos es una ventaja para desarrollar sus negocios. Se puede decir que este elemento fortalece el factor de la propiedad en la teoría de OLI. Aunque la ventaja de la proximidad a Estados Unidos es común a todas las industrias, las maneras de aprovechar esta ventaja son distintas, dependiendo de la industria.

Las teorías del comercio de inter- e intra-industrial ayudan a entender los cambios acontecidos en los flujos comerciales. En las últimas décadas, hay más países que participan en el comercio internacional, gracias al desarrollo económico alcanzado especialmente por los países emergentes como los países asiáticos y algunos latinoamericanos como México y Brasil. Esto ha facilitado que haya más participantes en el comercio internacional, como exportadores, como importadores y, sobre todo, como consumidores de los productos. Un factor del desarrollo del comercio intra-industrial es 
el comportamiento de los consumidores. Cuando ellos quieren más variedades de los productos, las empresas tienen que corresponder a sus demandas. Además, desde el punto de vista del exportador, si hay más consumidores, puede aprovechar mejor las economías de escala al fabricar sus productos. Cuando hay demanda de los nuevos productos, si la diferencia entre los productos "originales" y "nuevos" no es tan grande, los fabricantes pueden aprovechar las economías de escala para producir nuevos productos. Como hemos visto, la teoría del comercio intra-industrial está ligada al aumento de los consumidores y al aprovechamiento de las economías de escala.

En el marco normativo del comercio internacional, también, se puede encontrar el efecto del cambio en la situación del comercio internacional. Uno de los motivos principales de la fundación de la OMC fue la ampliación de las reglas de GATT a los países emergentes. Por eso, la entrada de China en la OMC fue un símbolo de la nueva gobernanza del comercio internacional. Desde el punto de vista de México, este tipo de negociación con la OMC no fue tan difícil, porque México era miembro del GATT desde 1986. En cambio, la negociación de los tratados plurilaterales de libre comercio, como el AAE con Japón y el TLCAN con Canadá y Estados Unidos, fue algo más compleja. Esta situación se puede volver a reproducir en el corto plazo para el caso del TLCAN ante la petición de la nueva administración estadounidense de renegociar el tratado de libre comercio.

Normalmente, la negociación bilateral y/o plurilateral es más fácil que la negociación multilateral, porque es más factible encontrar los beneficios comunes entre los países participantes, gracias a la limitación del número de participantes. Sin embargo, en el caso del TLCAN y el AAE, para México, no fueron tan fáciles, porque de partida había importantes diferencias estructurales entre los socios que negociaban el tratado de libre comercio. Sin embargo, hay algunas ideas nuevas que han sido incorporadas a las negociaciones de México. Por ejemplo, en el Tratado de AAE con Japón, se incluyó un artículo más integral sobre las reglas de origen, que puede ayudar a lograr otro tipo de desarrollo económico en México.

Respecto a la teoría de la política industrial en México, se observa que la definición de la política industrial ha cambiado desde la década de los noventa. La intervención del gobierno mexicano en este ámbito se ha justificado ante el bajo crecimiento económico del país. La intervención gubernamental ha tenido un papel muy 
importante para impulsar el desarrollo económico nacional. Asimismo, el gobierno ha de establecer una política que muestre a otros países cómo se trata la IED en su país. Por otro lado, en el caso de México, el término "gobierno" no significa solo el gobierno central, sino también el de los estados. Como se analiza en capítulo IV, el papel de los gobiernos locales es muy importante para las empresas extranjeras que hacen IED en México.

Las teorías desarrolladas en este capítulo son un punto de partida para analizar la situación de la IED en México. En el próximo artículo, se analiza la IED en México desde las perspectivas de su evolución histórica, las políticas implicadas y los flujos comerciales. 
Anexos Capítulo I 
Lista Anexo I-1. Capítulos de Tratado Libre Comercio de América del Norte (TLCAN)

$1^{\text {a }}$ PARTE: ASPECTOS GENERALES

Capítulo I: Objetivos

Capítulo II: Definiciones Generales

$2^{\mathrm{a}}$ PARTE: COMERCIO DE BIENES

Capítulo III: Tratado Nacional y Acceso de Bienes al Mercado

Sección A - Trato Nacional

Sección B- Aranceles

Sección C -Medidas no arancelarias

Sección D - Consultas

Sección E - Definiciones

Anexo 300 - A: Comercio e inversión en el sector automotriz

Apéndice 300-A. 1: Canadá

Apéndice 300-A. 2: México

Apéndice 300-A. 3: Estados Unidos

: Promedio Corporativo de rendimiento de combustible

Anexo 300 - B: Bienes textiles y del vestido

Capítulo IV: Reglas de Origen

Capítulo V: Procedimientos Aduaneros

Sección A - Certificación de origen

Sección B - Administración y aplicación

Sección C - Resoluciones anticipadas

Sección D - Revisión e impugnación de las resoluciones de determinación de origen y de las resoluciones anticipadas

Sección E - Reglamentaciones Uniformes

Sección F - Cooperación

Capítulo VI: Energía y Petroquímica Básica

Capítulo VII: Sector Agropecuario y Medidas Sanitarias y Fitosanitarias

Sección A - Sector agropecuario

Sección B- Medidas sanitarias y fitosanitarias

Capítulo VIII: Medidas de Emergencia

$3^{\text {a }}$ PARTE: BARRERAS TECNICAS AL COMERCIO

Capítulo IX: Medidas Relativas a Normalización 
4 PARTE: COMPRAS DEL SECTOR PÚBLICO

Capítulo X: Compras del sector público

Sección A - Ámbito de aplicación y trato nacional

Sección B - Procedimientos de licitación

Sección C- Procedimientos de impugnación

Sección D: Disposiciones generales

5 PARTE: INVERSION, SERVICIOS Y ASUNTOS RELACIONADOS

Capítulo XI: Inversión

Sección A - Inversión

Sección B- Solución de controversias entre una Parte y un inversionista de otra Parte

Sección C: Definiciones

Capítulo XII: Comercio Transfronterizo de Servicios

Capítulo XIII: Telecomunicaciones

Capítulo XIV: Servicios Financieros

Capítulo XV: Política en Materia de Competencia, Monopolios y Empresas del Estado

Capítulo XVI: Entrada Temporal de Personas de Negocios

6 ${ }^{\mathrm{a}}$ PARTE: PROPIEDAD INTELECTUAL

Capítulo XVII: Propiedad Intelectual

7 a PARTE: DISPOSICIONES ADMINISTRATIVAS INSTITUCIONALES

Capítulo XVIII: Publicación, notificación y administración de leyes

Capítulo XIX: Revisión y Solución de Controversias en Materia de Cuotas

Antidumping y Compensatorias

Capítulo XX: Disposiciones Institucionales y Procedimientos para la Solución de Controversias

Sección A - Instituciones

Sección B - Solución de controversias

Sección C - Procedimientos internos y solución de controversias comerciales privadas

$8^{\text {a }}$ PARTE: OTRAS DISPOSICIONES

Capítulo XXI: Excepciones

Capítulo XXII: Disposiciones Finales

Sección A - Nota General Interpretativa

Sección B - Reglas de Origen Específicas

Anexo 401: Reglas de Origen Específicas

Anexo I: Reservas en relación con medidas existentes y compromisos de liberalización

Fuente. Tomado desde SICE (Sistema de Información Sobre Comercio Exterior), disponible en http://www.sice.oas.org/trade/nafta_s/indice1.asp, fecha de consulta 15/3/2014. 


\section{Lista Anexo I-2. Capítulos del Acuerdo de Asociación Económica México-Japón}

(AAE)

Preámbulo

Capítulo 1: Objetivos

Artículo 1: Objetivos

Capítulo 2: Definiciones Generales

Artículo 2: Definiciones Generales

Capítulo 3: Comercio de Bienes

Sección 1: Reglas Generales

Artículo 3: Trato Nacional

Artículo 4: Clasificación de Bienes

Artículo 5: Eliminación de Aranceles Aduaneros

Artículo 6: Impuestos a la Exportación

Artículo 7: Restricciones a la Importación y Exportación

Artículo 8: Protección de las Indicaciones Geográficas para Bebidas

Espirituosas

Artículo 9: Subcomité de Comercio de Bienes

Artículo 10: Reglamentaciones Uniformes

Artículo 11: Definición

Sección 2: Medidas Sanitarias y Fitosanitarias

Artículo 12: Confirmación de Derechos y Obligaciones

Artículo 13: Puntos de Contacto

Artículo 14: Subcomité de Medidas Sanitarias y Fitosanitarias

Artículo 15: No Aplicación del Capítulo 15

Sección 3: Normas, Reglamentos Técnicos y Procedimientos de Evaluación de la Conformidad

Artículo 16: Confirmación de Derechos y Obligaciones

Artículo 17: Cooperación en Materia de Normas, Reglamentos Técnicos y

Procedimientos de Evaluación de la Conformidad

Artículo 18: Puntos de Contacto

Artículo 19: Subcomité de Normas, Reglamentos Técnicos, y

Procedimientos de Evaluación de la Conformidad

Artículo 20: No Aplicación del Capítulo 15

Artículo 21: Relación con la Sección 2

Capítulo 4: Reglas de Origen

Artículo 22: Bienes Originarios

Artículo 23: Valor de Contenido Regional

Artículo 24: Valor de los Materiales

Artículo 25: De Minimis

Artículo 26: Materiales Intermedios

Artículo 27: Acumulación

Artículo 28: Bienes y Materiales Fungibles

Artículo 29: Juegos, Conjuntos o Surtidos

Artículo 30: Materiales Indirectos

Artículo 31: Accesorios, Refacciones y Herramientas

Artículo 32: Envases y Materiales de Empaque para Venta al Menudeo

Artículo 33: Contenedores y Materiales de Embalaje para Embarque

Artículo 34: Operaciones que No Confieren Origen

Artículo 35: Transbordo

Artículo 36: Aplicación e Interpretación

Artículo 37: Subcomité, Consulta y Modificaciones

Artículo 38: Definiciones 
Capítulo 5: Certificado de Origen y Procedimientos Aduaneros

Sección 1: Certificación de Origen

Artículo 39: Certificado de Origen

Artículo 40: Obligaciones Respecto a las Importaciones

Artículo 41: Obligaciones Respecto a las Exportaciones

Artículo 42: Excepciones

Sección 2: Administración y Aplicación

Artículo 43: Registros Contables

Artículo 44: Verificaciones de Origen

Artículo 45: Confidencialidad

Artículo 46: Sanciones

Artículo 47: Revisión e Impugnación

Artículo 48: Bienes en Tránsito o Depósito

Artículo 49: Definiciones

Sección 3: Cooperación Aduanera para la Facilitación del Comercio

Artículo 50: Cooperación Aduanera para la Facilitación del Comercio

Capítulo 6: Medidas de Salvaguardia Bilaterales

Artículo 51: Disposición General

Artículo 52: Compatibilidad

Artículo 53: Condiciones

Artículo 54: Medidas de Salvaguardia Bilateral Provisionales

Artículo 55: Procedimientos de las Medidas de Salvaguardia Bilateral

Artículo 56: Definiciones

Capítulo 7: Inversión

Sección 1: Inversión

Artículo 57: Ámbito de Aplicación

Artículo 58: Trato Nacional

Artículo 59: Trato de Nación Más Favorecida

Artículo 60: Trato General

Artículo 61: Expropiación e Indemnización

Artículo 62: Protección en caso de Conflicto

Artículo 63: Transferencias

Artículo 64: Altos Ejecutivos y Consejos de Administración

Artículo 65: Requisitos de Desempeño

Artículo 66: Reservas y Excepciones

Artículo 67: Notificación

Artículo 68: Formalidades Especiales y Requisitos de Información

Artículo 69: Relación con Otros Capítulos

Artículo 70: Denegación de Beneficios

Artículo 71: Apoyo a la Inversión

Artículo 72: Medidas de Salvaguardia Temporales

Artículo 73: Derechos de Propiedad Intelectual

Artículo 74: Medidas Medioambientales 
Sección 2: Solución de Controversias entre una Parte y un Inversionista de la Otra Parte Artículo 75: Objetivo

Artículo 76: Reclamación del Inversionista

Artículo 77: Consulta y Negociación

Artículo 78: Solicitud por Escrito

Artículo 79: Sometimiento de una Reclamación a Arbitraje

Artículo 80: Consentimiento al Arbitraje

Artículo 81: Condiciones y Limitaciones al Consentimiento de cada Parte

Artículo 82: Integración del Tribunal

Artículo 83: Acumulación de Procedimientos Múltiples

Artículo 84: Derecho Aplicable

Artículo 85: Notificación

Artículo 86: Participación de una Parte

Artículo 87: Documentación

Artículo 88: Sede del Procedimiento Arbitral

Artículo 89: Interpretación de los Anexos

Artículo 90: Dictámenes de Expertos

Artículo 91: Medidas Provisionales de Protección

Artículo 92: Laudo Definitivo

Artículo 93: Definitividad y Ejecución del Laudo

Artículo 94: Disposiciones Generales

Artículo 95: Excepciones a la Solución de Controversias

Sección 3: Definiciones

Artículo 96: Definiciones

Capítulo 8: Comercio Transfronterizo de Servicios

Artículo 97: Ámbito de Aplicación

Artículo 98: Trato Nacional

Artículo 99: Trato de Nación Más Favorecida

Artículo 100: Presencia Local

Artículo 101: Reservas

Artículo 102: Notificación

Artículo 103: Subcomité de Comercio Transfronterizo de Servicios

Artículo 104: Otorgamiento de Licencias y Certificados

Artículo 105: Denegación de Beneficios

Artículo 106: Definiciones

Capítulo 9: Servicios Financieros

Artículo 107: Ámbito de Aplicación

Artículo 108: Compromisos Conforme a Acuerdos Internacionales

Artículo 109: No Aplicación del Capítulo 15

Artículo 110: Excepciones

Artículo 111: Relación con Otros Capítulos

Artículo 112: Definiciones

Capítulo 10: Entrada y Estancia Temporal de Nacionales con Propósitos de Negocios

Artículo 113: Principios Generales

Artículo 114: Ámbito de Aplicación

Artículo 115: Autorización de Entrada y Estancia Temporal

Artículo 116: Suministro de Información

Artículo 117: Subcomité de Entrada y Estancia Temporal

Artículo 118: Solución de Controversias 
Capítulo 11: Compras del Sector Público

Artículo 119: Ámbito de Aplicación

Artículo 120: Trato Nacional

Artículo 121: Reglas de Origen

Artículo 122: Procedimientos de Compras y Otras Disposiciones

Artículo 123: Condiciones Compensatorias Especiales

Artículo 124: Suministro de Información

Artículo 125: Procedimientos de Impugnación

Artículo 126: Excepciones

Artículo 127: Subcomité de Compras del Sector Público

Artículo 128: Rectificaciones o Modificaciones

Artículo 129: Privatización de Entidades

Artículo 130: Disposiciones Diversas

Capítulo 12: Competencia

Artículo 131: Actividades Anticompetitivas

Artículo 132: Cooperación para el Control de Actividades

Anticompetitivas

Artículo 133: No Discriminación

Artículo 134: Justicia Procesal

Artículo 135: No Aplicación del Artículo 164 y del Capítulo 15

Capítulo 13: Mejora del Ambiente de Negocios

Artículo 136: Consultas para la Mejora del Ambiente de Negocios

Artículo 137: Comité para la Mejora del Ambiente de Negocios

Artículo 138: No Aplicación del Capítulo 15

Capítulo 14: Cooperación Bilateral

Artículo 139: Cooperación en Materia de Promoción del Comercio y la Inversión

Artículo 140: Cooperación en Materia de Industrias de Soporte

Artículo 141: Cooperación en Materia de Pequeñas y Medianas Empresas

Artículo 142: Cooperación en Materia de Ciencia y Tecnología

Artículo 143: Cooperación en Materia de Educación Técnica y

Vocacional y Capacitación

Artículo 144: Cooperación en Materia de Propiedad Intelectual

Artículo 145: Cooperación en Materia de Agricultura

Artículo 146: Cooperación en Materia de Turismo

Artículo 147: Cooperación en Materia de Medio Ambiente

Artículo 148: No Aplicación del Capítulo 15

Artículo 149: Relación con Otros Acuerdos

Capítulo 15: Solución de Controversias

Artículo 150: Ámbito de Aplicación

Artículo 151: Selección del Procedimiento de Solución de Controversias

Artículo 152: Consultas

Artículo 153: Establecimiento del Tribunal Arbitral

Artículo 154: Laudos de los Tribunales Arbitrales

Artículo 155: Conclusión de los Procedimientos del Tribunal Arbitral

Artículo 156: Implementación del Laudo

Artículo 157: Modificación de los Plazos

Artículo 158: Costos

Artículo 159: Reglas de Procedimiento 
Capítulo 16: Implementación y Operación del Acuerdo

Artículo 160: Transparencia

Artículo 161: Procedimientos de Comentarios Públicos

Artículo 162: Procedimientos Administrativos

Artículo 163: Revisión e Impugnación

Artículo 164: Información Confidencial

Artículo 165: Comité Conjunto

Artículo 166: Comunicaciones

Capítulo 17: Excepciones

Artículo 167: Relación con Otros Acuerdos

Artículo 168: Excepciones Generales

Artículo 169: Seguridad Nacional

Artículo 170: Tributación

Artículo 171: Pagos y Transferencias y Restricciones para Proteger la

Balanza de Pagos

Capítulo 18: Disposiciones Finales

Artículo 172: Índice y Encabezados

Artículo 173: Anexos y Notas

Artículo 174: Modificaciones

Artículo 175: Entrada en Vigor

Artículo 176: Denuncia

Artículo 177: Textos Auténticos

\section{ANEXOS}

Anexo 1 referido en el Capítulo 3: Listas en relación con el Artículo 5

Sección 1: Notas generales

Sección 2-1: Notas de Japón

Sección 2-2: Listas de Japón

Sección 3-1: Notas de México

Sección 3-2: Lista de México

Anexo 2 referido en el Capítulo 3: Medidas de México en Relación con el Artículo 7

Anexo 3 referido en el Capítulo 3: Indicaciones Geográficas para Bebidas Espirituosas

Anexo 4 referido en el Capítulo 4: Reglas de Origen Específicas

Anexo 5 referido en el Artículo 5: Verificaciones de Origen

Anexo 6 referido en el Capítulo 7 y 8: Reservas en Relación con Medidas Vigentes

Anexo 7 referido en el Capítulo 7 y 8: Reservas en Relación con Medidas Futuras

Anexo 8 referido en el Capítulo 7: Actividades Reservadas al Estado

Anexo 9 referido en el Capítulo 7: Excepciones al Trato de la Nación Más Favorecida

Anexo 10 referido en el Capítulo 10: Categorías de Entrada y Estancia Temporal de

Nacionales con Propósitos de Negocios

Anexo 11 referido en el Capítulo 11: Entidades

Anexo 12 referido en el Capítulo 11: Bienes

Anexo 13 referido en el Capítulo 11: Servicios

Anexo 14 referido en el Capítulo 11: Servicios de Construcción

Anexo 15 referido en el Capítulo 11: Umbrales

Anexo 16 referido en el Capítulo 11: Notas Generales de México

Anexo 17 referido en el Capítulo 11: Publicaciones

Anexo 18 referido en el Capítulo 11: Procedimientos de Compra

Fuente. Tomado desde SICE (Sistema de Información Sobre Comercio Exterior), disponible en http://www.sice.oas.org/trade/nafta_s/indice1.asp, fecha de consulta 15/3/2014. 


\section{Capítulo II}

Las inversiones japonesas en México: su historia 


\section{II-0. Introducción}

En este capítulo, analizaremos la evolución histórica de las inversiones japonesas en México, a lo largo de más de medio siglo. Sus actividades empezaron en la década de 1960 y aumentaron especialmente a partir de los años 1980. En el fondo de este aumento hubo varios factores: la crisis del petróleo, los conflictos económicos entre Japón y Estados Unidos, los cambios en las políticas industriales de México y en las condiciones económicas de Japón, etc.

Esta revisión histórica comienza con las inversiones japonesas en Estados Unidos, como antecedente de sus inversiones en México. Las actividades de las empresas japonesas en Estados Unidos estuvieron muy relacionadas con las inversiones en México. Por eso, necesitamos analizar las inversiones en Estados Unidos para poder entender bien las inversiones en México.

El análisis de las inversiones japonesas en México empieza en la década de 1960 y se continúa con un análisis de dichas inversiones en cada una de las décadas posteriores. Desde una perspectiva de largo plazo, analizaremos década a década los factores que más han influido en las inversiones japonesas en México y sus efectos. A través de este análisis histórico se identificarán los principales factores explicativos de estas inversiones. 


\section{II-1. Antecedentes de las inversiones japonesas en México: inversiones en Estados Unidos}

Antes de analizar la historia de las inversiones japonesas en México, tenemos que analizar las inversiones japonesas en Estados Unidos, como antecedente de sus inversiones en México. Fueron sus inversiones en Estados Unidos las que dieron lugar, en buena medida, a las inversiones japonesas en México.

Las empresas japonesas empezaron a exportar a Estados Unidos desde los años 50. Después de terminar la Segunda Guerra Mundial, para la mayor parte de empresas japonesas, Estados Unidos era casi el único mercado para vender sus productos. Los países europeos estaban recuperándose de los daños de la Segunda Guerra Mundial. Los países asiáticos, incluyendo Japón, estaban muy empobrecidos también por la guerra. En este contexto, era muy natural que Estados Unidos fuera el principal mercado. Además, en 1951 se permitió que las empresas japonesas pudieran establecer sus filiales en Estados Unidos (IIDA, 1981). Estas empresas japonesas se dirigieron a Estados Unidos para vender sus productos.

Especialmente, las empresas manufactureras japonesas tenían esperanzas de poder vender sus productos en Estados Unidos, ya que en 1955 la demanda de automóviles en Estados Unidos había aumentado. Las empresas japonesas aprovecharon esta oportunidad y exportaron sus productos (MIYAKAWA, 1984). Cuando se observa la penetración en distintas sociedades de los productos de consumo duradero se aprecia que Estados Unidos era una sociedad más rica, con una demanda más fuerte de estos productos. Los datos ilustran la riqueza de la economía estadounidense, lo que es un motivo para que las empresas japonesas buscaran exportar sus productos a Estados Unidos (véase la Tabla II1.1). Efectivamente, los números de Estados Unidos son bastante altos, aproximadamente el $30 \%$ de su población ya había obtenido estos "productos de lujo" en la mitad de la década de 1950. Esta situación da motivos suficientes para exportar sus productos a Estados Unidos. 
Tabla II-1.1. Número de productos electrodomésticos y coches por cada 1000 habitantes, 1955-1957

\begin{tabular}{|c|c|c|c|c|}
\hline & COCHES & TELEVISORES & FRIGORIFICO & LAVADORA \\
\hline Estados Unidos & 315 & 274 & 265 & 235 \\
\hline Canada & 187 & 165 & 178 & 173 \\
\hline Francia & 70 & 16 & 49 & 56 \\
\hline Alemania Oeste & 36 & 23 & 39 & 45 \\
\hline Italia & 18 & 14 & 20 & 6 \\
\hline Suiza & 54 & 6 & 98 & 39 \\
\hline Suecia & 88 & 12 & 187 & 119 \\
\hline Japón & 2 & 7 & 27 & 4 \\
\hline
\end{tabular}

Fuente. Tomado de Cabinet Office, Gobierno de Japón, disponible en http://www5.cao.go.jp/keizai3/sekaikeizaiwp/wp-we60/wp-we60bun-24h.html, fecha de consulta: $24 / 2 / 2105$.

En la segunda mitad de los años 1960, mientras que siguieron exportando sus productos desde Japón a Estados Unidos, las empresas manufactureras japonesas empezaron a buscar el establecimiento de filiales y fábricas para producir y vender los productos en Estados Unidos (ISHII, 2013). Sin embargo, la mayor parte de sus ganancias en Estados Unidos era a través de exportaciones. Hubo algunos motivos por los que las empresas japonesas manufactureras, como las de automóviles y las de electrodomésticos, empezaron a invertir -además de exportar- en Estados Unidos en esta década.

El primero motivo tenía que ver con el mercado de destino de estas inversiones, con la L (localización) del paradigma OLI (Ownership, Location and Internalization). Es la época del boom económico en Estados Unidos en los años 1960. Como se ha comentado antes, el mercado estadounidense había sido casi el único que había sobrevivido a la Segunda Guerra Mundial. Además, en los años 1960, hubo un boom económico muy fuerte. En la primera mitad de los años 1960, el gobierno de Estados Unidos hizo políticas para aumentar la demanda y el consumo. Para aumentar la demanda de los consumidores estadounidenses, el gobierno de J.F. Kennedy decidió establecer un sistema de impuestos favorables para las inversiones, por ejemplo, reducir los impuestos a los salarios e impulsar un bajo tipo de interés para los préstamos. ${ }^{1}$ Además, en esta época, podemos encontrar un cambio demográfico en Estados Unidos con un aumento

\footnotetext{
${ }^{1}$ Según información de Cabinet Office, Government of Japan, disponible en http://www5.cao.go.jp/keizai3/sekaikeizaiwp/wp-we66-1/wp-we66-00202.html, , fecha de consulta: 21/10/2014.
} 
del número de personas que formaban las generaciones jóvenes (véase el Gráfico II-1. 1). La natalidad venía cayendo en Estados Unidos desde principios del siglo XX, pero a partir de la Segunda Guerra Mundial se produce un aumento de la natalidad que da lugar al periodo del llamado "baby boom" (1946-1964). Esto supone que la población entre 1830 años que antes había bajado, desde los años 1960, empieza a aumentar. A estas generaciones de jóvenes consumidores estadounidenses les gustaba comprar nuevos productos en esa época.

Gráfico II-1. 1. Tasa de natalidad en Estados Unidos, 1940-2008 (número de nacimientos por cada 1.000 habitantes)

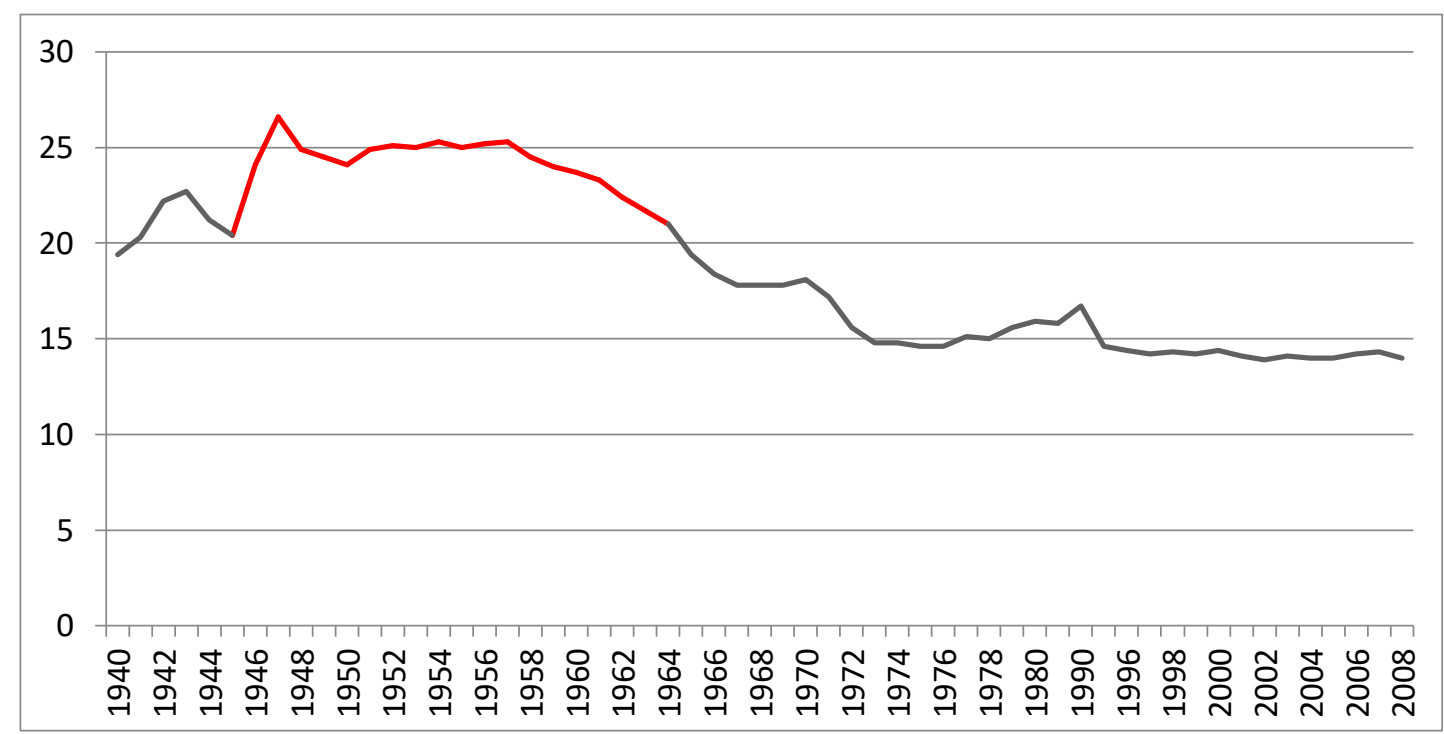

Fuente. Elaboración propia a partir de informaciones de United Satates Census Bureau, disponible en http://www2.census.gov/prod2/statcomp/documents/CT1970p1-03.pdf para (1940-1970), http://www.census.gov/prod/1/gen/95statab/vitlstat.pdf para (1971-1980) y http://www2.census.gov/library/publications/2011/compendia/statab/131ed/tables/12s0080.xls para (1981-2008), fecha de consulta: 16/2/2017.

Además, desde finales de los años 1950 en Estados Unidos se han inventado nuevos productos, por ejemplo, televisores a color, lavadoras y equipos de aire acondicionado (RAPOSO y MOYA, 2004). Estos tipos de electrodomésticos eran para disfrutar más de la vida cotidiana, mientras que los principales electrodomésticos en los años 1950 habían sido para sustituir trabajos en la casa. Por eso, disponer de este tipo de productos nuevos era un símbolo de status en Estados Unidos, especialmente para los jóvenes. 
Estos factores -el aumento del consumo, el crecimiento de la población y de las generaciones jóvenes y el desarrollo de los nuevos productos en Estados Unidosindujeron el aumento de las ventas de bienes de consumo duradero, como automóviles y electrodomésticos. Este aumento de la demanda de los productos era un motivo de las exportaciones desde Japón y de las primeras inversiones japonesas de empresas manufactureras en Estados Unidos.

El segundo motivo de las inversiones japonesas viene de la situación económica en Japón, esto es, en el país emisor. En esta década, hubo un aumento del número de empresas en Japón. Por ejemplo, en la industria de automóviles, nuevas empresas aparecieron desde el fin de los años 1950. Las empresas que habían fabricado motos, como Honda, Suzuki, Daihatsu, empezaron a fabricar automóviles (ONO Hiroshi, 1995). Esto significaba que sus producciones aumentaron también en el mercado en Japón (véase el Grafico II-1.2).

Gráfico II-1. 2. Producción de automóviles en Japón, 1950-1975 (en unidades)

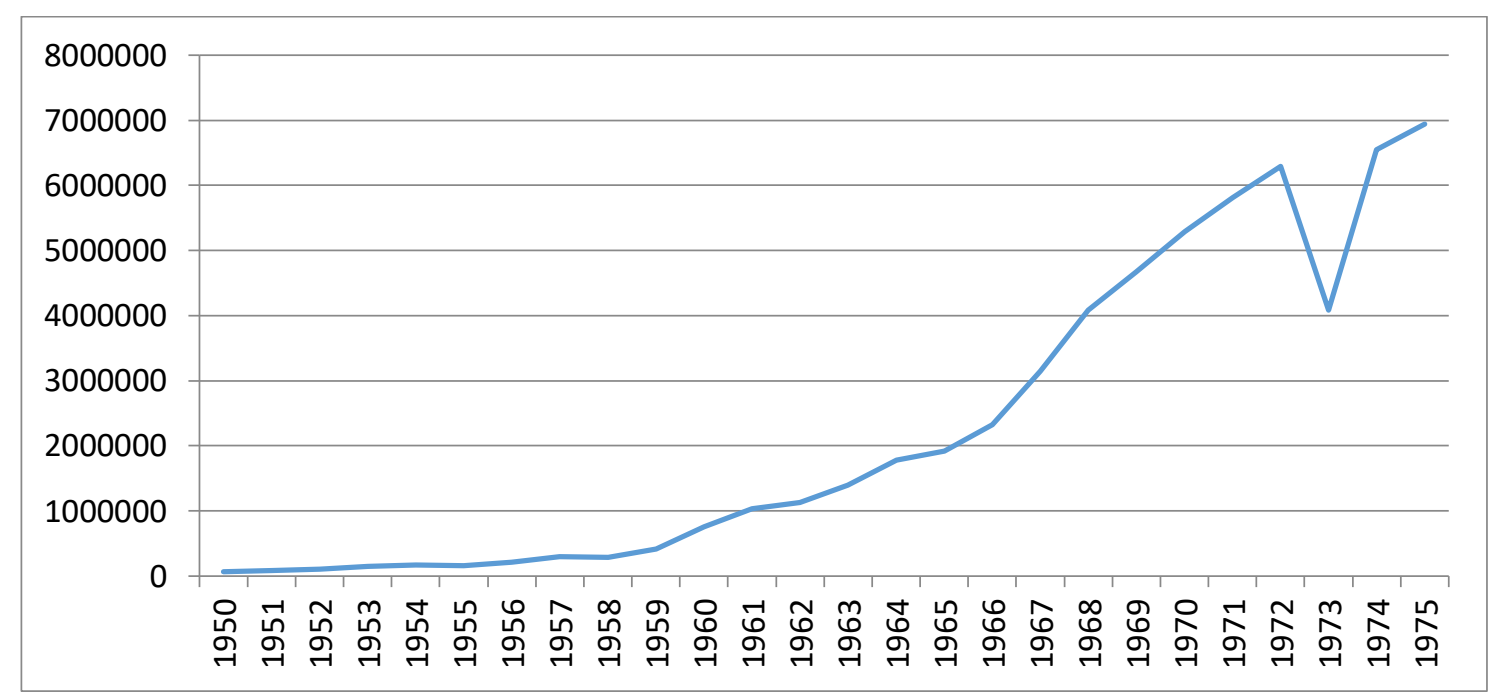

Fuentes. Elaboración propia a partir de ONO, Hiroshi. 1995. "Sengono nihonnno jidousyasangyouhatten", Economic Studies, Universidad de Hokkaido, 45(1), Pp. 68-76, disponible en http://hdl.handle.net/2115/31994, fecha de consulta: 10/4/2015.

Sin embargo, los consumidores japoneses no tenían capacidades para comprar todos estos productos. El número de automóviles que los japoneses tenían en los años 1960 y 1970 era muy pequeño en comparación con los números de su producción (véase 
la Tabla II-1.2). Dentro de Japón, la producción de automóviles era excesiva y por eso, aumentar el número de las empresas y la producción significaba, directamente, aumentar la necesidad de proyectarse hacia otros países. Primero, estas empresas de automóviles empezaron a exportar sus automóviles a Estados Unidos. La mayor parte de sus exportaciones habían sido al principio de camiones, pero, en los años 1970, su exportación de turismos aumentó. ${ }^{2}$ En Estados Unidos, los consumidores querían en ese momento coches para la vida urbana, no para la vida rural. En este contexto, era un momento favorable para vender turismos en Estados Unidos.

Tabla II-1. 2. Número de automóviles que los japoneses tenían en Japón (miles)

\begin{tabular}{|c|c|c|c|}
\hline & $\mathbf{1 9 6 5}$ & $\mathbf{1 9 7 0}$ & $\mathbf{1 9 7 5}$ \\
\hline $\begin{array}{c}\text { NÚMEROS DE } \\
\text { AUTOMOVILES }\end{array}$ & 6300 & 17582 & 28091 \\
\hline
\end{tabular}

Fuente. Ministerio de Tierra, Infraestructura, Transporte y Turismo, Gobierno de Japón, disponible en www.mlit.go.jp/statistics/pdf/23000000x024.pdf, fecha de consulta: 10/4/2015.

El tercer motivo viene de la situación económica de Japón. Aunque la economía japonesa estaba todavía muy débil, empezó a desarrollarse a finales de la década de 1960 y 1970. Es lo que se conoció como el "milagro japonés", que logró aumentos medios del PIB japonés de más de $10 \%$ cada año, como se ve en el Gráfico II-1. 3. Este boom económico produjo aumento de salarios de trabajadores y falta de trabajadores al mismo tiempo (IIDA, 1981, p.128). Para las empresas japonesas, esta situación no era favorable para producir en Japón, aunque para vender sus productos Japón era un buen destino. Esta situación fue otro motivo por el que las empresas japonesas comenzaron a considerar la inversión extranjera directa (IED) en otros países.

\footnotetext{
2 Información de Japan Automobile Manufacturers Association, disponible en http://www.jama.or.jp/lib/jamagazine/200802/02.html, fecha de consulta: 12/10/2014.
} 
Gráfico II-1. 3. Aumento del PIB real de Japón, 1955-1985

(En porcentaje)

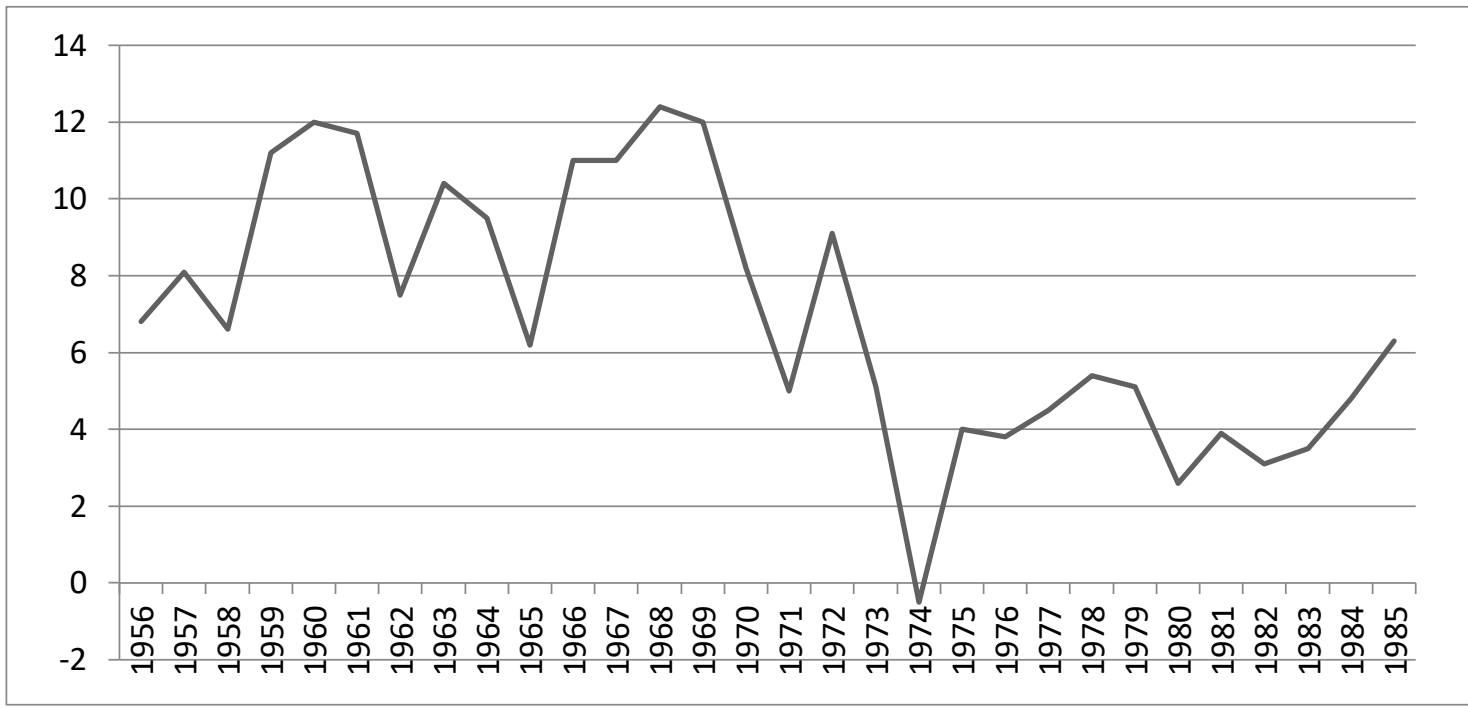

Fuente. Elaboración propia a partir de Cabinet office, Gobierno de Japón, disponible en http://www5.cao.go.jp/j-j/wp/wp-je15/pdf/p08001.pdf, fecha de consulta: 20/2/2017

El cuarto motivo tiene que ver con la situación política internacional en esta época: la Guerra Fría. El gobierno de Estados Unidos tenía necesidades para fortalecer las relaciones con los países “capitalistas," para contener a los países "comunistas." Por eso, para fortalecer las relaciones con Japón, el gobierno de Estados Unidos permitió entrar a los capitales japoneses en su mercado (KO, 2012). Además, las empresas estadounidenses daban oportunidades de aprendizaje para las empresas japonesas. Estas relaciones muy cercanas entre las empresas japonesas y estadounidenses eran otro motivo de las inversiones japonesas en Estados Unidos. En los años 1950 y 1960, las empresas japonesas que fueron a Estados Unidos aprovecharon este contexto. Por supuesto, su competencia con las empresas estadounidenses en los mercados de Estados Unidos era muy dura. Sin embargo, especialmente las industrias manufactureras japonesas aumentaron su actividad en Estados Unidos y establecieron sus fábricas en Estados Unidos. Habían conseguido popularidad y la confianza de los consumidores estadounidenses. En los años 70 las actividades de las empresas japonesas seguían creciendo, especialmente la exportación a Estados Unidos de Automóviles y electrodomésticos japoneses (véase el Gráfico II-1.4). Este aumento de exportaciones japonesas indujo un problema en la economía en Estados Unidos e indirectamente, fue un motivo importante para las inversiones japonesas en México. 
Hasta esta parte, hemos analizado sobre los movimientos de las inversiones japonesas en Estados Unidos. Sin embargo, estos primeros movimientos de inversión directa en los años 1960 y 1970 no eran tan significativos, porque la mayor parte de sus ganancias en Estados Unidos vinieron de exportaciones de productos desde Japón. Es decir, hasta los años 1970, la mayor actividad con Estados Unidos eran exportación, no procedía de fabricación en Estados Unidos. Por eso, el aumento de la venta de productos japonesas significaba un aumento de exportaciones desde Japón.

Gráficos II-1. 4. Exportaciones japonesas a Estados Unidos: automóviles y electrodomésticos, 1970-1979

(En unidades)

\section{1). Automóviles}

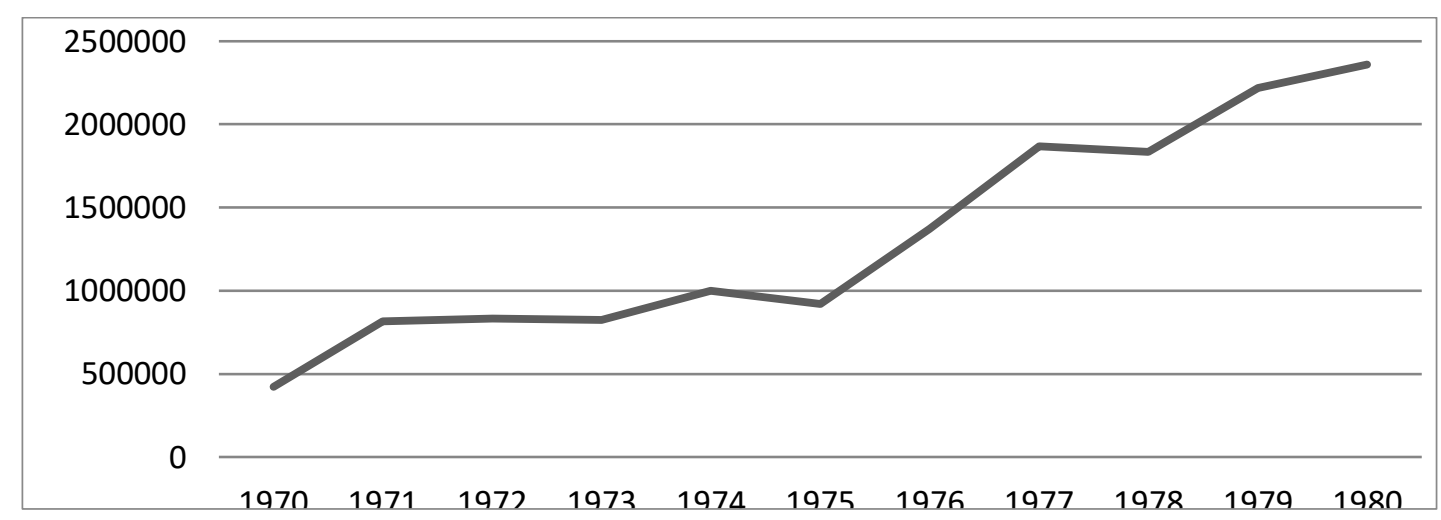

Fuente. Elaboración propia a partir de información de Estadísticas de Negocios de Japón, Ministerio de Finanzas, gobierno de Japón, disponible en http://www.customs.go.jp/toukei/suii/gphk_1979.htm, fecha de consulta: 11/4/2015.

\section{2). Televisores}

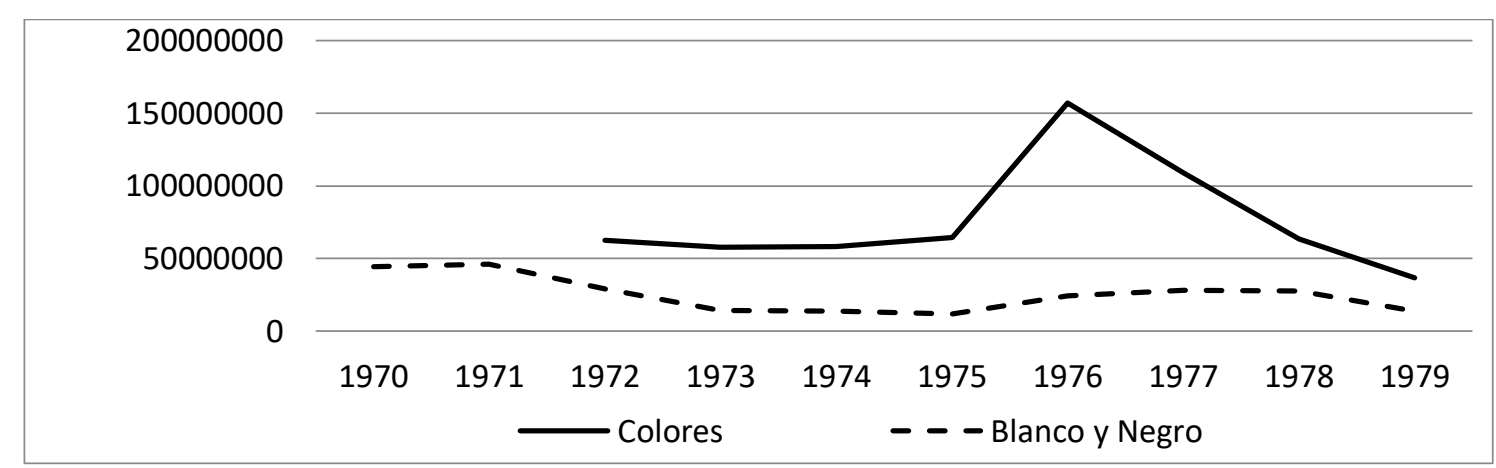

Fuente. Elaboración propia a partir de información de Estadísticas de Negocios de Japón, Ministerio de Finanzas, gobierno de Japón, disponible en http://www.customs.go.jp/toukei/suii/gphk_1979.htm, fecha de consulta: 11/4/2015. 


\section{3). Electrodomésticos}

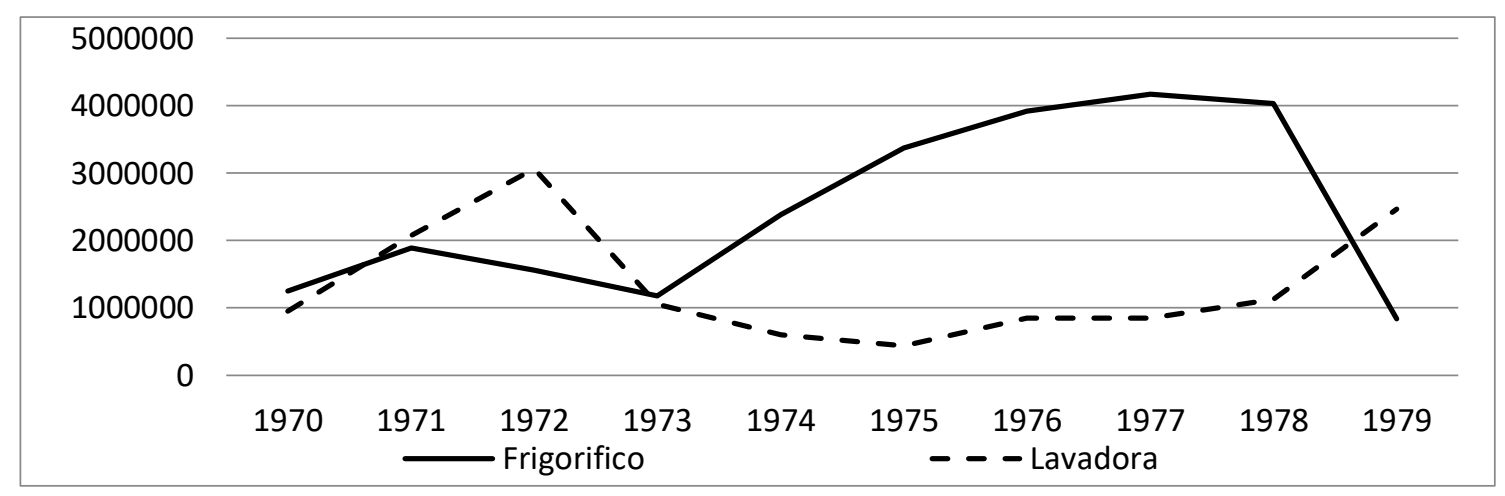

Fuente. Elaboración propia a partir de información de Estadísticas de Negocios de Japón, Ministerio de Finanzas, gobierno de Japón, disponible en http://www.customs.go.jp/toukei/suii/gphk_1979.htm, fecha de consulta: 11/4/2015.

Sin embargo, desde la década de 1970, las empresas japonesas comenzaron a invertir para establecer sus fábricas en Estados Unidos. Las exportaciones japonesas a Estados Unidos se redujeron en la segunda mitad de las 1970 (véase el Gráfico II-1. 3).

El primero motivo de este cambio de estrategia se debió al impuesto anti-dumping del Gobierno de Estados Unidos, especialmente, a las empresas japonesas en la industria de televisores (ONO Isao, 1995). En 1968, el gobierno estadounidense insistió en que los precios de los televisores japoneses importados eran injustamente baratos. Basándose en esta crítica, en 1970 el Departamento del Tesoro de Estados Unidos decidió fijar un impuesto anti-dumping del 9\% (BURTON y SAELENS, 1987). Para terminar con este conflicto, las 11 empresas japonesas de televisores tuvieron que pagar impuestos de antidumping (BURTON y SAELENS, 1987, p. 290). Este impuesto por anti-dumping a las empresas japonesas de televisores era un ejemplo de cómo el gobierno de Estados Unidos intentó controlar las actividades de las empresas extranjeras. En este contexto, para las empresas japonesas de televisores, seguir exportando productos desde Japón y venderlos en Estados Unidos era más costoso que antes. Por eso, la decisión de las empresas de televisores japonesas fue fabricar los productos en Estados Unidos. Este impuesto abre otra frase, fue un importante motivo para las inversiones en Estados Unidos de las empresas japonesas.

Además, como ya hemos analizado, las empresas japonesas habían establecido sus redes de ventas en Estados Unidos desde los 1960. Establecer este tipo de cadenas de 
ventas fue el primer motivo de la IED japonesa en Estados Unidos (ONO Isao, 1995, p.71). Para vender electrodomésticos y automóviles en Estados Unidos, este tipo de redes de venta era necesario. Por ejemplo, para vender los televisores de Trinitron, Sony había hecho crecer su red de vendedores norteamericanos, que se llamaba "REP," para dar información y servicio a los consumidores. ${ }^{3}$ Este tipo de redes de ventas ayudó a las inversiones japonesas en Estados Unidos.

Por tanto, las inversiones japonesas aumentaron en los años 1970 (véase el Gráfico II-1. 5). Con ello las ventas de las empresas japonesas en el mercado de Estados Unidos, también aumentaron. En esta situación, podemos decir que las empresas japonesas obtenían alta competitividad en el mercado de Estados Unidos. Por supuesto, los consumidores estadounidenses tenían confianza y ganas de comprar los productos japoneses. Esto significaba que las empresas norteamericanas que competían con las empresas japonesas tenían problemas de reducción de sus ventas y de sus ganancias en el mercado doméstico. Esta tendencia era más destacada en la industria automóviles, la industria principal de la economía norteamericana en el fin de los años 1960 y en los primeros años de 1970.

En la primera parte de los años 1970, los avances de las empresas japonesas ya fueron aún más claros. Los motivos que hicieron aumentar la IED japonesa en la década de 1970 fueron la crisis del patrón oro-dólar en 1971 y la crisis del petróleo en 1974 (MASUDA, 2015). Estas dos crisis obligaron a invertir fuera de Japón a las empresas japonesas, para bajar los costes de producción. Especialmente, después de la crisis cambiaria de 1971, el yen se apreció. En este contexto, los costes de la mano de obra en los países extranjeros eran más bajos que en Japón. Por eso, las empresas japonesas hicieron IED para bajar el coste de la mano de obra (SME Support, 2003)

\footnotetext{
${ }^{3}$ Según website de Sony, disponible en http://www.sony.co.jp/SonyInfo/CorporateInfo/History/SonyHistory/2-18.html, fecha de consulta: $2 / 4 / 2015$.
} 
Gráfico II-1. 5. Inversiones japonesas en Estados Unidos. 1951-1979

(En millones dólares)

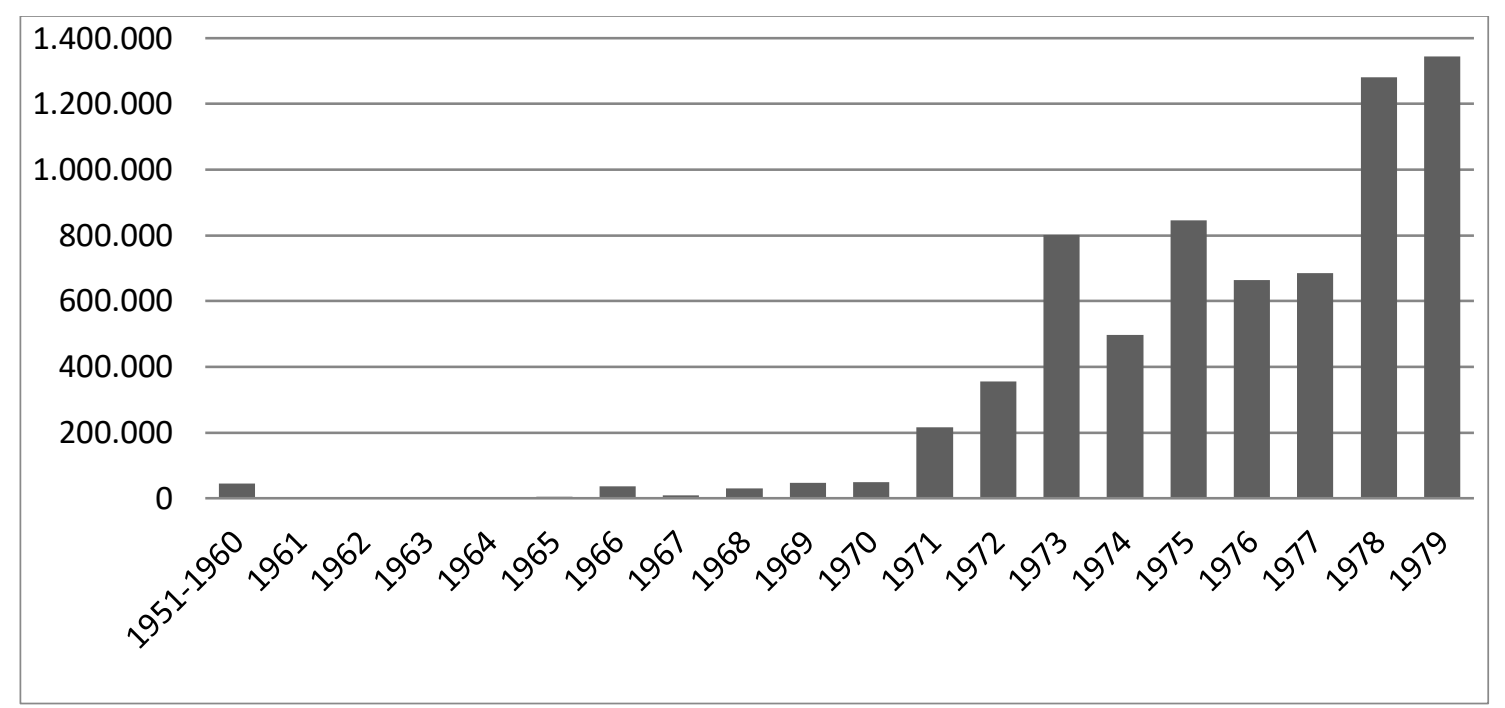

Fuentes: Elaboración propia a partir de informaciones de Policy Research Institute, Ministry of Finance, Government of Japan. Disponible en http://warp.da.ndl.go.jp/info:ndljp/pid/8379094/www.mof.go.jp/pri/publication/zaikin_geppo/hyou/g 380/380.htm, fecha de consulta: 1/12/2013.

Además, sus productos estaban dominando en el mercado del Estados Unidos ${ }^{4} \mathrm{y}$ las cuotas de mercado de las empresas japonesas en el país aumentaron. Esta situación era favorable para las empresas japonesas. Sin embargo, al contrario, para las empresas estadounidenses en las mismas industrias, no eran favorables. Disminuir sus ventas significaba ver reducida la demanda de sus productos. Esta tendencia era muy clara en los años 1980.

Es importante tener en cuenta que las industrias estadounidenses más afectadas por las inversiones japonesas eran industrias muy importantes para la economía estadounidense: la industria de automóviles y la de electrodomésticos, por ejemplo. ${ }^{5}$ Especialmente, en la historia económica de Estados Unidos, la importancia de la industria del automóvil es muy destacada. Las grandes empresas de automóviles en Estados Unidos,

\footnotetext{
${ }^{4}$ Según información de Cabinet Office, Government of Japan. 1981. Keizai-Hakusyo, Syowa 56nenndo. Disponible en http://www5.cao.go.jp/keizai3/keizaiwp/wp-je81/wp-je81bun-2-3-3z.html, fecha de consulta: $1 / 12 / 2013$.

${ }^{5}$ Según información de Cabinet Office Government of Japan 1981. Keizai-Hakusyo, Syowa 56nenndo. Disponible en http://www5.cao.go.jp/keizai3/keizaiwp/wp-je81/wp-je81bun-2-3-3z.html, fecha de consulta:1/12/2013.
} 
que se llamaban Big 3 (General Motors, Ford y Chrysler), tenían importancia en el mundo político también. Para ellos, el aumento de las empresas japonesas de automóviles en Estados Unidos era muy problemática, porque dio lugar a una reducción de sus ganancias. Las empresas estadounidenses consideraban que el mayor motivo de esta reducción era la competencia de las empresas japonesas.

En la realidad, el motivo del aumento de las ventas de las empresas japonesas en Estados Unidos no era solo uno. Hubo varias circunstancias en Estados Unidos que dieron ventaja a las empresas japonesas en esta época. La primera fue un cambio de preferencia de los consumidores estadounidenses, que estuvo motivado en el fondo, por la crisis del petróleo de los años setenta (BRESNAHAN y RAMEY, 1993).

En 1974, los países tenían que enfrentar la subida de los precios del petróleo de los países productores árabes de la OPEP (LEE y NI, 2002). Desde el punto de vista de los países industrializados, esta situación significaba que el aumento de costes de sus productos. Entonces, los productos que gastan más petróleo aumentaron más sus costes. Para los consumidores, la subida de los costes era un motivo para no comprar esos productos. En la industria de automóviles en Estados Unidos, las empresas estadounidenses habían dominado ese mercado. Sin embargo, en los años 1970, después de la crisis del petróleo, los automóviles japoneses empezaron a ser populares en el mercado de Estados Unidos, porque las empresas japonesas produjeron coches pequeños, que gastaban menos gasolina que los coches norteamericanos (ONO Hiroshi, 1995, p. 70). Esta diferencia de costes era muy importante para los consumidores estadounidenses en los años 1970. La crisis de petróleo y los cambios de preferencias de los consumidores estadounidenses fueron motivos importantes.

Esta misma estructura de cambio de posiciones de las empresas japonesas en el mercado de Estados Unidos, podemos encontrarla también en la historia de la industria de televisores japoneses y sus inversiones en Estados Unidos. Las empresas japonesas hicieron inversiones en Estados Unidos en los años 1960 para establecer sus filiales. Sin embargo, para el auge de las inversiones japonesas en la industria de electrodomésticos en Estados Unidos tenemos que esperar hasta los años 1970. En 1972, Sony estableció su primera fábrica en San Diego, California. La disposición desde la empresa de Motorola 
era uno de los motivos del avance de Sony a Estados Unidos. Además, en el mismo periodo, Matushita llegó a Estados Unidos y estableció su primera fábrica (AMANO y HAN, 2003). Como hemos visto, las dos empresas más grandes de la industria de electrodomésticos japonesas invirtieron en Estados Unidos. Otras empresas japonesas de la industria de electrodomésticos que eran más pequeñas, por ejemplo, Sanyo, Hitachi y Mitsubishi, habían invertido en Taiwán y Singapur desde los años 1960 (AMANO y HAN, 2003, pp. 135-136). Sin embargo, estás empresas japonesas "pequeñas" invirtieron también en Estados Unidos en el fin de los años 1970.

Al mismo tiempo de las inversiones japonesas en Estados Unidos, hubo un gran cambio en la tecnología de televisores: de los televisores en blanco y negros a los televisores a color. Este cambio de tecnología indujo la necesidad de una mayor complejidad en el proceso de fabricación y un más alto nivel de calidades (YOSHIDA, 2008). Estas dos necesidades para el desarrollo tecnológico de los televisores tienden a inducir el aumento de los precios de los productos finales. Después de la popularidad de los televisores en color, las empresas de televisores japonesas y estadounidenses tenían que mantener la alta calidad en los productos y bajar sus precios. Estas dos condiciones parecían opuestas.

Sin embargo, las empresas japonesas en la industria de televisores estaban consiguiendo estas condiciones opuestas. Primero, para mejorar sus calidades de productos, varias empresas japonesas fabricaban los televisores de Circuito Integrado (CI) (YOSHIDA, 2008, pp. 43-45). Justo después de las primeras inversiones en Estados Unidos, las empresas japonesas habían fabricado los televisores de tubos. Sin embargo, en los años 1960, Sony intentó fabricar los televisores de Solid-State, y dentro de la década, ya tenía capacidad para fabricar los televisores de CI (AMANO y HAN, 2003, p. 140). Además, otras empresas de televisores japonesas que habían invertido en Estados Unidos adoptaron las fabricaciones de televisores CI. Al contrario, en el mismo tiempo, las empresas estadounidenses tenían algunos motivos por los que no pudieron adoptar las producciones de este nuevo tipo de televisión. Primer motivo era la situación del mercado en Estados Unidos. Cuando se fabricaban los televisores de tubos en Estados Unidos, las empresas estadounidenses, por ejemplo, Zenith y General Electric y RCA, estaba dominando el mercado (NAKAGAWA, 2009; KLEPPER y SIMONS, 2000). Por eso, no 
consideraron que hubiera necesidades para desarrollar más sus tecnologías. El segundo motivo era que las empresas japonesas que invirtieron en Estados Unidos tenían una ventaja para producir nuevos televisores con CI y pudieron establecer sus fábricas para fabricación de televisores de CI desde el principio. Al contrario, las empresas estadounidenses, que habían fabricado los televisores de tubos, tenían que cambiar su línea de producción para adoptar la tecnología de televisores de CI. Al considerar el costo del cambio de las líneas producción, era muy natural que las empresas estadounidenses se resistieran a adoptar el nuevo sistema de los televisores.

Como hemos visto, las empresas japonesas aumentaron su presencia en la economía estadounidense. Sin embargo, para las empresas estadounidenses, esta situación en el mercado nacional no era favorable. Además, como hemos visto antes, especialmente, las empresas de automóviles estadounidenses tenían influencias muy fuertes en la política industrial en Estados Unidos. A través del aumento de la competencia en el mercado, las empresas estadounidenses tenían menos posibilidades para aumentar sus ganancias. Por eso, ellos intentaron usar políticas para recuperar sus ganancias. Esto fue el inicio del conflicto económico entre Japón y Estados Unidos. La IED japonesa tuvo que reaccionar, especialmente desde la segunda década de 1970, para poder resolver este conflicto (APIR, 2014).

El conflicto del negocio de los televisores entre Estados Unidos y Japón había empezado desde el 1968 (OOYANE, 1992). En los años 1970, las empresas japonesas de televisores tenían que responder a las regulaciones de control del gobierno de Estados Unidos (OOYANE, 1992, p. 40). Como hemos visto, en 1970, el gobierno estadounidense obligaba a las empresas japonesas a pagar el 9\% como impuesto de anti-dumping (NAMIMITSU, 1992). Esta obligación era un motivo para inducir las inversiones directas de las empresas japonesas en Estados Unidos. Sin embargo, aunque después llegaron las inversiones japonesas a Estados Unidos, esta industria siguió siendo un motivo de conflicto económico entre Japón y Estados Unidos.

Hubo un nuevo conflicto económico en la industria de televisores en 1977 (OOYANE, 1992, pp. 60-14). En los años anteriores, las exportaciones japonesas procedentes de Estados Unidos aumentaron. Esta vez, el gobierno de Estados Unidos 
obligó al gobierno de Japón a limitar la exportación de los productos japoneses a su país. Esta limitación de exportación se llamaba Orderly Marketing Agreement (OMA) y duró de julio en 1977 a junio a 1980 (NAMIMITSU, 1992, p.173). Esta restricción de exportación desde Japón era un motivo directo del aumento de las inversiones japonesas de las empresas de televisores en Estados Unidos. Además, hubo otro motivo para el aumento de las inversiones en Estados Unidos en los años 1970: el tipo de cambio entre el yen y el dólar. Después de la ruptura del patrón oro-dólar en 1971 y el cambio hacia un sistema de tipos de cambio flexibles, el yen japonés se apreció. En este contexto, exportar los productos era más costoso que fabricarlos en otros países. Para las empresas japonesas manufactureras, el tipo de cambio del yen frente a otras monedas fue uno de los motivos del cambio de estrategia y de sus planes de fabricación (FUKAO y EN, 2001).

Todos estos motivos aumentaron las inversiones japonesas en Estados Unidos en la década de 1970. En el mercado estadounidense, hubo una presencia muy fuerte de las empresas japonesas. Mientras tanto las empresas estadounidenses perdieron cuota de mercado en el mercado doméstico. Además, en los años 1980, la economía estadounidense perdió competitividad. En esta situación, el gobierno de Estados Unidos intentó reducir la competitividad de las empresas japonesas, para proteger las empresas estadounidenses. Especialmente, las empresas de automóviles japonesas tenían que enfrentar políticas económicas muy restrictivas en Estados Unidos. La manera que eligieron las empresas japonesas en Estados Unidos para corresponder estas políticas estadounidenses, era trasladar sus fábricas a México. ${ }^{6}$ Éste fue el primer paso de las inversiones japonesas en México.

\footnotetext{
${ }^{6}$ Según informaciones de Japan Automobile Manufacture Association. Disponible en http://www.jama.or.jp/lib/jamagazine/200802/07.html, fecha de consulta:1/12/2013.
} 


\section{II-2. Tímido pero firme comienzo de las inversiones japonesas en México: los años 1960 y 1970}

Las inversiones japonesas empezaron a destacar especialmente desde los años 1980 en la economía mexicana. Sin embargo, podemos encontrar algunos antecedentes de las inversiones japoneses en México desde los años 1960, aunque apenas eran significativos ni en la economía mexicana ni en las actividades japonesas. En esta sección, analizamos los primeros pasos de las inversiones japonesas en México, en los años 1960 y 1970.

En 1952, Japón recuperó las relaciones diplomáticas con México. ${ }^{7}$ Sin embargo, desde el punto de vista de las actividades de las empresas japonesas, no podemos encontrar cosas llamativas en ese momento. En esa década, apenas la economía japonesa se empezaba a recuperar de los daños de la Segunda Guerra Mundial y todavía las empresas japonesas no tenían suficiente fuerza como para invertir en otros países.

Esta situación comenzó a cambiar desde los años 1960. Las empresas japonesas, especialmente, las de las industrias manufactureras, invirtieron en México para establecer sus fábricas. Por ejemplo, Nissan empezó su actividad en México en 1961 y estableció su primera fábrica en Aguascalientes en 1966 (MIRANDA, 2007). Mitsubishi estableció su fábrica en 1969 para producir compresores de frigorífico y Hitachi fabricaba televisores en Ciudad de México desde $1963 .^{8}$ Además, $N E C$ se estableció en Cuernavaca, Morelos, en 1968. ${ }^{9}$ Como muestra el Gráfico II-2. 1, las inversiones japonesas comienzan en México en los años 1960 de la mano de las empresas japonesas más grandes. En este periodo el gobierno de México tenía limitación de participaciones de los capitales extranjeros al establecer empresas en México. En 1973, La Ley para Promover la Inversión Mexicana y Regular la Inversión Extranjera decidió que las empresas extranjeras pudieran tener una participación máxima entre 40\% - 49\% del capital de empresas y actividades de exportación (DUSSEL PETERS, 2000, pp. 15-26). Sin embargo, la industria de petróleo, por ejemplo, no permitía la participación de los

\footnotetext{
${ }^{7}$ Durante de la Segunda Guerra Mundial, las relaciones diplomáticas entre los dos países se rompieron.

${ }^{8}$ Ministerio de Economía, Negocios e Industria del Gobierno de Japón. 1986. Situación Actual de la industria electrodoméstica. p. 56

${ }^{9}$ Ministerio de Economía, Negocios e Industria del Gobierno de Japón. 1986. Situación Actual de la industria electrodoméstica. p. 58
} 
capitales extranjeros. Las industrias mexicanas en las que las empresas japonesas querían participar eran industrias manufactureras. Por eso, todas estas empresas japonesas eran empresas conjuntas o joint-ventures con las empresas mexicanas.

Gráfico II-2. 1. Inversiones japonesas en México: en los años 1960 (En miles de dólares de Estados Unidos)

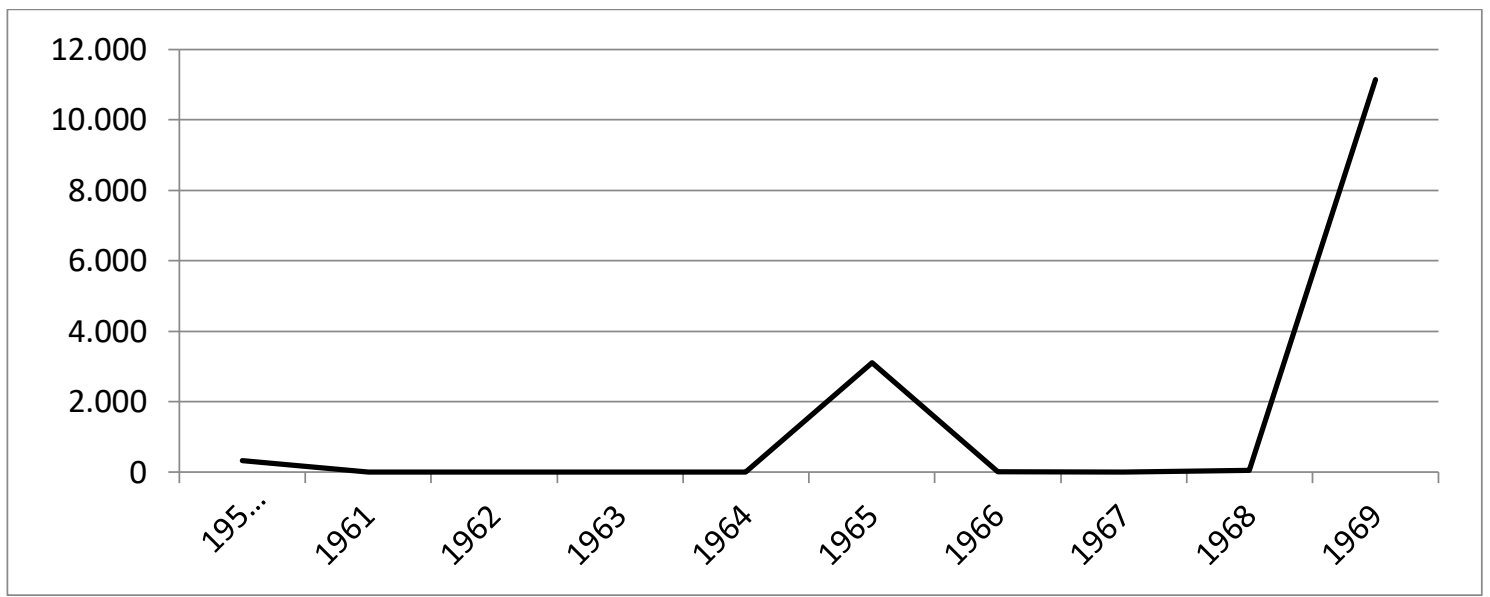

Fuentes. Elaborada propia a partir de informaciones de Policy Research Institute, Ministry of Finance, Government of Japan. Disponible en http: //warp.da.ndl.go.jp/info: ndljp/pid/8379094/www.mof.go.jp/pri/publication/zaikin_geppo/hyou/g380/380.htm, fecha de consulta: 5/12/2013.

Tal como muestra el Gráfico II-2. 1, las inversiones japonesas en la década de 60 eran muy pequeñas. Podemos encontrar la misma información respecto al número de casos de las inversiones japonesas en México en la década de 1960: en esta década, hubo solo 6 casos. ${ }^{10}$ Sin embargo, tenemos que enfocarnos en el año 1969 donde su volumen aumentó muy rápidamente. A pesar de este aumento, según estos datos, podemos decir que las inversiones japonesas en México no estaban activas en los años 1960. Desde el punto de vista de las empresas japonesas, hubo algunos motivos por los que no querían invertir en grandes volúmenes en México.

Primero, en este tiempo, en Japón, hubo un problema por el que no pudo promover las inversiones extranjeras. Para controlar las reservas de divisas (la mayor parte eran de dólares estadounidenses), todas las inversiones a países extranjeros estaban bajo el control del Ministerio de Finanzas del Gobierno de Japón (Ministerio de Fianzas del Gobierno de

\footnotetext{
${ }^{10}$ Ministerio de Economía, Negocios e Industria del Gobierno de Japón. 1986. Situación Actual de la industria electrodoméstica. pp. 60-62.
} 
Japón, 1987). O sea, las empresas que querían hacer inversiones en otros países tenían que obtener el permiso del gobierno.

Mientras en Japón, hubo restricciones para hacer inversión y, en México, también, hubo restricción para la llegada de capitales extranjeros. Sin embargo, las empresas japonesas invirtieron en México como una forma de dar sus primeros pasos en México. Entonces, tenemos que considerar qué motivos tenían las empresas japonesas que invirtieron en México es esta época.

El primer motivo era el mejoramiento económico de México en esta época (otra vez la L del Paradigma OLI). El gobierno de México tenía una política especial para desarrollar su economía: industrialización por sustitución de importaciones (VIEYRA, 2003). Para industrializar su economía, el gobierno de México decidió promover la fabricación de los productos necesarios dentro de México para consumirlos dentro de México. Para las empresas extranjeras, como las japonesas, esta estrategia del gobierno de México tenía unas implicaciones claras: 1) Para entrar en la economía mexicana para vender sus productos, la exportación desde Japón tenía menos posibilidades; 2) Había la necesidad de fabricar en México. En este contexto, la manera para entrar al mercado de México era invertir y establecer fábricas en el país (LARRIVA y VEGA, 1982; CARRILLO y GOMIS, 2014). Las empresas extranjeras tenían que elegir las inversiones en México. Esta política se empezó a ampliar desde el año 1960 (VIEYRA, 2003, p. 220). Durante los primeros años, esta estrategia funcionaba bien en la economía mexicana. Éste es el primer motivo del aumento de las inversiones japonesas en los años 1960.

El segundo motivo era que las empresas japonesas pudieron esperar una continua expansión del mercado dentro de México en este periodo, como se ve en el Gráfico II-2. 2. El crecimiento del PIB fue continuo durante toda la década de los años 1960. Por ejemplo, entre los años 1960 y 1970, en la industria de electrodomésticos en México, la actividad de las empresas mexicanas era creciente. Además, sus capacidades para satisfacer la demanda doméstica eran suficientes: en los primeros años de 1970, el 85\% $90 \%$ de los valores totales en los televisores a color se fabricaban dentro de México y el $95 \%$ de los valores totales en los televisores en blanco y negro se fabricaban en México (LOWE y KENNEY, 1999). 
Gráfico II-2. 2. México: Producto Interno Bruto por habitante, 1960-1969

(En pesos mexicanos a precios de 1970)

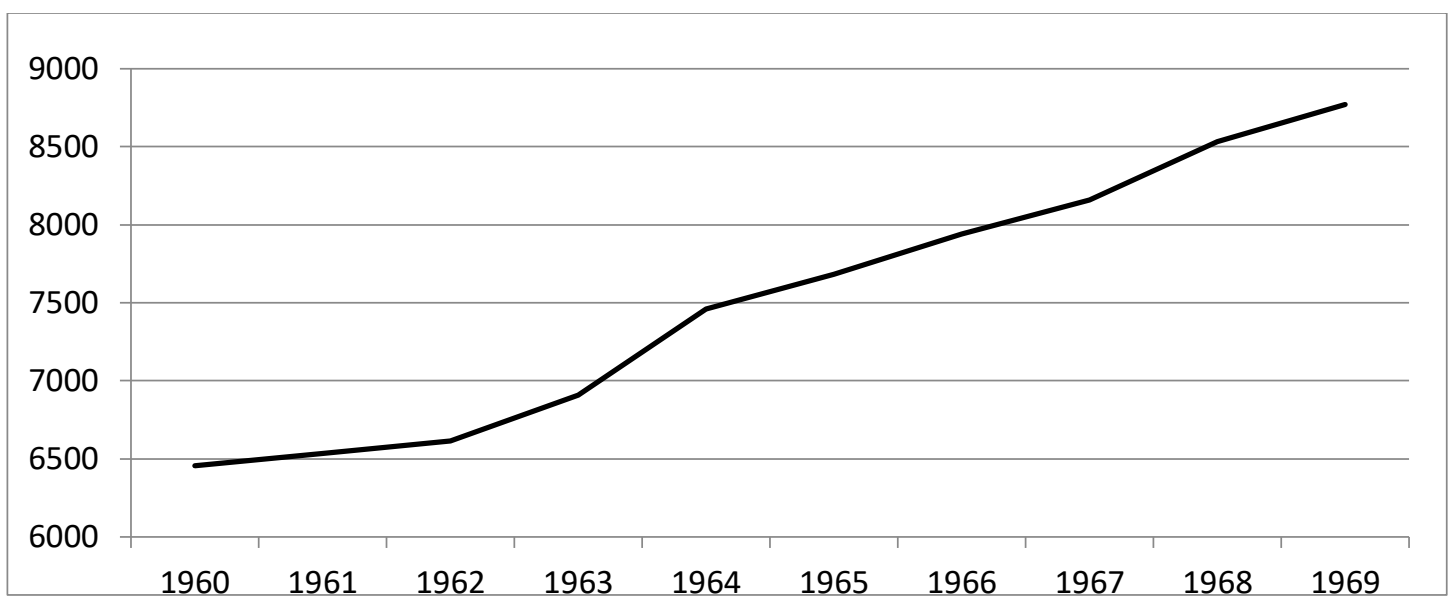

Fuentes. Elaboración propia a partir de información del INEGI (Instituto Nacional de Estadística y Geografía). Disponible en www.inegi.org.mx/, fecha de consulta: 15/3/2013.

Además, en las industrias de electrodomésticos en México, hubo un conglomerado de empresas mexicanas: Majestic Corporation. Tenía 57 empresas filiales mexicanas y vendía sus televisores blanco-y-negro y radios en México y en otros países de América Latina en los años 1960 (LOWE y KENNEY, 1999, p. 1431). Además de Majestic Corporation, había varias empresas mexicanas en la industria de electrodomésticos. En los años 1960, las empresas estadounidenses y europeas de la industria de electrodomésticos invirtieron en México: Philips, Motorola, General Electric, Emerson, RCA, etc. (LOWE y KENNEY, 1999, p. 1433). Todas estas empresas esperaban una expansión del mercado o un aumento de las capacidades de compra de los consumidores en México. Esta tendencia no ocurría solo en la industria de electrodomésticas. Esta esperanza se mantuvo en los años 1970. Como se ve en el Gráfico II-2.3, comparada con la poca producción en la década 1960, en la década 1970 se aumentó las producciones de televisores y radios.

La situación de la industria de electrodomésticos era solo un ejemplo de la situación económica en México de los 1960 y 1970. La economía mexicana estaba en boom en estas dos décadas. Éste es el segundo motivo de las inversiones japonesas en México. 


\section{Gráfico II-2. 3. Producción de televisores y radios en México, 1965-1984 (Unidades)}

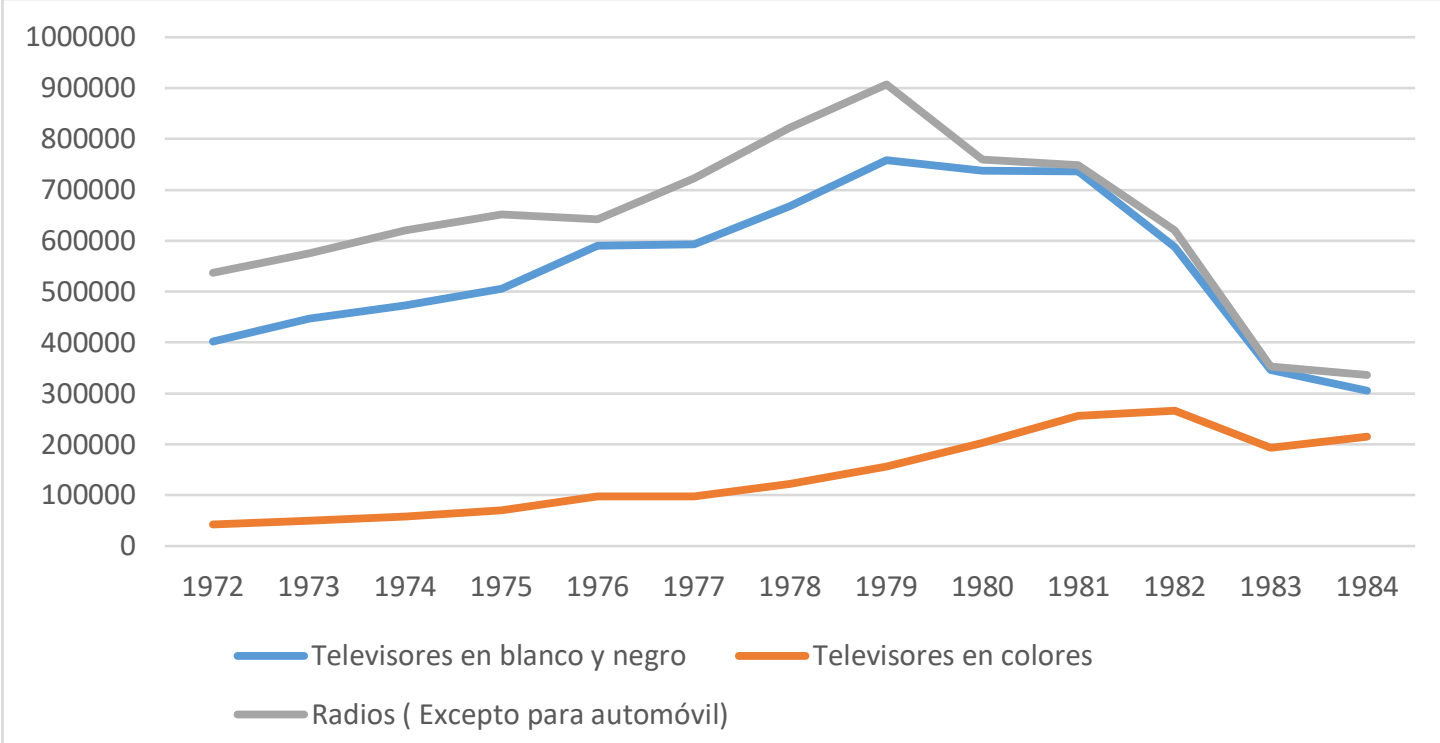

Fuentes. Elaborado propia de Estadísticas Históricas de México, INEGI. Disponible en www.inegi.org.mx, fecha de consulta: 5/12/2013.

El tercer motivo de las inversiones niponas en los años 1960 y 1970 está relacionado con el segundo motivo: hubo una coincidencia entre las empresas que querían invertir en México y las industrias que ya se habían desarrollado en México. Es decir, gracias a que hubo antecedentes de desarrollo de la misma industria, las empresas japonesas pudieron invertir en México (LOWE y KENNEY, 1999, p. 1440), como se ve en el Gráfico II-2.3. Especialmente, la industria de electrodomésticos se estaba desarrollando en México, por eso las empresas japonesas de electrodomésticos pudieron invertir en México. Si consideramos la restricción a los capitales extranjeros en México, podemos entender que esta tendencia era muy natural. Tal como se expuso antes, las entradas de los capitales extranjeros a las empresas mexicanas tenían una limitación hasta 49\% (DUSSEL PETERS, 2000, p.11). Esto significaba que las empresas extranjeras tenían que encontrar a empresas socias para invertir en México. En este periodo, las empresas japonesas eligieron tener alianzas con empresas de sus mismas industrias. Por eso, en los años 1960 y 1970, las empresas japonesas pudieron invertir en México.

Estos tres motivos de las inversiones japonesas, -mejora económica de México en esta época, expectativas de expansión del mercado mexicano y desarrollo industrial de 
las mismas industrias que querían invertir en México-, fueron importantes para marcar el primer paso en México. Como hemos visto en la sección anterior, las empresas japonesas empezaron a invertir en otros países desde los años 1960. Sin embargo, solo las empresas japonesas grandes pudieron invertir en México. Generalmente, en esta época, podemos decir que, salvo excepciones, no hubo tantas empresas japonesas que pudieron hacer inversiones en otros países. México fue uno de los primeros países en los que las empresas japonesas invirtieron.

A partir de aquí, analizaremos las inversiones japonesas en México en los años 1970, tanto los montos de las inversiones (Gráfico II-2.4), como el número de casos (Gráfico II-2. 5). Podemos afirmar que las inversiones japonesas en México aumentaron muy rápidamente en los años 70. Según el Grafico II-2.5, podemos encontrar que el primer motivo del aumento de las inversiones japonesas fue el aumento del número de los casos de las inversiones japonesas. Solo en esta década, hubo 122 casos en total. Este aumento en la década de 1970 era una característica de la historia de las inversiones japonesas en México.

Gráfico II-2.4. Las inversiones japonesas en México, 1970-1979

(En millones dólares de Estados Unidos)

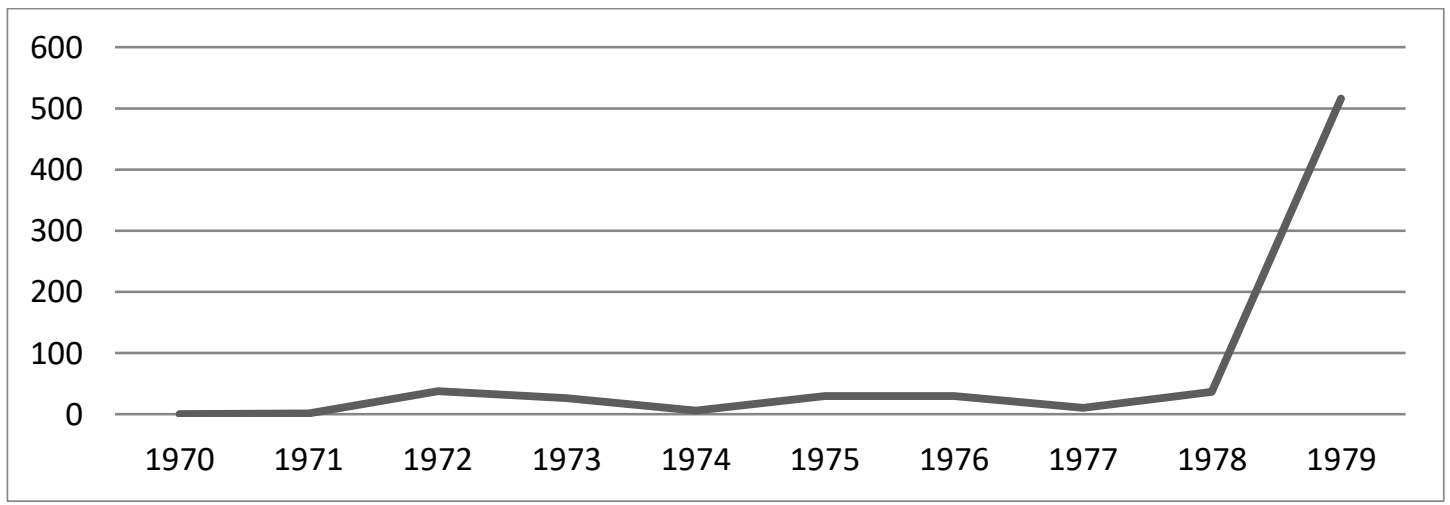

Fuentes. Elaboración propia a partir de informaciones de Policy Research Institute, Ministry of Finance, Government of Japan. Disponible en http: //warp.da.ndl.go.jp/info: ndljp/pid/8379094/www.mof.go.jp/pri/publication/zaikin_geppo/hyou/g380/380.htm, fecha de consulta: 5/12/2013. 
Gráfico II-2.5. Número de casos de las inversiones japonesas en México, 1970-1979

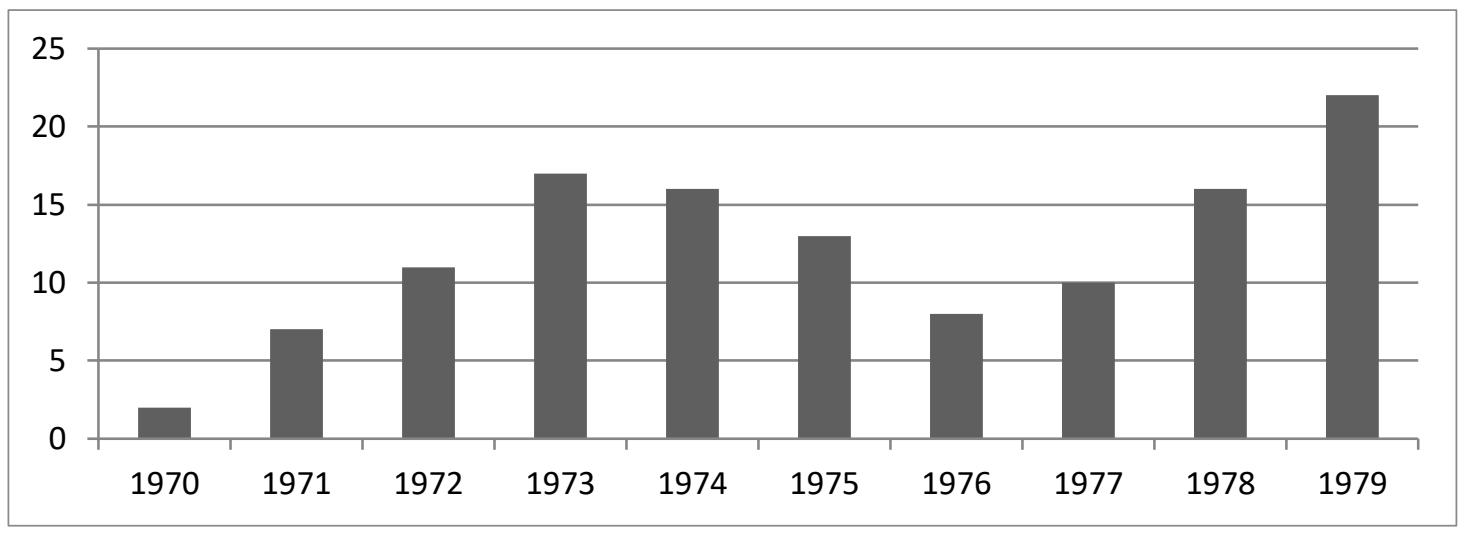

Fuentes. Elaboración propia a partir de informaciones de Policy Research Institute, Ministry of Finance, Government of Japan. Disponible en

http://warp.da.ndl.go.jp/info:ndljp/pid/8379094/www.mof.go.jp/pri/publication/zaikin_geppo/hyou/g 380/380.htm, fecha de consulta: 5/12/2013.

El primer motivo del aumento de las inversiones japonesas en México fue el desarrollo de la economía mexicana. Como hemos visto en el Grafico II-2.2, la economía mexicana estaba viviendo un boom. Podemos ver el boom de la economía mexicana desde otras cifras. Por ejemplo, aunque hay algunos años en los cae su cifra, se nota que el aumento del PIB de México alcanzó un alto nivel en la década 1970 (véase el Gráfico II2.6). En esa época, el gobierno de México seguía con la política de sustitución de las importaciones. Entonces, lo que el gobierno de México quería era que las empresas japonesas produjeran y vendieran sus productos en México. Es decir, el gobierno de México quería satisfacer la demanda interna y hacer crecer sus empresas domésticas (VILLARREAL y DE VILLARREA, 2001).

Gráfico II-2.6. Crecimiento de PIB per cápita, 1969-1980 (En porcentaje)

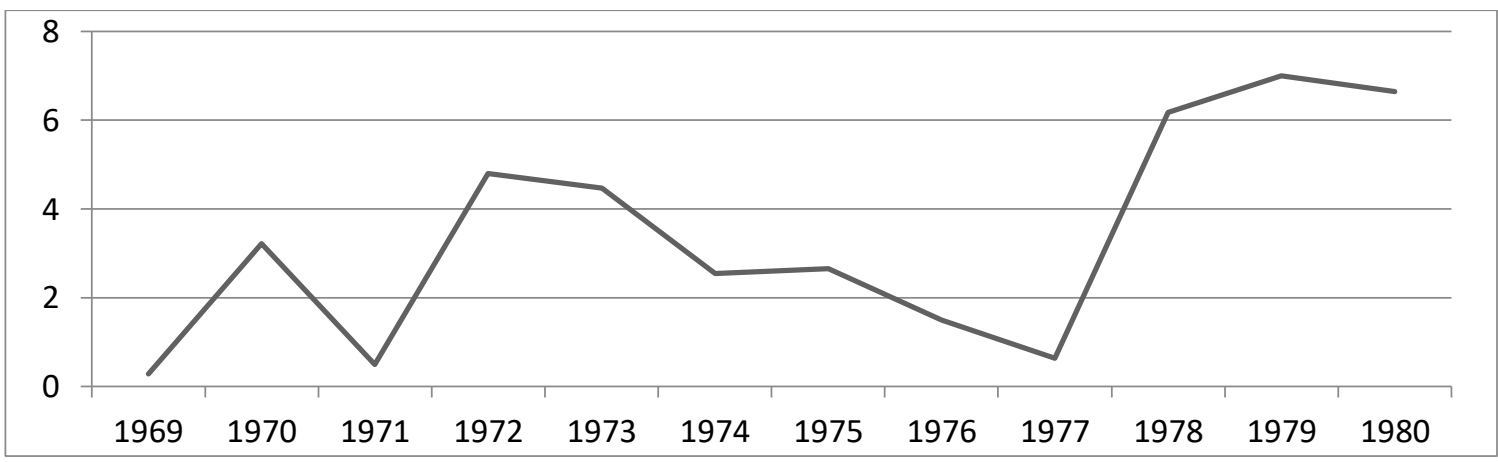

Fuente. Tomado de Banco Mundial, disponible en http://datos.bancomundial.org/indicador/NY.GDP.PCAP.KD.ZG?end=1980\&locations=MX\&start= $1969 \&$ view=chart\&year_high_desc=false, Fecha de consulta: 27/11/2016. 
Este boom de la economía mexicana aceleró las inversiones japonesas en México en los años 1970. Además, como se analizará en detalle en el próximo capítulo, en 1965 empezó el programa de maquiladora. Este programa tuvo influencia en las inversiones japonesas en este periodo. Para el gobierno de México, los objetivos del programa fueron tres: 1) Atraer empresas para aumentar el empleo; 2) Obtener fuentes de divisas; y 3) Promover la transferencia de tecnologías a México y mejorar su inserción en la economía internacional (KENNY y FLORIDA, 1994). Principalmente, la zona de la industria maquiladora estaba en la frontera Norte entre México y Estados Unidos. Como hemos visto, en los años 1960, la economía estadounidense estaba en boom. El nivel de tecnología de las empresas estadounidenses era alto. Por eso, establecer la zona especial en la frontera con Estados Unidos era muy natural para atraer IED estadounidense. Además, como hemos visto en las secciones anteriores, las industrias de Estados Unidos, especialmente las industrias manufactureras tenían fuerte competencia en esta época. En esta situación, el programa de Maquiladora era para promover que los capitales estadounidenses fueran a México, para exportar a Estados Unidos.

Este programa de Maquiladora indujo un cambio en la geografía industrial en México. En los años 1960, las empresas extranjeras habían establecido sus fábricas y filiales cerca de la Ciudad de México. Principalmente porque las empresas extranjeras (y no solo las empresas extranjeras, las empresas mexicanas, también) habían querido acercar las fábricas a sus mercados principales, para reducir los costes para fabricar sus productos (LOWE y KENNY, 1999, p.1430). Basándose en la buena condición de su economía, las empresas habían considerado que México era un lugar adecuado para vender sus productos. Sin embargo, después de la Maquiladora, esta consideración cambió. Podemos decir que, a través del establecimiento de la zona de Maquiladora, el gobierno de México dio una imagen nueva a todo el mundo, que México era un lugar adecuado para importar insumos intermedios, fabricar los productos con estos insumos intermedios y exportar los productos finales a Estados Unidos. Por eso, después de establecer la Maquiladora, las empresas extranjeras empezaron a establecer sus fábricas en el Norte de México.

Las empresas japonesas no eran una excepción a esta tendencia. En los años 1970, más empresas japonesas invirtieron en México. Al mismo tiempo, el gobierno de México 
estableció algunos parques industriales en el país ${ }^{11}$. El primer parque industrial se estableció en Ciudad Juárez y en Tijuana en 1966, para atraer a las empresas de televisores extranjeras. En 1968, se estableció otro parque industrial en Nogales, Sonora. Este parque industrial era para las empresas de plásticos. ${ }^{12}$ En 1973, se establecieron más parques industriales en la frontera Norte de México. Destacaron los números de empresas en el estado de Baja California con 102 empresas distribuidas en los municipios de Ensenada, Mexicali, Tecate y Tijuana; en orden de importancia le siguió el estado de Tamaulipas con 56 industrias, distribuidas en los municipios de Nuevo Laredo, Reynosa y Matamoros. ${ }^{13}$

Para las empresas japonesas, que se habían planteado trasladar sus fábricas desde Estados Unidos, por efecto de los conflictos económicos con Estados Unidos, estos movimientos en México eran muy atractivos. Los parques industriales ofrecían una posibilidad para que las industrias manufactureras japonesas tuvieran alta competitividad. Por eso, sus fábricas estaban localizadas en la frontera norte de México y las cantidades de las inversiones japonesas también, aumentaron (véase el Gráfico II-2. 4).

Como hemos visto, uno de motivos de las inversiones japonesas en México en los años 1970 era la Maquiladora. Aunque hubo limitaciones para la participación de los capitales extranjeros, establecer fábricas en esta zona se convirtió en otra opción de las inversiones japonesas en México. Sin embargo, los mayores protagonistas de las maquiladoras en los años 1970 eran las empresas estadounidenses, porque desde la primera mitad de los años de esta década, la estructura de las industrias en Estados Unidos empezó a cambiar. El aumento de los salarios de los trabajadores en la industria de manufactureras era un motivo importante de las inversiones de las empresas estadounidenses fuera de su país (IWATA, 2013).

Sin embargo, esta actitud de las empresas japonesas en México cambió durante en los años 1970. El primero motivo de este cambio fue por las dos crisis del petróleo de

\footnotetext{
${ }^{11}$ Según información de La Asociación Mexicana de Parques Industriales (AMPIP), disponible en http://ampip.org.mx/es/acerca/, fecha de consulta: 8/4/2014.

${ }^{12}$ Según información de IMMEX. Disponible en http://www.index.org.mx/IMMEX/antecedentes.php, fecha de consulta: 8/4/2014.

13 Según información de IMMEX. Disponible en http://www.index.org.mx/IMMEX/antecedentes.php, fecha de consulta: 8/4/2014.
} 
esa década (TANAKA, 2012). Para las empresas japonesas que exportaban sus productos a los otros países, esta crisis obligó a cambiar sus estrategias, porque el aumento de los precios del petróleo significaba directamente un aumento del coste de transporte y un aumento de los precios finales de los productos. Aunque el valor del yen japonés era bajo, el aumento de coste no era favorable. Además, la subida de los precios de los combustibles disminuyó la venta de automóviles. Entonces, para las empresas japonesas en estas dos industrias, la subida del precio del petróleo indujo un doble problema (el aumento del coste de transporte y las posibilidades de que disminuyera la demanda de los productos) para exportar desde Japón. Por eso, las empresas japonesas en ambas industrias tenían que decidir aumentar las inversiones exteriores para fabricar en otros países más cerca de sus mercados. En este contexto, para las empresas japonesas México era un buen lugar para invertir y fabricar sus productos, porque tenía proximidad al mercado de Estados Unidos y podían bajar el coste de transporte y fabricación y así reducir el precio final de sus productos. Por eso, desde el fin de los años 1970, la IED japonesa en México empezó a aumentar. (TANAKA, 2012, pp. 152-153).

A continuación, vamos a revisar los motivos de las inversiones japonesas en América Latina según las respuestas de las encuestas que el gobierno de Japón organiza cada año a sus empresas (véanse las Tablas II-2.1, II-2.2 y II-2.3). Estas tablas indican los motivos de las empresas japonesas que invertían en América Latina. En esta década de los años 70, hubo dos países principales en América Latina en los que las empresas japonesas invirtieron: México y Brasil. Al ver solo la cantidad de las inversiones, las empresas japonesas invirtieron más en Brasil que en México. ${ }^{14}$ Por eso, su respuesta en estas listas anteriores refleja opiniones de las empresas japonesas sobre Brasil, sin embargo, podemos entender algunas características de los motivos de la inversión japonesa en la década 1970.

\footnotetext{
${ }^{14}$ Desde 1971 hasta 1979, las inversiones japonesas totales en Brasil fueron 2451 millones de dólares y en México fueron 694 millones de dólares, según información de Ministerio de finanzas del gobierno de Japón. Disponible en http://warp.da.ndl.go.jp/info:ndljp/pid/8379094/www.mof.go.jp/pri/publication/zaikin_geppo/hyou/g380/ 380.htm, fecha de consulta: 10/4/2014.
} 
Tabla II-2.1. Cinco principales motivos de las inversiones japonesas en América Latina, 1977

\begin{tabular}{|c|l|}
\hline & Motivos \\
\hline 1 & Búsqueda de mercados \\
\hline 2 & Diversificación e internacionalización de sus actividades \\
\hline 3 & Búsqueda de recursos naturales \\
\hline 4 & Políticas favorables para las actividades \\
\hline 5 & $\begin{array}{l}\text { Exportación a terceros países/ Bajo coste de salarios/ Ganancia desde } \\
\text { rendimiento }\end{array}$ \\
\hline
\end{tabular}

Fuente. Ministerio de Economía del Gobierno de Japón. 1978, Wagakuni Kigyouno kaigai jigyou Katsudou, Tokyo: Ministerio de Economía del Gobierno de Japón. p. 248. Fecha de consulta: 20/3/2013.

Tabla II-2.2. Cuatro principales motivos de las inversiones japonesas en América Latina por sectores, 1974

\begin{tabular}{|l|l|l|l|l|}
\hline & \multicolumn{1}{|c|}{$\mathbf{1}$} & \multicolumn{1}{c|}{$\mathbf{2}$} & \multicolumn{1}{c|}{$\mathbf{3}$} \\
\hline $\begin{array}{l}\text { Maquinaria } \\
\text { General }\end{array}$ & $\begin{array}{l}\text { Expansión de redes } \\
\text { de ventas }\end{array}$ & $\begin{array}{l}\text { Empeoramiento } \\
\text { condiciones para } \\
\text { exportación }\end{array}$ & $\begin{array}{l}\text { Diversificación e } \\
\text { Internacionalización } \\
\text { de sus actividades }\end{array}$ & $\begin{array}{l}\text { Aumento de } \\
\text { coste de } \\
\text { salarios }\end{array}$ \\
\hline $\begin{array}{l}\text { Maquinaria } \\
\text { Eléctrica }\end{array}$ & $\begin{array}{l}\text { Aumento de coste de } \\
\text { salarios }\end{array}$ & $\begin{array}{l}\text { Diversificación e } \\
\text { Internacionalización } \\
\text { de sus actividades }\end{array}$ & $\begin{array}{l}\text { Empeorar } \\
\text { condiciones para } \\
\text { exportación }\end{array}$ & $\begin{array}{l}\text { Expansión } \\
\text { de redes de } \\
\text { ventas }\end{array}$ \\
\hline $\begin{array}{l}\text { Maquinaria } \\
\text { de Transporte }\end{array}$ & $\begin{array}{l}\text { Diversificación e } \\
\text { Internacionalización } \\
\text { de sus actividades }\end{array}$ & $\begin{array}{l}\text { Empeoramiento } \\
\text { condiciones para } \\
\text { exportación }\end{array}$ & $\begin{array}{l}\text { Aumento de coste de } \\
\text { salarios }\end{array}$ & $\begin{array}{l}\text { Expansión } \\
\text { de redes de } \\
\text { ventas }\end{array}$ \\
\hline $\begin{array}{l}\text { Maquinaria } \\
\text { de Precisión }\end{array}$ & $\begin{array}{l}\text { Diversificación e } \\
\text { Internacionalización } \\
\text { de sus actividades }\end{array}$ & $\begin{array}{l}\text { Expansión de redes de ventas / Aumento de } \\
\text { coste de salarios }\end{array}$ & $\begin{array}{l}\text { Empeora- } \\
\text { miento de } \\
\text { condiciones } \\
\text { para } \\
\text { exportación }\end{array}$ \\
\hline
\end{tabular}

Fuente. Ministerio de Economía del Gobierno de Japón. 1975. Wagakuni Kigyouno kaigai jigyou Katsudou, Tokyo.: Ministerio de Economía el gobierno de Japón, p. 266. Fecha de consulta: 20/3/2013. 
Tabla II-2.3. Cuatro principales motivos de las inversiones japonesas en América Latina por sectores, 1978

\begin{tabular}{|l|l|l|l|l|}
\hline & \multicolumn{1}{|c|}{$\mathbf{2}$} & \multicolumn{1}{c|}{$\mathbf{2}$} & \multicolumn{1}{c|}{$\mathbf{3}$} \\
\hline $\begin{array}{l}\text { Maquinarias } \\
\text { Generales }\end{array}$ & $\begin{array}{l}\text { Búsqueda de } \\
\text { mercado }\end{array}$ & $\begin{array}{l}\text { Diversificación e Internacionalización de sus } \\
\text { actividades / Exportación a 30 países }\end{array}$ & \\
\hline $\begin{array}{l}\text { Maquinarias } \\
\text { Eléctricos }\end{array}$ & $\begin{array}{l}\text { Búsqueda de } \\
\text { mercado }\end{array}$ & $\begin{array}{l}\text { Diversificación e } \\
\text { Internacionalización } \\
\text { de sus actividades }\end{array}$ & $\begin{array}{l}\text { Aumento de coste de salarios / } \\
\text { Exportación a terceros países / } \\
\text { Políticas favorables para las } \\
\text { actividades }\end{array}$ \\
\hline $\begin{array}{l}\text { Maquinarias } \\
\text { Transportes }\end{array}$ & $\begin{array}{l}\text { Búsqueda de } \\
\text { mercado }\end{array}$ & $\begin{array}{l}\text { Políticas favorables } \\
\text { para las actividades }\end{array}$ & $\begin{array}{l}\text { Diversificación e } \\
\text { Internacionalización de sus } \\
\text { actividades /Ganancia desde } \\
\text { rendimiento }\end{array}$ \\
\hline $\begin{array}{l}\text { Maquinarias } \\
\text { Prisiones }\end{array}$ & $\begin{array}{l}\text { Búsqueda de } \\
\text { mercado }\end{array}$ & & \\
\hline
\end{tabular}

Fuentes. Ministerio de Economía del Gobierno de Japón. 1979, Wagakuni Kigyouno kaigai jigyou Katsudou, Tokyo: Ministerio de Economía del Gobierno, p. 240. Fecha de consulta: 20/3/2013

Primero, se observa que el principal motivo para invertir en América Latina es la búsqueda de mercados. Sin embargo, al ver los datos en 1974, notamos que cada industria tenía sus motivos para sus inversiones en los primeros años de 1970. Por ejemplo, las industrias de transportes tienen como motivo la "Diversificación e internacionalización de sus actividades." Esta industria de Japón ya tenía su mercado en Estados Unidos. Además, en la década de 1970, esta industria no se enfrentaba con los conflictos económicos entre el gobierno de Estados Unidos y el de Japón. Esta situación significaba que las empresas japonesas en esta industria no necesitaban trasladar sus fábricas a México en esta década. En esta situación, para ellas, las inversiones en México eran para aumentar su opción de diversificar mercados y nada más. Por eso, su primero motivo de las inversiones en América Latina era "diversificación de las actividades." Al contrario, las inversiones eléctricas japonesas estaban en otra situación. Su primero motivo era el “aumento de costes de salarios." En la década 70, las empresas japonesas eléctricas, especialmente, en las industrias de televisores y otros electrodomésticos ya tenían que trasladar sus fábricas. En esta situación, el "aumento del coste de salarios" afectaba no solo en Japón, sino también en Estados Unidos. Para las empresas japonesas que 
invirtieron en México, el aumento del coste de salarios era un motivo importante. Además, su segundo motivo "Diversificación e Internacionalización de sus actividades" tenía sentido. Esta industria japonesa tenía mercado en todo el mundo, no solo en Estados Unidos, también en los países europeos y asiáticos. Por eso, invertir en América Latina era una manera para aumentar sus opciones. Como hemos analizado, los resultados de las encuestas del año 1974 son diferentes, dependiendo de la industria.

Sin embargo, en las encuestas de los años 1977 y 1978, se puede encontrar una característica clara. Casi todas industrias tenían un mismo motivo para invertir a América Latina: la "búsqueda de mercado." Una razón de este cambio de motivo de las inversiones en América Latina era el desarrollo de la economía mexicana. Como se ha comentado anteriormente, el boom de la economía mexicana siguió desde los años 1960. No solo en México, Brasil también estaba en boom económico. En esta situación, las empresas japonesas empezaron a considerar a los países América Latina como mercados que tenían posibilidades

A modo de balance de lo planteado en este epígrafe, las inversiones japonesas en México de los años 60 y 70 eran muy tímidas y no eran tan significativas dentro de la economía mexicana. Además, la relación entre las economías de Japón y México era fruto de la relación entre Japón y Estados Unidos. Por eso, no hubo tantas empresas japonesas invirtiendo en México en estas dos décadas. Sin embargo, podemos encontrar una primera clave de las inversiones japonesas en México en estas dos décadas, la que se relaciona con la política de promover las inversiones de las industrias de manufactureras a través del Programa de Maquiladora. A pesar de eso, tenemos que decir que en estas dos décadas las inversiones japonesas en México dependieron de las condiciones económicas mundiales y de Estados Unidos, además del crecimiento de México. 


\section{II-3. Cambios en el marco legal y llegada de las PYMEs japonesas a México: los años 1980}

En la sección anterior se ha mostrado que las inversiones japonesas en las décadas de 60 y 70 no fueron tan significativas para la economía mexicana. Sin embargo, en los 1980, esta situación cambió drásticamente. Hubo varios motivos de los cambios de las condiciones y las situaciones de las empresas japonesas en México. En esta sección se analizan los cambios de estrategia de esas inversiones japonesas en México y sus motivos.

Después de las dos crisis del petróleo de los años 1970, las empresas japonesas aumentaron sus inversiones exteriores (véase el Gráfico II-3.1). Las inversiones exteriores japonesas totales tuvieron un gran aumento en los años 1980. Las inversiones en México no fueron una excepción a esta tendencia. Hay dos tipos de motivos del aumento de las inversiones japonesas en México en esa década: los motivos que vienen de la situación dentro de Japón y los motivos que vienen de fuera de Japón. Podemos encontrar influencias múltiples entre los dos motivos.

Gráfico II-3. 1. Inversiones japonesas en todo el mundo 1975-1996 e inversiones japonesas en México, 1980-1993

(En millones de dólares de Estados Unidos)

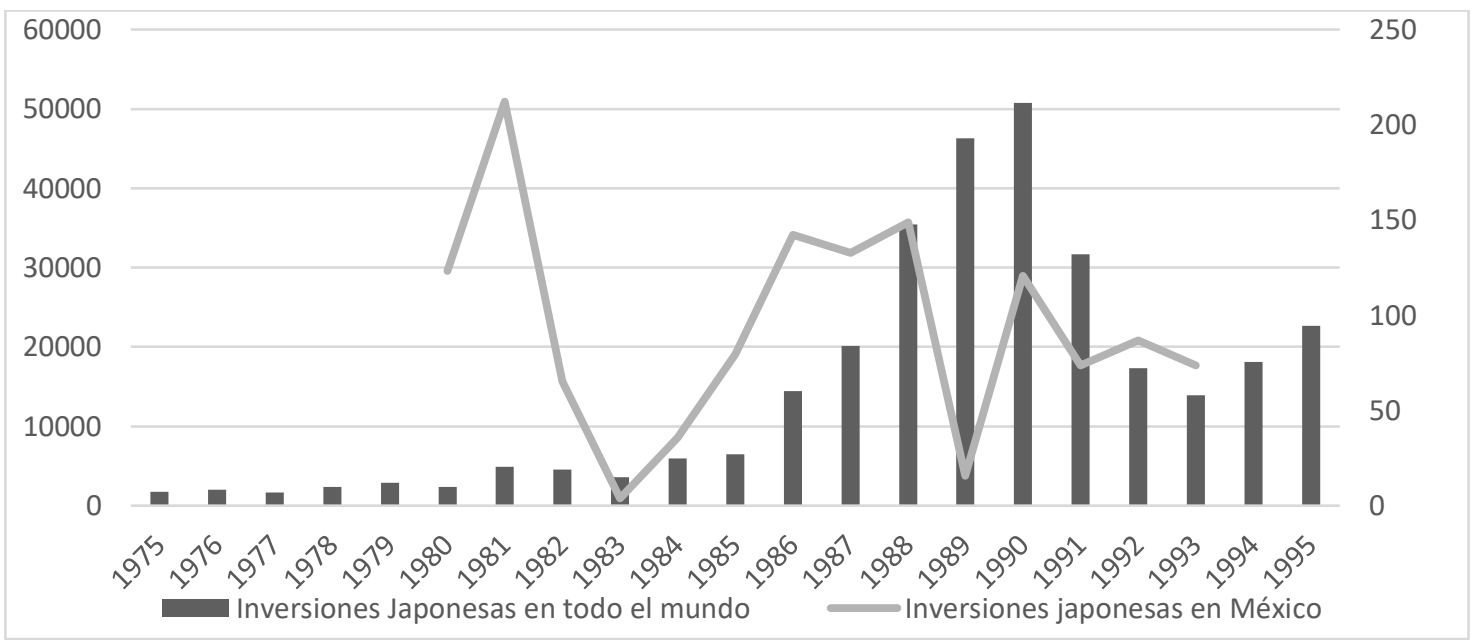

Fuente. Elaboración propia a partir de UNCTAD, disponible en http://unctadstat.unctad.org/wds/TableViewer/tableView.aspx; y de Secretaría de Economía, el Gobierno de México, disponible en https://datos.gob.mx/busca/dataset/inversion-extranjeradirecta/resource/cca9e797-29d7-4daf-802d-e038d297ece6, fecha de consulta26/2/2014.

El primer motivo del aumento de las inversiones japonesas en México en los 80 era el boom económico en Japón (véase el Gráfico II-3.2) (CHAKRABORTY, 2009), con 
un fuerte crecimiento del PIB per cápita. Por eso, era muy natural que hubiera un aumento de las inversiones japonesas en el todo el mundo durante dicha década. Además, al tener en cuenta la balanza por cuente corriente de Japón, se nota que el saldo fue positivo y creciente, especialmente hasta 1986 (véase el Grafico II-3.3). Uno de los motivos del boom en Japón en esta década fue una combinación entre el bajo valor del yen japonés y el alto valor del dólar estadounidense (TAKANAKA, 2001; SUZUKI, 2013).

Como hemos visto anteriormente, desde el fin de los años 70, la economía de Estados Unidos estaba en recesión. En la primera parte de los años 80, Estados Unidos tenía dos déficits en su economía (los llamados "déficits gemelos"): uno era el déficit en la balanza de cuenta corriente y el otro era el déficit en la balanza presupuestaria del gobierno (SATO, 1994). La economía estadounidense estaba perdiendo competitividad, no solo en su comercio exterior sino también en sus cuentas públicas.

\section{Gráfico II-3.2. PIB Per Cápita de Japón, 1975-1989}

(En Dólares de Estados Unidos)

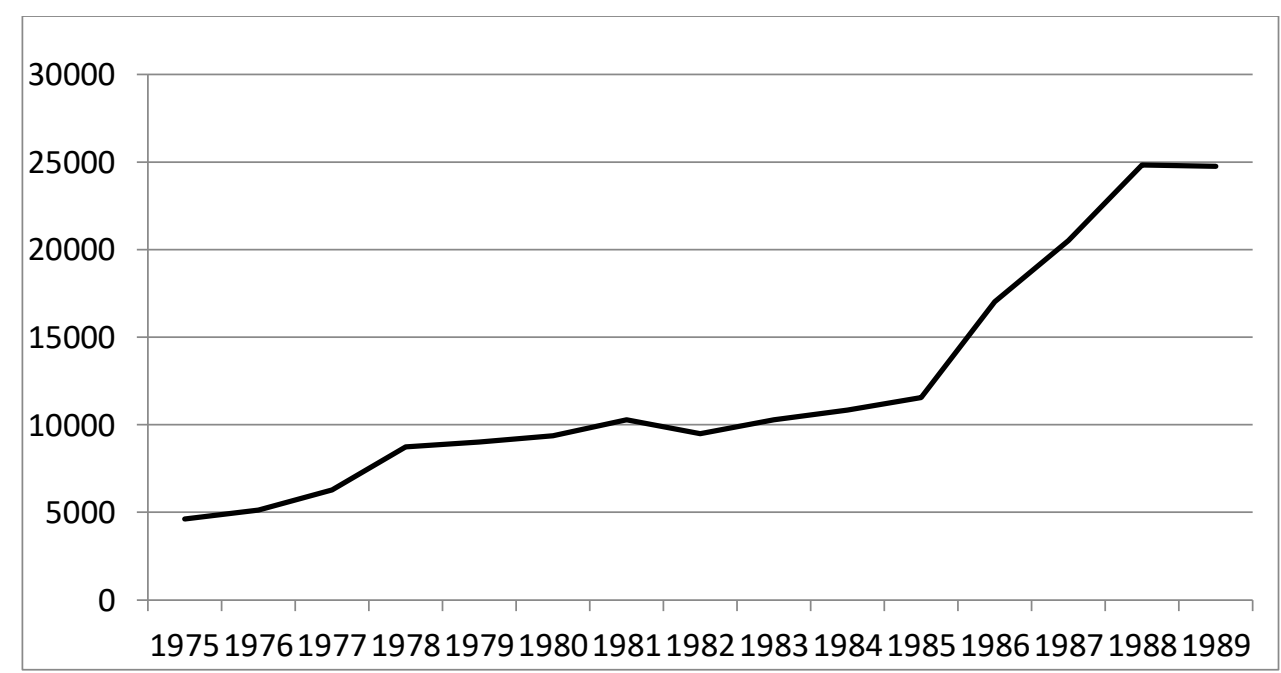

Fuente. Elaboración propia a partir de UNCTAD

http://unctadstat.unctad.org/wds/TableViewer/downloadPrompt.aspx , fecha de consulta 15/6/2015. 
Gráfico II-3.3. Saldo de la balanza por cuenta corriente de Japón, 1980-1990 (En millones de Dólares de Estados Unidos)

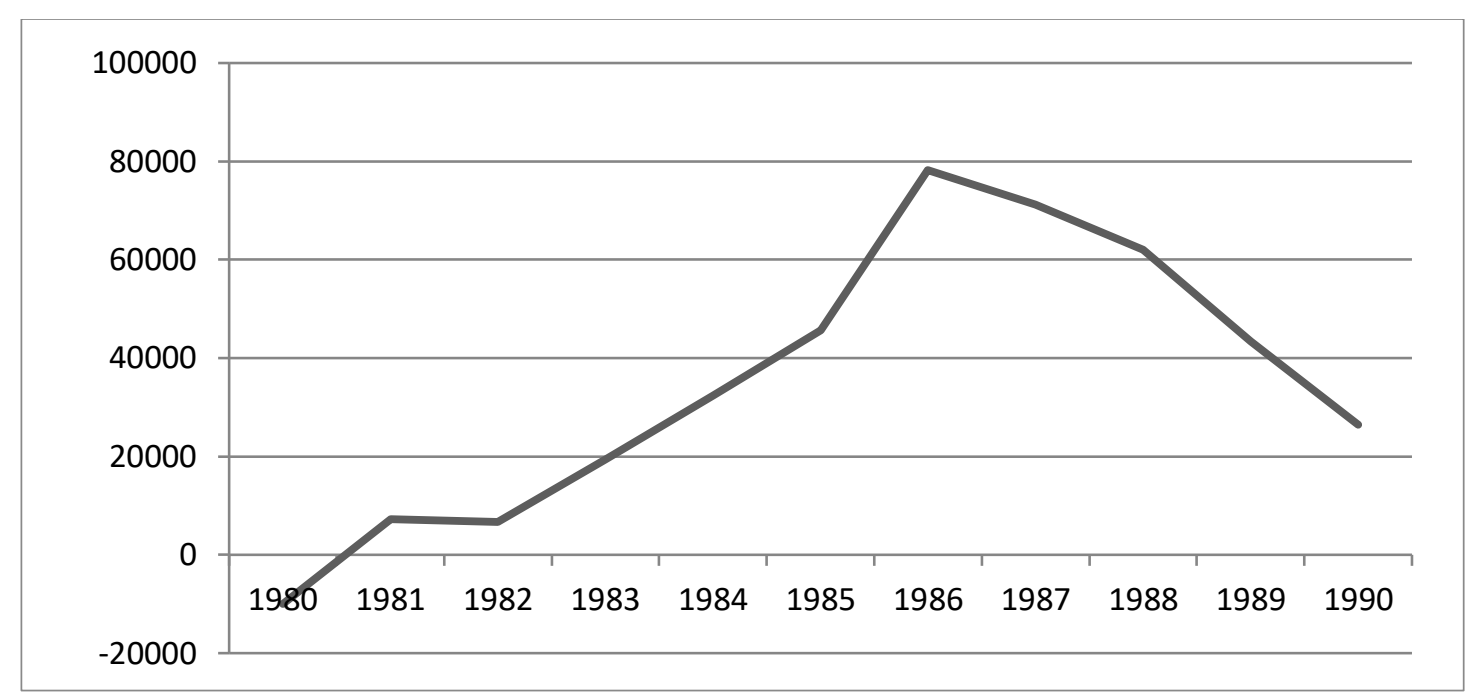

Fuente. Elaboración propia a partir de UNCTAD,

http://unctadstat.unctad.org/wds/TableViewer/tableView.aspx, fecha de consulta 15/6/2015.:

Un motivo de los déficits gemelos de Estados Unidos en los 80 era la pérdida de competitividad de sus empresas y sus industrias en la economía mundial (TAKANAKA, 2001, p.47). Además, el boom económico en Japón se relacionó con la pérdida de influencia de la economía estadounidenses en los años 1980.

En esta década, las industrias manufactureras de Estados Unidos perdieron productividad y salieron de los mercados mundiales, especialmente, las industrias de manufacturas que tenían menos desarrollo que las empresas japonesas en la misma industria. Por ejemplo, hasta la década anterior, México había sido un lugar para las empresas de televisores de Estados Unidos. Sin embargo, después de la competencia con sus rivales japoneses y europeos, las empresas estadounidenses de electrodomésticos perdieron capacidad para competir. Por ejemplo, RCA y General Electric vendieron sus fábricas a Thompson, que es una empresa francesa. PHILIPS, empresa holandesa adquirió las marcas Sylvania y Magnavox. Matsushita compró Quasar. LG Electronics compró las operaciones de Zenit (CARRILLO Y CONTRERAS, 2005). Al final, las empresas estadounidenses de televisores desaparecieron. Este caso de las empresas de televisores de Estados Unidos es un ejemplo. Las empresas extranjeras (desde el punto de vista de las empresas estadounidenses) que tenían mayor capacidad de desarrollo tecnológico y 
de gestión de la producción (por ejemplo, a través del just-in-time) y que empezaron a dominar en el mercado mundial en la década de 80, eran las empresas japonesas (ALONSO, CARRILLO y CONTRERAS, 2000). Por eso, las empresas manufactureras tradicionales de Estados Unidos perdieron sus actividades, siendo desplazadas por las empresas de otros países.

Los problemas derivados de la recesión y de las condiciones de las industrias manufactureras de Estados Unidos fueron motivos importantes para el aumento de las inversiones japonesas en México en los años 80. Primero, para retirar sus actividades desde México, las empresas estadounidenses tuvieron que vender sus fábricas en México (CARRILLO Y CONTRERAS, 2005, p. 280-283). Las empresas japonesas compraron sus fábricas y eso redujo sus costes iniciales para establecer sus fábricas en México. Es decir que las empresas japonesas no necesitaron construir sus fábricas en México. La retirada de las empresas estadounidenses desde México fue un motivo del aumento de las inversiones japonesas en México.

Otro motivo del aumento de las inversiones japonesas en México, fue el cambio de la ley del programa de la industria maquiladora. En los años 1970 hubo una limitación de la participación de las capitales extranjeras en las empresas mexicanas: las capitales extranjeras solo podían participar hasta 49\% de las acciones (DUSSEL PETERS, 2000, p. 11). Sin embargo, en febrero de 1984, las empresas extranjeras pudieron aumentar sus participaciones hasta el $100 \%$ de sus empresas en México (CARRILLO, MORTIMORE y ESTRADA, 1998). Es decir, la Comisión Nacional de Inversiones Extranjeras (CNIE) del gobierno de México decidió y anunció que de acuerdo con la nueva ley, la inversión extranjera podía ser mayoritaria y llegar hasta el $100 \%{ }^{15}$. El gobierno México tenía un motivo importante por este cambio de la Ley para Promover la Inversión Mexicana y Regular la Inversión: era el de diversificar los orígenes de las inversiones extranjeras. ${ }^{16}$

\footnotetext{
${ }^{15}$ Página Web de Miguel de la Madrid Hurtado, disponible en http://www.mmh.org.mx/showbookcambio.php?book=Segundo, fecha de consulta: 09/10/2014. ${ }^{16}$ Página Web de Miguel de la Madrid Hurtado, disponible en http://www.mmh.org.mx/showbookcambio.php?book=Segundo, fecha de consulta: 09/10/2014.
} 
Históricamente, Estados Unidos era (o, más correcto, es) el mayor inversor en México $^{17}$. Además, México tenía la experiencia con los capitales estadounidenses de corto plazo que se retiraron cuando ocurrió la crisis de la deuda externa. Esta experiencia enseñó la necesidad de multiplicar los orígenes de las inversiones y la búsqueda de inversiones estables como las inversiones directas. Tras el estallido de la crisis de la deuda externa en 1982, el gobierno mexicano quería aumentar su productividad y su exportación rápidamente. Es decir, en el fondo de este cambio de la Ley de Maquiladora se pueden encontrar los efectos del "Consenso de Washington" (GUILLÉN, 2012).

Después de la crisis de la deuda externa, el gobierno de México tenía que cambiar sus políticas industriales, desde la industrialización sustitutiva de importaciones a la industrialización orientada a las exportaciones (DELGADILLO ESCOBAR y JIMÉNEZ RIVERA, 2008). Sin embargo, en esta década, no había empresas mexicanas que tuvieran capacidad para exportar sus productos a otros países y ganar divisas porque en la economía mexicana, las empresas extranjeras habían invertido para producir para el mercado interno (primero, las empresas estadounidenses y luego, las japonesas y europeas). Además, por la política de sustitución de importaciones, las empresas mexicanas no habían tenido oportunidades para ganar capacidades para competir en el exterior y para llevar sus productos a otros países (FITZGERALD, 1998). En esta situación, para obtener ganancias a través de las exportaciones, el gobierno de México tenía que depender de las empresas extranjeras. La eliminación de la limitación de las participaciones de los capitales extranjeros era una manera para aumentar la exportación desde México.

Cualquiera que fuera el motivo del gobierno de México, este cambio de la Ley de las participaciones de los capitales extranjeros era un buen motivo para aumentar las inversiones japonesas. Por eso, casi al mismo tiempo del cambio de la ley de la participación de los capitales extranjeros, se produjo un nuevo tipo de inversión japonesa. Los proveedores japoneses, la mayor parte de ellos pequeñas y medianas empresas (PYMEs), se trasladaron a México. Este traslado de las PYMEs japonesas era una forma

\footnotetext{
${ }^{17}$ Información de "Inversión Extranjera Directa", la Secretaría de Economía, Gobierno de México. http://www.economia.gob.mx/files/comunidad_negocios/ied/analisis_publicaciones/Otros\%20estudios/ca rpeta_informacion_estadistica_1115.pdf, fecha de consulta: 26/02/2016.
} 
de internacionalización de la industria manufacturera japonesa, porque las empresas gigantes japonesas apoyaron al invitar a sus proveedores a México (STURGEON, 2002; DING, 2015). Esta tendencia era general en América Latina, no solo en México. Si observamos el número de empresas japonesas en América Latina clasificadas por el número de sus trabajadores, notamos que las empresas que tenían entre 1 y 99 trabajadores invirtieron en América Latina. Esto significa que las empresas pequeñas avanzaron a América Latina más que las “grandes” (véase el Gráfico II-3. 4).

Gráficos II-3. 4. Tamaño de las empresas japonesas que invierten en América Latina, 1980 у 1984

(Número de trabajadores)

1). Industria de maquinarias generales

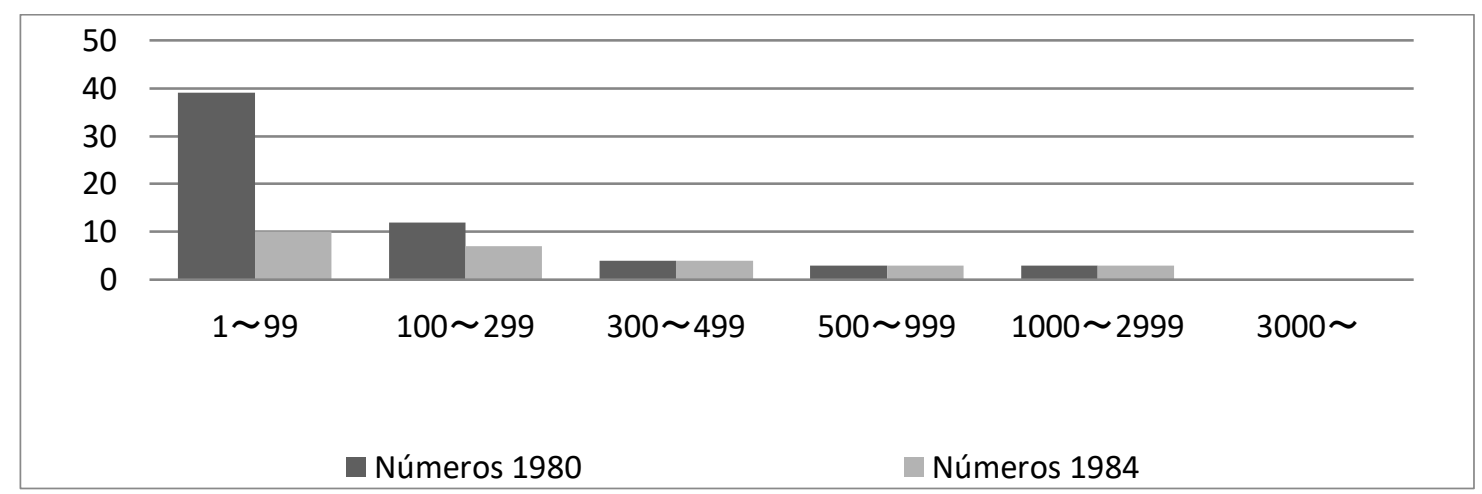

Fuente. Ministerio de Economía, Negocio e Industria del Gobierno de Japón. 1981 y 1985. Wagakuni Kigyouno Kaigai Jigyou Katsudou, Tokyo: Ministerio de Economía Negocio e Industria del gobierno de Japón.

\section{2). Industria eléctrica}

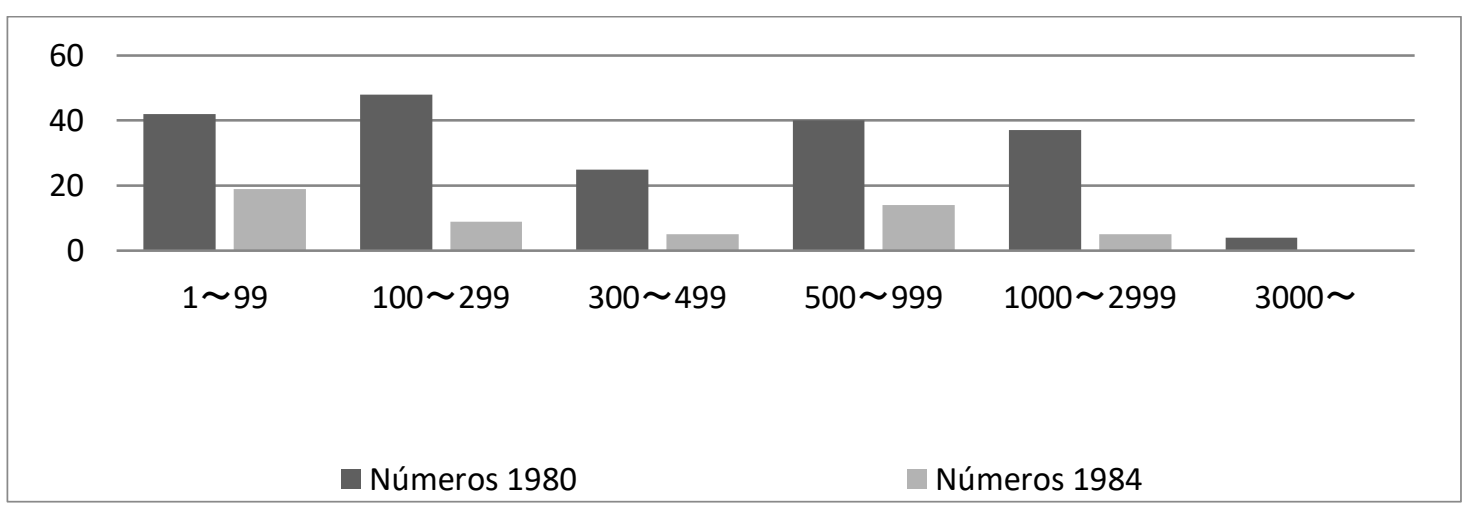

Fuente. Ministerio de Economía, Negocio e Industria del Gobierno de Japón. 1981 y 1985.

Wagakuni Kigyouno Kaigai Jigyou Katsudou, Tokyo: Ministerio de Economía, Negocio e Industria del gobierno de Japón 


\section{3). Industria de transportes}

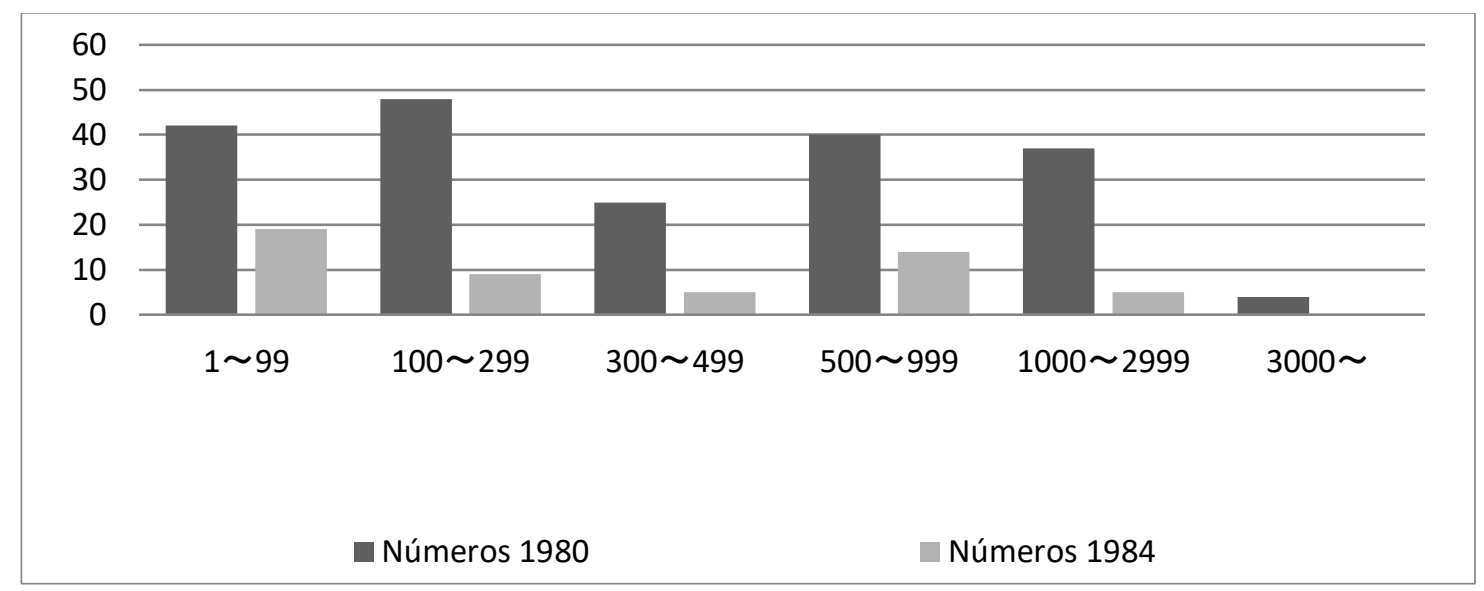

Fuente. Ministerio de Economía, Negocio e Industria del Gobierno de Japón. 1981 y1985. Wagakuni Kigyouno Kaigai Jigyou Katsudou, Tokyo: Ministerio de Economía, Negocio e Industria del gobierno de Japón

\section{4). Industria de presión}

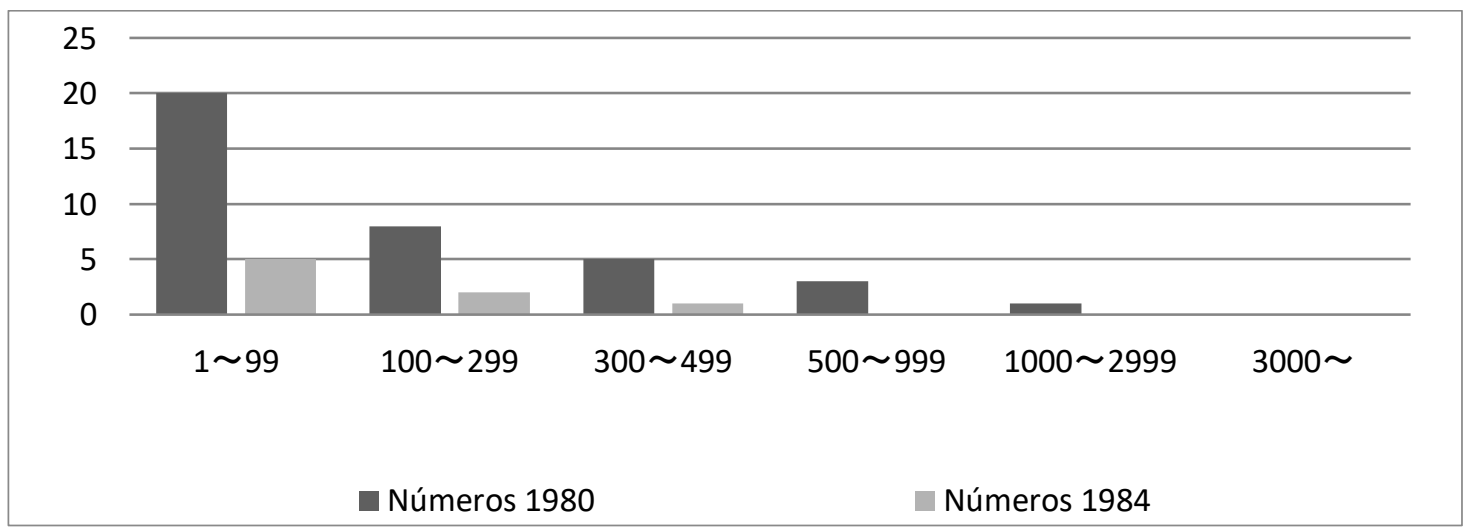

Fuente. Ministerio de Economía, Negocio e Industria del Gobierno de Japón. 1981 y 1985.

Wagakuni Kigyouno Kaigai Jigyou Katsudou, Tokyo: Ministerio de Economía, Negocio e Industria del gobierno de Japón

Históricamente, en las empresas japonesas las relaciones entre las empresas gigantes y sus proveedores son muy fuertes. Las empresas grandes esperan que sus proveedores fabriquen piezas con alta calidad y en el momento preciso. El "KANBAN" o "justo a tiempo (just-in-time)" es un símbolo de la gestión de las empresas japonesas, pero lo que es importante es que los proveedores deben tener capacidad para fabricar las cosas que las empresas patronales quieren (SAKAKIBARA, FLYNN y SCHROEDER, 1997). Los proveedores que tienen capacidad pueden recibir contratos de largo plazo. Por 
eso, las empresas japonesas multinacionales tenían que llevar a México a sus proveedores. Buscar nuevos proveedores en México era muy costoso para las empresas gigantes japonesas. Este coste no solo era problema de dinero, sino problema de tiempo y de adecuación de los proveedores mexicanos a las necesidades de las formas modernas de producir en Japón. En esta situación, las empresas internacionales de Japón llevaron a sus proveedores a México. Para las actividades de sus proveedores, las empresas gigantes japonesas establecen sus filiales en México y sus proveedores también establecieron sus filiales en México. Para hacer este tipo de actividad, la nueva ley de la Maquiladora que permitía participaciones del $100 \%$ de los capitales extranjeros era muy adecuada. Esto era otra evidencia de que el cambio de la ley de maquiladora indujo el aumento de las empresas japonesas.

Además, el aumento de los proveedores japoneses en México significaba otra cosa. Las empresas japonesas consideraban el papel de México dentro de sus actividades como un lugar para "fabricar" sus productos, no solo como un lugar para "vender" sus productos (TOKORO, 2006). Hasta la década 1970, las empresas japonesas que habían invertido a México habían considerado que México era un mercado. En el fondo de sus perspectivas sobre México, estaba el boom económico en México y la esperanza de desarrollo económico, como se ha analizado anteriormente. Sin embargo, desde esta década, después de la crisis de la deuda externa de 1982, el papel que las empresas japonesas esperaron de México empezó a cambiar. Por eso, las empresas japonesas gigantes en las industrias de las manufacturas llevaron sus proveedores japoneses para fabricar sus productos con alta calidad y precio ajustado en México (DING, 2015, pp.18-19). Por eso, para ellas, el cambio de la Ley en 1984 era motivo importante para aumentar sus inversiones en México.

Otro motivo del aumento de la IED japonesa en México en los 1980, se puede encontrar en los efectos del "Acuerdo del Plaza" en 1985 (TOKORO, 2006, pp. 57-59). En el Acuerdo del Plaza, el Yen japonés se valoró más alto que antes (Gráfico II-3.5). En esta situación el gobierno de Estados Unidos, quien había dirigido este acuerdo, pensaba que era muy favorable para equilibrar la balanza por cuenta corriente de Estados Unidos. Por el contrario, las empresas japonesas que tenían exportaciones desde Japón tenían problemas muy serios porque el alto valor de yen tenía posibilidad de reducir la 
exportación de los productos japoneses. La reducción de las exportaciones japonesas era muy favorable al gobierno de Estados Unidos para proteger sus industrias. Sin embargo, para las empresas japonesas, esta situación significaba que había necesidad de un cambio de sus estrategias: desde las exportaciones desde Japón a la fabricación en otros países. Por eso, el acuerdo de Plaza es otro motivo del aumento de las inversiones japonesas en México.

Gráfico II-3. 5. Tipo de cambo de yen-dólares de Estados Unidos, 1980-1990 (Yenes por dólar)

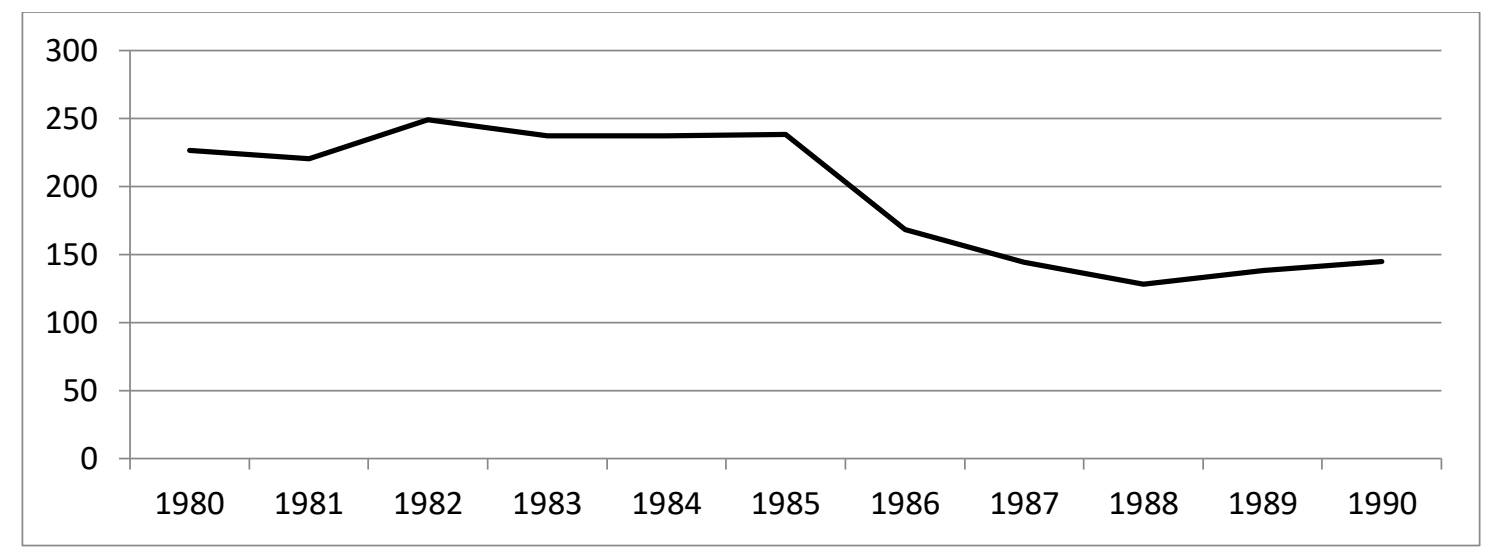

Fuente. Elaboración propia a partir de Principal Global Indicaste.

http://www.principalglobalindicators.org/Pages/Default.aspx, fecha de consulta: 16/6/2015.

El boom económico en Japón, la crisis de las industrias de manufacturas en Estados Unidos y el Acuerdo del Plaza fueron las tres principales razones para la internacionalización de las empresas japonesas y el aumento de las inversiones japonesas en la década de 80 . Además, en la primera parte de las 80 , después de la crisis de la deuda, por la devaluación del peso mexicano, los salarios en México estaban bajando relativamente. Este menor precio de los salarios en México fue otro motivo del aumento de las inversiones japonesas en los años 80 (KIMINO, SAAL y DRIFFIELD, 2007).

Como hemos visto, podemos encontrar varios motivos del aumento de las inversiones japonesas en México: el cambio de ley de las participaciones de los capitales extranjeros en la maquiladora, el boom económico en Japón, el bajo salario en México y la situación del mercado estadounidense. Aunque Estados Unidos estaba en recesión en el principio de los años 1980, su población tenía capacidad para consumir. 
En la segunda mitad de los 80, las empresas japonesas encontraron otro motivo para invertir: el inicio de la negociación del Tratado de Libre Comercio América del Norte (TLCAN). Cuando estas conversaciones empezaron las empresas japonesas ya habían aumentado sus inversiones en México.

Para las empresas japonesas, las negociaciones para el TLCAN eran un motivo importante para invertir en México, porque consideraban que a través del TLCAN el acceso al mercado de Estados Unidos sería más fácil (SASANAMI y KAWAI, 1998). Sin embargo, en el TLCAN hubo una condición muy sensible para las empresas japonesas: las reglas de origen. Una ventaja del Tratado de Libre Comercio era que se podía establecer aranceles comunes para los productos que se fabricaran fuera de los países de los miembros. Por eso, se necesitaba una definición de "qué producto está fabricado dentro de los países miembros." Es decir, en el caso de TLCAN, se necesita la definición de "fabricado en los países norteamericanos (made in North America)." Especialmente, las empresas japonesas que inviertían en México estaban en la industria de manufactureras y su objetivo principal era la exportación a Estados Unidos. Por eso, las reglas de origen fueron factores decisivos para sus actividades.

En los artículos del TLCAN, los productos principales de las empresas japonesas en México tenían sus reglas de origen. La mayor parte de sus reglas de origen estaban basadas en los precios de los valores añadidos de los productos. Por ejemplo, las empresas de televisores tenían que producir al menos $60 \%$ del valor añadido de los productos dentro de los países de miembros. ${ }^{18} \mathrm{El}$ caso de la industria de automóviles, principalmente, al menos el 50\% de valores añadidos debía proceder de los países miembros. ${ }^{19}$ Sin embargo, en las industrias más importante para las empresas japonesas, especialmente en la industria de automóviles, electrodomésticos y aparatos eléctricos, esta condición significaba que los productos importantes, que son aparatos caros, tenían que fabricarse en los países miembros de TLCAN, con colaboraciones de sus proveedores, las PYMEs japonesas en México.

\footnotetext{
${ }^{18}$ Sistema de Información Sobre Comercio Exterior. http://www.sice.oas.org/trade/nafta_s/indice1.asp, fecha de consulta 13/12/2014.

${ }^{19}$ Sistema de Información Sobre Comercio Exterior. http://www.sice.oas.org/trade/nafta_s/indice1.asp, fecha de consulta 13/12/2014.
} 
Las industrias japonesas que invirtieron en México tenían una característica: eran manufactureras que necesitaban varios tipos de proveedores para fabricar los productos finales. Es decir, para fabricar productos finales, se necesitaban varios niveles y tipos de proveedores (BUENO y SARAVÍ, 1997). Sin embargo, estos proveedores deberían satisfacer los estándares de calidad de las empresas grandes. Por eso, para las empresas japonesas, buscar nuevos proveedores en los países donde no tenían ningún conocimiento era muy costoso. Para evitar o eliminar este tipo de costes de ajuste, las empresas japonesas grandes llevaron sus proveedores japoneses a México. Por estos motivos, en la década de 80, las PYMEs japonesas aumentaron en México.

En la jerarquía de las empresas japonesas, el tamaño de las empresas marca sus actividades. Por ejemplo, las empresas gigantes se encargan del diseño y la fabricación de los productos finales y de su marketing. Las PYMEs se encargan de la fabricación de partes y productos semi-finales (BUENO y SARAVÍ, 1997, pp. 13-16). Además, cada empresa tiene que controlar a sus proveedores. Es decir, los primeros proveedores controlan a los segundos proveedores y los segundos proveedores controlan a los terceros proveedores (véase la Ilustración II-3.1) (LÓPEZ y SOLER, 1993). En esta situación, los proveedores se pueden concentrar en el proceso de fabricación, porque sus empresas clientes multinacionales se encargan del marketing de sus productos. Esto es un ejemplo de los motivos de la alta competitividad de las PYMEs japonesas. El traslado de las PYMEs japonesas a México significaba que las empresas japonesas de manufacturas llevaron estas redes a México. En este contexto, satisfacer las reglas de origen del TLCAN no era complicado para las empresas japonesas: seguir fabricando sus productos contando con sus proveedores japoneses en México era la mejor respuesta de éstos al TLCAN. Además, generalmente, los contratos en Japón entre proveedores y sus empresas clientes multinacionales eran de largo plazo. Esta condición era otro motivo por el que las empresas japonesas pudieron traer a sus proveedores a México. 
Ilustración II-3. 1. Ejemplo de jerarquía de empresas japonesas en la industria de manufacturas

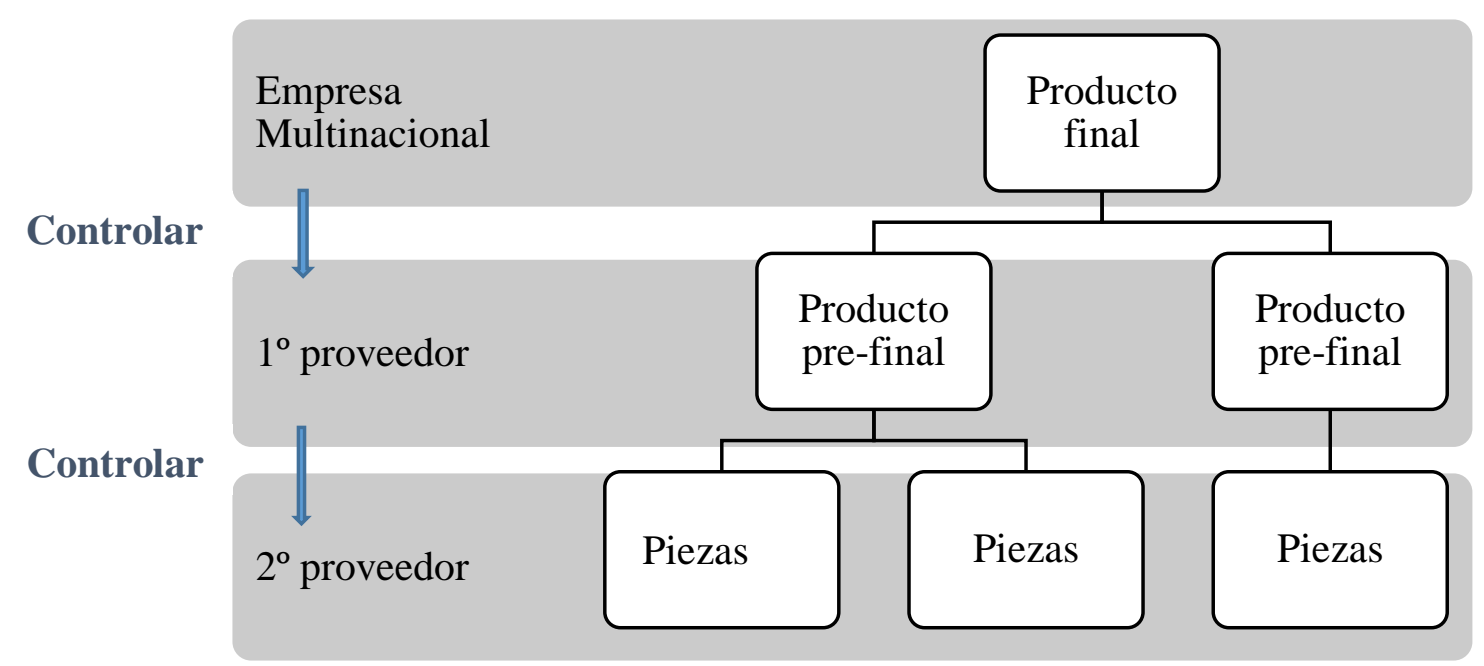

Fuente: Elaboración propia.

Se ha analizado que la relación entre las reglas de origen del TLCAN y las PYMEs japonesas fue otro motivo del aumento de las inversiones japonesas en México en la segunda mitad de la década 80. Como notamos anteriormente (véase el Gráfico II3. 2.) en la segunda mitad de los 80 , el aumento de las inversiones japonesas en México fue muy destacado.

Como se ha analizado hasta esta parte, en la década de 80, hubo varios motivos del aumento de las inversiones japonesas en México. Algunos motivos vinieron de las condiciones dentro de Japón y otros motivos vinieron de México y Estados Unidos. Las empresas japonesas consideraban a México como un lugar adecuado para sus inversiones en los 80, a pesar del terremoto de México en 1985 y de la crisis de la deuda externa.

Además, se puede decir que el aumento de las PYMEs japonesas decidió el papel de México desde el punto de la vista de las empresas japonesas. Es decir, México era un lugar para fabricar sus productos, no solo para vender. Las empresas japonesas tenían experiencias en la década de las políticas de la industrialización por sustitución de importaciones en los años 1960-70. Sin embargo, como hemos analizado en la sección anterior, bajo esta política en México las principales industrias japonesas no pudieron avanzar sus actividades con sus proveedores japoneses. Para las empresas japonesas de 
las industrias de automóviles y electrodomésticos, fabricar productos sin los proveedores de calidad significa que no podían asegurar las calidades de los productos. Especialmente, en la industria de automóviles, la calidad de los productos, a veces, significaba seguridad de los productos. Por eso, contar con proveedores creíbles era muy importante para las empresas japonesas. Antes de 1983, por la limitación de la participación de los capitales extranjeros, las empresas japonesas que habían avanzado en México, no pudieron fabricar productos como ellos querían.

Sin embargo, después de eliminar la limitación, las inversiones japonesas aumentaron. Los avances de PYMEs japonesas eran un motivo del aumento de las inversiones japonesas y eran un factor importante al decidir el papel de México, como "fabricante" para el mercado de Estados Unidos.

Generalmente, en la década de 80, las empresas japonesas fijaron el papel de México. Hubo varios motivos que empujaron los aumentos de sus inversiones, pero el mayor motivo fue la política mexicana de apertura a los capitales extranjeros. Además, el aumento de las inversiones japonesas de PYMEs, también, fijó el papel de México como país donde fabricar. 


\section{II-4. Inversiones japonesas en México tras el Tratado de Libre Comercio de América del Norte: los años 1990}

En la década de los 90, la firma del TLCAN entre Canadá, Estados Unidos y México en 1992 impulsó la expansión de las inversiones japonesas en México. Como se observa en el Gráfico II-4.1, las inversiones japonesas aumentaron desde 1994. Posteriormente, se redujeron en 1995 por la crisis mexicana, pero el nivel alcanzado para el resto de los años de la década es mayor que el existente para antes de 1993. La entrada en vigor del TLCAN el 1 de enero de 1994 fue el primer motivo de las inversiones japonesas en México en los años $1990^{20}$.

Como hemos analizado en la sección anterior, en los años 1980 el gobierno de México eliminó las limitaciones a las inversiones extranjeras. En la década 1990, nuevamente, el gobierno mexicano modificó su legislación en torno a las inversiones extranjeras debido a la entrada en vigor del TLCAN. El objeto principal de esta modificación fue desregular los flujos de IED a nivel internacional con la intención de vincular el comercio internacional con los flujos de IED (DUSSEL PETERS, 2000, p. 16). Por esta razón, en la Ley de Inversión Extranjera del 27 de diciembre de 1993, las inversiones extranjeras podían establecerse en México sin limitación alguna en cuanto a su ubicación. Antes de esta Ley, se había promovido la IED únicamente fuera de las zonas industriales de Ciudad de México, Guadalajara y Monterrey (DUSSEL PETERS, 2000, p. 17). Tras los cambios de la Ley en 1993, las empresas extranjeras podían tener sus filiales donde quisieran dentro del territorio de México.

En los primeros años posteriores a la modificación de la Ley, las empresas japonesas en México no dieron mucha importancia a esta modificación, porque sus inversiones estaban concentradas en la zona de las maquiladoras. Sin embargo, desde la segunda mitad de los 1990 hasta hoy, esta modificación legislativa ha tenido relevancia para sus estrategias y actividades.

\footnotetext{
${ }^{20}$ Se ha analizado el TLCAN en el Capítulo I.
} 
Gráfico II-4. 1. Inversiones japonesas en México, 1990-1998

(En millones de dólares)

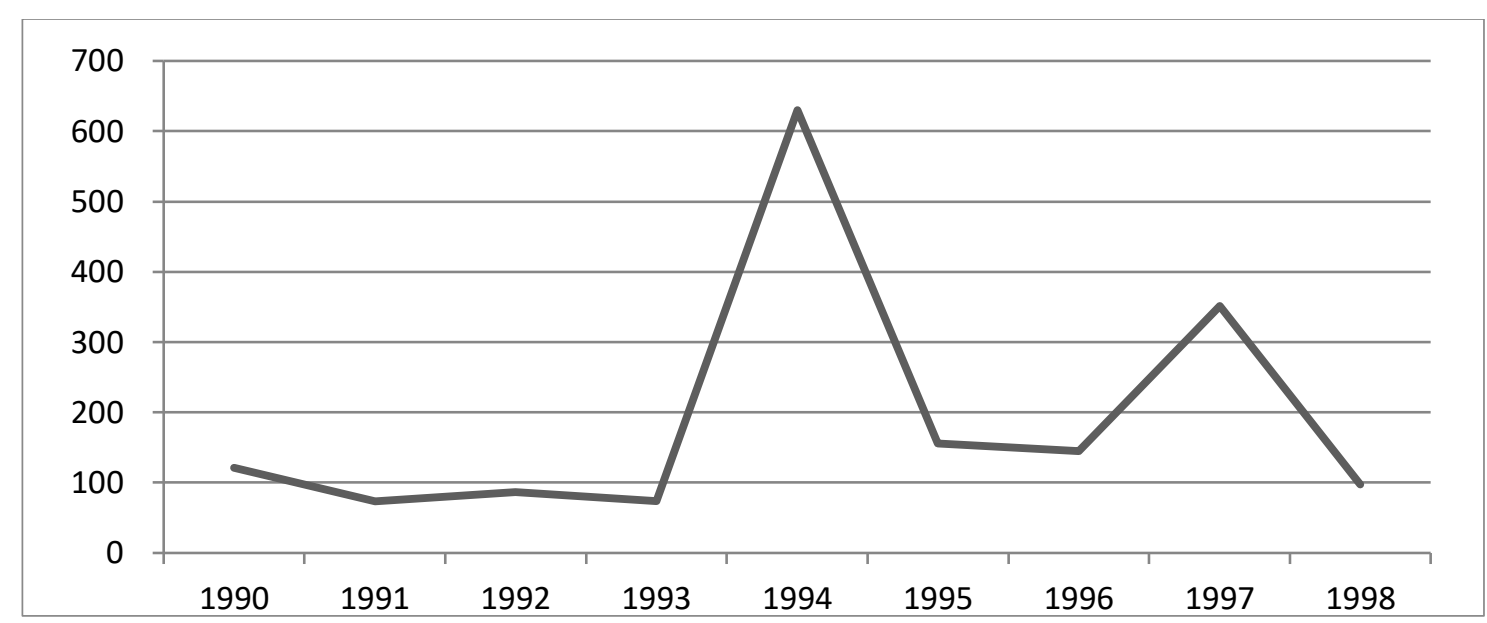

Fuente. Elaboración propia a partir de informaciones de Secretaría de Economía, el Gobierno de México, disponible en http://www.economia.gob.mx/comunidad-negocios/competitividadnormatividad/inversion-extranjera-directa/estadistica-oficial-de-ied-en-mexico, fecha de consulta: $7 / 8 / 2014$

El segundo motivo de las inversiones japonesas en los años 1990 fue la situación económica en Estados Unidos. La economía estadounidense tenía algunos años de recesión desde los años 1980. Sin embargo, se empezó a recuperar a partir de marzo de 1991 y, al final, casi en todos los años de la década de los 90, la economía estadounidense disfrutó de una importante expansión (FRANKEL y ORSZAG, 2002). Este boom de la economía en Estados Unidos era motivo suficiente para las inversiones japonesas en México (MEJÍA REYES, GUTIÉRREZ ALVA y FARÍAS SILVA, 2006). Como muestra el Gráfico II-4.2, las empresas japonesas en México aumentaron rápidamente sus exportaciones a Estados Unidos en la primera mitad de los años 1990. Dependiendo de la industria, este aumento fue diferente. Es destacable el incremento de las exportaciones de las industrias de automóviles, máquinas generales, máquinas de telecomunicaciones y otras industrias manufactureras. 
Gráfico II-4. 2. Actividad productiva de las empresas japonesas en México: el peso de la exportación sobre la producción de principales exportados, 1990-1999

(En porcentaje)

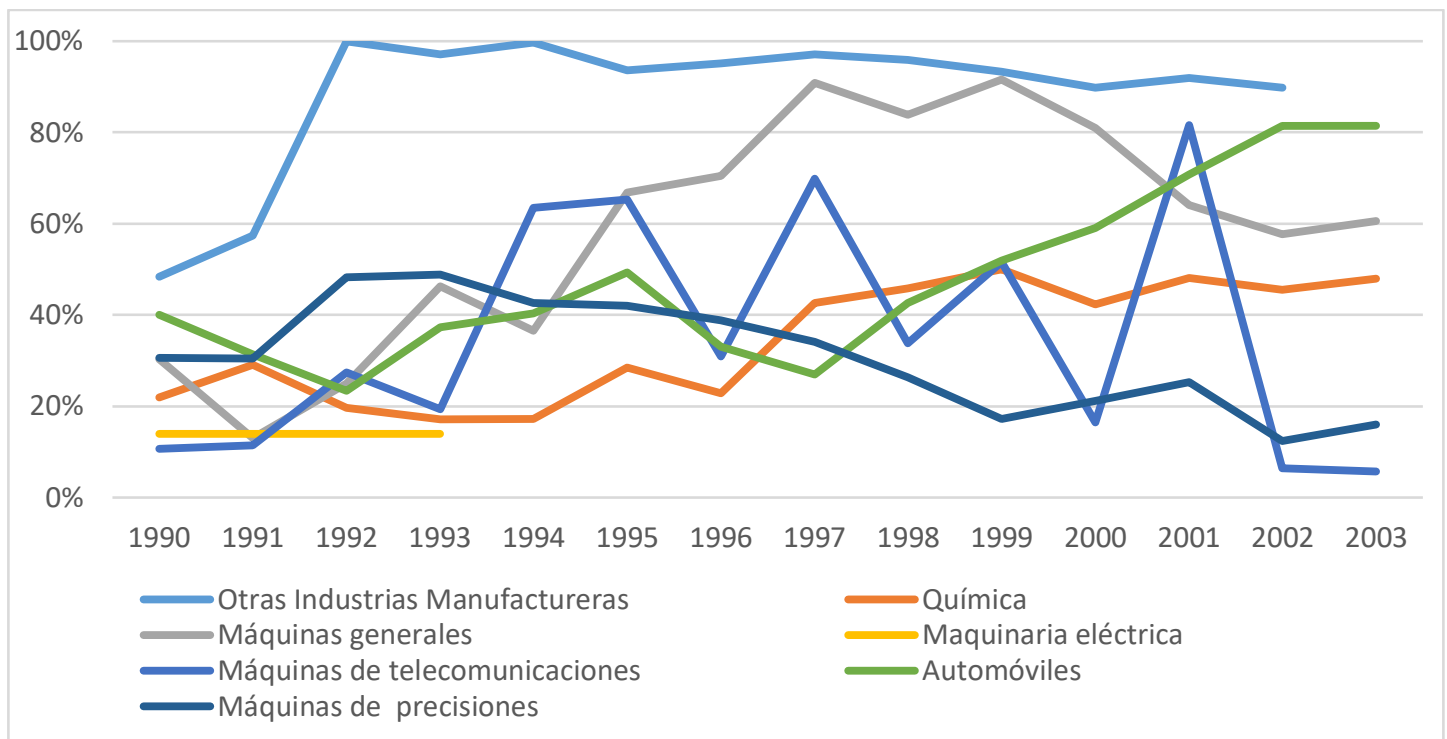

Fuente. Elaboración propia a partir de informaciones de Research Institute of Economy, Trade and Industry, Japón. Disponible en http://www.rieti.go.jp/jp/database/d05.html, fecha de consulta:7/8/2014.

Esta buena condición de la economía estadounidense indujo nuevas tendencias en las preferencias de sus consumidores, que buscaban productos más sofisticados, es decir, productos más ligeros, más pequeños y más multifuncionales (PORTER, 2007). Además de productos sofisticados, los consumidores querían que esos productos se adecuaran a su vida cotidiana. Por ejemplo, el consumidor que quería ver la televisión en el baño, necesitaba un televisor pequeño y resistente al agua, mientras que otro consumidor requería un televisor con imagen y sonido de alta calidad. Además, el avance de internet indujo un aumento de la demanda de monitores de calidad similar a la de los televisores para que el consumidor pudiera ver sus programas televisivos en sus ordenadores.

Estos cambios en las preferencias de los consumidores estadounidenses por la "sofisticación" y la "diversificación" se pueden encontrar en los productos duraderos como automóviles, electrodomésticos y productos electrónicos-, que son los principales productos generados por las empresas japonesas en México. Este cambio de las preferencias de los consumidores significaba que las empresas japonesas en México tenían que fabricar productos más sofisticados y variados. El boom económico de Estados 
Unidos en la década de los 90 generó a las empresas japonesas ubicadas en México la necesidad de fabricar productos de alta tecnología que fueran ofrecidos al consumidor en diferentes tipos de modelos para adaptarse a sus requerimientos. Para corresponder a estas demandas del consumidor estadounidense, las empresas japonesas aumentaron sus líneas de productos en México. En el caso de la industria de televisores, el número de modelos aumentó de forma destacada, al igual que ocurrió con la elaboración de otros productos como componentes y monitores para ordenadores (CARRILLO y CONTRERAS, 2005, p.283). Como era muy complicado que una única empresa fabricara todos los productos, las empresas japonesas decidieron crear redes con otras empresas japonesas para facilitar la multi-fabricación en México (véase la Ilustración II-4.1). Estas redes se fueron desarrollando a lo largo de los años 1990.

\section{Ilustración II-4. 1. Redes de las empresas de televisores japonesas en México}

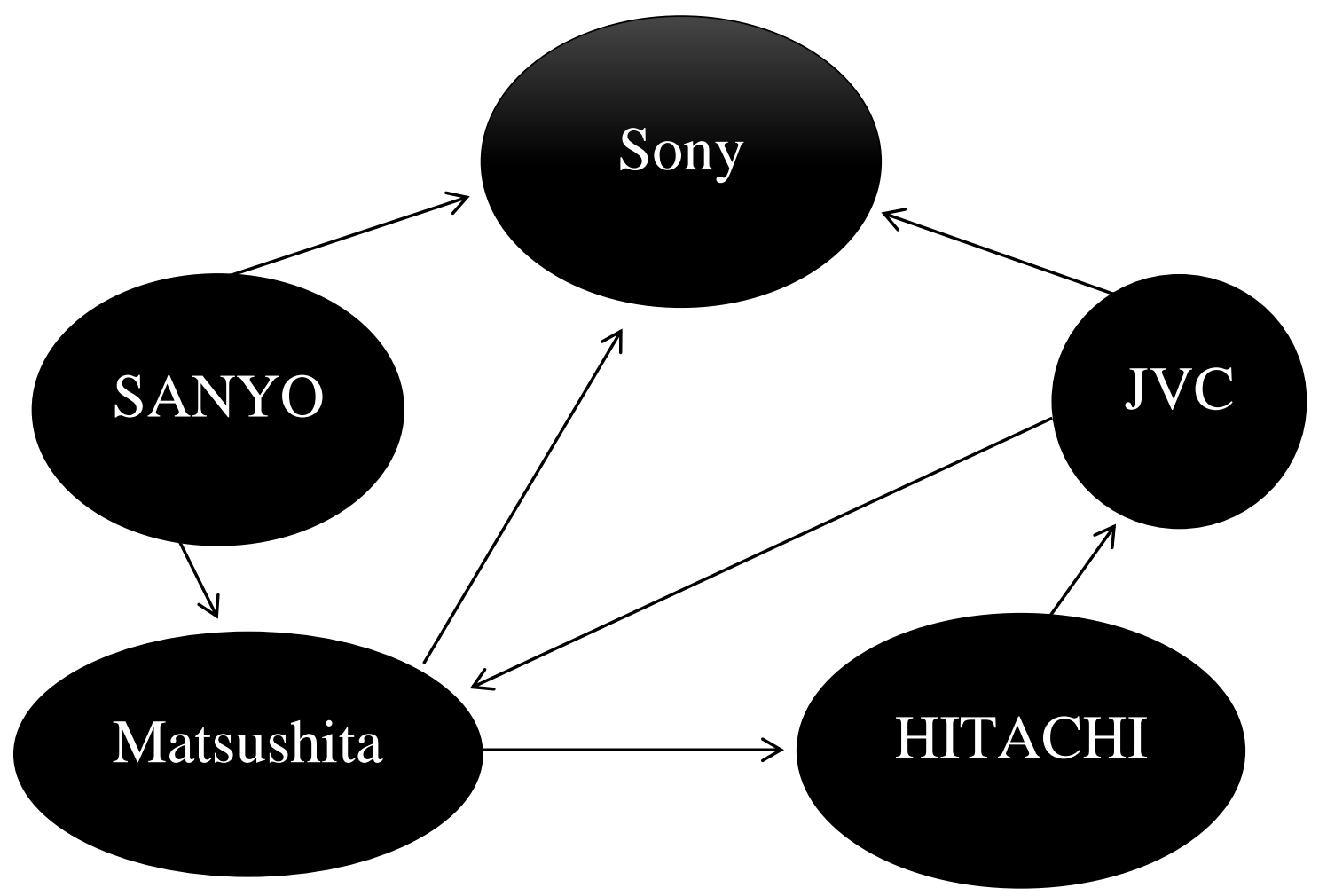

Fuente. Tomado de CARILLO y CONTRERAS. (2005). "Corporaciones Transnacionales y Redes de Abastecimiento Local en la Industria del Televisor en el Norte de México," en Dussel Peters y Palacios Lara (Coordinadores), Condiciones y Retos de la Electrónica en México, NYCE, p 283. 
Para establecer estas complejas redes, las empresas japonesas necesitaban contar con proveedores fiables de los componentes requeridos en la producción. Los Gráficos II-4. 3 y II-4. 4 recogen respectivamente, el contenido local e importado en la producción de las empresas japonesas establecidas en México. Se nota que en 1992 hay un aumento de los contenidos locales en las industrias de telecomunicaciones, eléctrica, máquinas de precisión, mientras que se percibe un descenso en los casos de la industria automovilística y de otras industrias manufactureras. Por el contrario, en el mismo año se produce un aumento de los contenidos importados en la industria de automóviles y de otras industrias manufactureras.

En casi todas las industrias, el contenido importado tiende a representar más del 60\% en la mayor parte de los años del período 1990-1999 (véase el Gráfico II-4.4). En cuanto al origen de este contenido importado, se observa que entre 1992 y 1993, las industrias de automóviles redujeron los contenidos importados desde Japón, mientras que las otras industrias los aumentaron (véase el Gráfico II-4.5). Para esos mismos años, también se observa un aumento de los contenidos importados desde terceros países, excepto para el caso de la industria de maquinaria de precisión (véase el Gráfico II-4.6).

Gráfico II-4.3. Actividad productiva de las empresas japonesas en México: contenidos locales por grupos de productos, 1990-1999

(En porcentajes)

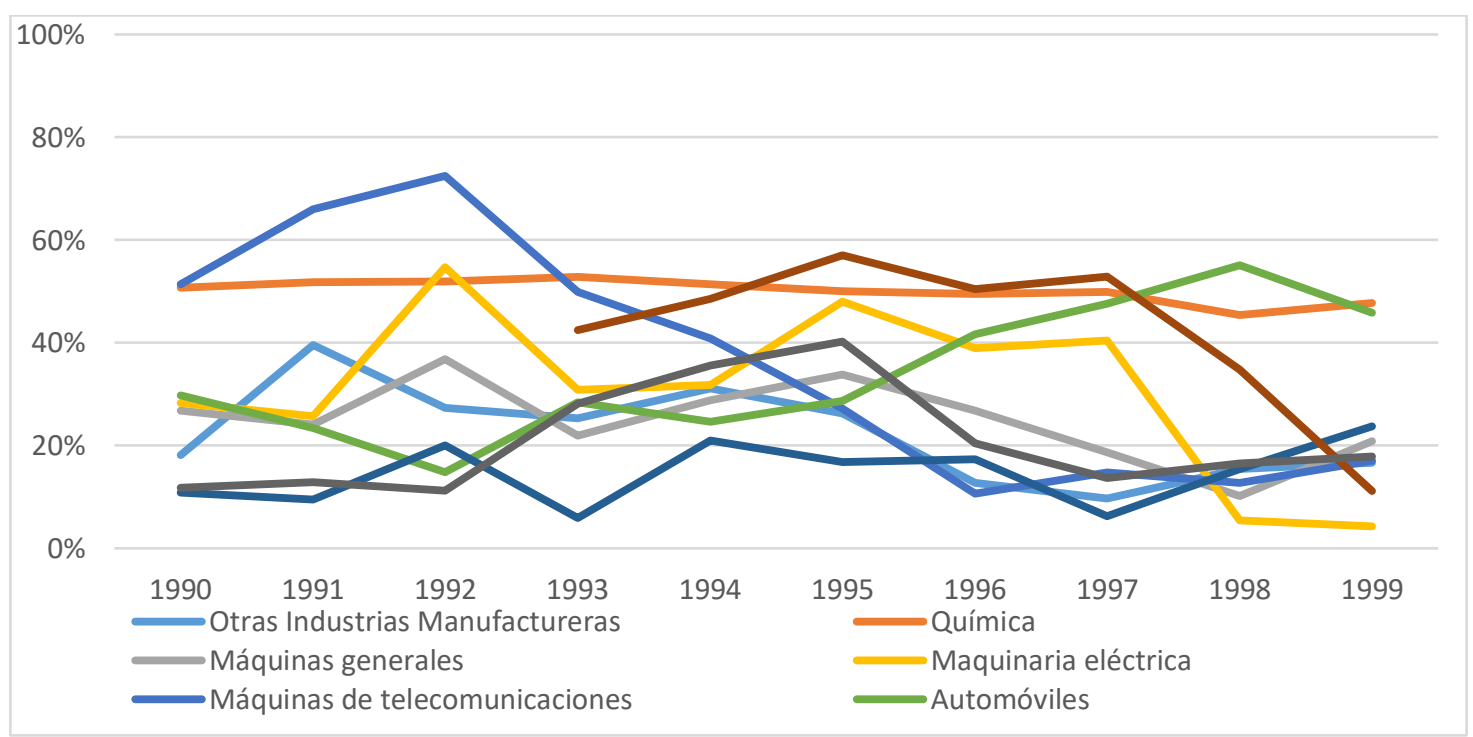

Fuente. Elaboración propia a partir de informaciones de Research Institute of Economy, Trade and Industry, Japón. Disponible en http://www.rieti.go.jp/jp/database/d05.html, fecha de consulta:7/8/2014. 
Gráfico II-4.4. Actividad productiva de las empresas japonesas en México: contenidos importados por grupos de productos, 1990-1999

(En porcentajes)

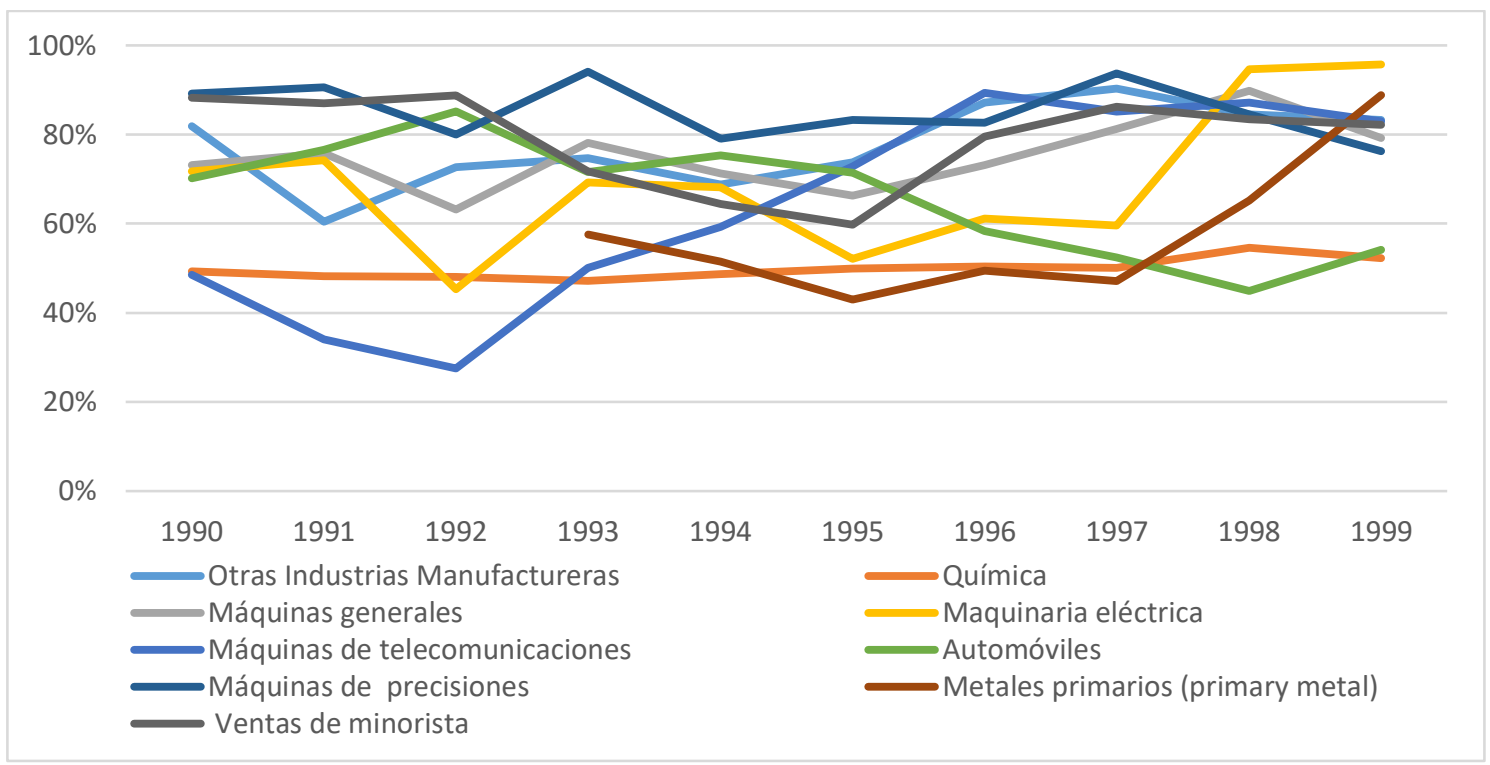

Fuente. Elaboración propia a partir de informaciones de Research Institute of Economy, Trade and Industry, Japón. Disponible en http://www.rieti.go.jp/jp/database/d05.html, fecha de consulta:7/8/2014.

Gráfico II-4.5. Actividad productiva de las empresas japonesas en México: contenidos importados desde Japón por grupos de productos, 1990-1999 (En porcentajes)

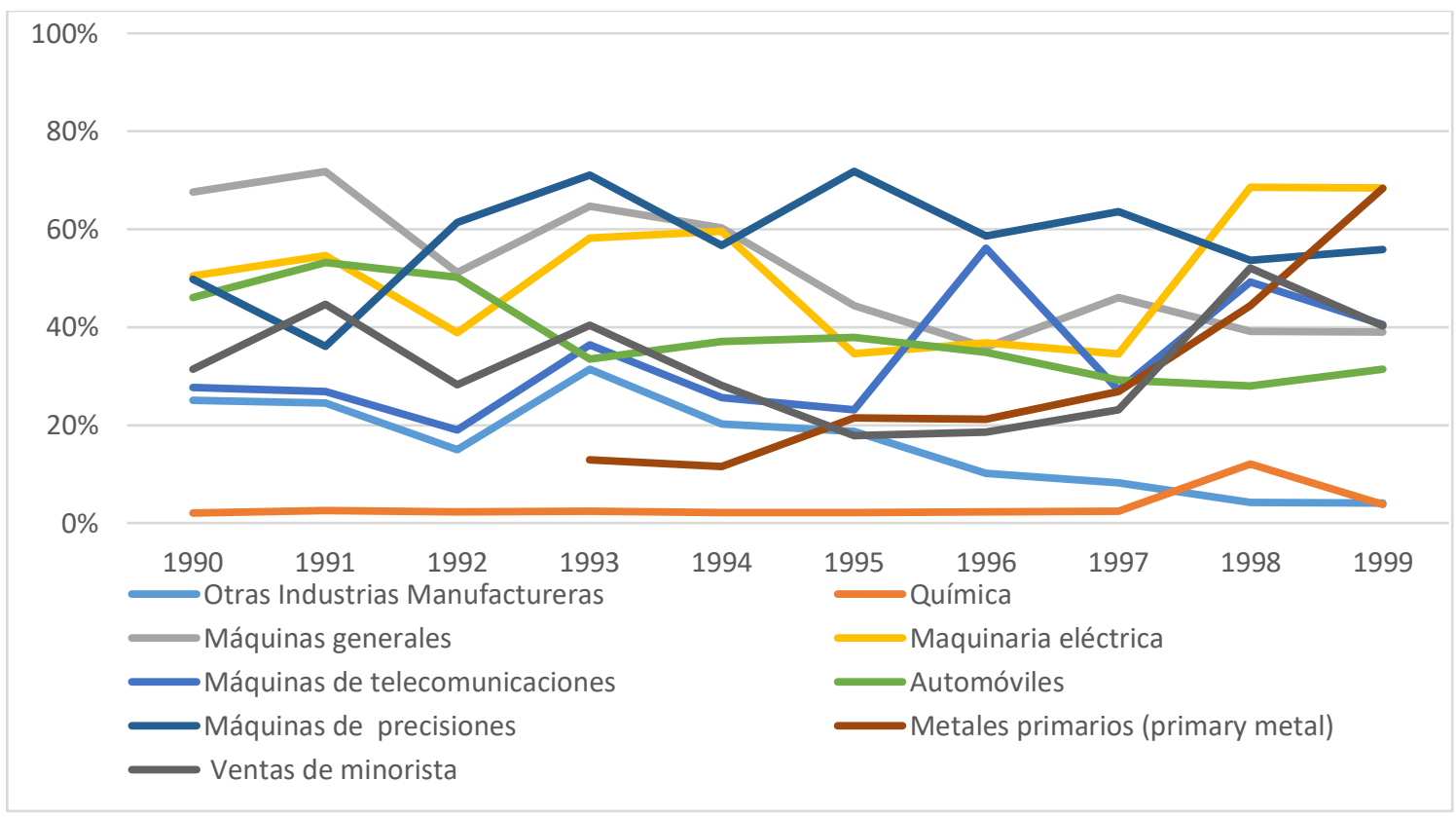

Fuente. Elaboración propia a partir de informaciones de Research Institute of Economy, Trade and Industry, Japón. Disponible en http://www.rieti.go.jp/jp/database/d05.html, fecha de consulta:7/8/2014. 
Gráfico II-4.6. Actividad productiva de las empresas japonesas en México: contenidos importados desde los terceros países por grupos de productos, 1990-1999 (En porcentajes)

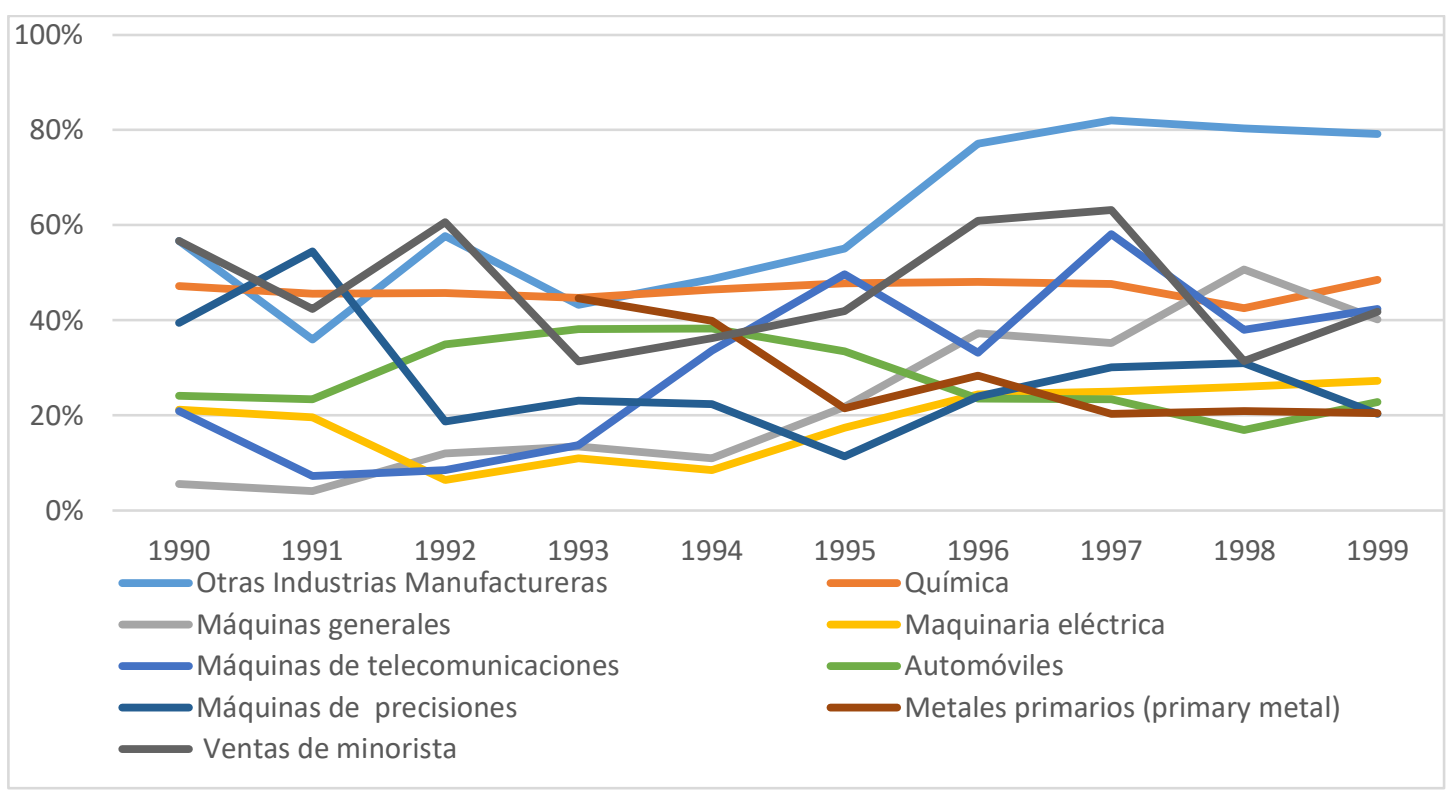

Fuente. Elaboración propia a partir de informaciones de Research Institute of Economy, Trade and Industry, Japón. Disponible en http://www.rieti.go.jp/jp/database/d05.html, fecha de consulta:7/8/2014.

La estrategia de contenidos locales e importados de las empresas japonesas en México fue variando a partir de 1992-1993. Los Gráficos II-4.7 recogen esta evolución de contenidos a lo largo de los años 90 para cada una de las industrias. Se nota en general, que en todas las industrias, los contenidos importados son mayores que los contenidos locales. Sólo en 1998 en la industria automóviles, los contenidos locales fueron más altos que los importados. Conviene indicar que, en estos gráficos, los contenidos locales significan "contenidos hechos en México." Para satisfacer las reglas de origen del TLCAN, las empresas tienen que comprar los contenidos fabricados en Estados Unidos, Canadá o México; y por eso, los porcentajes bajos de contenidos locales no siempre significan que no se cumplan las reglas de origen. Por eso, las industrias de maquinaria de precisión, eléctrica y máquinas generales tienen un mayor porcentaje de contenidos importados desde Japón que desde terceros países. Las otras industrias manufactureras tienen un alto porcentaje de componentes importados desde terceros países. En las industrias de automóviles y máquinas de telecomunicaciones, los porcentajes varían dependiendo de los años. 
Gráficos II-4.7. Actividad productiva de las empresas japonesas en México: Orígenes de los contenidos por grupos de productos, 1990-1999

\section{(En porcentajes)}

\section{1). Máquinas generales}

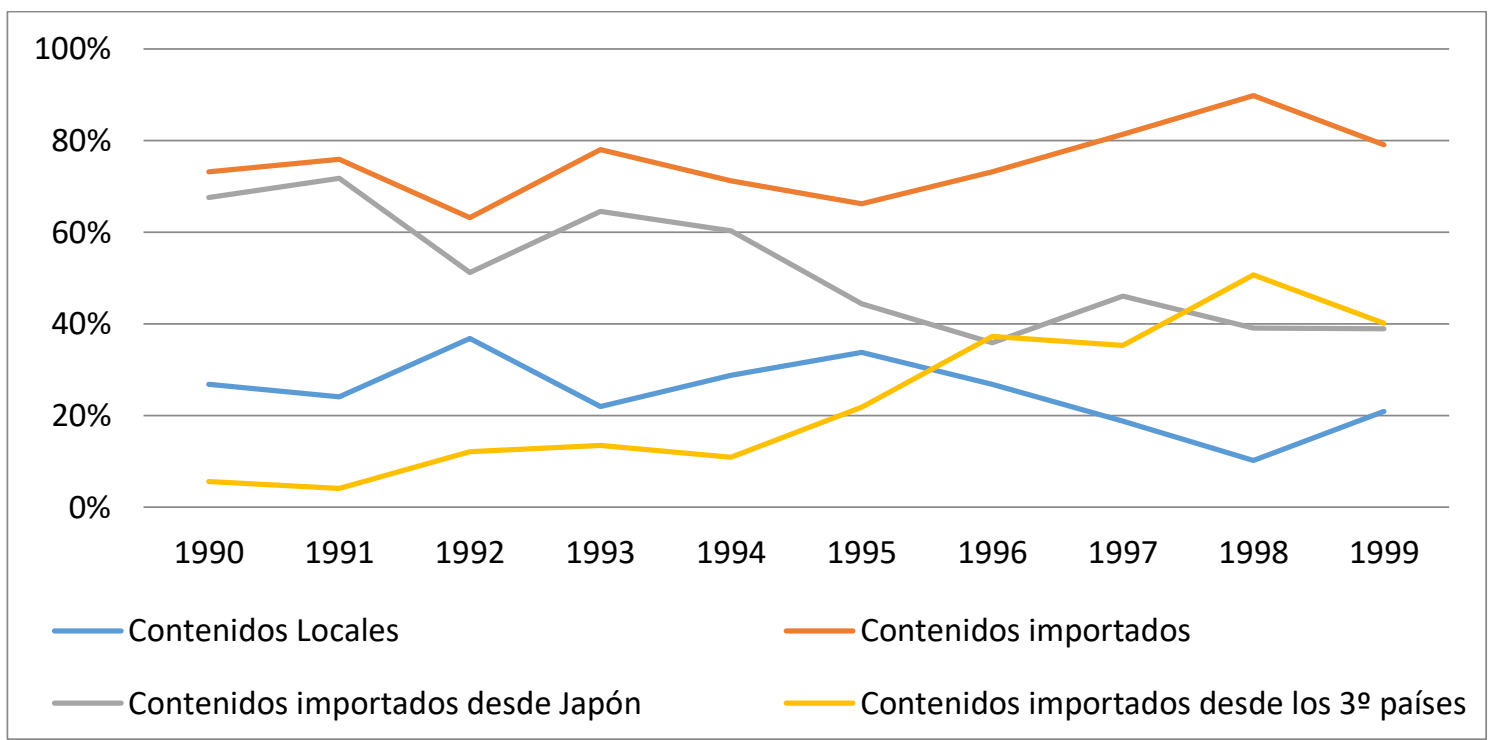

Fuente. Elaboración propia a partir de informaciones de Research Institute of Economy, Trade and Industry,Japón. Disponible en http://www.rieti.go.jp/jp/database/d05.html, fecha de consulta:7/8/2014.

\section{2). Maquinaria eléctrica}

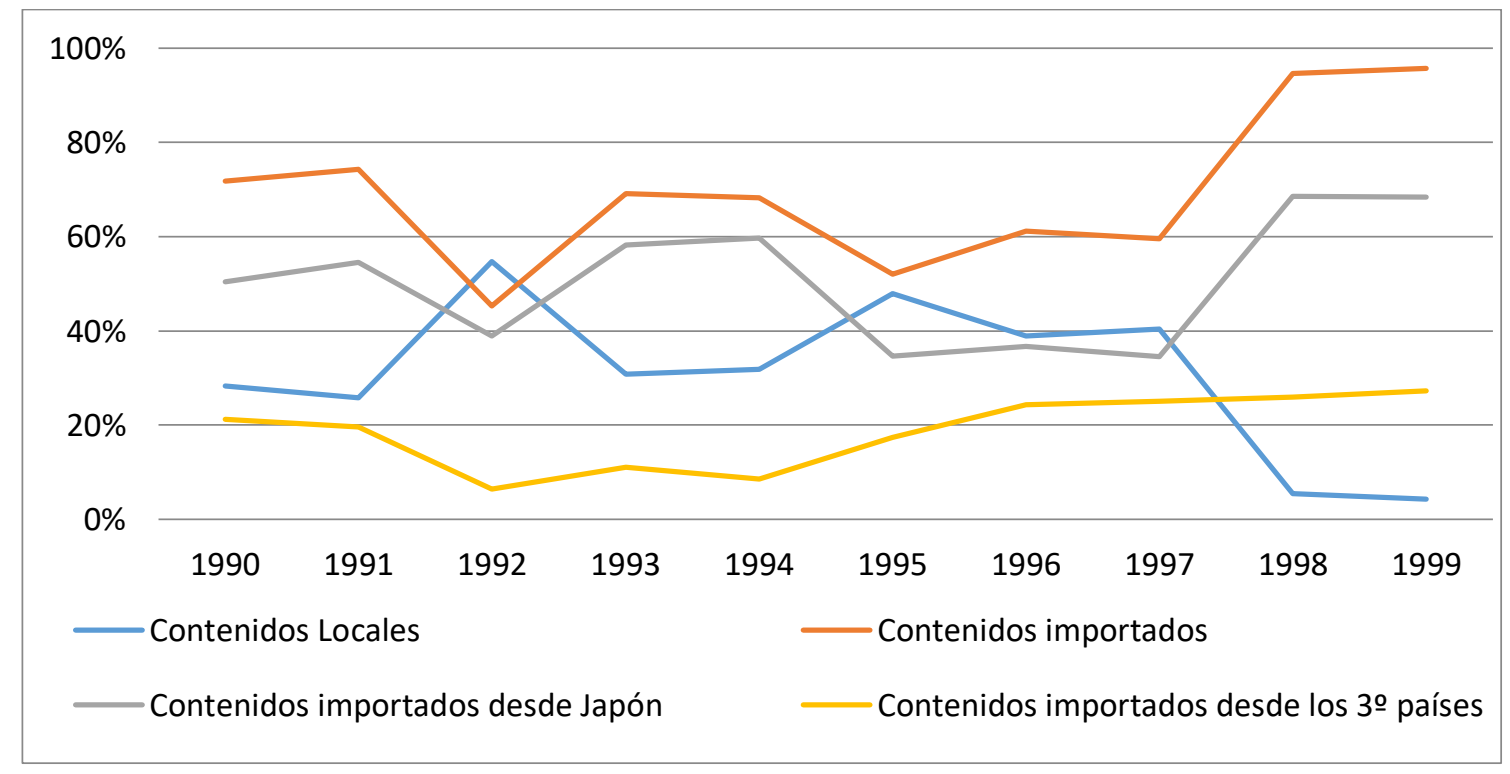

Fuente. Elaboración propia a partir de informaciones de Research Institute of Economy, Trade and Industry, Japón. Disponible en http://www.rieti.go.jp/jp/database/d05.html, fecha de consulta:7/8/2014. 


\section{3). Máquinas de telecomunicaciones}

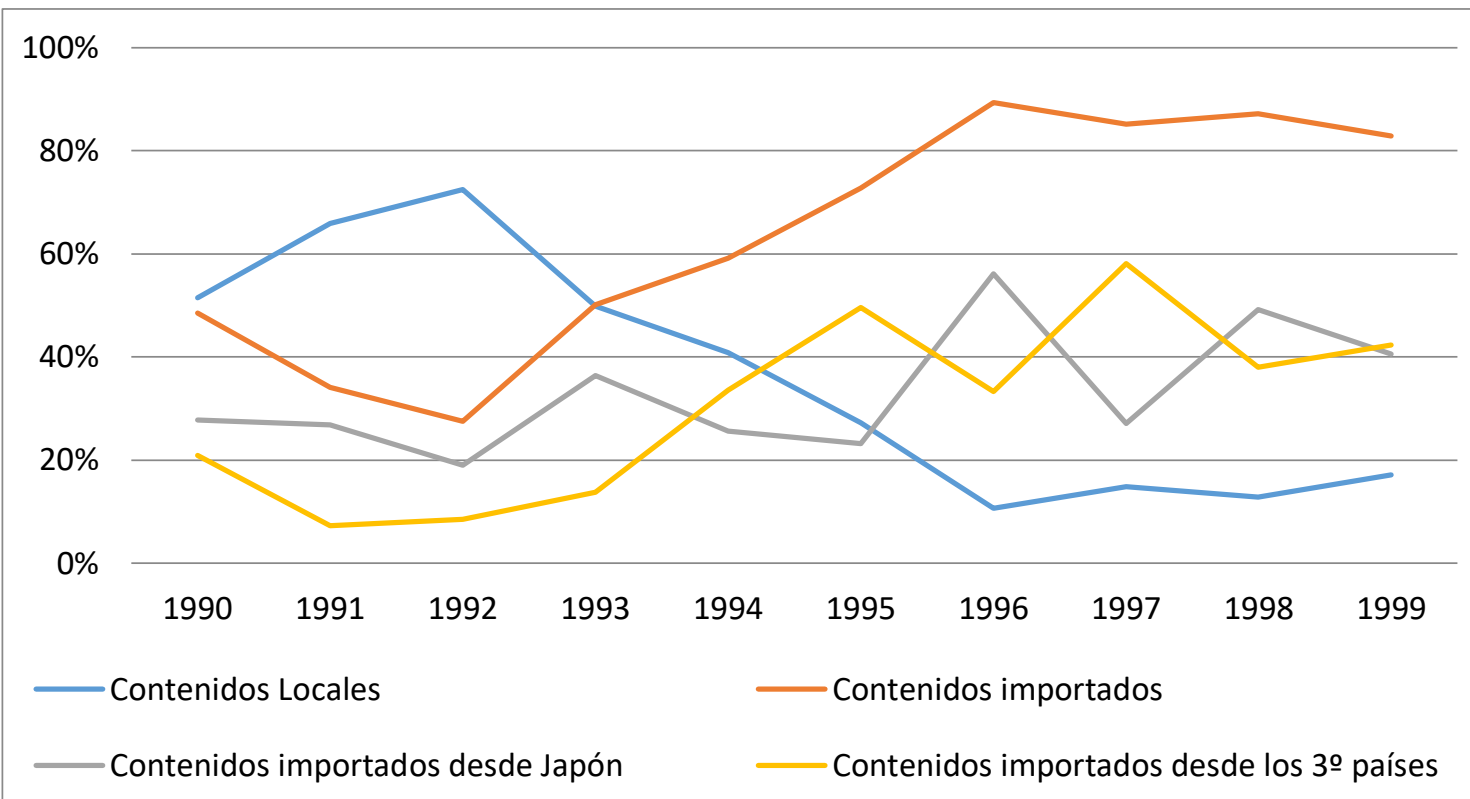

Fuente. Elaboración propia a partir de informaciones de Research Institute of Economy, Trade and Industry, Japón. Disponible en http://www.rieti.go.jp/jp/database/d05.html, fecha de consulta:7/8/2014.

\section{4). Automóviles}

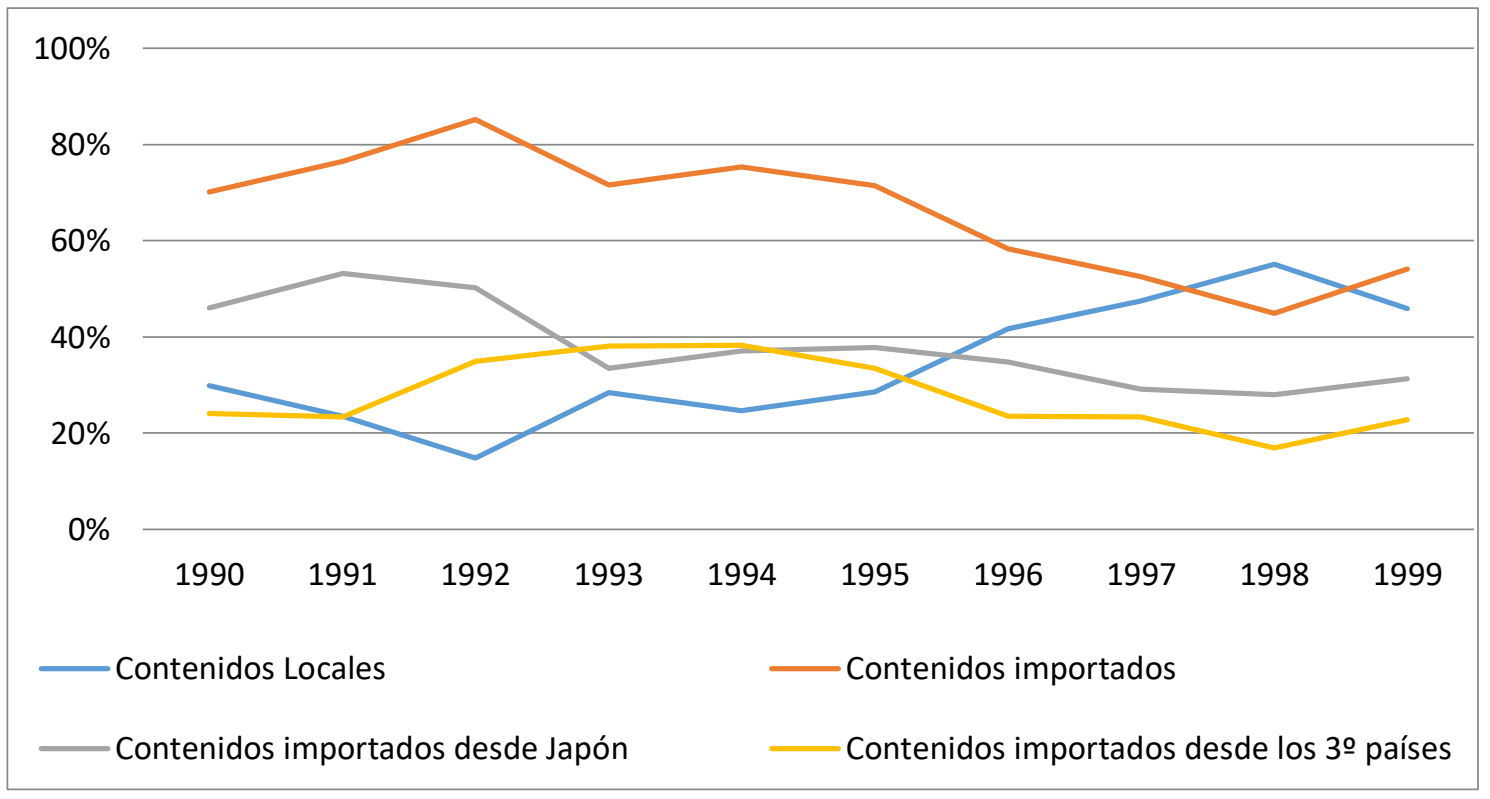

Fuente. Elaboración propia a partir de informaciones de Research Institute of Economy, Trade and Industry, Japón. Disponible en http://www.rieti.go.jp/jp/database/d05.html, fecha de consulta:7/8/2014. 


\section{5). Maquinaria de precisión}

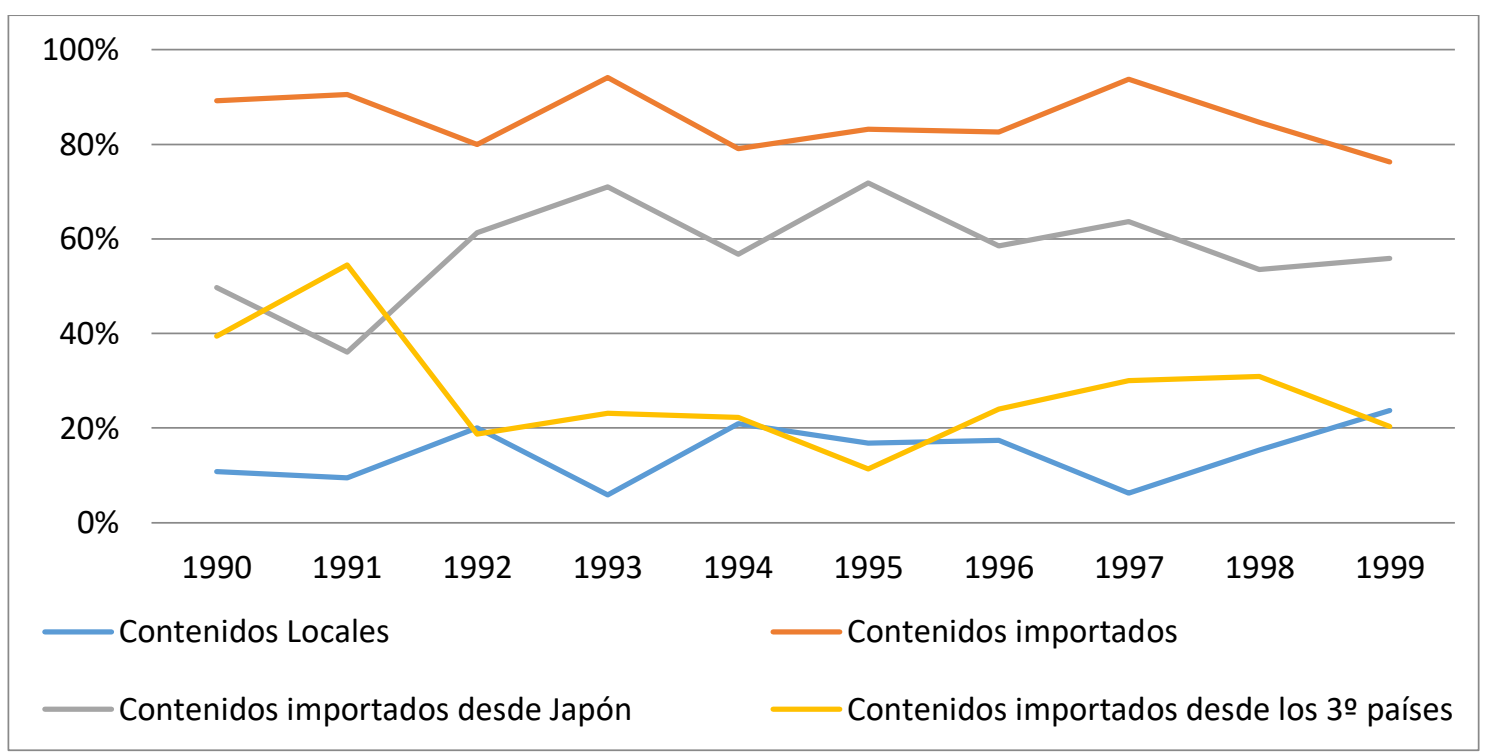

Fuente. Elaboración propia a partir de informaciones de Research Institute of Economy, Trade and Industry, Japón. Disponible en http://www.rieti.go.jp/jp/database/d05.html, fecha de consulta:7/8/2014.

\section{6). Otras Industrias manufactureras}

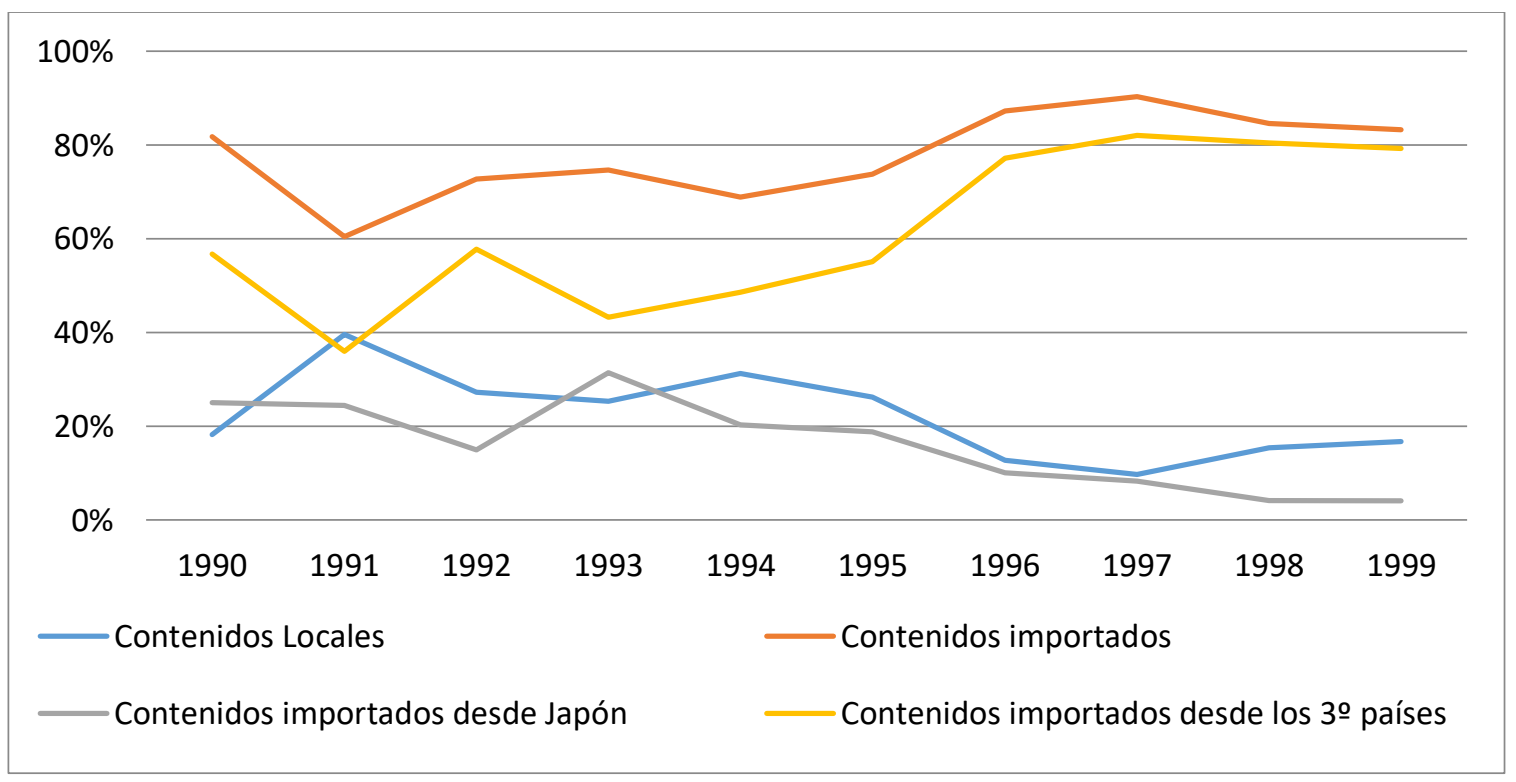

Fuente. Elaboración propia a partir de informaciones de Research Institute of Economy, Trade and Industry, Japón. Disponible en http://www.rieti.go.jp/jp/database/d05.html, fecha de consulta:7/8/2014. 
A partir de los datos mostrados para la década de los 90, se puede ver que, en general, para las empresas japonesas en México, las contribuciones de los contenidos locales eran muy bajas. La mayor parte de su producción dependía de componentes importados. Algunas industrias, como las de maquinaria de precisión y eléctrica dependían de los componentes importados desde Japón, mientras que otras industrias dependían de los componentes importados desde terceros países. De esta estrategia de contenidos de los productos elaborados en México en la década de los 90 se infiere lo siguiente:

a) Desde la década de los 1980, las estrategias de las empresas japonesas en México habían considerado a este país principalmente como un lugar para el ensamblaje de sus productos finales (CARRILLO, PLASCENCIA y GOMIS, 2011). En la década de los 1990, las empresas japonesas aceleran esta estrategia.

b) Después de la entrada en vigor del TLCAN, la mayor parte de los componentes utilizados por las empresas japonesas vinieron de fuera de México; esto es, el país no se consideró como un lugar para buscar y comprar componentes (KENNEY y FLORIDA, 1994, pp. 38-39).

c) Teniendo en cuenta las dos consideraciones anteriores, se puede concluir que las relaciones entre las empresas japonesas en México y los proveedores mexicanos eran muy reducidas (CASTILLO y RAMÍREZ, 1992, p. 41). Si hay relaciones, se han desarrollado redes de abastecedores locales bajo esquemas de estrecha coordinación y alrededor del sistema "justo a tiempo" (CARRILLO y HUALDE ALFARO, 2000).

Hasta ahora se ha analizado el origen de los proveedores de las empresas japonesas en México en los años 1990. Tras ello, se va a examinar el destino de la producción final de dichas empresas; esto es sus ventas locales y sus exportaciones. En el Gráfico II-4.8 se muestran los porcentajes de ventas locales y exportaciones de dichas empresas en el período 1990-1999. Se nota que varias industrias destinan su producción más al mercado local que a las exportaciones a otros países. Sólo las industrias de máquinas generales presentan más exportaciones que ventas locales. En principio, esto puede parecer un resultado no esperado. Sin embargo, no debemos olvidar que éstos indican únicamente los destinos de sus productos, pero no especifican las nacionalidades de los consumidores 
y compradores de esos productos. Es decir, aunque las empresas japonesas en México vendan sus productos en el mercado mexicano, hay una alta probabilidad de que sus consumidores sean otras empresas japonesas, estadounidenses y de otras nacionalidades. Esto significa que, dependiendo del tipo de productos, es decir, productos finales o productos intermedios, hay diferencias en los mercados de destino.

Por esta razón, los productos finales, como las máquinas generales tienen un alto porcentaje de exportaciones. Por el contrario, la maquinaria de precisión y la maquinaria eléctrica son productos intermedios y sus ventas locales son mayores que sus exportaciones,

Gráficos II-4. 8. Actividad productiva de las empresas japonesas en México: Ventas locales y exportaciones por grupos de productos, 1990-1999

(En porcentajes)

\section{1). Máquinas generales}

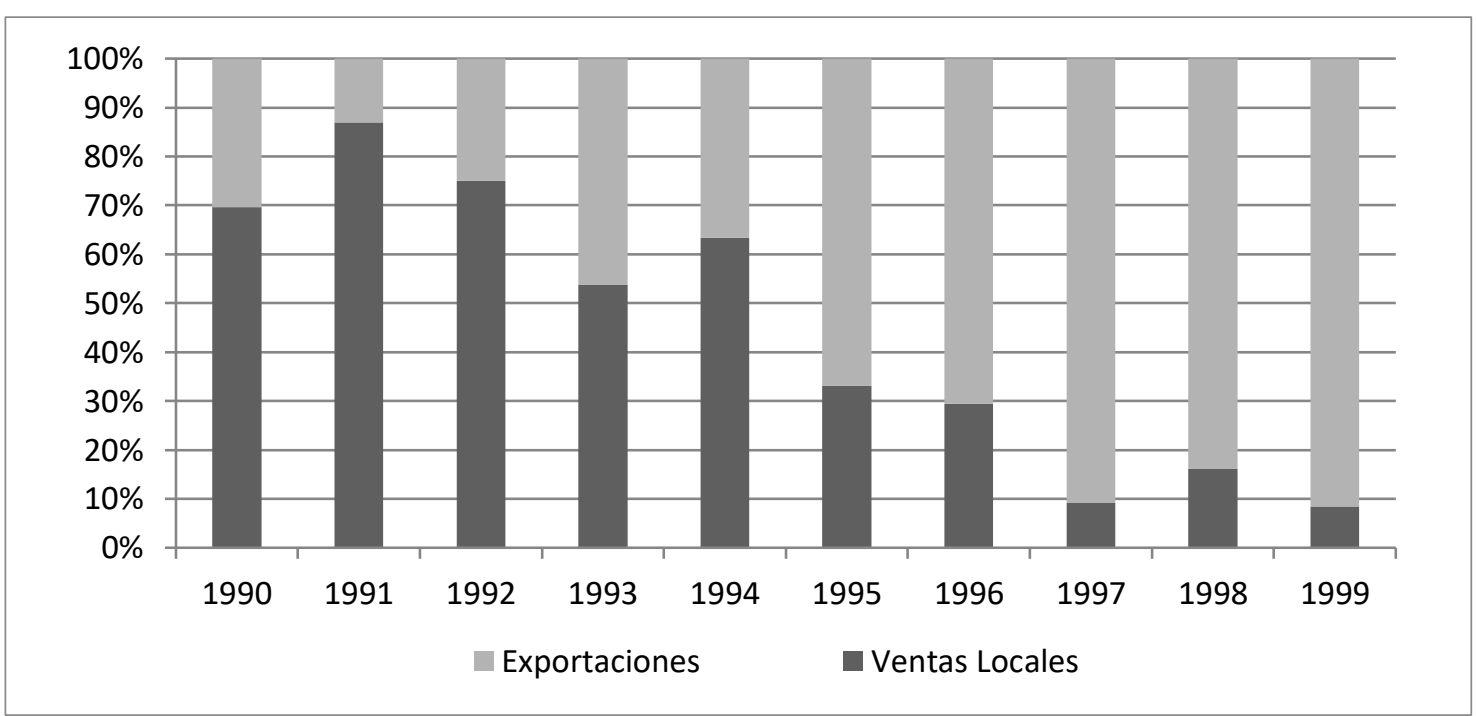

Fuente. Elaboración propia a partir de informaciones de Research Institute of Economy, Trade and Industry, Japón. Disponible en http://www.rieti.go.jp/jp/database/d05.html, fecha de consulta:7/8/2014. 


\section{2). Maquinaria eléctrica}

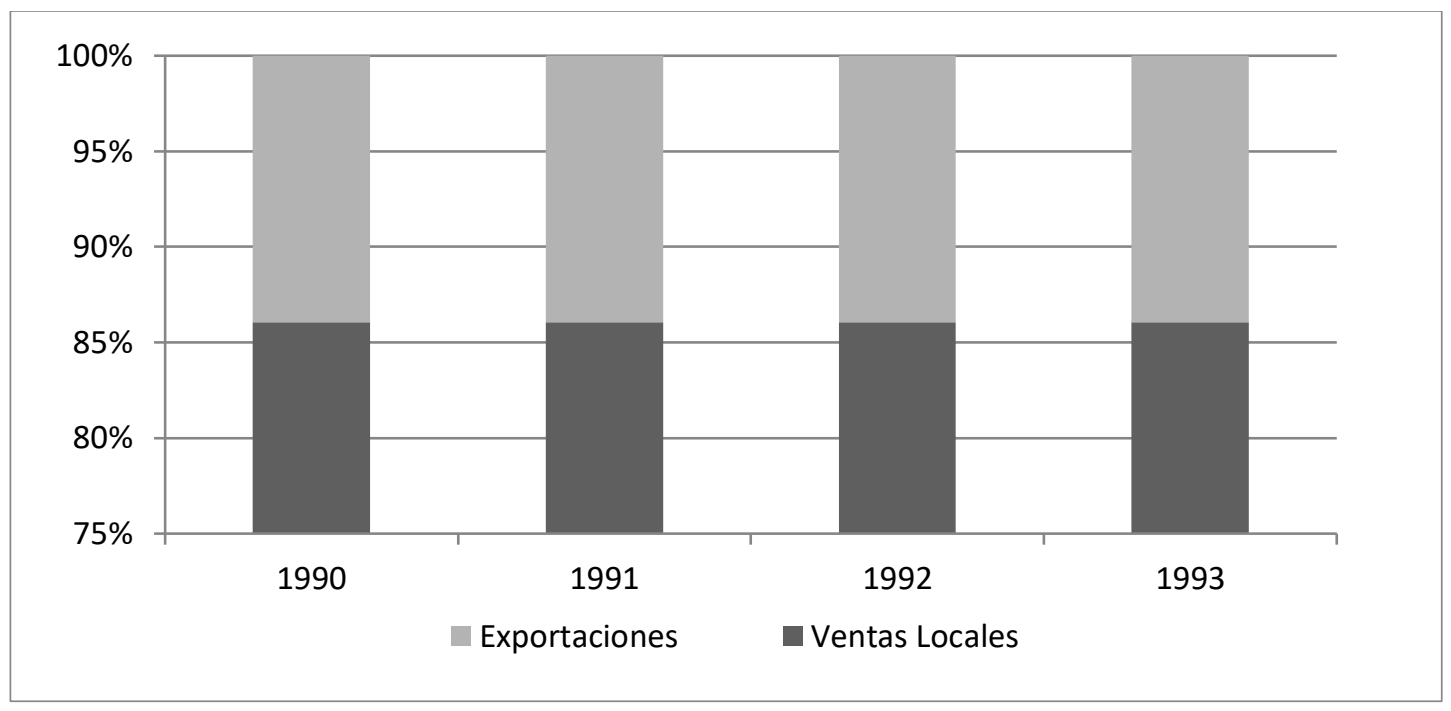

Fuente. Elaboración propia a partir de informaciones de Research Institute of Economy, Trade and Industry, Japón. Disponible en http://www.rieti.go.jp/jp/database/d05.html, fecha de consulta: 7/8/2014.

\section{3). Máquinas de telecomunicaciones}

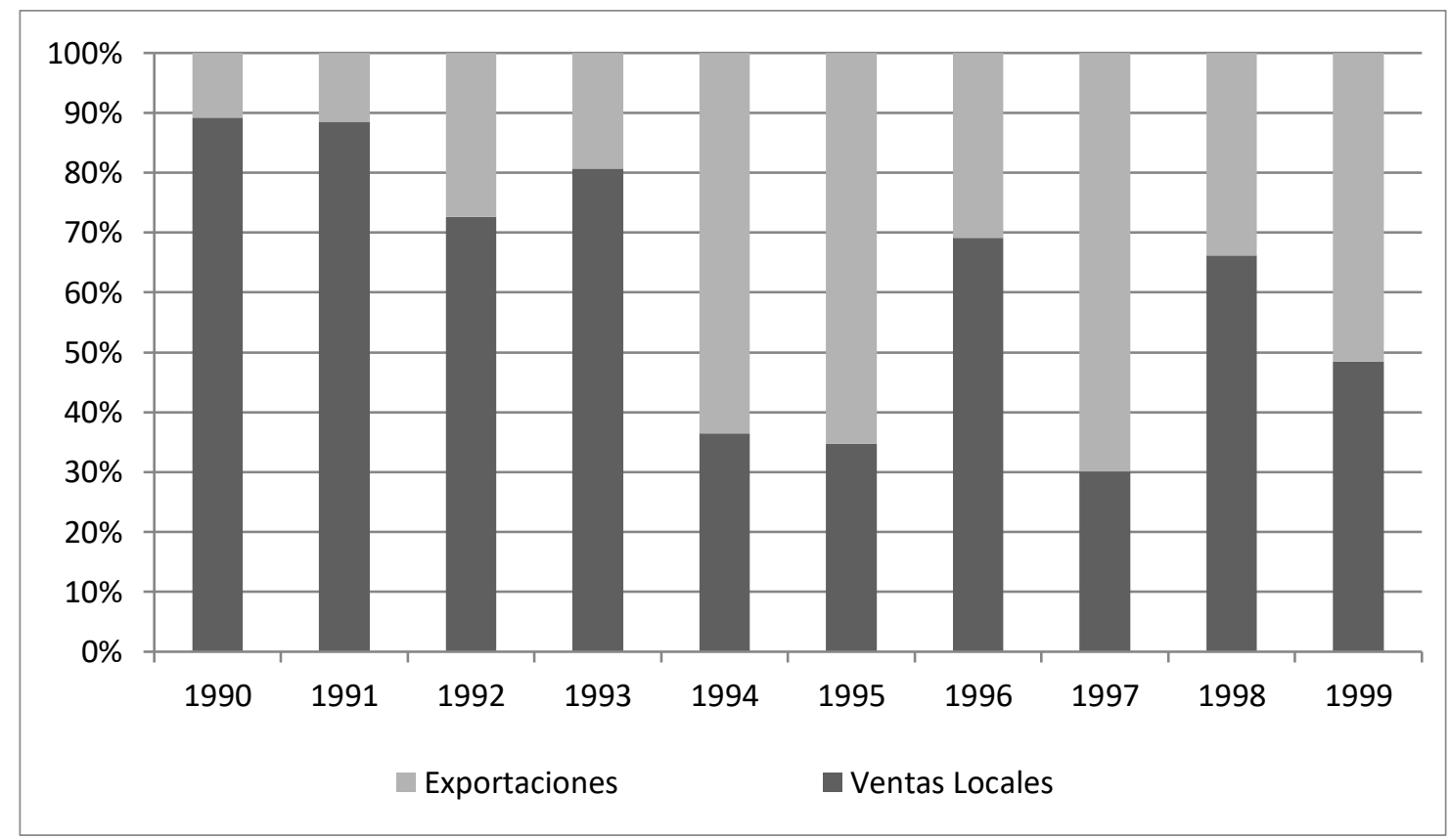

Fuente. Elaboración propia a partir de informaciones de Research Institute of Economy, Trade and Industry, Japón. Disponible en http://www.rieti.go.jp/jp/database/d05.html, fecha de consulta: 7/8/2014. 


\section{4). Automóviles}

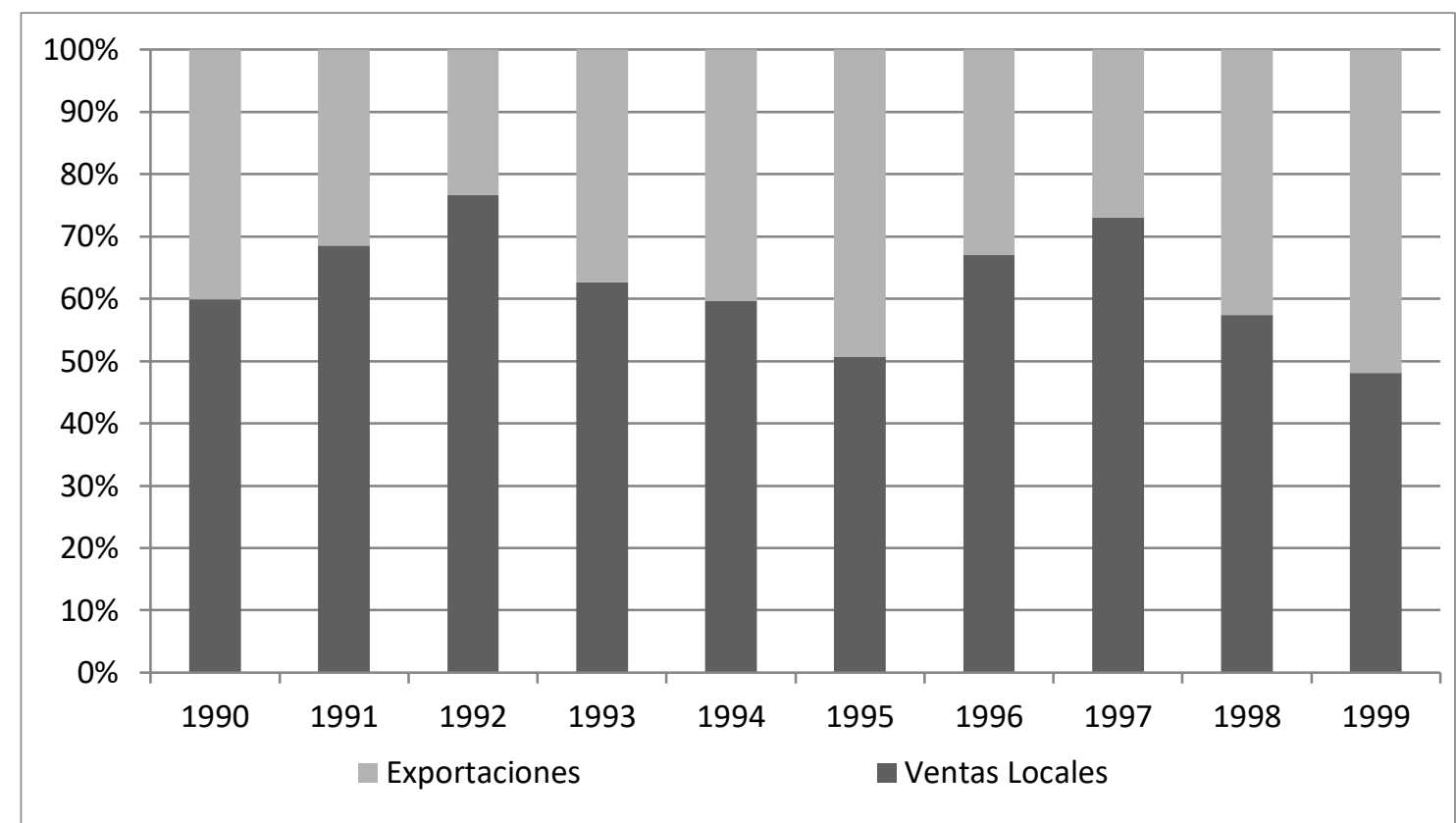

Fuente. Elaboración propia a partir de informaciones de Research Institute of Economy, Trade and Industry, el Gobierno de Japón. Disponible en http://www.rieti.go.jp/jp/database/d05.html, fecha de consulta:7/8/2014.

\section{5). Maquinaria de precisión}

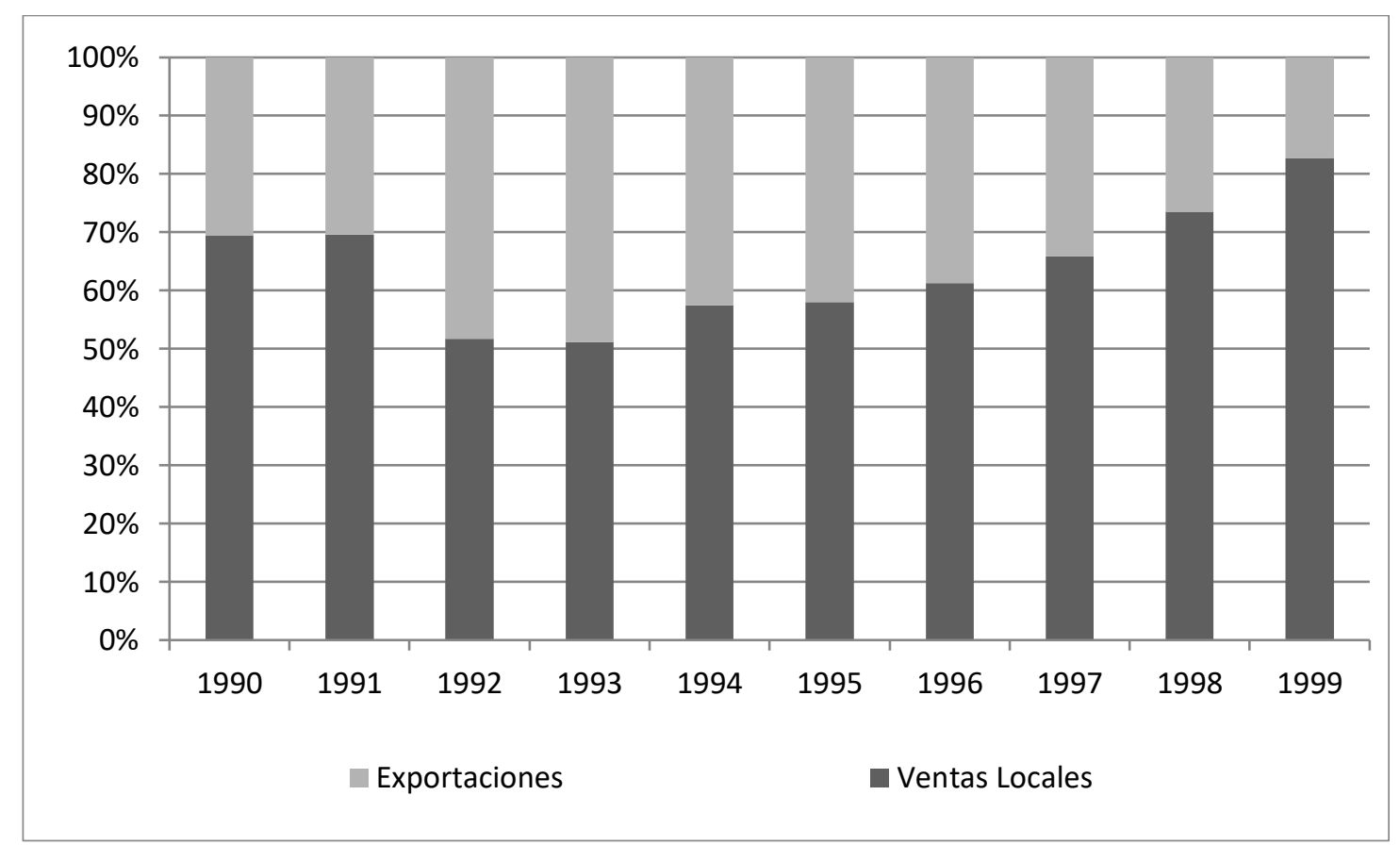

Fuente. Elaboración propia a partir de informaciones de Research Institute of Economy, Trade and Industry, Japón. Disponible en http://www.rieti.go.jp/jp/database/d05.html, fecha de consulta:7/8/2014. 


\section{6). Otras Industrias manufactureras}

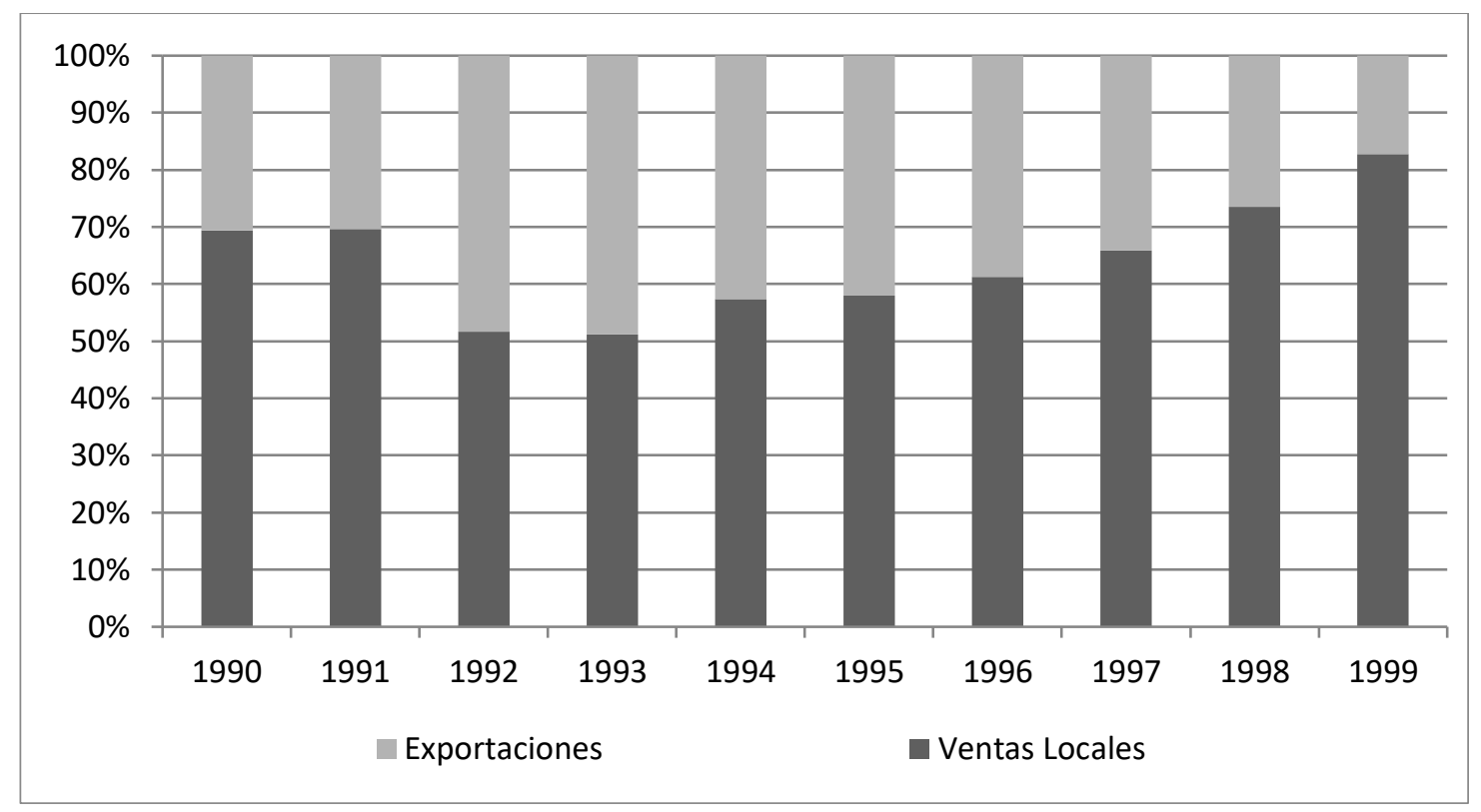

Fuentes. Elaboración propia a partir de informaciones de Research Institute of Economy, Trade and Industry, Japón. Disponible en http://www.rieti.go.jp/jp/database/d05.html, fecha de consulta:7/8/2014.

\section{8). Industrias de servicios (menos venta de minoristas)}

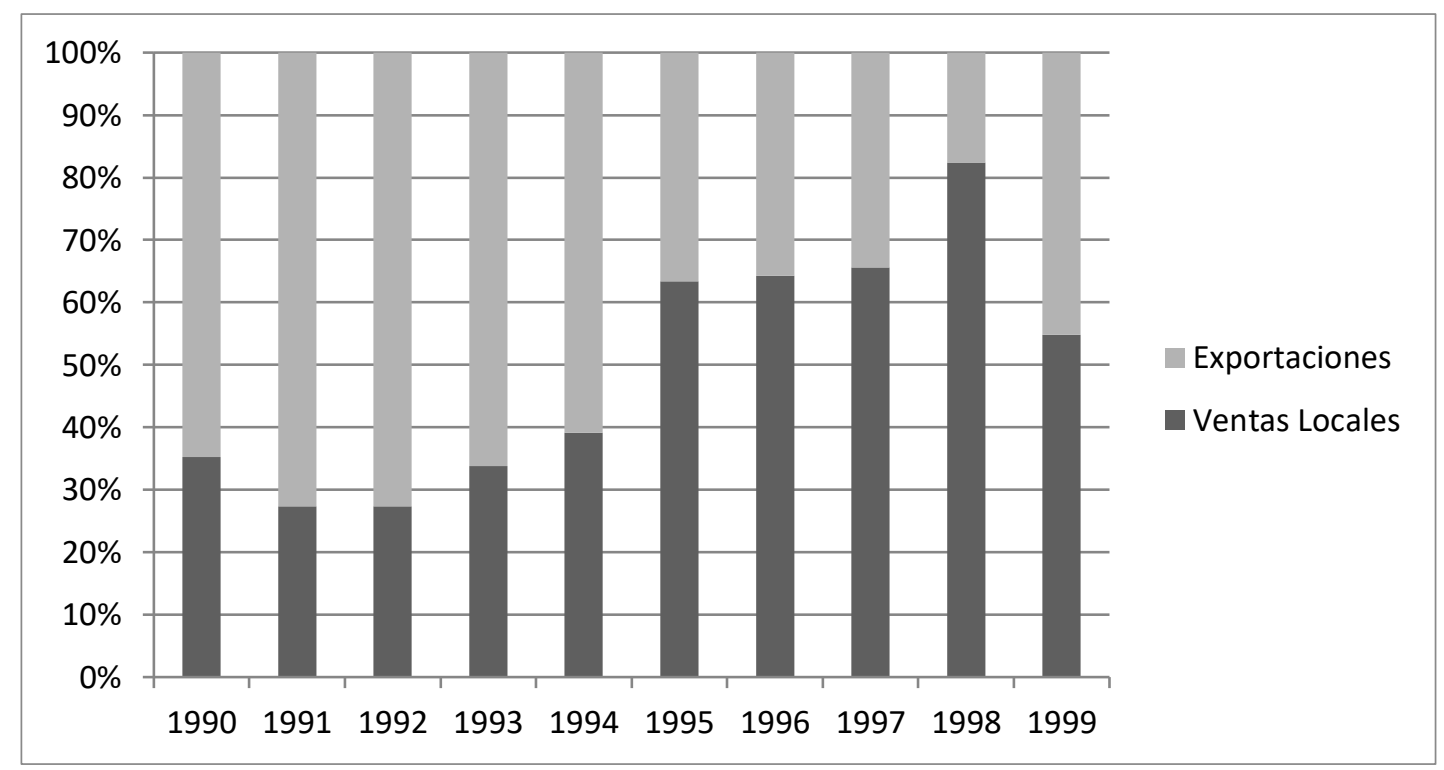

Fuente. Elaboración propia a partir de informaciones de Research Institute of Economy, Trade and Industry, Japón. Disponible en http://www.rieti.go.jp/jp/database/d05.html, fecha de consulta:7/8/2014. 
El principal objetivo de las inversiones japonesas en México es aumentar sus exportaciones a Estados Unidos, lo que explica que dichas empresas quieran exportar los productos finales desde México a Estados Unidos. Esta tendencia no ha cambiado después de la entrada en vigor del TLCAN. En la década de 1990, las inversiones japonesas intensificaron el papel de México dentro de sus estrategias empresariales: México era un lugar para el ensamblaje de productos finales para su posterior exportación a Estados Unidos. En general, en la industria manufacturera, las empresas japonesas empezaron a llevar sus proveedores japoneses en la década de los 1980 a México. Como esto funcionó bien, las empresas japonesas fueron capaces de cumplir satisfactoriamente las reglas de origen del TLCAN (ALONSO, CARRILLO y CONTRERAS, 2000, pp. 1821).

La Tabla II-4.2 presenta los resultados de las encuestas realizadas a las empresas japonesas que tenían sus actividades localizadas en América Latina en 1996. Dichas encuestas muestran los problemas identificados por las empresas para ese año, así como aquellos problemas que habían empeorado en los últimos años. Se observa que las empresas japonesas en América Latina tenían tres problemas principales: la inestabilidad política, la inflación y la dura competencia en el mercado. Para las inversiones japonesas, los dos primeros problemas son muy importantes, ya que influyen en la toma de decisiones para sus inversiones de largo plazo. Si no hay gobiernos estables, no pueden plantear sus planes de las inversiones en el largo plazo; y si hay inflación, sus inversiones pierden valor en el futuro. Por eso, las empresas japonesas consideran estos dos problemas muy importantes. Además, se trata de dos problemas sobre los que los gobiernos locales pueden actuar para crear un clima más propicio para la llegada de inversiones japonesas. 
Tablas II-4.1. Problemas y obstáculos de las empresas japonesas en América Latina, 1996

\section{1). Problemas y obstáculos en 1996}

\begin{tabular}{|l|l|l|l|}
\hline & \multicolumn{1}{|c|}{1} & \multicolumn{1}{|c|}{2} & \\
\hline $\begin{array}{l}\text { Máquinas } \\
\text { generales }\end{array}$ & $\begin{array}{l}\text { Inestabilidad política / } \\
\text { Inflación / Dura competencia } \\
\text { en el mercado }\end{array}$ & Políticas de altos impuestos & Falta de proveedores \\
\hline $\begin{array}{l}\text { Maquinaria } \\
\text { eléctrica }\end{array}$ & $\begin{array}{l}\text { Inflación / Dura competencia } \\
\text { en el mercado }\end{array}$ & Inestabilidad política & Falta de infraestructuras \\
\hline Transportes & $\begin{array}{l}\text { Dura competencia en el } \\
\text { mercado }\end{array}$ & Inflación & Inestabilidad política \\
\hline $\begin{array}{l}\text { Maquinaria de } \\
\text { precisión }\end{array}$ & $\begin{array}{l}\text { Inestabilidad política / } \\
\text { Inflación / Dura competencia } \\
\text { en el mercado }\end{array}$ & $\begin{array}{l}\text { Falta de proveedores/ Relación } \\
\text { con los sindicatos }\end{array}$ & \\
\hline
\end{tabular}

Fuente. Elaboración propia a partir de informaciones del Ministerio de Economía, Negocio e Industria, 1997, Wagakuni Kigyouno kaigaikatudou houkoku, Tokyo: Ministerio de Economía, p. 240.

2). Problemas y obstáculos que han empeorado en los últimos años (en el momento del 1996)

\begin{tabular}{|l|l|l|l|}
\hline & \multicolumn{1}{|c|}{1} & \multicolumn{1}{|c|}{2} & \multicolumn{1}{|c|}{3} \\
\hline $\begin{array}{l}\text { Máquinas } \\
\text { generales }\end{array}$ & $\begin{array}{l}\text { Dura competencia en el } \\
\text { mercado }\end{array}$ & Políticas de altos impuestos & $\begin{array}{l}\text { Inestabilidad política/ } \\
\text { Inflación }\end{array}$ \\
\hline $\begin{array}{l}\text { Maquinaria } \\
\text { eléctrica }\end{array}$ & $\begin{array}{l}\text { Dura competencia en el } \\
\text { mercado }\end{array}$ & Inestabilidad política & Inflación \\
\hline $\begin{array}{l}\text { Transportes } \\
\text { precisión }\end{array}$ & $\begin{array}{l}\text { Inestabilidad política } \\
\text { mercado }\end{array}$ & $\begin{array}{l}\text { Inflación/ Dura competencia } \\
\text { en el mercado }\end{array}$ & $\begin{array}{l}\text { Demandas de aumento de } \\
\text { contenidos locales/ } \\
\text { venta doméstica/ Control } \\
\text { de divisas/ Políticas de } \\
\text { altos impuestos/ Falta de } \\
\text { proveedores, etc. }\end{array}$ \\
\hline
\end{tabular}

Fuente. Elaboración propia a partir de informaciones del Ministerio de Economía, Negocio e Industria, 1997, Wagakuni Kigyouno kaigaikatudou houkoku, Tokyo: Ministerio de Economía, p. 240. 
En la segunda mitad de la década 1990, la economía japonesa estaba en recesión (DELGADO SELLEY, 2016). La crisis económica en Japón tuvo el efecto de cambiar la estrategia de la IED japonesa (FALCK REYES, 2012). Especialmente, su inversión en México se vio afectada por este cambio de estrategia de las empresas patronales japonesas y en la década de 2000, se puede encontrar problemas de sus actividades en México.

Además, a partir de la segunda mitad de los años 1990, las empresas japonesas encontraron nuevos rivales en su acceso al mercado estadounidense, en concreto: los productos procedentes de Taiwán, de Corea del Sur y de China (CARRILLO, 2009; FALCK REYES y RODRÍGUEZ ALEGRIA, 2004). Ellos invirtieron e México para exportar sus productos a Estados Unidos, como las empresas japonesas, aunque en la década de 1990. Su presencia fue mucho menor que la japonesa. 


\section{II-5. Surgimiento de la economía china y cambio de las tendencias de las inversiones japonesas en México: los años 2000}

En la primera década del nuevo siglo, las empresas japonesas tuvieron que replantearse sus estrategias de inversión en el exterior. La crisis económica sufrida por el país en los noventa obligó a llevar a cabo una nueva configuración de su IED (KAKU, 2010). En este contexto, se tenían que reducir sus inversiones extranjeras y México no fue una excepción. Los flujos de IED japonesa en México fueron muy bajos en los cinco primeros años de la década de 2000 y llegaron a ser incluso negativos en 2006 debido a la retirada de una parte importante de las inversiones en dicho país (véase el Gráfico II$5.1)$.

Gráfico II-5. 1. Flujos de inversiones japonesas en México, 2000-2013 (En millones de dólares)

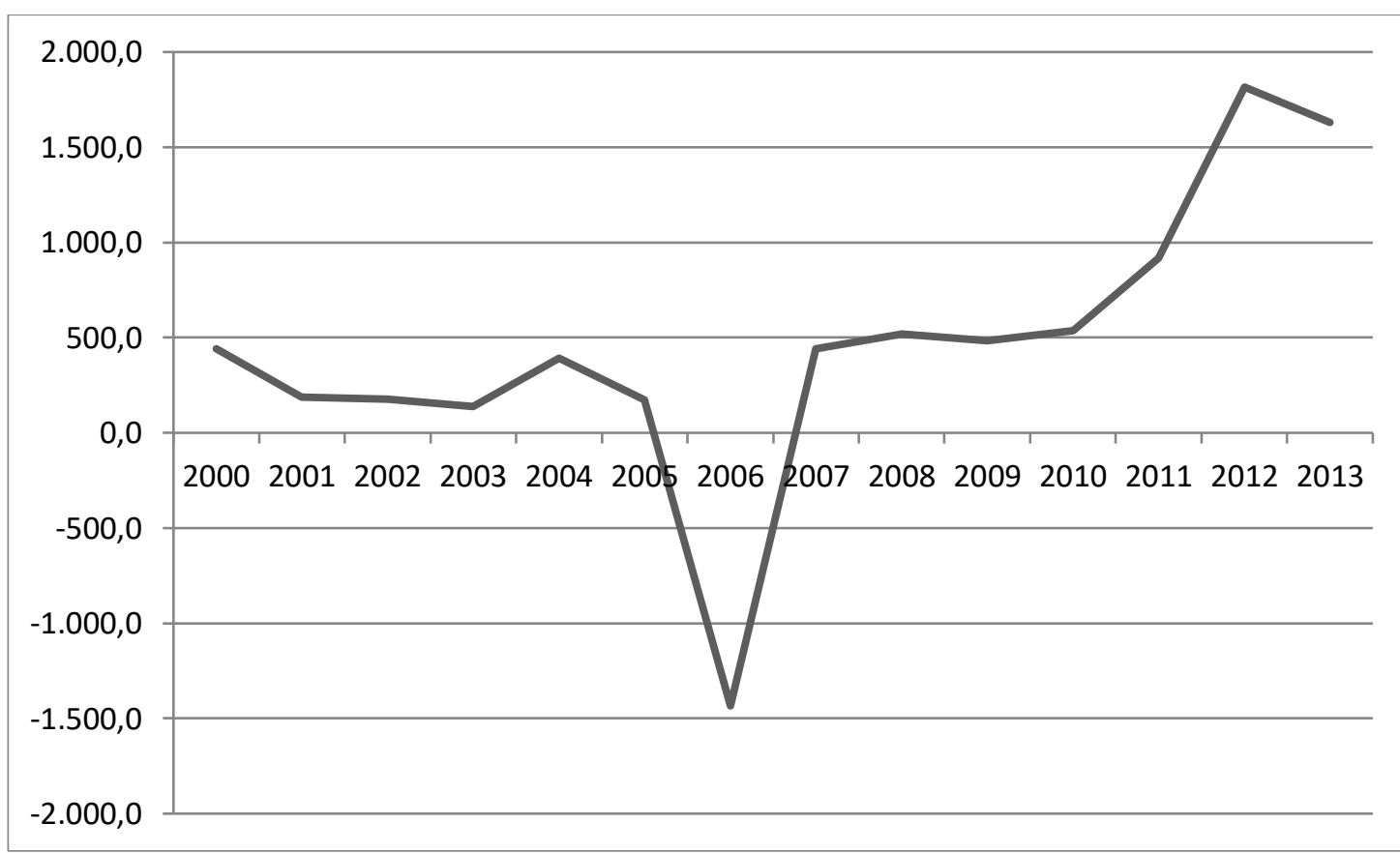

Fuente. Elaboración propia a partir de información de la Secretaría de Economía, Gobierno de México, disponible en http://www.economia.gob.mx/comunidad-negocios/competitividadnormatividad/inversion-extranjera-directa/estadistica-oficial-de-ied-en-mexico, fecha de consulta: $15 / 8 / 2014$

La reducción de las inversiones japonesas en México en 2006 se debía también a otro motivo: los factores chinos. Desde la década de 1990, el gobierno chino permitió las entradas de capitales extranjeros, lo cual fue aprovechado por las empresas japonesas (TAI, 2014). En realidad, desde los años 1970, las empresas japonesas habían entrado en 
China como una forma de cooperación tecnológica con las empresas estatales chinas, porque el gobierno chino en la década 1970 había dado prioridad a su política industrial: primero, para promover el aumento de las capacidades de las empresas estatales chinas; y segundo, para incrementar sus capacidades de fabricación de productos para satisfacer las demandas internas (LIAO, 2014). El gobierno chino era reacio a permitir la entrada de capitales extranjeros, pero necesitaba la tecnología extranjera para fabricar dichos productos. En este contexto, las empresas japonesas ingresaron en el país y enseñaron sus tecnologías a las empresas estatales chinas (AMANO y HAN, 2003, p.67). La mayor parte de las empresas japonesas que entraron en China eran de las industrias manufactureras, como la industria de electrodomésticos y de automóviles. Las demandas de los productos de estas industrias aumentaron en China desde los años 1980 (AMANO y HAN, 2003, p.70). Lo que facilitó el posicionamiento de las empresas japonesas ya que tenían un conocimiento adquirido de las condiciones productivas de las empresas chinas.

En la mitad de los 1980, el gobierno chino empezó a permitir la entrada de capitales extranjeros. Para poder instalarse una empresa extranjera en China, se necesitaba contar con empresas chinas que actuaran como socios de una joint-venture ${ }^{21}$. En este contexto, las empresas japonesas ya tenían ventajas para invertir en China, porque habían tenido relación con las empresas estatales chinas, a través de las cooperaciones tecnológicas descritas anteriormente. Aunque las inversiones japonesas en China empezaron en la década de 1980, este movimiento no fue importante hasta los años 1990. Como se muestra en el Gráfico II-5. 2, el aumento de las inversiones japonesas en China fue muy alto a partir de 1993, año en el que el gobierno chino abrió su mercado a los capitales extranjeros. Esta decisión del gobierno chino aceleró las inversiones japonesas en China.

\footnotetext{
${ }^{21}$ Información de Japan External Trade Organización, Japón. https://www.jetro.go.jp/world/asia/cn/invest_02.html, fecha de consulta, 28/2/2015.
} 
Gráfico II-5. 2. Inversiones japonesas en México y China, 1985-2012

(En millones de dólares)

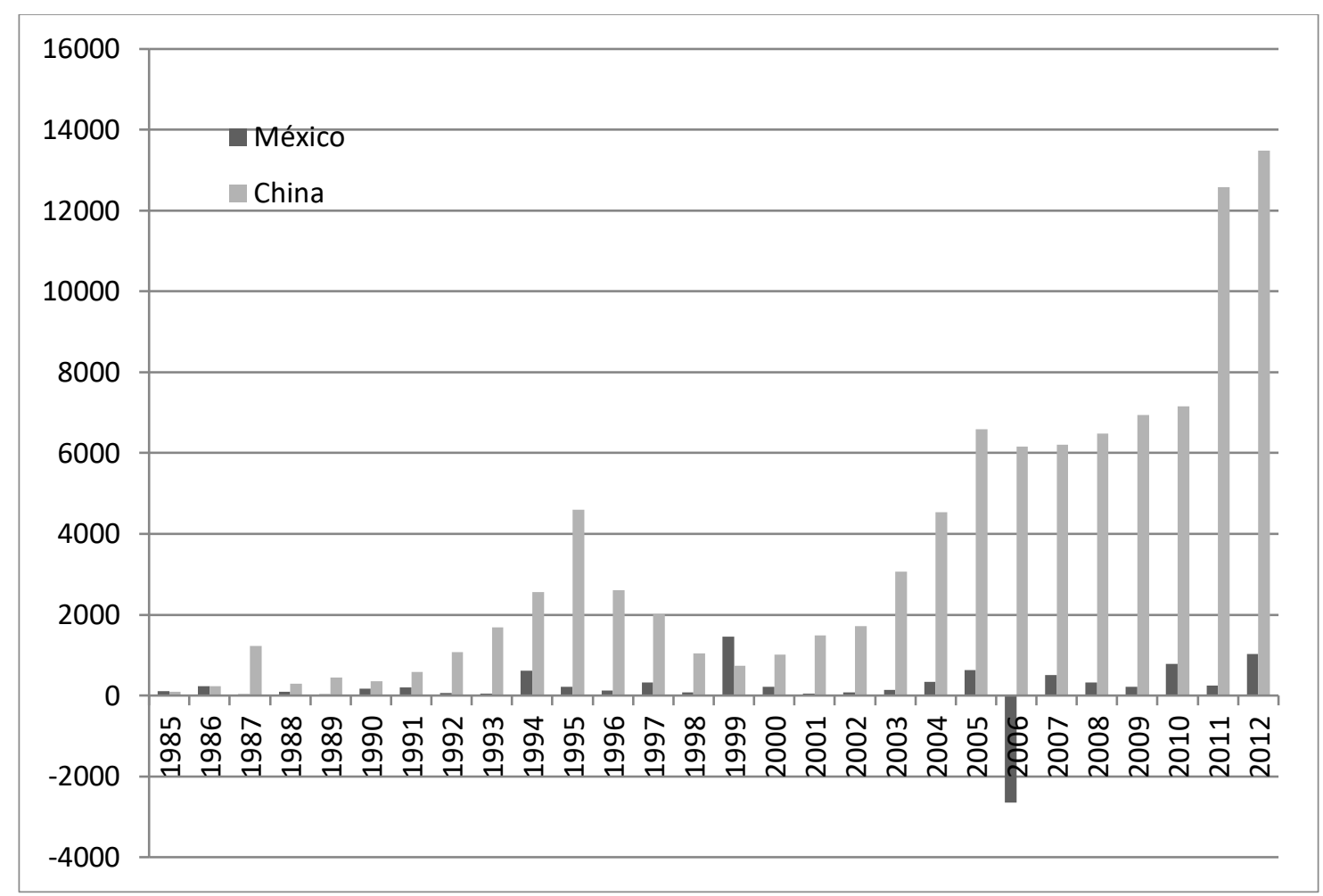

Fuente. Elaboración propia a partir de informaciones de OECD (Organizatión For Economic Coperation and Dvelopment), disponible en http://stats.oecd.org/Index.aspx?DatasetCode=FDI_FLOW_PARTNER\#, fecha de consulta:15/8/2014.

Comparando con las inversiones japonesas en México, las inversiones en China aumentaron a un mayor ritmo a lo largo de los 2000, mientras que la expansión en México fue sustancialmente menor e incluso sufrió un descenso en 2006.

Hubo varios motivos para este significativo avance de las empresas japonesas en China. El principal motivo fue el dinámico desarrollo económico de China (CEPAL N.U, 2010, pp.10-15 y 2011, pp.5-6.) Su mercado interno tenía grandes posibilidades de expansión. Las empresas japonesas tenían experiencia de actividades en China, como hemos visto anteriormente. Esta experiencia era una ayuda para las inversiones japonesas en dicho país. Además, la estrategia del gobierno chino para promover las inversiones funcionaba bien para las empresas japonesas. El gobierno chino quería promover industrias importantes, tales como la de electrodomésticos (incluyendo televisores) y la de automóviles. Estas industrias eran las principales industrias en las que de las empresas 
japonesas tenían presencia en el país. Esto era una ventaja para las inversiones japonesas en China.

El segundo motivo tiene que ver con la crisis económica en Japón. Como hemos visto, por la crisis las empresas japonesas tenían que reconsiderar sus planes de expansión en otros países. Para estas empresas, el desarrollo económico de China fue como un remedio para sus problemas. Había proximidad geográfica y cultual entre China y Japón, lo que redujo los costes de adaptación y transporte de las inversiones japonesas (ONIZUKA, 2003). Además, la crisis de la economía japonesa desde la década de la 90 obligaba a las empresas japonesas a reducir sus costes (ONIZUKA, 2003, pp. 89). Una de las razones de invertir en México era la reducción de los costes laborales. Pero, en este período, las empresas japonesas tenían que reducir aún más sus costes, para poder mantener la calidad de sus productos. Para lograr esto, China era un lugar muy adecuado para invertir. El coste de la mano de obra en China era más bajo que el de México. Especialmente, para las empresas manufactureras japonesas, este bajo coste salarial era el motivo más importante para sus inversiones a China. Como pone de manifiesto la Tabla II-5. 1, las diferencias de los costes laborales entre China y México eran muy amplias en 2012. Las empresas japonesas que avanzaron en China eran las mismas industrias que tenían actividades en México, esto es, las industrias manufactureras. Sin embargo, las principales funciones de las fábricas japonesas en China eran diferentes a las localizadas en México: las fábricas en México eran para exportar a Estados Unidos, mientras que las fábricas en China eran para vender a consumidores dentro y alrededores de China. ${ }^{22}$

\footnotetext{
${ }^{22}$ Según informaciones de Ministerio de Economía, Negocio E industria del Japón, disponible en http://www.meti.go.jp/statistics/tyo/kaigaizi/result/result_3/pdf/h2c402gj.pdf, fecha de consulta: 28/2/2015.
} 


\section{Tablas II-5. 1. Costes en México y China, 2012}

\begin{tabular}{|c|c|c|c|c|c|c|}
\hline China & & Shenzhen & $\begin{array}{c}\begin{array}{c}\text { Shenyang } \\
\text { (Liaoning) }\end{array} \\
\end{array}$ & Dalian & \begin{tabular}{|c|}
$\begin{array}{c}\text { Qingdao } \\
\text { (Shandong ) }\end{array}$ \\
\end{tabular} & $\begin{array}{l}\text { Wuhan } \\
\text { (Hubei ) }\end{array}$ \\
\hline \multirow{4}{*}{$\begin{array}{l}\text { Salarios (Dólares de } \\
\text { Estados Unidos) }\end{array}$} & Trabajadores/mes & 390 & 405 & 347 & 327 & 365 \\
\hline & Ingenieros/mes & 671 & 589 & 590 & 535 & 645 \\
\hline & Ejecutivo de nivel medio/mes & 1356 & 975 & 1,044 & 885 & 1,128 \\
\hline & Salarios Minimos/mes & 750 & $213 / 172$ & $213 / 197$ & $226 / 200$ & $213 / 167$ \\
\hline \multirow{2}{*}{ Seguridad Social } & Empresas & $\begin{array}{l}16,7 \%+8 \text { yuan } \\
\sim 39,9 \%+8 \text { yuan }\end{array}$ & $37,6 \sim 43 \%$ & $39,65 \sim 55,4 \%$ & $34,7 \sim 41,7 \%$ & $39,2 \sim 44,7 \%$ \\
\hline & Trabajadores & $\begin{array}{l}13,2 \%+4 \text { yuan } \\
\sim 30 \%+4 \text { yuan }\end{array}$ & $19 \sim 23 \%$ & $21 \sim 26 \%$ & $16 \sim 23 \%$ & $19 \sim 23 \%$ \\
\hline \multirow{3}{*}{$\%$ de aumento de salario } & En 2011 & 8 & 8,6 & 15,1 & 12,4 & 18 \\
\hline & En 2012 & 9,3 & 9,2 & 11,5 & 14,8 & 16,1 \\
\hline & En 2013 & 7 & 9,1 & 15,3 & 14,2 & 7,2 \\
\hline \multirow{3}{*}{$\begin{array}{l}\text { Coste de Oficina } \\
\text { (Dólares de Estados } \\
\text { Unidos) }\end{array}$} & $\begin{array}{l}\text { Alquilar una fabrica en zona } \\
\text { industria } 1 / \mathrm{m} 2\end{array}$ & $1,6 /$ mes & $3,3 \sim 4,17 /$ mes & $1,77 \sim 3,68 /$ mes & $1,64 \sim 2,95 / \mathrm{mes}$ & $1,97 \sim 3,28 / \mathrm{mes}$ \\
\hline & $\begin{array}{l}\text { Complar una fabrica en zona } \\
\text { industrial/m2 }\end{array}$ & 771 & 78,6 & $59 \sim 92$ & 41 & $49 \sim 79$ \\
\hline & $\begin{array}{l}\text { Alquilar una oficina en zona } \\
\text { industrial } / \mathrm{m} 2\end{array}$ & 26/mes & $20,5 /$ mes & $39,3 \sim 47,2 /$ mes & $25 \sim 29 / \mathrm{mes}$ & $18 \sim 25 /$ mes \\
\hline \multirow{3}{*}{$\begin{array}{l}\text { Transportación(Dólares } \\
\text { de Estados Unidos) }\end{array}$} & $\begin{array}{l}\text { Contenas (40ft) para } \\
\text { exportación a los } 3^{\mathrm{a}} \text { paises } \\
\end{array}$ & 2175 & 3087 & 2539 & 2081 & 3246 \\
\hline & $\begin{array}{l}\text { Contenas (40ft) para } \\
\text { importación desde Japón }\end{array}$ & 350 & 738 & 189 & 198 & $346 \sim 446$ \\
\hline & $\begin{array}{l}\text { Contenas para exportación a } \\
\text { Japón }\end{array}$ & 700 & 788 & 239 & 1090 & 400 \\
\hline
\end{tabular}

Fuente. Tomado de JETRO (Japan External Trade Organization), disponible en

http://www.jetro.go.jp/jfile/search/cost?c=123\&c=130\&c=125\&c=131\&c=054\&c=056\#link4, fecha de consulta: $18 / 8 / 2014$. 


\begin{tabular}{|c|c|c|c|c|c|c|c|}
\hline México & & $\begin{array}{l}\text { Aguascalientes } \\
\text { (Aguascalientes) }\end{array}$ & $\begin{array}{l}\text { Irapuato } \\
\text { (Guanajuato) }\end{array}$ & $\begin{array}{l}\text { Querétaro } \\
\text { (Querétaro) }\end{array}$ & $\begin{array}{l}\text { San Luis Potosí } \\
\text { (San Luis Potosí) }\end{array}$ & $\begin{array}{l}\text { Tijuana (B aja } \\
\text { California) }\end{array}$ & $\begin{array}{c}\text { Monterrey (Nuevo } \\
\text { León) }\end{array}$ \\
\hline \multirow{4}{*}{$\begin{array}{l}\text { Salarios (Dólares } \\
\text { de Estados } \\
\text { Unidos) }\end{array}$} & Trabajadores & $288,41 \sim 389,90 /$ mes & $265,97 \sim 403,29 / \mathrm{mes}$ & $311,89 \sim 450,26 / \mathrm{me}$ & $292,37 \sim 447,49 / \mathrm{mes}$ & $320,49 \sim 469,48 /$ mes & $332,46 \sim 484,59 / \mathrm{mes}$ \\
\hline & Ingenieros & $866,12 \sim 2187,73 / \mathrm{mes}$ & $866,12 \sim 2187,73 / \mathrm{mes}$ & $1033,66 \sim 2356,17 / 1$ & $975,32 \sim 227,61 / \mathrm{mes}$ & $1038,37 \sim 2459,24 / \mathrm{mes}$ & $1082,12 \sim 2558,49 / \mathrm{mes}$ \\
\hline & Ejecutivo de nivel medio & $2476,74 \sim 3772,85 / \mathrm{mes}$ & $2476,74 \sim 3772,85 / \mathrm{me}$ & $2768,89 \sim 4083,69 / 1$ & $2627,97 \sim 4023,34 / \mathrm{mes}$ & $2929,02 \sim 4399,10 / \mathrm{mes}$ & $2862,45 \sim 4379,81 / \mathrm{mes}$ \\
\hline & Salarios Minimos & \multicolumn{4}{|c|}{ 4,77/día } & \multicolumn{2}{|c|}{ 5,03/dia } \\
\hline \multirow{2}{*}{ Seguridad Social } & Empresas & \multicolumn{6}{|c|}{$23,94 \%$} \\
\hline & Trabajadores & \multicolumn{6}{|c|}{$2,38 \%$} \\
\hline \multirow{3}{*}{$\%$ de aumento de } & En 2011 & $3,97 \%$ & $3,58 \%$ & $3,88 \%$ & 0,0567 & $2,26 \%$ & 0,04 \\
\hline & En 2012 & $1,53 \%$ & $2,72 \%$ & $3,27 \%$ & 0,0532 & $1,71 \%$ & 0,0286 \\
\hline & En 2013 & $1,68 \%$ & $2,78 \%$ & $3,30 \%$ & 0,0535 & $2,09 \%$ & 0,0325 \\
\hline \multirow{3}{*}{$\begin{array}{l}\text { Coste de } \\
\text { Oficina/m2 } \\
\text { (Dólares de } \\
\text { Estados Unidos) }\end{array}$} & $\begin{array}{l}\text { Alquilar una fabrica en zona } \\
\text { industria } 1 / \mathrm{m} 2\end{array}$ & $2,77 \sim 3,58 / \mathrm{mes}$ & $4,35 / \mathrm{mes}$ & $4,5 / \mathrm{mes}$ & $3,8 / \mathrm{mes}$ & $3,43 \sim 4,58 /$ mes & $3,58 \sim 4,48 /$ mes \\
\hline & $\begin{array}{l}\text { Complar una fabrica en zona } \\
\text { industria } 1 \mathrm{~m} 2\end{array}$ & $26,88 \sim 59,14$ & $40-44$ & 65 & 34 & $65 \sim 120$ & $39,78 \sim 139,78$ \\
\hline & $\begin{array}{l}\text { Alquilar una oficina en zona } \\
\text { industria } 1 / \mathrm{m} 2\end{array}$ & $6 \sim 12 / \mathrm{mes}$ & $13 \sim 20 /$ mes & $13 \sim 21 / \mathrm{mes}$ & $10 \sim 14 / \mathrm{mes}$ & $15 \sim 19 /$ mes & $20 \sim 24 / \mathrm{mes}$ \\
\hline \multirow{3}{*}{$\begin{array}{l}\text { Transportación } \\
\text { (Dólares de } \\
\text { Estados Unidos) }\end{array}$} & $\begin{array}{l}\text { Contenas (40ft) para } \\
\text { exportación a los } 3^{\text {a }} \text { paises }\end{array}$ & 1850 & 2200 & 2100 & 2000 & 1350 & 900 \\
\hline & \begin{tabular}{|l} 
Contenas (40ft) para \\
importación desde Japón \\
\end{tabular} & 3800 & 3900 & 4050 & 4400 & 2750 & 4650 \\
\hline & $\begin{array}{l}\text { Contenas para exportación a } \\
\text { Japón }\end{array}$ & 4750 & 4830 & 4935 & 5000 & 4350 & 6490 \\
\hline
\end{tabular}

Fuente: Tomado de JETRO (Japan External Trade Organization), disponible en

http://www.jetro.go.jp/jfile/search/cost?c=123\&c=130\&c=125\&c=131\&c=054\&c=056\#link4, fecha de consulta: $18 / 8 / 2014$. 
Sin embargo, estas diferencias en los papeles de las empresas japonesas en México y China desaparecieron tras el aumento de las exportaciones chinas a Estados Unidos, especialmente a partir de 2002 (véase el Gráfico II-5. 3). En ese momento, las empresas japonesas entendieron que era posible exportar desde China a Estados Unidos y las fábricas japonesas en México perdieron su razón principal de ser. Por eso, las inversiones japonesas en México en la primera parte de la década de 2000 se redujeron.

Gráfico II-5. 3. Importaciones de Estados Unidos desde China y México, 1990-2011 (En miles de dólares)

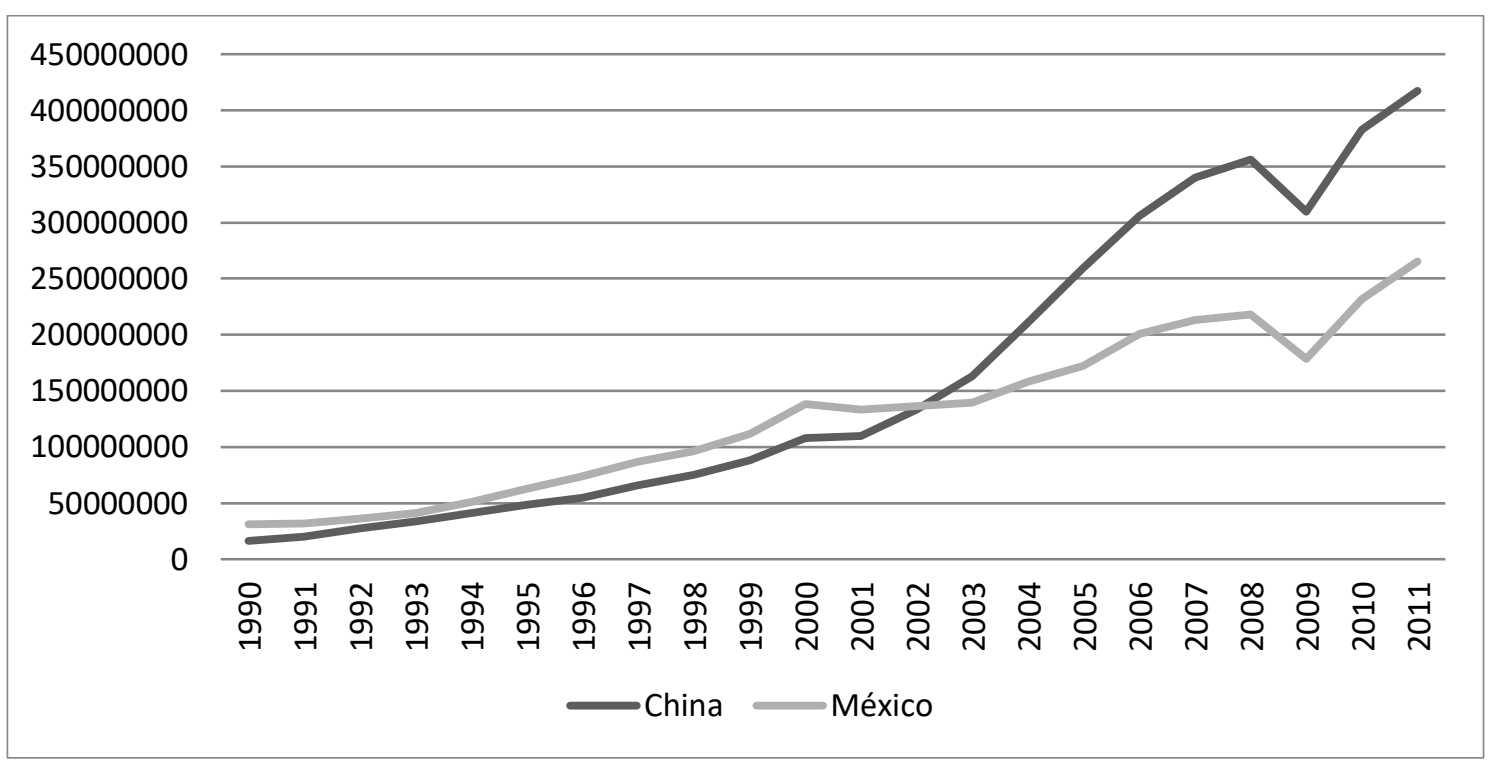

Fuente. Elaboración propia a partir de informaciones de OECD (Organizatión For Economic Coperation and Dvelopment), disponible en http://stats.oecd.org/Index.aspx?DatasetCode=FDI_FLOW_PARTNER\#, fecha de consulta: $15 / 8 / 2014$.

El surgimiento de la economía china y su dominio en el mercado de Estados Unidos son muy claros, a través del análisis de las importaciones de Estados Unidos desde China y México en el Gráficos II-5.4 y se estudiará con más detenimiento en el capítulo III. Se nota que la mayor parte de las industrias manufactureras mexicanas perdieron participación en sus exportaciones a Estados Unidos en los primeros años de la década de 2000. Especialmente las industrias chinas de radios, televisores y equipos de comunicaciones y de transportes exportaron a Estados Unidos más que desde México. 
Gráficos II-5. 4. Importaciones de Estados Unidos desde China y México por grupos de productos, 1990-2011

(En miles de dólares)

\section{1). Textiles, productos textiles, cueros y calzados}

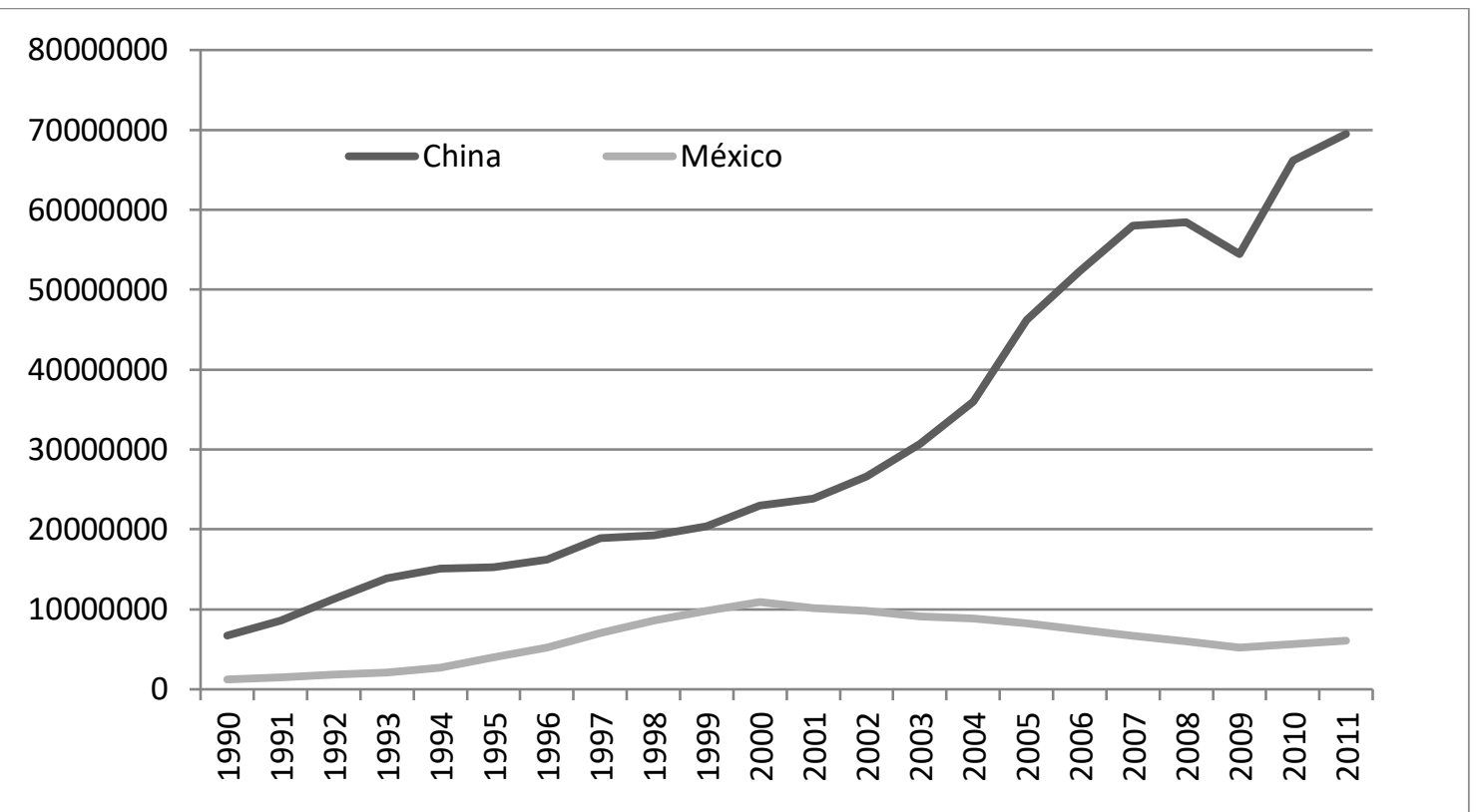

Fuente. Elaboración propia a partir de informaciones de OECD (Organizatión For Economic Coperation and Dvelopment), disponible en

http://stats.oecd.org/Index.aspx?DatasetCode=FDI_FLOW_PARTNER\#, fecha de consulta: $15 / 8 / 2014$.

\section{2). Químicas}

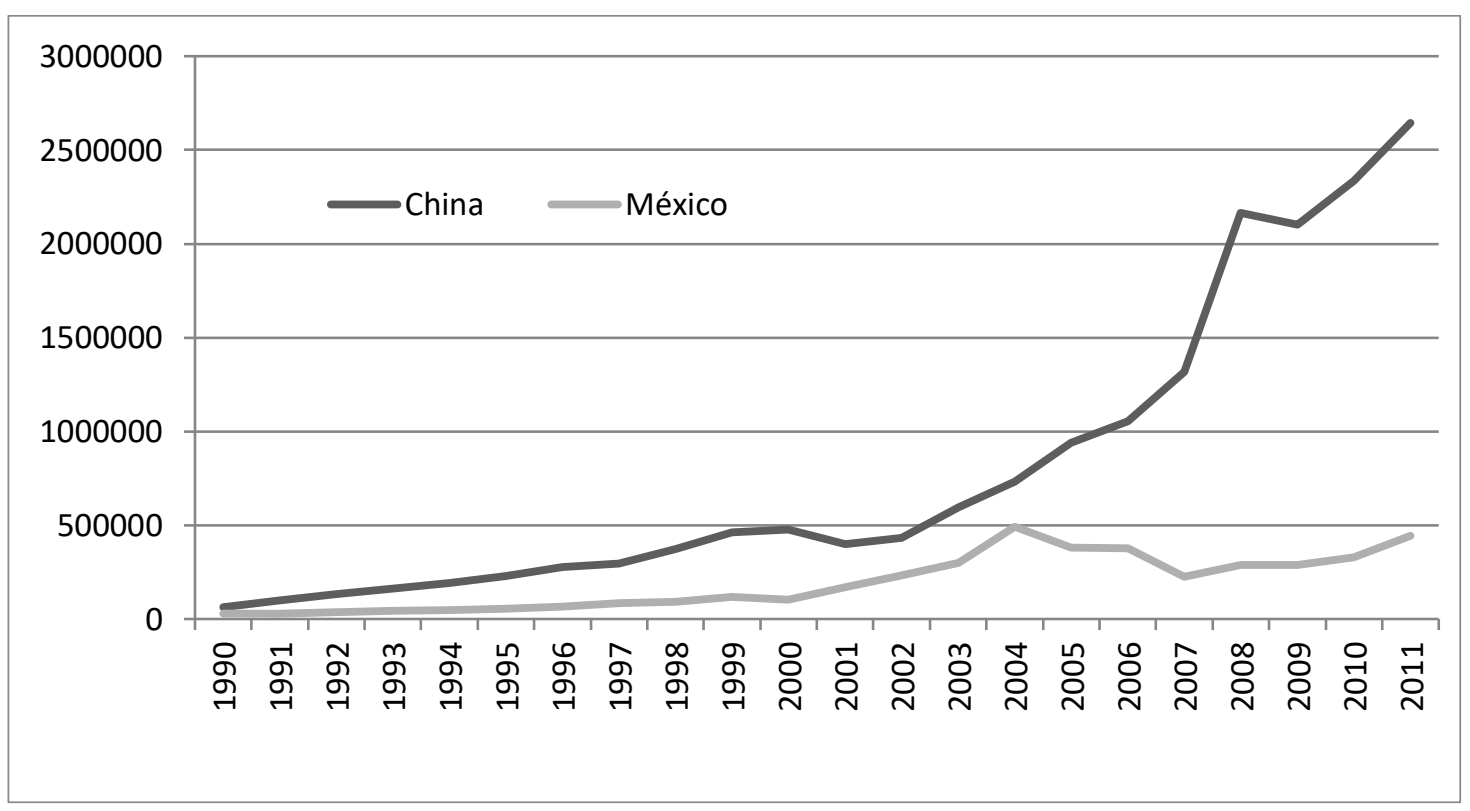

Fuente. Elaboración propia a partir de informaciones de OECD (Organizatión For Economic Coperation and Dvelopment), disponible en

http://stats.oecd.org/Index.aspx?DatasetCode=FDI_FLOW_PARTNER\#, fecha de consulta: $15 / 8 / 2014$ 


\section{3). Metales básicos y productos metálicos}

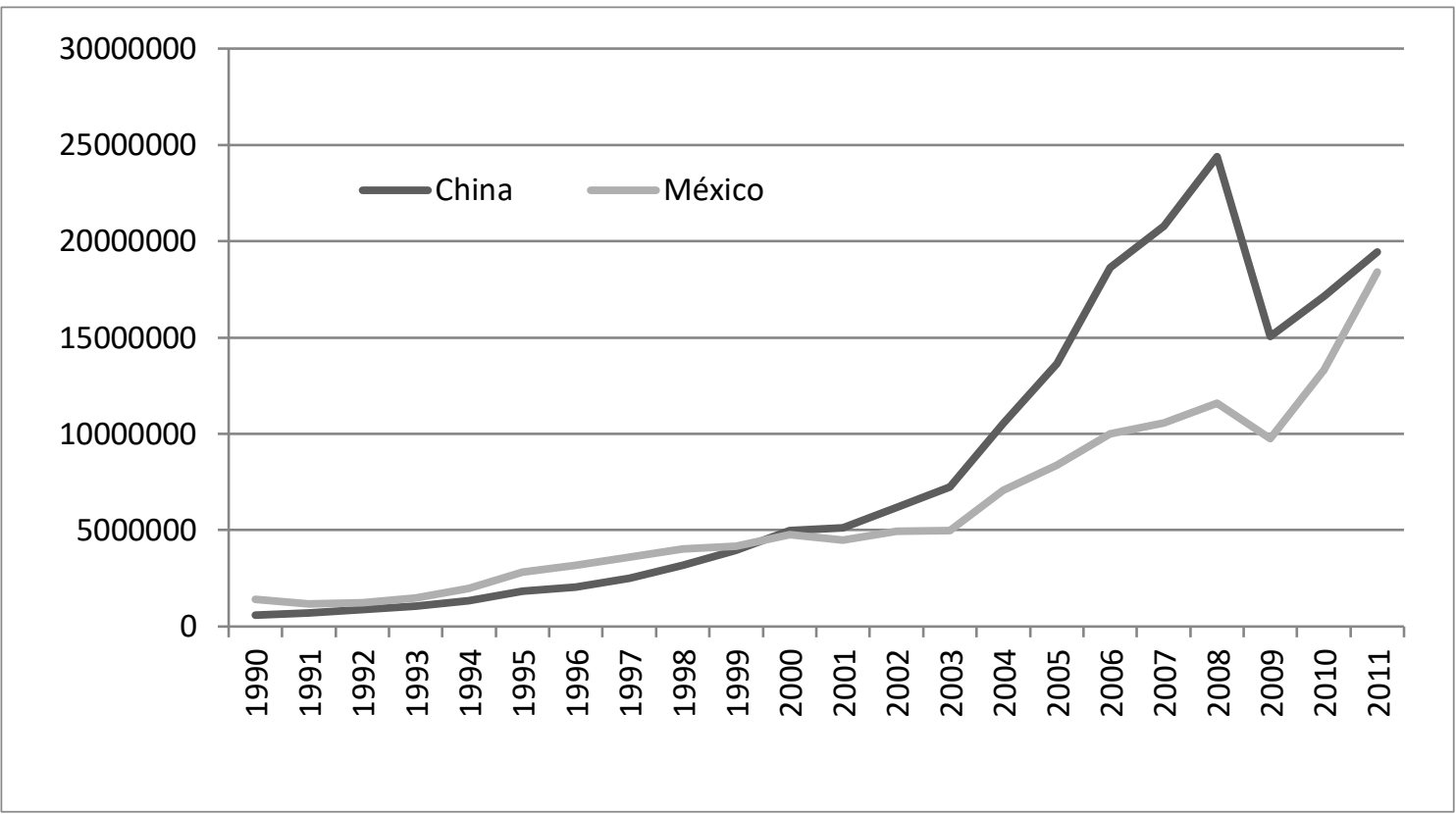

Fuente. Elaboración propia a partir de informaciones de OECD (Organizatión For Economic Coperation and Dvelopment), disponible en

http://stats.oecd.org/Index.aspx?DatasetCode=FDI_FLOW_PARTNER\#, fecha de consulta: $15 / 8 / 2014$

\section{4). Maquinarias y equipos}

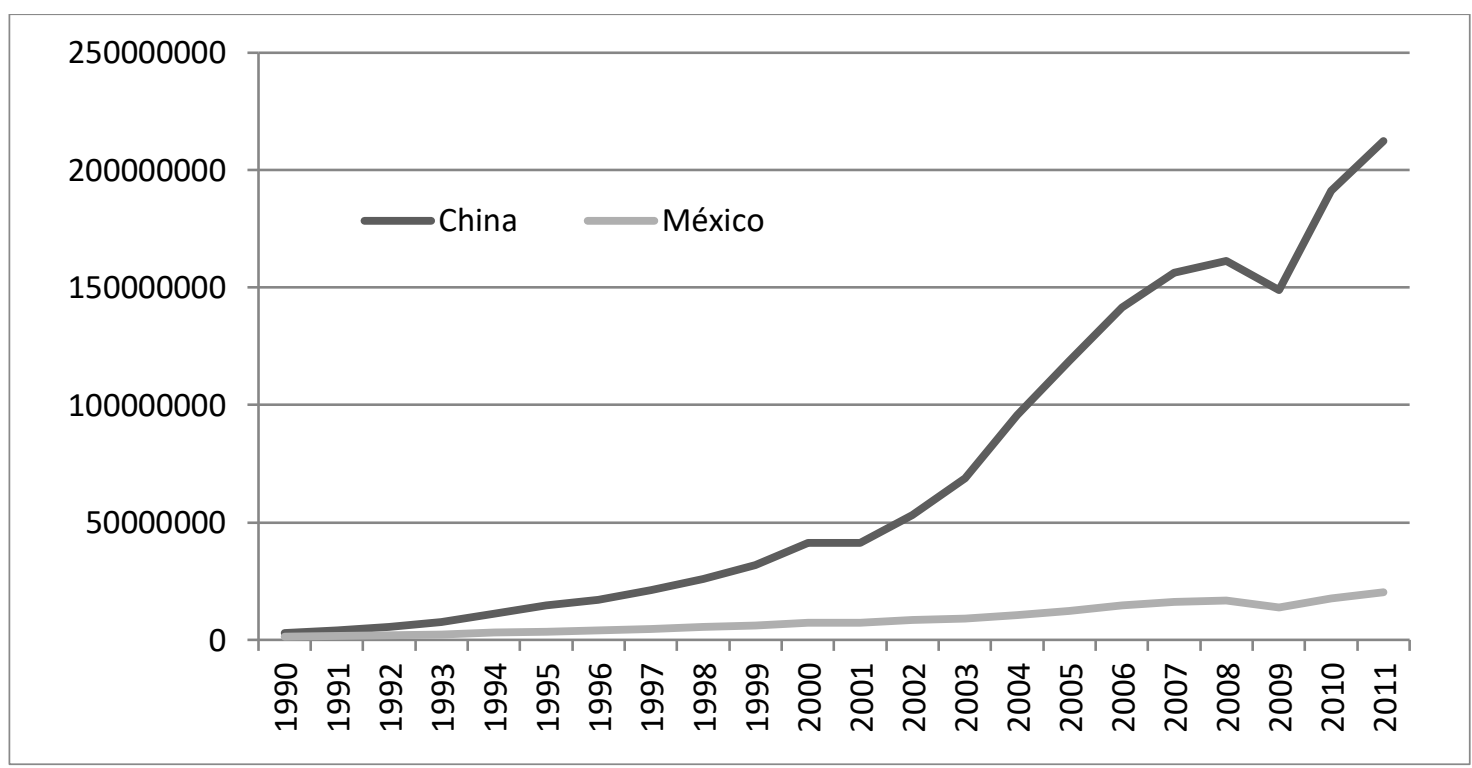

Fuente. Elaboración propia a partir de informaciones de OECD (Organizatión For Economic Coperation and Dvelopment), disponible en

http://stats.oecd.org/Index.aspx?DatasetCode=FDI_FLOW_PARTNER\#, fecha de consulta: $15 / 8 / 2014$ 
5). Maquinarias de oficina, contabilidad e informática

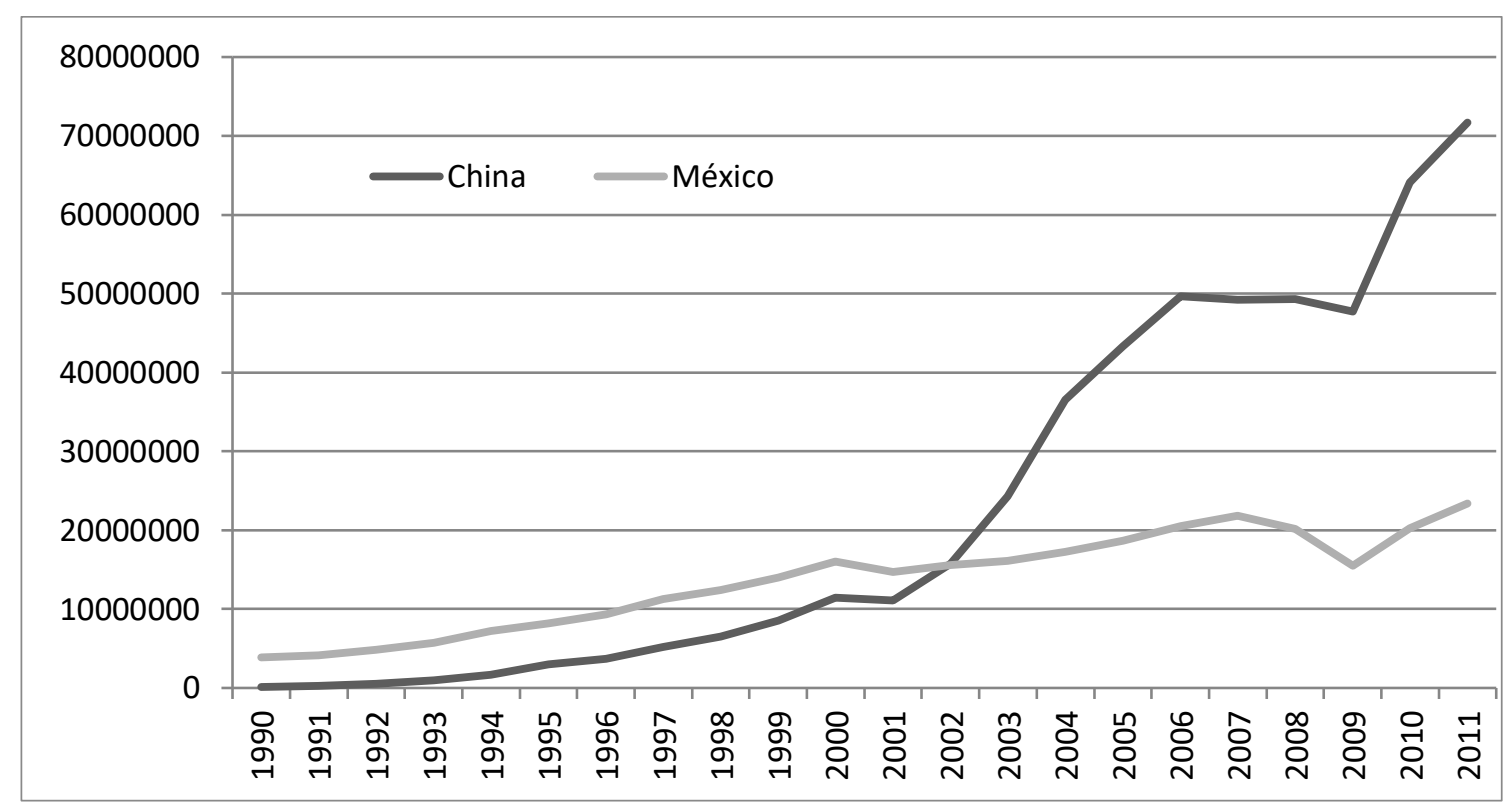

Fuente. Elaboración propia a partir de informaciones de OECD (Organizatión For Economic Coperation and Dvelopment), disponible en http://stats.oecd.org/Index.aspx?DatasetCode=FDI_FLOW_PARTNER\#, fecha de consulta: $15 / 8 / 2014$

\section{6). Radios, televisores y equipos de comunicaciones}

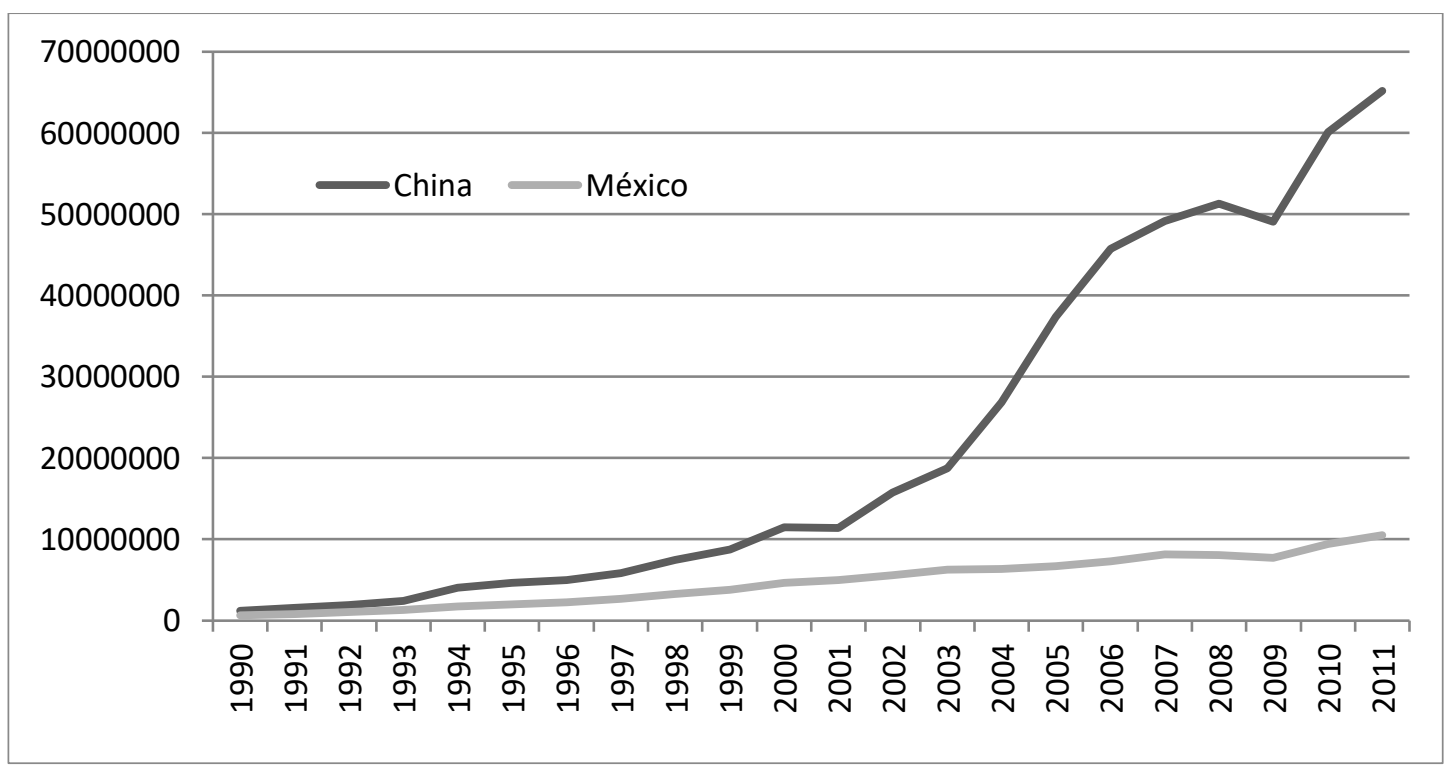

Fuente. Elaboración propia a partir de informaciones de OECD (Organizatión For Economic Coperation and Dvelopment), disponible en http://stats.oecd.org/Index.aspx?DatasetCode=FDI_FLOW_PARTNER\#, fecha de consulta: 15/8/2014. 


\section{7). Instrumentos médicos, ópticos y de precisión}

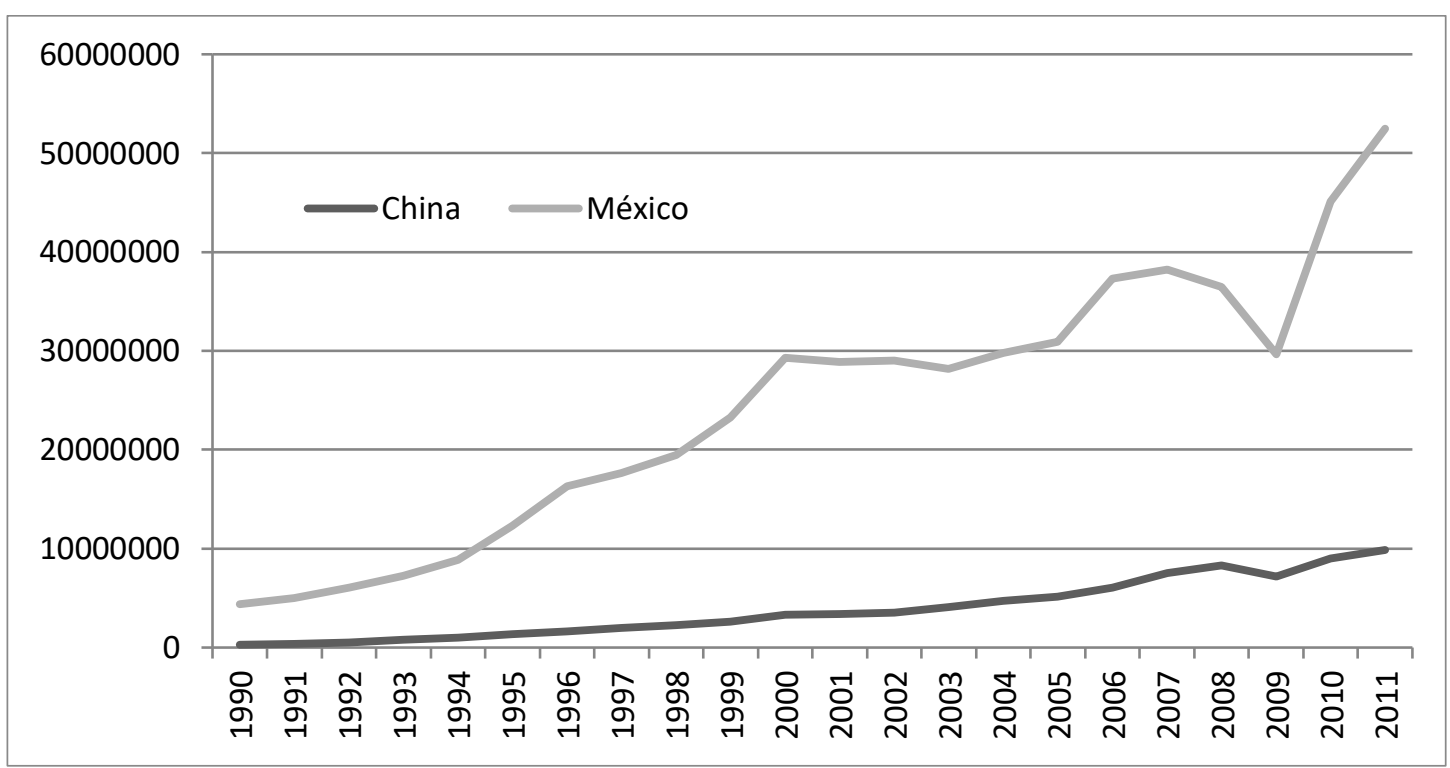

Fuente. Elaboración propia a partir de informaciones de OECD (Organizatión For Economic Coperation and Dvelopment), disponible en

http://stats.oecd.org/Index.aspx?DatasetCode=FDI_FLOW_PARTNER\#, fecha de consulta: $15 / 8 / 2014$.

\section{8). Transportes}

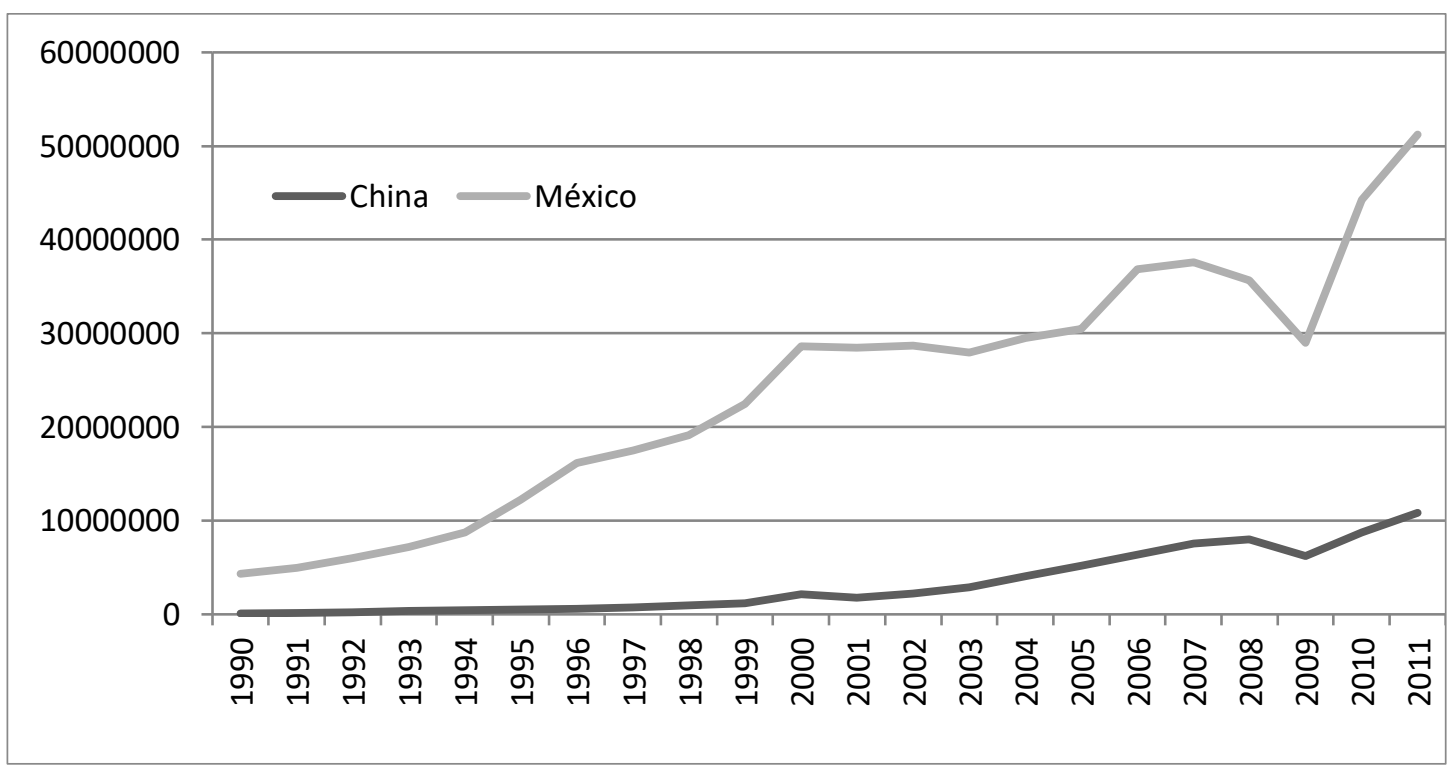

Fuente. Elaboración propia a partir de informaciones de OECD (Organizatión For Economic Coperation and Dvelopment), disponible en

http://stats.oecd.org/Index.aspx?DatasetCode=FDI_FLOW_PARTNER\#, fecha de consulta: $15 / 8 / 2014$. 


\section{9). Vehículos de motor, remolques y semirremolques}

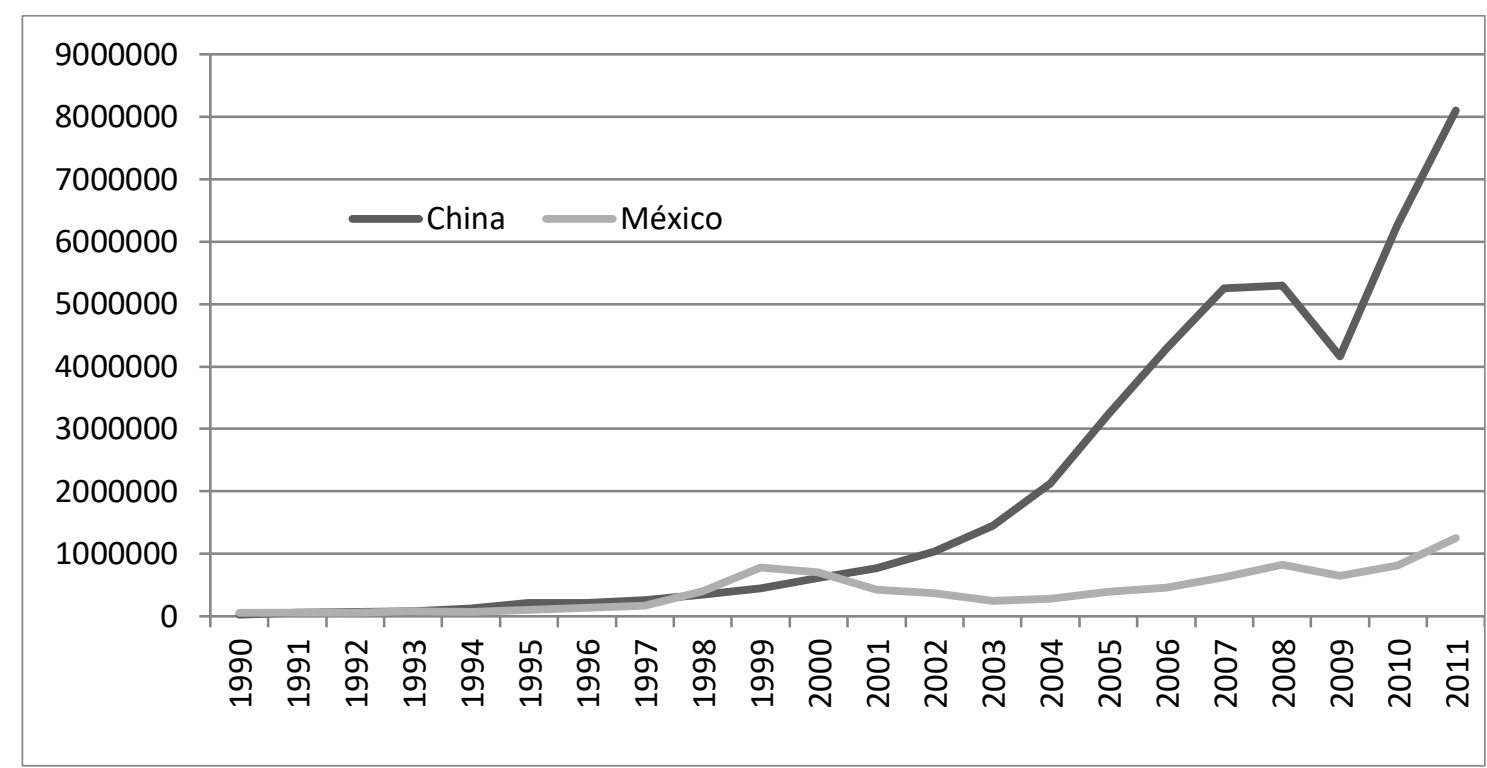

Fuente. Elaboración propia a partir de informaciones de OECD (Organizatión For Economic Coperation and Dvelopment), disponible en

http://stats.oecd.org/Index.aspx ?DatasetCode=FDI_FLOW_PARTNER\#, fecha de consulta: $15 / 8 / 2014$.

\section{0). Aviones y naves espaciales}

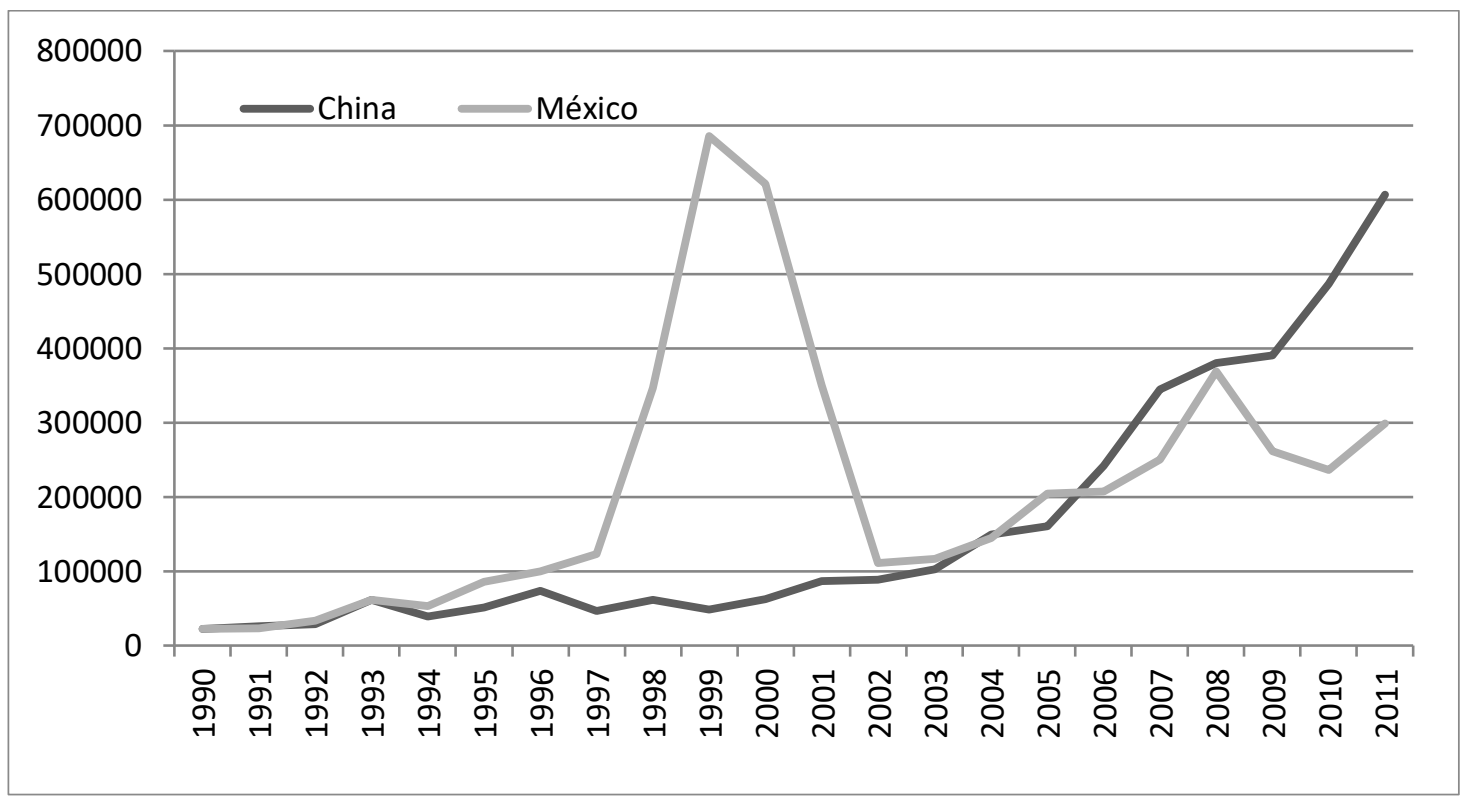

Fuente. Elaboración propia a partir de informaciones de OECD (Organizatión For Economic Coperation and Dvelopment), disponible en http://stats.oecd.org/Index.aspx ?DatasetCode=FDI_FLOW_PARTNER\#, fecha de consulta: $15 / 8 / 2014$

En estas condiciones, para las empresas japonesas era muy complicado encontrar motivos para aumentar las inversiones en México. El surgimiento de la economía china y sus aumentos de las exportaciones a Estados Unidos eran motivos suficientes para reducir las inversiones japonesas en México. Podemos notar el descenso de las 
inversiones japonesas en México, especialmente en el año 2006 (véase el Gráfico II-5. 1). En ese año, hubo una retirada de capitales japoneses en México, pero no una caída generalizada de la IED japonesa en el mundo. Como se aprecia en el Gráfico II-5. 5, las inversiones japonesas globales no se redujeron en 2006; es decir, las inversiones japonesas sólo bajaron en México en ese año.

\section{Gráficos II-5.5. Inversiones japonesas en el mundo, 1995-2012}

\section{1). Flujo (En millones dólares)}

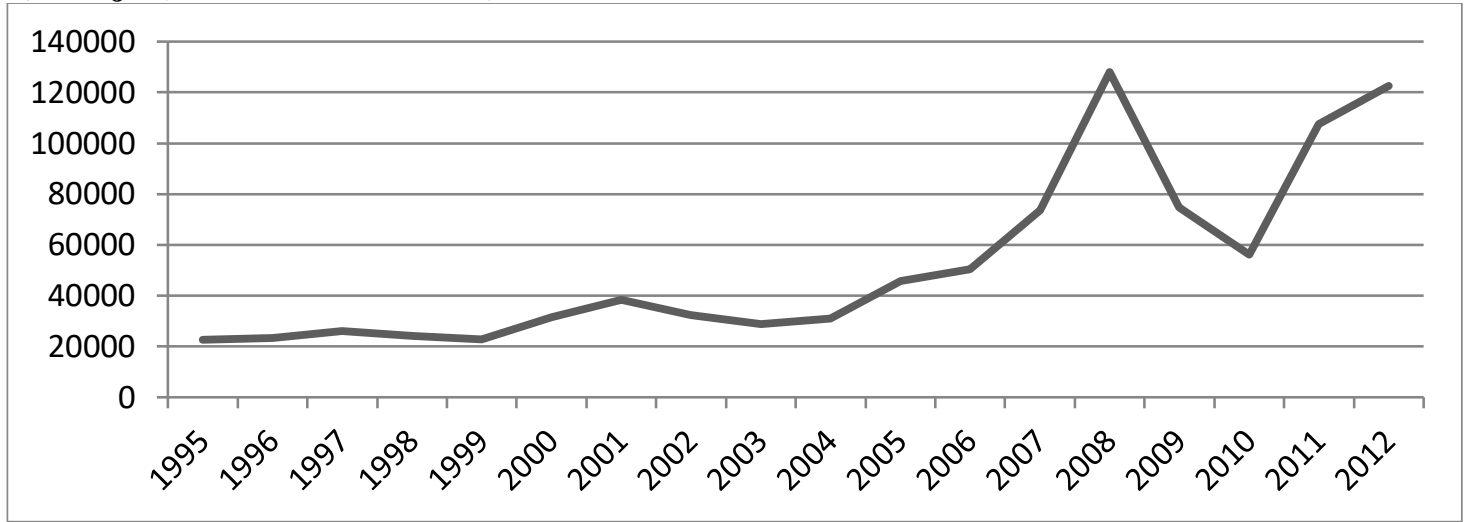

Fuente. Elaboración propia a partir de información de UNCTAD. Disponible en http://unctadstat.unctad.org/wds/TableViewer/tableView.aspx, fecha de consulta: 16/8/2014.

\section{2). Stock (En millones dólares)}

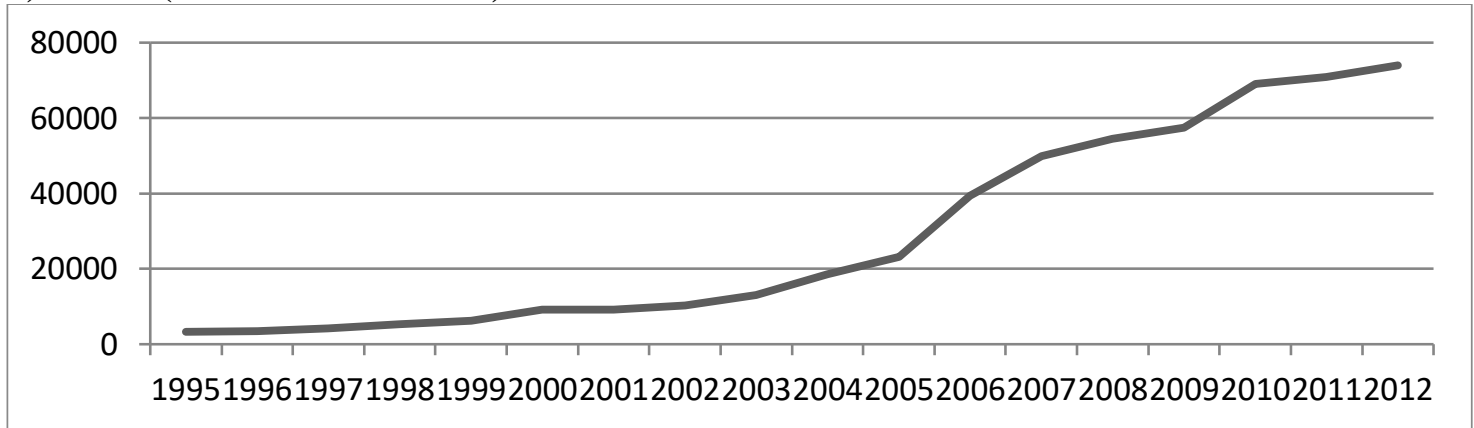

Fuente. Elaboración propia a partir de información de UNCTAD. Disponible en http://unctadstat.unctad.org/wds/TableViewer/tableView.aspx, fecha de consulta: 16/8/2014.

El motivo principal del descenso de los capitales japoneses en 2006 fue el descenso del número de sociedades que se presentaron en México. Como muestra el Gráfico II-5. 6, sólo en el año 2006, el número de sociedades japonesas está por debajo de las chinas. En este contexto, se puede considerar que uno de los motivos del descenso en 2006 fue el descenso de números de casos de asociados mexicanos. 
Gráfico II-5. 6. Número de los flujos de inversión extranjera directa planeados hacia México por país de origen, 1999-2012

(En millones dólares)

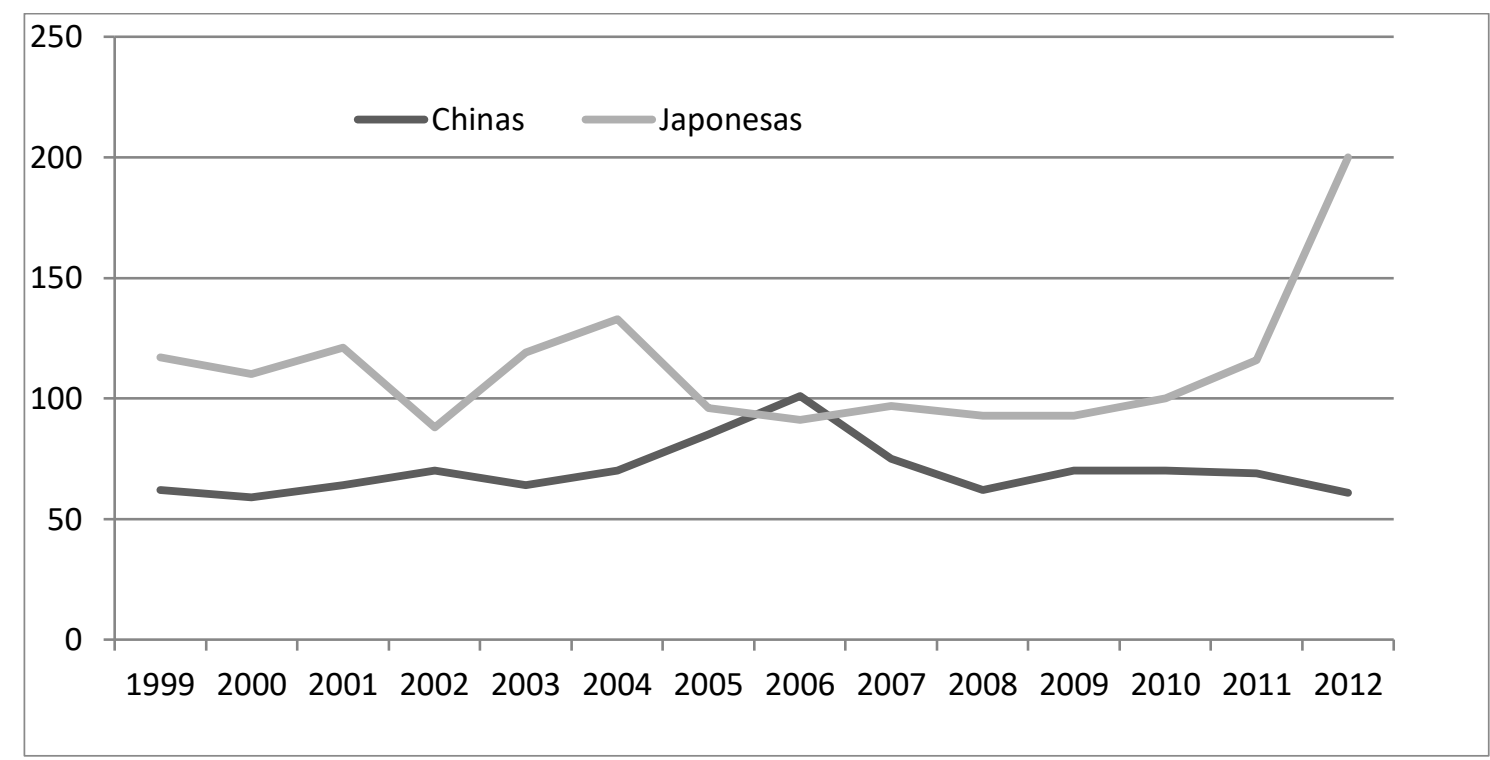

Fuente. Elaboración propia a partir de Secretaría de Economía, el gobierno de México. Disponible en http://www.economia.gob.mx/comunidad-negocios/competitividad-normatividad/inversionextranjera-directa/estadistica-oficial-de-ied-en-mexicot, fecha de 16/8/2014.

Después del descenso de las inversiones japonesas del año 2006 en México, las ventas de las empresas japonesas en dicho país se redujeron muy rápidamente, aunque su evolución fue diferente dependiendo de la industria. Como se aprecia en el Gráfico II-5.7, las ventas en las industrias de equipos de información y comunicación electrónica y de equipos de maquinaria eléctrica, que son los principales sectores de los capitales japoneses en México, se contrajeron de forma considerable tras la caída de 2006. Por el contrario, las ventas de la industria de transportes, que es otra industria importante de los capitales japoneses, no disminuyeron, a pesar de la reducción de las inversiones japonesas en México. 
Gráficos II-5. 7. Ventas de las empresas japonesas en México por grupos de productos, 1997 2012

(En millones de dólares)

\section{1). Transportes}

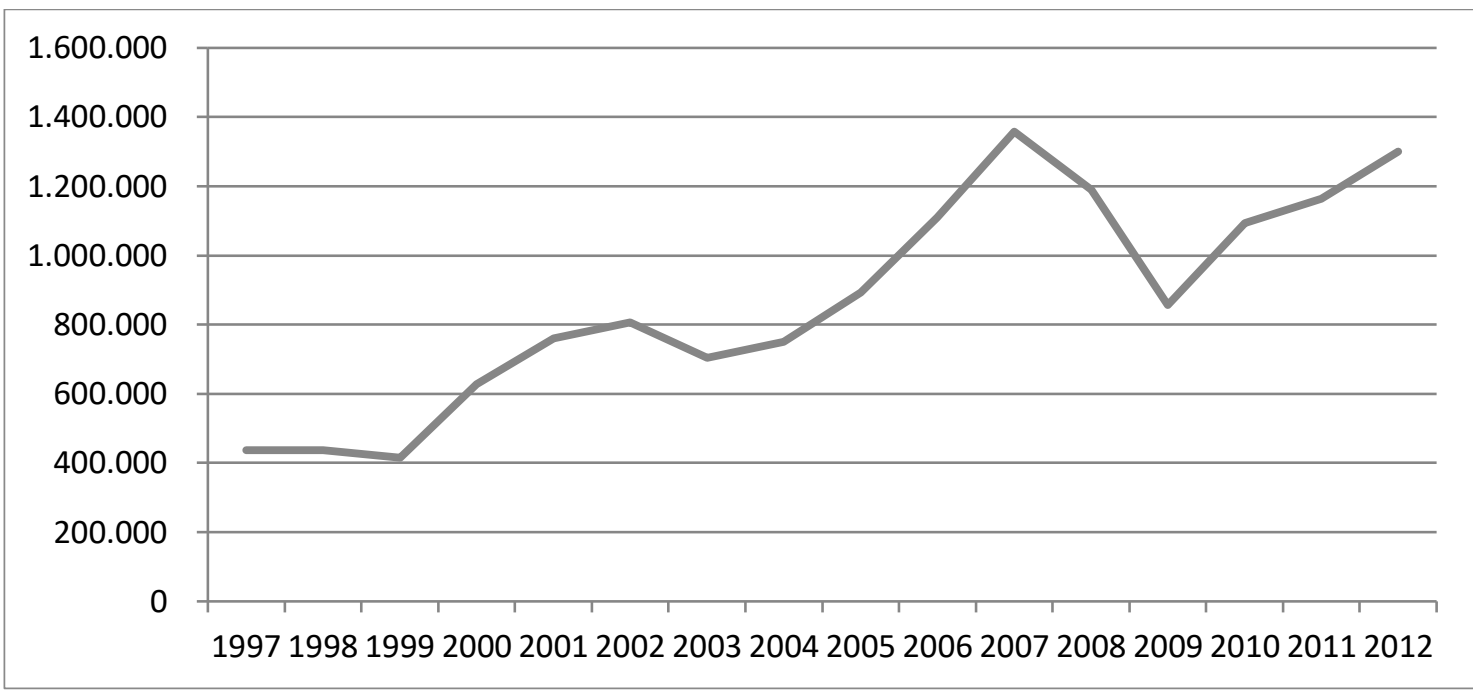

Fuente: Elaboración propia a partir de información de Ministerio de Economía, Negocio e Industria del Japón. Disponible en http://www.meti.go.jp/statistics/tyo/kaigaizi/, fecha de consulta: 16/8/2014.

\section{2). Equipos de información y comunicación electrónica}

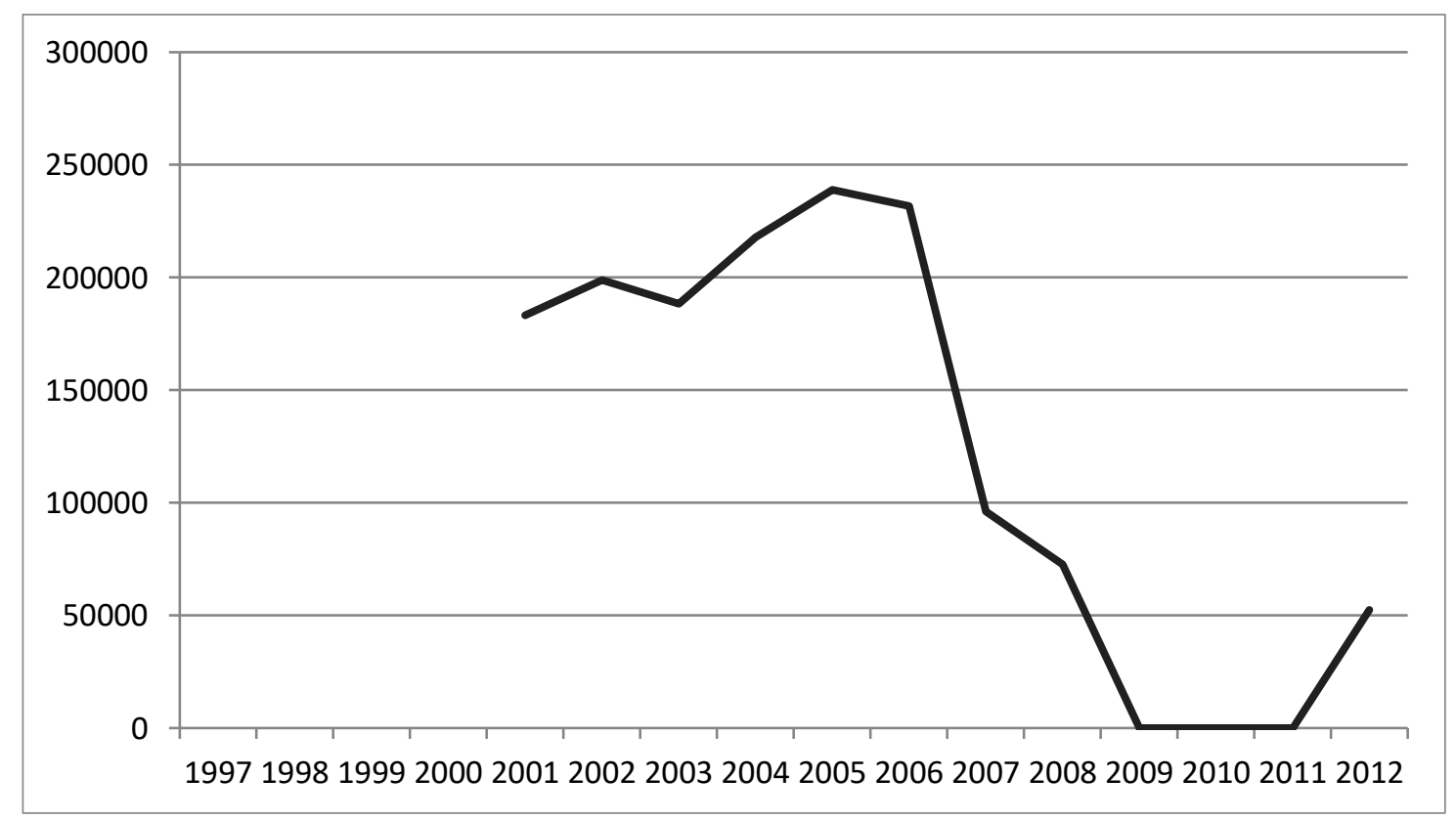

Fuente: Elaboración propia a partir de información de Ministerio de Economía, Negocio e Industria del Japón. Disponible en http://www.meti.go.jp/statistics/tyo/kaigaizi/, fecha de consulta: 16/8/2014. 


\section{3). Maquinaria eléctrica}

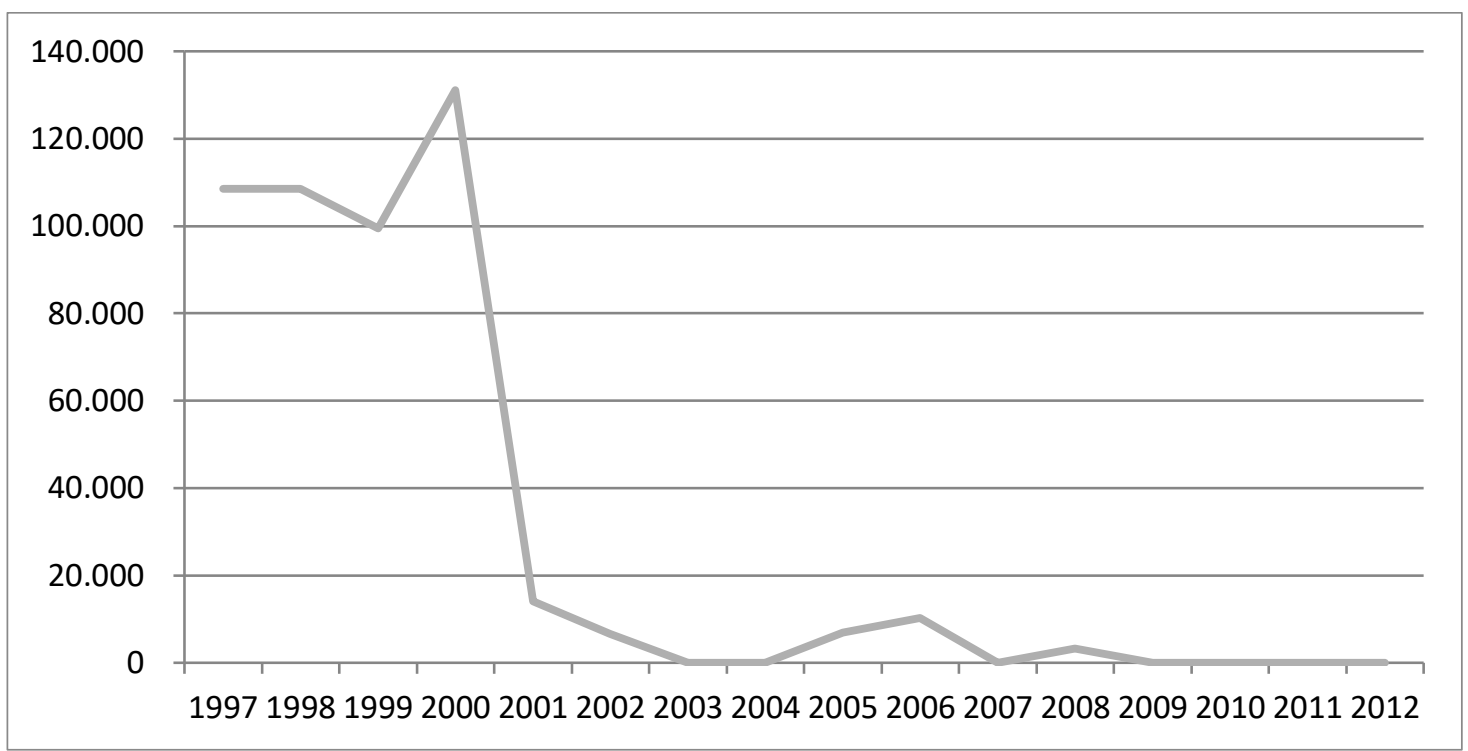

Fuente: Elaboración propia a partir de información de Ministerio de Economía, Negocio e Industria del Japón. Disponible en http://www.meti.go.jp/statistics/tyo/kaigaizi/, fecha de consulta: 16/8/2014.

\section{4). Química}

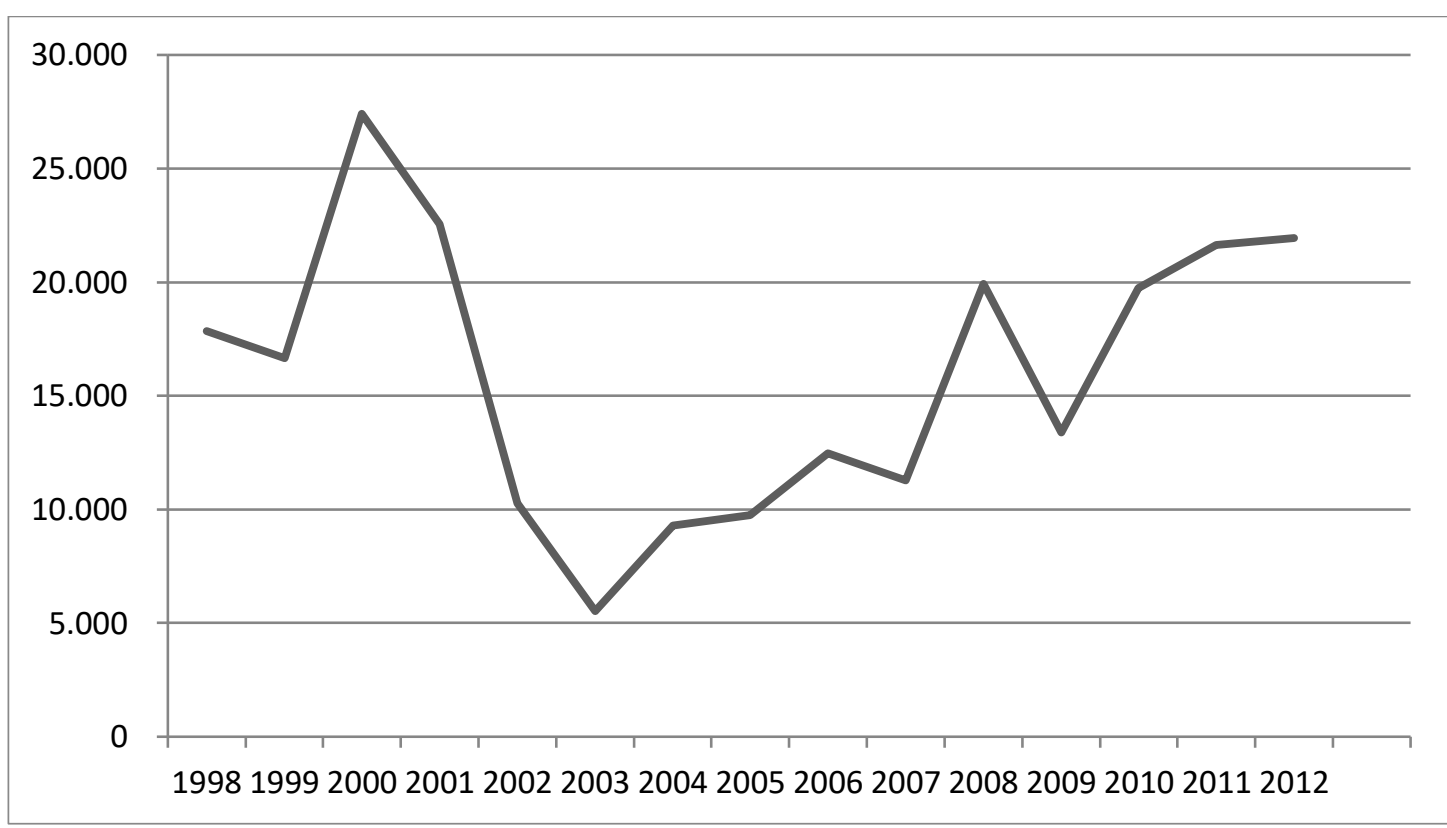

Fuente: Elaboración propia a partir de información de Ministerio de Economía, Negocio e Industria del Japón. Disponible en http://www.meti.go.jp/statistics/tyo/kaigaizi/, fecha de consulta: 16/8/2014. 
6). Ventas de minoristas en totales de las empresas japonesas en México

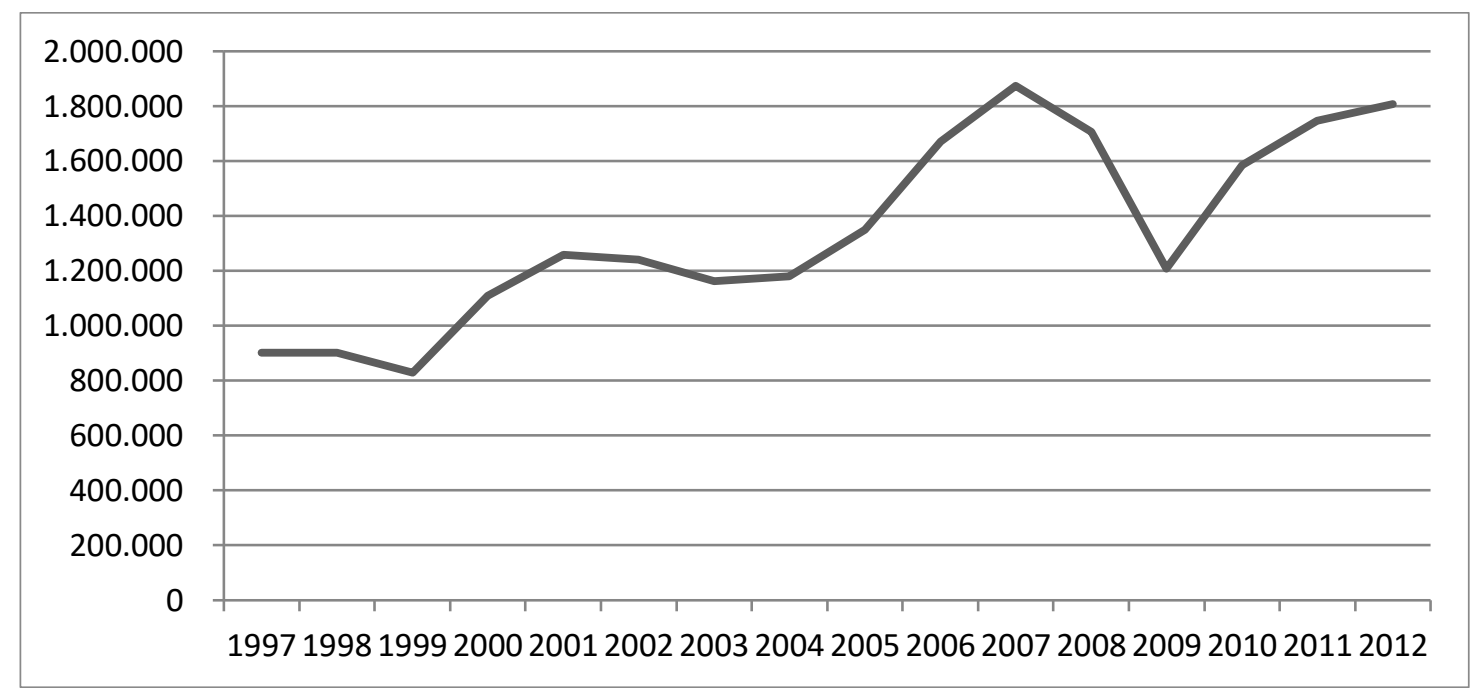

Fuente. Elaboración propia a partir de información de Ministerio de Economía, Negocio e Industria del Japón. Disponible en http://www.meti.go.jp/statistics/tyo/kaigaizi/, fecha de consulta: 16/8/2014.

Desde el punto de la vista de las ventas de las empresas japonesas en México, el descenso del año 2006 no fue tan dañino. Sin embargo, desde otros puntos de vistas, hay algunas evidencias que apuntan a que las actividades de estas empresas cambiaron a partir de 2006.

Primero, analizamos el número de trabajadores en las empresas japonesas instaladas en México. Se nota que después de 2006, el nivel de empleo proporcionado por estas empresas ha vuelto al existente en la primera parte de la década de 2000 (véase el Gráfico II-5. 8). Sin embargo, en la industria de transportes, esta tendencia es distinta: el número de trabajadores en dicha industria tiende a aumentar en los últimos años. Sólo la industria de transportes aumenta su número de trabajadores, mientras que en otras industrias dicho número se reduce. 
Gráfico II-5. 8. Números de Trabajadores en las empresas japonesas en México, 2000-2012

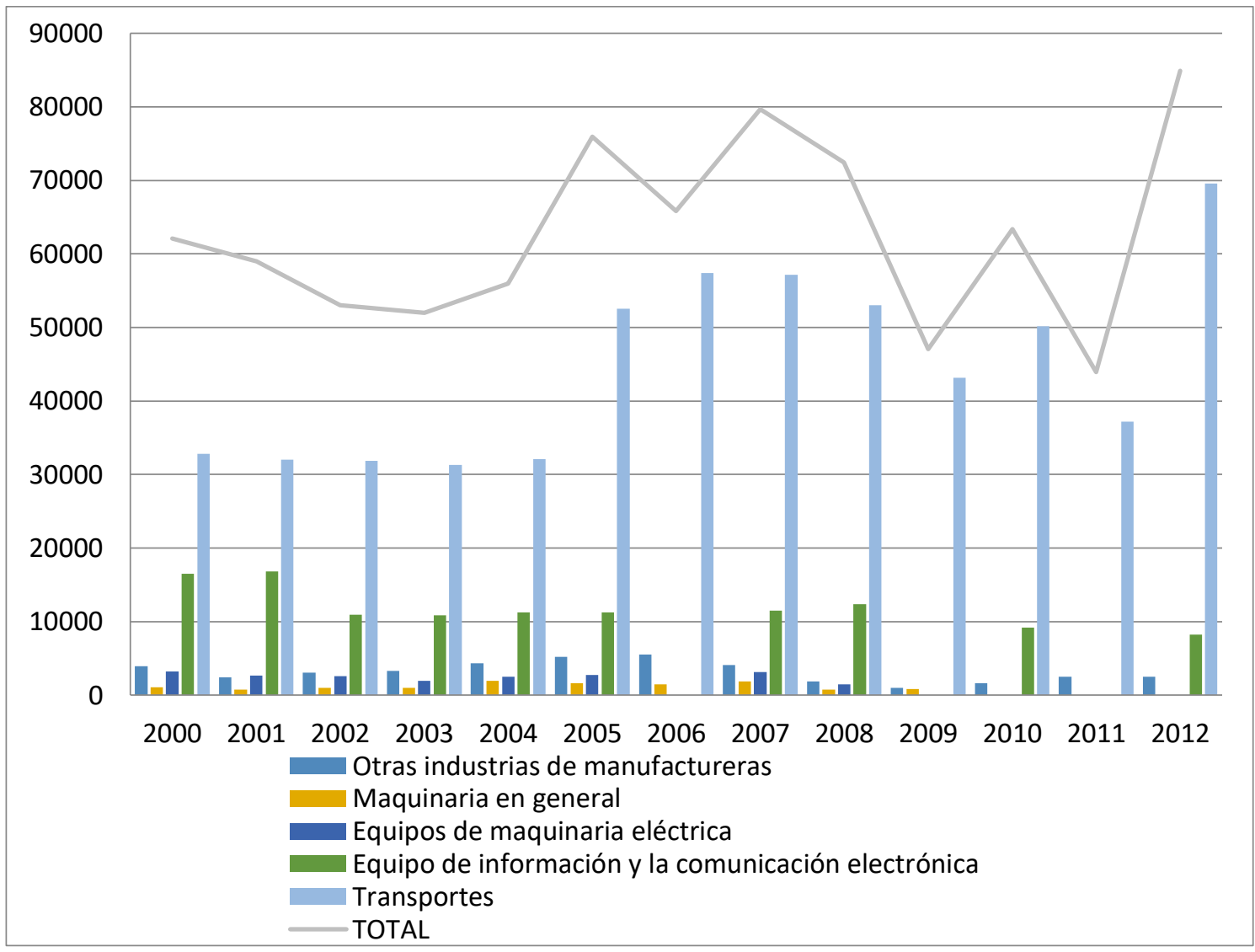

Fuente. Elaboración propia a partir de información del Ministerio de Economía, Negocio e Industria del gobierno de Japón. Disponible en http://www.meti.go.jp/statistics/tyo/kaigaizi/ , fecha de consulta: 24/9/2014.

Segundo, el número de empresas japonesas en México ha aumentado constantemente en la segunda mitad de la década de 2000, al tiempo que el número de empresas japonesas retiradas en América Latina ha tendido a reducirse en el mismo período, excepto en 2009 tras la Gran Recesión (véase el Gráfico II-5. 9). 
Gráfico II-5. 9. Números de empresas japonesas en México y números de empresas japonesas retiradas de sus actividades en América Latina, 1999 - 2012

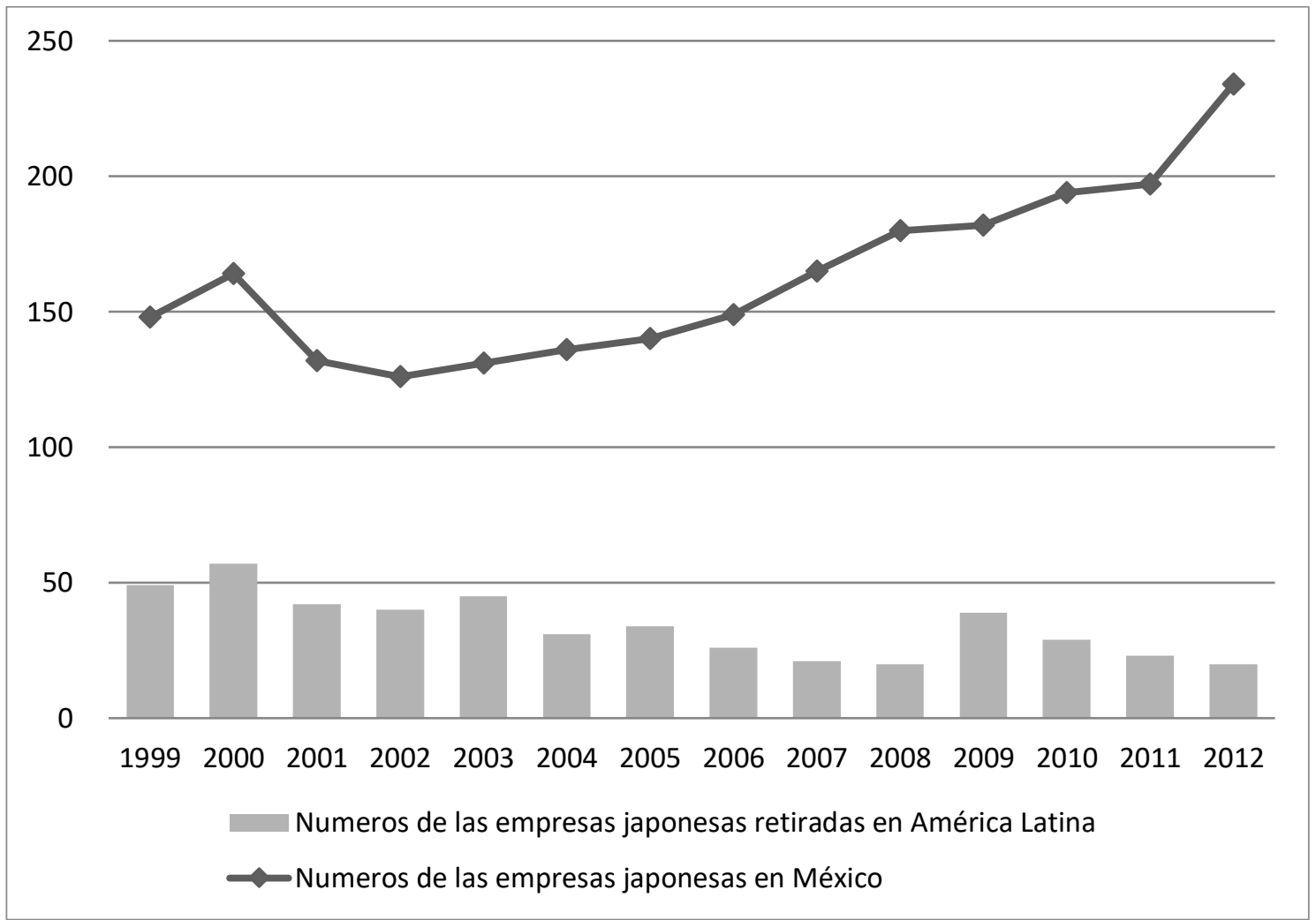

Fuente. Elaboración propia a partir de información del Ministerio de Economía, Negocio e Industria del gobierno de Japón. Disponible en http://www.meti.go.jp/statistics/tyo/kaigaizi/, fecha de consulta: 24/9/2014.

Teniendo en cuenta esta evolución, se puede decir que apenas hubo descenso de las inversiones japonesas en México en la primera década de 2000 debido al desarrollo económico de China basado en su papel de "fábrica del mundo" y a la crisis económica japonesa. De hecho, las actividades de las empresas japonesas en México han seguido aumentado hasta hoy. No obstante, esto no significa que dichas actividades continúen desarrollándose de igual manera que en los años 1970. Hay cambios en las actividades de las empresas japonesas en México. Estos cambios de sus actividades se empiezan a destacar desde la década de 2000.

Ahora, veamos la Tablas II-5. 2 en la que se muestran las localizaciones de las empresas japonesas en México. Se pueden apreciar algunos cambios en estas localizaciones. 
Tablas II-5. 2. Localizaciones de las empresas japonesas en México por entidad federativa de destino, 1999-2014

(En millones de dólares)

1). IED japonesa: Las diez principales entidades federativas de destino, 1999-2014

\begin{tabular}{|c|c|c|}
\hline TOP10 & Estados & Millones de dólares \\
\hline 1 & Aguascalientes & $2.495,5$ \\
\hline 2 & Distrito Federal & $1.157,1$ \\
\hline 3 & Guanajuato & $1.259,9$ \\
\hline 4 & Jalisco & 994,6 \\
\hline 5 & Nuevo León & 794,0 \\
\hline 6 & Baja California & 408,3 \\
\hline 7 & Chihuahua & 323,8 \\
\hline 8 & Querétaro & 306,0 \\
\hline 9 & San Luis Potosí & 248,5 \\
\hline 10 & Zacatecas & 206,2 \\
\hline
\end{tabular}

Fuente. Tomado de la Secretaría de Economía del Gobierno de México. Disponible en http://www.economia.gob.mx/comunidad-negocios/competitividad-normatividad/inversionextranjera-directa/estadistica-oficial-de-ied-en-mexico, fecha de consulta: 25/9/2014.

2). IED japonesa: Las siete principales entidades federativas de destino, 1999

\begin{tabular}{|c|c|c|}
\hline & Estados & Millones de dólares \\
\hline 1 & Distrito Federal & $1.173,0$ \\
\hline 2 & Baja California & 32,3 \\
\hline 3 & Nuevo León & 25,8 \\
\hline 4 & Morelos & 16,9 \\
\hline 5 & Chihuahua & 12,5 \\
\hline 6 & Aguascalientes & 6,1 \\
\hline 7 & Veracruz & 5,1 \\
\hline
\end{tabular}

Fuente. Tomado de la Secretaría de Economía del Gobierno de México. Disponible en http://www.economia.gob.mx/comunidad-negocios/competitividad-normatividad/inversionextranjera-directa/estadistica-oficial-de-ied-en-mexico, fecha de consulta: 25/9/2014. 
3). IED japonesa: Las ocho principales entidades federativas de destino, 2000-2004

\begin{tabular}{|c|c|c|}
\hline & Estados & Millones de dólares \\
\hline 1 & Distrito Federal & 465,7 \\
\hline 2 & Baja California & 227,8 \\
\hline 3 & Nuevo León & 225,8 \\
\hline 4 & Aguascalientes & 212,2 \\
\hline 5 & Chihuahua & 98,3 \\
\hline 6 & Querétaro & 46,3 \\
\hline 7 & Coahuila & 18,6 \\
\hline 8 & Veracruz & 14,8 \\
\hline
\end{tabular}

Fuente. Tomado de la Secretaría de Economía del Gobierno de México. Disponible en http://www.economia.gob.mx/comunidad-negocios/competitividad-normatividad/inversionextranjera-directa/estadistica-oficial-de-ied-en-mexico, fecha de consulta: 25/9/2014.

4). IED japonesa: Las diez principales entidades federativas de destino, 2005-2009

\begin{tabular}{|c|c|c|}
\hline & Estados & Millones de dólares \\
\hline 1 & Aguascalientes & 942,8 \\
\hline 2 & Nuevo León & 166,1 \\
\hline 3 & Zacatecas & 127,7 \\
\hline 4 & Estado de México & 120,5 \\
\hline 5 & Chihuahua & 93,5 \\
\hline 6 & Querétaro & 92,1 \\
\hline 7 & Jalisco & 77,7 \\
\hline 8 & Baja California & 53,3 \\
\hline 9 & Guanajuato & 14,4 \\
\hline 10 & San Luis Potosí & 13,1 \\
\hline
\end{tabular}

Fuente. Tomado de la Secretaría de Economía del Gobierno de México. Disponible en $\mathrm{http} / / / \mathrm{www}$.economia.gob.mx/comunidad-negocios/competitividad-normatividad/inversionextranjera-directa/estadistica-oficial-de-ied-en-mexico, fecha de consulta: 25/9/2014. 
5). IED japonesa: Las diez principales entidades federativas de destino, 2010-2014

\begin{tabular}{|c|c|c|}
\hline & Estados & Millones de dólares \\
\hline 1 & Guanajuato & $1.483,4$ \\
\hline 2 & Aguascalientes & $1.334,3$ \\
\hline 3 & Distrito Federal & $1.014,1$ \\
\hline 4 & Jalisco & 909,9 \\
\hline 5 & Nuevo León & 850,5 \\
\hline 6 & Zacatecas & 262,9 \\
\hline 7 & San Luis Potosí & 229,2 \\
\hline 8 & Estado de México & 229,0 \\
\hline 9 & Querétaro & 189,7 \\
\hline 10 & Chihuahua & 119,4 \\
\hline
\end{tabular}

Fuente. Tomado de la Secretaría de Economía del Gobierno de México. Disponible en http://www.economia.gob.mx/comunidad-negocios/competitividad-normatividad/inversionextranjera-directa/estadistica-oficial-de-ied-en-mexico, fecha de consulta: 25/9/2014.

Desde estas tablas, primero, se puede notar que las inversiones de los últimos años son mayores que las observadas en los períodos anteriores de la década de 2000.

Segundo, las inversiones japonesas tienen tres zonas principales para invertir en México: primero, es la capital y sus alrededores: Distrito Federal, Estado de México, Veracruz y Morelos; segundo, es la zona del norte de México, en la que las empresas japonesas han invertido tradicionalmente: Baja California, Chihuahua, Coahuila y Nuevo León. ; y por último, es la zona central de México: Aguascalientes, Guanajuato, Jalisco, Querétaro, Zacatecas, Guanajuato y San Luis Potosí. Si clasificamos estas localizaciones en función de las tres zonas indicadas, podemos obtener un nuevo punto de vista (véanse las Tablas II-5.3). 
Tablas II-5. 3. Localizaciones de las empresas japonesas en México por grupos de zonas de destino, 1999-2014. (En millones de dólares)

1). IED Japonesa: Las diez principales entidades federativas de destino, 1999-2014: Zonas

\begin{tabular}{|c|c|c|}
\hline & Zonas & Millones de dólares \\
\hline 1 & DF y sus alrededores & $1.157,1$ \\
\hline 2 & Norte & $1.526,1$ \\
\hline 3 & Central & $3.015,2$ \\
\hline
\end{tabular}

Fuente. Tomado de la Secretaría de Economía del Gobierno de México, disponible en http://www.economia.gob.mx/comunidad-negocios/competitividad-normatividad/inversionextranjera-directa/estadistica-oficial-de-ied-en-mexico, fecha de consulta: 25/9/2014.

2). IED japonesa: Las siete principales entidades federativas de destino, 1999: Zonas

\begin{tabular}{|c|c|c|}
\hline & Zonas & Millones de dólares \\
\hline 1 & DF y sus alrededores & 1.195 \\
\hline 2 & Norte & 60,6 \\
\hline 3 & Central & 6,1 \\
\hline
\end{tabular}

Fuente. Tomado de la Secretaría de Economía del Gobierno de México, disponible en http://www.economia.gob.mx/comunidad-negocios/competitividad-normatividad/inversionextranjera-directa/estadistica-oficial-de-ied-en-mexico, fecha de consulta: 25/9/2014

3). IED japonesa: Las diez principales entidades federativas de destino, 2000-2004: Zonas

\begin{tabular}{|c|c|c|}
\hline & Zonas & Millones de dólares \\
\hline 1 & DF y sus alrededores & 495,4 \\
\hline 2 & Norte & 570,5 \\
\hline 3 & Central & 258,5 \\
\hline
\end{tabular}

Fuente. Tomado de la Secretaría de Economía del Gobierno de México, disponible en http://www.economia.gob.mx/comunidad-negocios/competitividad-normatividad/inversionextranjera-directa/estadistica-oficial-de-ied-en-mexico, fecha de consulta: 25/9/2014

4). IED japonesa: Las diez principales entidades federativas de destino, 2005-2009: Zonas

\begin{tabular}{|c|c|c|}
\hline & Zonas & Millones de dólares \\
\hline 1 & DF y sus alrededores & 120,5 \\
\hline 2 & Norte & 312,9 \\
\hline 3 & Central & $1.267,8$ \\
\hline
\end{tabular}

Fuente. Tomado de la Secretaría de Economía del Gobierno de México, disponible en http://www.economia.gob.mx/comunidad-negocios/competitividad-normatividad/inversionextranjera-directa/estadistica-oficial-de-ied-en-mexico, fecha de consulta: 25/9/2014 
5). IED japonesa: Las diez principales entidades federativas de destino, 2010-2014: Zonas

\begin{tabular}{|c|c|c|}
\hline & Zonas & Millones de dólares \\
\hline 1 & DF y sus alrededores & 1243,1 \\
\hline 2 & Norte & 969,9 \\
\hline 3 & Central & $4.409,4$ \\
\hline
\end{tabular}

Fuente. Tomado de la Secretaría de Economía del Gobierno de México, disponible en http://www.economia.gob.mx/comunidad-negocios/competitividad-normatividad/inversionextranjera-directa/estadistica-oficial-de-ied-en-mexico, fecha de consulta: 25/9/2014

Se nota que las inversiones en los estados centrales de México han aumentado, mientras que las inversiones en los estados del Norte de la frontera han bajado. Ésta es la nueva tendencia de las inversiones japonesas en México. Hay algunos motivos por los que las empresas japonesas han cambiado sus estrategias de destinos para sus inversiones en México.

Uno de los motivos de este cambio de destino es el bajo coste de la fabricación (CARRILLO REGALADO, 2016). Por ejemplo, los costes salariales en los estados centrales son más baratos que en los estados del Norte (véase la Tabla II-5.1). Además, al comparar los costes de alquilar lugares para las fábricas, son más baratos en los estados centrales que en los de Tijuana y Monterrey. Estos bajos costes pueden compensar las diferencias de los costes de transporte.

Además, el gobierno de México era consciente de la necesidad de aumentar la presencia de los capitales extranjeros en otras zonas distintas a las de la frontera Norte. Con este objetivo, lanzó el Programa para la Industria Manufacturera, Maquiladora y de Servicios de Exportación (IMMEX) ${ }^{23}$. Este Programa, que empezó en noviembre de 2006, “integra los programas para el Fomento y Operación de la Industria Maquiladora de Exportación (Maquila) y el que establece Programas de Importación Temporal para Producir Artículos de Exportación (PITEX), cuyas empresas representan en su conjunto el $85 \%$ de las exportaciones manufactureras de México." 24 Analizamos este Programa de IMMEX en el Capítulo IV, sin embargo, en este momento conviene indicar que a través del mismo, el gobierno de México quería promover la industrialización más avanzada y

\footnotetext{
${ }^{23}$ Secretaría de Economía, el Gobierno de México, http://www.economia.gob.mx/comunidadnegocios/industria-y-comercio/instrumentos-de-comercio-exterior/immex, fecha de consulta: 2/3/2015.

${ }^{24}$ Secretaría de Economía, el Gobierno de México, http://www.economia.gob.mx/comunidadnegocios/industria-y-comercio/instrumentos-de-comercio-exterior/immex, frcha de consulta: 2/3/2015.
} 
moderna en todo el país. Este Programa es otro factor explicativo de los cambios de localización de las inversiones japonesas en México.

Como hemos visto en esta sección, se puede decir que las inversiones japonesas desde 2000 han sufrido algunos cambios. Uno de los factores que ha promovido estos cambios ha sido el desarrollo económico de China, que ha obligado a las empresas japonesas a reducir más sus costes de producción. Con este objetivo, las empresas japonesas en México han trasladado sus fábricas hacia el centro de México. 


\section{II-6. Cambio de destino de la inversión japonesa en México: del norte hacia El Bajío}

Como se ha mostrado anteriormente, el destino principal de las inversiones japonesas en México ha sido el norte del país. Sin embargo, en los últimos años se puede encontrar una nueva tendencia en la localización geográfica de las mismas. Desde la década de 2000, las inversiones japonesas se han desplazado a los estados de Aguascalientes, San Luis Potosí y Querétaro. Esta zona conocida como "El Bajío" es el nuevo destino de las inversiones japonesas en México ${ }^{25}$.

Geográficamente, "El Bajío" significa centro de México que comprende los territorios no montañosos de los Estados de Guanajuato, Querétaro, Aguascalientes, zona oriente de Jalisco, zona norte de Michoacán y San Luis Potosí. ${ }^{26}$ Desde el punto de vista de los clústeres industriales, los estados de Aguascalientes, San Luis Potosí y Guanajuato son los más importantes. Este cambio del destino de las inversiones japonesas ha producido nuevas tendencias en la inversión en México. En esta sección se analiza la historia y los motivos de la deslocalización de las inversiones japonesas desde el norte a El Bajío en la última década.

Las inversiones japonesas empezaron a llegar a El Bajío en la década de 1980. En 1981, la empresa de automóviles Nissan estableció su fábrica en Aguascalientes y empezó a operarla en 1982. ${ }^{27}$ Históricamente, la estrategia de llegada a México de Nissan tiene, en comparación con las otras empresas automovilísticas japonesas, esta característica de localización geográfica ya que estableció sus fábricas en el centro de México. Su primera fábrica en México estaba, o más correcto, está en Cuernavaca, en Morelos, en $1966 .{ }^{28}$ Esta localización de las fábricas viene inducida por la diferencia de sus mercados: para Nissan tiene especial importancia el mercado doméstico de México, más que las exportaciones a Estados Unidos, por la política de Industrialización por Sustitución de

\footnotetext{
${ }^{25}$ Antes del avance de las empresas japonesas en El Bajío, las empresas de automóviles estadounidenses invirtieron a esta zona. Por ejemplo, Chrysler tenía redes de sus proveedores en ciudades de Monterrey, Saltillo, Matamoros y Nuevo Laredo. Volkswagen instaló su fábrica en Puebla (UNGER y CHICO, 2004).

${ }^{26}$ Página web del Gabinete de Innovación Europea, disponible en http://www.hispanialink.com/PDF/pqBajio.pdf, fecha de consulta: 11/8/2015.

${ }^{27}$ Página web de Nissan Mexicana. Disponible en http://www.nissan.com.mx/corporativo/, fecha de consulta:11/7/2015.

${ }^{28}$ Página web de Nissan Mexicana. Disponible en http://www.nissan.com.mx/corporativo/, fecha de consulta: $11 / 7 / 2015$.
} 
Importaciones de México (VILLARREAL y VILLEGAS, 2005). Es decir, para vender sus productos en México, establece sus fábricas en México.

Para la llegada de las empresas de automóviles a esta zona del país, se necesitaba simultáneamente la llegada de sus proveedores. El caso de la llegada a México de Nissan no fue una excepción. Con la inversión de Nissan, también sus proveedores japoneses establecieron sus fábricas (AGUILAR-PÉREZ y CRUZ-COVARRUBIAS, 2015). Según muestra la Tabla II-6.1, en la década de 1990, las empresas japonesas llegaron a Aguascalientes y, además, estas empresas son los proveedores de Nissan. En esta década, Nissan ya tenía la cadena de sus productos en Aguascalientes. Es decir, Nissan pudo producir tanto las partes como sus productos completos en Aguascalientes.

Tabla II-6. 1. Plantas japonesas en Aguascalientes, 1980-1999

\begin{tabular}{|c|c|c|c|}
\hline AÑO & PLANTAS JAPONESAS & PRODUCTOS & ORIGEN \\
\hline 1981 & Nissan Mexicana & Automóviles y motores & Japón \\
\hline \multirow{2}{*}{1991} & Kantus Mexicana & Hules y Plásticos & Japón \\
\cline { 2 - 4 } & Sanoh Industrial & Tubos automotriz & Japón \\
\hline \multirow{2}{*}{1992} & Industria de Asiento Sup. & Asientos & Japón \\
\hline 1993 & Nabco Mexicana & Frenos & Japón \\
\hline 1994 & Yoruzu & Suspensión & Japón \\
\hline \multirow{2}{*}{1995} & Nicometal Mexicana & Lamina & Japón \\
\cline { 2 - 4 } & A.T.C. Mexicana & Polímeros & Japón \\
\cline { 2 - 4 } & Yamakawa o Unipress & Estampado & Japón \\
\hline 1996 & K\&S Mexicana & Arneses & Japón y Estados Unidos \\
\hline 1998 & Estándar Productos & Hules y metales & Jántados Unidos \\
\hline \multirow{2}{*}{1999} & A.P. Mexitech Co. & Cristales & Japón \\
\cline { 2 - 4 } & San-S Mexicana & Estampado & . cón \\
\hline
\end{tabular}

Fuente. Tomado de GARCÍA, LOZANO y CASTORENA. (2014). "Las Políticas Públicas del Desarrollo Regional de Aguascalientes, México 1980-2012." Disponible en http://www.uhu.es/IICIED/pdf/6_4_poltica.pdf, fecha de consulta: 30/11/2015

Hasta antes de la década de 1980, Nissan ha sido casi la única empresa japonesa que tenía operaciones productivas en El Bajío. Sin embargo, desde la segunda mitad de la década de 1980, esta condición empezó a cambiar. Otras empresas japonesas de automóviles empezaron a establecer sus fábricas en El Bajío. Por ejemplo, en 1986 Honda 
estableció una planta para producir motocicletas y autopartes en el Salto, Jalisco. ${ }^{29}$ Esta tendencia de llegada de las empresas japonesas de automóviles a El Bajío empezó a destacar a partir de la década de 1990 y ya era muy clara en la década de 2000 (MORENOCODINA, 2015). Más correctamente, las inversiones japonesas en El Bajío han aumentado desde el año 2000. Hay algunos motivos de este aumento de las inversiones japonesas.

El primer motivo es la diferencia de costes de fabricación. No solo los salarios en El Bajío son más baratos que los salarios en la frontera norte (VALDENEBRO, 2017); sino que también otros costes, como por ejemplo, los costes de vivienda y de transporte son más baratos en El Bajío (véase la Tabla II-6.2). Estos menores costes son un importante factor que incentiva el establecimiento de fábricas en El Bajío.

Hay otros costes de la vida cotidiana que también son más bajos: por ejemplo, el coste del alquiler de las viviendas que pagan los trabajadores mexicanos. Los menores costes para vivir son una ventaja para los trabajadores, no solo para las empresas. Aquí se puede encontrar un motivo por el que los trabajadores se mueven desde la frontera norte a El Bajío.

La diferencia destacada de las condiciones entre El Bajío y la Frontera Norte es la diferencia de los costes que pagan los trabajadores y no pagan las empresas. Actualmente, no se pueden encontrar grandes diferencias en los costes de empresas entre las dos zonas. Sin embargo, en los costes que pagan los trabajadores sí hay diferencias.

En la Tabla II-6.3 se pueden apreciar las diferencias de las condiciones económicas de costes entre El Bajío y la Frontera Norte en enero de 2016. Primero, se pueden observar algunas diferencias de salarios entre El Bajío y la Frontera Norte. Principalmente, los salarios en El Bajío están en niveles más altos que en la Frontera Norte. Además, en las posiciones profesionales de más alto rango, se observan mayores diferencias salariales entre las dos regiones

Segundo, sobre los costes de oficina, fábrica y casa: principalmente, el coste de las instalaciones en la frontera norte está más caro que en El Bajío. Aunque esto es así, también se nota que los costes para alquilar fábricas en la zona industrial de ambos clústeres no tienen grandes diferencias. En los últimos años, las empresas japonesas han

29 Página web de Honda México. Disponible en http://www.honda.mx/corporativo/honda-de-mexico/, fecha de consulta: 4/5/2015. 
llegado a El Bajío y por eso, se ha producido un aumento de la demanda de alquilar espacios para instalar fábricas en El Bajío. En este contexto, es muy natural que el coste de alquilar espacios para fábricas se haya incrementado en El Bajío. Una de las diferencias más llamativas es la diferencia de los costes de las casas para japoneses: el coste en la Frontera Norte es más caro que en El Bajío. Los japoneses en la Frontera Norte viven en San Diego (Estados Unidos) porque en esta ciudad hay una institución para aprender japonés y una importante comunidad japonesa instalada desde hace años. Por el motivo de la educación de sus hijos, por ejemplo, los japoneses en el norte prefieren vivir en San Diego e ir a trabajar a sus oficinas en Tijuana. En el caso de El Bajío, también hay una comunidad japonesa, que se concentra principalmente en los municipios de Celaya, Irapuato, León, Salamanca y Guanajuato. ${ }^{30}$ En estas ciudades, se pueden encontrar periódicos japoneses publicados en México, así como escuelas para aprender japonés. Para seguir fabricando sus productos, las empresas japonesas que se desplazan hacia El Bajío tienen que pagar este tipo de costes para que sus empleados japoneses trabajen en esta zona.

\footnotetext{
${ }^{30}$ Según información de El Economista, disponible en http://eleconomista.com.mx/estados/2015/05/31/guanajuato-se-adapta-sus-10000-japoneses, fecha de consulta: 20/8/2015.
} 
Tabla II-6. 2. Costes en EI Bajío versus la Frontera Norte (diciembre de 2014- enero de 2016)

(En Pesos Mexicanos)

\begin{tabular}{|c|c|c|c|c|c|c|c|}
\hline & & $\begin{array}{c}\text { Aguascalientes } \\
\text { (Aguascalientes) }\end{array}$ & Irapuato (Guanajuato) & Querétaro (Querétaro) & $\begin{array}{l}\text { San Luis Potosí } \\
\text { (San Luis Potosî) }\end{array}$ & Tijuana (Baja California) & Monterrey (Nuevo León) \\
\hline \multirow{4}{*}{ Salarios } & Trabajadores & $4864 \sim 5813 / \mathrm{mes}$ & $4512 \sim 7061 /$ mes & 4989 5917/mes & $5610 \sim 5962 /$ mes & 3909 5733/mes & $4977 \sim 5865 / \mathrm{mes}$ \\
\hline & Ingenieros & $11026 \sim 25863 / \mathrm{mes}$ & $13430 \sim 22782 / \mathrm{mes}$ & $11695 \sim 26116 / \mathrm{mes}$ & $13362 \sim 29527 / \mathrm{mes}$ & $13002 \sim 29394 / \mathrm{mes}$ & $12138 \sim 24895 / \mathrm{mes}$ \\
\hline & Ejecutivo de nivel medio & $41781 \sim 59992 / \mathrm{mes}$ & $32451 \sim 50738 / \mathrm{mes}$ & 41959 69269/mes & $54055 \sim 66776 / \mathrm{mes}$ & $39000 \sim 64468 / \mathrm{mes}$ & 40967 67164/mes \\
\hline & Salarios mínimos & \multicolumn{4}{|c|}{ 73.04/día } & \multicolumn{2}{|c|}{$73,04 / \mathrm{dia}$} \\
\hline \multirow{5}{*}{$\%$ de aumento de salarios } & 2011 & $3,97 \%$ & $3,58 \%$ & $3,88 \%$ & $5,67 \%$ & $2,26 \%$ & \\
\hline & 2012 & $4,16 \%$ & $4,56 \%$ & $4,48 \%$ & $5,44 \%$ & $2,86 \%$ & $4,15 \%$ \\
\hline & 2013 & $3,73 \%$ & $3,71 \%$ & $4,14 \%$ & $4,56 \%$ & $2,94 \%$ & $3.76 \%$ \\
\hline & 2014 & $4,9 \%$ & $5,37 \%$ & $4,38 \%$ & $5,33 \%$ & $2,69 \%$ & $4,07 \%$ \\
\hline & 2015 & $5,37 \%$ & $4,92 \%$ & $4,46 \%$ & $6,04 \%$ & $4 \%$ & $4,78 \%$ \\
\hline \multirow{4}{*}{ Coste de Oficina y Casa } & $\begin{array}{l}\text { Alquilar una fábrica en zona } \\
\text { industria } / \mathrm{m} 2\end{array}$ & $55 \sim 78 / \mathrm{mes}$ & $69 \sim 95 /$ mes & $69 \sim 88 /$ mes & $57 \sim 69 / \mathrm{mes}$ & $68 \sim 83 /$ mes & $64 \sim 81 /$ mes \\
\hline & $\begin{array}{l}\text { Comprar una fábrica en } \\
\text { zona industrial/m2 }\end{array}$ & $658 \sim 866$ & $693 \sim 1212$ & $1039 \sim 1732$ & $693 \sim 3953$ & $1178 \sim 2165$ & $692 \sim 1905$ \\
\hline & $\begin{array}{l}\text { Alquilar una oficina en zona } \\
\text { industria } / \mathrm{m} 2\end{array}$ & 78 234/mes & $178 \sim 222 / \mathrm{mes}$ & $203 \sim 272 / \mathrm{mes}$ & $136 \sim 160 /$ mes & $167 \sim 312 /$ mes & $277 \sim 334 / \mathrm{mes}$ \\
\hline & $\begin{array}{l}\text { Alquilar una casa para } \\
\text { japoneses } / \mathrm{m} 2\end{array}$ & $10500 \sim 19000 / \mathrm{mes}$ & $14000 \sim 28000 / \mathrm{mes}$ & $12000 \sim 25000 / \mathrm{mes}$ & $13000 \sim 20000 /$ mes & $\begin{array}{c}25,980 \sim 43,300 / \text { mes } \\
\text { (San Diego) }\end{array}$ & $20,000 \sim 35,000 / \mathrm{mes}$ \\
\hline \multirow{3}{*}{ Costes para transporte } & $\begin{array}{l}\text { Contenedores (40ft) para } \\
\text { exportación a los } 3^{\text {a }} \text { paises }\end{array}$ & 32042 & 32890 & 36372 & 34640 & 23382 & 15588 \\
\hline & $\begin{array}{l}\text { Contenedores (40ft) para } \\
\text { importación desde Japón }\end{array}$ & 65816 & 83655 & 85474 & 86600 & 65032,5 & 112407 \\
\hline & $\begin{array}{l}\text { Contenedores(40ft) para } \\
\text { exportación a Japón }\end{array}$ & 82270 & 67548 & 70146 & 76208 & 75342 & 80538 \\
\hline
\end{tabular}

Fuente. Tomado de JETRO (Japan External Trade Organization), disponible en

http://www.jetro.go.jp/world/search/cost_result?countryId[]=261\&countryId[]=332\&countryId[]=331\&countryId[]=333\&countryId[]=325\&countryId[]=326\&countr yId[]=327, fecha de consulta: 25/1/2017. 
Tabla II-6. 3. Las Diferencias de costes en El Bajío versus la Frontera Norte (diciembre de 2014- enero de 2016)

(En Pesos Mexicanos)

\begin{tabular}{|c|c|c|c|c|}
\hline & & Promedio de Bajío & $\begin{array}{c}\text { Promedio de la Fontera } \\
\text { Norte } \\
\end{array}$ & $\begin{array}{c}\text { Diferencia } \\
\text { (Frontera Norte - Bajio) } \\
\end{array}$ \\
\hline \multirow{3}{*}{ Salarios } & Trabajadores & $4993 \sim 6188$ & $4453 \sim 5799$ & $-540 \sim-389$ \\
\hline & Ingenieros & $12378 \sim 26972$ & $11490 \sim 27144$ & $-888 \sim 172$ \\
\hline & Ejecutivo de nivel medio & $42561 \sim 61693$ & $39983 \sim 65816$ & $-2578 \sim 4123$ \\
\hline \multirow{5}{*}{$\%$ de aumento de salarios } & 2011 & 4,28 & 2,26 & $-2,02$ \\
\hline & 2012 & 4,66 & 3,5 & $-1,16$ \\
\hline & 2013 & 4 & 3,35 & $-0,65$ \\
\hline & 2014 & 5 & 3,38 & $-1,62$ \\
\hline & 2015 & 5,2 & 4,39 & $-0,81$ \\
\hline \multirow{4}{*}{ Costes de Oficina y Casa } & $\begin{array}{l}\text { Alquilar una fábrica en zona } \\
\text { industrial } / \mathrm{m} 2\end{array}$ & $62,5 \sim 82,5 / \mathrm{mes}$ & $66 \sim 82 / \mathrm{mes}$ & $3,5 \sim-0,5 /$ mes \\
\hline & $\begin{array}{l}\text { Comprar una fábrica en zona } \\
\text { industria } 1 / \mathrm{m} 2\end{array}$ & $770 \sim 1940$ & $935 \sim 2035$ & $165 \sim 95$ \\
\hline & $\begin{array}{l}\text { Alquilar una oficina en zona } \\
\text { industria } 1 / \mathrm{m} 2\end{array}$ & $149 \sim 222 /$ mes & $222 \sim 323 /$ mes & $73 \sim 101 /$ mes \\
\hline & $\begin{array}{l}\text { Alquilar una casa para } \\
\text { japoneses } / \mathrm{m} 2\end{array}$ & $12375 \sim 23000 /$ mes & $22990 \sim 39000 /$ mes & $10615 \sim 16000 /$ mes \\
\hline \multirow{3}{*}{ Costes para transporte } & $\begin{array}{l}\text { Contenedores (40ft) para } \\
\text { exportación a los } 3^{\mathrm{a}} \text { paises }\end{array}$ & 33986 & 19485 & -14501 \\
\hline & $\begin{array}{l}\text { Contenedores (40ft) para } \\
\text { importación desde Japón }\end{array}$ & 80386 & 88719 & 8333 \\
\hline & $\begin{array}{l}\text { Contenedores(40ft) para } \\
\text { exportación a Japón }\end{array}$ & 74043 & 77945 & 3902 \\
\hline
\end{tabular}

Fuente. Elaboración propia a partir de la Tabla II-6.2.

+ si es mayor en la Frontera Norte y - si es mayor en El Bajío. 
Con respecto a los salarios, los porcentajes de aumento de los salarios en El Bajío son más altos que en la Frontera Norte. Veamos el Gráfico II-6.1. Se nota que los aumentos de los estados de El Bajío en 2014 son más altos que en otros años. Por el contrario, en la Frontera Norte, los salarios en Monterrey han aumentado en 2014, mientras que en Tijuana, no hay diferencias. Además, generalmente, en 2013, los porcentajes de los aumentos se reducen en los dos estados. Los aumentos salariales en San Luis Potosí están en el nivel más alto mientras que en Tijuana están en el nivel más bajo.

Gráfico II-6.1. Porcentaje de aumento de los salarios (En porcentaje)

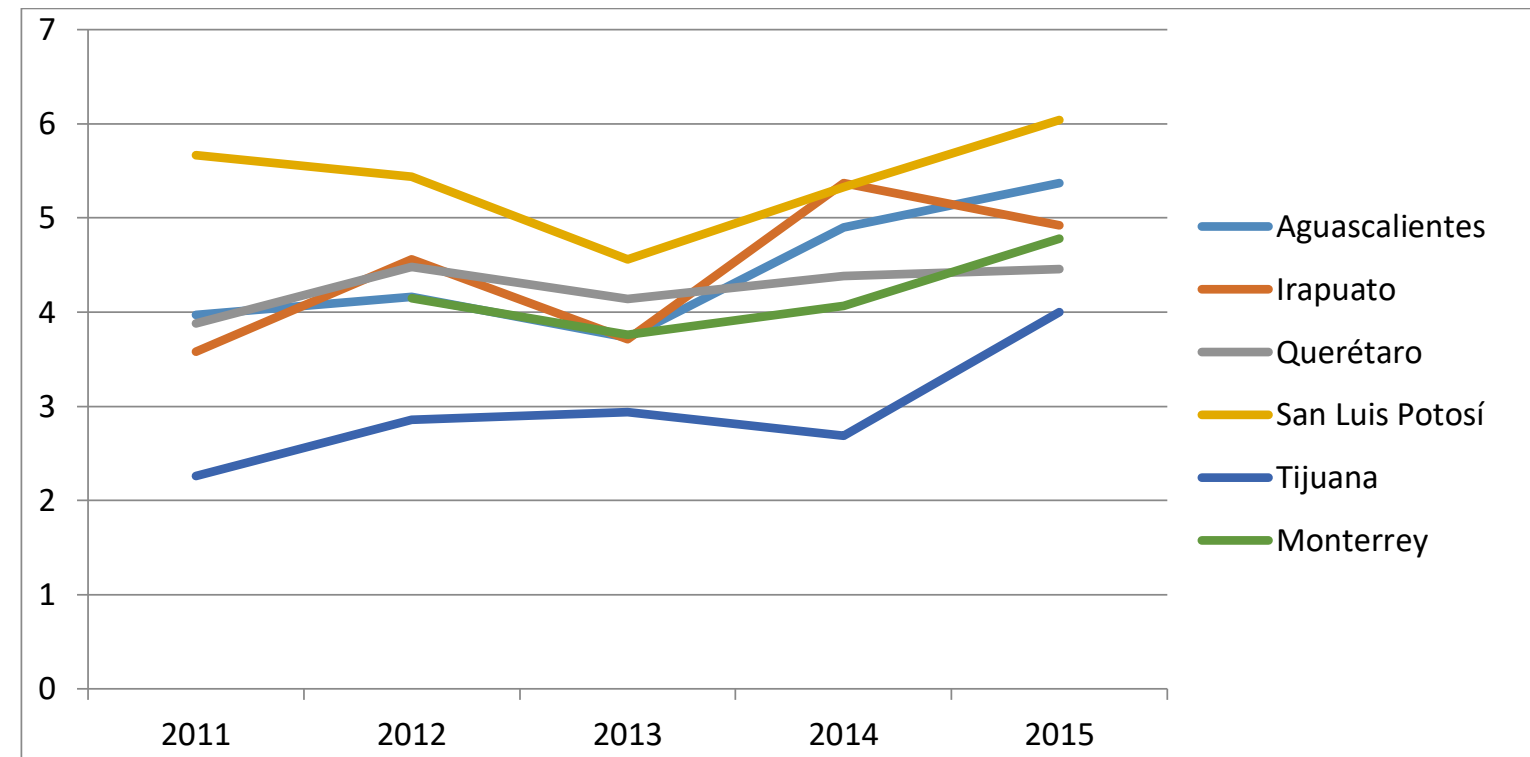

Fuente. Tomado de informaciones de JETRO (Japan External Trade Organization), disponible enhttp://www.jetro.go.jp/world/search/cost_result?countryId[]=261\&countryId[]=332\&countryId[]= $331 \&$ countryId[] $=333 \&$ countryId[] $=325 \&$ countryId[] $=326 \&$ countryId[] $=327$, fecha de consulta: 25/1/2017.

En cuanto al coste de transporte, para las empresas extranjeras en México este coste es muy importante para sus exportaciones. Según el Gráfico II-6.2, los costes para la exportación a terceros países desde El Bajío son más altos que desde la Frontera Norte. En esta tabla, el tercer país es Estados Unidos. ${ }^{31}$ Además, al considerar los costes de las exportaciones a Japón desde El Bajío no es más caro que desde la Frontera Norte. Hay diferencias de los costes de importación desde Japón entre El Bajío y La Frontera Norte,

\footnotetext{
${ }^{31}$ Información de Japan External Trade Organization (JETRO), disponible en http://www.jetro.go.jp/world/search/cost_result?countryId[]=261\&countryId[]=332\&countryId[]=331\&c ountryId[]=333\&countryId[]=325\&countryId[]=326\&countryId[]=327, fecha de consulta: 20/8/2015.
} 
pero su diferencia es notable en el caso de Monterrey. Basándose en estas condiciones, para las empresas que planean exportaciones a Estados Unidos y/o a otros países en el mundo, todavía la zona de la Frontera Norte de México tiene ventajas.

\section{Gráfico II-6.2. Costes de Transporte} (En pesos mexicanos)

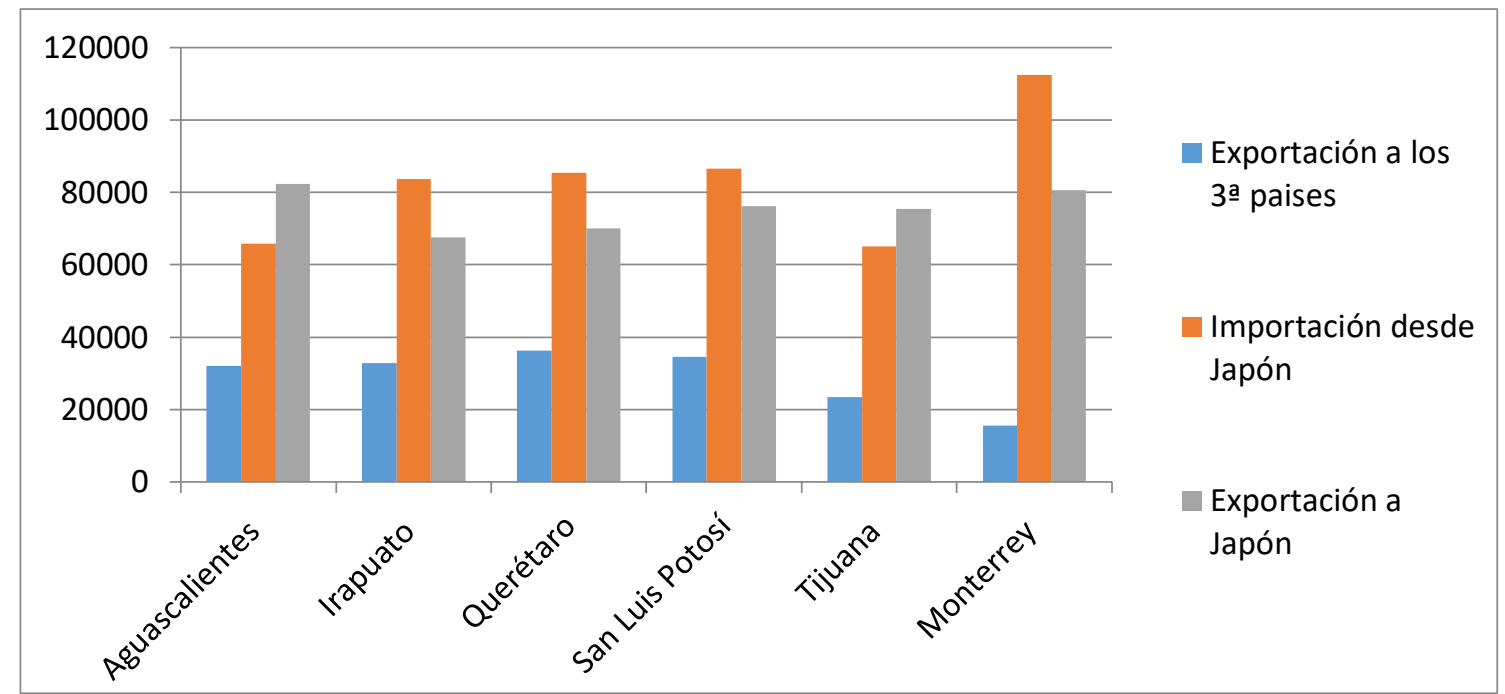

Fuente. Elaboración propia a partir de JETRO (Japan External Trade Organization), disponible en http://www.jetro.go.jp/world/search/cost_result?countryId[]=261\&countryId[]=332\&countryId[]=33 $1 \&$ countryId[]=333\&countryId[]=325\&countryId[]=326\& countryId[]=327, fecha de consulta: $25 / 1 / 2017$.

Desde el punto de vista de las empresas instaladas en El Bajío, uno de sus problemas es el coste de las exportaciones a Estados Unidos. Sin embargo, los gobiernos de los Estados en El Bajío intentan solucionar este problema para seguir atrayendo inversiones extranjeras.

Primero, El Bajío tiene un buen transporte tanto terrestre por tren como marítimo a través del puerto de Lázaro Cárdenas, lo que le permite estar muy bien comunicado tanto con Asia como con el centro y Este de Estados Unidos. Además, se habla de crear las líneas férreas llamadas "El nuevo canal" para poder llegar competitivamente a la zona Este de Estados Unidos. ${ }^{32}$ Además las líneas férreas más importantes de México se entrelazan aquí, por ello se ha construido en Celaya un complejo ferroviario intermodal terminado en 2012. ${ }^{33}$ Esta línea de ferrocarril es una manera importante para exportar los

\footnotetext{
32 Página web del Gabinete de Innovación Europea, disponible en http://www.hispanialink.com/PDF/pqBajio.pdf, fecha de consulta:11/8/2015.

${ }_{33}$ Página web del Gabinete de Innovación Europea, disponible en http://www.hispanialink.com/PDF/pqBajio.pdf, fecha de consulta:11/8/2015 y Poyry, disponible en
} 
productos desde El Bajío a Estados Unidos, por lo que esto significa que las empresas extranjeras en El Bajío pueden tener otra ruta alternativa para la exportación.

Actualmente, el transporte en ferrocarril en México no es un transporte importante. La mayor parte de los transportes desde México dependen del transporte por carretera. El comercio entre México y Estados Unidos ha aumentado, pero los porcentajes de los distintos modos de transporte no han cambiado mucho. Según muestra el Gráfico II-6.3, el principal tipo de transporte es el transporte por carretera: cada año representa aproximadamente el 70\%-75\% del comercio entre ambos países. Luego hay transporte marítimo y por ferrocarril. Se puede apreciar esta misma tendencia en el Gráfico II-6.4 para el caso de las exportaciones desde México a Estados Unidos. En el Gráfico II-6.5 sobre las importaciones desde Estados Unidos hacia México, se observa que el porcentaje del transporte aéreo ha aumentado en los últimos años; sin embargo, sus características principales son las mismas que las de la exportación. En resumen, en el comercio entre México y Estados Unidos, el transporte por carretera es el más importante. Luego el transporte ferroviario y marítimo son la segunda y tercera manera para el comercio bilateral, pero sus porcentajes son mucho más bajos.

http://www.poyry.com/latin/projects/libramiento-ferroviario-de-celaya-gerencia-de-proyecto-mexico, fecha de consulta:11/8/2015 
Gráficos II-6.3. Transporte desde México a Estados Unidos: comercio total, 1995-2013.

\section{1) Costes (En millones de dólares estadounidenses a precios corrientes)}

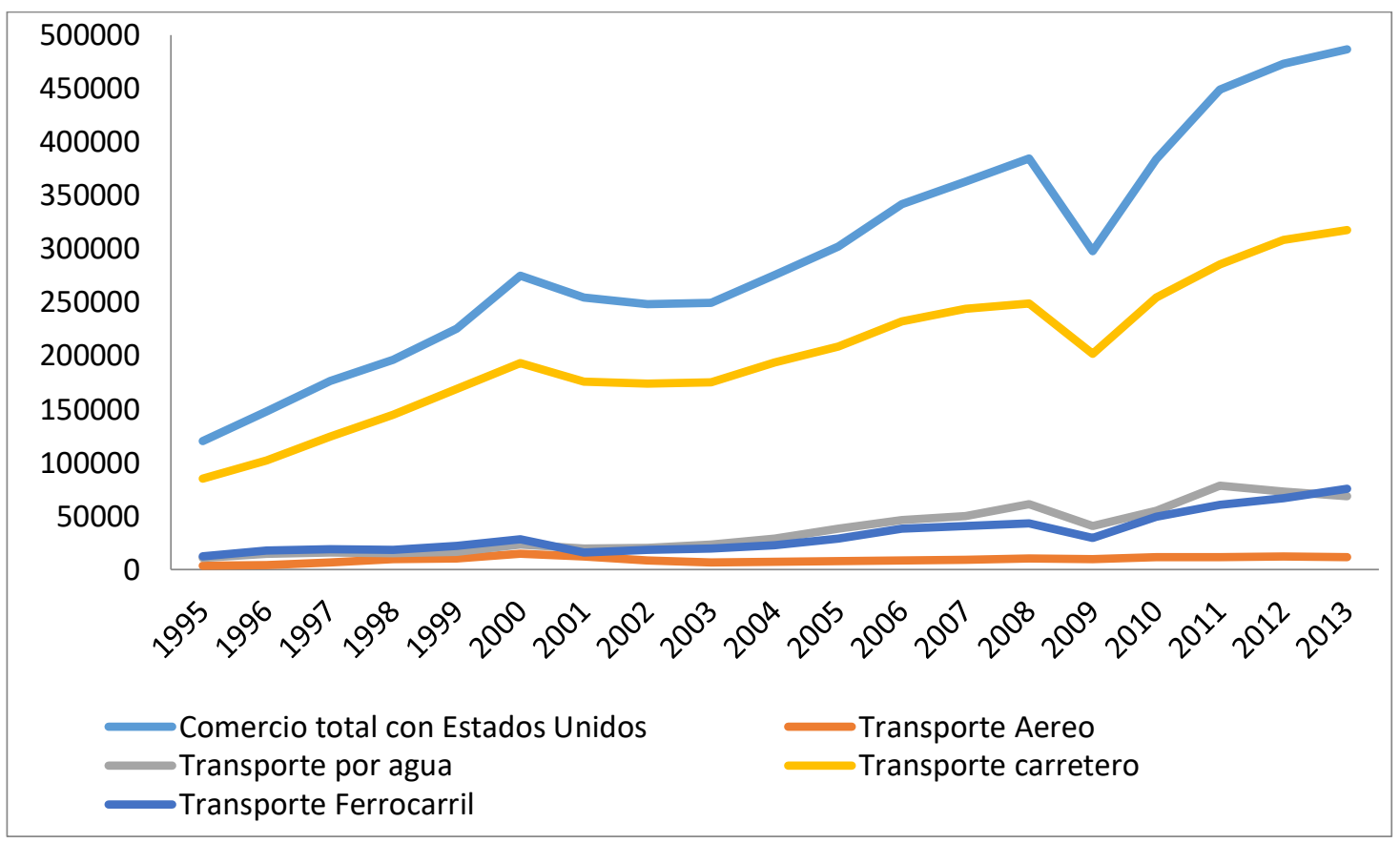

Fuente. Elaboración propia a partir de la Secretaría de Comunicaciones y Transportes del Gobierno de México, disponible en http://nats.sct.gob.mx/espanol/ir-a-las-tablas-2/tabla-6-comercio-exteriorde-mercancias-en-america-del-norte/cuadro-6-1b-comercio-exterior-de-mexico-con-canada-yestados-unidos-segun-modo-de-transporte-dolares/\# , fecha de consulta: 30/10/2015.

\section{2) Ocupaciones de medios de trasportes (En porcentajes)}

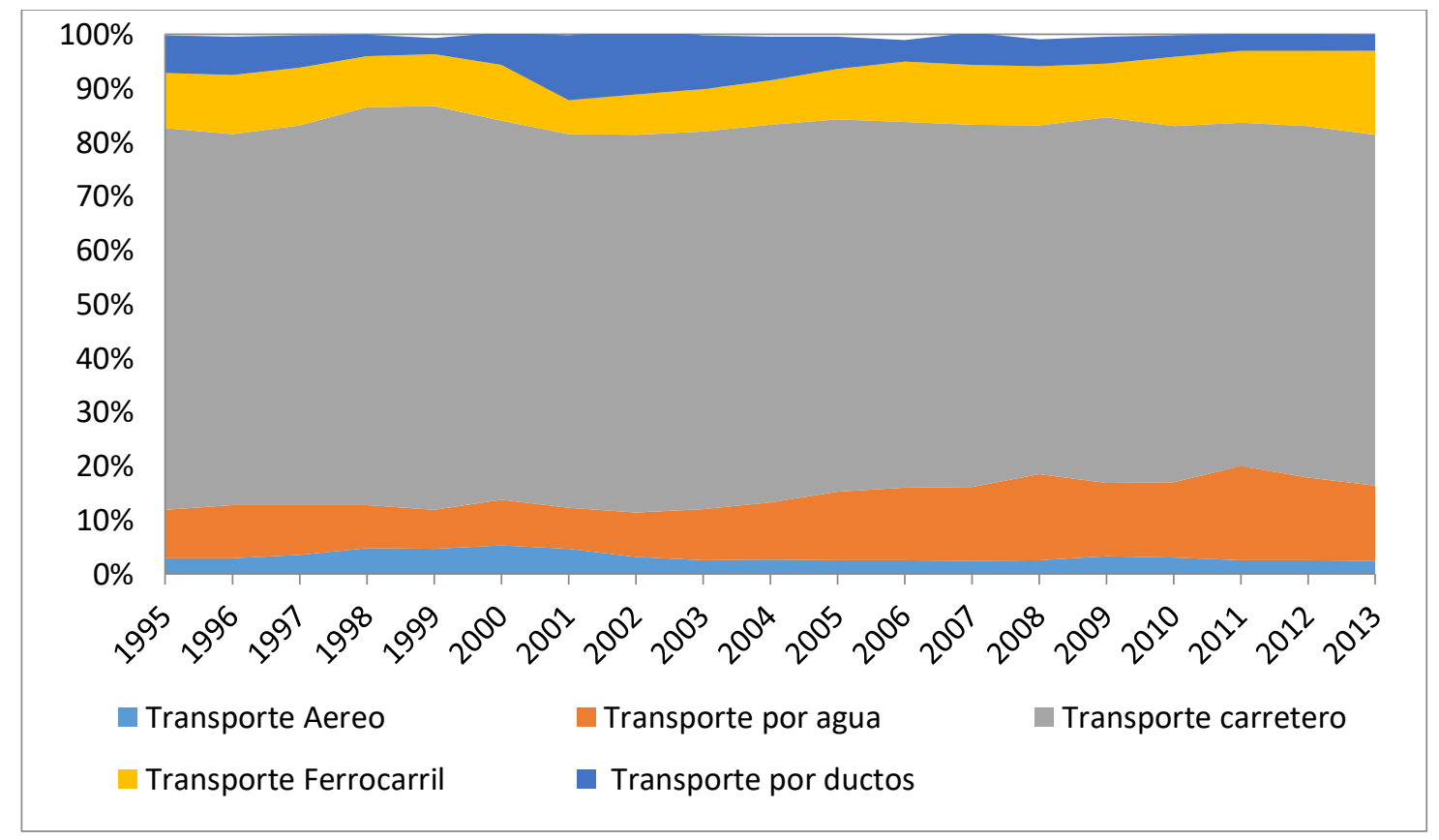

Fuente. Elaboración propia a partir de la Secretaría de Comunicaciones y Transportes del Gobierno de México, disponible en http://nats.sct.gob.mx/espanol/ir-a-las-tablas-2/tabla-6-comercio-exteriorde-mercancias-en-america-del-norte/cuadro-6-1b-comercio-exterior-de-mexico-con-canada-yestados-unidos-segun-modo-de-transporte-dolares/\# , fecha de consulta: 30/10/2015. 
Gráficos II-6. 4. Transporte desde México a Estados Unidos: exportaciones, 1995-2013

\section{1) Costes (En millones de dólares estadounidenses a precios corrientes)}

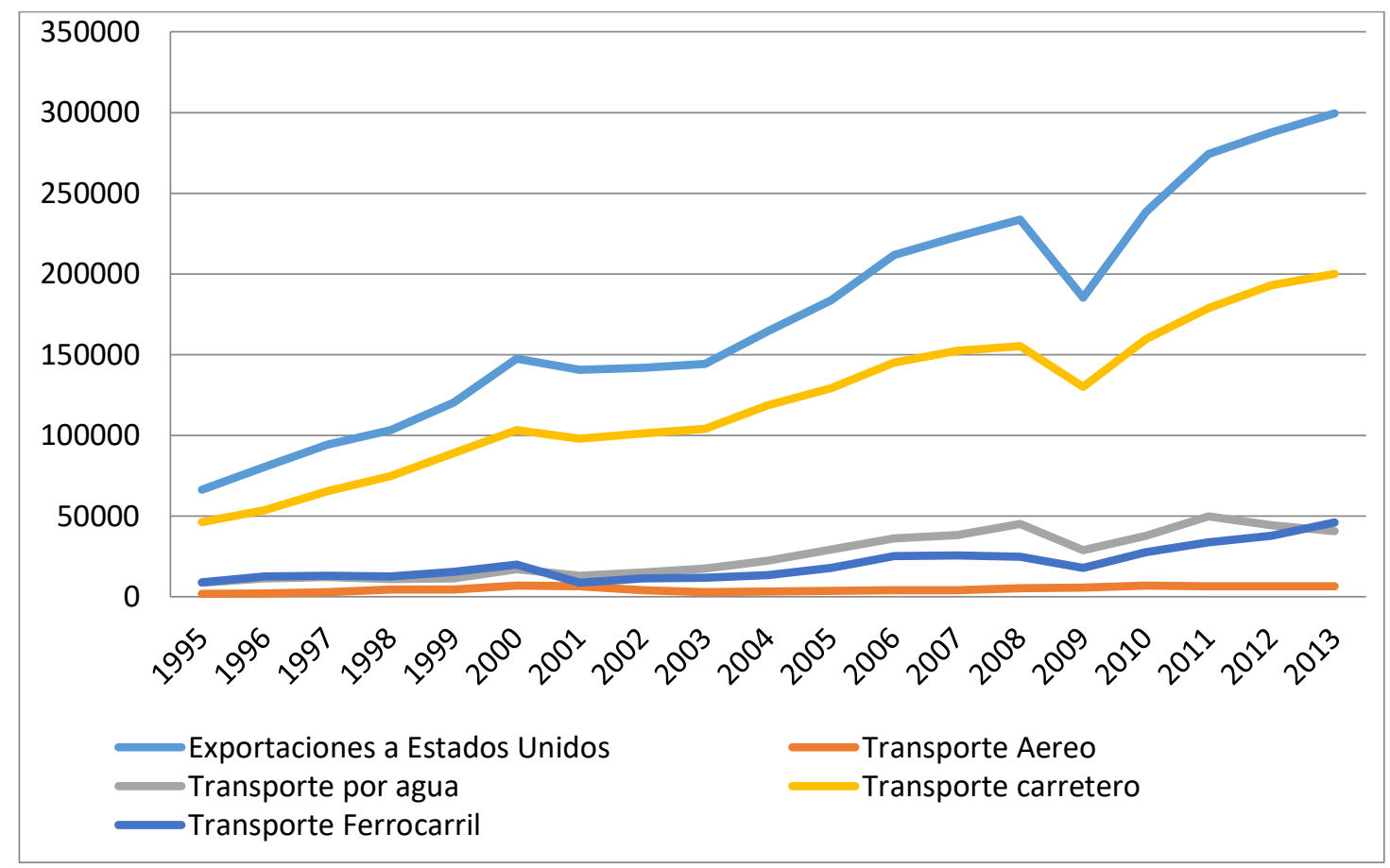

Fuente. Elaboración propia a partir de la Secretaría de Comunicaciones y Transportes del Gobierno de México, disponible en http://nats.sct.gob.mx/espanol/ir-a-las-tablas-2/tabla-6-comercio-exteriorde-mercancias-en-america-del-norte/cuadro-6-1b-comercio-exterior-de-mexico-con-canada-yestados-unidos-segun-modo-de-transporte-dolares/\# fecha de consulta: 30/10/2015.

\section{2) Ocupaciones de medios de trasportes (En porcentajes)}

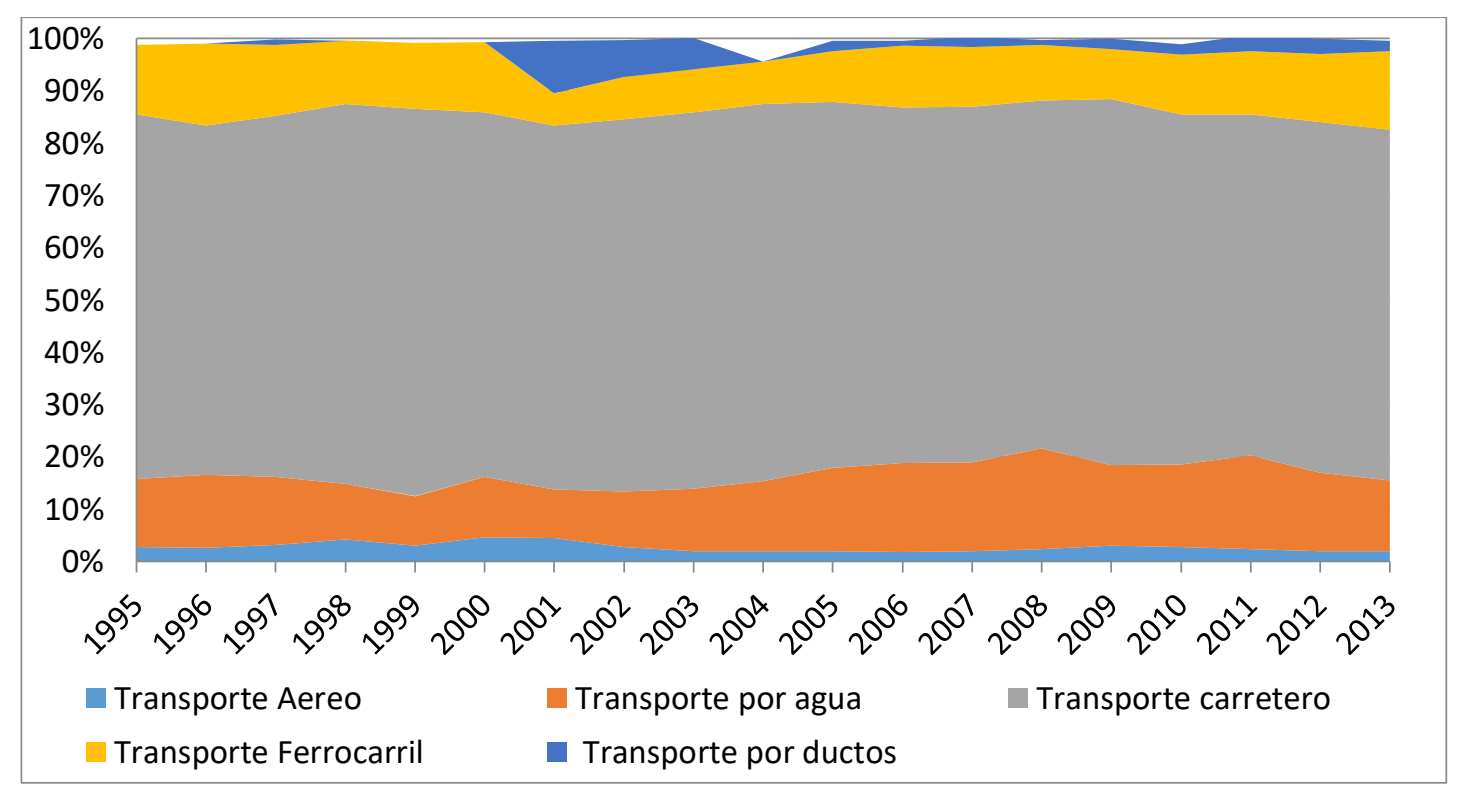

Fuente. Elaboración propia a partir de la Secretaría de Comunicaciones y Transportes del Gobierno de México, disponible en http://nats.sct.gob.mx/espanol/ir-a-las-tablas-2/tabla-6-comercio-exteriorde-mercancias-en-america-del-norte/cuadro-6-1b-comercio-exterior-de-mexico-con-canada-yestados-unidos-segun-modo-de-transporte-dolares/\# , fecha de consulta: 30/10/2015. 
Gráficos II-6. 5. Transporte desde Estados Unidos a México: importaciones, 1995-2013

\section{1) Costes (En millones de dólares estadounidenses a precios corrientes)}

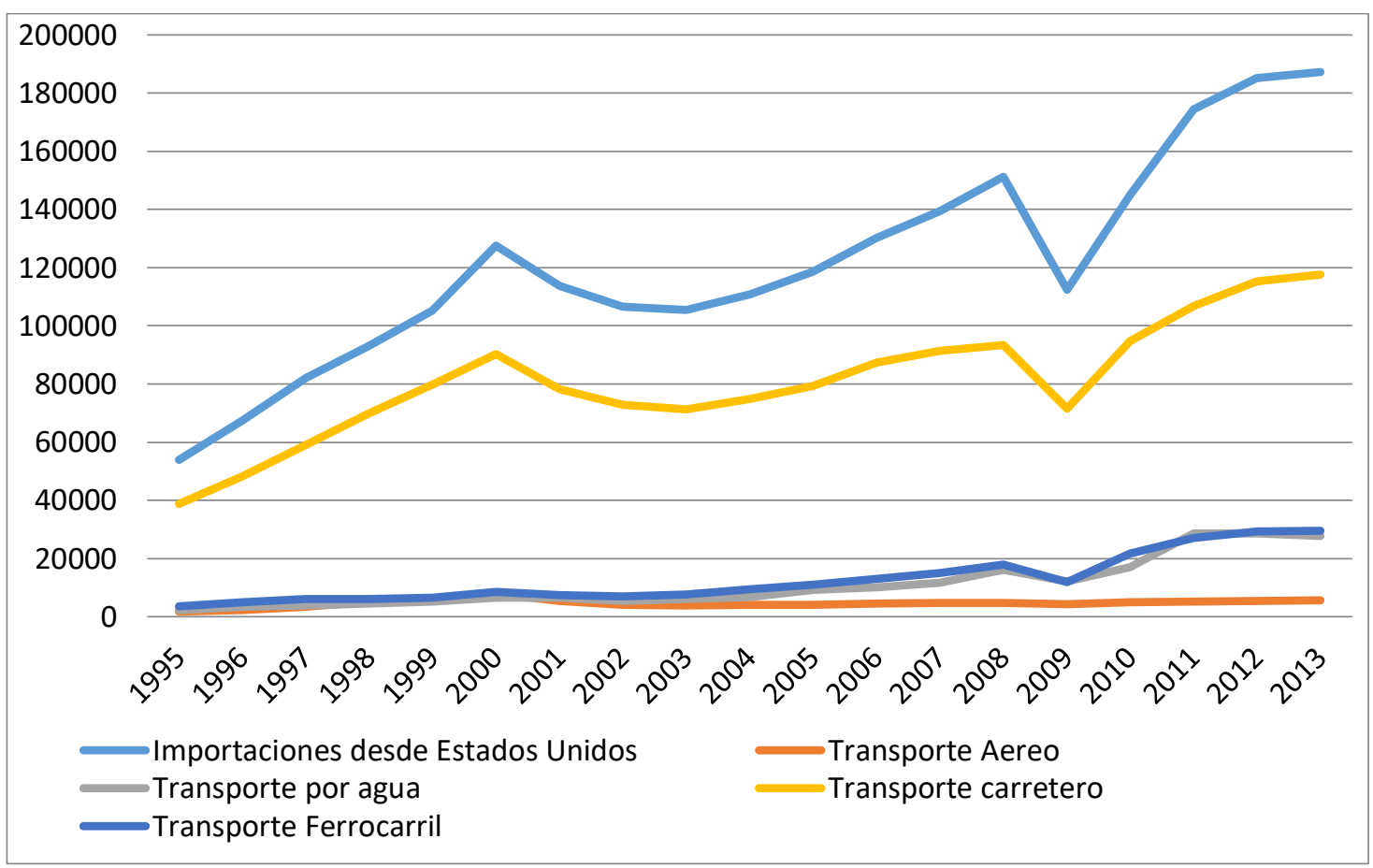

Fuente. Elaboración propia a partir de la Secretaría de Comunicaciones y Transportes del Gobierno de México, disponible en http://nats.sct.gob.mx/espanol/ir-a-las-tablas-2/tabla-6-comercio-exteriorde-mercancias-en-america-del-norte/cuadro-6-1b-comercio-exterior-de-mexico-con-canada-yestados-unidos-segun-modo-de-transporte-dolares/\# , fecha de consulta: 30/10/2015.

\section{2) Ocupaciones de medios de trasportes. (En porcentajes)}

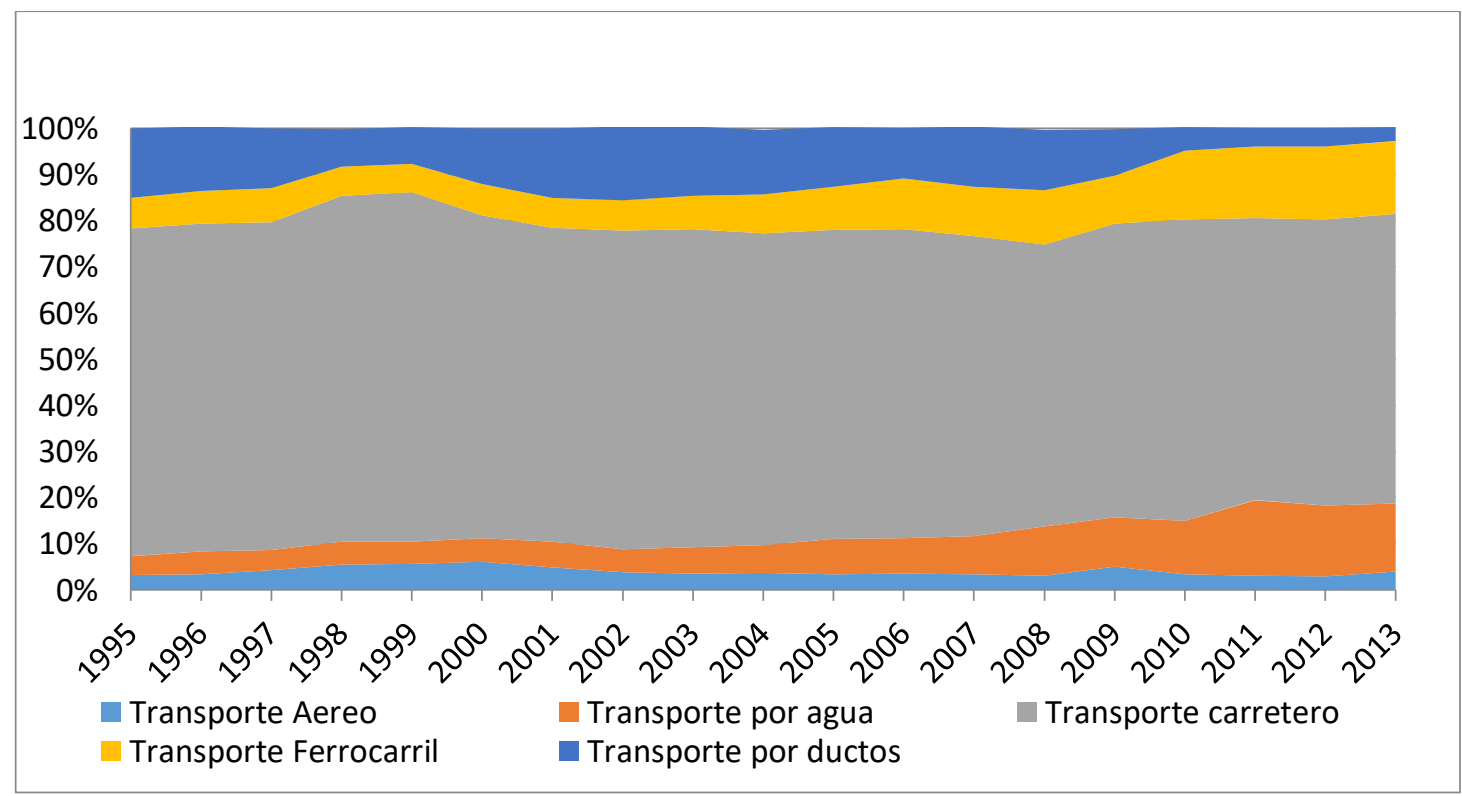

Fuente. Elaboración propia a partir de la Secretaría de Comunicaciones y Transportes del Gobierno de México, disponible en http://nats.sct.gob.mx/espanol/ir-a-las-tablas-2/tabla-6-comercio-exteriorde-mercancias-en-america-del-norte/cuadro-6-1b-comercio-exterior-de-mexico-con-canada-yestados-unidos-segun-modo-de-transporte-dolares/\# , fecha de consulta: 30/10/2015. 
Al considerar los costes para el transporte por carretera, las empresas en la Frontera Norte tienen más ventaja que las de El Bajío. Desde el punto de vista del gobierno local en El Bajío, este coste de transporte es casi el único problema para atraer a las inversiones extranjeras. Teniendo en cuenta esta situación, el gobierno mexicano decidió mejorar la línea ferroviaria para exportar los productos al Norte. Para las empresas de automóviles en México, la línea de ferrocarriles es una buena alternativa para exportar sus productos hacia Estados Unidos.

En la década de 1990 hubo un proceso de privatización del ferrocarril en México, del que nacieron dos empresas que se encargan de las dos principales líneas de ferrocarriles desde Celaya en Guanajuato al Norte. (ZEPEDA BUSTOS, 2012). Una de las líneas de ferrocarriles pertenece a la empresa estadounidense, Kansas City Southern México (KCSM) que va desde Laredo o Tampico-Celaya-Lázaro Cárdenas (véase la Ilustración II-6. 1). ${ }^{34}$ Además, KCSM tiene conexión con la BNSF Railway Company, con lo que puede distribuir sus productos a otros lugares dentro de Estados Unidos ${ }^{35}$. La otra línea de ferrocarriles es la que maneja la empresa mexicana FERROMEX, que va desde El Paso-Celaya-Veracruz o Manzanillo. Además, como se puede apreciar en la Ilustración II-6. 2, la red de FERROMEX conecta a cinco ciudades fronterizas del norte de México: Mexicali, Nogales, El Paso, Ojinaga y Piedras Negras. Lo más importante sobre estas redes de ferrocarriles es que conectan el norte con el centro de México y esta conexión garantiza que la importación y exportación de mercancías sea más fácil.

\footnotetext{
${ }^{34}$ Promoción de inversión Celaya, disponible en http://www.investincelaya.com/, fecha de consulta $10 / 11 / 2015$

35 Artículo de México Xport de 16 de noviembre en 2016. Disponible en http://mexicoxport.com/noticias/25921/kcs-y-bnsf-se-unen-para-proporcionar-transporte-intermodalentre-mexico-y-estados-unidos, fecha de consulta: 2/3/2017.
} 
Ilustración II-6.1. Ferrocarriles en El Bajío: Kansas City Southern México, con conexión con BNSF Railway Company

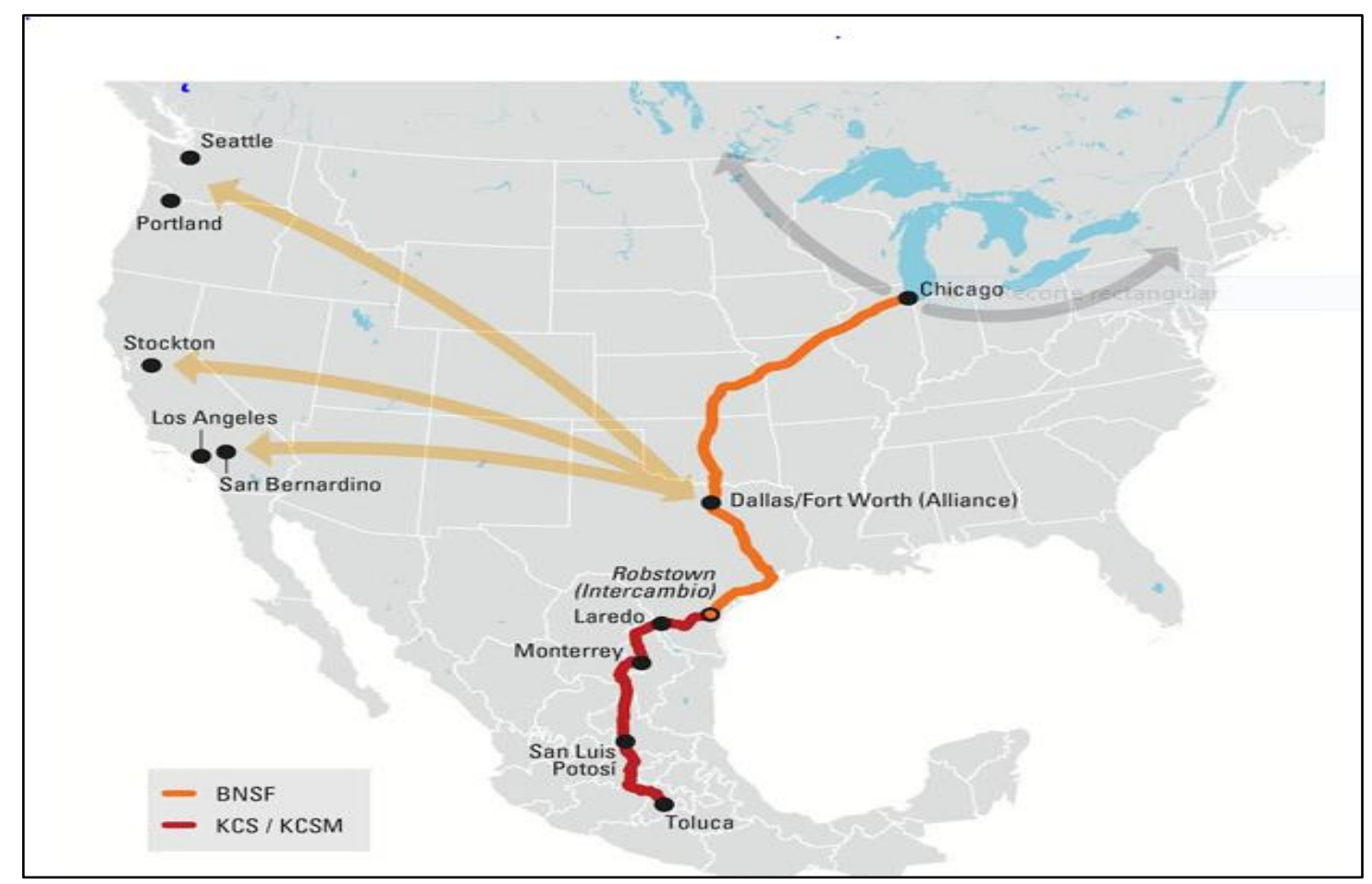

Fuente. Tomado de México Xport, disponible en http://mexicoxport.com/noticias/25921/kcs-y-bnsfse-unen-para-proporcionar-transporte-intermodal-entre-mexico-y-estados-unidos, fecha de consulta: $2 / 3 / 2017$.

\section{Ilustración II-6.2. Ferrocarriles en El Bajío: red de FERROMEX}

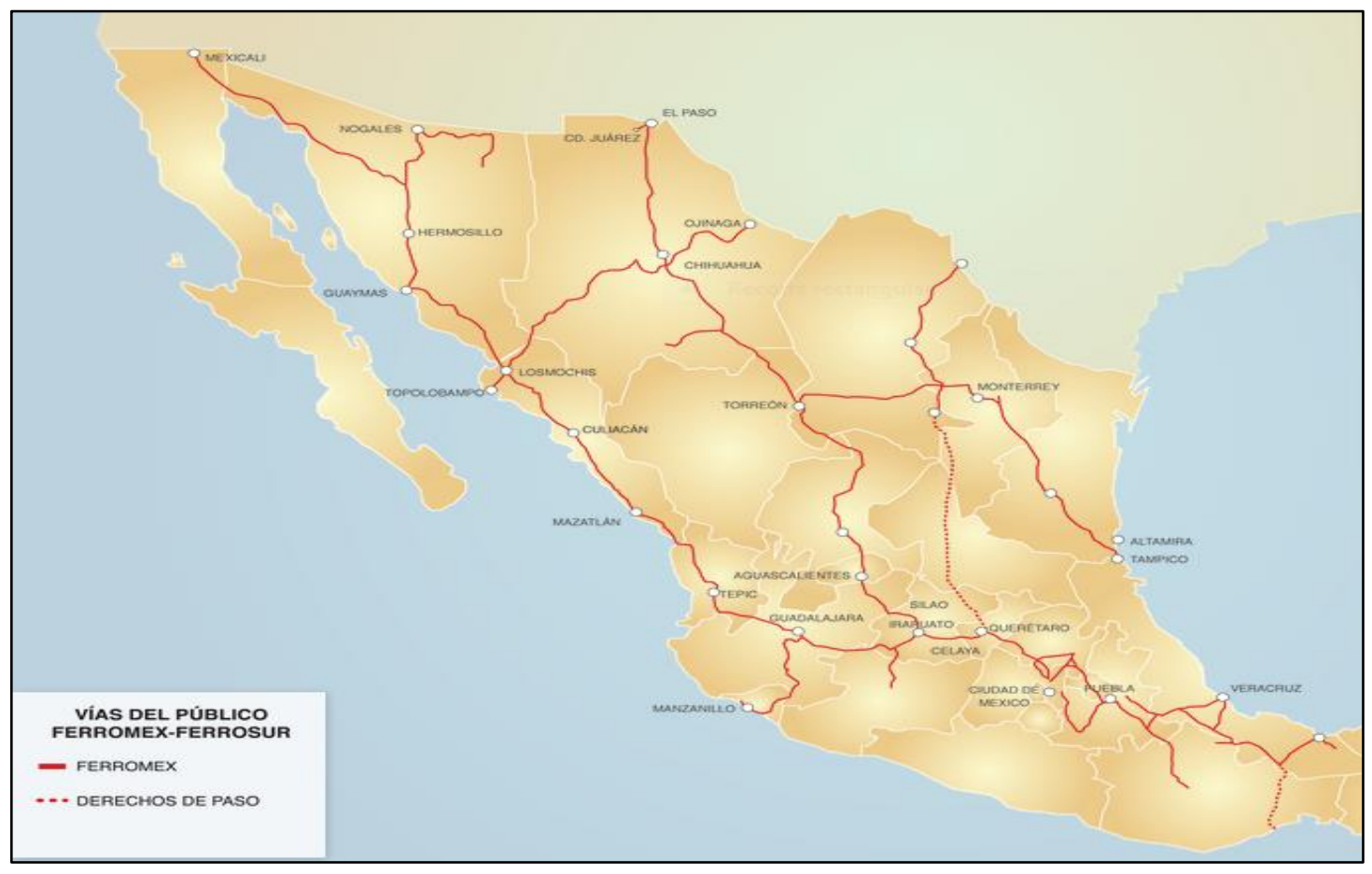

Fuente. Tomando de FERROMEX. Disponible en https://www.ferromex.com.mx/ferromex-lomueve/sistema-ferromex.jsp, fecha de consulta: 2/3/2017. 
Por lo que se refiere a otros costes, los más bajos costes de alquilar fábricas y de fabricación son dos motivos importantes para decidir a las empresas de automóviles a instalarse en El Bajío. Sin embargo, no debemos olvidar otro factor importante como motivo de atracción de las inversiones japonesas en esta zona: la posibilidad de establecer clústeres en El Bajío (UNGER, DETRAUX, MARTÍNEZ y REVILLA, 2003).

Los clústeres son concentraciones geográficas de empresas e instituciones interconectadas que compiten, pero también cooperan entre sí (PORTER, 2000; CHÁVEZ-MARTÍN DEL CAMPO y GARCÍA LORED, 2015). También, las ganancias de productividad que se generan al interior de estas aglomeraciones de actividad económica contribuyen a aumentar la competitividad de las empresas involucradas y, por lo tanto, inciden de manera positiva en su desempeño potencial (PORTER, 2003; CHÁVEZ-MARTÍN DEL CAMPO y GARCÍA LOREDO. 2015, p. 1). En el caso de las empresas japonesas, la relación estrecha y fuerte entre las empresas proveedoras y las empresas patronales es un motivo fundamental para formar el cluster (LINCOLN y SHIMOTANI, 2009).

Como se observa en la la Ilustración II-6.3, hay más parques industriales en El Bajío que en la frontera norte. En el caso de los clústeres en El Bajío, antes de la llegada de las empresas japonesas, hubo un tiempo en que las empresas de automóviles estadounidenses hicieron inversiones a esta zona.

Como se ha analizado anteriormente, las empresas de automóviles japonesas no habían pensado que sus inversiones en El Bajío eran tan importantes, hasta la década de 1990 (CARRILLO REGALADO, 2016, pp.2-3). Se conocía el éxito de Nissan en Aguascalientes, pero para las otras empresas japonesas, la inversión en El Bajío tenía un obstáculo: los costes para la exportación a Estados Unidos. Sin embargo, en las últimas décadas, las condiciones de transporte desde El Bajío han mejorado. Éste es un motivo muy importante para los aumentos de las inversiones japonesas en esta zona.

Al mismo tiempo, se puede decir que la formación de clústeres en el Bajío es un factor de mejora para las redes de ferrocarriles en México. Construir las líneas de ferrocarriles produce economías de escala. Es decir, si hay más clústeres, hay más motivos para construir las líneas de ferrocarriles (GARNICA VERA y GANGA CONTRERAS, 2007). 


\section{Ilustración II-6.3. Parques industriales en México.}

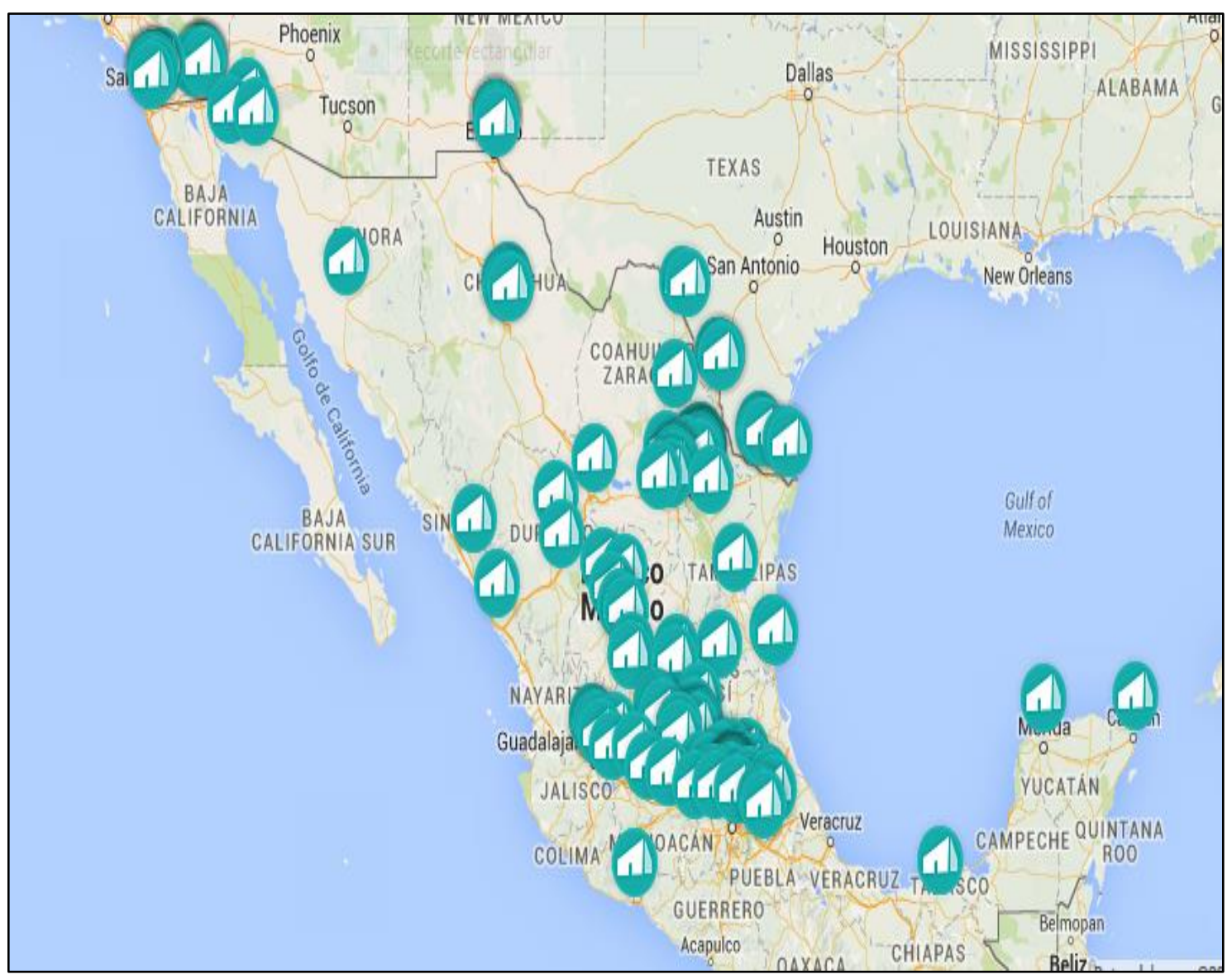

Fuente. Tomado de la AMPIP (Asociación Mexicana de Parques Industriales), disponible en http://ampip.org.mx/es/mapa-parques-industriales/, fecha de consulta: 24/7/20016.

Hasta esta parte, se han analizado los avances de las inversiones japonesas en El Bajío. Ahora, tenemos que considerar qué tipos de razones tienen actualmente las empresas japonesas que han estado en La Frontera Norte, como Tijuana. ${ }^{36}$

Desde 2015 las empresas japonesas en Tijuana empezaron a encontrar un problema de falta de recursos humanos; especialmente, en el nivel de trabajadores de las líneas de producción. ${ }^{37}$ Sin embargo, este problema de recursos no se encuentra en todas las empresas japonesas en Tijuana. Como resultado de las entrevistas realizadas en Tijuana, se observó que las empresas japonesas pequeñas, es decir las empresas japonesas proveedoras, son las más afectadas por la falta de trabajadores en las líneas de producción.

\footnotetext{
${ }^{36}$ Véase, por ejemplo, el artículo de El Economista, "Baja California con rezago en personal para Maquiladoras". 17 de mayo, 2016. Disponible en http://eleconomista.com.mx/estados/2016/05/17/bajacalifornia-rezago-personal-maquiladoras, fecha de consulta: 2/3/2017.

${ }^{37}$ Información obtenida de la entrevista de la doctoranda con el Sr. Hiraiwa, de la Asociación Japonesa de Maquiladoras, en mayo de 2015.
} 
Comparado con las empresas pequeñas, las empresas japonesas grandes, que son empresas patronales, no consideran la falta de estos trabajadores como un problema muy serio y urgente.

Esta diferente valoración de la falta de recursos humanos en la línea de fabricación entre las empresas grandes y las pequeñas induce dos reflexiones importantes sobre las actividades de las empresas japonesas en Tijuana.

En primer lugar, los papeles de las empresas japonesas dependen del tamaño de las mismas. Es decir, las empresas pequeñas y medianas son fabricantes y las empresas grandes son exportadoras de los productos finales (NISHIJIMA, 2009). Actualmente, la falta de trabajadores se encuentra en el nivel de las empresas de fabricación y por ello, afecta más a las empresas pequeñas y medianas.

En segundo lugar, aunque sea el mismo nivel de trabajadores en las líneas de producción, hay diferencias salariales entre las empresas grandes y pequeñas. Los salarios en las empresas grandes japonesas son más altos que en las empresas proveedoras japonesas. Este mayor salario es un motivo por el que las empresas japonesas grandes no consideran que la falta de recursos sea un problema suyo. Por el contrario, las empresas pequeñas se ven muy afectadas, porque sus niveles de salarios son más comparables con los salarios en el Bajío. Se puede encontrar esta tendencia en el porcentaje de rotación de sus recursos humanos. Según las entrevistas realizadas en Tijuana, la rotación en las empresas japonesas grandes en Tijuana era del 8\% en 2013 y ahora era más bajo. Sin embargo, en las empresas japonesas proveedoras la rotación en 2015 era del 20\% en cada mes. ${ }^{38}$ Esta alta rotación puede ser un resultado de la llegada de las empresas japonesas a El Bajío: los trabajadores en Tijuana se trasladan a El Bajío. Además, como una tendencia clara, los trabajadores que han trabajado antes en las empresas japonesas vuelven a trabajar en las empresas japonesas. Por eso, los trabajadores que han trabajado en las empresas japonesas en Tijuana se trasladan a El Bajío para trabajar en otras empresas japonesas allí. Las empresas japonesas en El Bajío inducen movimientos de trabajadores en México.

\footnotetext{
${ }^{38}$ Información obtenida por la doctoranda a partir de la entrevista realizada con un gerente de las empresas japonesas en Tijuana, en mayo de 2015.
} 


\section{II-7. Conclusiones}

En este capítulo se ha analizado la evolución histórica de las empresas japonesas en México. Las principales industrias en las que estas empresas han invertido han sido la de automóviles y la de electrodomésticos. Algunas empresas japonesas empezaron a invertir en México. Éste fue el caso de la empresa japonesa de automóviles Nissan que eligió el Estado de Morelos en los años 60 para fabricar coches para el mercado de México dentro de la estrategia de sustitución de importaciones y posteriormente en los 70 invirtió en Aguascalientes como lugar para profundizar sus inversiones, dirigidas a la producción para el mercado mexicano.

Sin embargo, desde la década de 1980, las inversiones japonesas empezaron a aumentar en México. Las empresas japonesas de electrodomésticos y automóviles habían tenido problemas debido al conflicto comercial entre las empresas japonesas y el gobierno estadounidense. Para las empresas japonesas, México fue un lugar para resolver este conflicto y evitar el problema de fabricar en Estados Unidos. El aumento de estas inversiones definió el papel de México como un lugar para fabricar los productos finales y posteriormente, exportarlos a Estados Unidos. En esta década de 1980 hubo varias razones que explicaron el aumento de las inversiones japonesas. Un incentivo importante fue el bajo valor relativo del peso mexicano, lo que dio lugar a una buena combinación para atraer a las inversiones japonesas. Asimismo, otro factor importante fue la eliminación de la limitación a las participaciones de los capitales extranjeros en las empresas mexicanas. Este cambio fue esencial para que las empresas japonesas grandes llevaran a sus proveedores japoneses a México para establecer sus plantas, ya que era muy costoso encontrar buenos proveedores en México. Gracias a los avances de las PYMEs japonesas, las grandes empresas japonesas pudieron fabricar sus productos. Sin embargo, desde el punto de vista de las empresas mexicanas, esto significó que tuvieron obstáculos para entrar en la cadena de fabricación de las empresas japonesas. En este contexto, aunque las empresas japonesas de automóviles y de productos electrónicos que son las principales empresas japonesas en México- aumentaron sus ganancias y exportaciones, no hubo beneficios tan sustanciales para las empresas o los ciudadanos de México.

En la década de 1990, por efecto del TLCAN, las inversiones japonesas aumentaron en México. Asimismo, la crisis económica de Japón en la mitad de esa década hizo que, posteriormente, las inversiones se redujeran en el país. No obstante, este 
descenso fue temporal. Después del descenso, sus inversiones aumentaron otra vez y esta tendencia ha seguido hasta hoy.

Esto no significa que las empresas japonesas no hayan cambiado su manera de hacer inversiones en México. Después de los años 2000, las inversiones japonesas se han trasladado hacia los estados centrales de México. Los motivos de este traslado se encuentran en el aumento de los costes salariales en la zona de la frontera Norte y en el Programa IMMEX del gobierno de México. Además, en las últimas dos décadas, las empresas japonesas en México han tenido rivales en el mercado de Estados Unidos: primero fue Corea del Sur y después, China. Para mantener una alta competitividad de sus productos en el mercado estadounidense y hacer frente a estas nuevas competencias, las empresas japonesas han invertido en el centro de México.

Teniendo en cuenta esta evolución histórica, se puede decir que las inversiones japonesas en México se han debido a tres grupos de motivos. El primero es el de las relaciones económicas entre Japón y Estados Unidos. Para las empresas japonesas en México, Estados Unidos siempre ha sido su mercado principal. Para mantener su dominio en este mercado, las empresas japonesas han instalado sus fábricas en México. La importancia de este factor no ha cambiado desde la primera etapa de las inversiones en México.

El segundo grupo de motivos tiene que ver con las condiciones económicas japonesas. Es decir, cuando la economía japonesa está en boom, las inversiones japonesas aumentan. Al contrario, cuando la economía está en recesión, las inversiones japonesas se reducen. Este cambio de los movimientos de sus capitales depende de las condiciones económicas del país de origen de los mismos.

El último grupo de motivos hace referencia a la condición de México, es decir, si este país es aceptable o no como destino para las actividades productivas de las empresas japonesas. Por ejemplo, eliminar la limitación a las participaciones de los capitales extranjeros en las empresas mexicanas facilitó la llegada de capital japonés al país.

Se puede decir que históricamente, las inversiones japonesas en México han sido fruto de las relaciones económicas entre Japón y Estados Unidos. Esto era claro en la década de 1970. Sin embargo, en las últimas décadas, los factores mexicanos han influido muy notablemente en las actividades de las empresas japonesas en México. 
La Ilustración II-7.1 recoge los factores decisivos de las inversiones japonesas en México y las relaciones entre ellos. Se nota que los factores de las relaciones económicas entre Japón y Estados Unidos tienen influencia tanto en Japón como en México. Los factores de México son sus políticas industriales -como los Programas de Maquiladora, PITEX e IMMEX ${ }^{39}$ - y sus menores costes laborales y de transporte a Estados Unidos. La influencia de estos factores ha aumentado en los últimos años. Por otro lado, los factores japoneses inciden más sobre la situación económica.

Sin embargo, hay algunos factores no se incluyen en estos tres factores, por ejemplo, el Acuerdo del Plaza y la crisis del petróleo. El Acuerdo del Plaza indujo la apreciación del yen, que tuvo influencia en las actividades de las empresas japonesas. La crisis del petróleo influyó en las relaciones entre Japón y Estados Unidos y en los factores de Japón. Estos dos factores exteriores también fueron importantes para entender la historia de las inversiones japonesas en México.

\section{Ilustración II-7. 1. Factores decisivos de las inversiones japonesas en México}

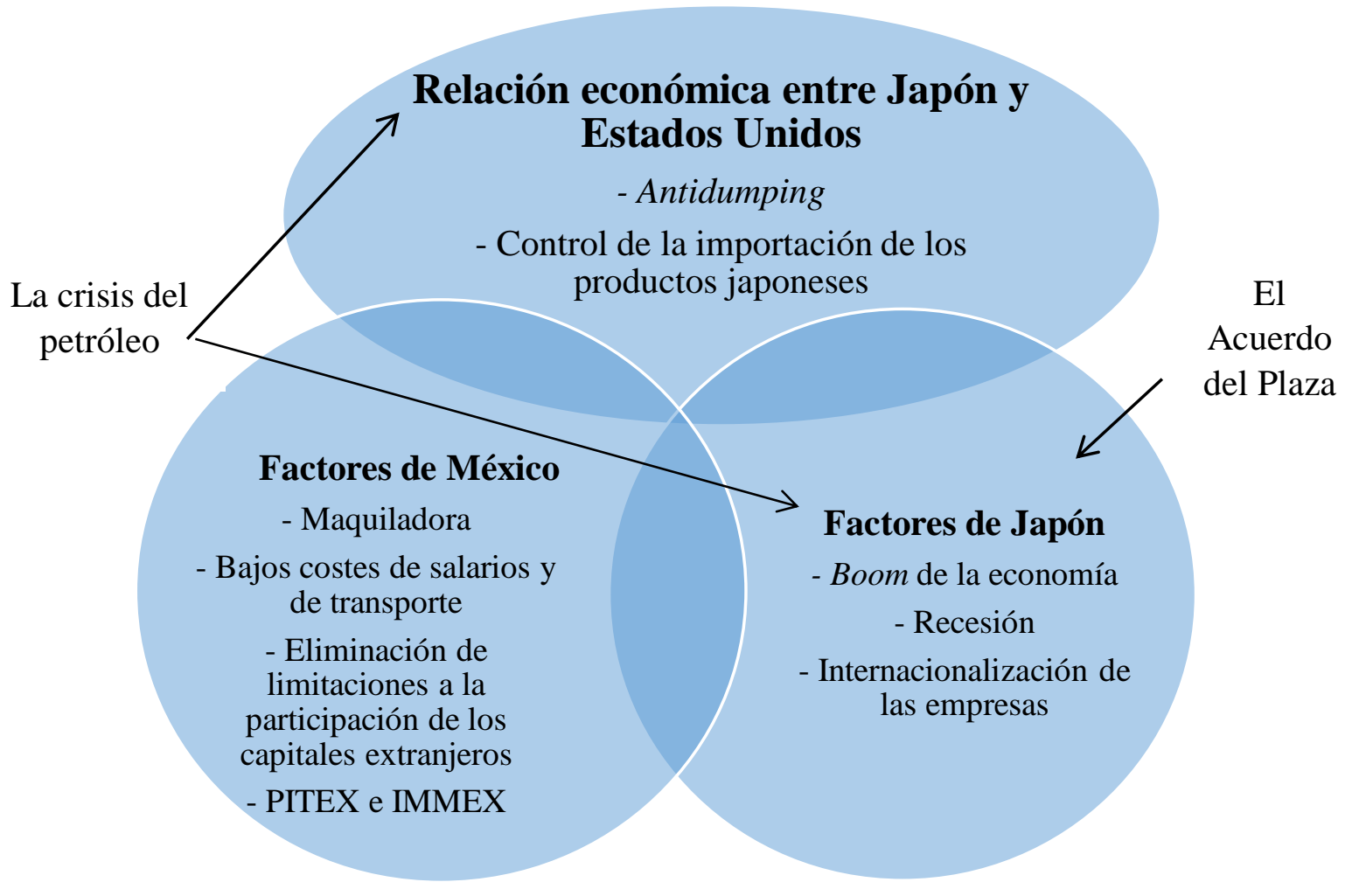

Fuente: Elaboración propia

\footnotetext{
${ }^{39}$ Estos tres Programas -Maquiladora, PITEX e IMMEX- se analizan con más detalle en el Capítulo IV.
} 


\section{Capítulo III}

El comercio de China y México con Estados Unidos 


\section{III-0. Introducción}

En este capítulo, se analiza el comercio de México. Como hemos analizado en el capítulo anterior, el principal motivo actual de las inversiones japonesas en México es para exportar sus productos a Estados Unidos. Por ello, el análisis del comercio de México es muy importante y útil para entender las actividades de las empresas japonesas en México.

Además, para analizar el comercio de México, se compara con el comercio de China. Hay un motivo para hacer esta comparación. El principal motivo es que a partir de su entrada en la Organización Mundial del Comerico (OMC) China se ha convertido en el primer socio comercial de Estados Unidos (Gráfico III-0.1). En 2014 China sumaba el $21 \%$ de las importaciones de Estados Unidos, seguida por Canadá con el 15\%, México con el $13 \%$ y, más atrás, Japón con el $6 \%$ (Gráfico III-0.2) ${ }^{1}$. El crecimiento de las exportaciones de China supone un gran cambio, puesto que en 1995 Canadá suponía el $20 \%$ de las importaciones, Japón el 17\%, México el 8\% y China solo el 7\% (Gráfico III0.3). En estos casi 20 años Japón ha perdido 11 puntos de cuota de mercado en Estados Unidos, mientras que al mismo tiempo, las exportaciones desde México y China crecen, en parte por la deslocalización de la producción de las empresas japonesas en estos países a través de las inversiones directas, donde crean empresas desde las que producen para exportar al mercado de Estados Unidos. Creemos que la comparación del comercio de México y de China con Estados Unidos es una manera efectiva para entender las actividades de las empresas japonesas en México, aunque los datos de comercio están desagregados por países y no llegan al nivel de empresas ${ }^{2}$.

\footnotetext{
${ }^{1}$ La economía china se ha convertido en la segunda mayor economía mundial, el primer exportador y segundo importador a nivel mundial, según información de FMI (Fondo Monetario Internacional), World Economic Outlook, IMF Data Mapper http://www.imf.org/external/datamapper/NGDP_RPCH@WEO/OEMDC/ADVEC/WEOWORLD, fecha de consulta: 12/11/2016.

${ }^{2}$ Ahora China es el primer receptor de inversión extranjera directa (IED) de la economía mundial (123.500 milliones de dólares) y el tercero con mayor flujo de IED (116.000 milliones de dólares) en 2014 (UNCTAD, 2015).
} 
Gráfico III-0.1. Importaciones de Estados Unidos, 1995-2014

(En trillones de dólares corrientes)

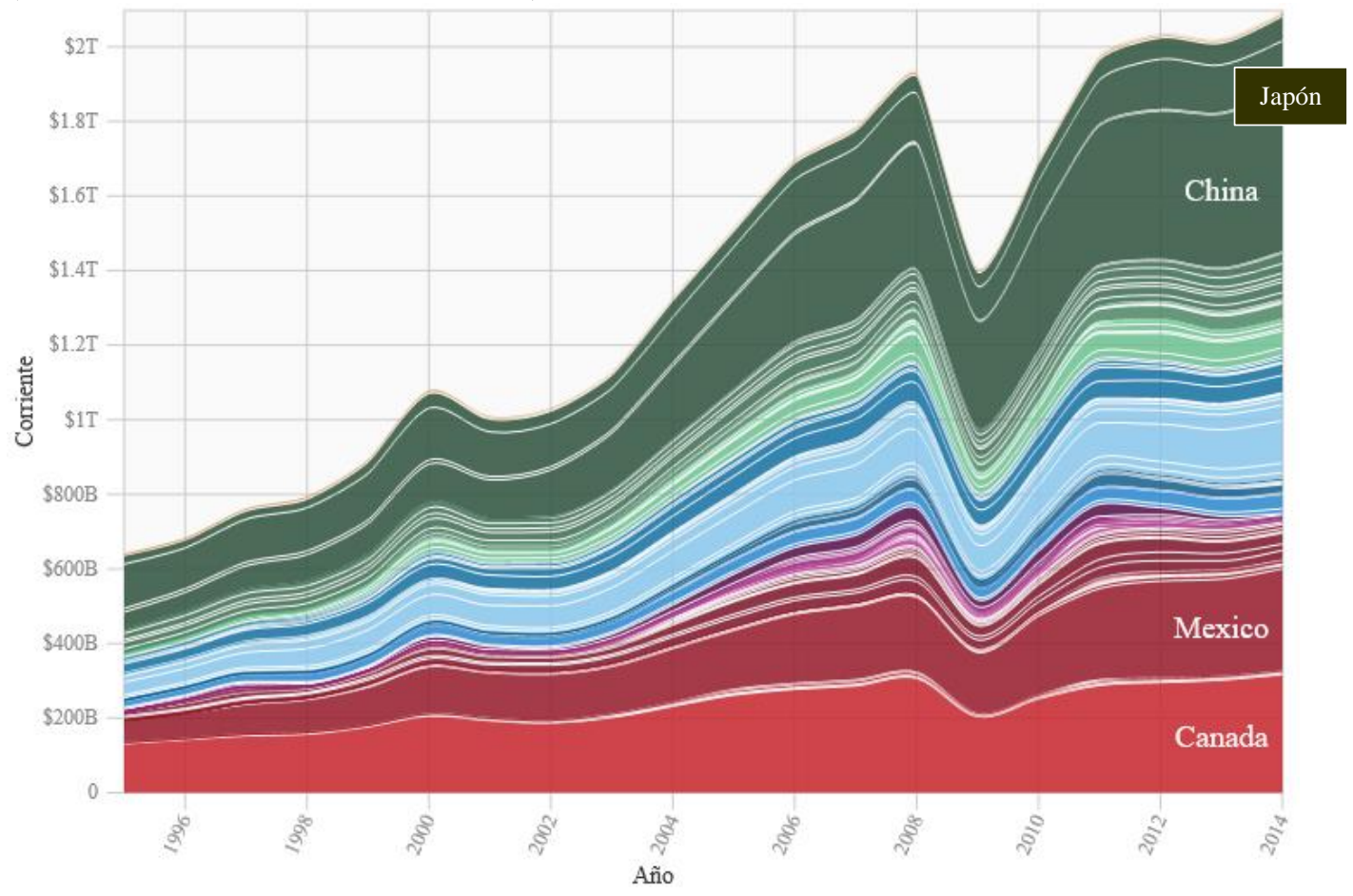

Fuente. Tomado de Atlas of Economic Complexity, disponible en

http://atlas.cid.harvard.edu/explore/stacked/import/usa/show/all/1995.2014.2/, fecha de consulta: 7/12/2016.

Gráfico III-0.2. Distribución de las importaciones de Estados Unidos por países, 2014 (En trillones de dólares corrientes)

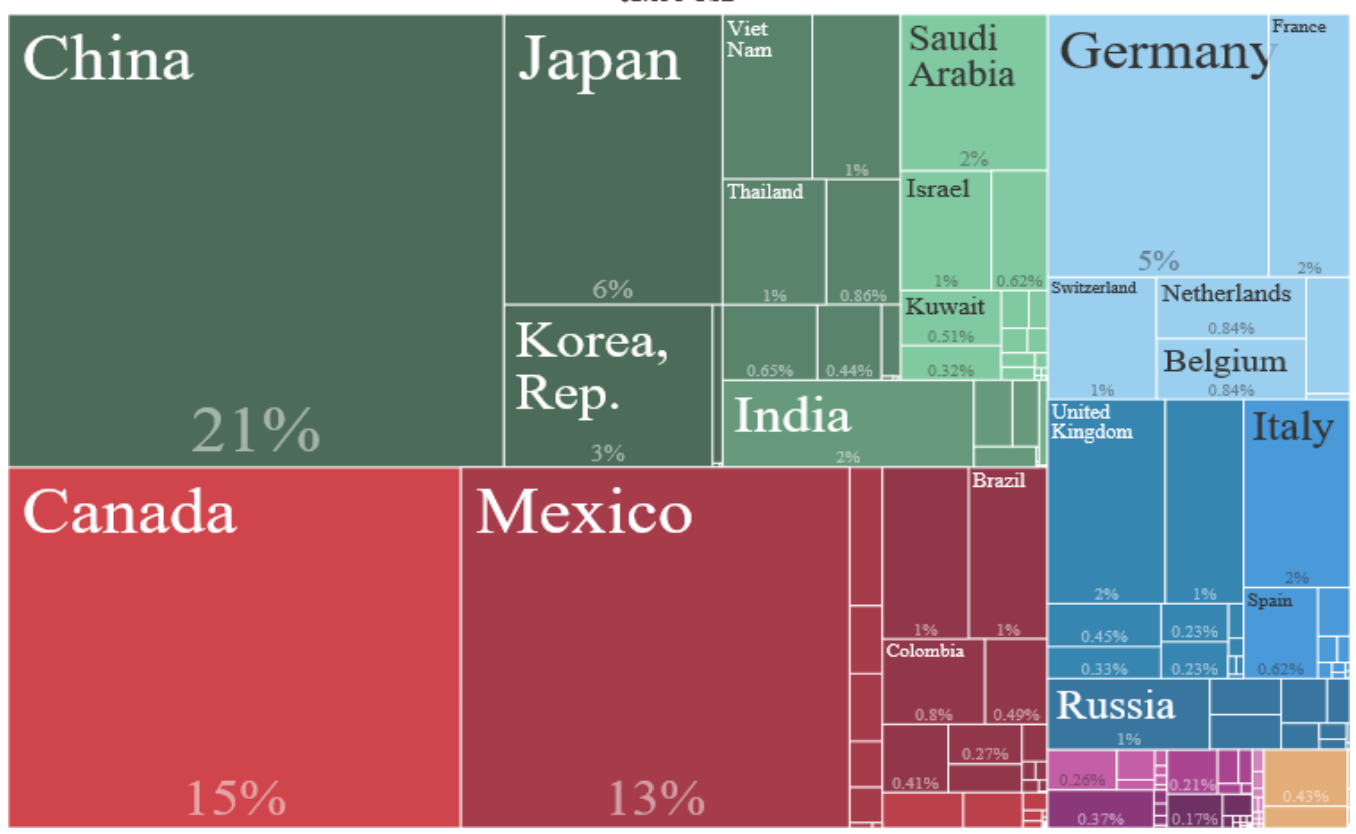

Fuente. Tomado de Atlas of Economic Complexity, disponible en

http://atlas.cid.harvard.edu/explore/tree_map/import/usa/show/all/2014/, fecha de consulta: 7/12/2016. 
Gráfico III-0.3. Distribución de las importaciones de Estados Unidos por países, 1995 (En biliones de dólares corrientes)

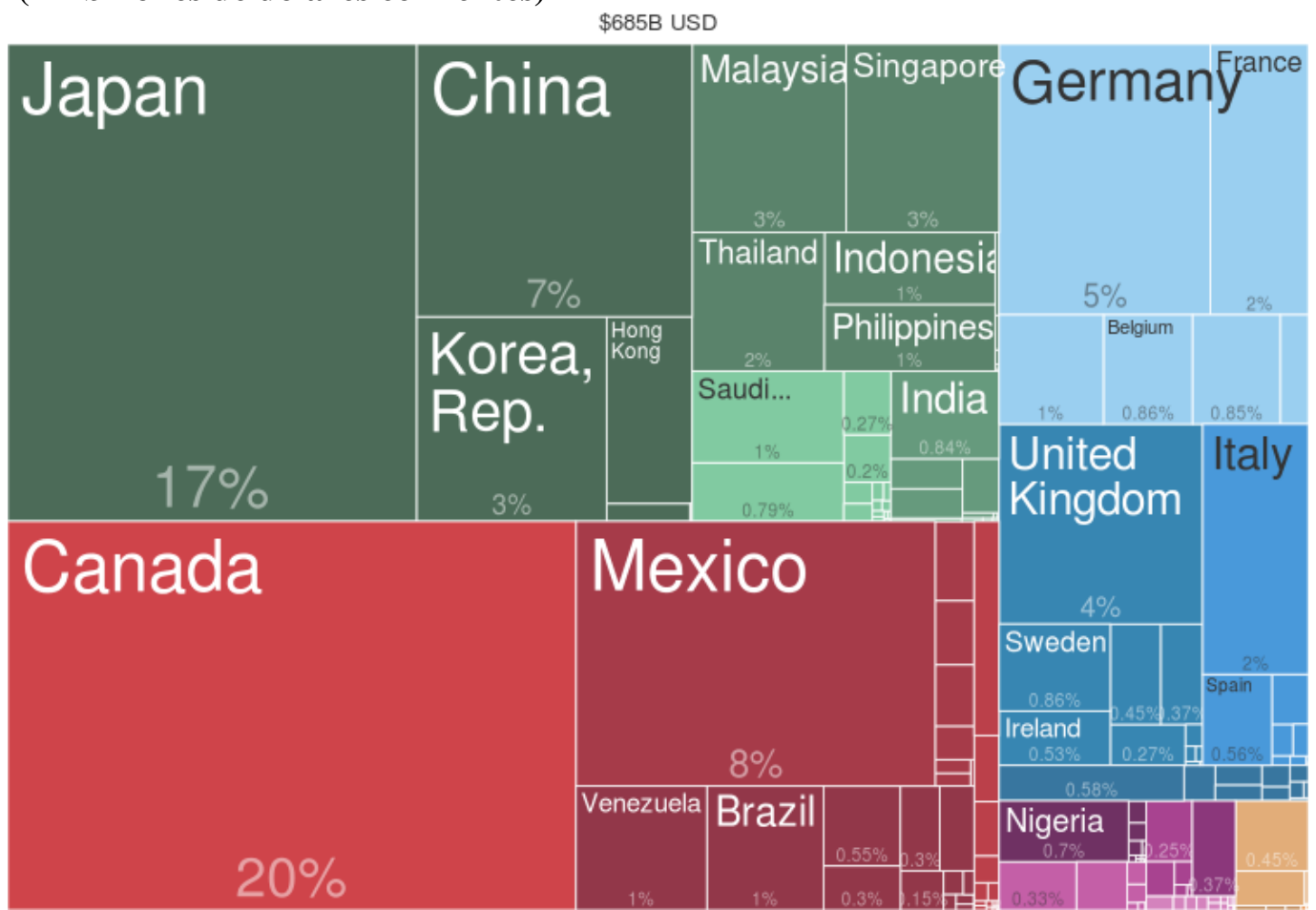

Fuente. Tomado de Atlas of Economic Complexity, disponible en

http://atlas.cid.harvard.edu/explore/tree_map/import/usa/show/all/1995/, fecha de consulta: 7/12/2016.

El avance de la economía china como "fábrica del mundo" es muy notable, pues ha multiplicado por más de 11 su capacidad exportadora en menos de 20 años, pasando de 200 mil millones de dólares en 1995 a más de 2,2 billones en 2014, particularmente a partir de su entrada en la OMC (Gráfico III-0.4). Aunque su creciente presencia es evidente en todos los mercados mundiales, su huella es particularmente clara en Estados Unidos que, en términos de países, constituye su principal mercado de exportación, pues recibe el $19 \%$ de sus ventas. Esta creciente presencia china en Estados Unidos ha significado una fuerte competencia para México. Es decir, en el mercado de Estados Unidos, los productos chinos son rivales directos para los productos de México. Analizar y comparar sus actividades es una manera de entender la economía mundial (DUSSEL PETERS, 2016a). 
Gráfico III-0.4. Distribución de las exportaciones de China por países, 1995-2014 (En trillones de dólares corrientes)

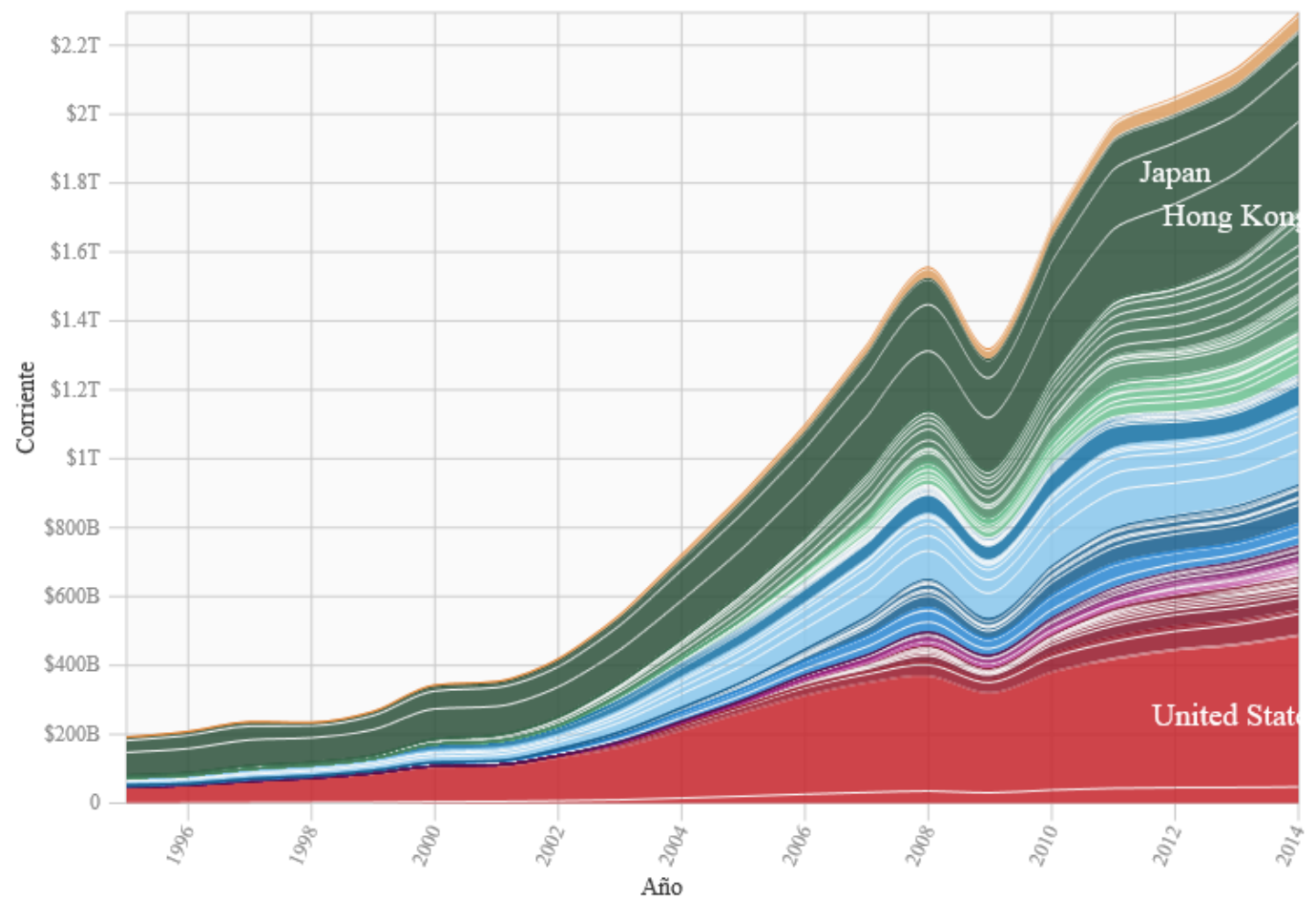

Fuente. Tomado de Atlas of Economic Complexity, disponible en

http://atlas.cid.harvard.edu/explore/stacked/export/chn/show/all/1995.2014.2/, fecha de consulta: 7/12/2016.

Para analizar los flujos comerciales de México y China hacia Estados Unidos, se analiza la situación general del comercio con ambos países. En este capítulo, la mayor parte de los datos son de los años desde 1990 hasta 2014, salvo en los datos tomados del Atlas de Complejidad Económica de la Universidad de Harvard que comienzan en 1995. Sin embargo, en función de la disponibilidad de los datos, en ocasiones las series son posteriores a la entrada de China en la OMC y van desde desde el año 2002 hasta el 2014 o 2015 . 


\section{III-1. China y México: Exportaciones e importaciones a Estados Unidos}

En este epígrafe, se analiza el comercio de México y China con Estados Unidos, desde el año 1984 hasta 2014. Durante estas tres décadas, la situación del comercio de ambos países ha cambiado. Este cambio del comercio ha sido un motivo del cambio de la estrategia de las empresas japonesas en México.

\section{III-1.1. El Comercio de México}

Primero, veamos el Gráfico III-1.1 que presenta el comercio de México. En este gráfico, hay cuatro líneas que representan la exportación total al mundo, el total de la importación desde el mundo, la exportación a Estados Unidos y las importaciones desde Estados Unidos. Se puede decir que todo el comercio de México tiende a aumentar en el periodo considerado. Solo en 1995 tras la crisis mexicana, en 2001 tras la explosión de la burbuja de las “.com” y en 2010 tras la crisis en Estados Unidos, se reducen (CARRILLO y GOMIS, 2003; CARRILLO y BENSUNSAN, 2012). Sin embargo, podemos decir que la tendencia es clara y que el comercio de México ha aumentado mucho en las últimos tres décadas.

Sin embargo, si vemos en detalle, podemos encontrar algunas características. La primera característica es la diferencia entre exportación e importación con Estados Unidos: ambas han aumentado desde el año 2000, pero han crecido mucho más las exportaciones. Se puede encontrar esta tendencia en el Gráfico III-1.2 que recoge el saldo del comercio de México con Estados Unidos (1984-2014). En el Gráfico III-1.2, se puede notar que su saldo es positivo y aumenta desde la segunda mitad de 1990, tras la firma del Tratado de Libre Comercio con Estados Unidos y Canadá (TLCAN) (DUSSEL PETERS y GALLAGHER, 2013) Además, como segunda característica, puede señalarse que sus exportaciones al conjunto del mundo y sus importaciones del conjunto del mundo son casi iguales; es decir, el comercio de México con el total del mundo está equilibrado. Sin embargo, al ver su comercio con Estados Unidos, México, como hemos visto, tiene superávit. Esto significa que la importancia de Estados Unidos en los distintos flujos comerciales es diferente, siendo mucho mayor en sus exportaciones. Este rasgo se puede encontrar en los Gráficos III-1.3 y 4 que reflejan el peso de Estados Unidos en el comercio de México (1984-2014) y la distribución por países del comercio de México en 2014. 
Gráfico III-1.1. Comercio de México, 1984-2014

(En miles de millones de Dólares)

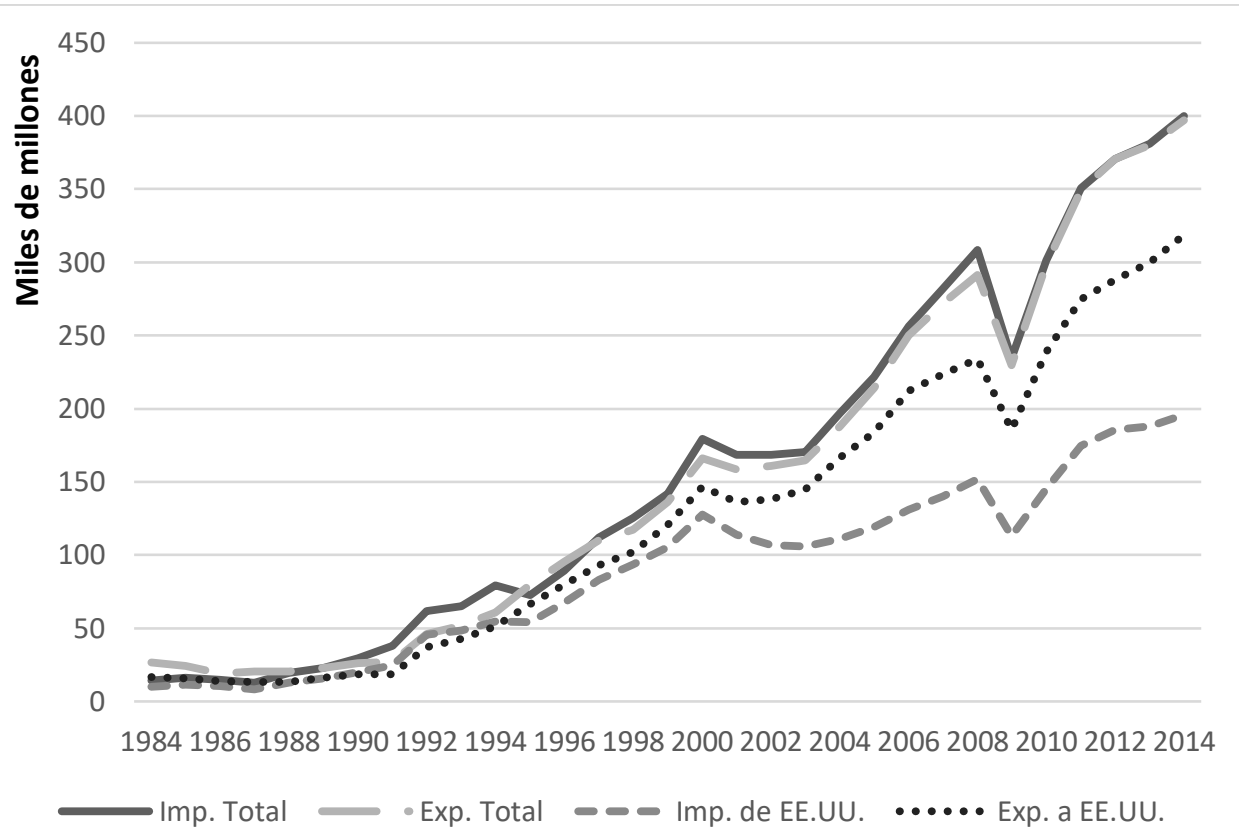

Fuente. Elaboración propia a partir de COMTRADE, Naciones Unidas, disponible en http://comtrade.un.org/data/, fecha de consulta: 11/08/2016.

Gráfico III-1.2. Saldos del comercio de México y China con Estados Unidos, 1984-2014 (En miles de millones de dólares)

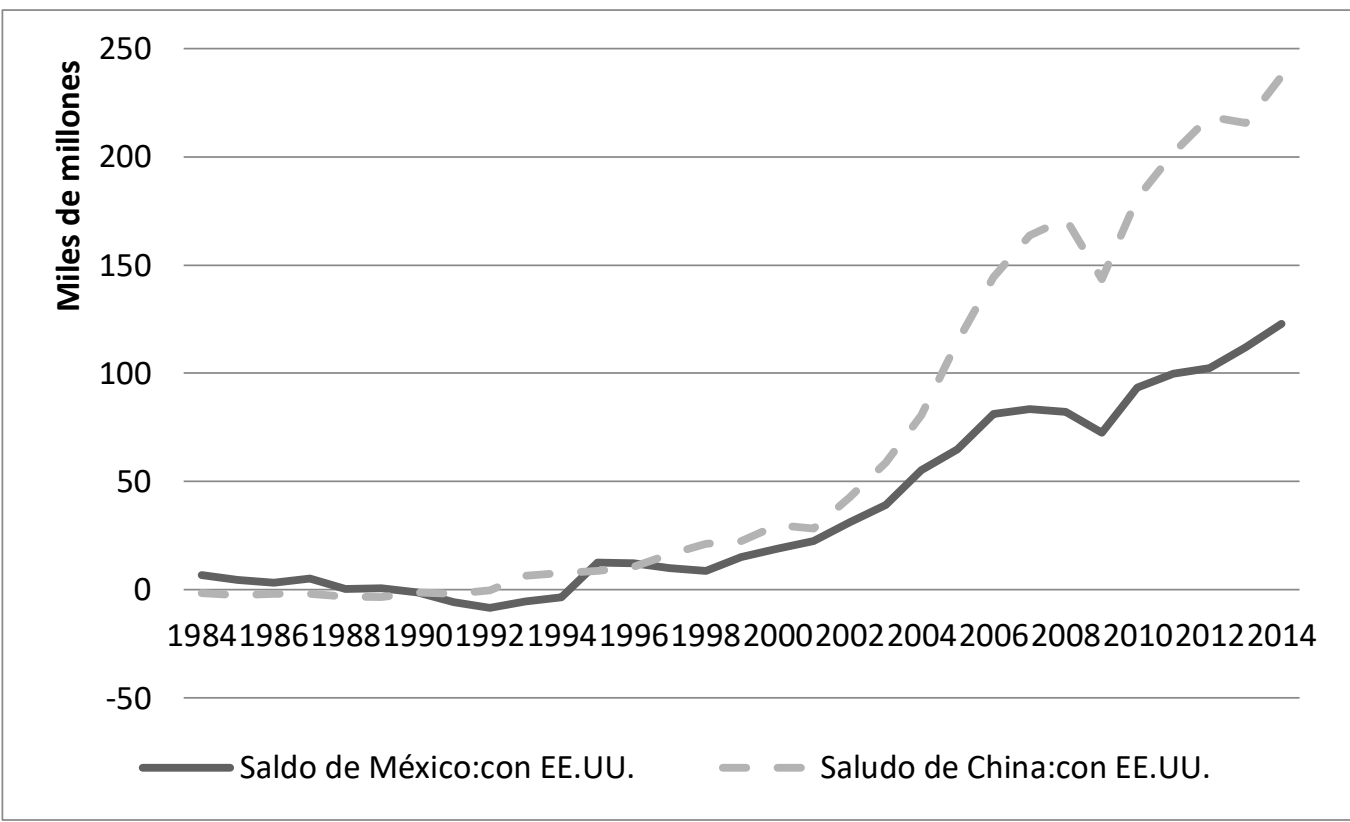

Fuente. Elaboración propia a partir de COMTRADE, Naciones Unidas, disponible en http://comtrade.un.org/data/, fecha de consuta 11/08/2016. 
Gráfico III-1.3. Peso de Estados Unidos en el comercio de México, 1984-2014 (En porcentaje)

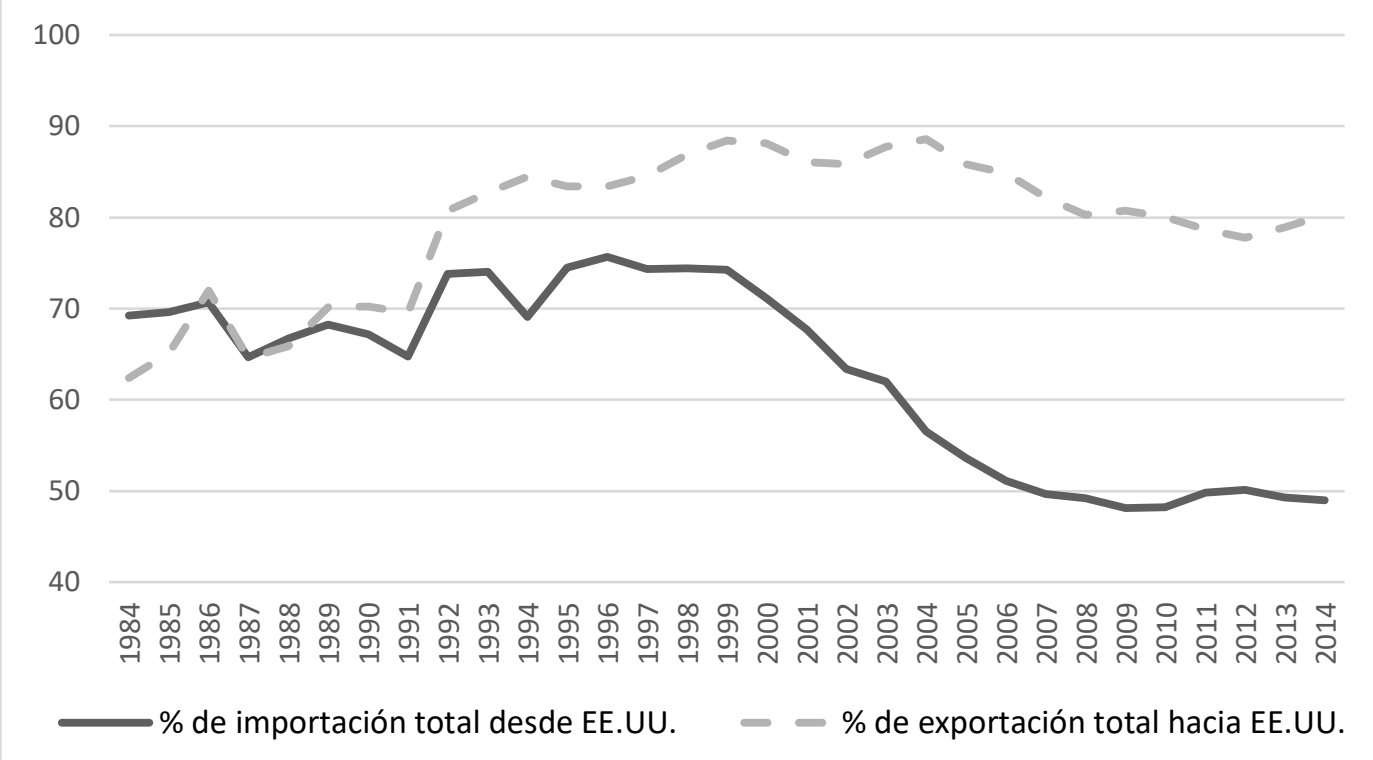

Fuente. Elaboración propia a partir de COMTRADE, Naciones Unidas, disponible en http://comtrade.un.org/data/, fecha de consuta 11/08/2016.

Gráfico III-1.4. Distribución por países de las exportaciones de México, 2014 (En billones de dólares)

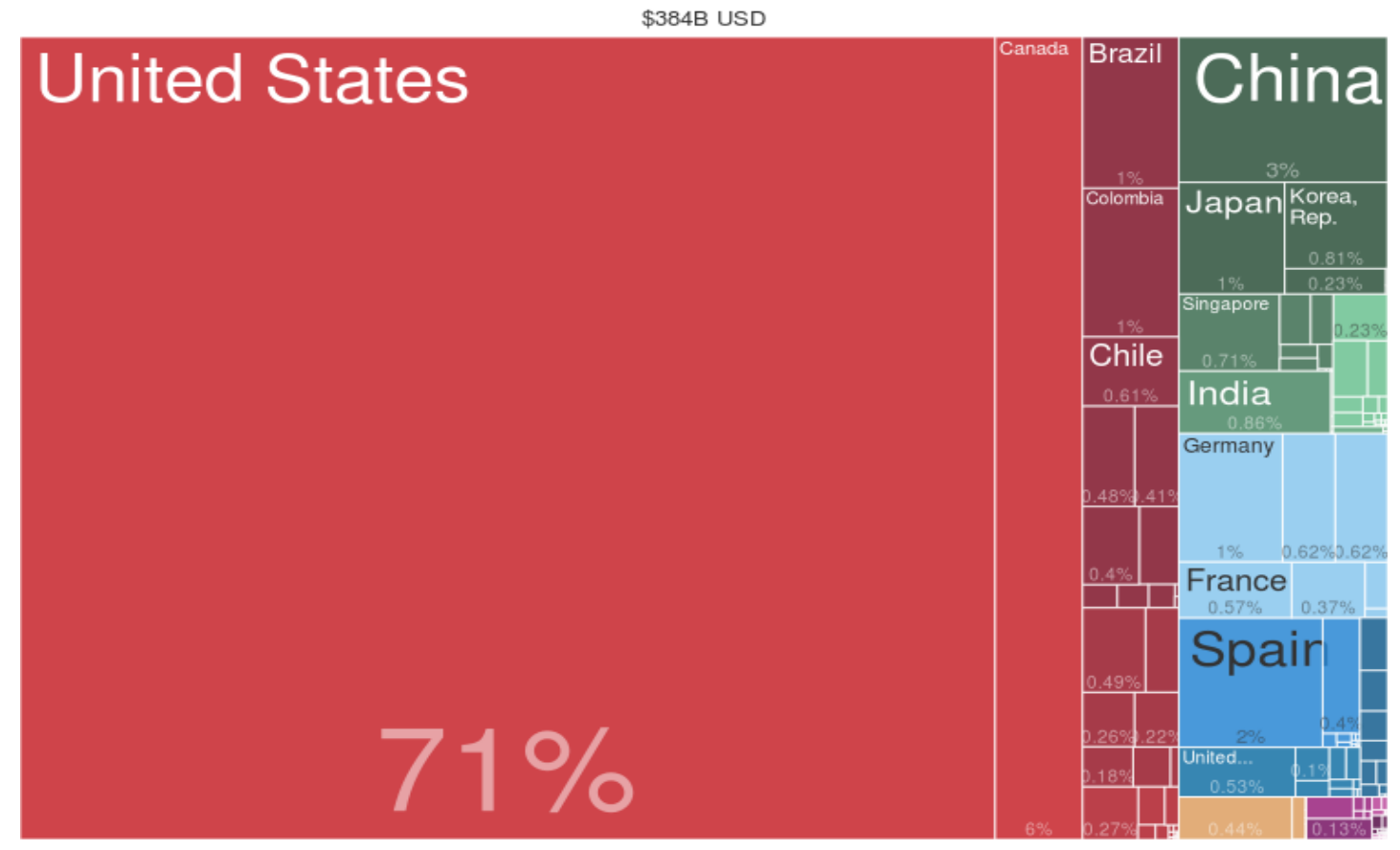

Fuente. Tomado de Atlas of Economic Complexity, disponible en http://atlas.cid.harvard.edu/explore/tree_map/export/mex/show/all/2014/, fecha de consulta: $07 / 12 / 2016$ 
En el Gráfico III-1.3, se puede encontrar que, en la economía de México, el peso de la exportación hacia Estados Unidos ha aumentado, mientras que el peso de la importación desde Estados Unidos se ha reducido. La diferencia entre los pesos de exportación e importación ha aumentado y en 2014, hay 30\% de diferencia. Es decir, para México, Estados Unidos es más importante como destino de sus exportaciones que como origen de sus importaciones (MORALES TORONCOSO, 2008).

La exportación desde México a Estados Unidos se ve influida por la situación de la economía en Estados Unidos, especialmente, por la evolución del índice de producción industrial de los Estados Unidos y por la evolución del tipo de cambio real. (GARCÉSDÍAZ, 2008). Por tanto, los cambios de la situación económica de Estados Unidos afectan directamente a la producción y las exportaciones de México (CARRILLO y BENSUNSAN, 2012, p. 734). Si la situación económica en Estados Unidos mejora, la demanda de los consumidores en este país sube. Además, desde 1993, el TLCAN entró en vigor, lo que permitió un comercio más fácil entre México y Estados Unidos (CARRILLO, 2013). Estos dos factores son motivos principales del aumento de la exportación de México a Estados Unidos.

\section{III-1.2. El comercio de China}

Los datos sobre comercio de China son desde 1984 hasta 2014 pueden encontrarse en el Gráfico III-I.5. Los cambios de la economía china en estas tres décadas han sido muy drásticos y en el gráfico se manifiestan en una creciente capacidad exportadora. Según este Gráfico, se nota que los aumentos de las exportaciones e importaciones chinas aumentaron mucho después de la entrada de China en la OMC en el año 2000 (GERBER y CARRILLO, 2006). Además, al comparar su comercio con el mundo y su comercio con Estados Unidos, hay una característica muy clara: tanto en el comercio con el mundo como con Estados Unidos, hay más exportaciones que importaciones. Además, su exportación al mundo empezó a aumentar desde 2004 muy rápido. Sin embargo, como otra característica, el aumento del comercio con Estados Unidos es menos marcado, en comparación con el comercio con el mundo, por lo que el peso de Estados Unidos en el comercio de China no es tan importante. Al ver el Gráfico III-I.6 que recoge el peso de Estados Unidos en el comercio de China (1984-2014), esta tendencia se ve aún más clara. 
Gráfico III-1.5. Comercio de China, 1984-2014

(En dólares de Estados Unidos)

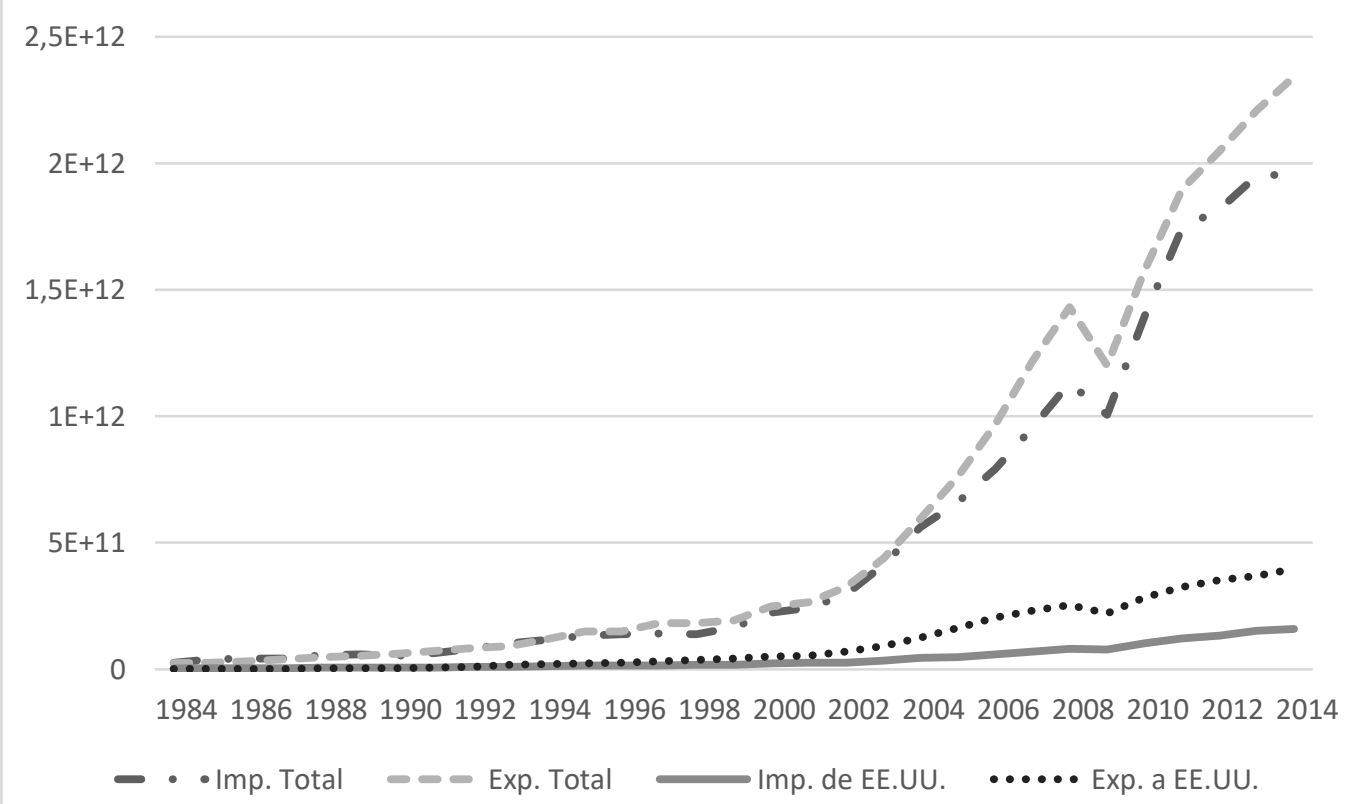

Fuente. Elaboración propia a partir de COMTRADE, Naciones Unidas, disponible en http://comtrade.un.org/data/, fecha de consulta: 12/08/2016

Gráfico III-I.6. Peso de Estados Unidos en el comercio de China, 1984-2014 (En porcentaje)

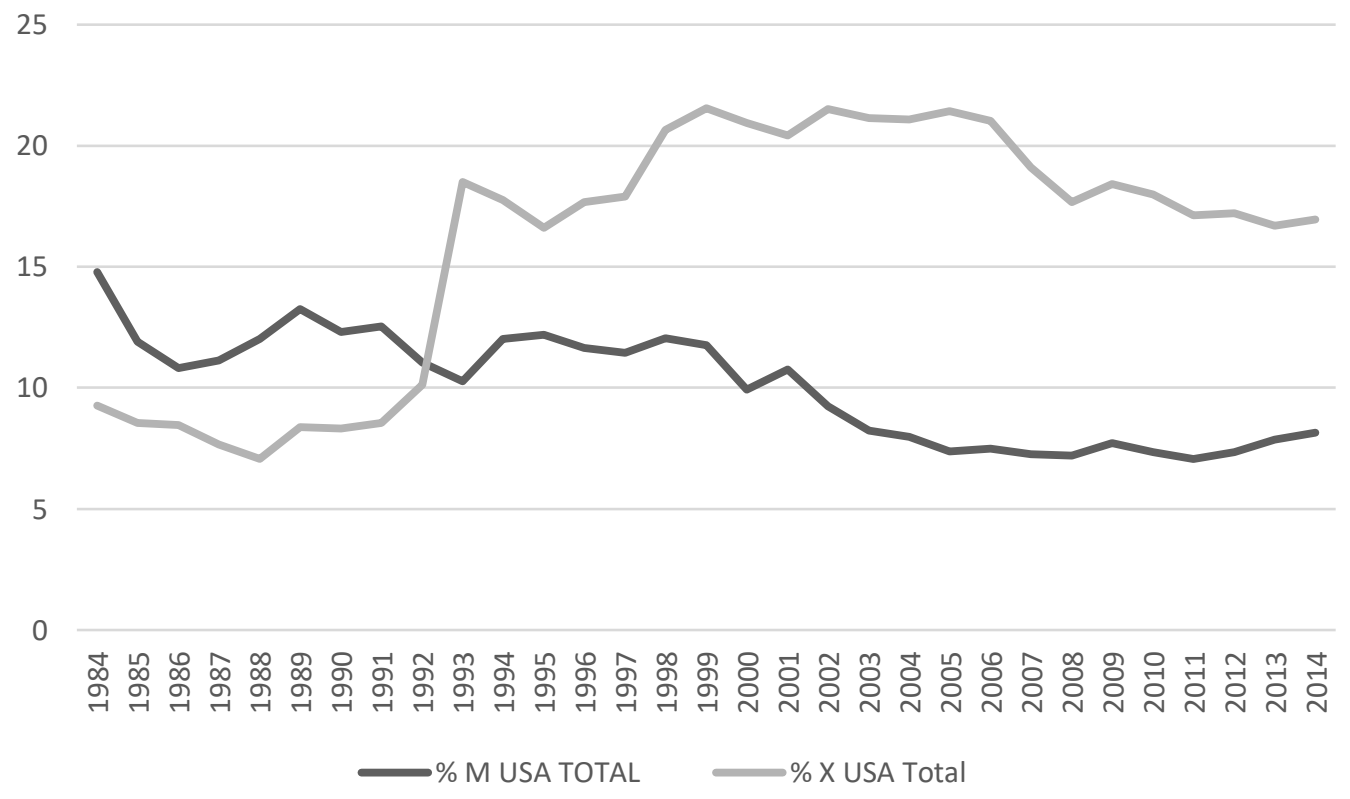

Fuente. Elaboración Propia, según COMTRADE, Naciones Unidas, disponible en http://comtrade.un.org/data/, fecha de consulta: 12/08/2016. 
En el Gráfico III-1.6, el peso del comercio con Estados Unidos para China cambia después de la entrada de China a la OMC. Es decir, principalmente, para China, Estados Unidos es un lugar para exportar, no es un lugar para importar. Más importante, el comercio con Estados Unidos no tiene tanto peso en el comercio total: en 2014, su peso en la exportación es de menos de $20 \%$ y su peso de la importación es de menos de $10 \%$. A lo largo de la serie el valor más alto de la importación desde Estados Unidos era 22\% en 1999 y la exportación era 15\% en 1984. Esta baja dependencia en la economía estadounidense es una característica del comercio de China en relación con el comercio de México.

Ahora, volvemos el Gráfico III-1.2 que muestra los saldos del comercio de México y China con Estados Unidos (1984-2014) para ver el saldo de China. Comparado con el de México, el saldo de China es más alto, después del año 1998. Desde 2001, esta diferencia se empezó a ampliar.

Basándose en estos gráficos anteriores, puede afirmarse que el comercio de China empezó a cambiar desde la década 2000. Ahora, se necesita considerar qué ocurre en la economía china dede el fin de los años 90s hasta la primera parte de la década de 2000.

El cambio más importante para el comercio de China es, como hemos visto, su participación en la OMC en el año 2001. ${ }^{3}$ Su entrada en esta organización conlleva una reducción de las tarifas arancelarias, una reducción de las barreras no arancelarias y la eliminación de los subsidios a los productos agrícolas (COLLADO ARMENGOL, 2002, p. 81). La participación de china en la OMC es un motivo fundamental para el aumento de su presencia en el comercio internacional.

Como hemos visto antes en el gráfico de la introducción, China es un gran exportador en el mundo. Si el principal objeto de su participación en la OMC en 2001 era para exportar más sus productos a todo el mundo, el objetivo parece que ya está cumplido. Esto significa que china tiene posibiliedaes de buscar próximo objeto en sus comercios internacionales.

\footnotetext{
${ }^{3}$ Según informaciones de OMC (Organización Mundial de Comercio). China y OMC. https://www.wto.org/spanish/thewto_s/countries_s/china_s.htm: fecha de consulta 4/11/2015.
} 


\section{III-1.3. Las diferencias de los comercios de ambos países con Estados Unidos.}

En esta parte, se compara los flujos comerciales de los dos países. Primero, veamos Gráfico III-1.7 que recoge la evolución de las exportaciones totales en el mundo de México y China en el periodo 1984-2014.

Según el Gráfico III-1.7, la evolución de las exportaciones de ambos países en el mundo está clara: el aumento de China es muy superior que el de México. Como hemos analizado, el aumento de la exportación de China se disparó desde el año 2002. Justo después de que China se convirtió en un miembro de la OMC. Es decir que esta entrada a la OMC es un motor básico de su aumento de la exportación (PRASAD y RUMBAUGH, 2003).

En el caso de México, el aumento de la exportación al mundo es, al lado del experimentado por China, muy tímido. No ha llegado a los 500 miles de millones dólares, mientras que China se acerca a los 2,5 billones.

Gráfico III-1.7. Evolución de las exportaciones totales de México y China, 1984-2014 (En miles de millones de dólares)

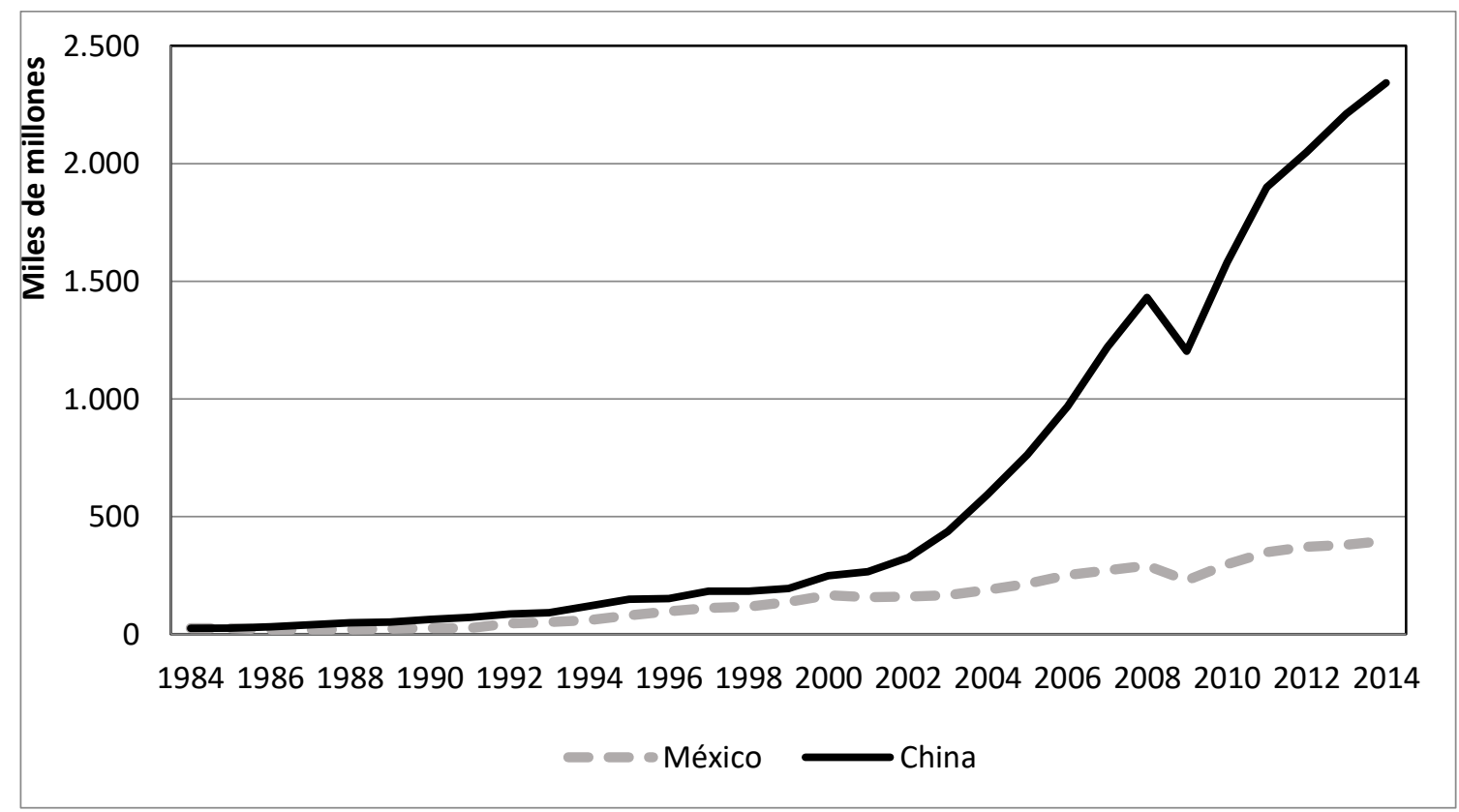

Fuente. Elaboración propia a partir de COMTRADE, Naciones Unidas, disponible en http://comtrade.un.org/data/, fecha de consulta: 12/08/2016

En el Gráfico III-1.8. que recoge el peso de Estados Unidos en las exportaciones se puede encontrar otra característica importante: la dependencia de Estados Unidos es 
mucho más alta para México que para China. Durante 1984-2014, casi el $80 \%$ de las exportaciones mexicanas fue a su vecino del norte, mientras que solo el $15 \%$ de las exportaciones chinas tuvo como destino a Estados Unidos.

Es decir, en el caso de México, "la exportación al mundo" significa, en buena medida, "exportación a Estados Unidos." Sin embargo, en el caso de China, Estados Unidos es, como vimos en la introducción, un país individual importante, pero que suma un porcentaje menor al $20 \%$ y por tanto no decisivo como lo es para México como destino para exportaciones. Los mercados principales de las exportaciones de China son los países asiáticos, principalmente sus países vecinos, comenzando por Japón, Hong Kong y Corea del Sur (Gráfico III-1.9), aunque Hong Kong también tiene un papel importante como plataforma de exportación (MORALES TORONCOSO, 2008, p. 890). Por tanto, un elemento común en las exportaciones de China y México es que sus mercados principales son sus vecinos. Se puede decir, por tanto, que las condiciones geográficas son un primer motivo que delimita sus principales mercados, en la línea con el planteamiento del modelo de gravedad (BERGSTRAND, 1985 y 1989).

Gráfico. III-1.8. Peso de Estados Unidos en las exportaciones de México y China, 19842014 (En porcentaje)

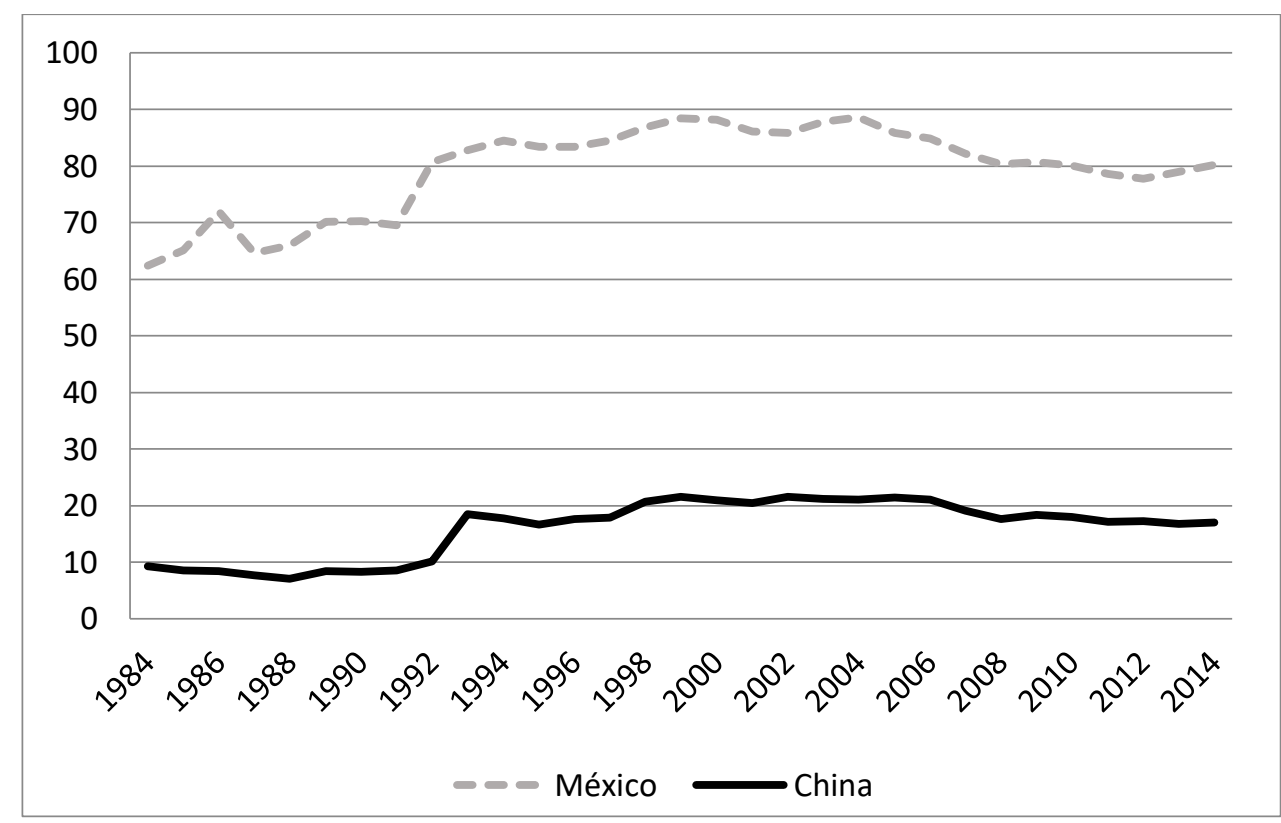

Fuente. Elaboración propia a partir de COMTRADE, Naciones Unidas, disponible en http://comtrade.un.org/data/, fecha de cnsulta 12/08/2016. 
Gráfico III-1.9. Distribución por regiones de las exportaciones de China, 2014 (En trillones de dólares)

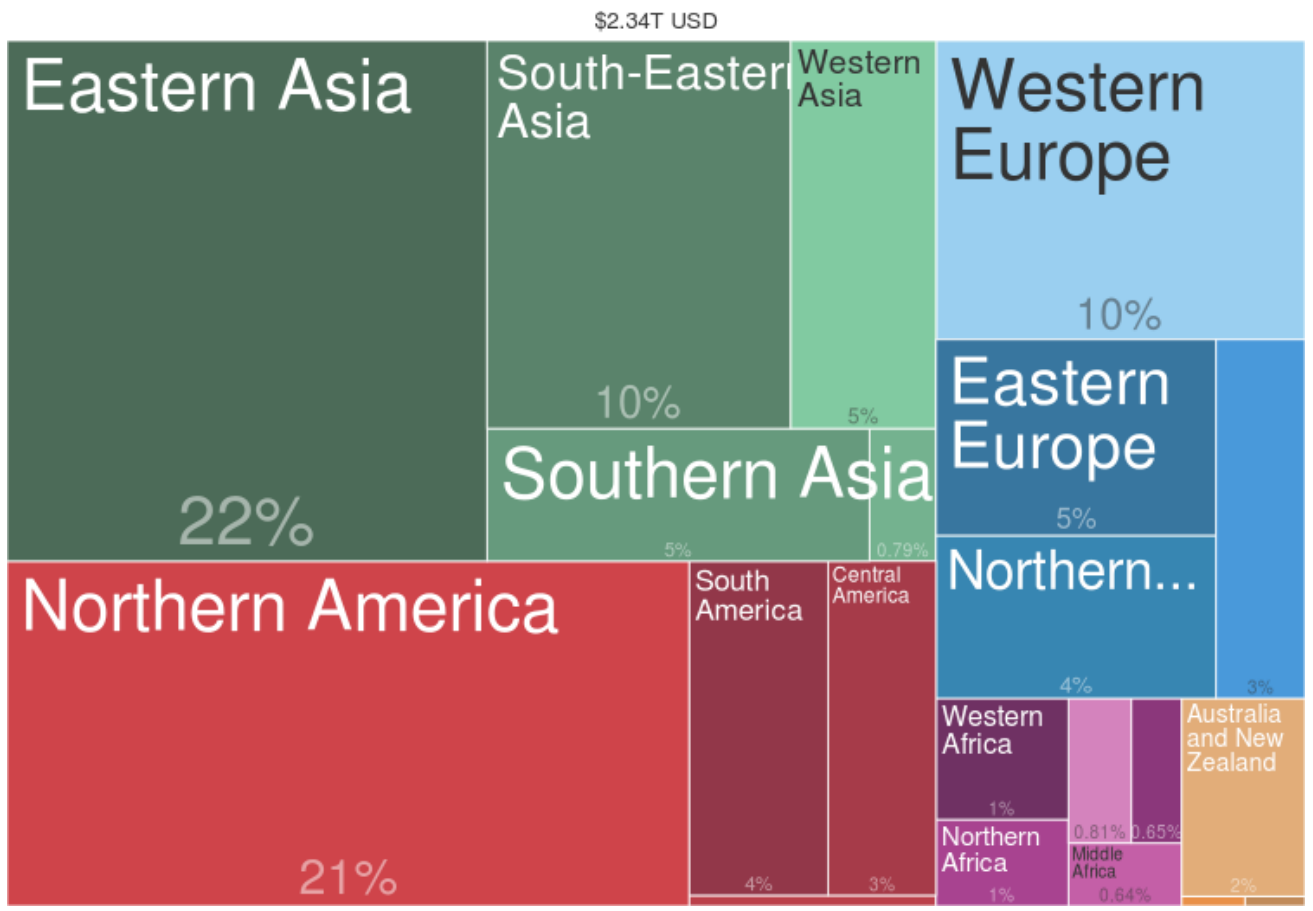

Fuente. Tomado de Atlas of Economic Complexity, disponible en http://atlas.cid.harvard.edu/explore/tree_map/export/chn/show/all/2014/, fecha de consulta: 07/12/2016.

Ahora, veamos el Gráfico III-1.10 que muestra las exportaciones a Estados Unidos (1984-2014). Desde este punto de vista, hubo más exportaciones desde México que desde China hasta el año 2006. La situación cambió en 2006 (DUSSEL PETERS, 2016b). Sin embargo, la cuestión importante es que las diferencias de las cantidades exportadas son 100 mil millones de dólares, como máximo.

Además de la integración en la OMC, otro de los motivos del aumento de las exportaciones chinas desde 2006 es el tipo de cambio entre la moneda china y el dólar de Estados Unidos (KUWAYAMA y ROSALES, 2012). Desde la segunda mitad de la década 1990, el gobierno chino buscó que su moneda estuviera relativamente barata en relación con el dólar para promover las exportaciones desde China (Gráfico III-1.11), sin embargo, en los últimos años el yuan se fue apreciando en términos nominales en relación con el dólar, mientras que el peso mexicano ha ido perdiendo valor en términos nominales. 
Gráfico III-1.10. Exportaciones a Estados Unidos de México y China, 1984-2014 (En miles de millones de dólares)

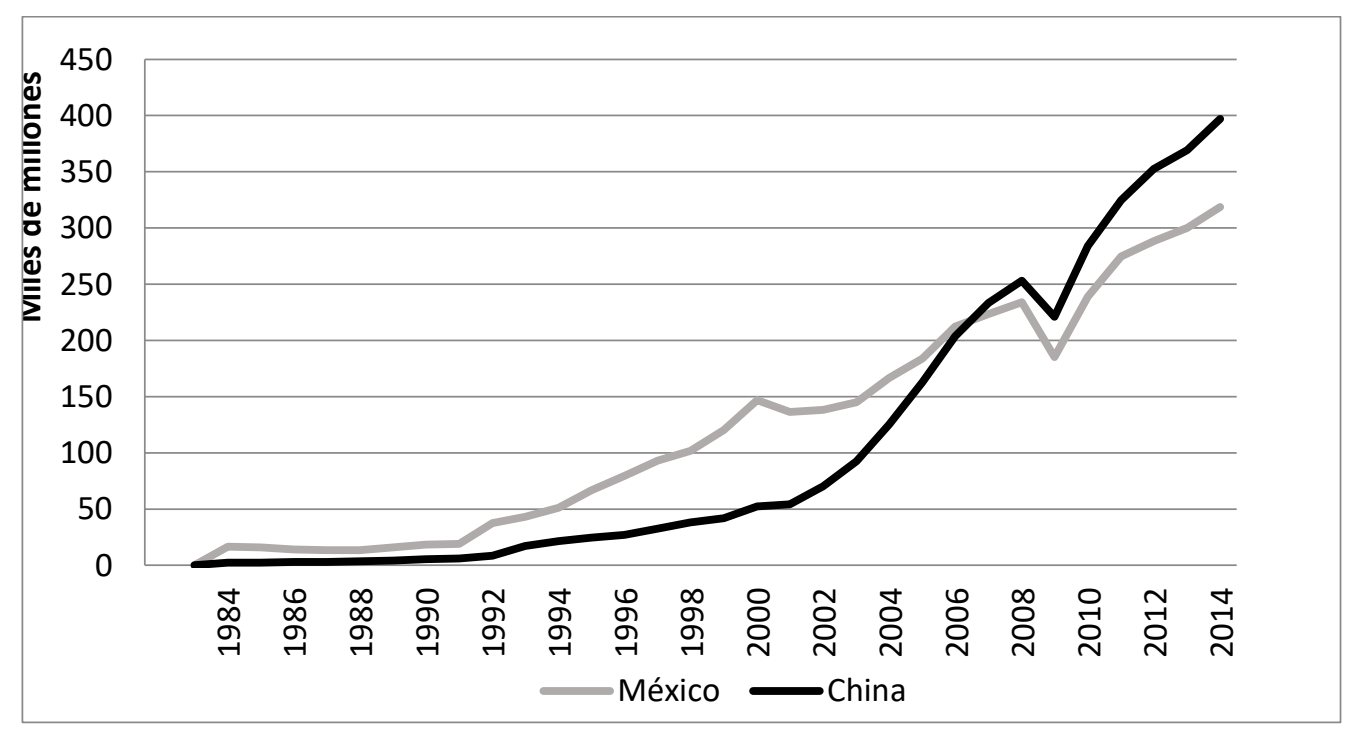

Fuente. Elaboración propia a partir de COMTRADE, Naciones Unidas, disponible en http://comtrade.un.org/data/, fecha de consulta: 12/08/2016.

Gráfico III-1.11. China y México: tipo de cambio frente al dólar estadounidense, 19902015 (En dólares)

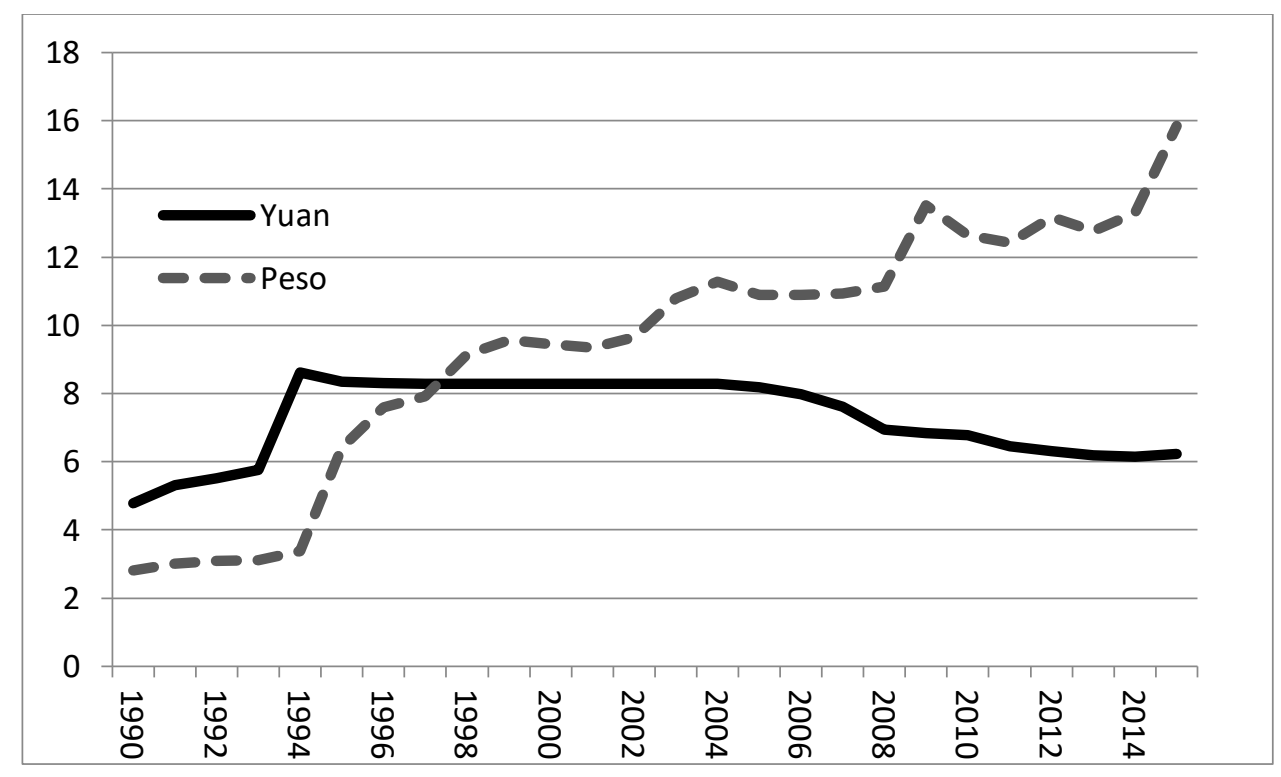

Fuente. Elaboración propia a partir de UNCTAD, disponible en http://unctadstat.unctad.org/wds/TableViewer/tableView.aspx, fecha de consulta: 7/12/2016

La evolución del tipo de cambio efectivo real indica que hay un encarecimiento relativo de los productos chinos desde 2006 (Gráfico III-1. 12a) (DUSSEL PETERS, 2013b, p. 54), al mismo tiempo que hay una tendencia al abaratamiento de los productos 
mexicanos (Gráfico III-1.12b), más marcada desde que la tercera ola de la crisis llegó a América Latina en 2014 (DUSSEL PETERS, 2012b).

Gráfico III-1.12a. Tipo de cambio efectivo real para China, 1994-2016

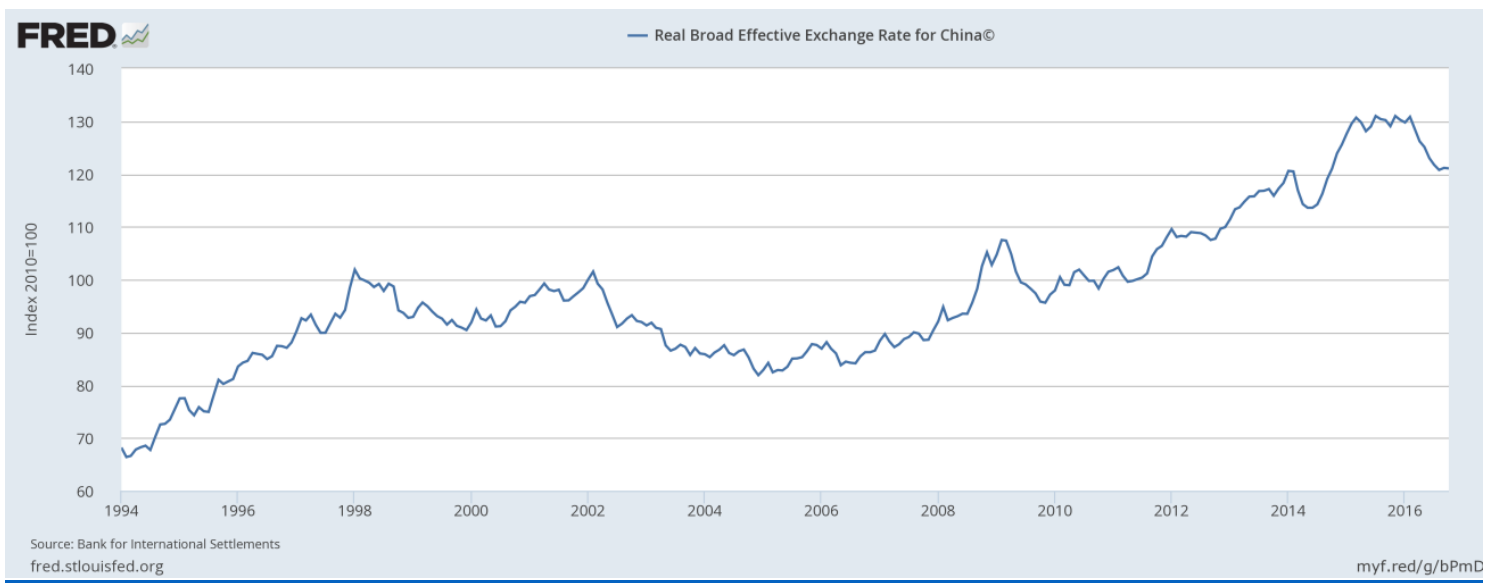

Gráfico III.1.12b. Tipo de cambio efectivo real para México, 1994-2016

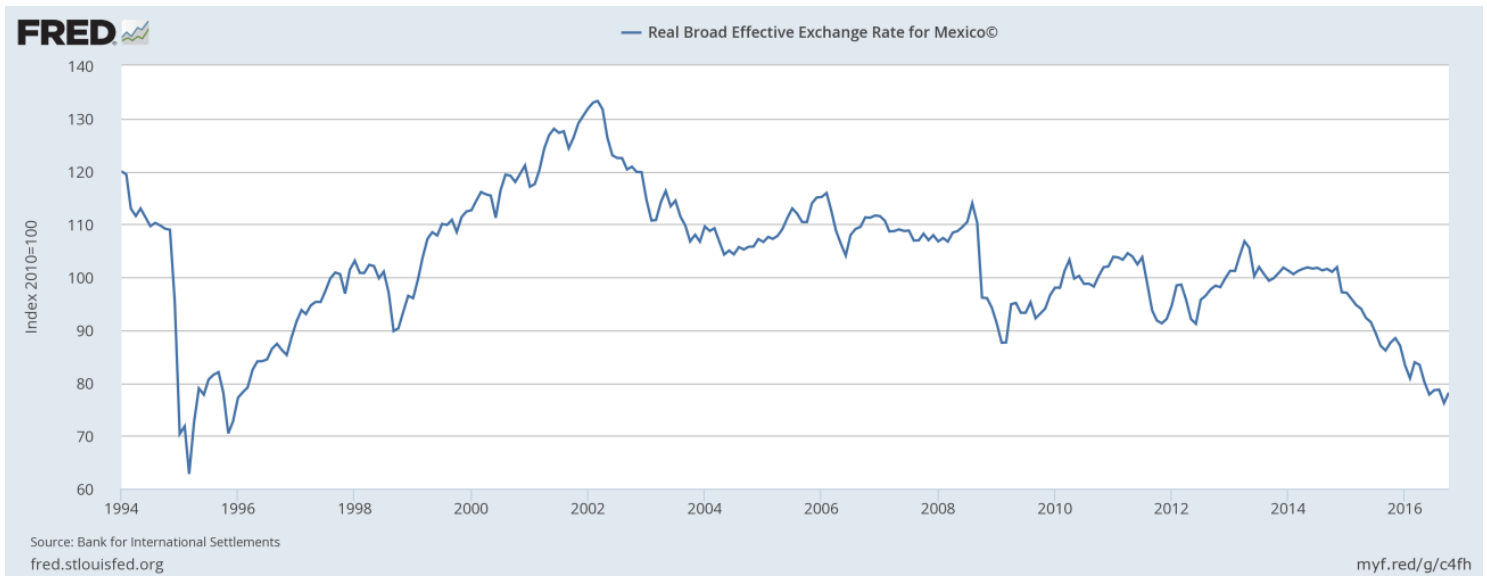

Fuente. Elaboración propia a partir de Banco de la Reserva Federal de San Luis, disponible en https://fred.stlouisfed.org/series/RBMXBIS, fecha de consulta: 7/12/2016

Ahora, veamos las situaciones de las importaciones que desde Estados Unidos realizan ambos países. El Gráfico III-1.13 presenta las importaciones desde el total del mundo mientras que el Gráfico III-1.14 se centra en las importaciones desde Estados Unidos en el periodo 1984-2014. Se nota que hay más importaciones a China desde todo el mundo, mientras que hay más importaciones a México desde Estados Unidos. Esto significa que, para México, Estados Unidos es el origen más importante de sus importaciones. Al contrario, China tiene orígenes más diversificados para su importación. 
Esto indica que la dependencia de México respecto a la economía estadounidense es muy clara tanto en su exportación como en su importación.

El aumento de las importaciones de China desde el mundo es otro efecto de su entrada en la OMC. Además, su importación desde Estados Unidos ha aumentado mucho desde 1991. Durante esta época, aunque su tipo de cambio es muy barato, sin embargo, las importaciones chinas aumentan. Este aumento de las importaciones desde el mundo es un ejemplo de desarrollo económico chino y de su integración progresiva en las cadenas globales de valor.

Según los dos gráficos (III-1.13 y 14), se nota que mientras el comercio mexicano depende de la economía estadounidense en sus exportaciones y sus importaciones, el comercio chino depende solo en su exportación y en mucha menor medida. En esta situación, tenemos que analizar qué países tienen negocios con estos dos países: es decir, a dónde exportan y de dónde importan. Primero, veamos sus exportaciones.

Gráfico III-1.13. China y México: importaciones desde todo el mundo, 1984-2014 (En miles de millones de dólares)

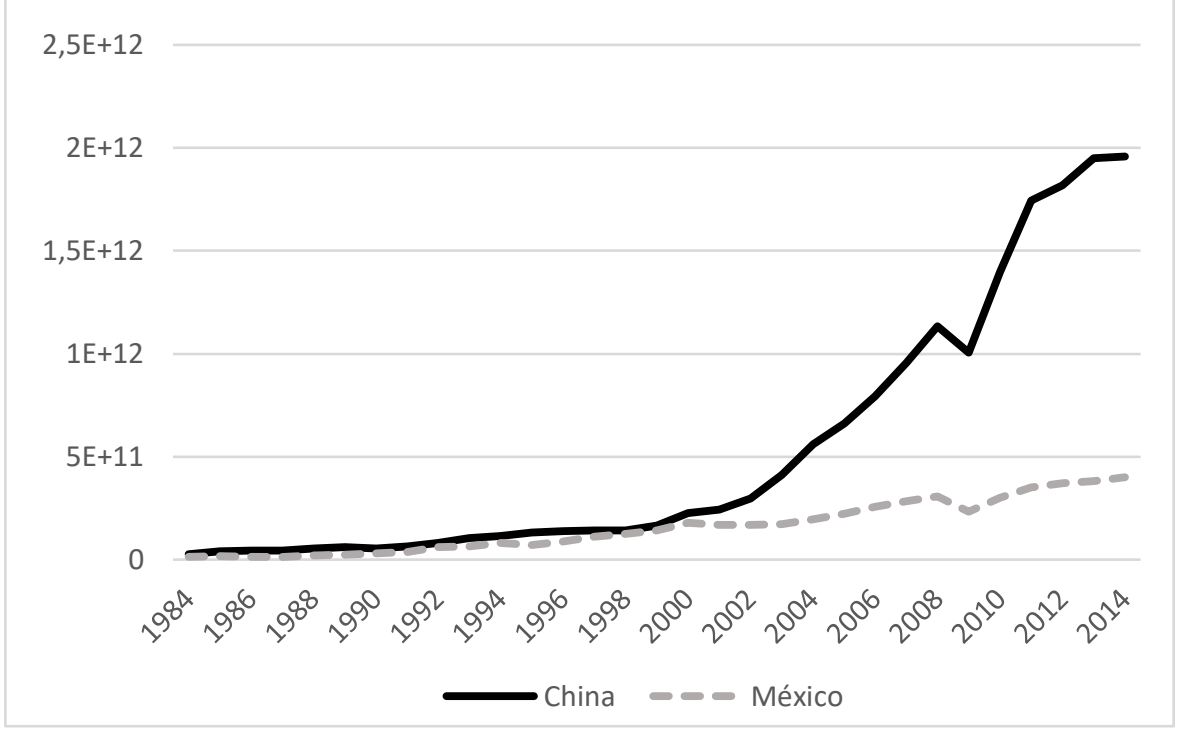

Fuente. Elaboración propia a partir de COMTRADE, Naciones Unidas, dispoible en http://comtrade.un.org/data/, fecha de consulta: 1/7/2016 
Gráfico III-1.14. China y México: importaciones desde Estados Unidos, 1984-2014 (En miles de millones de dólares)

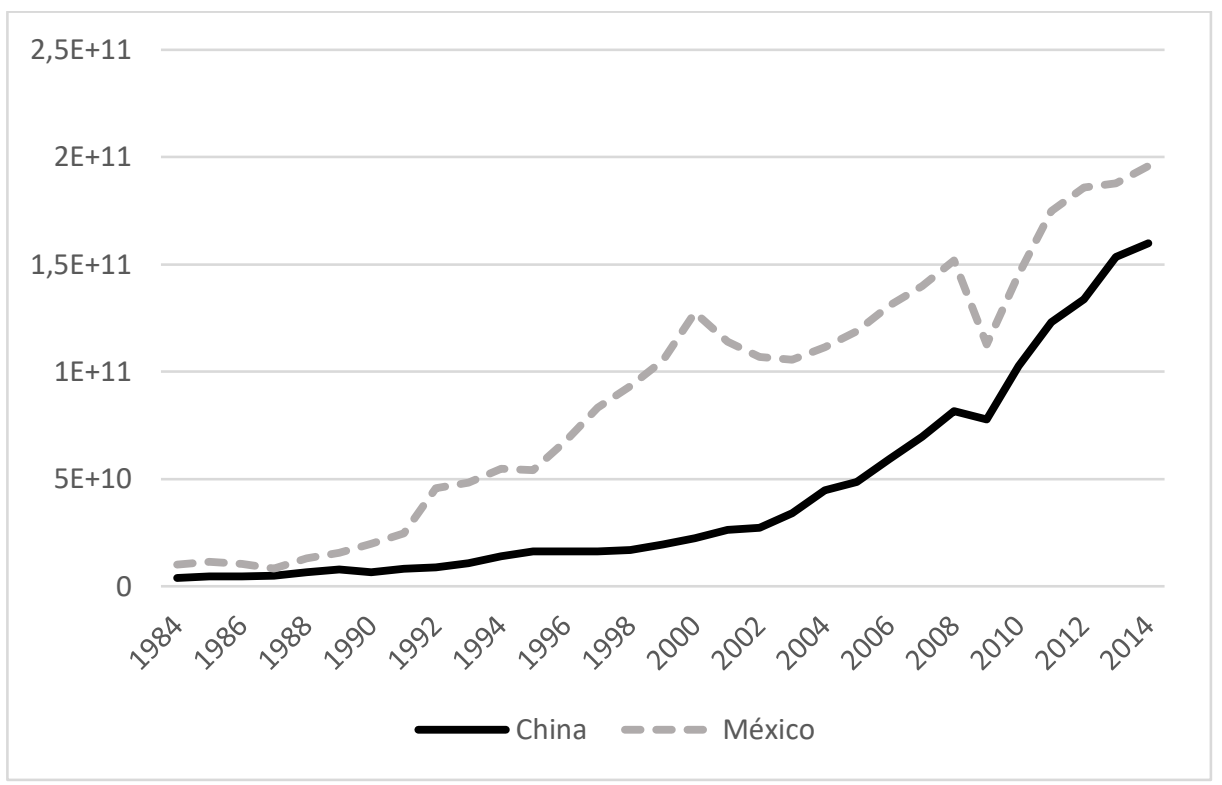

Fuente. Elaboración propia a partir de COMTRADE, Naciones Unidas, disponible en http://comtrade.un.org/data/, fecha de consulta: 1/7/2016

Los Gráficos III.1.15 y III.1.16 y las Tabla III-1.1 y III-1.2. recogen los destinos de las exportaciones de China y México. En primer lugar, se nota que, para ambos países, Estados Unidos es el primer país de destino de sus exportaciones. En segundo lugar, sin embargo, su nivel de dependencia del mercado estadounidense es distinto: en el caso de China, entre el 20 y el $25 \%$ de sus exportaciones son para Estados Unidos, mientras que el $75 \%$ de las exportaciones mexicanas son para Estados Unidos. Estos resultados coinciden con lo que hemos visto en el Gráfico III-1.8: la dependencia de exportaciones mexicanas de la economía estadounidenses es muy fuerte.

La Tabla III-1.1 destaca los principales socios de China. Se nota que los principales destinos de las exportaciones chinas son otros países asiáticos: Hong Kong, Japón, y Corea de Sur, tal y como se muestra en el Gráfico III-1.15. Al contrario, en el caso de México, los dos países vecinos del Norte, Estados Unidos y Canadá, son sus destinos principales, como se ve en el Gráfico III-1.16. Esta tendencia no se ha cambiado desde el año 1995, aunque en ambos casos, la dependencia de Estados Unidos se ha reducido, aunque sigue siendo mucho mayor para México. 
Gráfico III-1.15. Destinos de las exportaciones chinas, 1995-2014

(En porcentaje)

1995

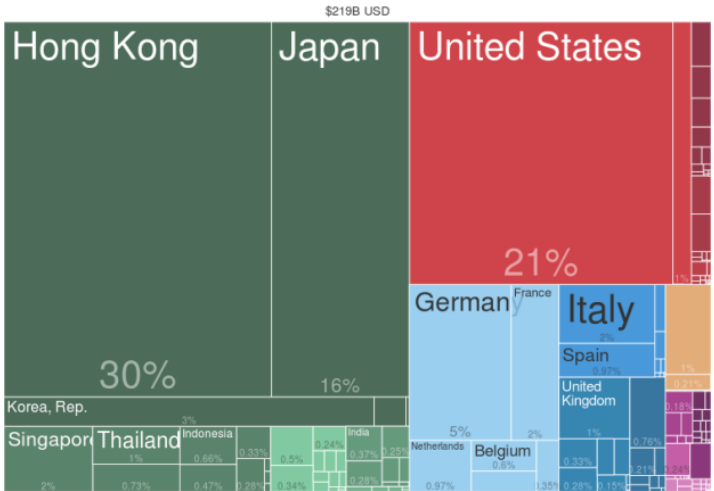

2005
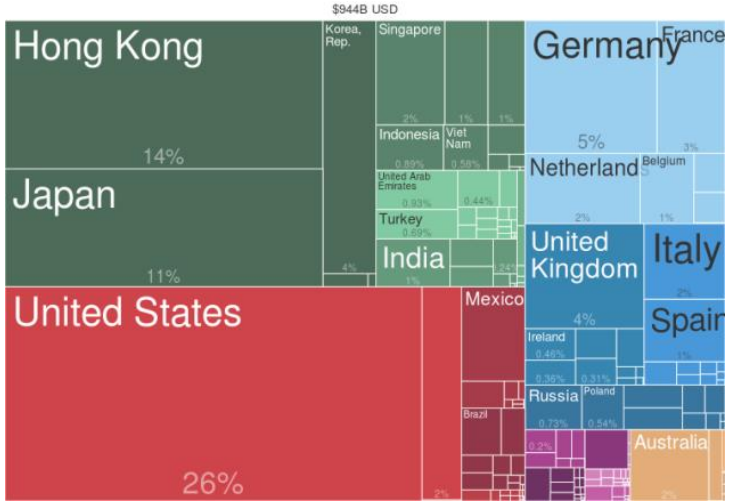

2014
2000

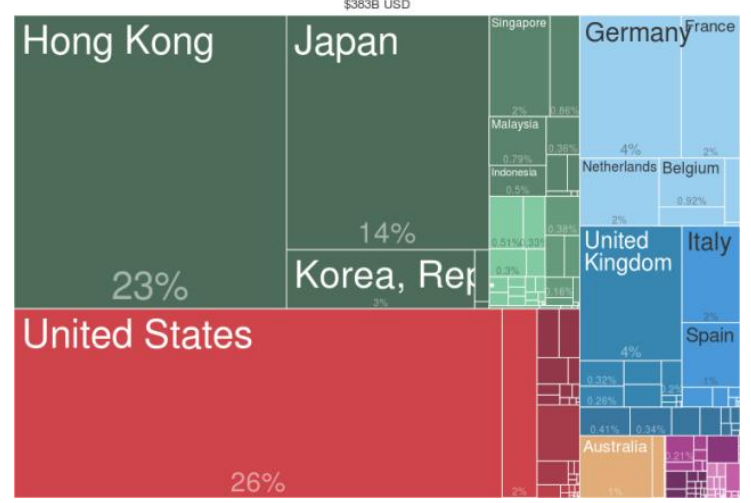

2010

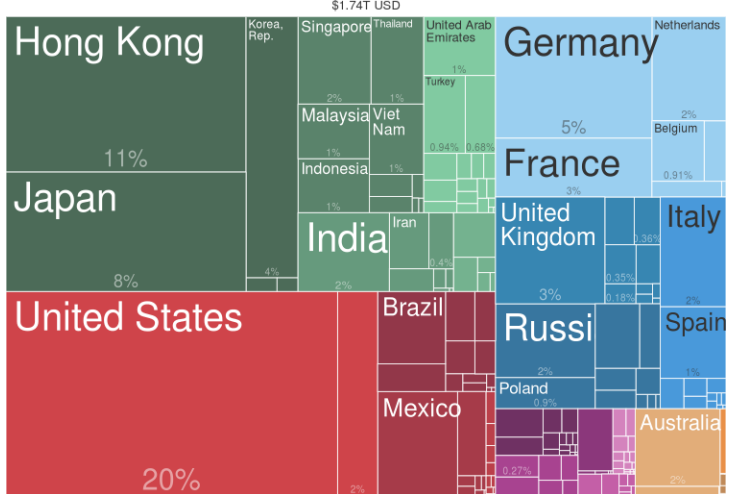

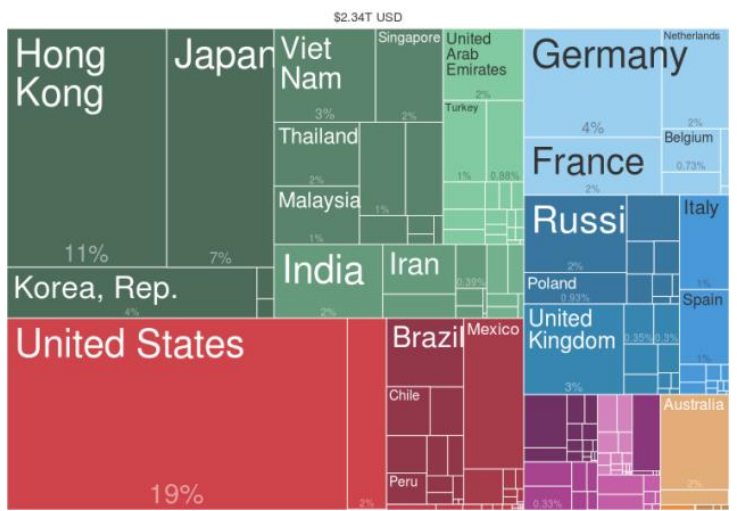

Fuente. Tomado de Atlas of Economic Complexity, disponible en http://atlas.cid.harvard.edu/explore/tree_map/export/chn/show/all/2014/, fecha de consulta: $8 / 12 / 2016$. 
Gráfico III-1.16. Destinos de las exportaciones mexicanas, 1995-2014

(En porcentaje)

1995

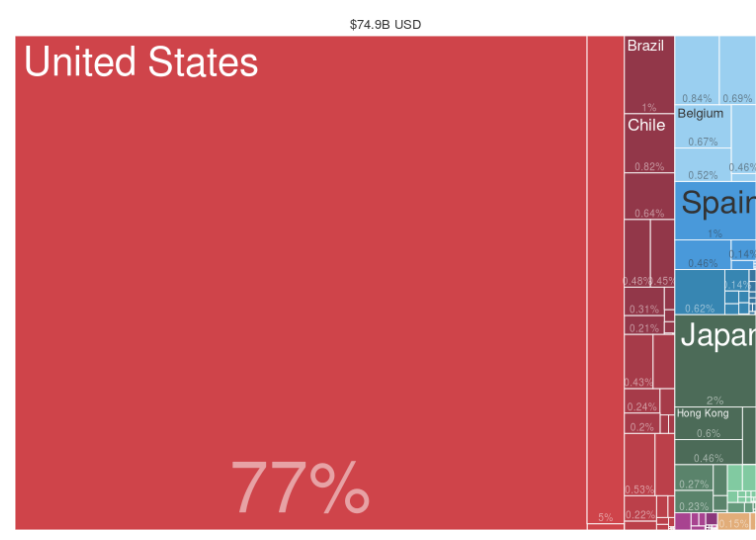

2005

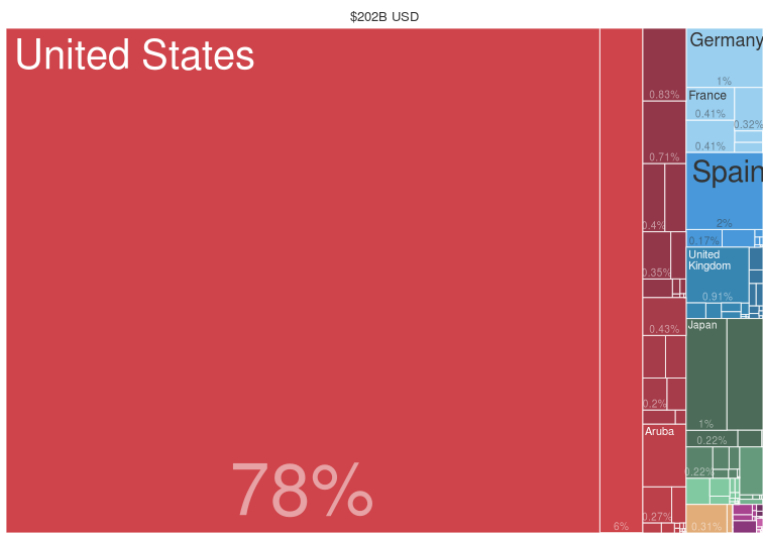

2014
2000

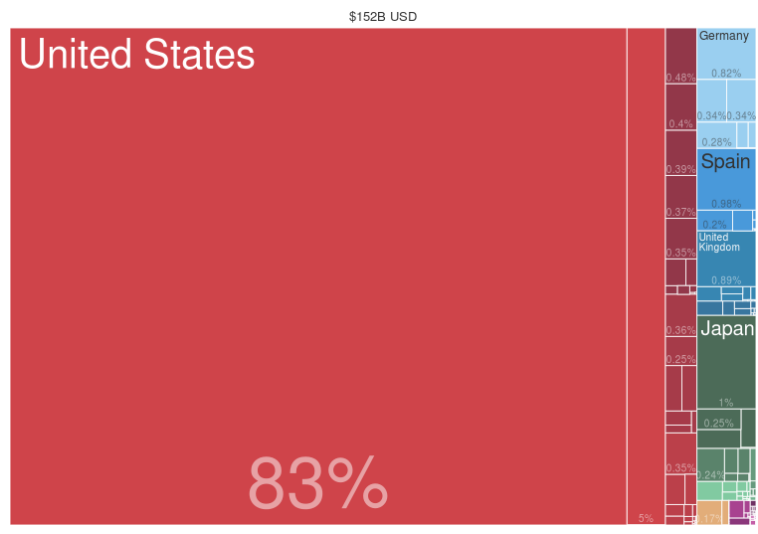

2010

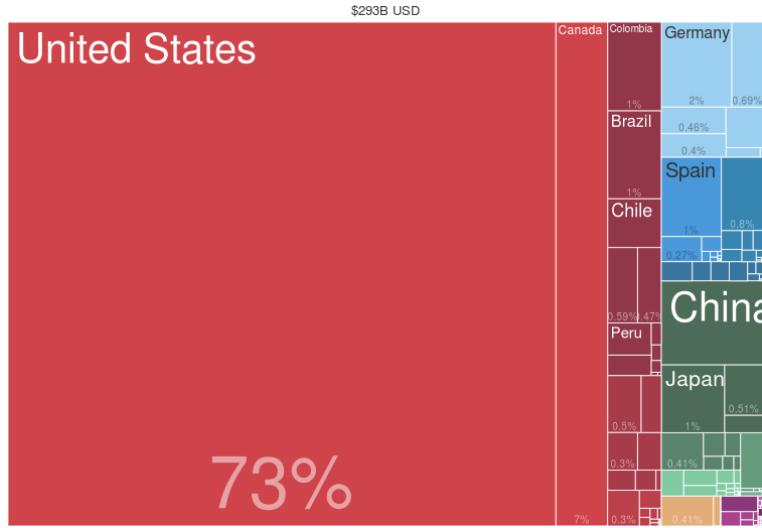

\$384B USD

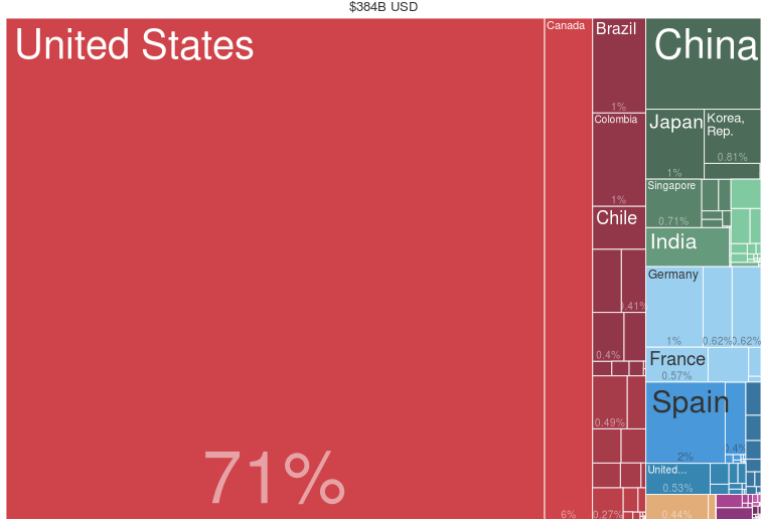

Fuente. Tomado de Atlas of Economic Complexity, disponible en http://atlas.cid.harvard.edu/explore/tree_map/export/mex/show/all/2014/, fecha de consulta: $8 / 12 / 2016$ 
Tabla III-1.1. China: principales destinos de las exportaciones, 1995-2014 (Países con $>5 \%)$ (En porcentaje)

\begin{tabular}{|l|l|l|l|l|}
\hline \multicolumn{1}{|c|}{$\mathbf{1 9 9 5}$} & \multicolumn{1}{|c|}{$\mathbf{2 0 0 0}$} & \multicolumn{1}{c|}{$\mathbf{2 0 0 5}$} & \multicolumn{1}{c|}{$\mathbf{2 0 1 0}$} & \multicolumn{1}{c|}{$\mathbf{2 0 1 4}$} \\
\hline $\begin{array}{l}\text { Hong Kong } \\
(30 \%)\end{array}$ & $\begin{array}{l}\text { Estados } \\
\text { Unidos (26\%) }\end{array}$ & $\begin{array}{l}\text { Estados } \\
\text { Unidos }(26 \%)\end{array}$ & $\begin{array}{l}\text { Estados } \\
\text { Unidos (20\%) }\end{array}$ & $\begin{array}{l}\text { Estados } \\
\text { Unidos (19\%) }\end{array}$ \\
\hline $\begin{array}{l}\text { Estados Unidos } \\
(21 \%)\end{array}$ & $\begin{array}{l}\text { Hong Kong } \\
(23 \%)\end{array}$ & $\begin{array}{l}\text { Hong Kong } \\
(14 \%)\end{array}$ & $\begin{array}{l}\text { Hong Kong } \\
(11 \%)\end{array}$ & $\begin{array}{l}\text { Hong Kong } \\
(11 \%)\end{array}$ \\
\hline Japón (16\%) & Japón (14\%) & Japón (11\%) & Japón (8\%) & Japón (7\%) \\
\hline Alemania (5\%) & $\begin{array}{l}\text { Alemania } \\
(5 \%)\end{array}$ & $\begin{array}{l}\text { Alemania } \\
(5 \%)\end{array}$ & $\begin{array}{l}\text { Alemania } \\
(5 \%)\end{array}$ & \\
\hline & $\begin{array}{l}\text { Reino Unido } \\
(5 \%)\end{array}$ & & & \\
\hline
\end{tabular}

Fuente. Elaboración propia, según The Atlas of Economic Complexity, disponible en http://atlas.cid.harvard.edu/, fecha de consulta: 2/9/2016.

Tabla III-1.2. México: principales destinos de las exportaciones, 1995-2014 (Países con $>5 \%)$ (En porcentaje)

\begin{tabular}{|c|c|c|c|c|}
\hline $\mathbf{1 9 9 5}$ & $\mathbf{2 0 0 0}$ & $\mathbf{2 0 0 5}$ & $\mathbf{2 0 1 0}$ & $\mathbf{2 0 1 4}$ \\
\hline $\begin{array}{c}\text { Estados Unidos } \\
(77 \%)\end{array}$ & $\begin{array}{c}\text { Estados Unidos } \\
(83 \%)\end{array}$ & $\begin{array}{c}\text { Estados Unidos } \\
(78 \%)\end{array}$ & $\begin{array}{c}\text { Estados Unidos } \\
(73 \%)\end{array}$ & $\begin{array}{c}\text { Estados Unidos } \\
(71 \%)\end{array}$ \\
\hline Canadá $(5 \%)$ & Canadá (5\%) & Canadá (6\%) & Canadá (7\%) & Canadá (6\%) \\
\hline
\end{tabular}

Fuente. Elaboración propia a partir de The Atlas of Economic Complexity, disponible en http://atlas.cid.harvard.edu/, fecha de consulta: 2/9/2016.

Basándose en estos datos, se puede decir que las exportaciones chinas están más diversificadas que las de México. Las exportaciones chinas son para países asiáticos, principalmente. Las exportaciones mexicanas van principalmente hacia sus vecinos del norte. Una característica común de las exportaciones de ambos países es que, sus principales destinos de exportación son sus países vecinos. En esta condición, China tiene más países vecinos relativamente ricos (Japón, Corea del Sur, Hong Kong y Singapur) que México. Son países donde hay consumidores que tienen una fuerte demanda. China tiene, por tanto, más opciones de destinos para exportar y se plantea su estrategia como un exportador global, sin centrarse en Estados Unidos. Aunque México tiene países vecinos en América Central y Sudamérica, sus vecinos del sur no son tan atractivos como mercados para exportar. Por eso, las exportaciones de México tienen que depender de Estados Unidos. Para ambos países, la geografía tiene gran importancia en los destinos de las exportaciones. 
Estas diferencias del número de los destinos potenciales para exportación producirán diferencias en las estrategias de las empresas. Las empresas que invierten en China tienen más opciones de países de destino para sus exportaciones, mientras que las empresas que invierten en México exportan principalmente a Estados Unidos.

Ahora, vemos los productos que exportan ambos países: los Gráfico III-1.17 y III-1.18 y las Tablas III-1.3 y III.1.4 recogen los principales productos en las exportaciones de China y México. Se nota que los principales productos de ambos países para las exportaciones son maquinarias eléctricas y mecánicas. Sin embargo, como una diferencia, mientras el porcentaje de la exportación desde China de las maquinarias eléctricas ha aumentado, a la vez que pierde peso el de los textiles, en el caso de México no ha cambiado (DUSSEL PETERS, 2013a, pp.568-577).

Como segunda característica, miramos el segundo producto principal de exportación: la maquinaria mecánica para China, mientras que el petróleo sigue siendo importante para México, así como también los automóviles. Estas situaciones significan que, principalmente, China y México son países que exportan productos industriales, pero, México tiene también todavía una cierta dependencia de las exportaciones de petróleo que realiza la empresa pública Petróleos Mexicanos (PEMEX), por lo que las finanzas públicas también son dependientes del precio del petróleo.

La tercera característica es que algunos productos son comunes entre ambos países, especialmente, los productos que se relacionan con textiles. Es decir, en esta industria, China y México son rivales en el mercado mundial.

La cuarta característica se puede encontrar solo en la lista de México. El grupo de los productos de Óptica, Foto, Cine e Instrumentos médicos ha aumentado su porcentaje en los últimos 20 años; especialmente en el caso de los instrumentos médicos, quirúrgicos y dentales o veterinarios. Como se ha explicado en los capítulos anteriores, la industria de instrumentos médicos y quirúrgicos en México se ha ido paulatinamente desarrollando en los últimos años.

En cambio, en China, sus productos de exportación son iguales a los que exporta México. Esta significa, desde el punto de vista de China, que todos sus productos exportados tienen rivalidades de productos mexicanos (DUSSEL PETERS, 2016b, pp. 85-86). 
Gráfico III-1.17. Composición de las exportaciones chinas, 1995-2014 (En porcentaje)
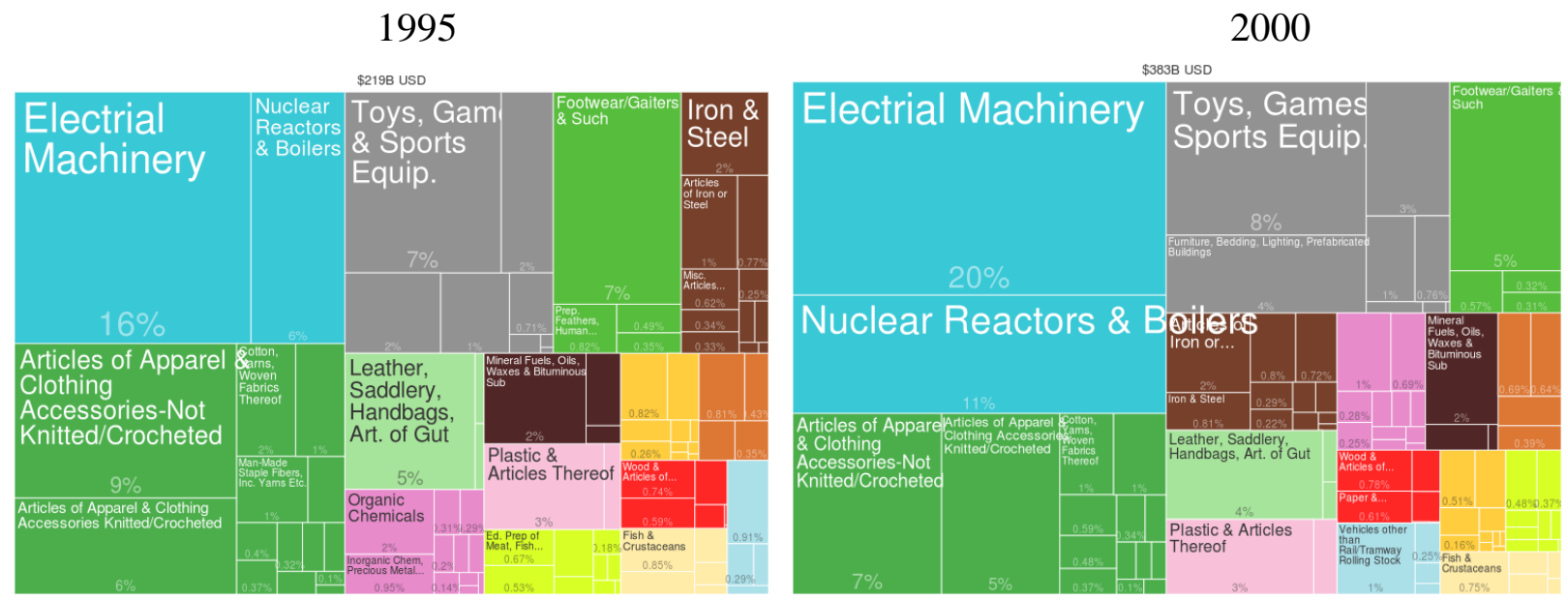

2005
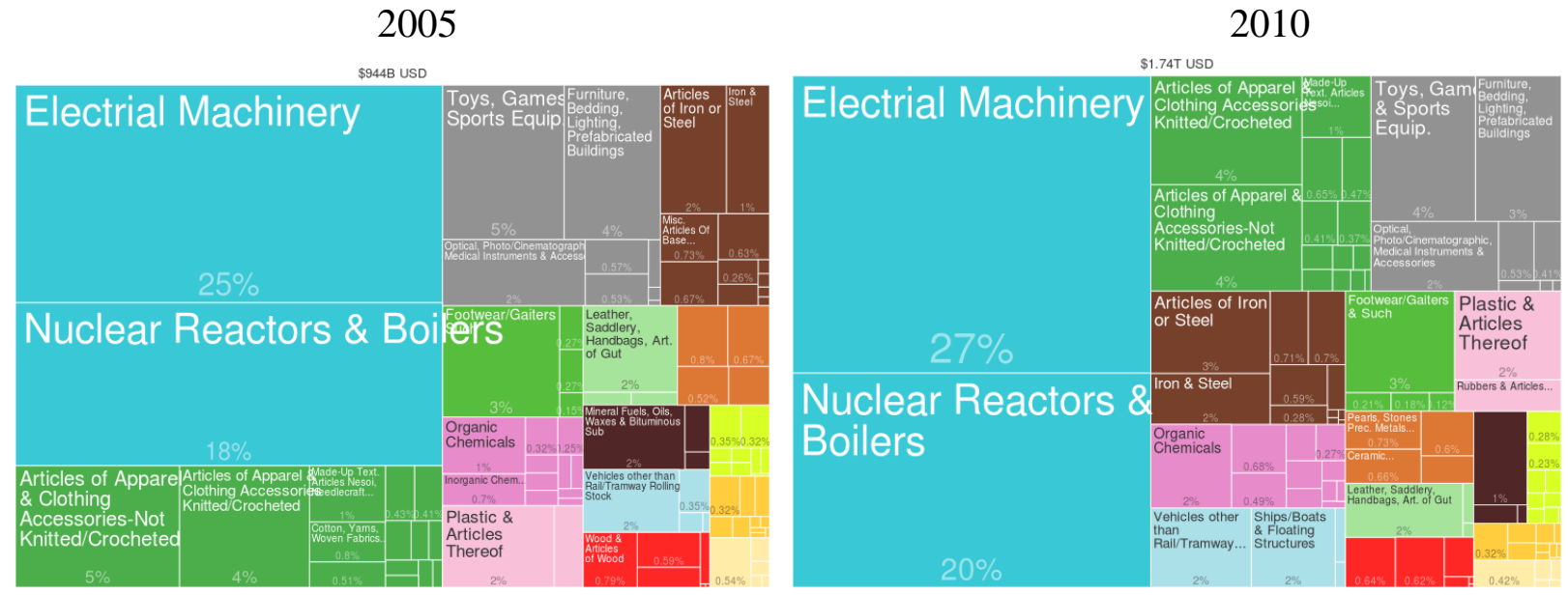

2014

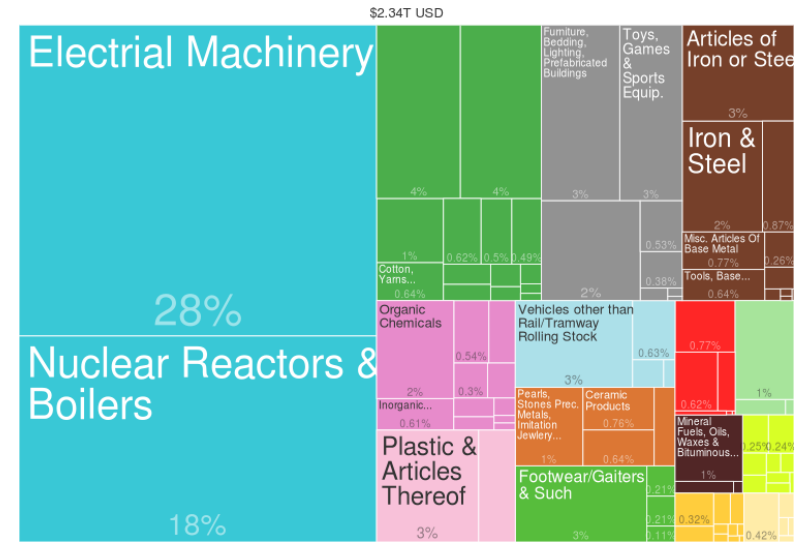

Fuente. Tomado de Atlas of Economic Complexity, Disponible en http://atlas.cid.harvard.edu/explore/tree_map/export/chn/all/show/2014/, fecha de consulta: $8 / 12 / 2016$. 
Gráfico III-1.18. Composición de las exportaciones mexicanas, 1995-2014 (En porcentaje)
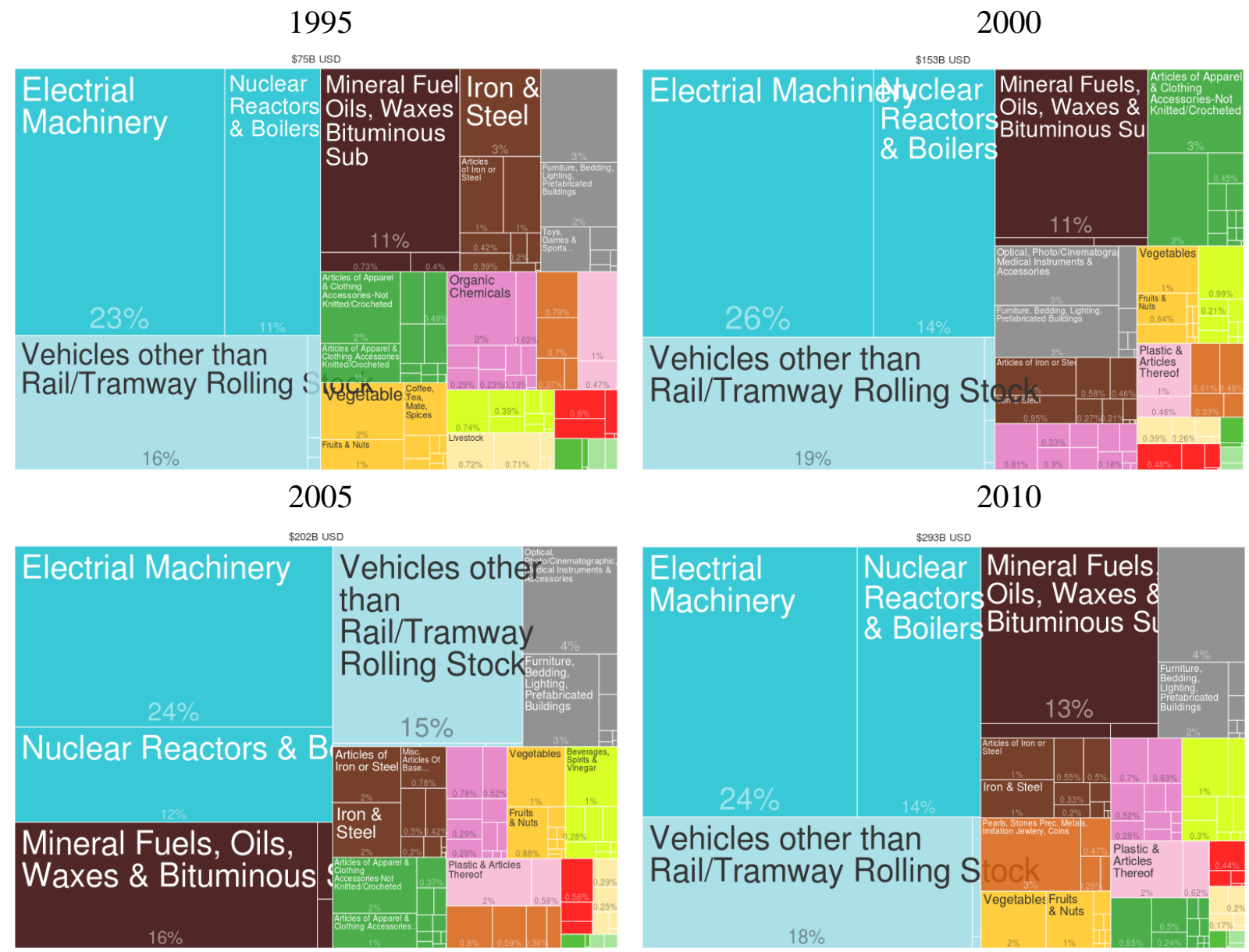

2014

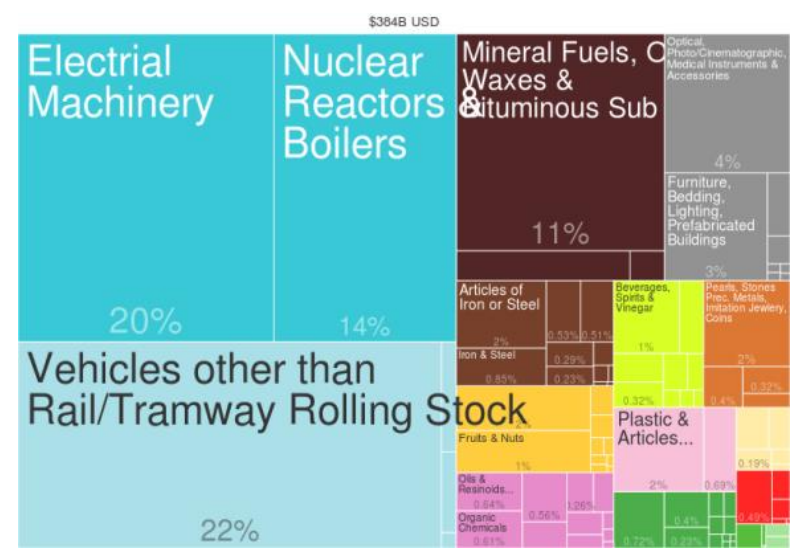

Fuente. Tomado de Atlas of Economic Complexity, disponible en

http://atlas.cid.harvard.edu/explore/tree_map/export/mex/all/show/2014/, fecha de consulta: $8 / 12 / 2016$ 
Tabla III-1.3. China: principales productos exportados al mercado mundial (>5\%)

(En porcentje)

\begin{tabular}{|l|l|l|l|l|}
\hline 1995 & 2000 & 2005 & 2010 & 2014 \\
\hline $\begin{array}{l}\text { Maquinaria eléctrica } \\
(16 \%)\end{array}$ & $\begin{array}{l}\text { Maquinaria eléctrica } \\
(20 \%)\end{array}$ & $\begin{array}{l}\text { Maquinaria eléctrica } \\
(25 \%)\end{array}$ & $\begin{array}{l}\text { Maquinaria eléctrica } \\
(27 \%)\end{array}$ & $\begin{array}{l}\text { Maquinaria eléctrica } \\
(28 \%)\end{array}$ \\
$\begin{array}{l}\text { Artículos de prendas de } \\
\text { vestir y ropa, sin puntos } \\
(9 \%)\end{array}$ & $\begin{array}{l}\text { Reactores y calderas de } \\
\text { nuclear (11\%) }\end{array}$ & $\begin{array}{l}\text { Reactores y calderas de } \\
\text { nuclear (18\%) }\end{array}$ & $\begin{array}{l}\text { Reactores y calderas de } \\
\text { nuclear (20\%) }\end{array}$ & $\begin{array}{l}\text { Reactores y calderas de } \\
\text { nuclear (18\%) }\end{array}$ \\
$\begin{array}{l}\text { Juguetes, juegos y } \\
\text { equipamientos } \\
\text { deportivos (7\%) } \\
\text { equipamientos } \\
\text { deportivos (8\%) }\end{array}$ & $\begin{array}{l}\text { Artículos de prendas de } \\
\text { vestir y ropa, sin puntos } \\
(5 \%)\end{array}$ & $\begin{array}{l}\text { Artículos de prendas de } \\
\text { vestir y ropa, sin puntos } \\
\text { (7\%) } \\
\text { Juguetes, juegos y } \\
\text { equipamientos } \\
\text { deportivos (5\%) }\end{array}$ & $\begin{array}{l}\text { Artículos de prendas de } \\
\text { vestir y ropa, de puntos } \\
(5 \%)\end{array}$ \\
$\begin{array}{l}\text { Artículos de prendas de } \\
\text { vestir y ropa, de puntos } \\
(6 \%)\end{array}$ & $\begin{array}{l}\text { Calzado (5\%) } \\
\begin{array}{l}\text { Reactores y calderas de } \\
\text { nuclear (6\%) } \\
\text { Cueros, asientos de } \\
\text { caballo y bolsas de piel } \\
(5 \%)\end{array}\end{array}$ & & & \\
\hline
\end{tabular}

Fuente. Elaboración propia a partir de The Atlas of Economic Complexity, disponible en http://atlas.cid.harvard.edu/, fecha de consulta: 9/12/2016 
Tabla III-1.4. México: principales productos exportados al mercado mundial (>5\%)

(En porcentje)

\begin{tabular}{|l|l|l|l|l|}
\hline $\mathbf{1 9 9 5}$ & $\mathbf{2 0 0 0}$ & $\mathbf{2 0 0 5}$ & $\mathbf{2 0 1 0}$ & $\mathbf{2 0 1 4}$ \\
\hline $\begin{array}{l}\text { Maquinaria eléctrica } \\
(23 \%)\end{array}$ & $\begin{array}{l}\text { Maquinaria eléctrica } \\
(26 \%)\end{array}$ & $\begin{array}{l}\text { Maquinaria eléctrica } \\
(24 \%)\end{array}$ & $\begin{array}{l}\text { Maquinaria eléctrica } \\
(24 \%)\end{array}$ & $\begin{array}{l}\text { Vehículos que no sean para } \\
\text { ferrocarriles }(22 \%)\end{array}$ \\
$\begin{array}{l}\text { Vehículos que no sean } \\
\text { para ferrocarriles (11\%) }\end{array}$ & $\begin{array}{l}\text { Vehículos que no sean } \\
\text { para ferrocarriles (19\%) }\end{array}$ & $\begin{array}{l}\text { Combustibles minerales, } \\
\text { aceites, ceras y } \\
\text { bituminosas (16\%) }\end{array}$ & $\begin{array}{l}\text { Vehículos que no sean } \\
\text { para ferrocarriles (18\%) }\end{array}$ & Maquinaria eléctrica (20\%) \\
$\begin{array}{l}\text { Combustibles minerales, } \\
\text { aceites, ceras y } \\
\text { bituminosas (11\%) }\end{array}$ & $\begin{array}{l}\text { Reactores y calderas } \\
\text { nucleares (14\%) }\end{array}$ & $\begin{array}{l}\text { Vehículos que no sean } \\
\text { para ferrocarriles (15\%) }\end{array}$ & $\begin{array}{l}\text { Reactores y calderas } \\
\text { nucleares (14\%) }\end{array}$ & $\begin{array}{l}\text { Reactores y calderas } \\
\text { nucleares (14\%) }\end{array}$ \\
$\begin{array}{l}\text { Reactores y calderas } \\
\text { nucleares (11\%) }\end{array}$ & $\begin{array}{l}\text { Combustibles minerales, } \\
\text { aceites, ceras y } \\
\text { bituminosas (11\%) }\end{array}$ & $\begin{array}{l}\text { Reactores y calderas } \\
\text { nucleares (12\%) }\end{array}$ & $\begin{array}{l}\text { Combustibles minerales, } \\
\text { aceites, ceras y } \\
\text { bituminosas (13\%) }\end{array}$ & $\begin{array}{l}\text { Combustibles minerales, } \\
\text { aceites, ceras y bituminosas } \\
(11 \%)\end{array}$ \\
\hline
\end{tabular}

Fuente. Elaboración propia a partir de The Atlas of Economic Complexity, disponible en http://atlas.cid.harvard.edu/, fecha de consulta: 9/12/2016. 
Ahora, se analiza el comercio con Estados Unidos de ambos países que se muestra en los Gráficos III-1.19 y III-1.20 y las Tablas III-1.5 y III-1.6 para China y México, respectivamente.

Comparando estas exportaciones, se nota como primera característica, que las exportaciones principales de ambos países a Estados Unidos son las maquinarias eléctricas. Esta tendencia es similar a la que se observa en sus exportaciones al mundo. Los productos de esta industria han cambiado sus rasgos: en México, inicialmente se fabricaban los productos intensivos en mano de obra, pero actualmente, estos productos necesitan de alta tecnología y de fuerte vinclación con el "ecosistema" (CARRILLO, $2015)^{4}$.

Además, se nota que sus segundos principales productos exportados a Estados Unidosson también iguales a sus exportaciones al mundo: para China, la maquinaria mecánica y para México, los vehículos. Sin embargo, en el caso de China, "Juguetes, juegos y equipamiento de deportes" tiene importancia como segundo producto para la exportación. Este tipo de productos son relativamente intensivos en mano de obra (UCHITA, 2003).

Desde el punto de vista del comercio mexicano, los "Combustibles" y los "Productos de óptica, Foto, Cine y otros instrumentos" son característicos de su exportación. Además, estos dos grupos de productos son representantes de sus exportaciones más tradicionales (combustibles) y más modernas (los instrumentos). Es decir, México exporta tanto sus productos más tradicionales como los más modernos a Estados Unidos. Además, se puede encontrar algunos productos frescos (Vegetables y Frutas). Este tipo de productos puede aprovechar las ventajas de localización geográfica al exportar desde México a Estados Unidos: la proximidad geográfica induce la capacidad para ofrecer sus productos más frescos. Además, se nota que las exportaciones de automóviles (vehicles other than rail/tramway rolling stock) representan un porcentaje importante del total en el caso de México; especialmente, las autopartes tienen un alto porcentaje de las exportaciones a Estados Unidos (DUSSEL PETERS, 2012a) . $^{5}$

\footnotetext{
4 "Ecosistema" es unas vinculaciones entre empresas que tienen diferentes tamaños y tecnologías (CARRILLO, 2015, pp. 58-59)

${ }^{5}$ Aunque no aparece en la tabla III-1.4, las exportaciones mexicanas de productos aeroespaciales a Estados Unidos han aumentado en las últimas décadas. Mientras que en 2004 significaron 1300 millones de dólares, en 2011 alcanzaron los 3800 millones. En 1995-2005, su crecimiento anual promedio fue del 14\% (CARRILLO y HUALDE ALFARO, 2013, p. 170).
} 
Al ver las exportaciones chinas hacia Estados Unidos, en sus productos no hay grandes cambios, aunque sí hay cambios grandes en los porcentajes que suponen las distintas partidas y se percibe un proceso de creciente complejidad con mayor peso de maquinaria y productos de alta tecnología. Principalmente, sus exportaciones son: Maquinarias Eléctricas y mecánicas y productos intensivos en mano de obra. Esta tendencia es igual con sus exportaciones al mundo. En esta situación, se puede decir que, las exportaciones chinas es un ejemplo de su manera de exportar al mundo, aunque su dependencia en el mercado de Estados Unidos, tal como hemos dicho, es pequeña. Además, como otra caracteristica, las exportaciones de China están crecientemente compuestas por bienes de consumo y de manera particular por bienes intermedios (DUSSEL PETERS y ORTIZ VELAZQUEZ, 2016).

Basada en estos análisis, para México, esta condición en el mercado de Estados Unidos significa que: una región como Baja California en México, donde hay varias empresas que fabrican máquinas eléctricas y exportan al Estados Unidos, compiten directamente con regiones como la de Shenzén o de Suzhou en China (CARRILLO y PLASCENCIA, 2010). 
Gráfico III-1.19. Composición de las exportaciones chinas a Estados Unidos, 1995-2014 (En porcentaje)
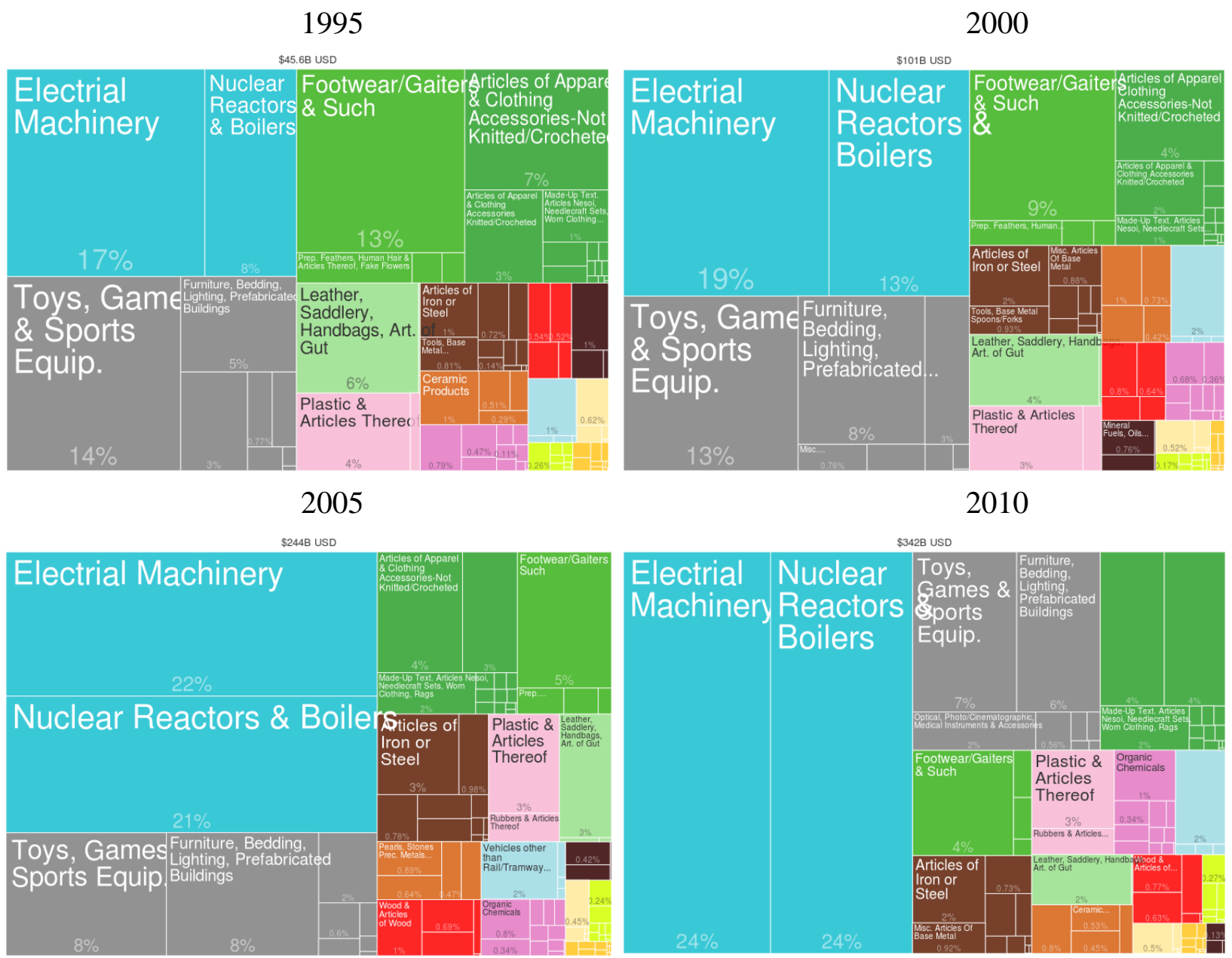

2014

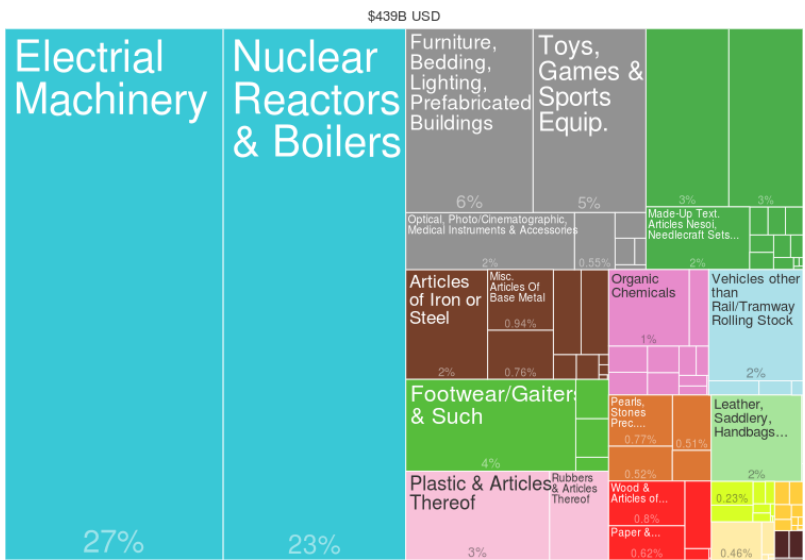

Fuente. Tomado de Atlas of Economic Complexity, disponible en http://atlas.cid.harvard.edu/explore/tree_map/export/chn/all/show/2014/, fecha de consulta: $8 / 12 / 2016$. 
Gráfico III-1.20. Composición de las exportaciones mexicanas a Estados Unidos, 19952014 (En porcentaje)

1995

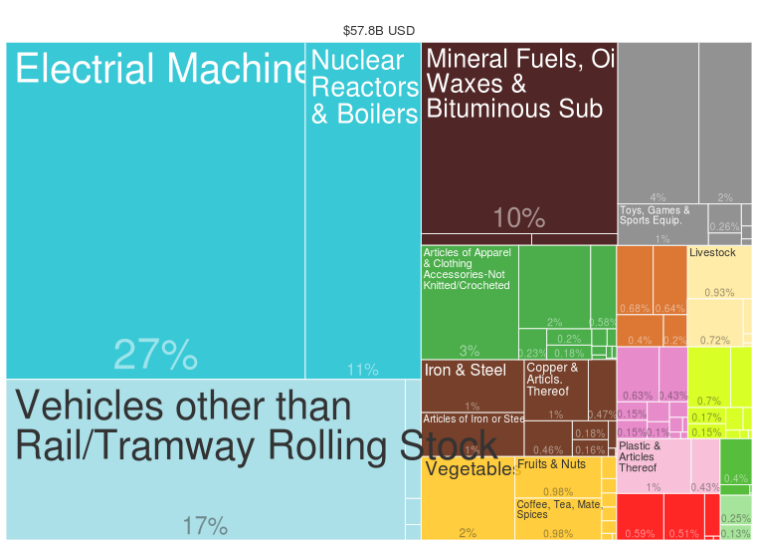

2005

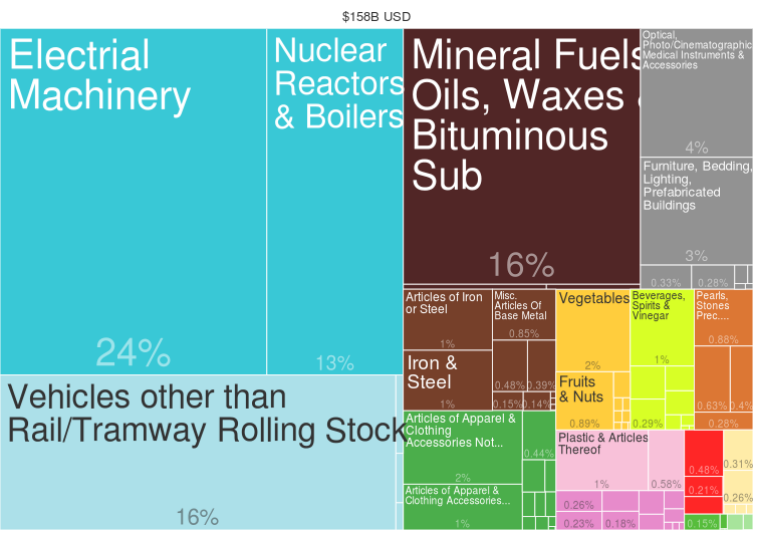

2014

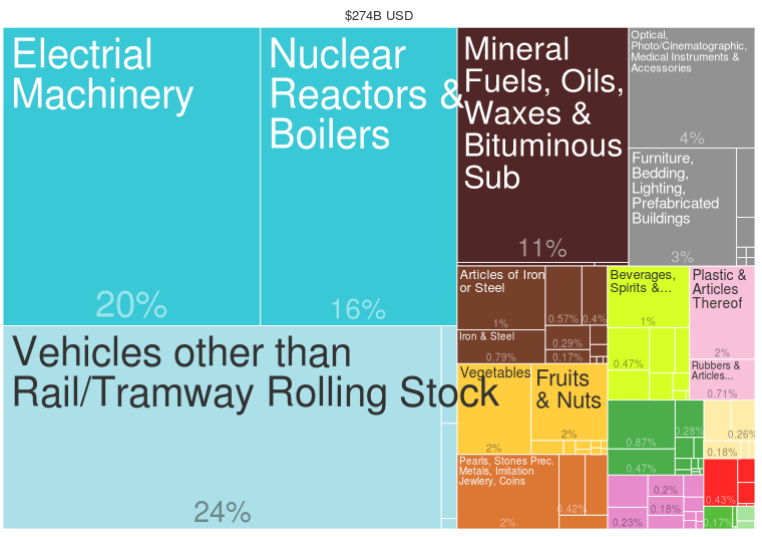

Fuente. Tomado de Atlas of Economic Complexity, disponible en http://atlas.cid.harvard.edu/explore/tree_map/export/mex/all/show/2014/, fecha de consulta: 8/12/2016.

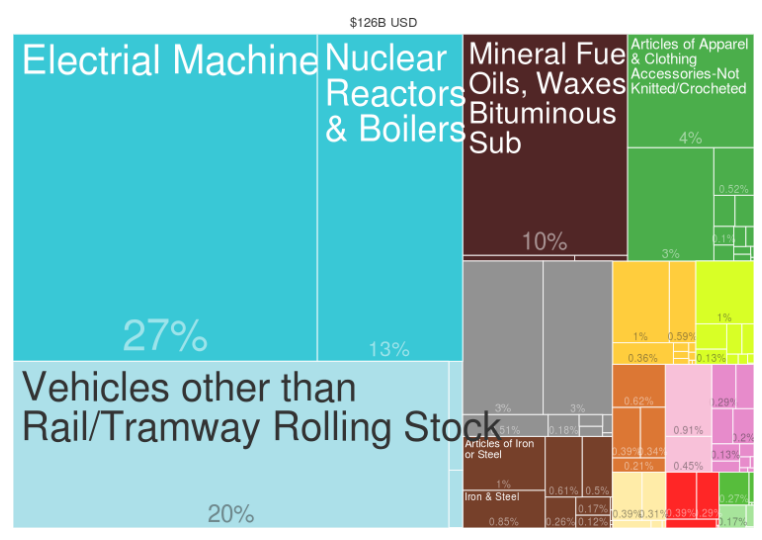

2010

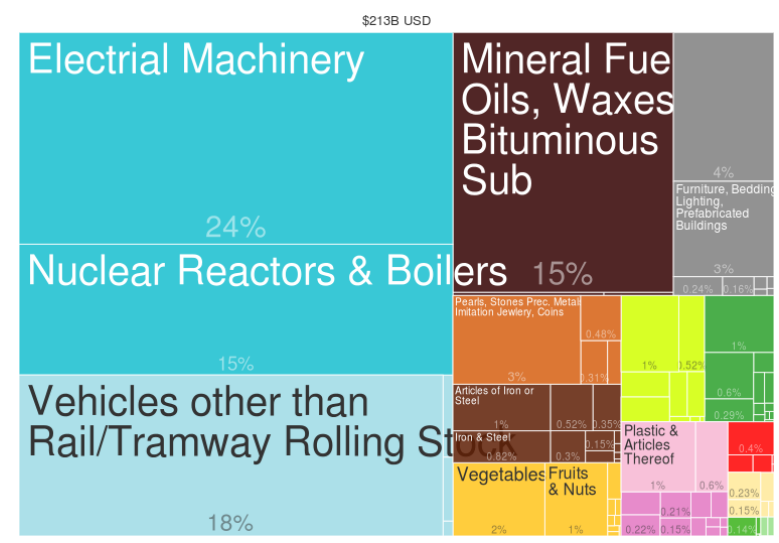


Tabla III-1.5. China: principales productos de exportación a Estados Unidos, 1995-2014(>5\%)

(En porcentaje)

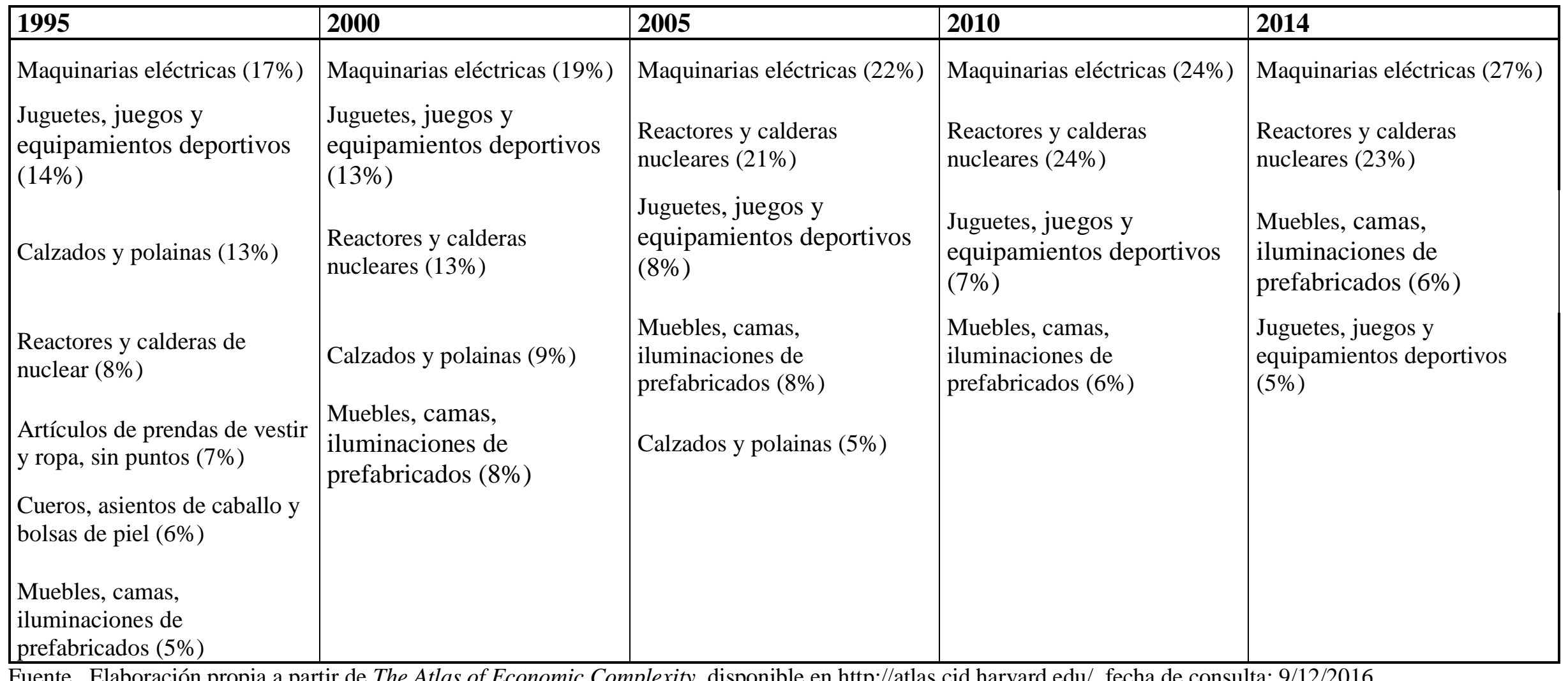


Tabla III-1.6. México: principales productos de exportación a Estados Unidos, 1995-2014 (>5\%)

(En porcentaje)

\begin{tabular}{|c|c|c|c|c|}
\hline 1995 & 2000 & 2005 & 2010 & 2014 \\
\hline $\begin{array}{l}\text { Maquinarias eléctricas } \\
(27 \%)\end{array}$ & $\begin{array}{l}\text { Maquinarias eléctricas } \\
(27 \%)\end{array}$ & $\begin{array}{l}\text { Maquinarias eléctricas } \\
(24 \%)\end{array}$ & $\begin{array}{l}\text { Maquinarias eléctricas } \\
(24 \%)\end{array}$ & $\begin{array}{l}\text { Vehículos que no sean para } \\
\text { ferrocarriles }(24 \%)\end{array}$ \\
\hline $\begin{array}{l}\text { Vehículos que no sean para } \\
\text { ferrocarriles }(17 \%)\end{array}$ & $\begin{array}{l}\text { Vehículos que no sean para } \\
\text { ferrocarriles }(20 \%)\end{array}$ & $\begin{array}{l}\text { Vehículos que no sean para } \\
\text { ferrocarriles }(16 \%)\end{array}$ & $\begin{array}{l}\text { Vehículos que no sean para } \\
\text { ferrocarriles }(16 \%)\end{array}$ & $\begin{array}{l}\text { Maquinarias eléctricas } \\
(20 \%)\end{array}$ \\
\hline $\begin{array}{l}\text { Reactores y calderas } \\
\text { nucleares }(11 \%)\end{array}$ & $\begin{array}{l}\text { Reactores y calderas } \\
\text { nucleares }(13 \%)\end{array}$ & $\begin{array}{l}\text { Combustibles minerales, } \\
\text { aceites, ceras y bituminosas } \\
(16 \%)\end{array}$ & $\begin{array}{l}\text { Reactores y calderas } \\
\text { nucleares }(15 \%)\end{array}$ & $\begin{array}{l}\text { Reactores y calderas } \\
\text { nucleares }(16 \%)\end{array}$ \\
\hline $\begin{array}{l}\text { Combustibles minerales, } \\
\text { aceites, ceras y bituminosas } \\
(10 \%)\end{array}$ & $\begin{array}{l}\text { Combustibles minerales, } \\
\text { aceites, ceras y bituminosas } \\
(10 \%)\end{array}$ & $\begin{array}{l}\text { Reactores y calderas } \\
\text { nucleares }(13 \%)\end{array}$ & $\begin{array}{l}\text { Combustibles minerales, } \\
\text { aceites, ceras y bituminosas } \\
(15 \%)\end{array}$ & $\begin{array}{l}\text { Combustibles minerales, } \\
\text { aceites, ceras y bituminosas } \\
(11 \%)\end{array}$ \\
\hline
\end{tabular}

Fuente. Elaboración propia a partir de The Atlas of Economic Complexity, disponible en http://atlas.cid.harvard.edu/, fecha de consulta: 9/12/2016. 
Ahora, se compara sus importaciones. Primero, veamos los orígenes de sus importaciones totales en las Tablas III-1.7. y III-1.8y los Gráficos III-1.21 y III-1.22. Según estas tablas y gráficos, la mayor parte de las importaciones chinas vienen de los países asiáticos, mientras que la mayor parte de las importaciones mexicanas vienen de Estados Unidos. En el caso de China, aproximadamente el 10\% de sus importaciones son de Estados Unidos y este porcentaje no se ha alterado desde 1995.

En el caso de México, sus importaciones desde Estados Unidos en 2014 son 25 puntos porcentuales menos que en el año 1995. En el mismo tiempo, se nota que las importaciones desde China hacia México han aumentado, desde menos de un 1\% en 1995 a un $17 \%$ en 2014. Esta situación significa que, para México, China es un país importante como un origen de las importaciones y refleja la progresiva integración de México en cadenas globales de valor donde los productos procedentes de China y otros países se incorporan, a su vez, en las exportaciones mexicanas. Como otra característica, en el caso de México, las importaciones desde los países asiáticos han aumentado: en 1995, el 7\% de las importaciones proceden de los países asiáticos, mientras que en 2014 este porcentaje se eleva hasta el $26 \%$. En el caso de China, hubo 53\% de sus importaciones desde los países asiáticos en 1995, mientras en 2014 hubo solo 31\%. Estas situaciones muestran que la importancia de los países asiáticos como exportadores ha aumentado en México; sin embargo, en China, su importancia se ha reducido. 
Tabla III-1.7. China: principales orígenes de las importaciones (>5\%) (En porcentaje)

\begin{tabular}{|l|l|l|l|l|}
\hline $\mathbf{1 9 9 5}$ & $\mathbf{2 0 0 0}$ & $\mathbf{2 0 0 5}$ & $\mathbf{2 0 1 0}$ & $\mathbf{2 0 1 4}$ \\
\hline $\begin{array}{l}\text { Hong Kong } \\
(27 \%)\end{array}$ & $\begin{array}{l}\text { Hong Kong } \\
(22 \%)\end{array}$ & Japón (19\%) & Japón (15\%) & $\begin{array}{l}\text { Corea de Sur } \\
(12 \%)\end{array}$ \\
$\begin{array}{l}\text { Estados Unidos }(18 \%) \\
(10 \%)\end{array}$ & $\begin{array}{l}\text { Japón (17\%) } \\
(10 \%)\end{array}$ & $\begin{array}{l}\text { Corea de Sur } \\
(10 \%)\end{array}$ & $\begin{array}{l}\text { Corea de Sur } \\
(12 \%)\end{array}$ & Japón (10\%) \\
$\begin{array}{l}\text { Corea de Sur } \\
(8 \%)\end{array}$ & $\begin{array}{l}\text { Unidos }(9 \%) \\
\text { Estados }\end{array}$ & $\begin{array}{l}\text { Estados } \\
\text { Unidos (9\%) }\end{array}$ & $\begin{array}{l}\text { Estados } \\
\text { Unidos (9\%) }\end{array}$ \\
Alemania $(9 \%)$ & $(6 \%)$ & $\begin{array}{l}\text { Alemania } \\
(6 \%)\end{array}$ & $\begin{array}{l}\text { Alemania } \\
(6 \%)\end{array}$ \\
\hline
\end{tabular}

Fuente. Elaboración propia a partir de The Atlas of Economic Complexity, disponible en http://atlas.cid.harvard.edu/, fecha de consulta: 2/9/2016

Tabla III-1.8. México: principales orígenes de las importaciones (>5\%) (En porcentaje)

\begin{tabular}{|l|l|l|l|l|}
\hline $\mathbf{1 9 9 5}$ & $\mathbf{2 0 0 0}$ & $\mathbf{2 0 0 5}$ & $\mathbf{2 0 1 0}$ & $\mathbf{2 0 1 4}$ \\
\hline $\begin{array}{l}\text { Estados Unidos } \\
(76 \%)\end{array}$ & $\begin{array}{l}\text { Estados Unidos } \\
(75 \%)\end{array}$ & $\begin{array}{l}\text { Estados Unidos } \\
(55 \%)\end{array}$ & $\begin{array}{l}\text { Estados Unidos } \\
(50 \%)\end{array}$ & $\begin{array}{l}\text { Estados Unidos } \\
(50 \%)\end{array}$ \\
\hline \multirow{2}{*}{ Japón (5\%) } & & China (8\%) & China (15\%) & China (17\%) \\
\cline { 2 - 5 } & & Japón (6\%) & Japón (5\%) & \\
\hline
\end{tabular}

Fuente. Elaboración propia a partir de The Atlas of Economic Complexity, disponible en http://atlas.cid.harvard.edu/, fecha de consulta: 2/9/2016. 
Gráfico III-1.21. Origen de las importaciones chinas, 1995-2014

(En porcentaje)
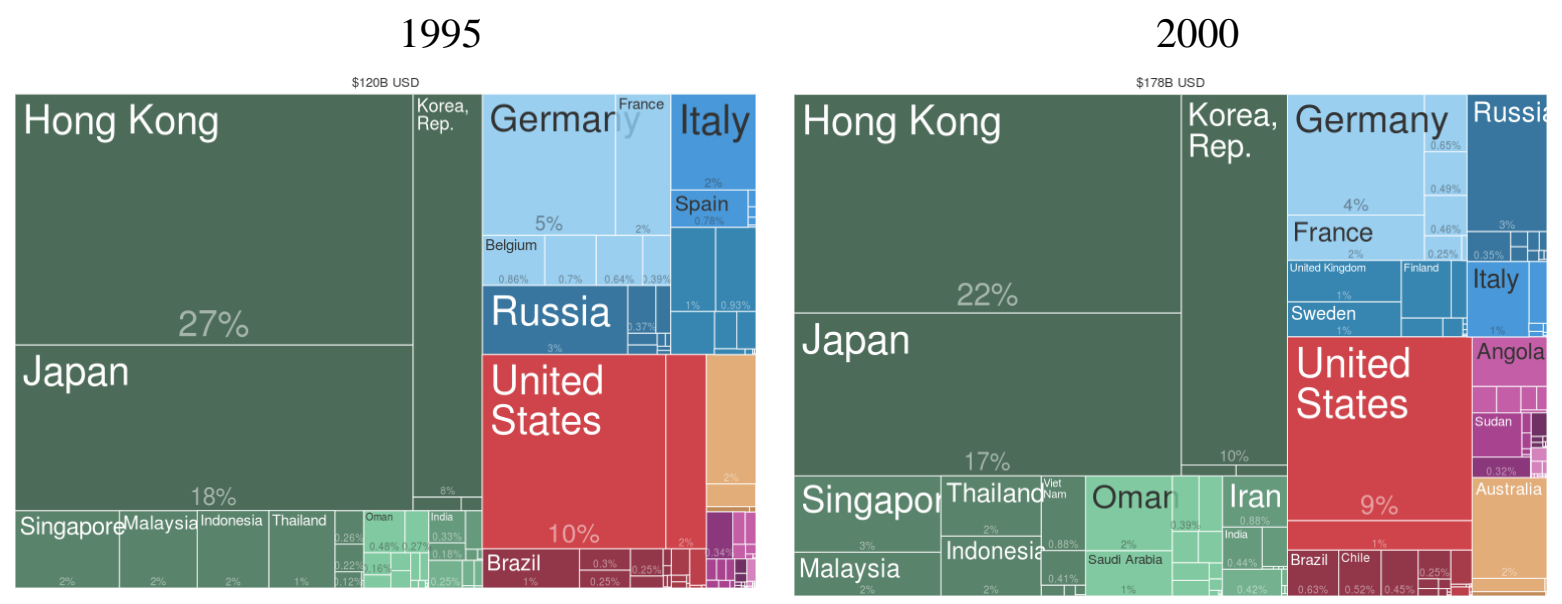

2005

\section{0}
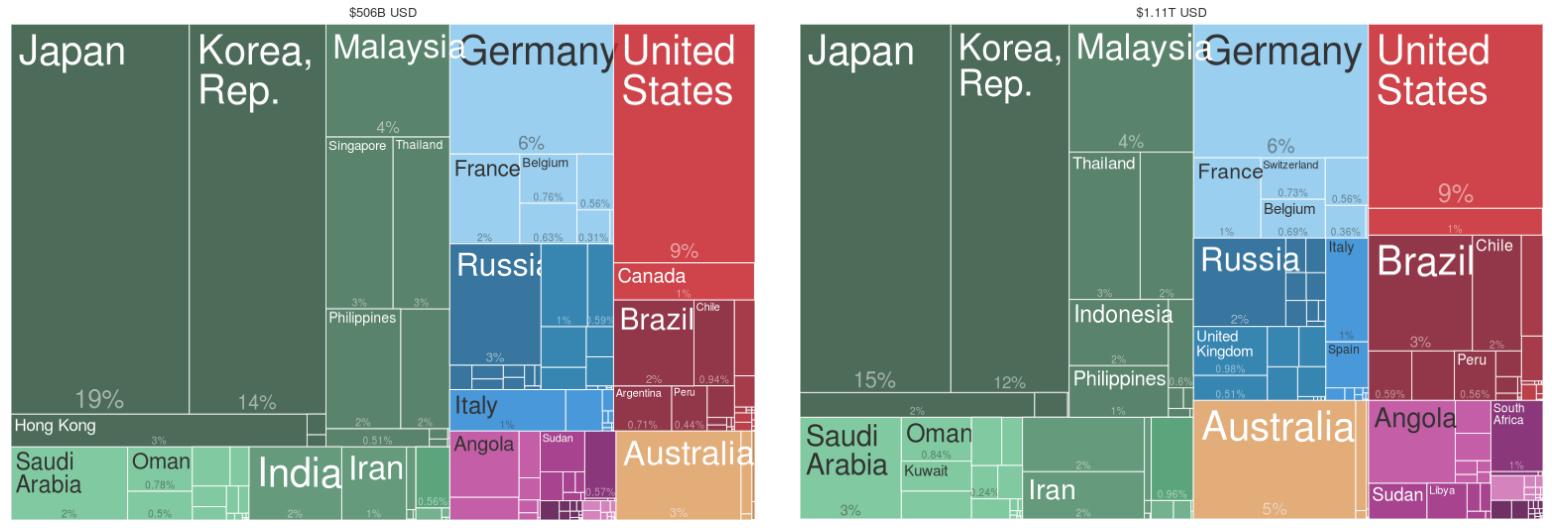

2014

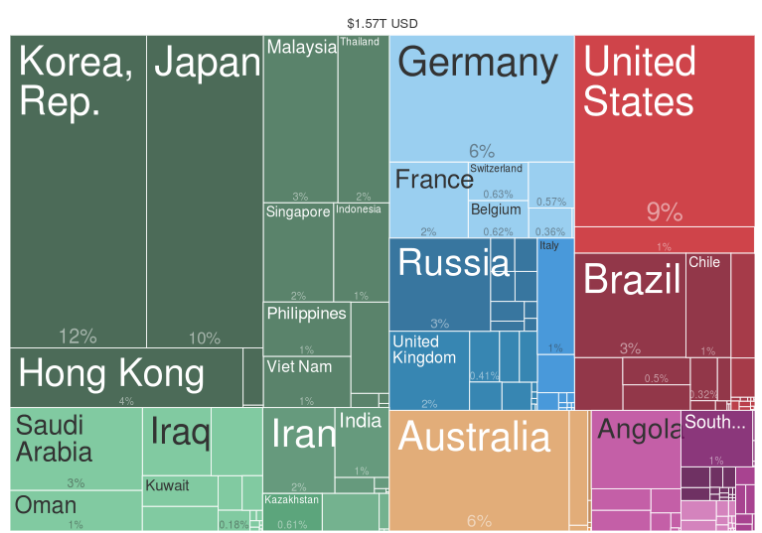

Fuente. Tomado de Atlas of Economic Complexity, disponible en http://atlas.cid.harvard.edu/explore/tree_map/import/chn/show/all/2014/, fecha de consulta: $8 / 12 / 2016$. 
Gráfico III-1.22. Origen de las importaciones mexicanas, 1995-2014

(En porcentaje)

1995

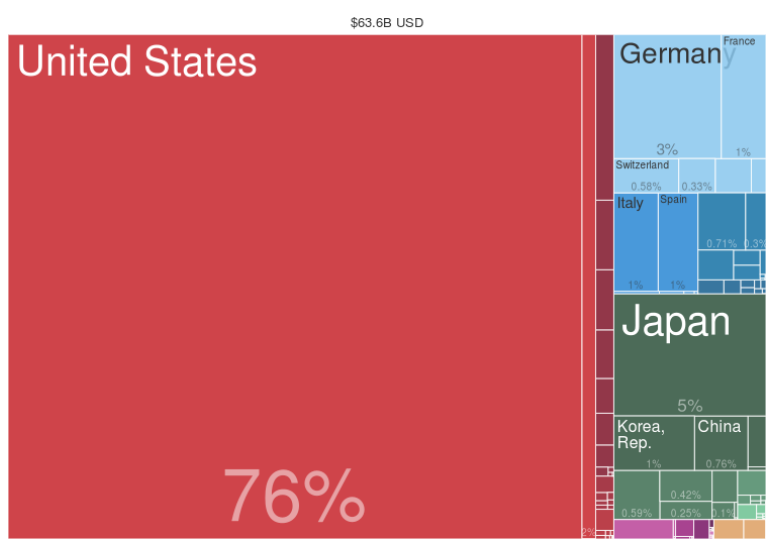

2005

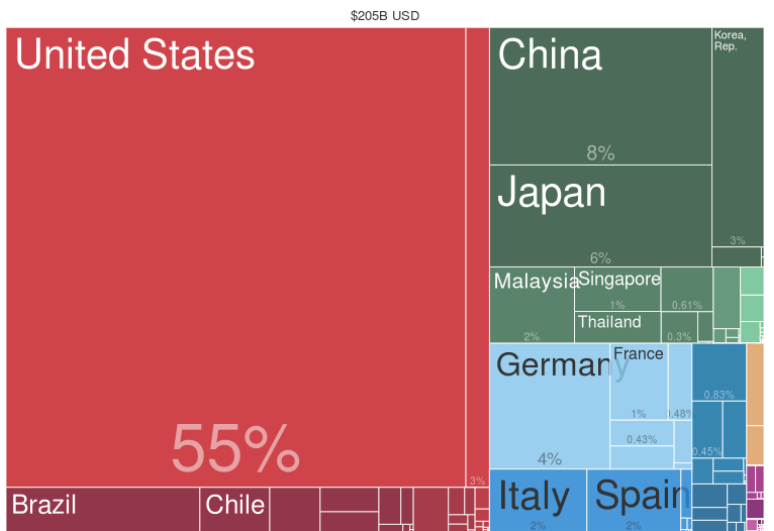

2014
2000

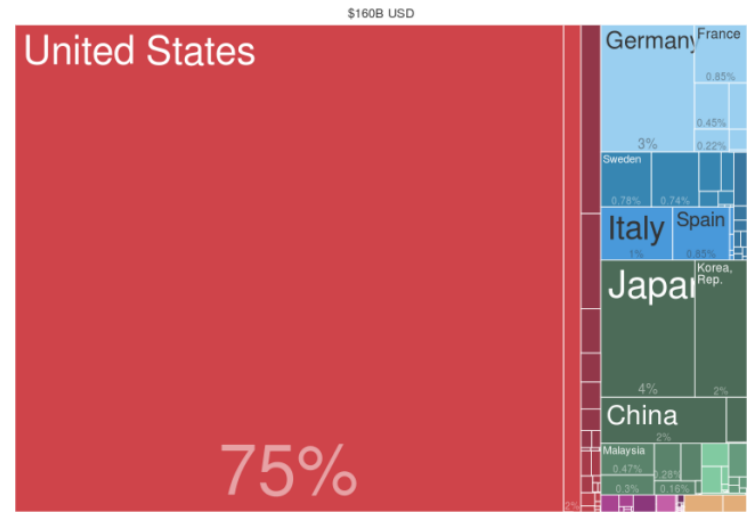

2010

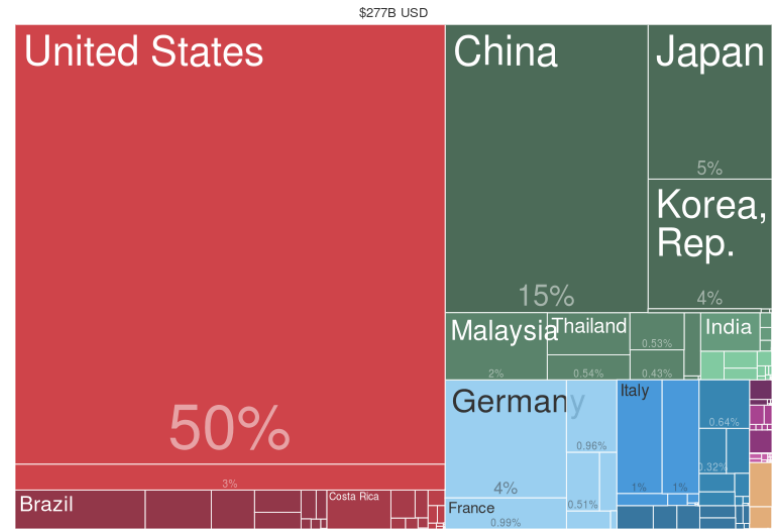

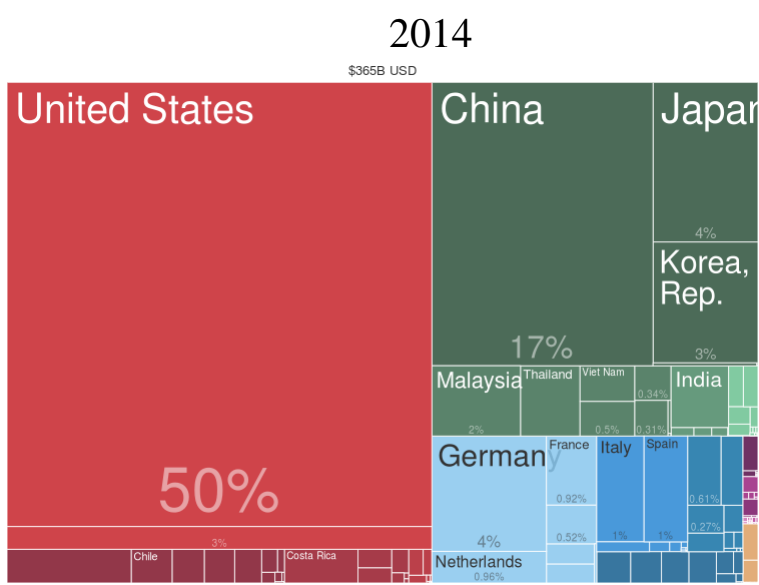

Fuente. Tomado de Atlas of Economic Complexity, disponible en http://atlas.cid.harvard.edu/explore/tree_map/import/mex/show/all/2014/, fecha de consulta: $8 / 12 / 2016$ 
Ahora, se analiza los productos de importación de ambos países en el total de su comercio que se muestran en los Gráficos III-1.23 y III-1.24 y en las Tablas III-1.9 y Tabla III-1.10.

Gráfico III-1.23. Composición de las importaciones chinas, 1995-2014 (En porcentaje)

1995

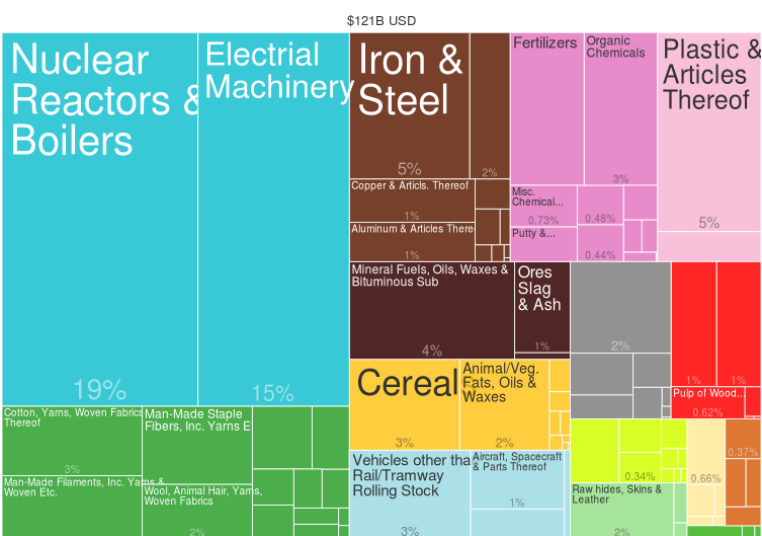

2005

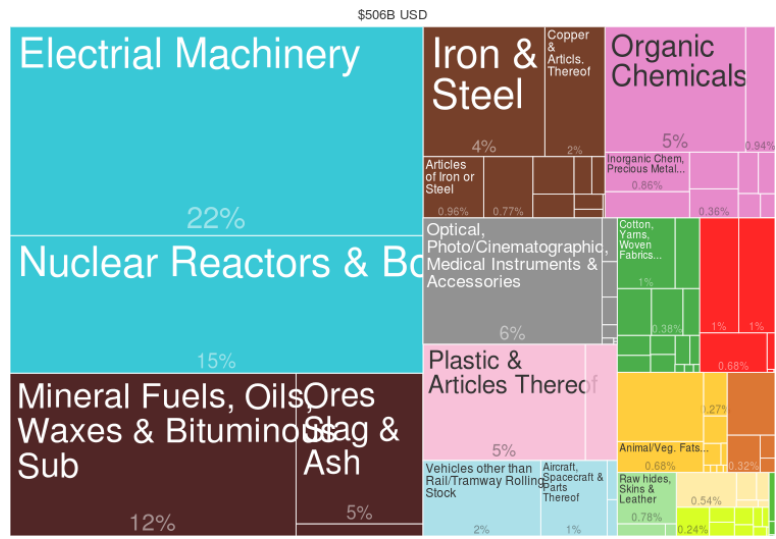

\section{4}

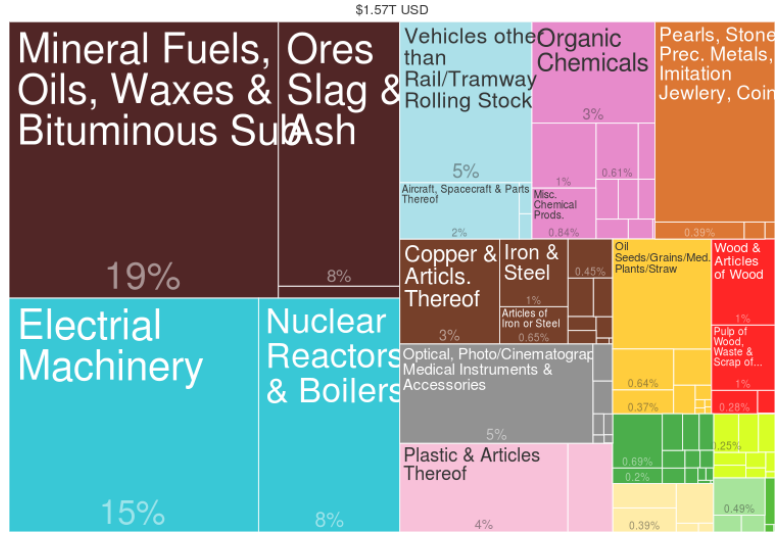

2000

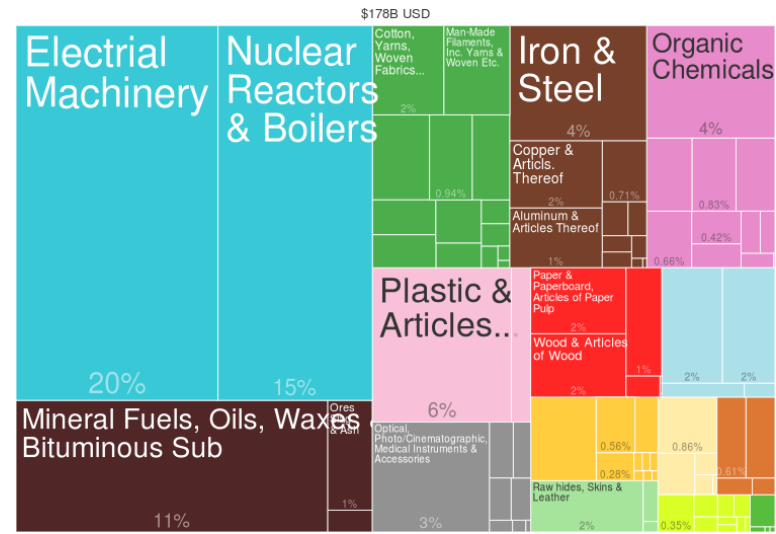

2010

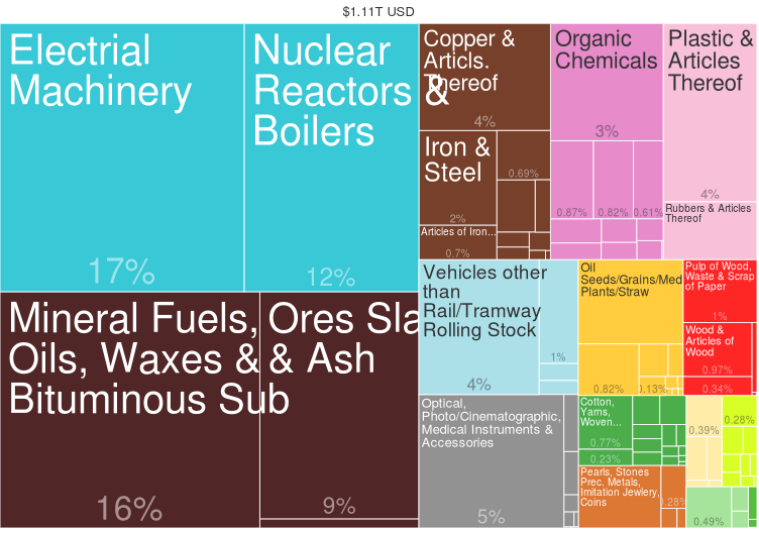

Fuente. Tomado de Atlas of Economic Complexity, disponible en http://atlas.cid.harvard.edu/explore/tree_map/import/chn/all/show/2014/, fecha de cnsulta $8 / 12 / 2016$ 
Gráfico III-1.24. Composición de las importaciones mexicanas, 1995-2014

(En porcentaje)

1995

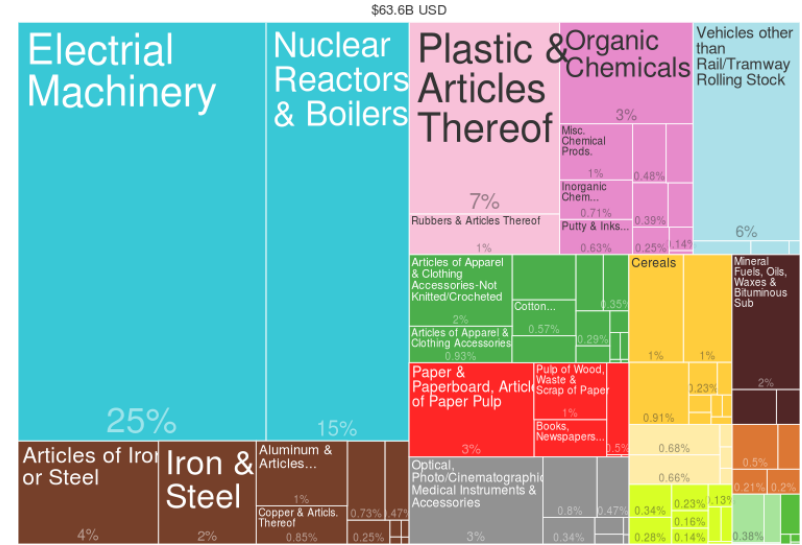

2005

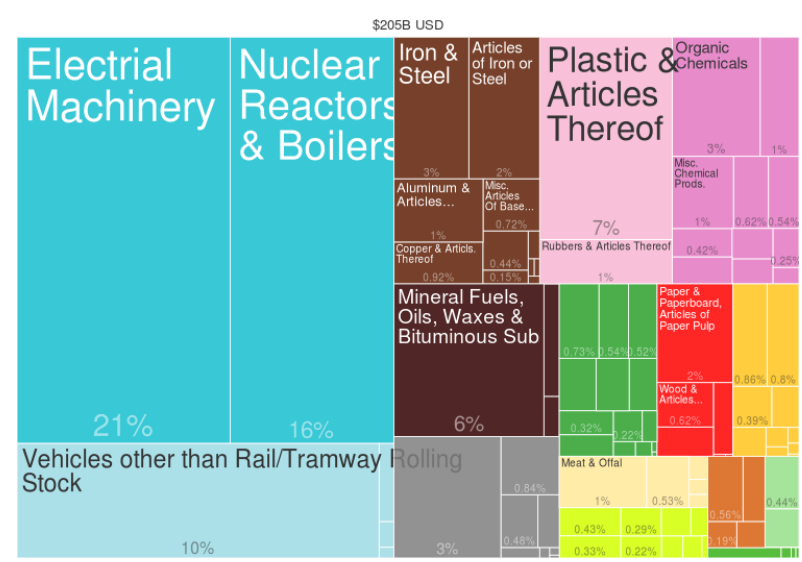

2014

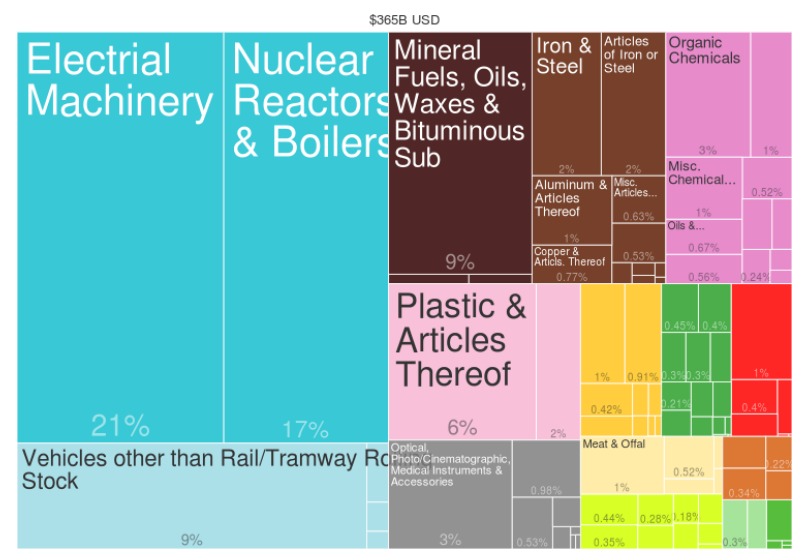

2000

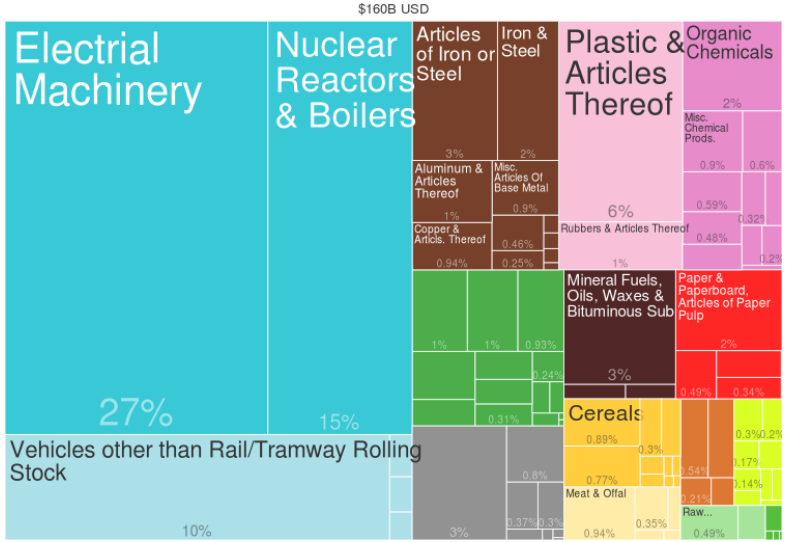

2010

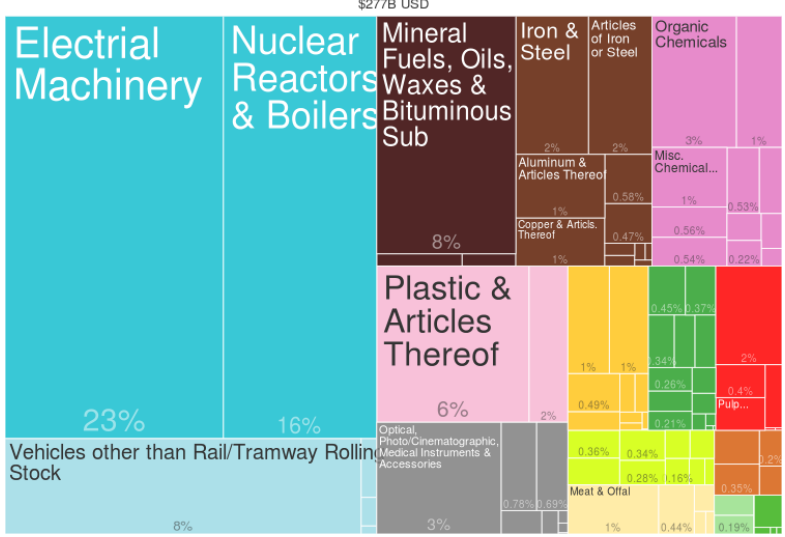

Fuente. Tomado de Atlas of Economic Complexity, disponible en http://atlas.cid.harvard.edu/explore/tree_map/import/mex/all/show/2014/, fecha de consulta: $8 / 12 / 2016$ 
Se nota, como la primera característica, que sus principales productos importados son comunes: maquinaria eléctrica y mecánica. Como se ha analizado anteriormente, en las Tablas III-1.3 y III-1.4, ambos productos son también las principales exportaciones. Se puede decir que en estas dos industrias, China y México tienen comercios horizontales.

En el caso de China, en 1995, estos dos productos ocupan el 34\% de sus importaciones, mientras que en 2014 su cuota sigue en el 34\%. En el caso de México, en 1995, el 40\% de sus importaciones son de estos dos productos, mientras que en 2014 es del $38 \%$. En ambos países, los porcentajes de las importaciones de estos dos productos apenas ha cambiado desde hace 20 años.

Como otra característica, al ver la Tabla III-1.10, se pueden encontrar los "Vehículos". Este producto es también la principal exportación de México. Además, México importa "Intrumentos de precisión”, que también exporta. Asimismo, últimamente, las industrias aeroespaciales y de productos médicos han desarollado y exportado sus productos a Estados Unidos (CARRILLO, PLASCENCIA y ZARÁTE, 2012). En estos productos, los aparatos de precisión son necesarios. Teniendo en cuenta esta situación, se puede decir que el comercio de México está más cerca del comercio horizontal. ${ }^{6}$

En el caso de China, se nota que su importación de Combustibles ha aumentado. Desde China, no se exporta este producto. Principalmente, los productos que China importa - como los combustibles y los minerales- no son los mismos productos que China exporta. Basado en estas condiciones de los comercios en el mundo de China y México, el comercio de México está, aparentemente, más cerca del comercio intra-industrial u horizontal, mientras que el comercio de China es más inter-industrial.

\footnotetext{
${ }^{6}$ Sin embargo, según VALDERRAMA SANTIBÁÑEZ y NEME CASTILLO (2011, p. 65), el comercio intraindustrial de esta industria es vertical. Dependiendo de su categoría, esta clasificación es distinta.
} 
Tabla III-1.9. China: principales productos importados desde el resto del mundo (>5\%)

(En porcentaje)

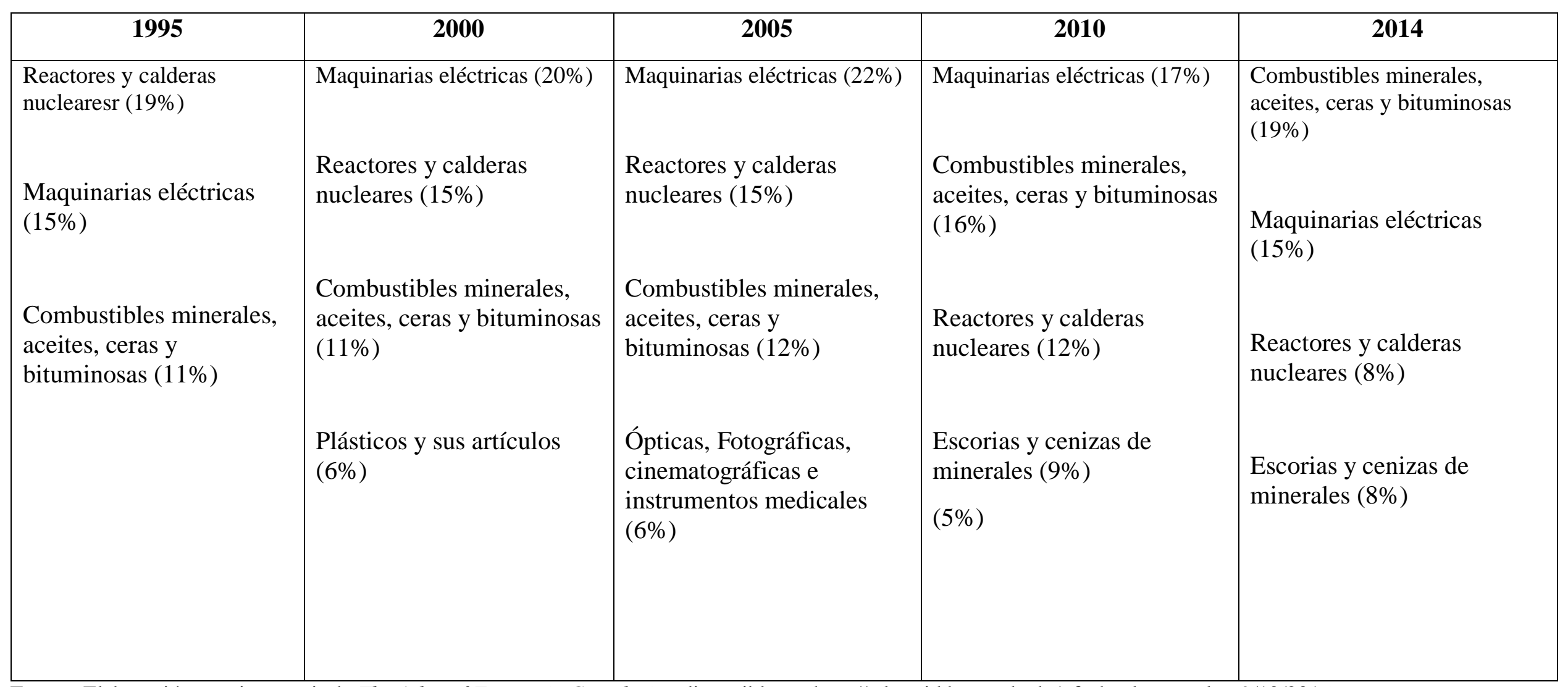

Fuente. Elaboración propia a partir de The Atlas of Economic Complexity, disponible en http://atlas.cid.harvard.edu/, fecha de consulta: 9/12/2016 
Tabla III-1.10. México: principales productos importados desde el resto del mundo (>5\%)

(En porcentaje)

\begin{tabular}{|c|c|c|c|c|}
\hline 1995 & 2000 & 2005 & 2010 & 2014 \\
\hline $\begin{array}{l}\text { Maquinarias eléctricas } \\
(25 \%)\end{array}$ & $\begin{array}{l}\text { Maquinarias eléctricas } \\
(27 \%)\end{array}$ & $\begin{array}{l}\text { Maquinarias eléctricas } \\
(21 \%)\end{array}$ & $\begin{array}{l}\text { Maquinarias eléctricas } \\
(23 \%)\end{array}$ & $\begin{array}{l}\text { Maquinarias eléctricas } \\
(21 \%)\end{array}$ \\
\hline $\begin{array}{l}\text { Reactores y calderas } \\
\text { nucleares }(15 \%)\end{array}$ & $\begin{array}{l}\text { Reactores y calderas } \\
\text { nucleares }(17 \%)\end{array}$ & $\begin{array}{l}\text { Reactores y calderas } \\
\text { nucleares }(16 \%)\end{array}$ & $\begin{array}{l}\text { Reactores y calderas } \\
\text { nucleares }(16 \%)\end{array}$ & $\begin{array}{l}\text { Reactores y calderas } \\
\text { nucleares }(17 \%)\end{array}$ \\
\hline $\begin{array}{l}\text { Plásticos y sus artículos } \\
(7 \%)\end{array}$ & $\begin{array}{l}\text { Vehículos que no sean para } \\
\text { ferrocarriles }(10 \%)\end{array}$ & $\begin{array}{l}\text { Vehículos que no sean para } \\
\text { ferrocarriles }(10 \%)\end{array}$ & $\begin{array}{l}\text { Vehículos que no sean } \\
\text { para ferrocarriles }(8 \%)\end{array}$ & $\begin{array}{l}\text { Vehículos que no sean para } \\
\text { ferrocarriles }(9 \%)\end{array}$ \\
\hline $\begin{array}{l}\text { Vehículos que no sean } \\
\text { para ferrocarriles }(6 \%)\end{array}$ & $\begin{array}{l}\text { Plásticos y sus artículos } \\
(6 \%)\end{array}$ & $\begin{array}{l}\text { Plásticos y sus artículos } \\
(7 \%)\end{array}$ & $\begin{array}{l}\text { Combustibles minerales, } \\
\text { aceites, ceras y } \\
\text { bituminosas }(8 \%)\end{array}$ & $\begin{array}{l}\text { Combustibles minerales, } \\
\text { aceites, ceras y } \\
\text { bituminosas }(9 \%)\end{array}$ \\
\hline & & $\begin{array}{l}\text { Combustibles minerales, } \\
\text { aceites, ceras y } \\
\text { bituminosas }(6 \%)\end{array}$ & $\begin{array}{l}\text { Plásticos y sus artículos } \\
(6 \%)\end{array}$ & $\begin{array}{l}\text { Plásticos y sus artículos } \\
(6 \%)\end{array}$ \\
\hline
\end{tabular}

Fuente. Elaboración propia a partir de The Atlas of Economic Complexity, disponible en http://atlas.cid.harvard.edu/, fecha de consulta: 9/12/2016 
Ahora, vemos las importaciones desde Estados Unidos de ambos países en las Tablas III-1.11. y III-1.12. y en los Gráficos III-1.25 y III-1.26.

Como las tablas anteriores, en el caso de las importaciones desde Estados Unidos, los productos principales importados de China y México son comunes: maquinaria eléctrica y mecánica. Estos productos son las exportaciones principales a Estados Unidos desde China y México, también. Especialmente, la maquinaria eléctrica es muy importante para el comercio de ambos países.

Sin embargo, sus productos para la exportación e importación no son totalmente los mismos cuando se desagrega esta categoría. Por ejemplo, en 2014, México exporta a Estados Unidos dentro de la categoría de la maquinaria eléctrica los siguientes productos: Máquinas de procesamiento automático de datos, Monitores y proyectores; Aparatos de televisión, Alambre aislado; cables de fibra óptica y Teléfonos; e importa desde Estados Unidos en esta categoría lo siguiente: Alambre aislado; cables de fibra óptica, y Aparato de protección de circuitos eléctricos.

Además, en la categoría de Vehículos en 2014, México exporta: Coches, Vehículos de motor para transporte y Partes y Accesorios de los vehículos; mientras que Estados Unidos exporta a México: Partes y Accesorios de los vehículos de motor.

En el comercio de China, este país en 2014 exporta a Estados Unidos: Máquinas de procesamiento automático de datos y Aparatos de transmisión de radio, teléfono y TV; e importa de Estados Unidos: Circuitos electrónicos integrados y Diodos, transistores, semiconductores; dispositivos semiconductores fotosensibles, incluso células fotovoltaicas.

Basándose en estos datos sobre el comercio de China y México, los principales productos de sus exportaciones e importaciones con Estados Unidos son comunes. Ambos países tienden a importar productos intensivos en tecnología y a exportar productos intensivos en mano de obra.

Generalmente, el comercio de México tiene alta dependencia de Estados Unidos en sus exportaciones e importaciones. Sin embargo, obviamente, su exportación depende más del mercado de Estados Unidos, que las importaciones. Sus principales productos principales de exportación son manufacturas y también, importan productos manufacturados (DUSSEL PETERS, 2005, p. 20). 
Tabla III-1.11. China: principales productos importados desde Estados Unidos (>5\%)

(En porcentaje)

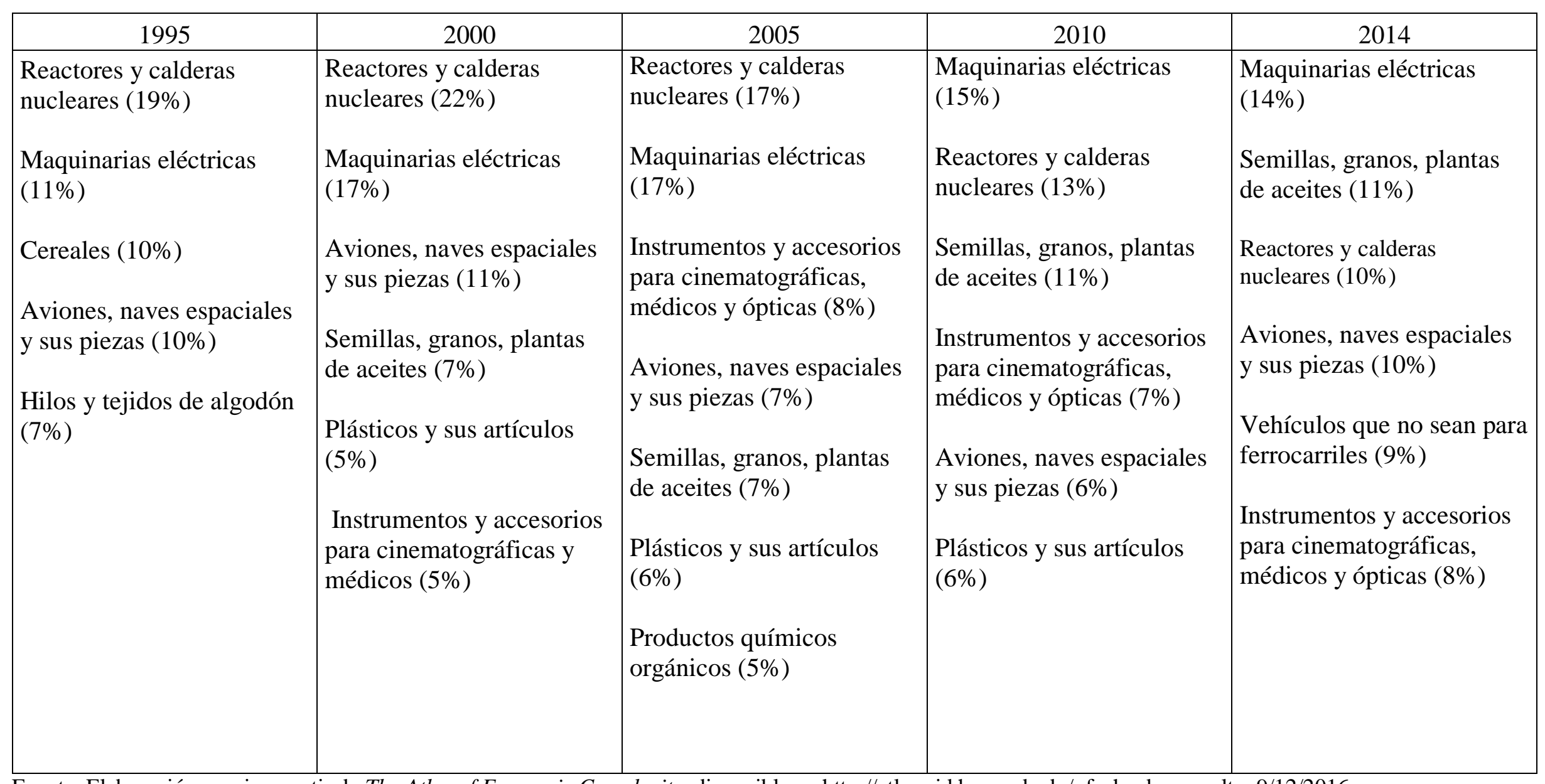

Fuente. Elaboración propia a partir de The Atlas of Economic Complexity, disponible en http://atlas.cid.harvard.edu/, fecha de consulta: 9/12/2016 
Tabla III-1.12. México: principales productos importados desde Estados Unidos (>5\%)

(En porcentaje)

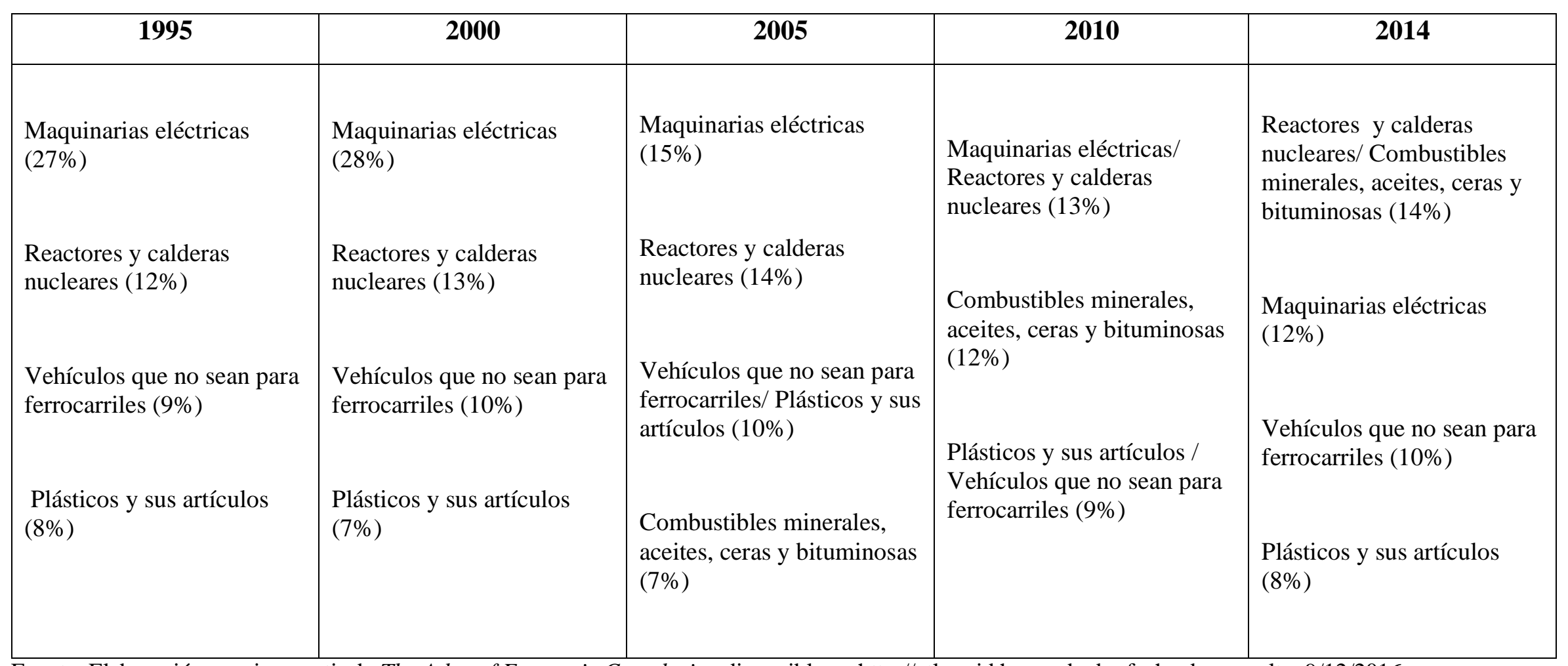

Fuente. Elaboración propia a partir de The Atlas of Economic Complexity, disponible en http://atlas.cid.harvard.edu, fecha de consulta: 9/12/2016 
Gráfico III-1.25. Composición de las importaciones chinas desde Estados Unidos, 19952014 (En porcentaje)
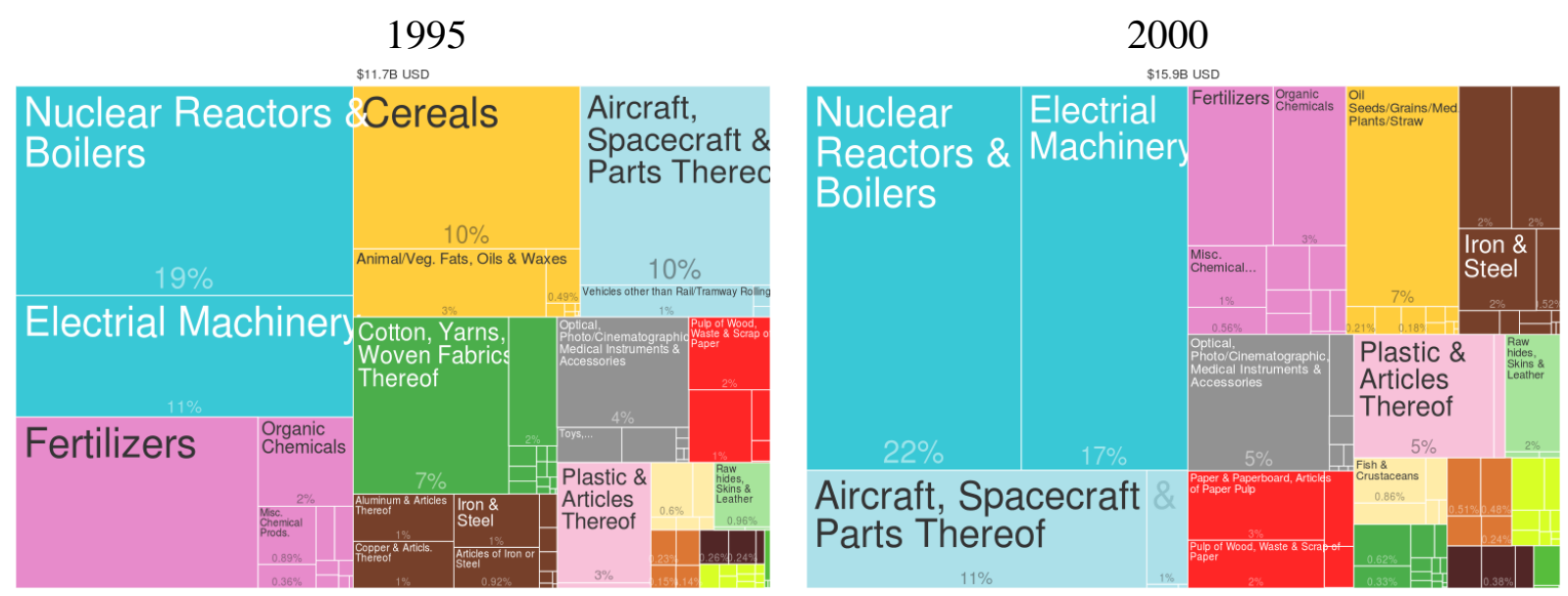

2005
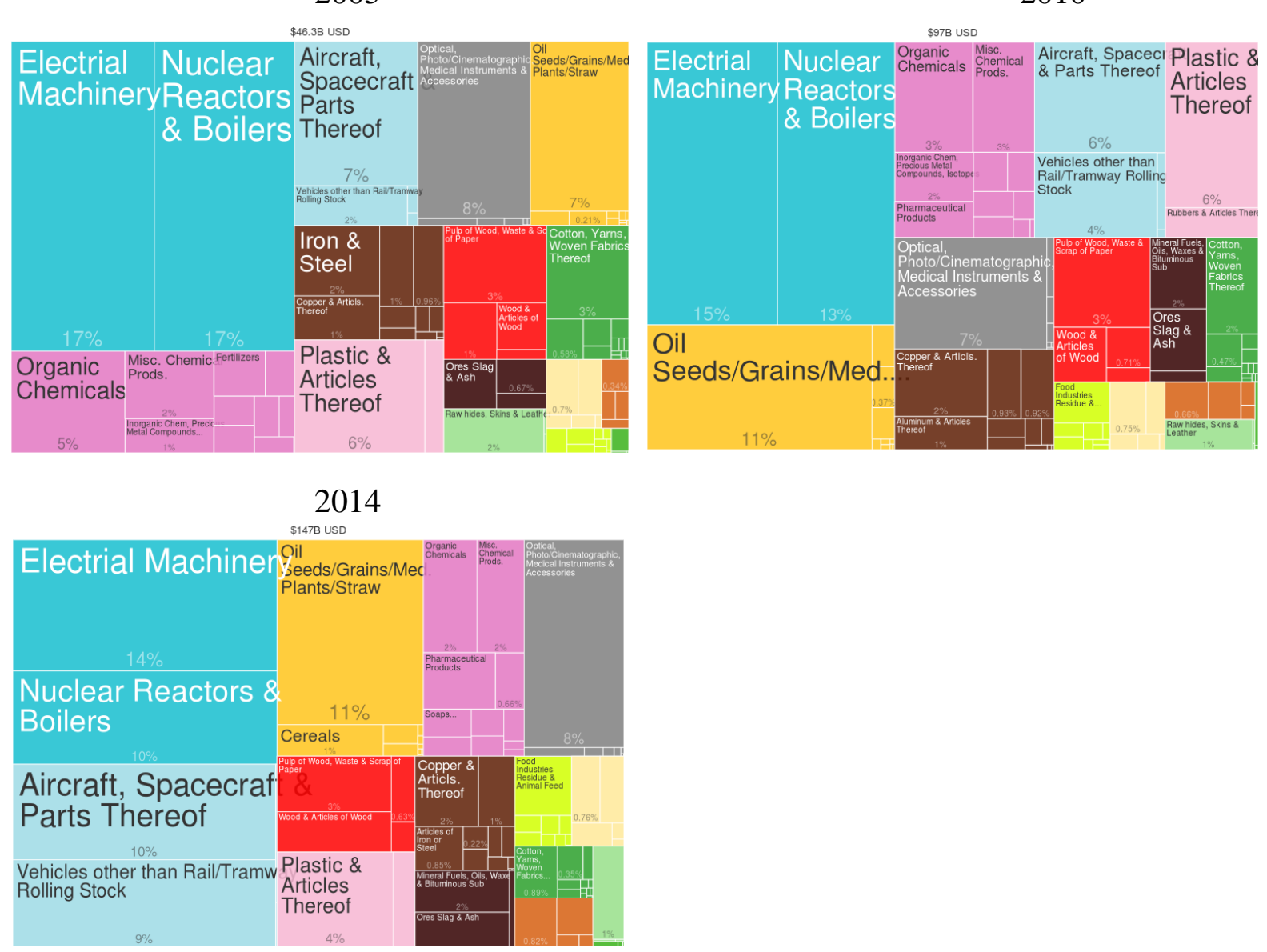

Fuente. Tomado de Atlas of Economic Complexity, disponible en http://atlas.cid.harvard.edu/explore/tree_map/export/chn/usa/ show/2014/, fecha de consulta: $8 / 12 / 2016$. 
Gráfico III-1.26. Composición de las importaciones mexicanas desde Estados Unidos, 1995-2014 (En porcentaje)

1995

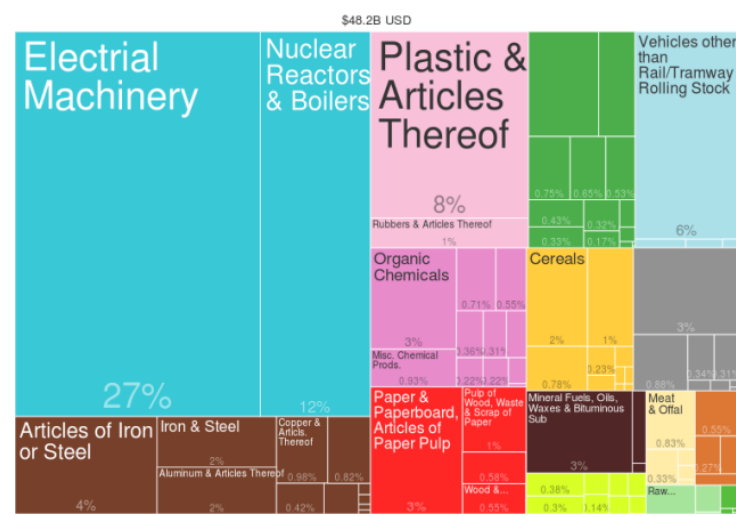

2005

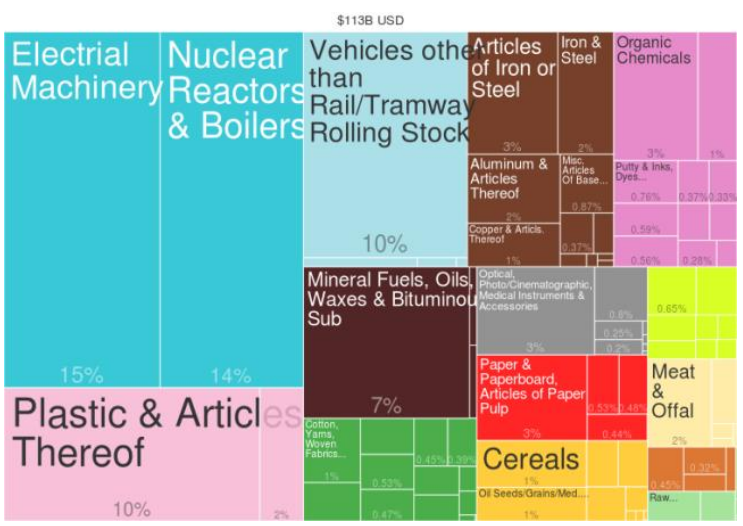

2014

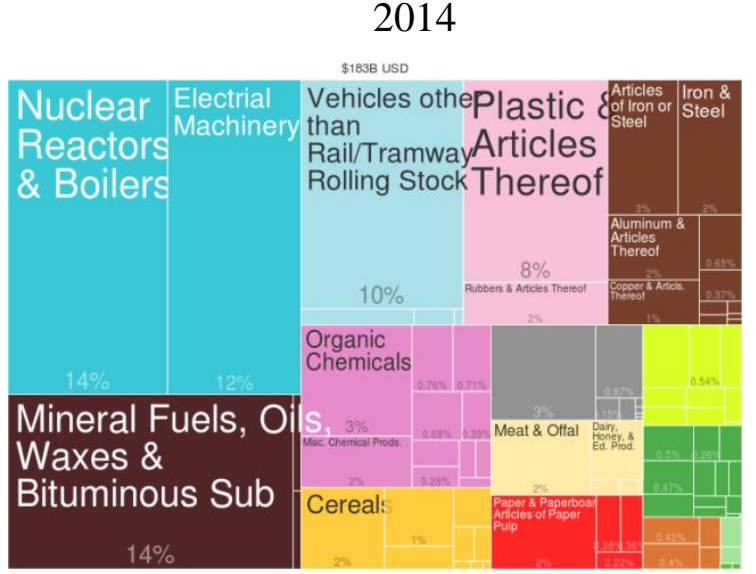

Fuente. Tomado de Atlas of Economic Complexity, disponible en http://atlas.cid.harvard.edu/explore/tree_map/export/mex/usa/show/2014/, fecha de consulta: 8/12/2016.
2000

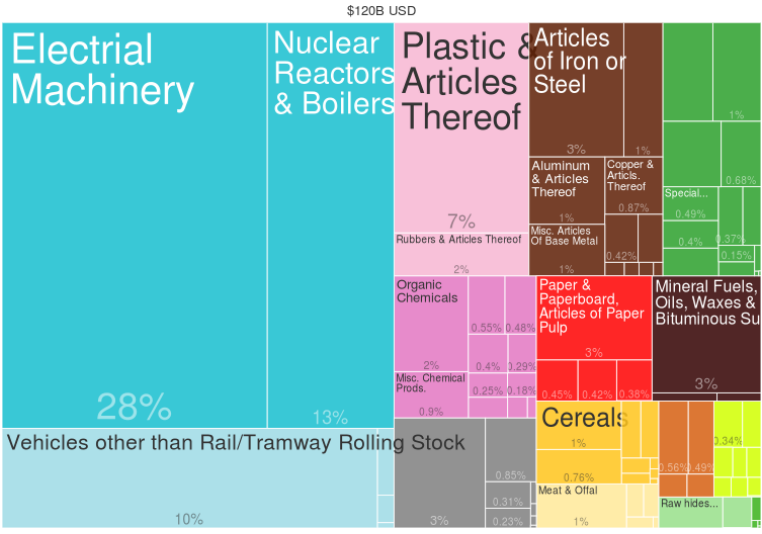

2010

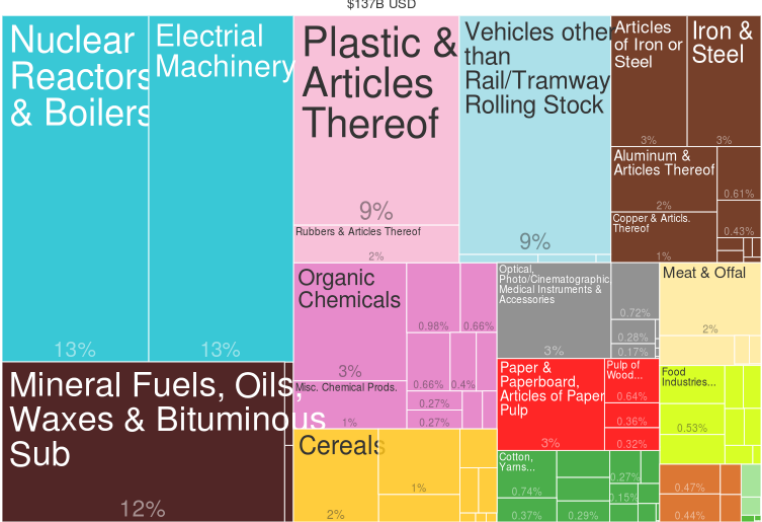


Para China, Estados Unidos es un mercado importante, pero no el principal origen de sus importaciones. Además, la mayor parte de sus socios comerciales son países asiáticos, tanto desde el punto de la vista de la exportación como de la importación. Por eso, la dependencia de China respecto al mercado de Estados Unidos es muy baja.

Los productos principales para importar $\mathrm{y}$ exportar son productos manufacturados. En el caso de México, exporta también su petróleo, pero principalmente, las exportaciones mexicanas son productos manufacturados de las industrias pesadas (GÓNGORA PÉREZ, 2013). Al contrario, en el caso de China, exporta productos manufacturados, pero sus principales productos para la exportación son de la industria ligera, por ejemplo, textiles, calzados, juguetes y equipamiento de deportes.

Además, en el caso del comercio de México, según MONROY-GÓMEZFRANCO (2014), esta situación de alta dependencia de Estados Unidos no ha supuesto que las exportaciones a Estados Unidos se hayan convertido en el motor de desarrollo de la economía mexicana. La razón de ello se atribuye a la gran cantidad de insumos importados que utiliza el sector exportador de México en sus procesos productivos. Esto podría explicar por qué México tiene superávit con Estados Unidos, pero no exporta tanto al resto del mundo.

Además, como se ha visto, las importaciones desde Estados Unidos tienen altos porcentajes en el mercado de México. Sin embargo, ahora, los productos chinos también participan en el mercado de México y debido a su competencia, los productos estadounidenses han visto disminuir su cuota en el mercado mexicano (DUSSEL PETERS y GALLAGHER, 2014). 


\section{III-2. Comercio Inter-industrial de China y México con Estados Unidos: Ventajas Comparativas Reveladas e Índice de Contribución al Saldo.}

\section{III-2.1. Comercio Inter-industrial en el comercio de China y México con Estados Unidos}

En este epígrafe se hace una primera aproximación al Comercio Interindustrial en el comercio de China y México con Estados Unidos. Tal como se ha presentado en el capítulo I, el comercio interindustrial constituye un intercambio de bienes distintos, un país exporta bienes de un sector, mientras que su socio comercial le exporta bienes de otro sector. Este tipo de comercio responde a procesos de especialización comercial como los propuestos en las teorías de Ricardo o Heckscher-Ohlin. Esta especialización se manifiesta en forma de ventajas y desventajas en los sectores de especialización en el comercio.

El indicador básico más habitual de las ventajas es el Saldo Comercial Relativo (SCR) o indicador de Ventaja Comparativa Revelada (ALONSO RODRIGUEZ, 1991).

$$
S C R_{i}=\left(\frac{X_{i}-M_{i}}{X_{i}+M_{i}}\right) \times 100
$$

donde X y M son las exportaciones e importaciones, respectivamente, y el subíndice i se refiere al sector considerado. El índice varía entre +100 y -100: en el primer caso sólo existen exportaciones y la ventaja comercial es máxima; en el segundo sólo existen importaciones y la desventaja comercial es máxima ${ }^{7}$.

La aplicación de este indicador al conjunto del comercio de China y México con Estados Unidos revela patrones de comercio diferentes (Gráfico III-2.1). En efecto, China ha tenido siempre una gran ventaja comercial respecto a Estados Unidos, han predominado sus ventajas respecto a sus desventajas, desde mucho antes de que China entrara en la OMC. Dicha entrada lo que ha permitido es amplificar el volumen de comercio, de sus exportaciones a Estados Unidos, pero las ventajas en los últimos 25 años han oscilado entre el 50 y el 75, con una media en el periodo de 65. Este valor de 65 se

\footnotetext{
${ }^{7}$ Un país cuenta con ventaja comparativa en la producción de un bien, si el costo de oportunidad de producir ese bien en términos de otro bien es menor en ese país que en otros (GIL LAMADRID, MARTINEZ, SALAZAR, MARTINEZ y NAÑEZ, 2012).
} 
puede interpretar como que el saldo positivo de China respecto a Estados Unidos es muy alto y supone un $65 \%$ de la suma total de las exportaciones e importaciones. Por el contrario, México presentaba una desventaja respecto a Estados Unidos antes de la firma del TLCAN, que se revierte posteriormente, pero la ventaja genera un indicador de más de 20 solo en un año (en 2007), con una media en el periodo de 12. Este indicador más bajo habla de la existencia de comercio en las dos direcciones que más adelante será explorado con más detenimiento en el epígrafe III-3.

\section{Gráfico III-2.1. Ventaja Comparativa Revelada en el comercio de China y México con Estados Unidos, 1991-2015}

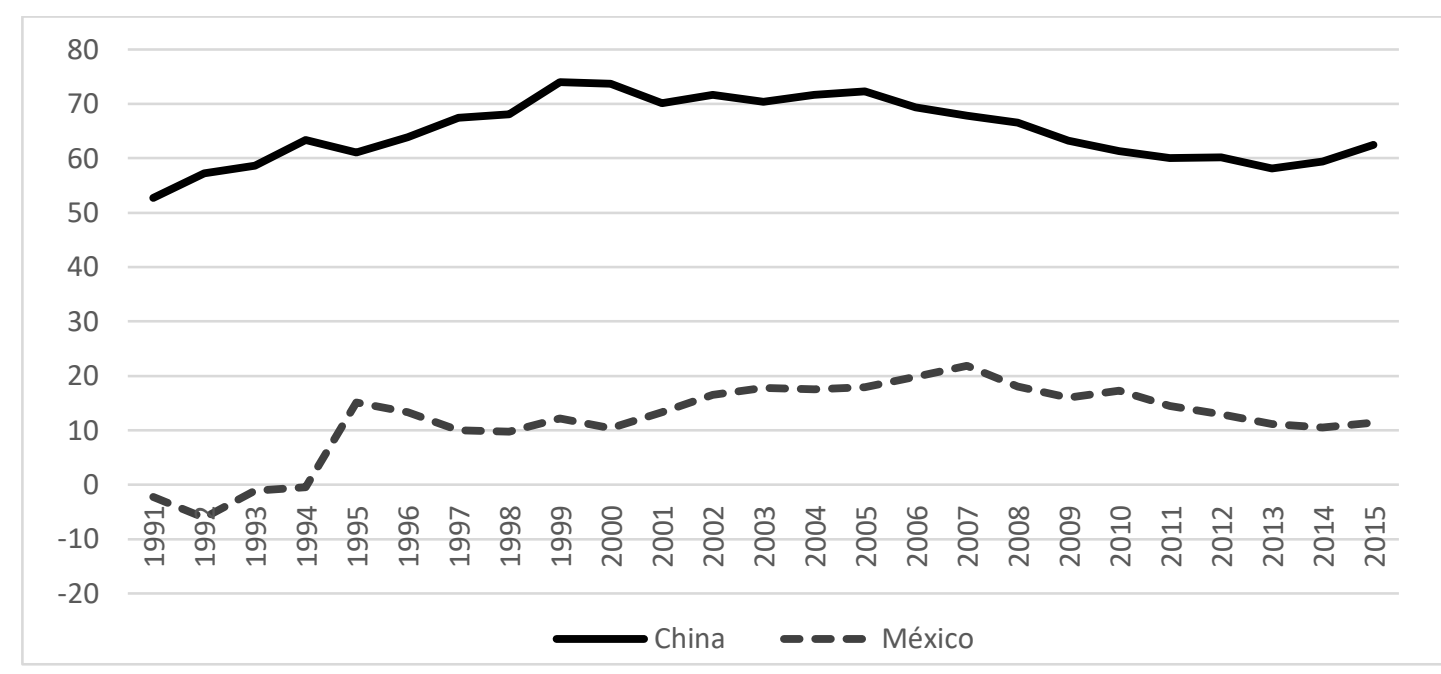

Fuente. Elaboración propia según COMTRADE, Naciones Unidas, disponible en http://comtrade.un.org/data/, fecha de consulta: 10/12/2016

\section{III-2.2. Ventajas Comparativas Reveladas}

Un segundo paso en el análisis del patrón de especialización puede lograrse mediante el análisis de las ventajas y desventajas de México y China en el comercio con Estados Unidos. Se han calculado las Ventajas Comparativas Reveladas de China y México en cada uno de los capítulos del Sistema Armonizado ${ }^{8}$ de clasificación del comercio (véanse el Cuadro Anexo III.1 con el detalle de los capítulos del Sistema Armonizado y los Cuadros Anexo III.2 y Anexo III.3). Los Gráficos III-2.2 y III-2.3 recogen, respectivamente las ventajas de China y México en su comercio con Estados

\footnotetext{
${ }^{8}$ El Sistema Armonizado (en Ingles, Harmonized System) es una nomenclatura internacional de productos multiusos, que se desarrollan por la Organización de Mundial de Aduanas (World Customes Organización: $W C O$ ). Más de 200 países y las organizaciones usan este sistema. Más de $98 \%$ del comercio internacional de productos se clasifican en SA. Según las informaciones del sitio Web de WCO.http://www.wcoomd.org/en/topics/nomenclature/overview/what-is-the-harmonized-system.aspx. fecha de nsulta: 12/6/2016.
} 
Unidos. Las líneas correspondientes a los casi 100 capítulos no resultan fáciles de interpretar, pero sí se pueden decir algunas cosas relevantes. En primer lugar, la evolución de cada uno de los sectores puede cambiar mucho en el tiempo, las líneas no siguen a menudo tendencias claras, sino comportamientos erráticos que tienen que ver con las cambiantes condiciones de precios en los mercados internacionales.

En segundo lugar, a pesar de la citada gran variabilidad, se aprecia una diferencia marcada entre ambos gráficos, en el de China la mayor parte de las líneas se encuentran en la parte de arriba, en la de ventajas, y hay muy pocas líneas en la parte de abajo. Esto quiere decir que China tiene ventajas respecto a Estados Unidos en la mayor parte de los productos. Por el contrario, en el caso de México, las líneas están más distribuidas a lo largo del gráfico, pero hay una mayoría de capítulos en los que México tiene desventajas, donde las líneas se encuentran en la parte de abajo del gráfico.

\section{III-2.3. Índices de Contribución al Saldo}

En el epígrafe III-1 se ha presentado la estructura de las exportaciones de China y México con Estados Unidos, en este epígrafe se profundizará en la comprensión de la contribución de los capítulos más importantes al saldo de estos países, a partir de la base de datos de las Naciones Unidas sobre el comercio de mercancías COMTRADE, con una desagregación de dos dígitos del Sistema Armonizado. Para ello se utilizará el Índice de Contribución al Saldo:

$$
I C S_{i}=\left[\frac{X_{i}-M_{i}}{X_{i}+M_{i}}-\frac{\sum_{i} X_{i}-\sum_{i} M_{i}}{\sum_{i} X_{i}+\sum_{i} M_{i}}\right]\left[\frac{X_{i}+M_{i}}{\frac{\sum_{i} X_{i}+\sum_{i} M_{i}}{2}}\right] \times 100
$$

donde $X$ y $M$ son las exportaciones e importaciones, respectivamente, y el subíndice $i$ se refiere al sector considerado. El índice de contribución al saldo (ICS) se expresa como diferencia entre el saldo comercial relativo de un sector y el correspondiente al conjunto de la economía, corregido por un factor de ponderación construido a partir del peso relativo de los flujos comerciales del sector en el total del comercio. Un sector con un valor elevado y positivo significa que el país tiene en ese sector una ventaja aún mayor que en conjunto del comercio y que el peso de ese sector es muy alto, y viceversa. 
Gráfico III-2.2. Ventajas Comparativas Reveladas de China en su comercio con Estados Unidos, 1991-2015

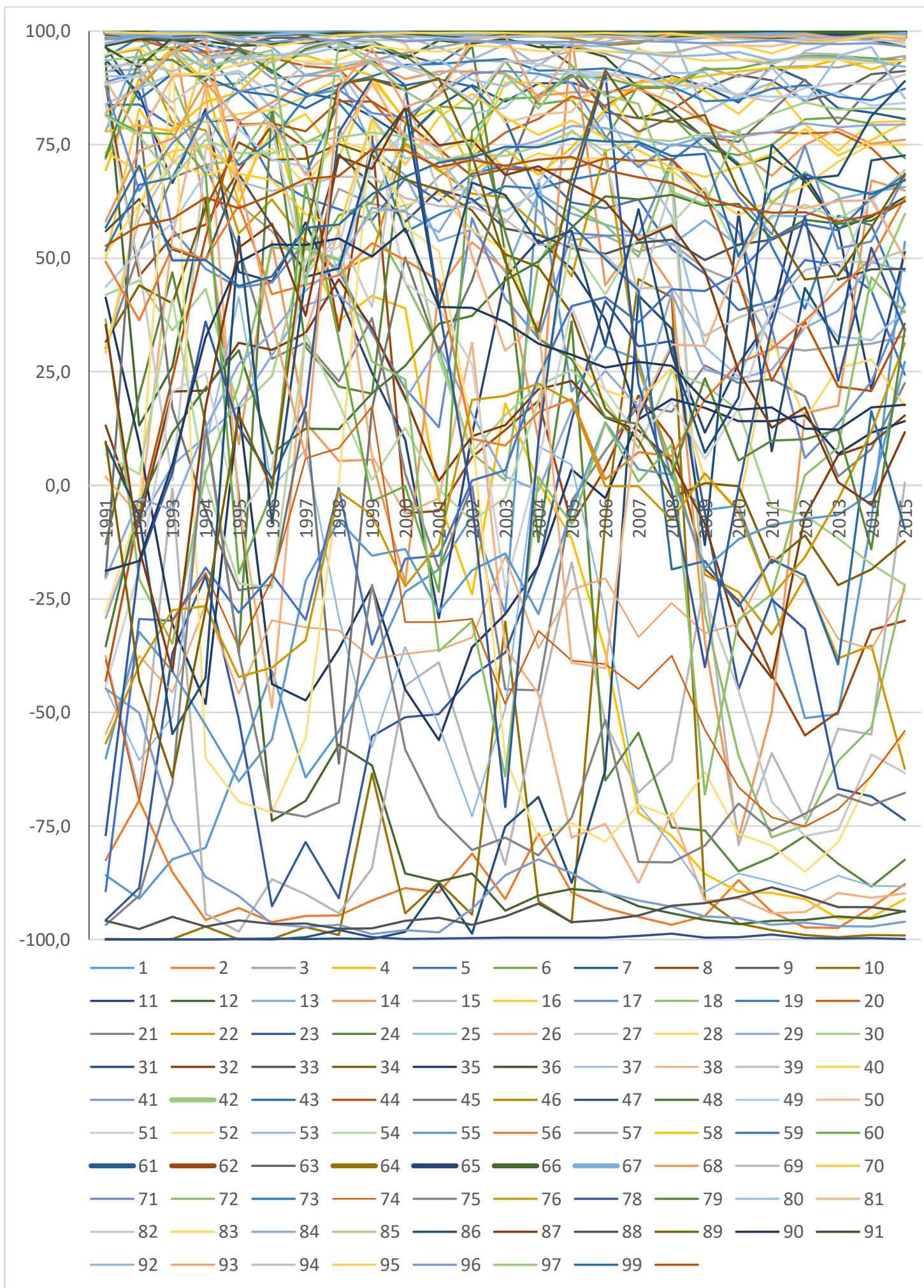

Fuente. Elaboración propia según COMTRADE, Naciones Unidas, disponible en http://comtrade.un.org/data/, fecha de consulta: 10/12/2016. 
Gráfico III-2.3. Ventajas Comparativas Reveladas de México en su comercio con Estados Unidos, 1991-2015

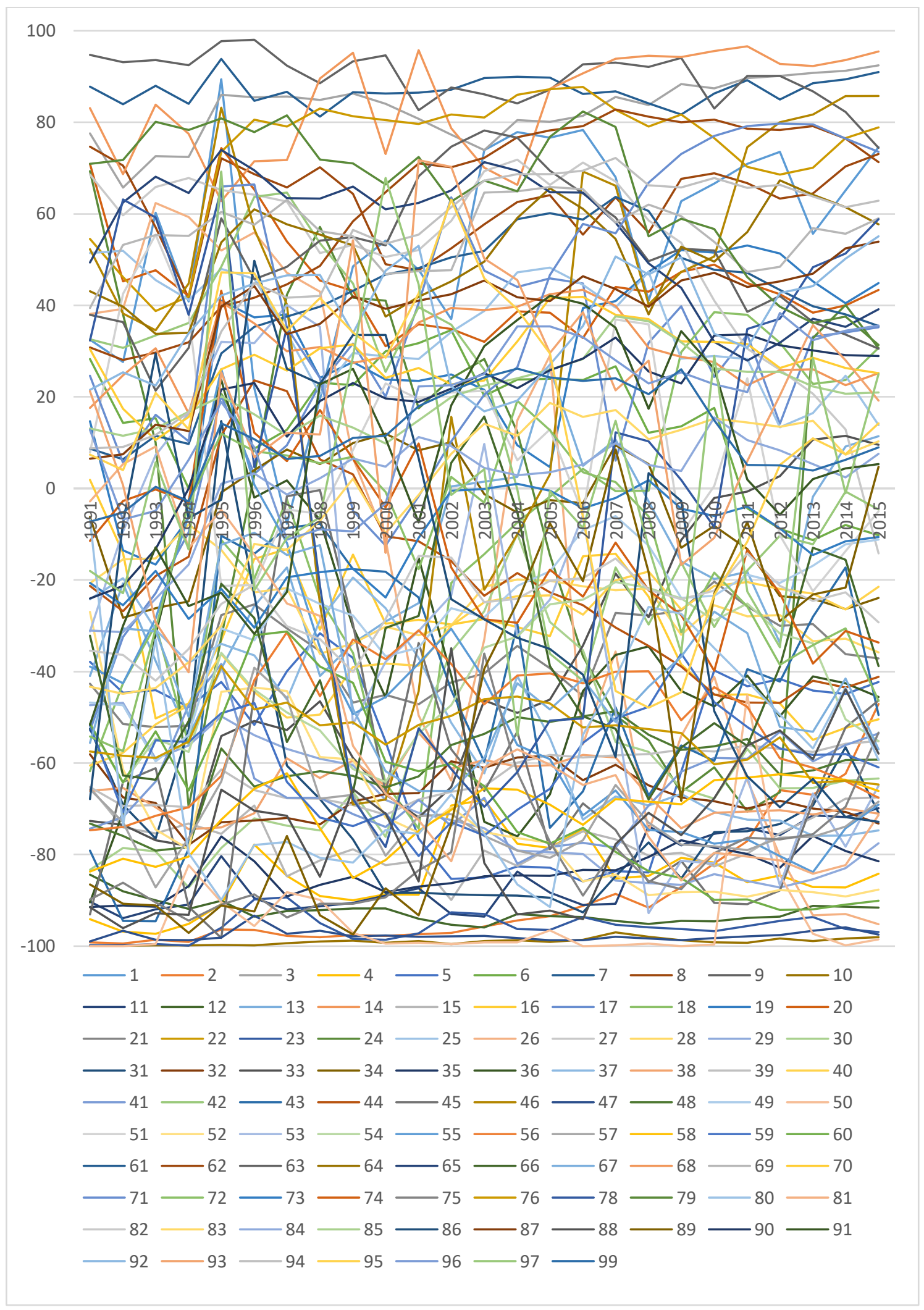

Fuente. Elaboración propia según COMTRADE, Naciones Unidas, disponible en http://comtrade.un.org/data/, fecha de consulta: 10/12/2016. 
Se han calculado también los Índices de Contribución al Saldo de China y México en cada uno de los capítulos del Sistema Armonizado de clasificación del comercio (véanse los Cuadros Anexo III.4 y Anexo III.5). Los Gráficos III-2.4 y III-2.5 recogen, respectivamente los principales sectores que destacan por su Contribución al Saldo de China y México en su comercio con Estados Unidos.

En el caso de China, podemos ver que la mayor parte de los sectores se sitúan en torno a 0 , ya sea porque son poco importantes en el comercio o porque la ventaja no se aleja mucho de la del conjunto de la economía. Destacan en positivo algunos sectores señalados con líneas discontinuas. Al comienzo del periodo, los más importantes eran el 95 (juguetes), el 64 (calzado) y 62 (textil), mientras que al final del periodo se observa que los sectores que contribuyen más en positivo a la formación del saldo son el 85 (maquinaria eléctrica y electrónica) y el 84 (maquinaria mecánica), a los que se suman los sectores citados anteriormente, que siguen teniendo una contribución positiva, pero con un peso mucho menor. Entre los sectores que tienen una contribución negativa destaca al principio del periodo el 88 (aviones). También en ese primer periodo los de maquinaria mecánica (84) y el 31 (abonos) tenían una contribución negativa que desaparece a lo largo del tiempo. En los últimos años los sectores que contribuyen más en negativo al saldo de China con Estados Unidos son los aviones (88), aunque en mucha menor medida que al inicio del periodo, los alimentos para el ganado (y entre ellos la soja, 12), los vehículos (87) y los aparatos de precisión (90). En cualquier caso, se aprecia una fuerte transformación en las ventajas hacia sectores de más alto contenido tecnológico a lo largo del periodo.

En el caso de México, destaca en primer lugar el petróleo (27) que ha pasado de ser un sector clave para el saldo positivo de México a tener una aportación negativa en los últimos años, a raíz del desarrollo de la explotación de petróleo no convencional en Estados Unidos. Hoy en día el principal producto por su contribución positiva al saldo, con mucha diferencia, es el de vehículos (87), donde están presentes empresas japonesas y norteamericanas que han realizado inversiones directas en México, sobre todo en la Frontera y en el Bajío, como hemos visto en el Capítulo II. Otro sector relevante y con una contribución positiva es el de maquinaria eléctrica y electrónica (85), aunque su contribución es muy variable en el tiempo. 
Al principio del periodo, destaca también el papel de la ropa (62), que pierde importancia desde la entrada de China en la OMC. Entre los sectores que más contribuyen negativamente al saldo destacan el de plásticos (39), química (29) y maquinaria mecánica (84).

\section{III-2.4. Estudios de caso}

En este epígrafe se presenta el análisis de algunos productos concretos y se comparara el comercio entre China y México con Estados Unidos. Se han seleccionado 2 productos del Sistema Armonizado a cuatro dígitos para ilustrar lo que ha pasado en el comercio a partir de estos ejemplos:

- Numero 8528: Receptores de televisores, monitores de video y proyectores.

- Numero 6104: Traje y vestido, falda etc. de punto o ganchillo de mujeres y chicas.

El motivo para elegir estos dos productos es que, primero, son productos donde las exportaciones de México y China a Estados Unidos han crecido mucho. En segundo lugar, el producto 8528 (televisiones y monitores de video) se ha seleccionado porque la idea original de la tesis era analizar las inversiones japonesas en México en la industria de televisores y su exportación a Estados Unidos. Además, es un sector con una muy importante presencia de inversión extranjera en México. El otro producto forma parte de la industria textil. En el mercado de Estados Unidos, el cambio de origen en esta industria es muy destacado desde México hasta China desde la entrada de este último país en la OMC. Este cambio no se puede explicar únicamente con la diferencia de costes de mano de obra entre China y México.

\section{III-2.4.1. Comercio de Sistema Armonizado en la Partida 8528: Receptores de televisores, monitores de video y proyectores.}

Este epígrafe forma parte del capítulo 85 (material eléctrico y electrónico) que es uno de los principales sectores por su contribución al saldo de China y México. Son sectores donde las exportaciones han crecido mucho en los últimos 25 años (Gráfico III2.6). 
Gráfico III-2.4. Índice de Contribución al Saldo de China en su comercio con Estados Unidos, 1991-2015

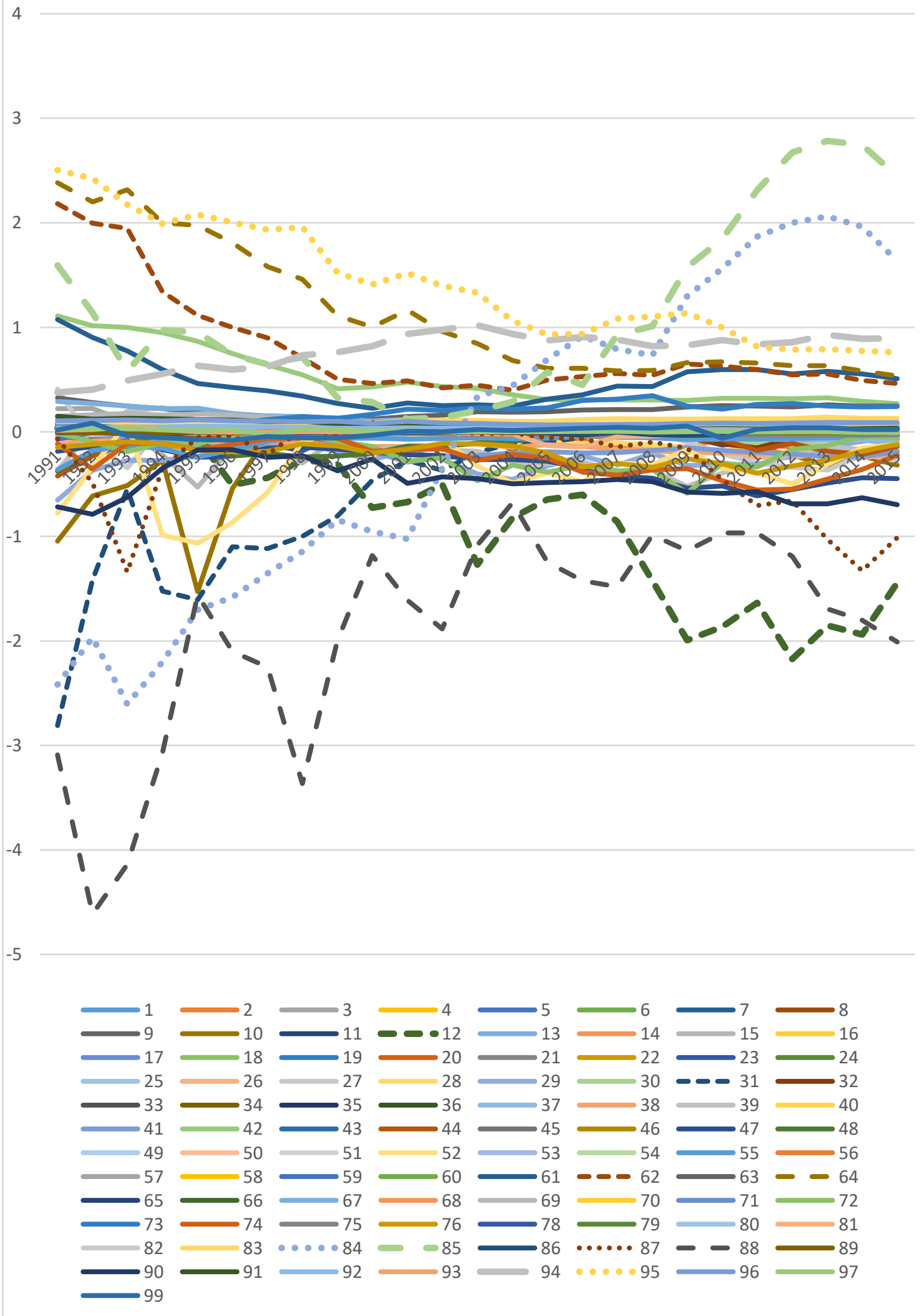

Fuente. Elaboración propia según COMTRADE, Naciones Unidas, disponible en http://comtrade.un.org/data/, fecha de consulta: 10/12/2016. 
Gráfico III-2.5. Índice de Contribución al Saldo de México en su comercio con Estados Unidos, 1991-2015

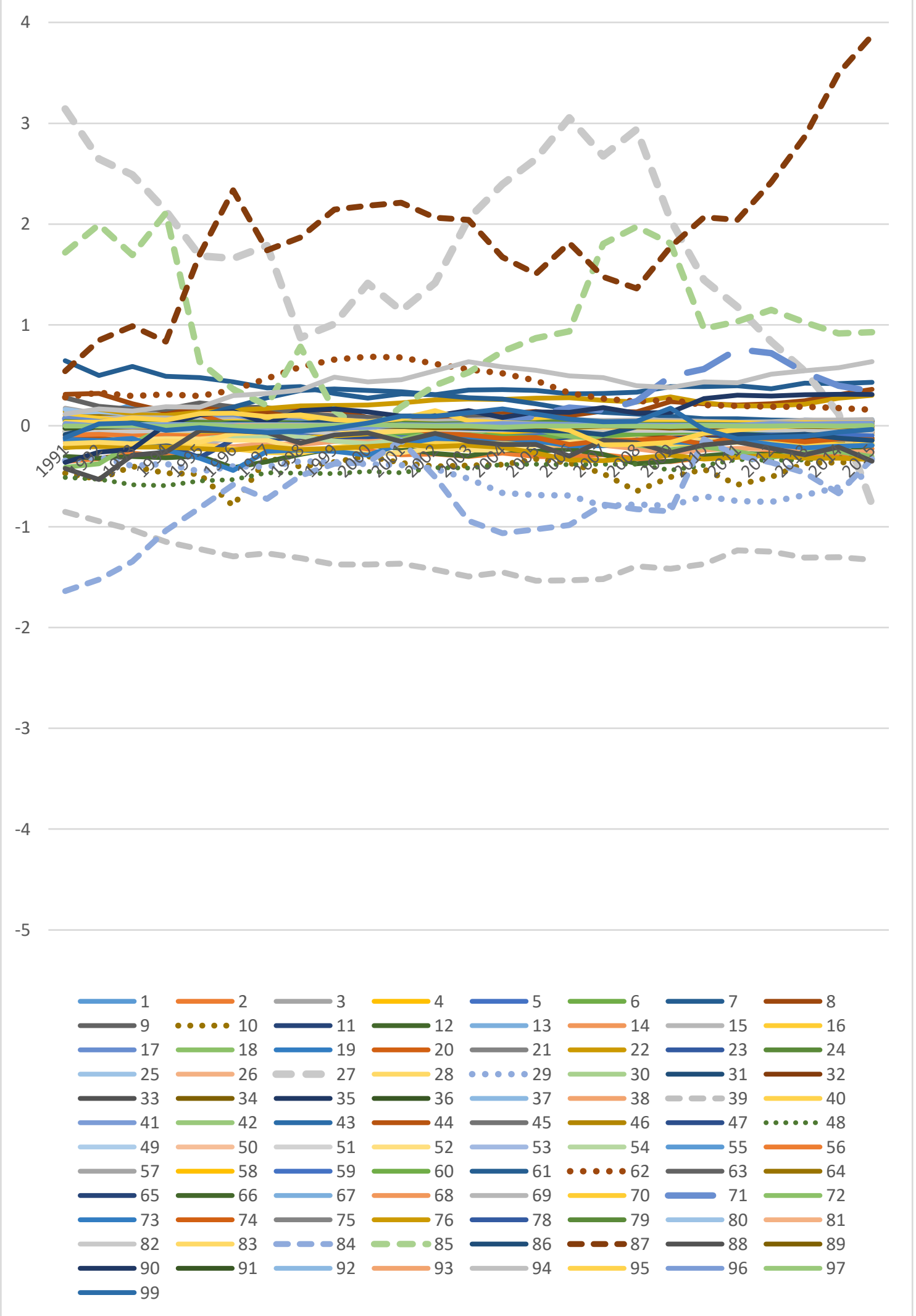

Fuente. Elaboración propia según COMTRADE, Naciones Unidas, disponible en http://comtrade.un.org/data/, fecha de consulta: 10/12/2016. 
Gráfico III-2.6. Exportaciones de México y China a Estados Unidos, capítulo 85. 19912015 (En miles de millones de dólares)

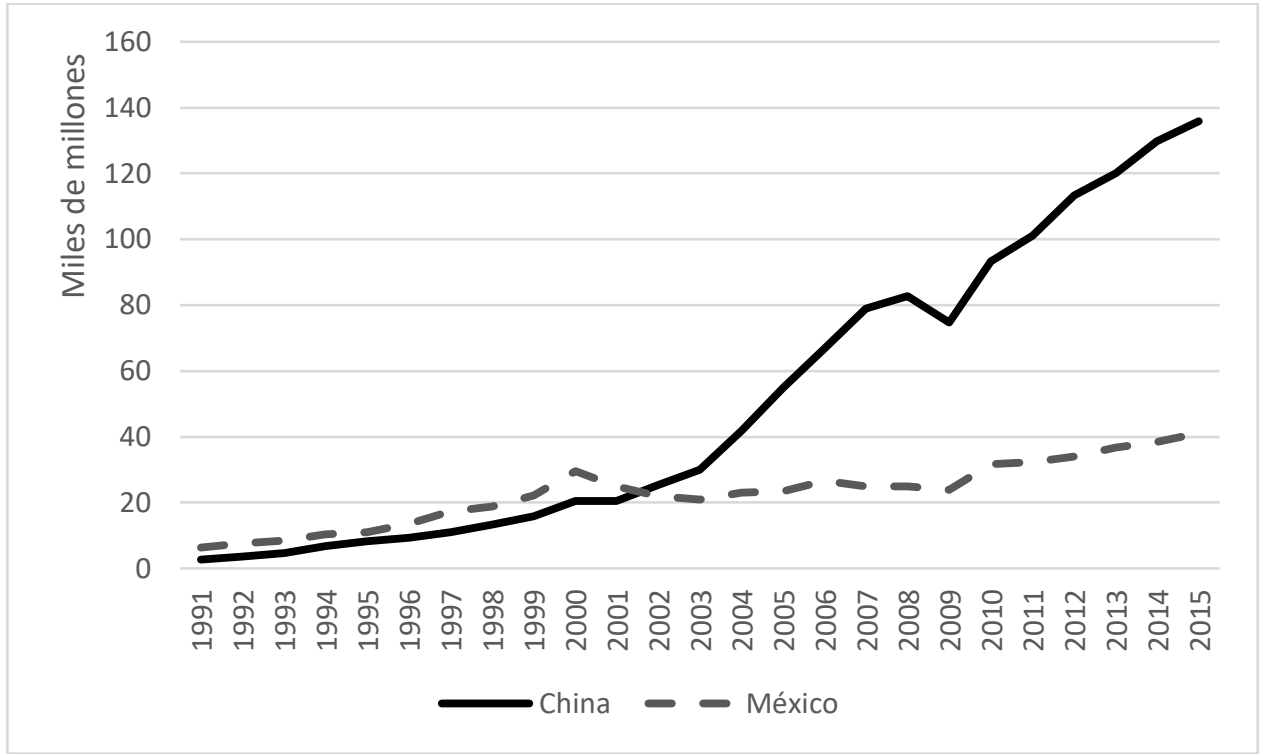

Fuente. Elaboración propia según COMTRADE, Naciones Unidas, disponible en http://comtrade.un.org/data/, fecha de consulta: 10/12/2016.

En los años 90 México tenía más cuota de mercado que China en el mercado de Estados Unidos gracias al TLCAN, pero desde la entrada de China en la OMC mejoran las condiciones de acceso de las exportaciones chinas al mercado estadounidense y llegan a más que triplicar las de México. El Saldo Comercial Relativo de China siempre ha sido más alto en este capítulo que el de México (Gráfico III-2.7), es decir, las ventajas de China estaban ya presentes antes de la entrada en la OMC, pero al obtener un acceso más fácil se manifiestan en un crecimiento muy fuerte de sus exportaciones.

El capítulo 85 constituye una parte importante de las exportaciones de ambos países a Estados Unidos, como hemos visto en el epígrafe 1 de este capítulo, y tiene en ambos países una contribución muy positiva al saldo comercial (Gráfico III-2.8). Debe tenerse en cuenta que es un capítulo que incluye muchos productos y donde la innovación es constante y, con ella, la dinámica de competencia en el mercado mundial, siendo un sector donde las cadenas de valor son particularmente importantes. 
Gráfico III-2.7. Saldo Comercial Relativo de México y China con Estados Unidos, capítulo 85, 1991-2015

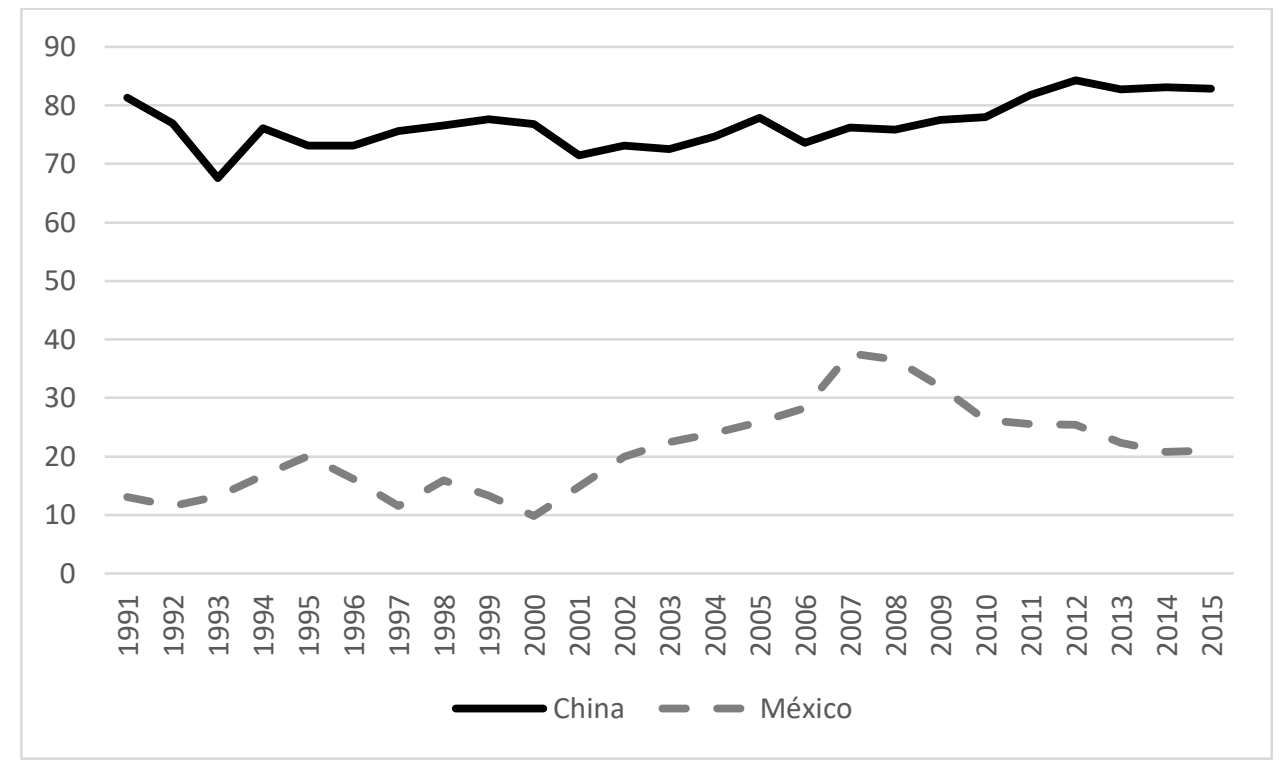

Fuente. Elaboración propia según COMTRADE, Naciones Unidas, disponible en http://comtrade.un.org/data/, fecha de consulta: 10/12/2016.

Gráfico III-2.8. Índice de Contribución al Saldo en el comercio de México y China con Estados Unidos, capítulo 85, 1991-2015

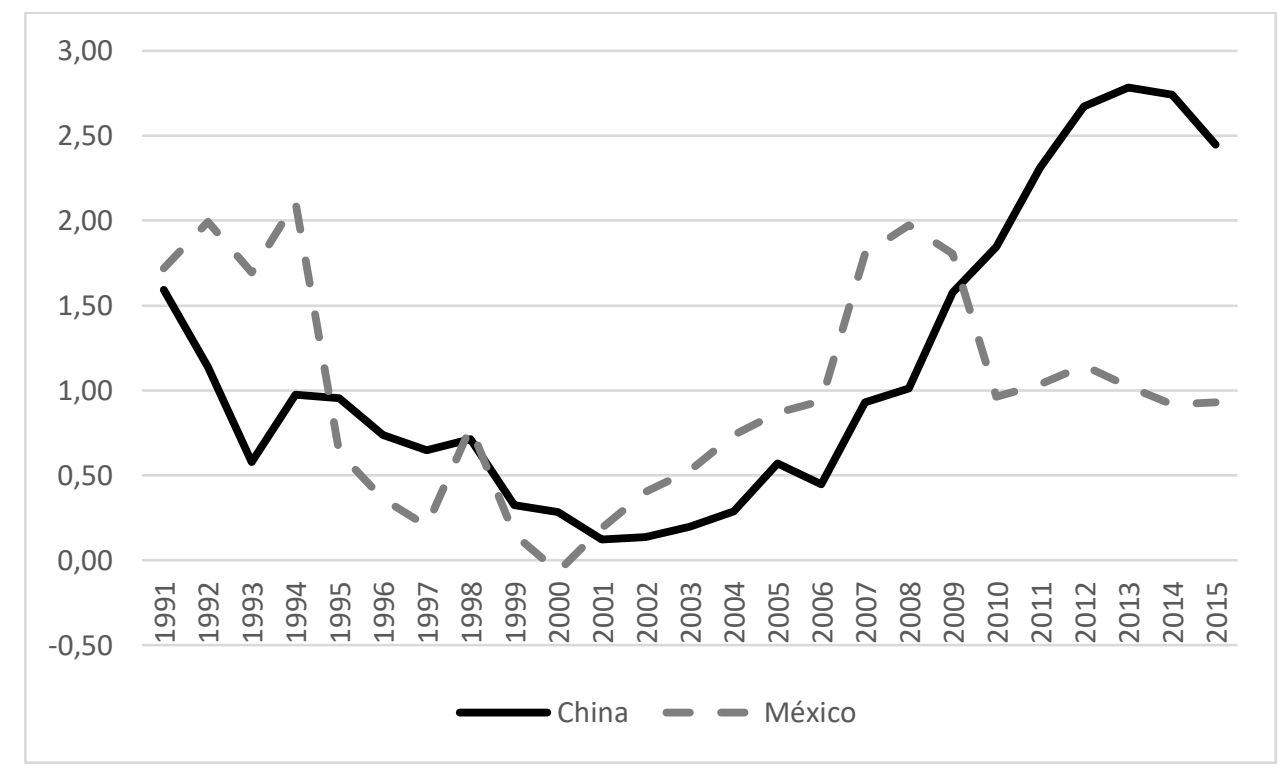

Fuente. Elaboración propia según COMTRADE, Naciones Unidas, disponible en http://comtrade.un.org/data/, fecha de consulta: 10/12/2016.

Dentro de este capítulo 85 se encuentra el epígrafe que vamos a analizar con más detenimiento, el 8528. Primero, vemos la situación del comercio de los productos en esta categoría de México y China con Estados Unidos. Los Gráficos III-2.9. y III-2.10 recogen 
el comercio de China y México con Estados Unidos en el epígrafe 8528. En los dos gráficos la escala es la misma para permitir la comparación de los flujos de ambos países.

Gráfico III-2.9. China: comercio con Estados Unidos, Partida 8528, 1992-2014 (En miles de millones de dólares)

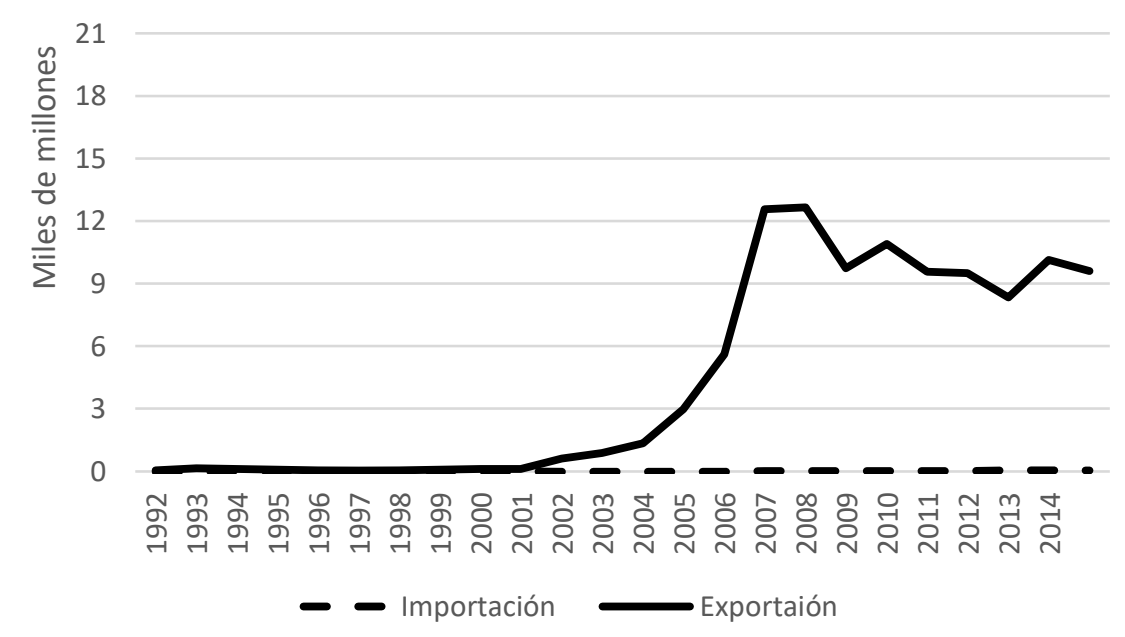

Fuente. Elaboración propia, según COMTRADE, Naciones Unidas, disponible en http://comtrade.un.org/data/, fecha de consulta: 10/12/2016.

Gráfico III-2.10. México: comercio con Estados Unidos, Partida 8528, 1992-2014 (En miles de millones de dólares)

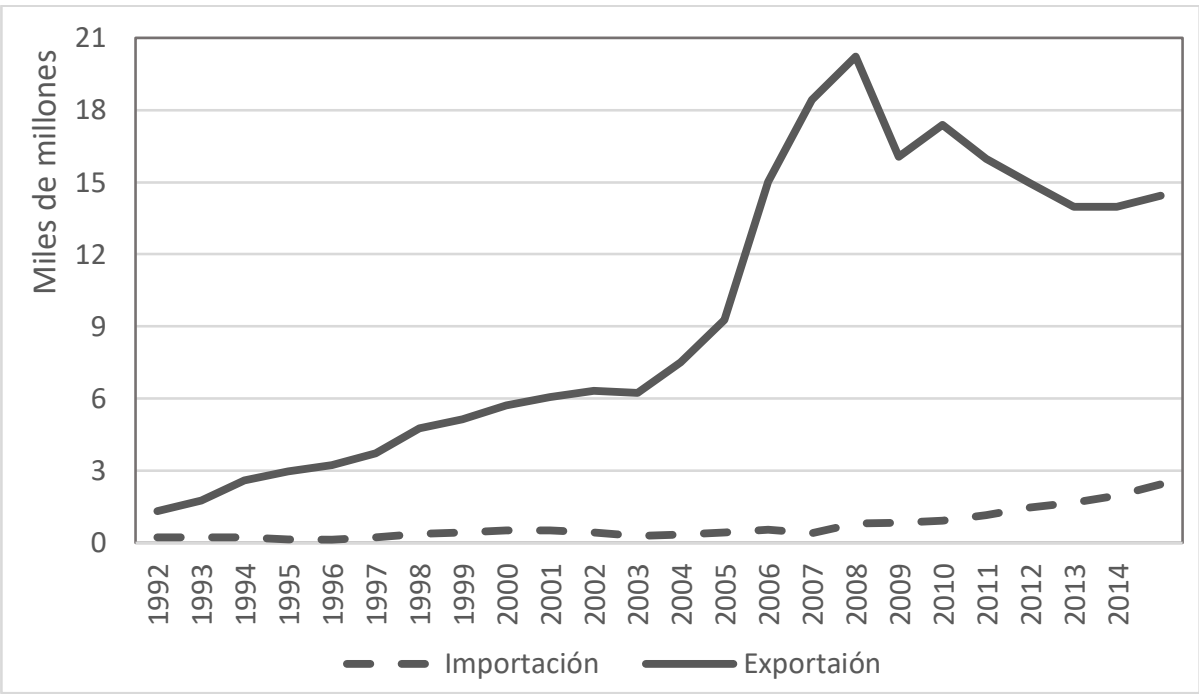

Fuente. Elaboracuón propia, según COMTRADE, Naciones Unidas, disponible en http://comtrade.un.org/data/, fecha de consulta: 10/12/2016.

Según el Gráfico III-2.9, el comercio de China con Estados Unidos en esta categoría tiene muchas más exportaciones que importaciones. Esto significa que Estados Unidos tiene un déficit comercial con China. Su déficit empezó a aumentar durante 2001- 
2007, pero luego, se redujo. Además, las importaciones de China son muy pequeñas en comparación con sus exportaciones.

En el caso de México, en el Gráfico III-2.10, hay más exportaciones desde México que importaciones desde Estados Unidos. Esta induce, también, a que Estados Unidos tenga déficit comercial con México. El punto de mayor exportación de México fue en el año 2008 y luego, su exportación bajó, tras la crisis de Estados Unidos. Estas crecientes exportaciones de México en el periodo 1992-2008 están relacionadas con la llegada de inversión extranjera direcata (IDE) a México y, dentro de ésta, de los fabricantes japoneses (Panasonic, Sony, Sanyo, Sharp...). Se nota que los puntos de mayor exportación de ambos países a Estados Unidos eran del mismo año, el 2007, justo antes de que la crisis de Lehman Brothers afectara a la economía de Estados Unidos. Además, lo más importante es que el volumen del comercio de México en este sector es más alto que el de China.

Se nota que las diferencias de los saldos de ambos países han aumentado desde 1994 hasta 2007. Ahora, necesitamos recordar qué ocurrió en esta década. El primer factor viene de la situación del comercio de México y China. En el caso de México, el TLCAN entró en vigor en 1993. Este Tratado tenía como efecto promocionar el comercio entre Estados Unidos, México y Canadá. Al recordar el Gráfico III-1.1 que recogía el comercio de México, se nota que las exportaciones de México al mundo aumentaron, mientras su exportación a Estados Unidos, también, aumentó, pues Estados Unidos fue el principal mercado para este crecimiento. Al contrario, como vimos en el Gráfico III-1.5, sobre el comercio de China, las exportaciones chinas al mundo empezaron a aumentar, pero su exportación a Estados Unidos no aumentó como sus exportaciones al mundo. Es decir, en el mercado de Estados Unidos en esta década, el comercio de México estaba más activo que el comercio de China. Este "Comercio" está incluyendo importaciones, también. Gracias a estar en vigor el TLCAN, México tiene la oportunidad de importar más fácilmente desde Estados Unidos.

El segundo motivo se puede encontrar en el gráfico anterior III-1.3 sobre el peso de Estados Unidos en el comercio de México y según ese gráfico, se puede encontrar que desde 1994, la diferencia de peso entre importaciones y exportaciones mexicanas desde y hacia Estados Unidos se empieza a ampliar, siendo más importante el peso de las exportaciones que el de las importaciones. 
Ahora, volvemos al epígrafe 8528 y el Gráfico III-2.11 refleja la Ventaja Comparativa Revelada (VCR) de China y México en el mercado de Estados Unidos. Las cifras en este Gráfico indican la existencia de VCR. Según el Gráfico III-2.11, en este producto, tanto China como México tienen cifras positivas. Además, la cifra de ambos países está, muy cerca de 100. Esta condición significa que, en estos tipos de productos, Estados Unidos depende altamente de las importaciones desde China y México. Además, China y México tienen claras ventajas para exportar al mercado estadounidense. En este mercado, los productos chinos tienen más ventaja que los productos mexicanos desde el año 1999.

\section{Gráfico III-2.11 Ventaja Comparativa Revelada de Estados Unidos con China y México, Partida 8528, 1992-2015}

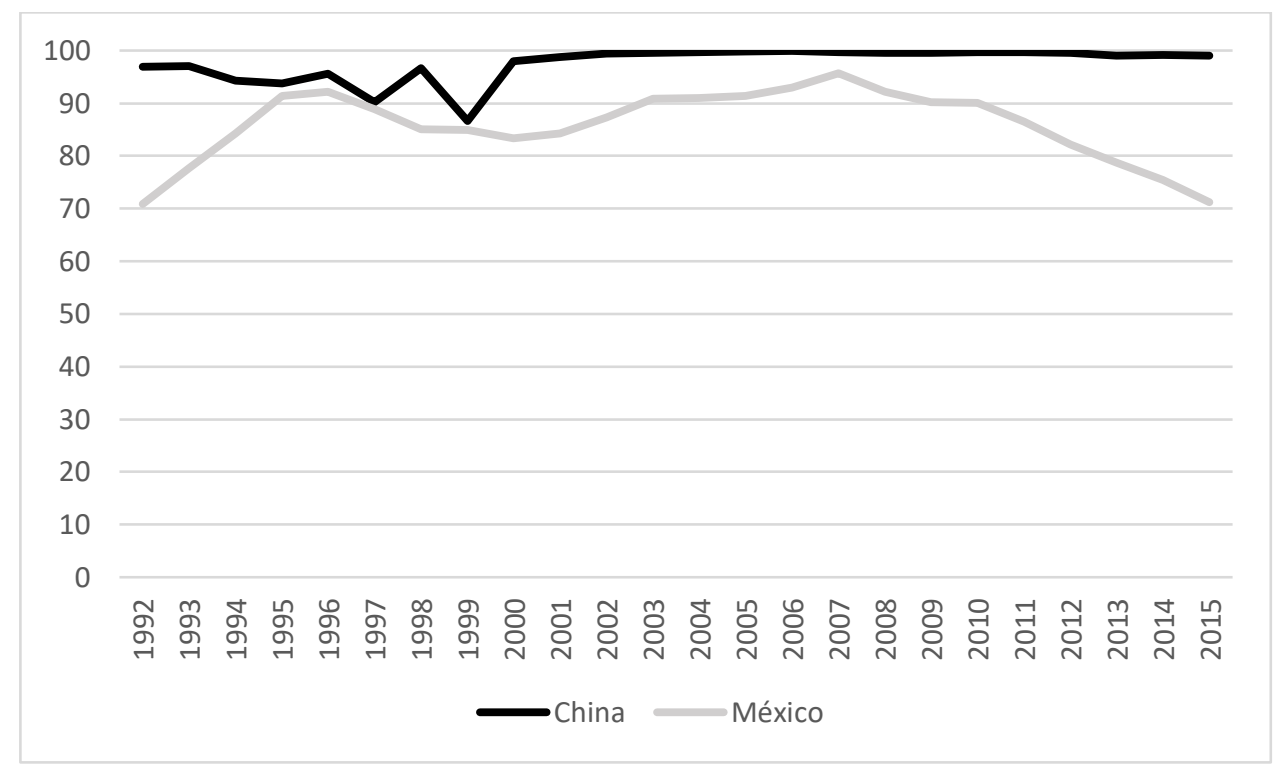

Fuente. Elaboración propia, según COMTRADE, Naciones Unidas, disponible en http://comtrade.un.org/data/, fecha de consulta: 11/12/2016.

Se nota que la ventaja de China no tiene tanto cambio durante 20 años, mientras la ventaja de México tiene su cifra entre desde 95,8 en 1994 hasta 70,7 al final del periodo. Ahora, se analiza qué factor produce este cambio de la ventaja de México. Principalmente, la ventaja comparativa de México al mercado estadounidense es su localización. La localización cercana induce un bajo coste de transporte. Es decir, una ventaja básica mexicana es el bajo coste de transporte. Sin embargo, el coste de transporte no solo depende de sus distancias al mercado, sino también del coste del combustible. Especialmente, muchos productos mexicanos se exportan a Estados Unidos en camión. El precio del combustible cambió frecuentemente. Por eso, el precio del combustible afecta a la ventaja de México y su cifra cambió frecuentemente. Al contrario, la mejor 
ventaja china es el bajo coste de la mano de obra abundante. Teóricamente, si hay más demanda de la mano de obra, su coste aumenta. Sin embargo, hay abundante oferta de mano de obra en China, y su coste no aumentó inmediatamente. Por eso, la ventaja de China no cambia tanto como la mexicana.

\section{III-2.4.2. Comercio de Sistema Armonizado en la Partida 6104: traje, vestido y falda etc. de punto o ganchillo, para mujeres y chicas.}

En primer lugar, se presenta la evolución del capítulo 61, correspondiente a ropa y complementos de vestir de punto. Es un capítulo también expresivo de lo ocurrido en los últimos años con la entrada de China en la OMC (Gráfico III-2.12) (DUSSEL PETERS y CÁRDENAS CASTRO, 2007).

Gráfico III-2.12. Exportaciones de México y China a Estados Unidos, capítulo 61, 19912015

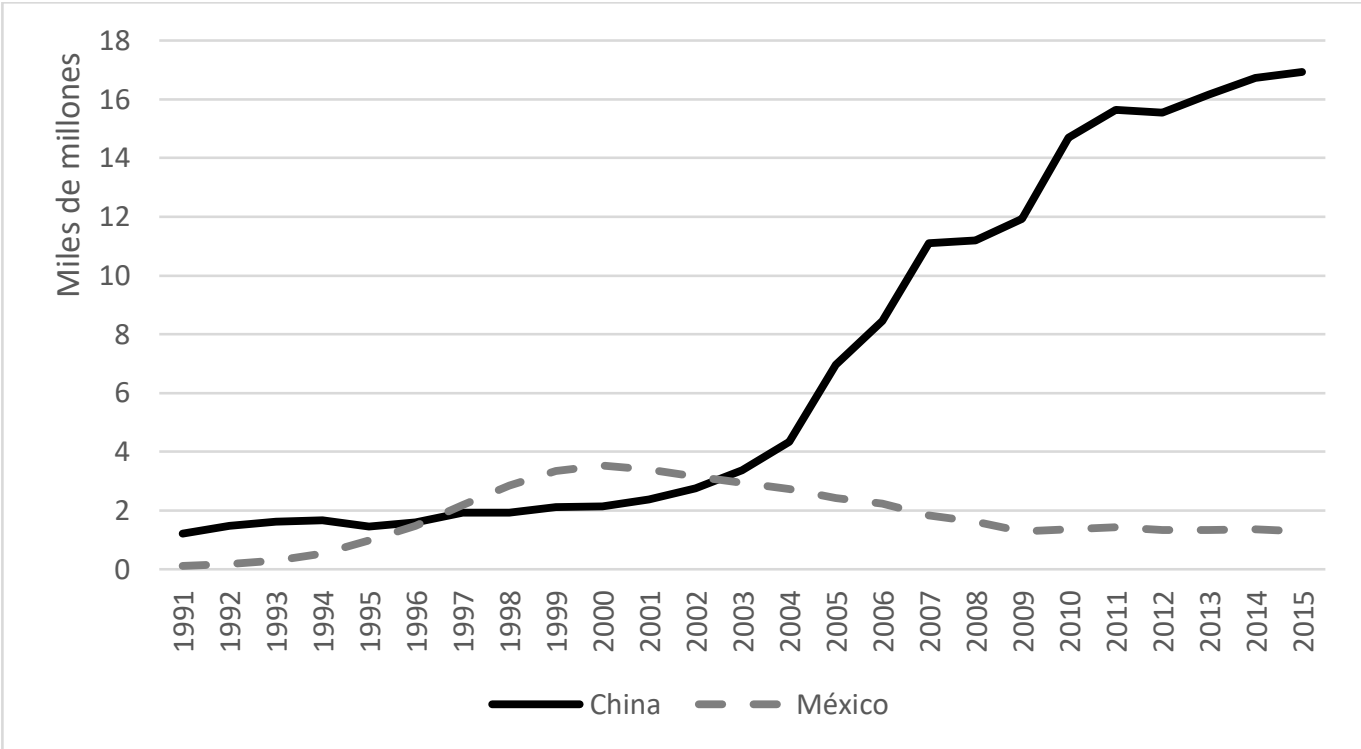

Fuente. Elaboración propia según COMTRADE, Naciones Unidas, disponible en http://comtrade.un.org/data/, fecha de consulta: 11/12/2016.

Al igual que lo que hemos visto en el Capítulo 85, en los años 90 México tenía más cuota de mercado que China en el mercado estadounidense gracias al TLCAN, pero desde la entrada de China en la OMC mejoran las condiciones de acceso de las exportaciones chinas al mercado de Estados Unidos y llegan multiplicar por 10 las de México. El Saldo Comercial Relativo de China siempre ha sido más alto en este capítulo que el de México (Gráfico III-2.13), es decir, las ventajas de China estaban ya presentes 
antes de la entrada en la OMC, pero al obtener un acceso más fácil se manifiestan en un crecimiento muy fuerte, casi exponencial, de sus exportaciones.

\section{Gráfico III-2.13. Saldo Comercial Relativo de México y China con Estados Unidos, capítulo 85, 1991-2015}

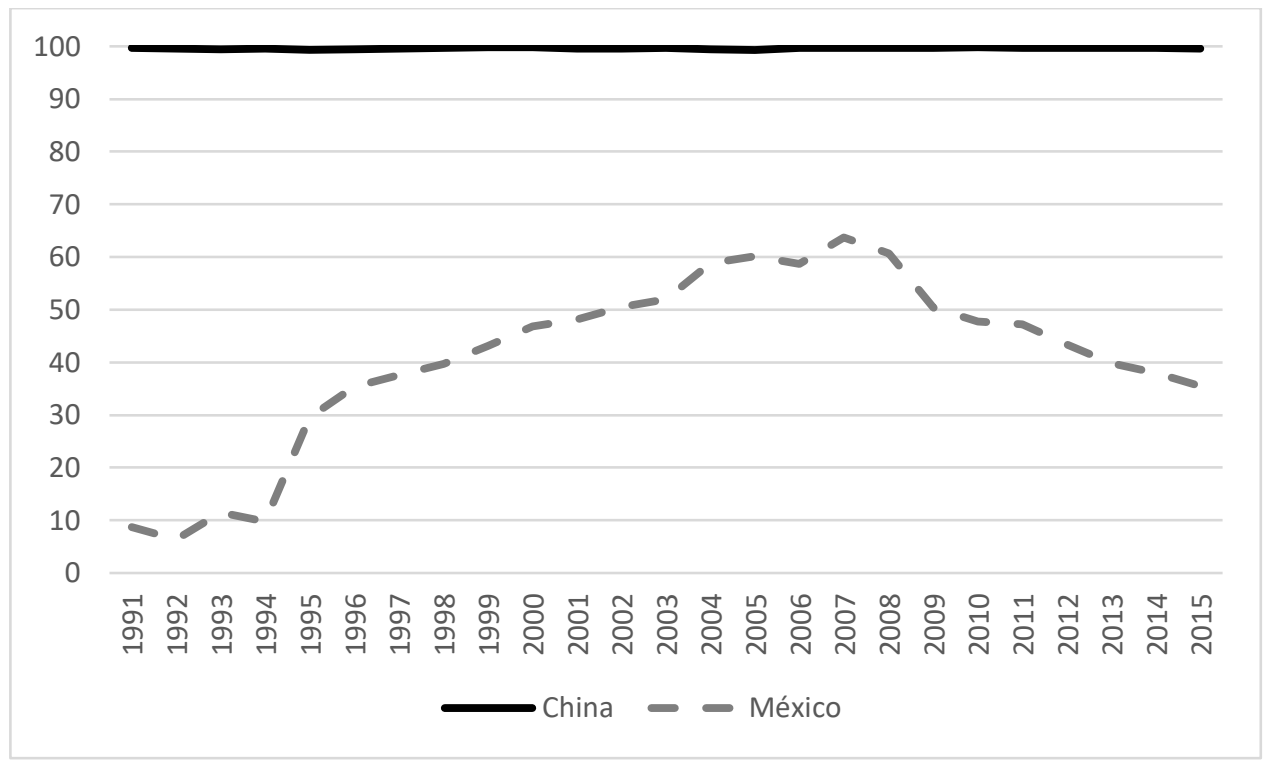

Fuente. Elaboración propia según COMTRADE, Naciones Unidas, disponible en http://comtrade.un.org/data/, fecha de consulta: 11/12/2016.

El capítulo 61 no constituye una parte tan importante de las exportaciones de ambos países a Estados Unidos como en el capítulo 85, pero tiene en ambos países una contribución positiva al saldo comercial (Gráfico III-2.14), aunque en el caso mexicano esta contribución se hizo más grande en la segunda mitad de los años 90 para posteriormente irse diluyendo y recuperar algo de protagonismo en la última década. Para China, era uno de los productos más importantes antes de la entrada en la OMC, posteriormente perdió peso en la formación del saldo, aunque en los últimos años su contribución ha sido positiva. 
Gráfico III-2.14. Índice de Contribución al Saldo en el comercio de México y China con Estados Unidos, capítulo 61, 1991-2015

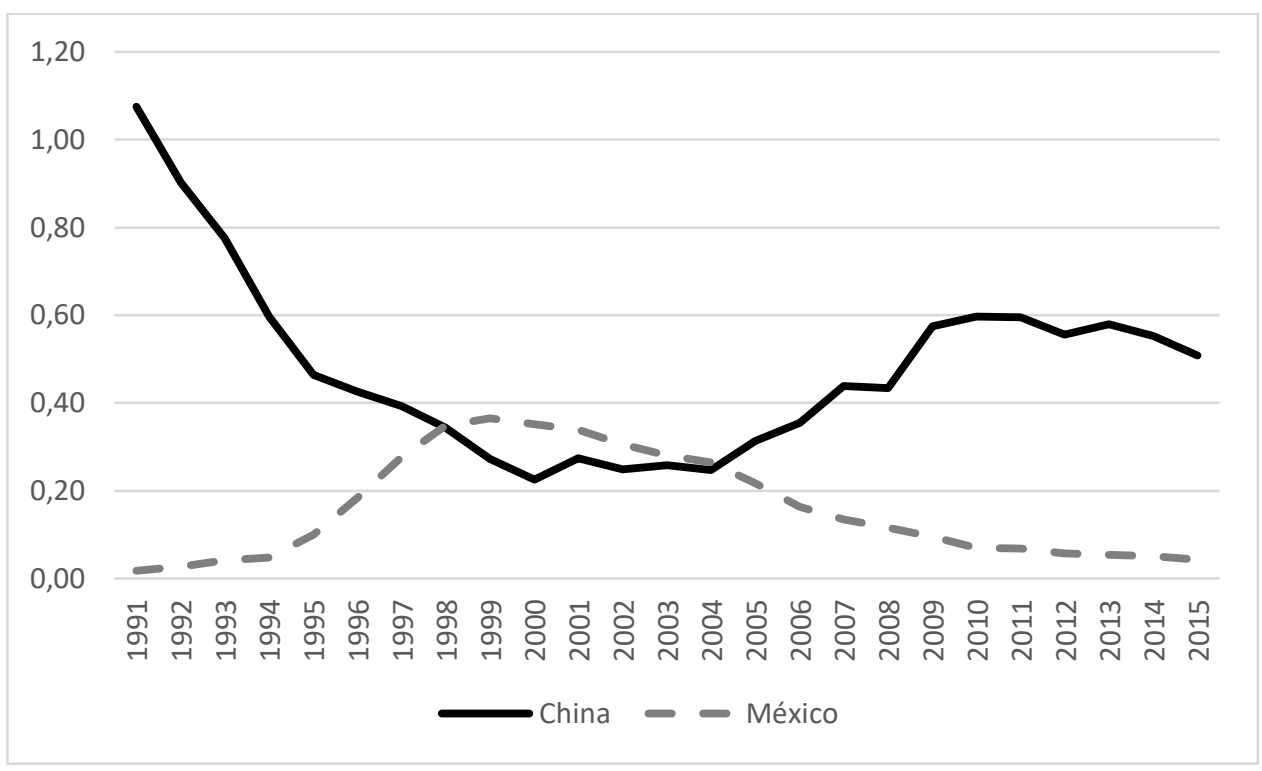

Fuente. Elaboración propia según COMTRADE, Naciones Unidas, disponible en http://comtrade.un.org/data/, fecha de consulta: 11/12/2016.

A continuación, se analiza el comercio de China y México en la industria de las ropas de punto para mujeres y chicas en el mercado de Estados Unidos, la partida 6104 que forma parte del capítulo 61. En primer lugar, los Gráficos III-2.15 y III-2.16 recogen el comercio de China y México con Estados Unidos en esta partida. Ambos gráficos tienen la misma escala en los ejes para permitir la comparación entre los flujos de Estados Unidos con los dos países. El Gráfico III-2.15 es sobre exportación e importación de China con Estados Unidos. Su importación desde Estados Unidos es de muy bajo nivel durante 20 años, mientras su exportación a Estados Unidos ha aumentado muy marcadamente desde el año 2003.

El Gráfico III-2.16 es sobre exportación e importación de México. Se nota que hay más exportación que importación. Además, su importación y su exportación han aumentado hasta el año 2000, pero se han reducido después.

La diferencia más importante es la diferencia entre el volumen del comercio entre los dos países. Especialmente, respecto a sus volúmenes de exportación en 2014, el volumen de China es casi el doble del volumen de México. Es decir, el comercio chino ha aumentado muy rápidamente en la última década y su volumen es más grande que el de México, de hecho, lo multiplica por más de 10 en 2014. 
Gráfico III-2.15. China: comercio con Estados Unidos, Partida 6104, 1992-2014 (En miles de millones)

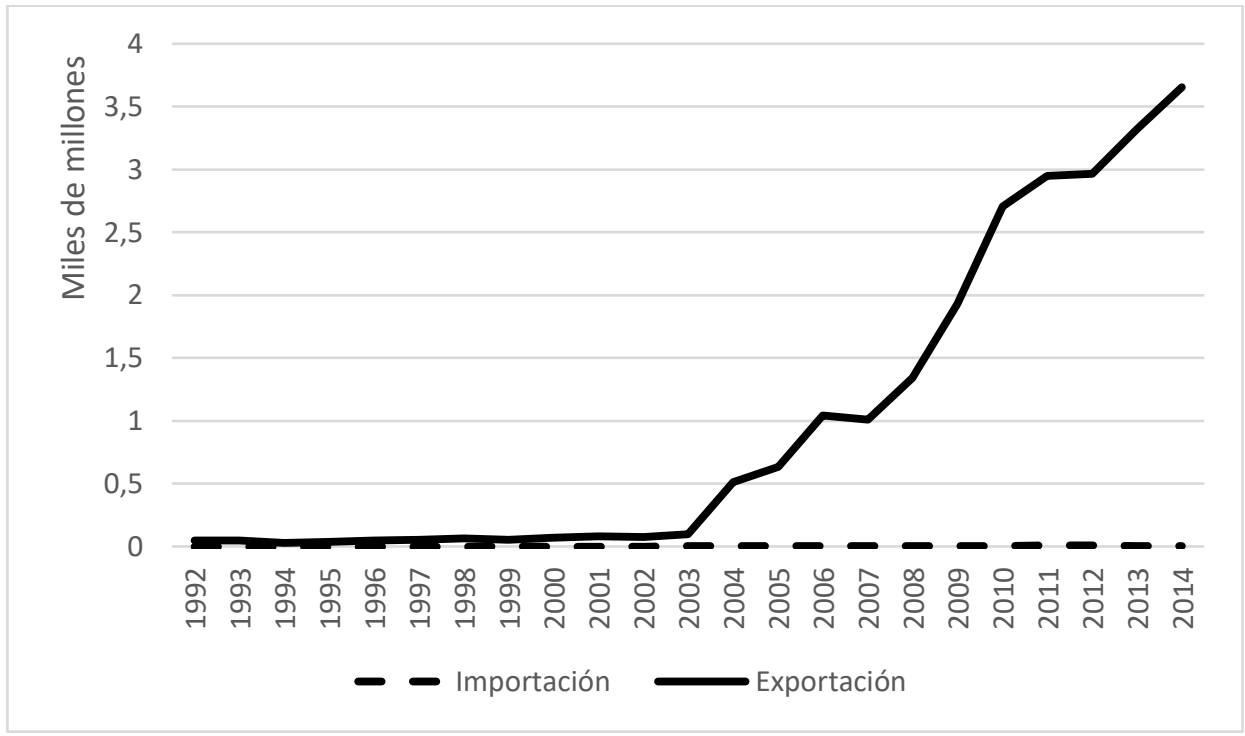

Fuente. Elaboración propia según COMTRADE, Naciones Unidas, disponible en http://comtrade.un.org/data/, fecha de consulta: 11/12/2016.

Gráfico III-2.16. México: comercio con Estados Unidos, Partida 6104, 1992-2014 (En miles de millones)

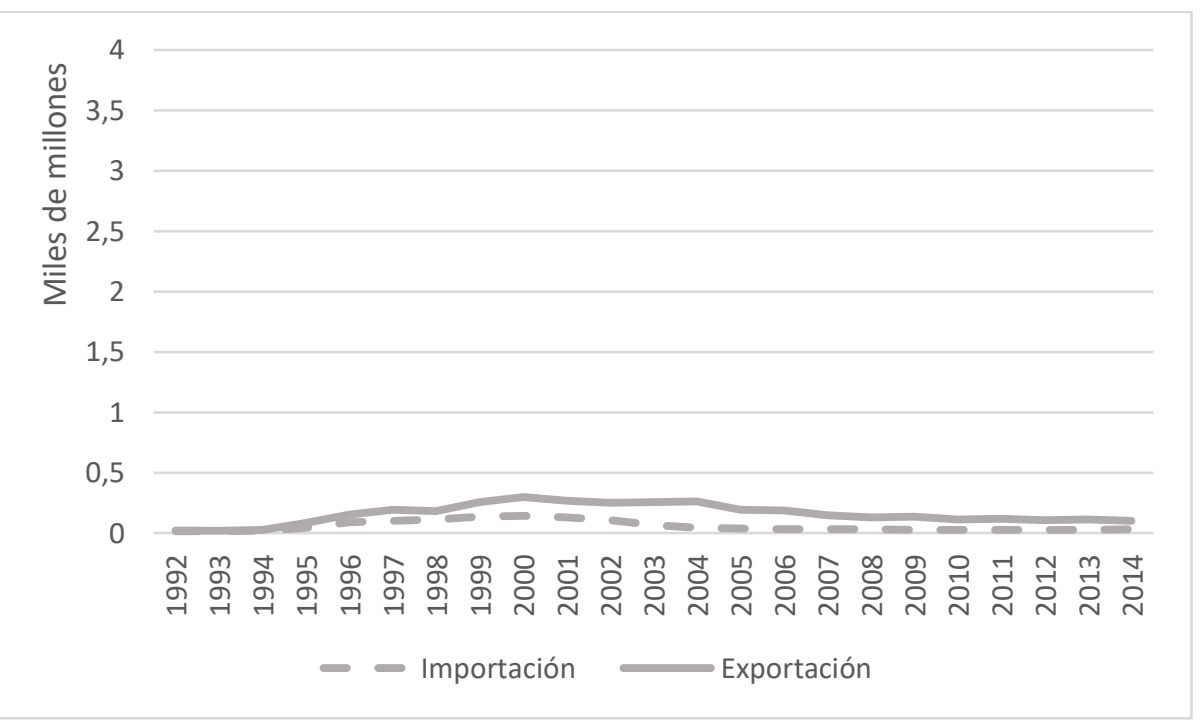

Fuente. Elaboración propia según COMTRADE, Naciones Unidas, disponible en http://comtrade.un.org/data/, fecha de consulta: 11/12/2016.

Según el Gráfico III-2.17 que recoge el saldo de Estados Unidos con China y México en la partida 6104, desde el punto de la vista de Estados Unidos, se nota que mientras el saldo negativo con México se amplía tras el TLCAN pero empieza a disminuir 
desde la entrada de China en la OMC hasta hacerse casi 0, mientras que el saldo negativo de Estados Unidos con China no deja de crecer. Esto significa que en el caso de México, su exportación e importación con Estados Unidos son casi iguales, mientras que en el caso de China, sus exportaciones a Estados Unidos han aumentado exponencialmente en la última década, como vimos en el Gráfico III-2.15.

\section{Gráfico III-2.17. Saldo de Estados Unidos con China y México, Partida 6104, 1991-2014} (En millones de dólares)

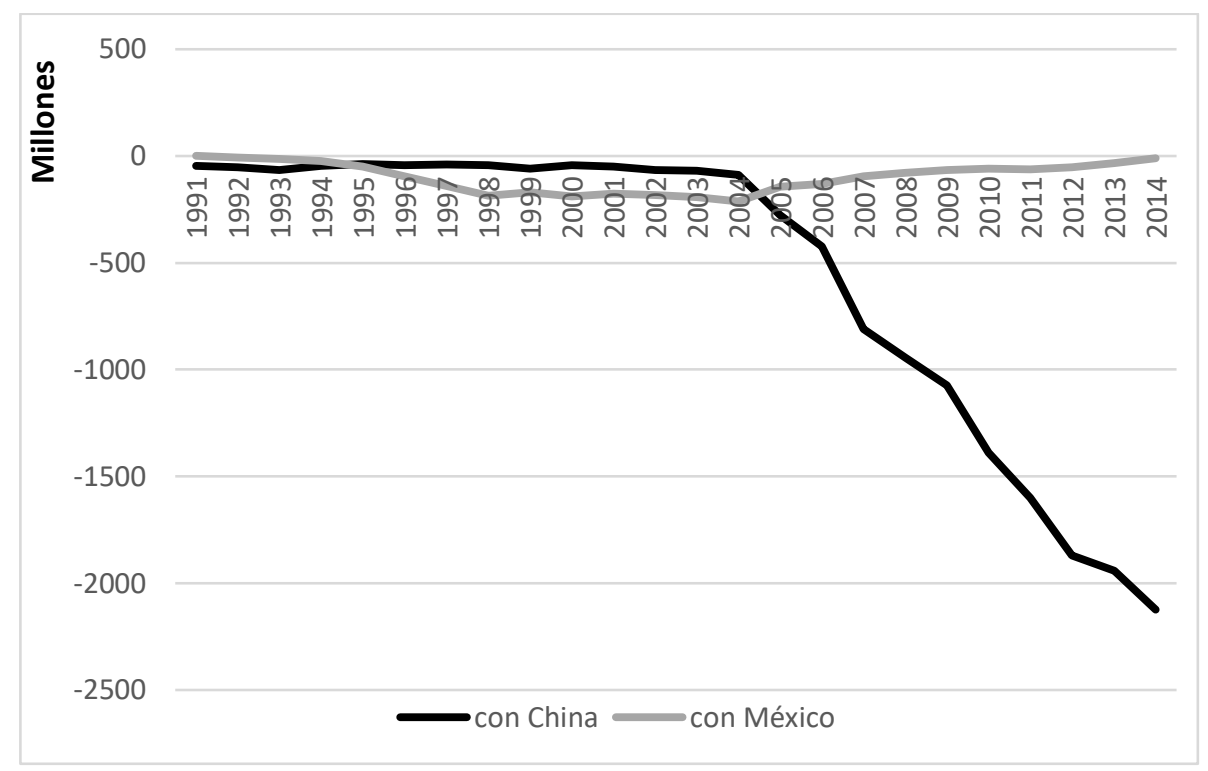

Fuente. Elaboración propia según COMTRADE, Naciones Unidas, disponible en http://comtrade.un.org/data/, fecha de consulta: 11/12/2016.

Ahora, podemos ver la Ventaja Comercial Revelada en el Gráfico III-2.18, los valores de la VCR de ambos países son positivos: esto significa que el mercado de Estados Unidos de este producto depende de la importación desde China y México. Especialmente, se nota que la ventaja de China es mayor que la de México, cercana a 100. Esto significa que Estados Unidos no exporta a China, o sea, que China no importa desde Estados Unidos. Esto da lugar a que Estados Unidos dependa más de las exportaciones chinas que de las exportaciones mexicanas.

Como otra característica interesante, el VCR de México ha aumentado durante 1991-2003 y se ha reducido durante 2004-2014. En el Gráfico III-2.16, se puede notar que la exportación de México a Estados Unidos empieza a reducirse, en gran medida por la entrada de China a la OMC y la creciente presencia de productos chinos en su mercado. Esta reducción de comercio induce la bajada de la VCR de México. 


\section{Gráfico III-2.18. Ventaja Comparativa Relevada de Estados Unidos con México y China, Partida 6104, 1993-2015}

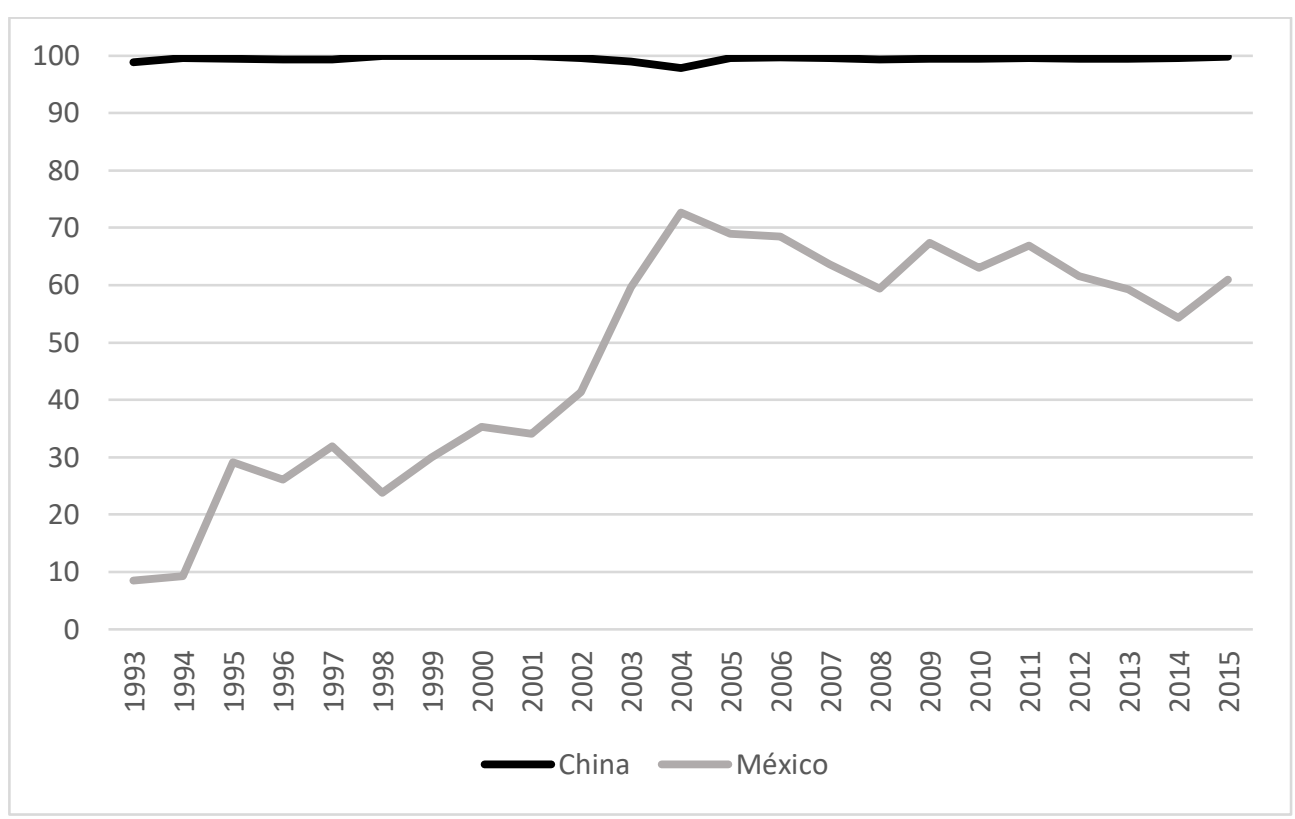

Fuente. Elaboración propia según COMTRADE, Naciones Unidas, disponible en http://comtrade.un.org/data/, fecha de consulta: 11/12/2016.

Por tanto, en la categoría 6104, la VCR de China no tiene apenas cambios, con valores muy cercanos a 100. Esto significa que los productos en la categoría 6104 son principalmente exportación desde China a Estados Unidos, mientras que no hay apenas exportaciones de Estados Unidos a China. En el caso de México, comienza no teniendo ventaja en este sector y su ventaja es creciente hasta 2004, a partir de ese momento su ventaja va cayendo hasta casi desaparecer en 2014.

En resumen, en relación al comercio en la partida 6104, hay cambios importantes en los años 2000, en los casos de ambos países. Especialmente, la bajada de la exportación de México y el crecimiento exponencial de las exportaciones de China desde su entrada en la OMC.

Los principales resultados, a través de estos análisis en las dos partidas (8528 y 6104) del Sistema Armonizado son los siguientes:

1) Sobre los productos de televisores (SA 8528): Las tendencias generales de ambos países son muy similares, aunque la exportación de México es todavía mayor que la de China. La VCR de China y México no tiene tantas diferencias, aunque la de China está más cercana al 100 que la de México. Es decir, nuevamente, en esta categoría, 
los productos chinos son rivales directos de los productos mexicanos en el mercado de Estados Unidos.

2) Sobre los productos de ropa de punto para mujeres y chicas (SA 6104): Principalmente, Estados Unidos es un gran importador de los productos en esta categoría desde ambos países. Hasta 2003, los saldos de Estados Unidos con ambos países no tienen diferencias y además, la importación china desde Estados Unidos está en un nivel muy bajo. Sin embargo, desde 2004, hay cambio en todos los gráficos. La VCR de México con Estados Unidos ha crecido hasta 2004, pero, después de 2005, ha ido casi desapareciendo. Su subida hasta 2004 viene de la entrada en vigor del TLCAN. El factor más importante que cambió esta tendencia fue el aumento exponencial de las exportaciones chinas en 2004 impulsadas por su entrada en la OMC.

Los productos que se han analizado en este capítulo son interesantes ilustraciones del efecto de los cambios institucionales como la firma del TLCAN y la entrada de China en la OMC en las importaciones de Estados Unidos desde ambos países. 


\section{III-3. Comercio Intra-Industrial en el comercio de México y China con Estados Unidos}

En esta sección, se analiza el comercio intra-industrial (CII) de México y China con Estados Unidos. Hay algunas ventajas al conocer el porcentaje de CII: la primera es que la mayor parte del CII se puede encontrar dentro de una cadena de producción. Esta "cadena de producción" es un sistema de empresas que comercian para aumentar o mantener los valores de sus productos. Además, actualmente, la mayor parte del comercio es entre empresas, especialmente, empresas internacionales, ya sea dentro de las empresas (comercio intra-empresa) o entre empresas. Es decir, analizar el CII significa acercarse a conocer más las actividades de las empresas. La segunda ventaja es que las naciones comercialmente más importantes son similares en tecnología y recursos. A menudo no hay ventaja comparativa en una industria basada en factores de producción tal como la entendían Heckscher-Ohlin y, por tanto, gran parte del comercio internacional toma la forma de intercambios en ambos sentidos dentro de las industrias, más que de especialización industrial, inducida por la ventaja comparativa (KRUGMAN y OBSTELD, 2006, p.135). La última ventaja es que, el comercio intra-industrial es un motivo importante de aumento de la variedad de productos. Como analizaremos a continuación, en los últimos años, el número de productos que se comercian está aumentando y las preferencias de los consumidores son variadas. El comercio intraindustrial es una manera de satisfacer las demandas de los consumidores y aumentar el beneficio de las empresas que comercian.

Sin embargo, antes de empezar a analizar, tenemos que recordar qué es el comercio intra-industrial que ya hemos presentado en el Capítulo I. Según KRUGMAN y OBSTFELD (2006, p. 137), el comercio intra-industrial "consiste en intercambios de bienes en doble sentido dentro de las clasificaciones industriales estándar."

En esta sección, usamos esta definición y como "clasificaciones industriales estándar”, usamos el Sistema Armonizado (Harmonized System), como lo hemos hecho en el capítulo anterior, aunque aquí vamos a trabajar con datos desagregados a 4 dígitos utilizando el índice de Grubel y Lloyd. Debe tenerse en cuenta que los cálculos son muy sensibles al nivel de desagregación utilizado. El nivel de 4 dígitos se suele considerar insuficiente, pues solo divide los flujos comerciales en 1259 productos, pero en este caso se ha considerado que puede ser suficiente para una dar una idea precisa de las diferencias entre el comercio de China y México con Estados Unidos. Debe tenerse en cuenta que se 
han utilizado más de 125.000 datos para realizar estos cálculos (1259 productos de dos países en dos flujos comerciales durante 25 años).

El índice para cada una de las partidas es el siguiente:

$I C I I_{i j}=\left[1-\frac{\left|X_{i j}-M_{i j}\right|}{\left(X_{i j}+M_{i j}\right)}\right]$

y para el comercio total de un país o de un sector sería:

$I C I I_{i}=\left[1-\frac{\sum_{j=1}^{n}\left|X_{i j}-M_{i j}\right|}{\sum_{j=1}^{n}\left(X_{i j}+M_{i j}\right)}\right]$

donde $\mathrm{X}_{\mathrm{ij}}$ y $\mathrm{M}_{\mathrm{ij}}$ son las exportaciones e importaciones del país i del producto j. Este índice varía entre 0 y 100 . Si se obtiene el valor cero, entonces se trata en su totalidad de comercio inter-industrial y si alcanza el valor 100, todo el comercio es intra-industrial. Cuando es cero significa que alguno de los flujos comerciales (bien las exportaciones o bien las importaciones) no existen, es decir, el país o sólo exporta el bien o sólo importa el bien, mientras que cuando es 100 es porque las exportaciones y las importaciones son iguales y, por tanto, todo el comercio se solapa.

Para analizar el CII, tenemos dos partes en este epígrafe. En la primera parte, analizamos la evolución general del CII de México y China con Estados Unidos para, a continuación, conocer el nivel de CII en cada una de las Secciones en las que se dividen los capítulos del Sistema Armonizado. Finalmente, se analiza el CII a 4 y 6 dígitos de algunos productos.

\section{III-3.1. Situación general del Comercio Intra-industrial de China y México con Estados Unidos.}

En esta parte, se analiza la situación general de CII de China y México con Estados Unidos, a través del análisis del porcentaje de CII en el total del comercio a partir de los datos del Gráfico III-3.1. 
Gráfico III-3.1. CII de China y México con Estados Unidos, 1991-2015

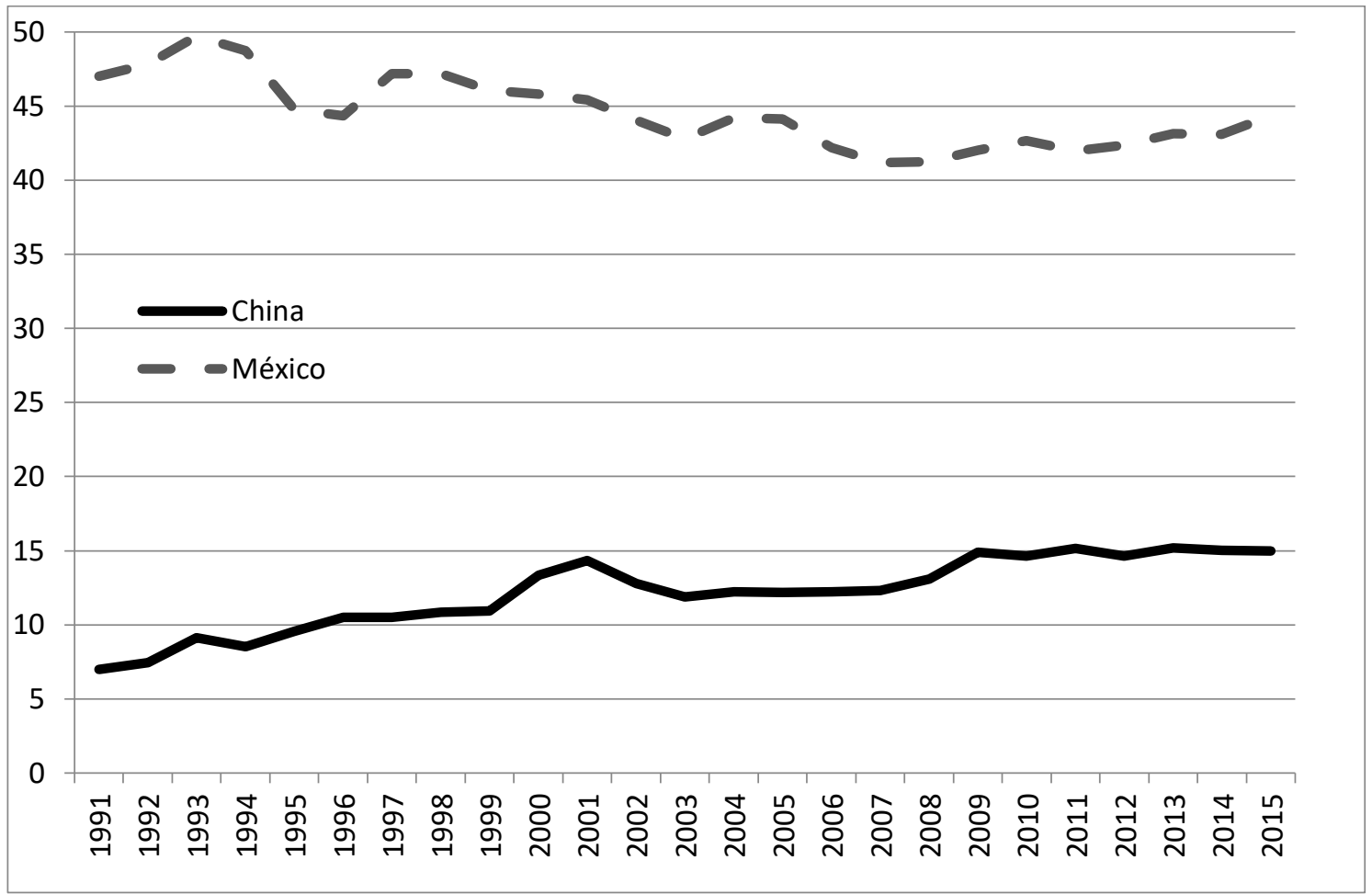

Fuente. Elaboración propia según COMTRADE, Naciones Unidas, disponible en http://comtrade.un.org/data/, fecha de consulta: 12/12/2016

El gráfico resulta revelador. La existencia de amplias ventajas comerciales reveladas de China que se han puesto de manifiesto en el epígrafe anterior indicaba que había poco margen para el CII entre China y Estados Unidos. Los cálculos realizados muestran un muy bajo nivel de CII entre China y Estados Unidos, aunque debe señalarse que se observa una tendencia creciente desde un 7 por 100 en 1991 hasta un 15 por 100 en 2015 que, posiblemente, tenga que ver con la subida del nivel de vida de China en los últimos 25 años y el que haya progresivamente más consumidores parecidos en China y Estados Unidos.

En el caso de México hemos visto ventajas comerciales menos marcadas que dejaban más espacio para la existencia de CII. En efecto, el Gráfico III-3.1 muestra valores para México entre los 50 y los 40 puntos porcentuales con una ligera tendencia decreciente en el largo plazo, aunque con importantes oscilaciones. Los motivos del alto CII de México y bajo CII de China son claros. Como se analiza en los capítulos anteriores, Estado Unidos es casi el único destino de la exportación y un origen importante de su importación para México (DUSSEL PETERS y CÁRDENAS CASTRO, 2011, p. 8). 
Además, durante 1981-1990, el CII de México aumentó muy rápidamente: del 27,9\% al 54,3\%. Esto es, en parte, un efecto del TLCAN. Sin embargo, para China, Estados Unidos es uno de sus destinos de exportación. La dependencia de China respecto a Estados Unidos es muy baja, en comparación con México. Por eso, también el CII de México es más alto. En el caso de México, se vio anteriormente que el peso de las importaciones de Estados Unidos en México baja rápidamente desde 2003, según el Gráfico III-I.3. Hay menos exportación de Estados Unidos a México en los últimos años. Por eso, el CII de México con Estados Unidos puede estar bajando, a medida que México se inserta más en las cadenas globales de valor (DUSSEL PETERS y CÁRDENAS CASTRO, 2011, p. 13).

Ahora, vamos a revisar los resultados de CII de cada Sección en que las se dividen los Capítulos del Sistema Armonizado. Son un total de 21 Secciones. Los Gráficos III3.2 y III-3.3 muestran respectivamente los niveles de CII en el comercio de China y México con Estados Unidos (el detalle puede consultarse en las Tablas Anexo III.6 y III.7). En la Tabla III-3.1 se presentan las Secciones en las que se clasifican los capítulos arancelarios del Sistema Armonizado. La clasificación de los capítulos de dos dígitos del Sistema Armonizado en Secciones se puede encontrar en la Tabla Anexo III.1 que presenta la división del Sistema Armonizado en Secciones y capítulos. Se ha mantenido la misma escala en los dos gráficos, lo que permite comprobar a simple vista que los niveles de CII son superiores en el caso de México que en el de China. Debe recordarse que la media de China al final del periodo es de solo $15 \%$ y la mayor parte de los sectores de China están entre 0 y $20 \%$, como no podía ser de otra manera pues el CII total es una media de los CII de cada uno de los sectores ponderada por su peso en el comercio total. Solo algunos destacan por encima de esa cifra: XXI (antigüedades y objetos de arte), XVIII (instrumentos de precisión) y VI (productos químicos). Algo por encima de la media se encuentran: I (productos del reino animal) y III (grasas y aceites animales o vegetales). Por el contrario, en el caso mexicano, la media se sitúa en torno al $45 \%$ y la variabilidad es mucho mayor. Entre los sectores con mayor CII destacan: XXI (antigüedades y objetos de arte), XVIII (instrumentos de precisión), XVII (vehículos), XVI (maquinaria eléctrica y mecánica), XIII (cerámica), VIII (cuero y piel) y XV (metales y sus manufacturas) (TAKII, 2002). Los niveles más bajos de CII se dan en sectores con bajo nivel de diferenciación de productos como II (productos del reino animal, V (minerales) y 14 (metales preciosos y joyería). 
Gráfico III-3.2. CII en el comercio de China con Estados Unidos por Secciones del Sistema Armonizado, 1991-2015

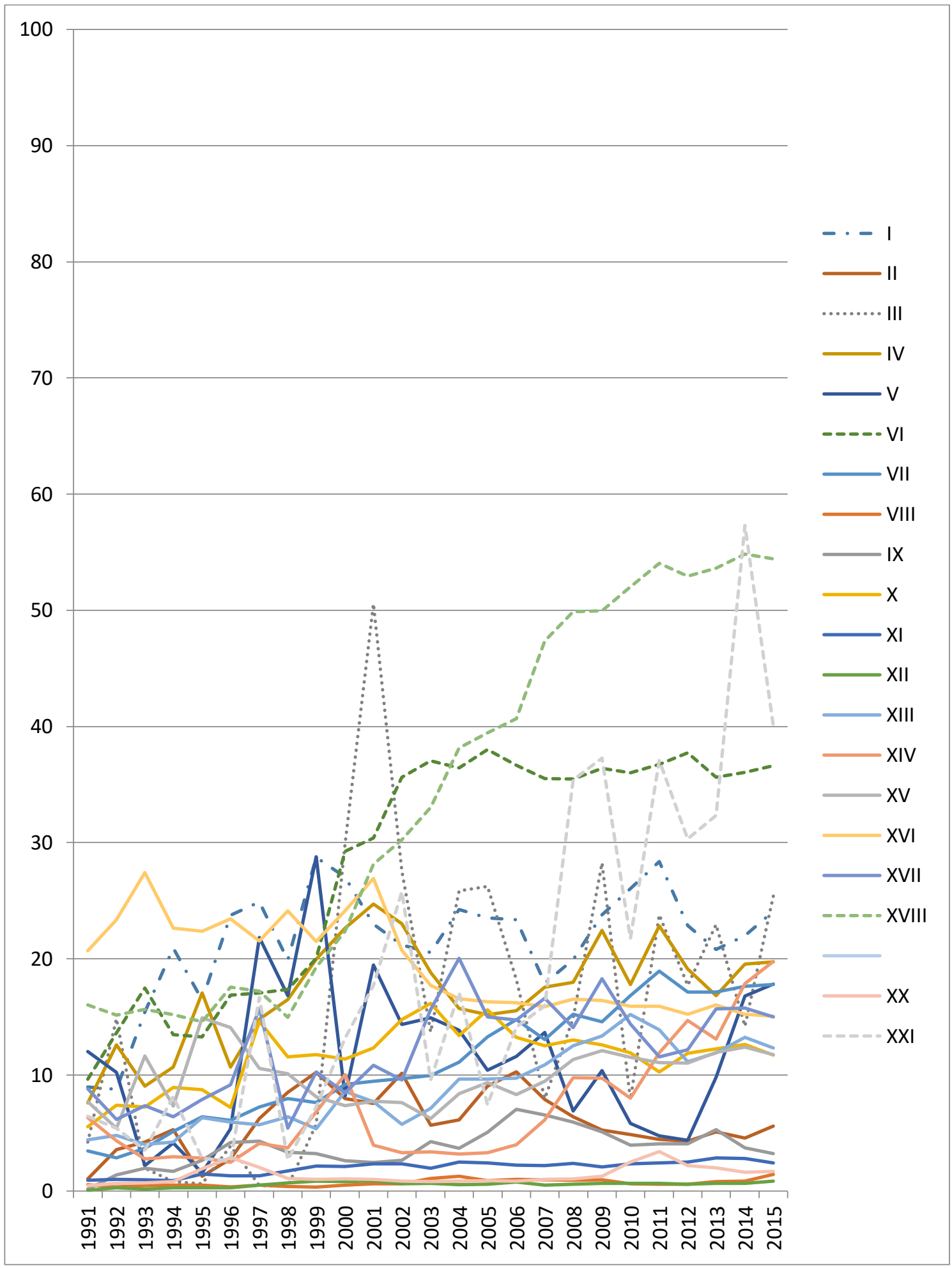

Fuente. Elaboración propia según COMTRADE, Naciones Unidas, disponible en http://comtrade.un.org/data/, fecha de consulta: 12/12/2016 
Gráfico III-3.3. CII en el comercio de México con Estados Unidos por Secciones del Sistema Armonizado, 1991-2015

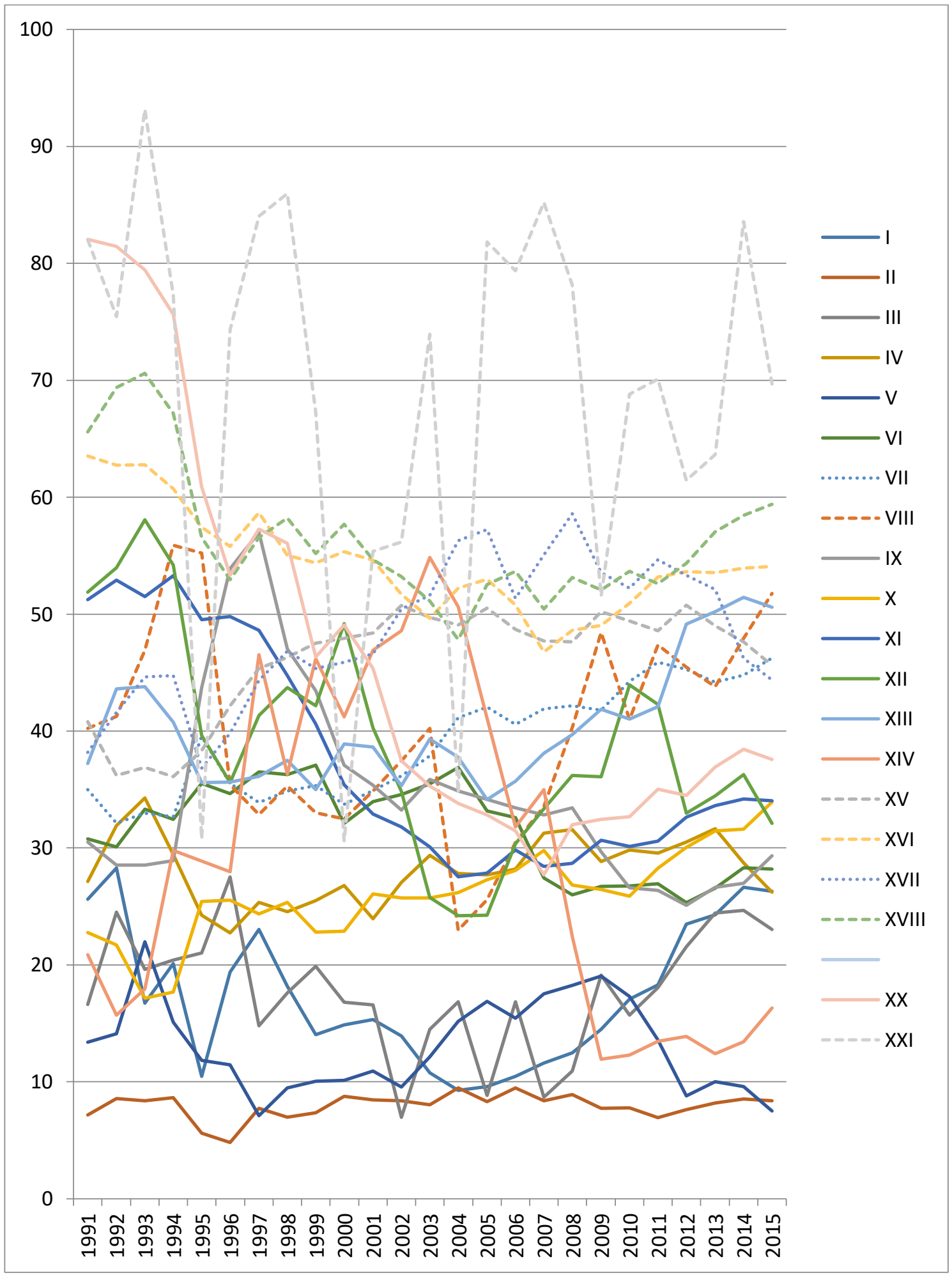

Fuente. Elaboración propia según COMTRADE, Naciones Unidas, disponible en http://comtrade.un.org/data/, fecha de consulta: 12/12/2016 
Tabla III-3.1. Secciones del Sistema Armonizado

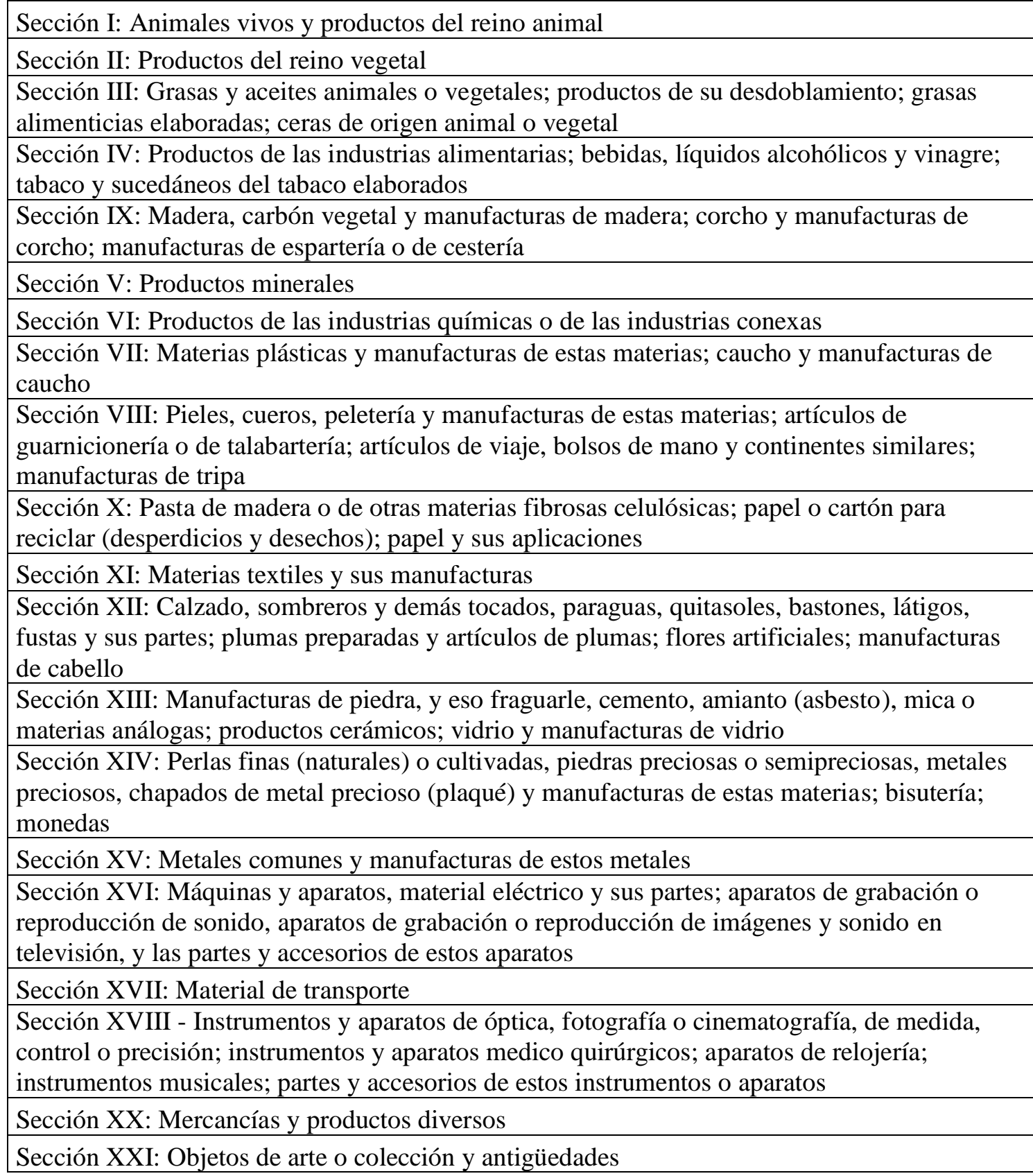

Fuente. Tomado de https://es.portal.santandertrade.com/gestionar-embarques/clasificacionarmonizada-arancelaria\#ancre_bloc, fecha de consulta: 12/12/2016.

Esta revisión permite poner de manifiesto las grandes diferencias entre el comercio de México y China con EE.UU. Debe recordarse que el CII implica un menor nivel de costes de ajuste, por lo que se puede afirmar que el CII de México con Estados Unidos implica menos destrucción de puestos de trabajo que el de China y que esto es relevante ahora que desde Estados Unidos se está cuestionando el TLCAN. El comercio de México tiene niveles de CII 30 puntos superiores al de China (45\% respecto a 15\%) y 
que México importa muchos más productos de Estados Unidos que China, por lo que sus importaciones también generan empleo en Estados Unidos.

\section{III-3.2. Comercio Intra-industrial de China y México con Estados Unidos. Estudios de caso.}

Para analizar con algo más de detalle el comercio intra-industrial de México y China con Estados Unidos, se compara ahora el CII en estos productos del Sistema Armonizado:

- Categoría 61: Prendas y complementos (accesorios), de vestir, de punto

- Categoría 87: Vehículos automóviles, tractores, velocípedos y demás vehículos terrestres, sus partes y accesorios

- Categoría 8528: Aparatos receptores de televisión, incl. con aparato receptor de radiodifusión o de grabación o reproducción de sonido o imagen incorporado; video monitores y tele proyectores

\section{III-3.2.1. Comercio Intra-Industrial en el Capítulo 61.}

Los productos en esta categoría son productos importantes en el comercio de China- Estados Unidos y México-Estados Unidos. Es decir, son productos comunes para la exportación de China y México a Estados Unidos. Las prendas de punto forman parte de la Sección XI.- Materias textiles y sus manufacturas. El Gráfico III-3.4 muestra los niveles de CII de China y México con Estados Unidos.

El Gráfico muestra muy claramente el casi nulo CII de China con Estados Unidos. Por el contrario, el nivel del CII de México empieza en torno a la media del país y se observa una caída inicial que puede estar asociada al incremento de las exportaciones dentro del TLCAN y a un posterior leve aumento asociado al desplazamiento de México como proveedor de Estados Unidos por parte de China.

A continuación, se analiza la situación general del CII de China y México en la categoría 61 en su comercio con Estados Unidos. Dentro de los textiles y sus manufacturas, en la categoría de Número 61 en el Sistema Armonizado, hay productos de "prendas y complementos de vestir y de punto". En el mercado de Estados Unidos, el 
cambio de los orígenes de la importación de los productos en esta industria es un ejemplo del avance de la economía china en Estados Unidos y de "la derrota" económica de México en términos de competencia en estos productos. En este marco, merece la pena analizar el comercio intra-industrial, para entender que estos niveles del comercio intraindustrial ofrecen una imagen de la penetración de productos chinos en Estados Unidos. Hay 17 partidas de productos a 4 dígitos en el capítulo 61 y se puede encontrar el detalle en Tabla III-3.2.

Gráfico III-3.4. CII en el comercio de México con Estados Unidos en la Sección XI, 19912015

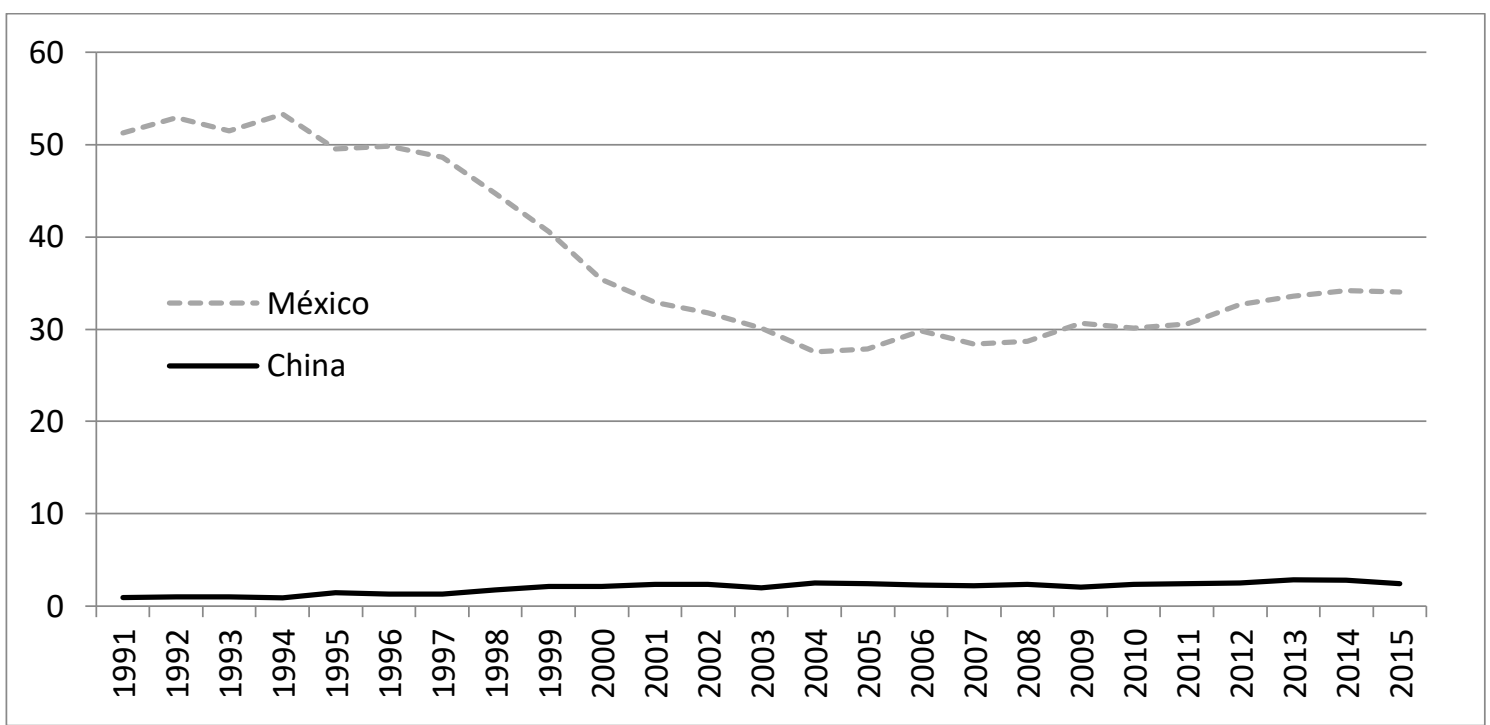

Fuente. Elaboración propia según COMTRADE, Naciones Unidas, disponible en http://comtrade.un.org/data/, fecha de consulta: 12/12/2016

La situación general del CII de China y México de los productos de la categoría 61 del Sistema Armonizada la podemos encontrar en los Gráficos III-3.5 y III-3.6. Las características son muy claras. Primero, el CII de China está en un muy bajo nivel, prácticamente en 0 . El motivo de este bajo nivel de CII de China es el bajo nivel de las importaciones chinas desde Estados Unidos. Esta característica se puede encontrar en casi todos productos de la categoría de SA61.Segunda, en el caso de México, los niveles son mucho más altos, aunque podemos ver que existe una muy elevada variabilidad y evoluciones que tienen que ver con los cambios en las estructuras de mercado y con las estrategias de las empresas. En medio de esa elevada variabilidad, al igual que en la Sección 11, parece intuirse que el CII en el Capítulo 61 tiene dos fases. Una inicial de reducción desde 1993, el año de entrada en vigor del TLCAN, porque aumentan las ventas de México en Estados Unidos más que las compras. A partir de la segunda mitad de los años 2000 la tendencia es creciente, esta vez por la reducción de las ventas mexicanas en 
Estados Unidos con la creciente competencia de China. El detalle de los valores de este

CII puede encontrarse en las Tablas Anexo III.8 y III.9.

Tabla III-3.2. Productos en el Capítulo 61 del Sistema Armonizado

\begin{tabular}{|c|c|}
\hline Partida & Productos \\
\hline 6101 & $\begin{array}{l}\text { Abrigos, chaquetones, capas, anoraks, cazadoras y artículos similares, de punto, } \\
\text { para hombres o niños (excepción. trajes o ternos, conjuntos, chaquetas sacos, incl. } \\
\text { los blazers, y pantalones) }\end{array}$ \\
\hline 6102 & $\begin{array}{l}\text { Abrigos, chaquetones, capas, anoraks, cazadoras y artículos similares, de punto, } \\
\text { para mujeres o niñas (excepción. trajes sastre, conjuntos, chaquetas sacos, incl. los } \\
\text { blazers, vestidos, faldas, faldas pantalón y pantalones) }\end{array}$ \\
\hline 6103 & $\begin{array}{l}\text { Trajes ambos o ternos, conjuntos, chaquetas sacos, pantalones largos, pantalones } \\
\text { con peto, pantalones cortos calzones y shorts, de punto, para hombres o niños } \\
\text { (excepción. cazadoras y artículos simularles, chalecos por separado, prendas de } \\
\text { deporte, monos y conjuntos de esquí y trajes de baño) }\end{array}$ \\
\hline 6104 & $\begin{array}{l}\text { Trajes sastre, conjuntos, chaquetas sacos, vestidos, faldas, faldas pantalón, } \\
\text { pantalones largos, pantalones con peto, pantalones cortos calzones y shorts, de } \\
\text { punto, para mujeres o niñas (excepción. cazadoras y artículos similares, } \\
\text { combinaciones, enaguas, bragas, prendas de deporte, monos y conjuntos de esquí y } \\
\text { trajes de baño) }\end{array}$ \\
\hline 6105 & $\begin{array}{l}\text { Camisas de punto, para hombres o niños (excepción. camisones, T-shirts y } \\
\text { camisetas) }\end{array}$ \\
\hline 6106 & $\begin{array}{l}\text { Camisas, blusas y blusas camiseras, de punto, para mujeres o niñas (excepción. T- } \\
\text { shirts y camisetas) }\end{array}$ \\
\hline 6107 & $\begin{array}{l}\text { Calzoncillos, incluido los largos y los slips, camisones, pijamas, albornoces de } \\
\text { baño, batas de casa y artículos similares, de punto, para hombres o niños } \\
\text { (excepción. camisetas) }\end{array}$ \\
\hline 6108 & $\begin{array}{l}\text { Combinaciones, enaguas, bragas bombachas, calzones, incluido las que no llegan } \\
\text { hasta la cintura, camisones, pijamas, saltos de cama, albornoces de baño, batas de } \\
\text { casa y artículos similares, de punto, para mujeres o niñas (excepción. T-shirts, } \\
\text { camisetas, sostenes, fajas, corsés y artículos similares.) }\end{array}$ \\
\hline 6109 & T-shirts y camisetas, de punto \\
\hline 6110 & $\begin{array}{l}\text { Suéteres jersey, pullovers, cardiganes, chalecos y artículos similares, de punto } \\
\text { (excepción. chalecos acolchados) }\end{array}$ \\
\hline 6111 & $\begin{array}{l}\text { Prendas y complementos accesorios de vestir, de punto, para bebés (excepción. } \\
\text { gorras) }\end{array}$ \\
\hline 6112 & $\begin{array}{l}\text { Conjuntos de abrigo para entrenamiento o deporte chándales, monos overoles y } \\
\text { conjuntos de esquí y bañadores, de punto }\end{array}$ \\
\hline 6113 & $\begin{array}{l}\text { Prendas de vestir confeccionadas con tejidos de punto, cauchutados o impregnados, } \\
\text { recubiertos o revestidos con plástico u otra materia (excepción. prendas para bebés } \\
\text { y complementos accesorios de vestir) }\end{array}$ \\
\hline 6114 & $\begin{array}{l}\text { Prendas de vestir especiales, para usos específicos, por ejemplo, profesional, } \\
\text { deportivo, etc., n.c.o.p., de punto }\end{array}$ \\
\hline 6115 & $\begin{array}{l}\text { Calzas, panty-medias, leotardos, medias, calcetines y demás artículos de calcetería, } \\
\text { incluido para varices, de punto (excepción. para bebés) }\end{array}$ \\
\hline 6116 & Guantes, mitones y manoplas, de punto (excepción. para bebés) \\
\hline 6117 & $\begin{array}{l}\text { Complementos accesorios de vestir confeccionados, de punto; partes de prendas o } \\
\text { de complementos accesorios de vestir, de punto, n.c.o.p. }\end{array}$ \\
\hline
\end{tabular}

Fuente. Elaboración propia según COMTRADE, Naciones Unidas, disponible en http://comtrade.un.org/data/, fecha de consulta: 12/12/2016. 
Gráfico III-3.5. CII en el Comercio de China con Estados Unidos, Capítulo 61, 1991-2015

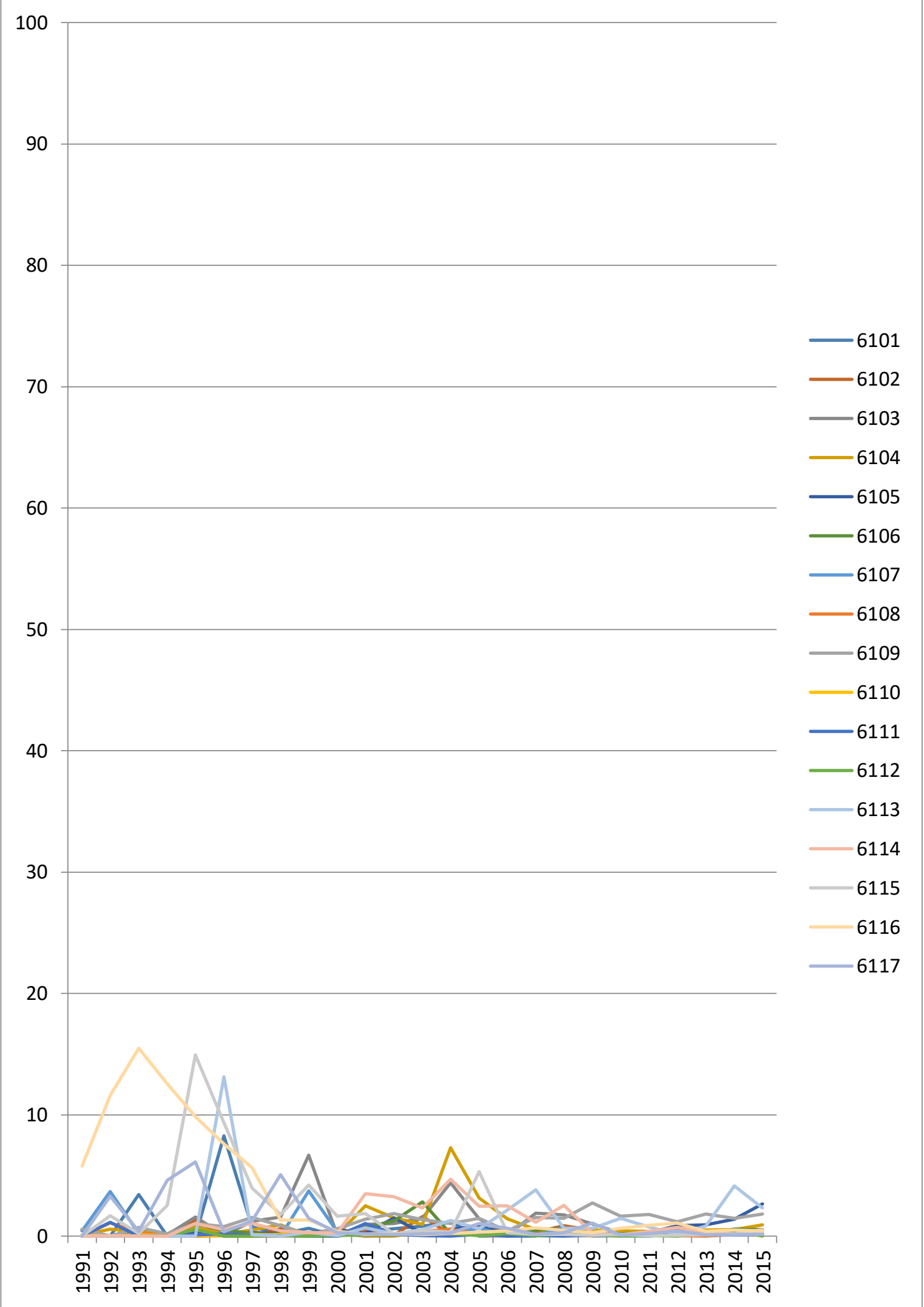

Fuente. Elaboración propia según COMTRADE, Naciones Unidas, disponible en http://comtrade.un.org/data/, fecha de consulta: 12/12/2016 
Gráfico III-3.6. CII en el Comercio de México con Estados Unidos, Capítulo 61, 1991-2015

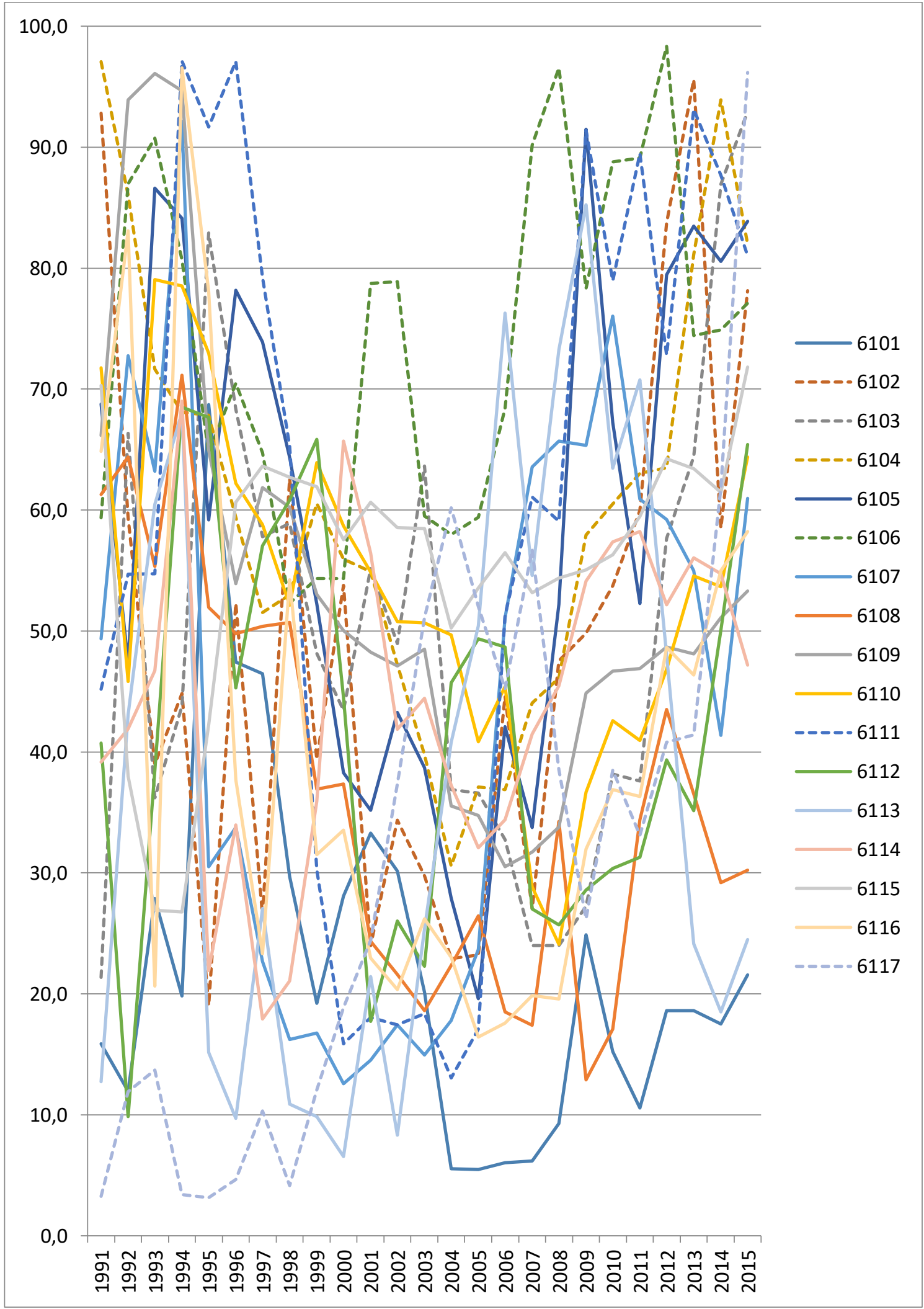

Fuente. Elaboración propia según COMTRADE, Naciones Unidas, disponible en http://comtrade.un.org/data/, fecha de consulta: 12/12/2016 


\section{III-3.2.2. Comercio Intra-industrial en el Capítulo 87: Vehículos automóviles,}

tractores, motos y demás vehículos terrestres, sus partes y accesorios.

En esta parte se analiza el CII de China y de México con Estados Unidos, en el Capítulo 87: Vehículos automóviles, tractores, motos y demás vehículos terrestres, sus partes y accesorios. Los productos en esta categoría son los principales productos en las exportaciones de México. Además, en esta industria hay varias grandes empresas internacionales instaladas tanto en México como en China, aunque las inversiones en México están más centradas en el mercado de Estados Unidos, mientras que las inversiones en China están centradas todavía en el mercado interno.

El Capítulo 87 forma parte de la Sección XVII. Material de transporte. El Gráfico III-3.7 muestra los niveles de CII de China y México con Estados Unidos.

Gráfico III-3.7. CII en el comercio de México con Estados Unidos en la Sección XVII, 1991-2015

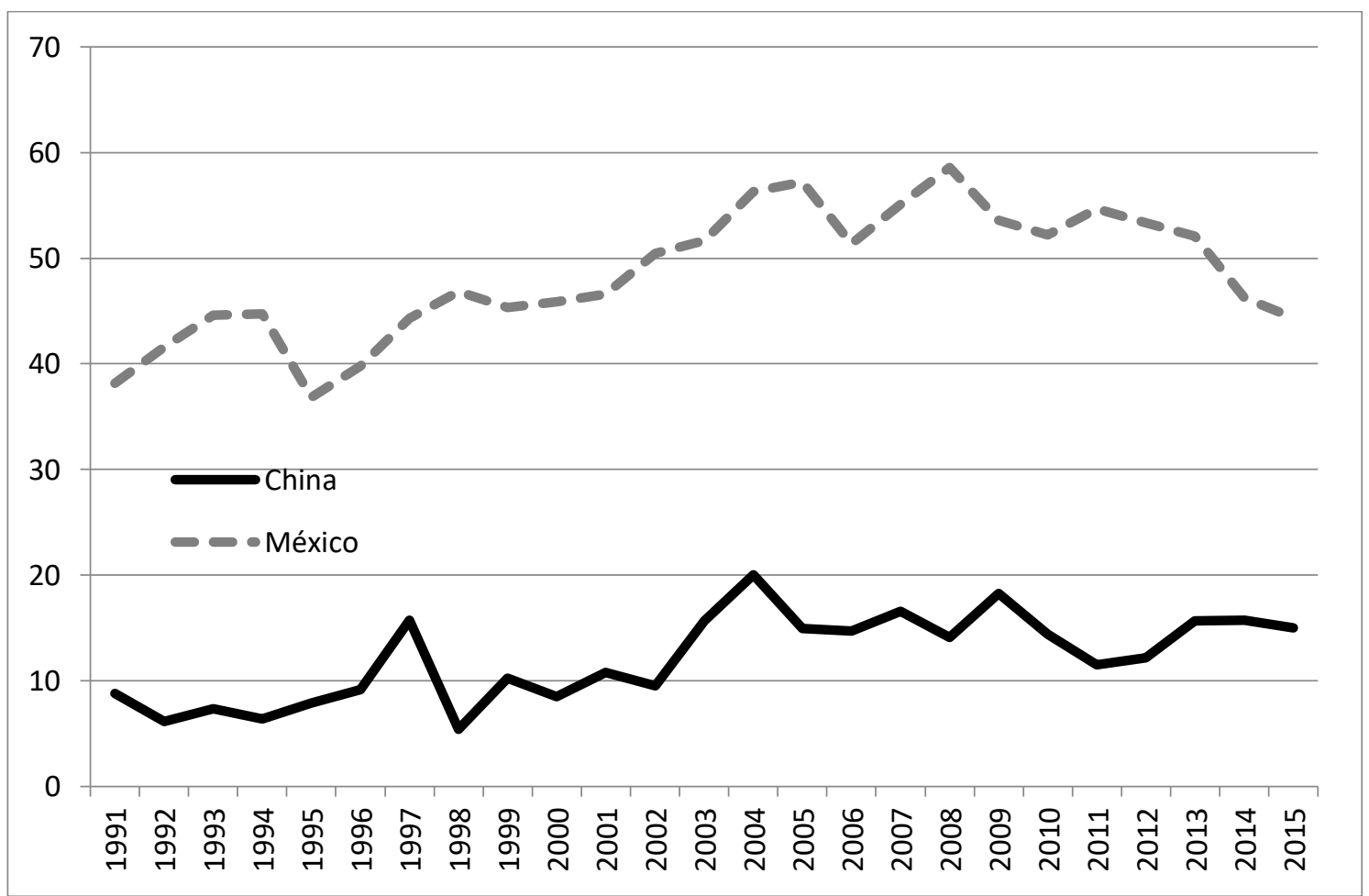

Fuente. Elaboración propia según COMTRADE, Naciones Unidas, disponible en http://comtrade.un.org/data/, fecha de consulta: 12/12/2016

En el conjunto del material de transporte, el nivel de CII de México con Estados Unidos es muy superior al de China entre 30 y 35 puntos porcentuales, aunque en los dos casos se observa una cierta tendencia creciente de largo plazo, con altibajos. Una vez más, esto da idea de un comercio cruzado mucho más importante entre Estados Unidos y 
México. La Sección XVII incorpora los Capítulos 86 (ferrocarril), 87 (automóviles, motos, camiones), 88 (aeronaves) y 89 (barcos). Dentro de la categoría 87 hay 16 productos clasificados (Tabla III-3.3).

Tabla III-3.3. Productos en el Capítulo 87 del Sistema Armonizado

\begin{tabular}{|c|c|}
\hline Números & Productos \\
\hline 8701 & Tractores o automotores (excepción de carretillas tractor de la partida 8709) \\
\hline 8702 & Vehículos automóviles para transporte de $\geq 10$ personas, incluye el conductor \\
\hline 8703 & $\begin{array}{l}\text { Automóviles de turismo y demás vehículos automóviles concebidos } \\
\text { principalmente para transporte de personas, incluye los del tipo familiar break o } \\
\text { station wagon y los de carreras (excepción de vehículos automóviles para } \\
\text { transporte de } \geq 10 \text { personas de la partida } 8702 \text { ) }\end{array}$ \\
\hline 8704 & $\begin{array}{l}\text { Vehículos automóviles para transporte de mercancías, incluye los chasis con } \\
\text { motor y las cabinas }\end{array}$ \\
\hline 8705 & $\begin{array}{l}\text { Vehículos automóviles para usos especiales (excepción de los concebidos } \\
\text { principalmente para transporte de personas o mercancías), como, por ejemplo, } \\
\text { coches para reparaciones auxilio mecánico, camiones grúa, camiones de } \\
\text { bomberos, camiones mercancías), como, por ejemplo, coches para reparaciones } \\
\text { auxilio mecánico, camiones grúa, camiones de bomberos, camiones hormigonera, } \\
\text { coches barredera, coches esparcidores, coches taller, coches radiológicos }\end{array}$ \\
\hline 8706 & $\begin{array}{l}\text { Chasis de tractores, vehículos automóviles para transporte de } \geq 10 \text { personas, } \\
\text { automóviles de turismo y vehículos automóviles para transporte de mercancías o } \\
\text { para usos especiales de las partidas } 8701 \text { a } 8705 \text {, equipados con su motor } \\
\text { (excepción de. los dotados de motor y cabina) }\end{array}$ \\
\hline 8707 & $\begin{array}{l}\text { Carrocerías, incluye las cabinas, de tractores, vehículos automóviles para } \\
\text { transporte de } \geq 10 \text { personas, automóviles de turismo, vehículos automóviles para } \\
\text { transporte de mercancías o para usos especiales de las partidas } 8701 \text { a } 8705\end{array}$ \\
\hline 8708 & $\begin{array}{l}\text { Partes y accesorios de tractores, vehículos automóviles para transporte de } \geq 10 \\
\text { personas, automóviles de turismo, vehículos automóviles para transporte de } \\
\text { mercancías o para usos especiales de las partidas } 8701 \text { a } 8705 \text {, n.c.o.p. }\end{array}$ \\
\hline 8709 & $\begin{array}{l}\text { Carretillas automóviles sin dispositivo de elevación de los tipos utilizados en } \\
\text { fábricas, almacenes, puertos o aeropuertos, para transporte de mercancías a corta } \\
\text { distancia; carretillas tractores de los tipos utilizados en las estaciones ferroviarias; } \\
\text { sus partes, n.c.o.p. }\end{array}$ \\
\hline 8710 & $\begin{array}{l}\text { Tanques y demás vehículos automóviles blindados de combate, incluye con su } \\
\text { armamento; sus partes, n.c.o.p. }\end{array}$ \\
\hline 8711 & $\begin{array}{l}\text { Motocicletas, incluye los ciclomotores, y velocípedos equipados con motor } \\
\text { auxiliar, incluye con sidecar o sin él; sidecares }\end{array}$ \\
\hline 8712 & Bicicletas y demás velocípedos, incluye. los triciclos de reparto, sin motor \\
\hline 8713 & $\begin{array}{l}\text { Sillones de ruedas y demás vehículos para inválidos, incl. con motor u otro } \\
\text { mecanismo de propulsión (excepción de automóviles y ciclos con mecanismos } \\
\text { especiales) }\end{array}$ \\
\hline 8714 & $\begin{array}{l}\text { Partes y accesorios de motocicletas y bicicletas, así como de sillones de ruedas y } \\
\text { demás vehículos para inválidos, n.c.o.p. }\end{array}$ \\
\hline 8715 & Coches, sillas y vehículos similares para transporte de niños, y sus partes, n.c.o.p. \\
\hline 8716 & $\begin{array}{l}\text { Remolques y semirremolques para cualquier vehículo, y los demás vehículos no } \\
\text { automóviles, así como sus partes, n.c.o.p. (excepción de los vehículos sobre } \\
\text { carriles rieles) }\end{array}$ \\
\hline
\end{tabular}

Fuente. Elaboración propia según COMTRADE, Naciones Unidas, disponible en http://comtrade.un.org/data/, fecha de consulta: 12/12/2016 
Los Gráficos III-3.8 y III-3.9 recogen el CII en el comercio de China y México con Estados Unidos en las partidas que componen el Capítulo 87.

Gráfico III-3.8. CII en el comercio de China con Estados Unidos, Capítulo 87, 1991-2015

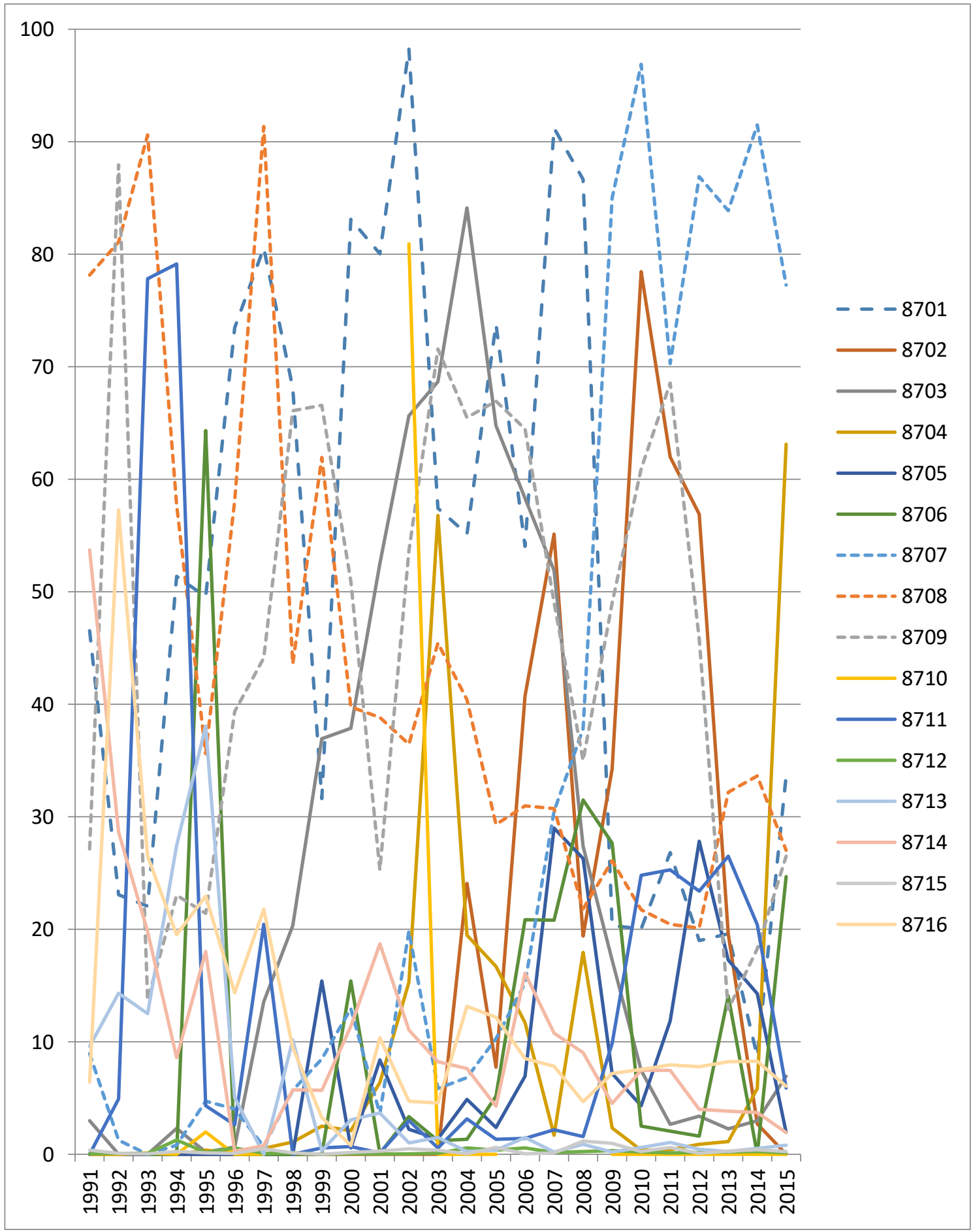

Fuente. Elaboración propia según COMTRADE, Naciones Unidas, disponible en http://comtrade.un.org/data/, fecha de consulta: 12/12/2016 
Gráfico III-3.9. CII en el comercio de México con Estados Unidos, Capítulo 87, 1991-2015

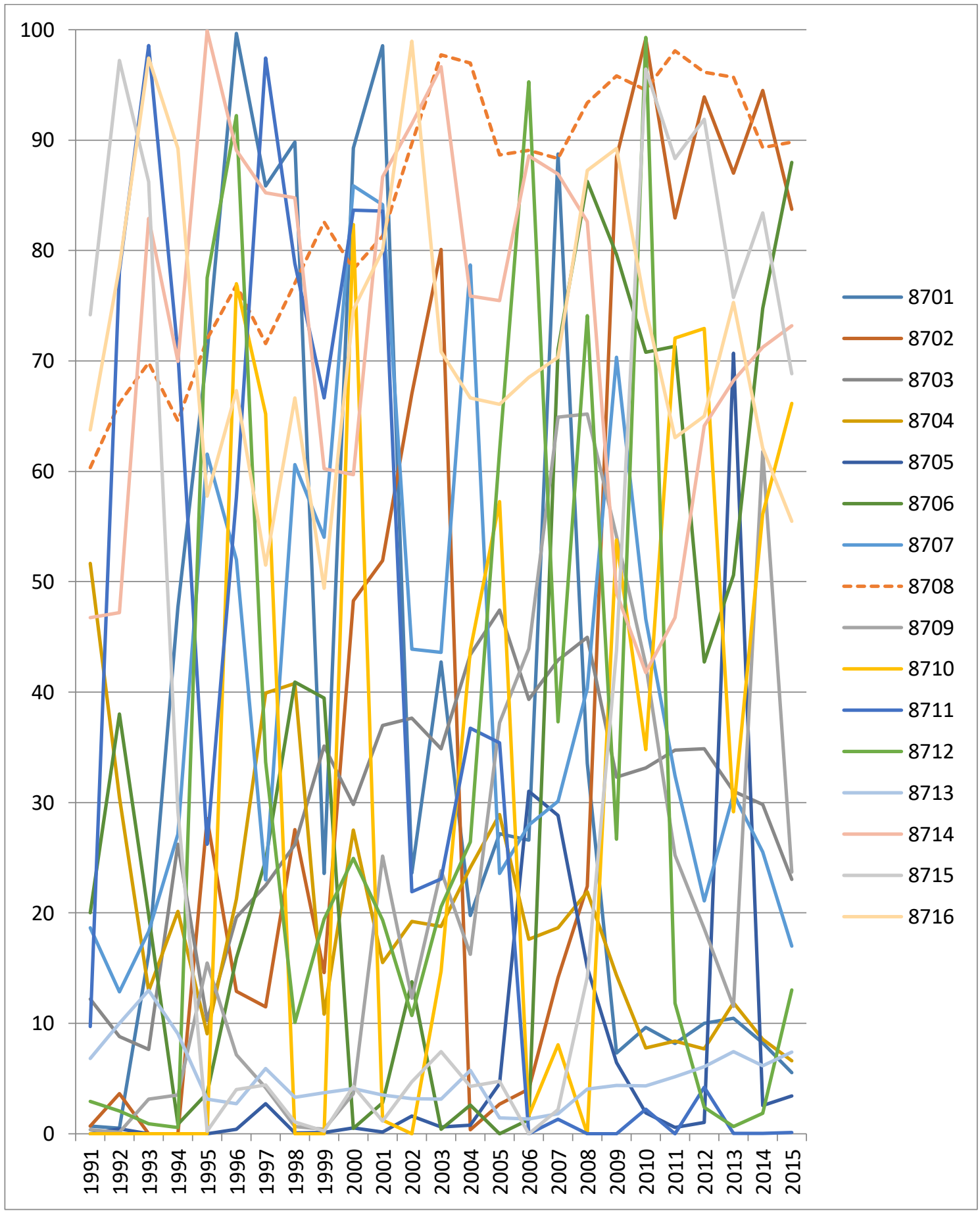

Fuente. Elaboración propia según COMTRADE, Naciones Unidas, disponible en http://comtrade.un.org/data/, fecha de consulta: 12/12/2016

Los gráficos muestran, en primer lugar, una extrema variabilidad de las series, hasta el punto de que resulta difícil reconocer tendencias. A la vez, es evidente que los valores del CII de México son superiores a los de China, también en este sector. 
Recordemos que China tiene sus destinos de exportación mucho más diversificados que los de México y su producción están todavía muy centrada en vehículos de gama baja para el mercado interno y para otros países en desarrollo. Es decir, los productos que China exporta a Estados Unidos reciben influencia de la demanda de los otros países asiáticos. Además, las importaciones chinas desde Estados Unidos, sus autopartes y los productos finales, son muy bajas (DUSSEL PETERS, 2014). Por eso, el CII de China está en un bajo nivel. En el caso de México, Estados Unidos es casi su único destino (además del mercado nacional) y las empresas que invierten en México fabrican vehículos ya diseñados para el mercado de Estados Unidos. Pueden fabricar sus productos como los consumidores en Estados Unidos quieren. Por eso, sus niveles de CII son muy altos.

III-3.2.3. Comercio Intra-industrial en la Partida 8528: Aparatos receptores de televisión, incluyendo con aparato receptor de radiodifusión o de grabación o reproducción de sonido o imagen incorporada; video-monitores y tele-proyectores

El Capítulo 85 forma parte de la Sección XVI.- Maquinaria mecánica, eléctrica y electrónica. El Gráfico III-3.10 muestra los niveles de CII de China y México con Estados Unidos en la sección XVI. En el conjunto de la maquinaria el nivel de CII de México con Estados Unidos es muy superior al de China también entre 30 y 35 puntos porcentuales. Una vez más, esto da idea de un comercio cruzado mucho más importante entre Estados Unidos y México.

En el caso de China, los artículos de la categoría 85 es uno de capítulos más dinámicos y con más alto nivel de CII de China con Estados Unidos (LÓPEZ ARÉVALO, RODIL MARZÁBAL y VALDEZ, 2014). Si se compara con los artículos textiles que se han analizado anteriormente, los niveles en esta categoría son muchos más altos. Además, este alto nivel de CII de China con Estados Unidos significa que China importa este tipo de productos desde Estados Unidos. Ésta es una gran diferencia del CII de China con Estados Unidos con respecto a lo que ocurre en el caso de los artículos textiles. 
Gráfico III-3.10. CII en el comercio de México con Estados Unidos en la Sección XVI, 1991-2015

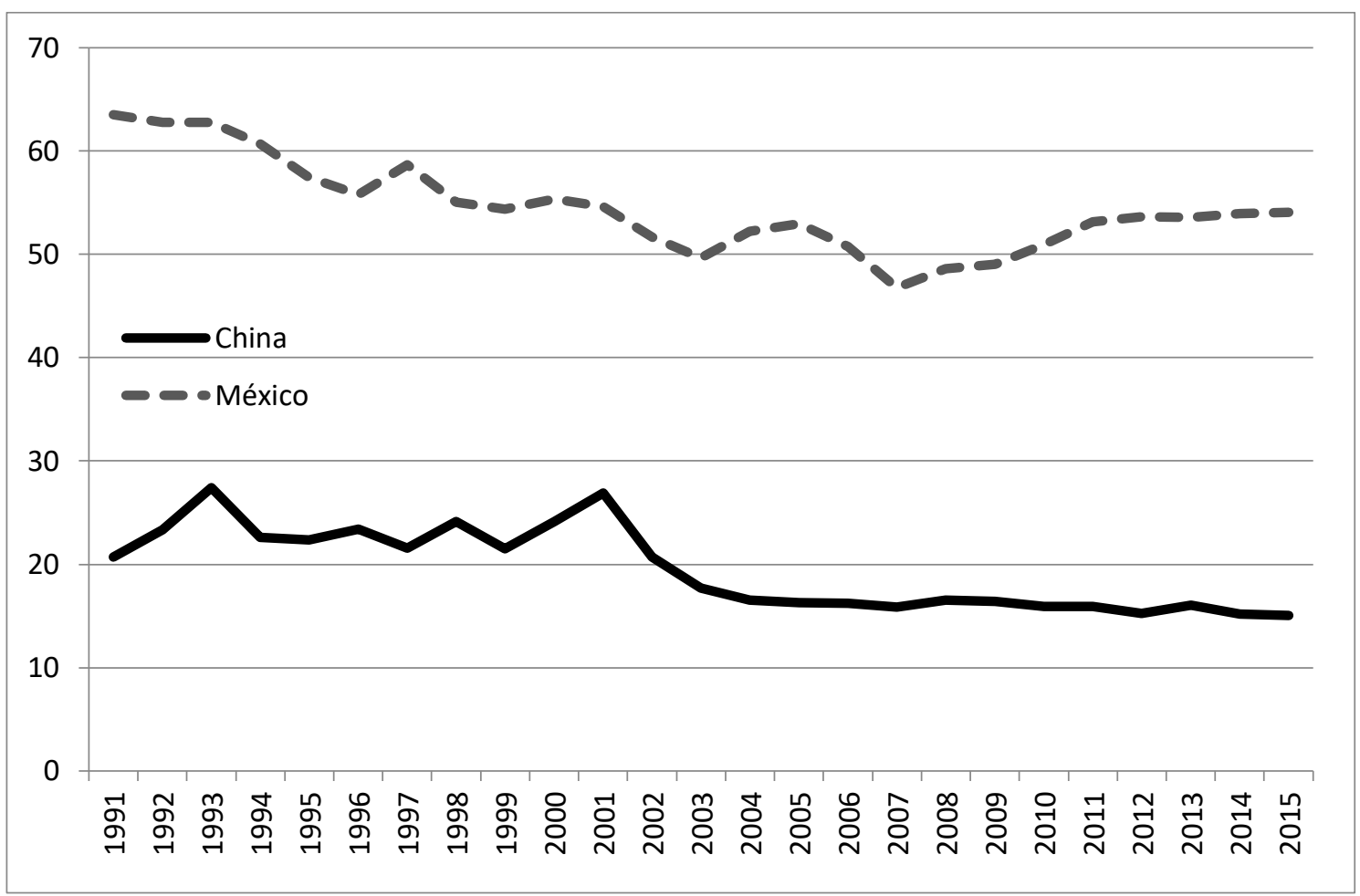

Fuente. Elaboración propia según COMTRADE, Naciones Unidas, disponible en http://comtrade.un.org/data/, fecha de consulta: 12/12/2016

El CII de México es más alto que el de China, esto es un efecto de las reglas de origen del TLCAN. Los productos de esta categoría necesitan de un alto porcentaje de contenidos locales para poder beneficiarse del TLCAN (al menos el 60\% del valor agregado tiene que añadirse en los países del TLCAN). Por eso, el CII de México en esta categoría es muy alto.

A continuación, se analiza el CII en la categoría de televisores y monitores. Sin embargo, antes de empezar el análisis, se necesita conocer algo de historia sobre esta categoría. En efecto, como se analiza en el Capítulo II, los televisores y monitores han experimentado grandes cambios y han sido objeto de un gran nivel de innovación que todavía no se ha detenido (blanco-negro y color con tubo de imagen, pantallas planas, plasma, TFT/LCD/LED, HD, smart TV/OLED...). Esta tendencia de aumento de variedades se basa en el desarrollo tecnológico y en la mayor variedad de preferencias demandada por los consumidores. En las estadísticas de la base de datos de Naciones Unidas COMTRADE es evidente esta tendencia. Es decir, hay más intercambios y más categorías de productos en los últimos periodos temporales. Por eso, para analizar el CII 
en esta categoría, se necesita clasificar varios periodos, porque depende en los periodos, las clasificaciones de los productos cambian y hay productos que van desapareciendo.

Los nombres de productos en esta categoría 8528 se han cambiado frecuentemente: Receptores de televisión, monitores de video, proyectores durante 19922001; Aparatos de televisión durante 2002-2006; Monitores y proyectores, que no incorporen aparatos de recepción de televisión; Aparatos de televisión, o no receptores de radiodifusión o de sonido o vídeo grabador durante 2006-2011 y Maquinaria eléctrica y equipos y sus partes; grabadores y reproductores, grabadoras de imagen y sonido de televisión y reproductores y partes y accesorios de este tipo de artículos de sonido, monitores y proyectores, que no incorporen aparatos de recepción de televisión; Aparatos de televisión, o no receptores de radiodifusión o de sonido o de video grabación o aparatos durante 2011- 2015. Este cambio del nombre de los artículos significa que, debido al desarrollo tecnológico, el papel y la importancia de los monitores de los televisores han aumentado.

La lista de productos en esta categoría en el Sistema Armonizado a 6 dígitos dentro del 8528 puede encontrarse en la Tabla III-3.4.

Primero, se analiza la situación general del comercio en la partida 8528 del Sistema Armonizado. Veamos el Gráfico III-3.11 que muestra el comercio de China y México con Estados Unidos en dicha partida. Se observa que las exportaciones de México comienzan a crecer desde comienzos de los años 90 y que, a diferencia de otros sectores, la entrada de China en la OMC, no desplaza a las exportaciones de México. Aunque las exportaciones chinas se multiplican, México sigue siendo el principal exportador de televisores al mercado de Estados Unidos, ligeramente por encima de China. A partir de la crisis de Estados Unidos, las exportaciones comienzan a caer en ambos países. En el caso de México, también se observa un crecimiento de las importaciones desde Estados Unidos en la última década.

Los niveles de CII (Gráfico III-3.12) en este sector son bajos y solo aumentan en los últimos años con el crecimiento de las importaciones mexicanas desde Estados Unidos. Debe tenerse en cuenta que el cambio de los productos ha sido tan fuerte que los productos comerciados en el sector en 2015 prácticamente no tienen mucho que ver en cuanto a las tecnologías empleadas con los vendidos en 1991. 
Tabla III-3.4. Productos en la Partida 8528 del Sistema Armonizado

\begin{tabular}{|c|l|}
\hline Números & \multicolumn{1}{|c|}{ Productos } \\
\hline 852810 & Receptores, monitores y proyectores de televisión color \\
\hline 852812 & Receptores de televisión de color \\
\hline 852813 & Receptores de televisión de blanco y negro \\
\hline 852820 & Blanco y negro u otros receptores de televisión monocromo \\
\hline 852821 & Monitores en color \\
\hline 852822 & Monitores de video blanco y negro \\
\hline 852830 & Proyectores de video \\
\hline 852841 & $\begin{array}{l}\text { Monitores de tubo de rayos catódicos no del tipo de exclusiva, principalmente } \\
\text { utilizado en un sistema de procesamiento automático de datos de la partida 84,71 }\end{array}$ \\
\hline 852849 & $\begin{array}{l}\text { Otro tipo de monitores de tubo de rayos catódicos, no del tipo de exclusiva, } \\
\text { principalmente utilizado en un sistema de procesamiento automático de datos de } \\
\text { la partida 84,71 }\end{array}$ \\
\hline 852851 & $\begin{array}{l}\text { Otro tipo de monitores, del tipo de exclusiva, principalmente utilizado en un } \\
\text { sistema de procesamiento automático de datos de la partida 84,71 }\end{array}$ \\
\hline $\begin{array}{l}\text { Otro tipo de monitores, no del tipo de exclusiva, principalmente utilizado en un } \\
\text { sistema de procesamiento automático de datos de la partida 84,71 }\end{array}$ \\
\hline 852861 & $\begin{array}{l}\text { Proyectores, del tipo de exclusiva / principalmente utilizado en un sistema de } \\
\text { procesamiento automático de datos de la partida 84,71 }\end{array}$ \\
\hline 852869 & $\begin{array}{l}\text { Proyectores, no del tipo de exclusiva / principalmente utilizado en un sistema de } \\
\text { procesamiento automático de datos de la partida 84,71 }\end{array}$ \\
\hline 852871 & Aparatos de televisión, no diseñado para incorporación en pantalla. \\
\hline 852872 & $\begin{array}{l}\text { Otros aparatos de televisión de color si / no incorporación receptores, sonido, } \\
\text { video de grabación y reproducción }\end{array}$ \\
\hline 852873 & $\begin{array}{l}\text { Otros aparatos de televisión, si / no incorporación receptores, sonido, video de } \\
\text { grabación, reproducción, monochorme blanco y negro y otro }\end{array}$ \\
\hline
\end{tabular}

Fuente. Elaboración propia según COMTRADE, Naciones Unidas, disponible en http://comtrade.un.org/data/, fecha de consulta: 12/12/2016.

Gráfico III-3.11. Comercio de China y México con Estados Unidos, Partida 8528, 19912015 (En miles de millones de dólares)

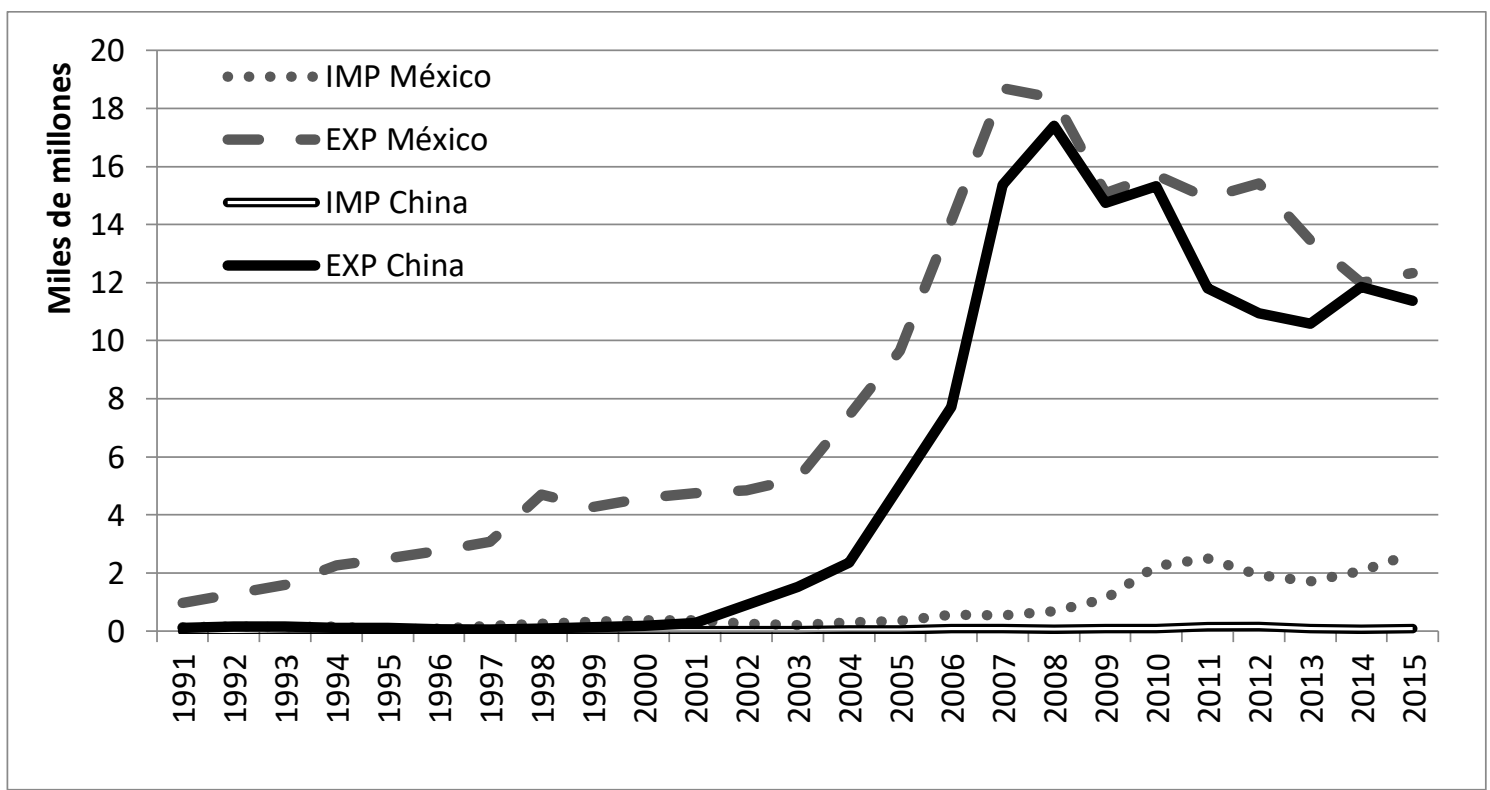

Fuente. Elaboración propia según COMTRADE, Naciones Unidas, disponible en http://comtrade.un.org/data/, fecha de consulta: 12/12/2016 
Gráfico III-3.12. CII de China y México con Estados Unidos, Partida 8528, 1991-2015

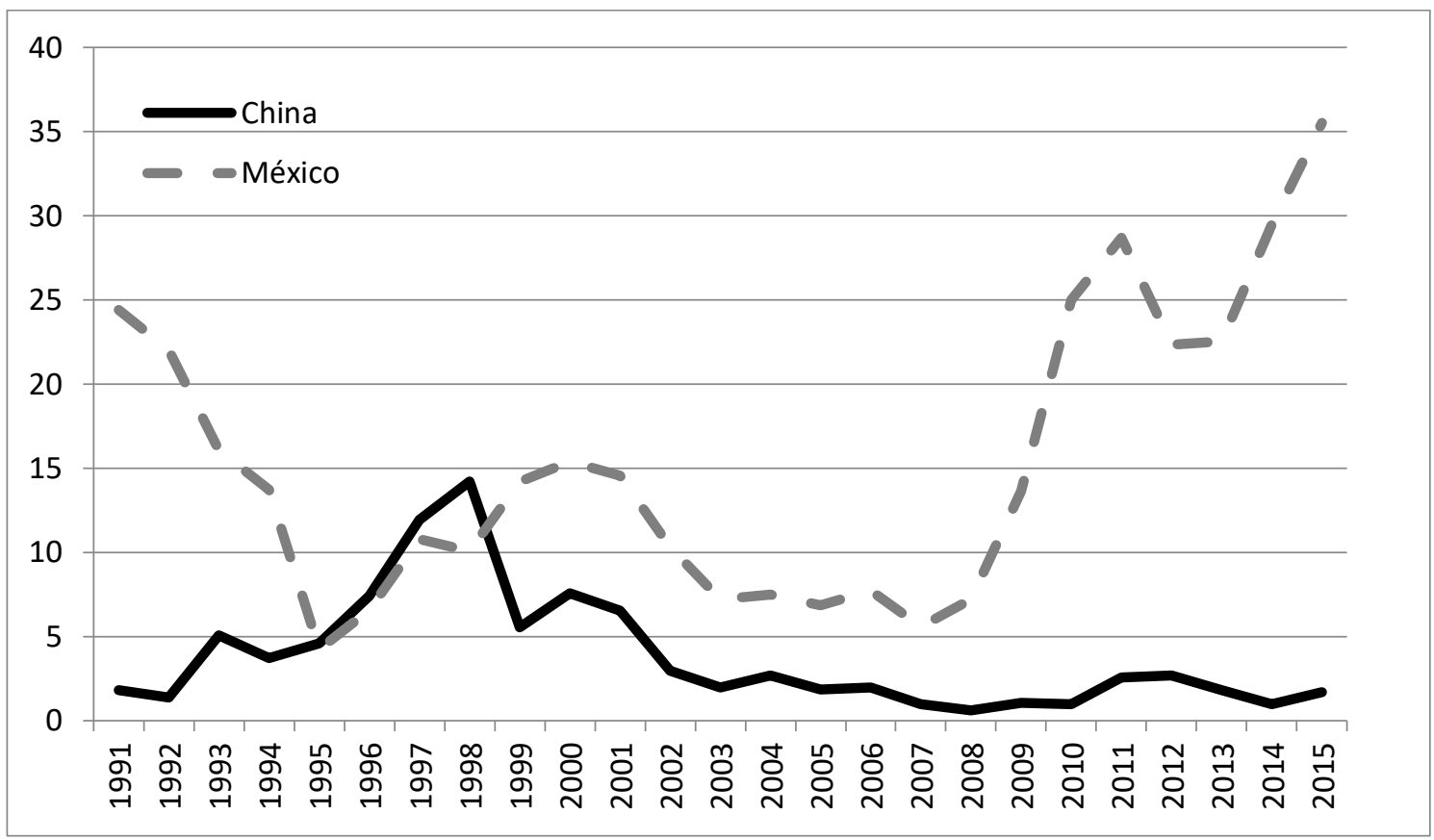

Fuente. Elaboración propia según COMTRADE, Naciones Unidas, disponible en

http://comtrade.un.org/data/ , fecha de consulta: 12/12/2016

\section{III-3.3. Comercio Intra-industrial de México y de China con Estados Unidos: ¿qué factores deciden el CII?}

Hasta aquí, se han analizado las condiciones del CII de México y China en el mercado de Estados Unidos. Los porcentajes de CII son distintos en función de los productos. Sin embargo, generalmente, en el mercado de Estados Unidos, el CII de México es en más alto nivel que el CII de China.

En la categoría de 61, la industria de textiles, principalmente, el CII de México está a un nivel más alto que el CII de China. Sin embargo, se debe notar que, en el mercado de Estados Unidos, las exportaciones chinas están más altas que las exportaciones de México en esta industria. Esta situación significa que en la industria de textiles, el bajo nivel del de CII de China no ha sido un obstáculo para aumentar sus exportaciones al mercado de Estados Unidos.

Ahora, se analizan las características del CII de México y China en la categoría 87: industrias de automóviles. En esta categoría, principalmente, el CII de México está también en un nivel más alto que el de China. La principal razón de este alto nivel del CII de México se encuentra en las reglas de origen del TLCAN. En el artículo 403 del 
TLCAN, se dice que tiene que haber contenidos locales en el 62,5\% de sus costes en el caso de automóviles, autobuses pequeños y pequeños camiones, motor y transmisión y en el $60 \%$ de sus costes de fabricación en el caso de automóviles grandes y sus motores y transmisiones. Esto significa que la mayor parte de sus costes debe venir desde México.

Además, tenemos que recordar que hay dos tipos del comercio intra-industrial: vertical y horizontal. El comercio intra-industrial horizontal es un comercio de productos iguales en calidad entre ambos países. Sin embargo, el comercio intra-industrial vertical es que, por ejemplo, el país A exporta un motor de automóviles al país B y el País B fabrica y exporta un automóvil que usa la parte importada desde el País A. También podría ser las exportaciones de coches de diferentes categorías, por ejemplo, el país A exporta automóviles pequeños y el país B exporta vehículos más grandes o de lujo.

El concepto de los "contenidos regionales" está basado en el comercio intraindustrial vertical, no en el comercio intra-industrial horizontal. Con Estados Unidos, México tiene ambos tipos de comercio intra-industrial, sin embargo, la mayor parte del comercio intra-industrial de China es de manera horizontal (LÓPEZ ARÉVALO, RODIL MARZÁBAL y VALDEZ, 2014, p. 100). Es decir, en la manera en que se lleva a cabo el comercio de China no tiene influencia el concepto de "contenidos regionales". Su exportación a los países del TLCAN es solo para vender: China no tiene intención de fabricar en los países de Norteamérica.

En el caso de la categoría de motos, hay otra historia. La demanda de motos es más alta en los países de Asia Oriental que en Estados Unidos. Por eso, las empresas de motos de los países asiáticos no tienen necesidad de exportar sus productos a Estados Unidos. Teniendo en cuenta esto, el bajo nivel de CII de China en la categoría 8711 no es una sorpresa. Al considerar esta condición, tenemos que considerar que la demanda de los mercados es un factor para aumentar o reducir el CII de las empresas. La teoría del CII indica que el CII será mayor entre países que tengan un nivel de desarrollo económico similar porque esto permitirá que las demandas de sus consumidores sean más parecidas.

En el caso de la industria de televisores, su principal característica es que, últimamente se ha aumentado el número de categorías. La segunda característica es que, el CII de México es más alto que el de China en la mayor parte de las categorías y es evidente en los últimos años han crecido las importaciones desde Estados Unidos. 
En general, en la mayor parte de los productos que se han analizado, el CII de México es más alto que el de China (DUSSEL PETERS, 2015a, p. 316; ORTIZ VELAZQUEZ y DUSSEL PETERS, 2016). En muchos productos, al analizar las importaciones de Estados Unidos, la exportación de China es más alta que las exportaciones de México y sus importaciones, por el contrario, son más bajas. Basándose en esta situación, el mayor CII de México no induce el que sean mayores las importaciones de Estados Unidos de productos mexicanos, sino que China ha tenido más éxito en el mercado de Estados Unidos, aunque su comercio es, básicamente, de tipo interindustrial y, por tanto, induce unos mayores costes de ajuste. 


\section{III-4. Conclusiones}

En esta parte, se ha comparado el comercio de China y México con Estados Unidos. Estos dos países han sido rivales en el mercado de Estados Unidos durante las dos últimas décadas y, especialmente, desde la incorporación de China a la OMC.

Un motivo de esta relación como países que compiten por captar la cuota del mercado estadounidense es que, ambos países tienen las mismas ventajas para la localización de la IED. Es decir, México y China han mostrado que el bajo coste de la mano de obra es una de sus ventajas para las empresas que hacen IED. Debido a la diferencia del tipo de cambio de la moneda nacional, es natural que el coste de la mano de obra de China haya sido hasta hace muy poco más barato que el de México.

Partiendo de esta situación, el volumen de la exportación china hacia Estados Unidos ha aumentado mucho, sobre todo a partir del año 2000. Sin embargo, lo más curioso es que, para China, tal y como hemos visto en la introducción, Estados Unidos es solamente una de las alternativas a las que se dirigen sus exportaciones, aunque sí es uno de los destinos con mayor renta. El principal destino de sus exportaciones son los países asiáticos que absorben en 2014 el 43\% de estos flujos, mientras que Estados Unidos solo suma un $19 \%$, una cifra muy parecida a la que sumaban en ese mismo año Hong Kong (11\%) y Japón (7\%) juntos. Esta característica puede dar otra opción a las empresas que hacen IED en China: las inversiones en China generan posibilidades de exportar a Estados Unidos y también a otros países asiáticos. Al contrario, en el caso de México, Estados Unidos ha sido el mayor importador de sus productos (con el $71 \%$ de todas las exportaciones en 2014) y también el mayor exportador a México con el 50\% de todas las compras. Por eso, las empresas que hacen IED en México tienen básicamente un único destino para sus exportaciones (Estados Unidos), aunque México está haciendo importantes esfuerzos para diversificar la estructura de su comercio exterior mediante la firma de tratados de libre comercio con la Unión Europea y con otros países.

Sobre el comercio intra-industrial (CII) de Estados Unidos con México y China, se encuentra que el CII de Estados Unidos con México está en un nivel más alto que el CII con China. El principal motivo de este bajo porcentaje de CII en el comercio bilateral Estados Unidos-China tiene que ver, en primer lugar, con su bajo nivel de importación desde Estados Unidos. En este análisis, se pueden encontrar menos importaciones desde Estados Unidos en muchos productos. Por la manera de calcular el nivel del CII, se puede 
resaltar el bajo porcentaje de CII. Un motivo de la baja importación de China desde Estados Unidos es por su política en el tipo de cambio de su moneda con respecto al dólar estadounidense. Desde los años 90, a pesar del gran crecimiento de su economía y a pesar de los grandes superávits comerciales que ha acumulado el país, la moneda china se ha apreciado muy poco con respecto al dólar, ya que el gobierno chino ha apostado siempre por un tipo de cambio competitivo que haga baratos sus productos en el exterior para aumentar sus exportaciones, a la vez que convierte a los productos extranjeros en productos caros, frenando las importaciones. En este contexto, es muy normal que menos empresas en China quieran importar productos desde Estados Unidos.

A pesar de la influencia del tipo de cambio de la moneda china con respecto al dólar, México ha conservado una alta cuota de mercado en Estados Unidos. Por otra parte, el CII de México con Estados Unidos es más alto que el de China. Sin embargo, debe destacarse que las cifras del CII de México no son tan altas, en parte por las diferencias en el nivel de desarrollo de ambos países que suponen diferencias en las preferencias de los consumidores (los estadounidenses con más renta y más centrados en variedades de gama alta y los mexicanos con menos renta y menos preferencia por la variedad o con preferencia por productos de gamas populares), aunque debe señalarse que la mala distribución de la renta en México da lugar a que haya un porcentaje de mexicanos con un elevado nivel de renta. No obstante, las diferencias en la demanda de consumidores entre México y Estados Unidos son muy importantes, así que las empresas no pueden satisfacer desde una única localización a las demandas de ambos países. Tal y como hemos visto en el capítulo I, según Krugman, donde hay CII, hay consumidores que quieren productos diferenciados (KRUGMAN, 1979, p. 472). Las empresas pueden fabricar en una misma localización los productos para ambos países y así aprovechar las economías de escala, pero esto solo ocurre si hay demandas muy similares en ambos países. Sin embargo, si las demandas en ambos países son muy distintas, aunque los productos sean de la misma categoría de industria en el Sistema Armonizado, las empresas no pueden producir los productos para satisfacer a ambos mercados. En el caso de Estados Unidos y México, hay grandes diferencias en los salarios de los trabajadores. Esta diferencia de salarios induce, a su vez, diferencias en los productos demandados en ambos países. Cuando estas diferencias son muy grandes, es más complicado que pueda darse CII entre dos países. Otro factor explicativo de esta baja cifra de CII mexicano es que, hay limitaciones para que las empresas con capital mexicano, es decir que no sean 
subsidiarias de empresas multinacionales, puedan exportar a Estados Unidos (LÓPEZ ARÉVALO y RODIL MARZÁBAL, 2008). Muchas empresas con capital mexicano siguen centradas en el mercado doméstico, que es un mercado muy distinto al de Estados Unidos

En el mercado de Estados Unidos, la competencia entre México y China ha empezado desde finales de 1990 y se va a seguir desarrollando en el futuro. En este momento, la victoria de Donald Trump señala un probable cambio en la política comercial de Estados Unidos que va a tomar, si su gestión responde a sus promesas de campaña, una visión más proteccionista, sobre todo de cara a China y México. Por tanto, de cara al futuro hay muchas incertidumbres sobre el futuro del comercio que tienen que ver con la caída de la tasa de crecimiento de China, sus desequilibrios macroeconómicos (sobre todo en términos de endeudamiento) y los cambios en la política comercial de Estados Unidos. En medio de estas incertidumbres, los salarios en China han crecido mucho en los últimos tiempos y también parece probable que tenga que cambiar en algún momento la situación económica de China, incluyendo su política cambiaria (especialmente, desde que el yuan ha ingresado en la cesta de monedas que determinan el valor de los Derechos Especiales de Giro del Fondo Monetario Internacional).

No debe olvidarse, finalmente, que los factores que las empresas tienen en cuenta para decidir hacer IED son múltiples y no solo tienen en cuenta el factor del coste de la mano de obra, ya que las variables que influyen sobre la rentabilidad de sus inversiones son muchas. El comercio de México y China con Estados Unidos recibirá la influencia de estos factores. 
Anexos Capítulo III 
Tabla Anexo III.1. Sistema Armonizado, secciones y capítulos

\begin{tabular}{|c|c|c|}
\hline Un dígito & $\begin{array}{c}\text { Dos } \\
\text { Dígitos }\end{array}$ & Productos \\
\hline \multirow{6}{*}{$\begin{array}{l}\text { Sección I: Animales vivos y productos } \\
\text { del reino animal }\end{array}$} & 1 & Animales vivos \\
\hline & 2 & Carne y despojos comestibles \\
\hline & 3 & $\begin{array}{l}\text { Pescados y crustáceos, moluscos y demás invertebrados } \\
\text { acuáticos }\end{array}$ \\
\hline & 4 & $\begin{array}{l}\text { Leche y productos lácteos; huevos de ave; miel natural; } \\
\text { productos comestibles de origen animal no expresados ni } \\
\text { comprendidos en otra parte }\end{array}$ \\
\hline & 5 & $\begin{array}{l}\text { Los demás productos de origen animal no expresados ni } \\
\text { comprendidos en otra parte }\end{array}$ \\
\hline & 6 & Plantas vivas y productos de la floricultura \\
\hline \multirow{8}{*}{ Sección II: Productos del reino vegetal } & 7 & Hortalizas, plantas, raíces y tubérculos alimenticios \\
\hline & 8 & $\begin{array}{l}\text { Frutas y frutos comestibles; cortezas de agrios (cítricos), } \\
\text { melones o sandías }\end{array}$ \\
\hline & 9 & Café, té, yerba mate y especias \\
\hline & 10 & Cereales \\
\hline & 11 & $\begin{array}{l}\text { Productos de la molinería; malta; almidón y fécula; } \\
\text { inulina; gluten de trigo }\end{array}$ \\
\hline & 12 & $\begin{array}{l}\text { Semillas y frutos oleaginosos; semillas y frutos diversos; } \\
\text { plantas industriales o medicinales; paja y forrajes }\end{array}$ \\
\hline & 13 & Gomas, resinas y demás jugos y extractos vegetales \\
\hline & 14 & $\begin{array}{l}\text { Materias trenzarles y demás productos de origen vegetal, } \\
\text { no expresados ni comprendidos en otra parte }\end{array}$ \\
\hline $\begin{array}{l}\text { Sección III: Grasas y aceites animales o } \\
\text { vegetales; productos de su } \\
\text { desdoblamiento; grasas alimenticias } \\
\text { elaboradas; ceras de origen animal o } \\
\text { vegetal }\end{array}$ & 15 & $\begin{array}{l}\text { Grasas y aceites animales o vegetales; productos de su } \\
\text { desdoblamiento; grasas alimenticias elaboradas; ceras de } \\
\text { origen animal o vegetal }\end{array}$ \\
\hline \multirow{9}{*}{$\begin{array}{l}\text { Sección IV: Productos de las industrias } \\
\text { alimentarias; bebidas, líquidos } \\
\text { alcohólicos y vinagre; tabaco y } \\
\text { sucedáneos del tabaco elaborados }\end{array}$} & 16 & $\begin{array}{l}\text { Preparaciones de carne, pescado o crustáceos, moluscos o } \\
\text { demás invertebrados acuáticos }\end{array}$ \\
\hline & 17 & Azúcares y artículos de confitería \\
\hline & 18 & Cacao y sus preparaciones \\
\hline & 19 & $\begin{array}{l}\text { Preparaciones a base de cereales, harina, almidón, fécula } \\
\text { o leche; productos de pastelería }\end{array}$ \\
\hline & 20 & $\begin{array}{l}\text { Preparaciones de hortalizas, de frutas u otros frutos o } \\
\text { demás partes de plantas }\end{array}$ \\
\hline & 21 & Preparaciones alimenticias diversas \\
\hline & 22 & Bebidas, líquidos alcohólicos y vinagre \\
\hline & 23 & $\begin{array}{l}\text { Residuos y desperdicios de las industrias alimentarias; } \\
\text { alimentos preparados para animales }\end{array}$ \\
\hline & 24 & Tabaco y sucedáneos del tabaco elaborados \\
\hline \multirow{3}{*}{ Sección V: Productos minerales } & 25 & Sal; azufre; tierras y piedras; yesos, cales y cementos \\
\hline & 26 & Minerales metalíferos, escorias y cenizas \\
\hline & 27 & $\begin{array}{l}\text { Combustibles minerales, aceites minerales y productos de } \\
\text { su destilación; materias bituminosas; ceras minerales }\end{array}$ \\
\hline
\end{tabular}




\begin{tabular}{|c|c|c|}
\hline \multirow{11}{*}{$\begin{array}{l}\text { Sección VI: Productos de las industrias } \\
\text { químicas o de las industrias conexas }\end{array}$} & 28 & $\begin{array}{l}\text { Productos químicos inorgánicos; compuestos inorgánicos } \\
\text { u orgánicos de metal precioso, de elementos radiactivos, } \\
\text { de metales de las tierras raras o de isótopos }\end{array}$ \\
\hline & 29 & Productos químicos orgánicos \\
\hline & 30 & Productos farmacéuticos \\
\hline & 31 & Abonos \\
\hline & 32 & $\begin{array}{l}\text { Extractos curtientes o tintóreos; taninos y sus derivados; } \\
\text { pigmentos y demás materias colorantes; pinturas y } \\
\text { barnices; mástiques; tintas }\end{array}$ \\
\hline & 33 & $\begin{array}{l}\text { Aceites esenciales y resinados; preparaciones de } \\
\text { perfumería, de tocador o de cosmética }\end{array}$ \\
\hline & 34 & $\begin{array}{l}\text { Jabones, agentes de superficie orgánicos, preparaciones } \\
\text { para lavar, preparaciones lubricantes, ceras artificiales, } \\
\text { ceras preparadas, productos de limpieza, velas y artículos } \\
\text { similares, pastas para modelar, «ceras para odontología» } \\
\text { y preparaciones para odontología a base de yeso fraguarle }\end{array}$ \\
\hline & 35 & $\begin{array}{l}\text { Materias albuminoideas; productos a base de almidón o } \\
\text { de fécula modificados; colas; enzimas }\end{array}$ \\
\hline & 36 & $\begin{array}{l}\text { Pólvora y explosivos; artículos de pirotecnia; fósforos } \\
\text { (cerillas); aleaciones pirofóricas; materias inflamables }\end{array}$ \\
\hline & 37 & Productos fotográficos o cinematográficos \\
\hline & 38 & Productos diversos de las industrias químicas \\
\hline \multirow{2}{*}{$\begin{array}{l}\text { Sección VII: Materias plásticas y } \\
\text { manufacturas de estas materias; caucho } \\
\text { y manufacturas de caucho }\end{array}$} & 39 & Plástico y sus manufacturas \\
\hline & 40 & Caucho y sus manufacturas \\
\hline \multirow{3}{*}{$\begin{array}{l}\text { Sección VIII: Pieles, cueros, peletería y } \\
\text { manufacturas de estas materias; } \\
\text { artículos de guarnicionería o de } \\
\text { talabartería; artículos de viaje, bolsos } \\
\text { de mano y continentes similares; } \\
\text { manufacturas de tripa }\end{array}$} & 41 & Pieles (excepto la peletería) y cueros \\
\hline & 42 & $\begin{array}{l}\text { Manufacturas de cuero; artículos de talabartería o } \\
\text { guarnicionería; artículos de viaje, bolsos de mano } \\
\text { (carteras) y continentes similares; manufacturas de tripa }\end{array}$ \\
\hline & 43 & $\begin{array}{l}\text { Peletería y confecciones de peletería; peletería facticia o } \\
\text { artificial }\end{array}$ \\
\hline \multirow{3}{*}{$\begin{array}{l}\text { Sección IX: Madera, carbón vegetal y } \\
\text { manufacturas de madera; corcho y } \\
\text { manufacturas de corcho; manufacturas } \\
\text { de espartería o de cestería }\end{array}$} & 44 & Madera, carbón vegetal y manufacturas de madera \\
\hline & 45 & Corcho y sus manufacturas \\
\hline & 46 & Manufacturas de espartería o cestería \\
\hline \multirow{3}{*}{$\begin{array}{l}\text { Sección X: Pasta de madera o de otras } \\
\text { materias fibrosas celulósicas; papel o } \\
\text { cartón para reciclar (desperdicios y } \\
\text { desechos); papel y sus aplicaciones }\end{array}$} & 47 & $\begin{array}{l}\text { Pasta de madera o de las demás materias fibrosas } \\
\text { celulósicas; papel o cartón para reciclar (desperdicios y } \\
\text { desechos) }\end{array}$ \\
\hline & 48 & $\begin{array}{l}\text { Papel y cartón; manufacturas de pasta de celulosa, de } \\
\text { papel o cartón }\end{array}$ \\
\hline & 49 & $\begin{array}{l}\text { Productos editoriales, de la prensa y de las demás } \\
\text { industrias gráficas; textos manuscritos o mecanografiados } \\
\text { y planos }\end{array}$ \\
\hline
\end{tabular}




\begin{tabular}{|c|c|c|}
\hline \multirow{14}{*}{$\begin{array}{l}\text { Sección XI: Materias textiles y sus } \\
\text { manufacturas }\end{array}$} & 50 & Seda \\
\hline & 51 & Lana y pelo fino u ordinario; hilados y tejidos de crin \\
\hline & 52 & Algodón \\
\hline & 53 & $\begin{array}{l}\text { Las demás fibras textiles vegetales; hilados de papel y } \\
\text { tejidos de hilados de papel }\end{array}$ \\
\hline & 54 & Filamentos sintéticos o artificiales \\
\hline & 55 & Fibras sintéticas o artificiales discontinuas \\
\hline & 56 & $\begin{array}{l}\text { Guata, fieltro y tela sin tejer; hilados especiales; cordeles, } \\
\text { cuerdas y cordajes; artículos de cordelería }\end{array}$ \\
\hline & 57 & $\begin{array}{l}\text { Alfombras y demás revestimientos para el suelo, de } \\
\text { materia textil }\end{array}$ \\
\hline & 58 & $\begin{array}{l}\text { Tejidos especiales; superficies textiles con mechón } \\
\text { insertado; encajes; tapicería; pasamanería; bordados }\end{array}$ \\
\hline & 59 & $\begin{array}{l}\text { Telas impregnadas, recubiertas, revestidas o } \\
\text { estratificadas; artículos técnicos de materia textil }\end{array}$ \\
\hline & 60 & Tejidos de punto \\
\hline & 61 & Prendas y complementos (accesorios), de vestir, de punto \\
\hline & 62 & $\begin{array}{l}\text { Prendas y complementos (accesorios), de vestir, excepto } \\
\text { los de punto }\end{array}$ \\
\hline & 63 & $\begin{array}{l}\text { Los demás artículos textiles confeccionados; juegos; } \\
\text { prendería y trapos }\end{array}$ \\
\hline \multirow{4}{*}{$\begin{array}{l}\text { Sección XII: Calzado, sombreros y } \\
\text { demás tocados, paraguas, quitasoles, } \\
\text { bastones, látigos, fustas y sus partes; } \\
\text { plumas preparadas y artículos de } \\
\text { plumas; flores artificiales; } \\
\text { manufacturas de cabello }\end{array}$} & 64 & $\begin{array}{l}\text { Calzado, polainas y artículos análogos; partes de estos } \\
\text { artículos }\end{array}$ \\
\hline & 65 & Sombreros, demás tocados, y sus partes \\
\hline & 66 & $\begin{array}{l}\text { Paraguas, sombrillas, quitasoles, bastones, bastones } \\
\text { asiento, látigos, fustas, y sus partes }\end{array}$ \\
\hline & 67 & $\begin{array}{l}\text { Plumas y plumón preparados y artículos de plumas o } \\
\text { plumón; flores artificiales; manufacturas de cabello }\end{array}$ \\
\hline \multirow{3}{*}{$\begin{array}{l}\text { Sección XIII :Manufacturas de piedra, } \\
\text { y eso fraguarle, cemento, amianto } \\
\text { (asbesto), mica o materias análogas; } \\
\text { productos cerámicos; vidrio y } \\
\text { manufacturas de vidrio }\end{array}$} & 68 & $\begin{array}{l}\text { Manufacturas de piedra, yeso fraguarle, cemento, amianto } \\
\text { (asbesto), mica o materias análogas }\end{array}$ \\
\hline & 69 & Productos cerámicos \\
\hline & 70 & Vidrio y sus manufacturas \\
\hline $\begin{array}{l}\text { Sección XIV: Perlas finas (naturales) o } \\
\text { cultivadas, piedras preciosas o } \\
\text { semipreciosas, metales preciosos, } \\
\text { chapados de metal precioso (plaqué) y } \\
\text { manufacturas de estas materias; } \\
\text { bisutería; monedas }\end{array}$ & 71 & $\begin{array}{l}\text { Perlas finas (naturales) o cultivadas, piedras preciosas o } \\
\text { semipreciosas, metales preciosos, chapados de metal } \\
\text { precioso (plaqué) y manufacturas de estas materias; } \\
\text { bisutería; monedas }\end{array}$ \\
\hline \multirow{12}{*}{$\begin{array}{l}\text { Sección XV: Metales comunes y } \\
\text { manufacturas de estos metales }\end{array}$} & 72 & Fundición, hierro y acero \\
\hline & 73 & Manufacturas de fundición, de hierro o acero \\
\hline & 74 & Cobre y sus manufacturas \\
\hline & 75 & Níquel y sus manufacturas \\
\hline & 76 & Aluminio y sus manufacturas \\
\hline & 77 & Reserva para futuro \\
\hline & 78 & Plomo y sus manufacturas \\
\hline & 79 & Cinc y sus manufacturas \\
\hline & 80 & Estaño y sus manufacturas \\
\hline & 81 & $\begin{array}{l}\text { Los demás metales comunes; cermets; manufacturas de } \\
\text { estas materias }\end{array}$ \\
\hline & 82 & $\begin{array}{l}\text { Herramientas y útiles, artículos de cuchillería y cubiertos } \\
\text { de mesa, de metal común, partes de estos artículos, de } \\
\text { metal común }\end{array}$ \\
\hline & 83 & Manufacturas diversas de metal común \\
\hline
\end{tabular}




\begin{tabular}{|c|c|c|}
\hline \multirow{2}{*}{$\begin{array}{l}\text { Sección XVI: Máquinas y aparatos, } \\
\text { material eléctrico y sus partes; aparatos } \\
\text { de grabación o reproducción de sonido, } \\
\text { aparatos de grabación o reproducción } \\
\text { de imágenes y sonido en televisión, y } \\
\text { las partes y accesorios de estos aparatos }\end{array}$} & 84 & $\begin{array}{l}\text { Reactores nucleares, calderas, máquinas, aparatos y } \\
\text { artefactos mecánicos; partes de estas máquinas o aparatos }\end{array}$ \\
\hline & 85 & $\begin{array}{l}\text { Máquinas, aparatos y material eléctrico, y sus partes; } \\
\text { aparatos de grabación o reproducción de sonido, aparatos } \\
\text { de grabación o reproducción de imagen y sonido en } \\
\text { televisión, y las partes y accesorios de estos aparatos }\end{array}$ \\
\hline \multirow{4}{*}{ Sección XVII: Material de transporte } & 86 & $\begin{array}{l}\text { Vehículos y material para vías férreas o similares, y sus } \\
\text { partes; aparatos mecánicos, incluso electromecánicos, de } \\
\text { señalización para vías de comunicación }\end{array}$ \\
\hline & 87 & $\begin{array}{l}\text { Vehículos automóviles, tractores, velocípedos y demás } \\
\text { vehículos terrestres, sus partes y accesorios }\end{array}$ \\
\hline & 88 & Aeronaves, vehículos espaciales, y sus partes \\
\hline & 89 & Barcos y demás artefactos flotantes \\
\hline \multirow{4}{*}{$\begin{array}{l}\text { Sección XVIII - Instrumentos y } \\
\text { aparatos de óptica, fotografía o } \\
\text { cinematografía, de medida, control o } \\
\text { precisión; instrumentos y aparatos } \\
\text { medico quirúrgicos; aparatos de } \\
\text { relojería; instrumentos musicales; } \\
\text { partes y accesorios de estos } \\
\text { instrumentos o aparatos }\end{array}$} & 90 & $\begin{array}{l}\text { Instrumentos y aparatos de óptica, fotografía o } \\
\text { cinematografía, de medida, control o precisión; } \\
\text { instrumentos y aparatos medico quirúrgicos; partes y } \\
\text { accesorios de estos instrumentos o aparatos }\end{array}$ \\
\hline & 91 & Aparatos de relojería y sus partes \\
\hline & 92 & Instrumentos musicales; sus partes y accesorios \\
\hline & 93 & Armas, municiones, y sus partes y accesorios \\
\hline \multirow[t]{3}{*}{$\begin{array}{l}\text { Sección XX: Mercancías y productos } \\
\text { diversos }\end{array}$} & 94 & $\begin{array}{l}\text { Muebles; mobiliario médico quirúrgico; artículos de cama } \\
\text { y similares; aparatos de alumbrado no expresados ni } \\
\text { comprendidos en otra parte; anuncios, letreros y placas } \\
\text { indicadoras, luminosos y artículos similares; } \\
\text { construcciones prefabricadas }\end{array}$ \\
\hline & 95 & $\begin{array}{l}\text { Juguetes, juegos y artículos para recreo o deporte; sus } \\
\text { partes y accesorios }\end{array}$ \\
\hline & 96 & Manufacturas diversas \\
\hline $\begin{array}{l}\text { Sección XXI: Objetos de arte o } \\
\text { colección y antigüedades }\end{array}$ & 97 & Objetos de arte o colección y antigüedades \\
\hline
\end{tabular}

Fuente. Tomado a partir de https://es.portal.santandertrade.com/gestionar-embarques/clasificacionarmonizada-arancelaria\#ancre_bloc, fecha de consulta: 8/11/2016 


\section{Tabla Anexo III.2. Ventajas Comparativas Reveladas de China en el comercio con Estados Unidos, 1991-2015}

\begin{tabular}{|c|c|c|c|c|c|c|c|c|c|c|c|c|c|c|c|c|c|c|c|c|c|c|c|c|c|}
\hline & 991 & 1992 & 1993 & 1994 & 1995 & 1996 & 1997 & 1998 & 1999 & 2000 & 2001 & 2002 & 2003 & 2004 & 2005 & 2006 & 2007 & 2008 & 2009 & 2010 & 2011 & 2012 & 2013 & 2014 & 2015 \\
\hline 1 & $-85,9$ & $-91,0$ & $-82,3$ & $-79,8$ & $-60,9$ & $-40,9$ & $-64,3$ & $-54,2$ & $-39,7$ & $-23,5$ & $-18,5$ & $-6,8$ & $-28,2$ & 67,2 & 20,7 & 30,6 & 27,7 & 1,5 & $-5,5$ & $-4,5$ & $-24,3$ & $-51,2$ & $-50,4$ & $-7,8$ & 53,6 \\
\hline 2 & $-82,5$ & $-69,4$ & $-85,2$ & $-95,6$ & $-93,1$ & $-96,2$ & $-94,8$ & $-94,7$ & $-91,4$ & $-88,6$ & $-89,7$ & $-81,0$ & $-91,1$ & $-76,7$ & $-89,6$ & $-93,1$ & $-95,0$ & $-96,7$ & $-94,8$ & $-86,9$ & $-93,9$ & $-97,3$ & $-97,4$ & $-92,9$ & $-87,7$ \\
\hline 3 & & & 82,7 & & & & & & & 60,4 & & & 68,9 & 60,4 & 54,0 & & 51,4 & 53,3 & 47,6 & & 30,6 & 29,7 & 30,6 & 31,2 & 32,8 \\
\hline 4 & 69,4 & 89,5 & 96,1 & 38 & 52,0 & & 4,0 & 36,2 & 41,7 & 39,0 & $-3,0$ & $-24,0$ & 18,1 & 0,8 & $-11,8$ & $-36,8$ & $-72,1$ & $-77,1$ & $-85,5$ & $-89,4$ & $-89,8$ & $-91,1$ & $-95,3$ & $-95,1$ & $-91,1$ \\
\hline 5 & 83,7 & 83,8 & 79,0 & 80,1 & 80,5 & 67,4 & 63,4 & 60,8 & 58,4 & 67,5 & 62,6 & 68,6 & 70,3 & 69,4 & 62,3 & 61,0 & 62,9 & 51,9 & 46,6 & 38,6 & 40,5 & 49,6 & 48,5 & 42,9 & 24,4 \\
\hline 6 & 71,9 & & 95,3 & & & 94,5 & 47,0 & 59,4 & 62,3 & 75,9 & 83,4 & 82,9 & 93,5 & & 84,9 & 76,1 & 88,1 & 81,2 & 74,0 & 72,7 & 74,9 & 80,6 & 81,0 & 79,6 & 72,0 \\
\hline 7 & 100,0 & 98,1 & 99,3 & 97,0 & 95,8 & 1,3 & 86,4 & 85,0 & 81,2 & 76,5 & 83,5 & 88,1 & 84,5 & 88,5 & 88,7 & 86,1 & 88,8 & 90,2 & 87,8 & 84,3 & 92,4 & 89,1 & 83,0 & 82,1 & 80,7 \\
\hline 8 & 88,2 & 46,1 & 54,7 & 57,4 & 69,2 & 79,2 & 74,5 & 34,0 & 76,9 & $-6,1$ & $-5,7$ & 6,2 & 12,2 & 18,7 & $-8,5$ & 3,7 & 19,8 & 10,1 & $-18,4$ & $-25,4$ & $-41,7$ & $-55,0$ & $-49,9$ & $-31,8$ & $-29,8$ \\
\hline 9 & 98,8 & 99,7 & 95,8 & 99,8 & 99,3 & 97,6 & 97,4 & 97,9 & 95,4 & 94,8 & 92,7 & 97,7 & 97,8 & 97,5 & 92,4 & 82,1 & 80,8 & 82,7 & 87,4 & 90,3 & 89,1 & 84,6 & 86,5 & 90,5 & 91,2 \\
\hline 10 & 100,0 & 100,0 & $-99,9$ & $-97,1$ & $-99,9$ & $-99,8$ & $-97,3$ & $-99,0$ & $-63,4$ & $-94,2$ & $-87,4$ & $-94,6$ & $-30,0$ & $-91,6$ & $-96,3$ & $-7,7$ & 45,4 & 41,4 & $-91,2$ & $-96,5$ & $-97,9$ & $-99,0$ & $-99,5$ & & $-99,1$ \\
\hline 11 & 93,6 & 86,4 & 66,5 & 82,8 & 46,9 & 44,8 & 57,9 & 41,9 & 24,8 & 10,0 & $-29,2$ & 11,2 & 45,8 & 54,0 & 47,8 & 36,5 & 15,0 & 30,6 & 11,6 & 26,7 & 37,1 & 68,2 & 56,6 & 21,0 & 51,4 \\
\hline 12 & 93,0 & 13,2 & 26,1 & & $-2,2$ & $-73,8$ & $-69,5$ & $-57,1$ & $-61,6$ & $-85,4$ & $-87,2$ & $-85,4$ & $-93,7$ & $-90,4$ & $-88,9$ & $-89,6$ & $-92,7$ & $-94,2$ & $-95,7$ & $-96,6$ & $-95,9$ & $-95,6$ & $-94,9$ & $-95,4$ & $-93,7$ \\
\hline 13 & 77, & 96,4 & 99,3 & 9 & 98,5 & 96,4 & 90,2 & 90,1 & 74,6 & 68,2 & 53,8 & 56,3 & 47,0 & 64,4 & 59,8 & 57,4 & 55,1 & 53,0 & 58,4 & 52,7 & 59,4 & 59,2 & 63,0 & 64,6 & 65,7 \\
\hline 14 & 9 & 97,7 & 100,0 & & 9,0 & & 13,8 & 5 , & 5,7 & $-21,4$ & 43,2 & 53,5 & 47,5 & 10,0 & 99,1 & 44,1 & 54,3 & 43,7 & $-34,4$ & $-77,6$ & $-49,9$ & 15,9 & 17,5 & & 64,9 \\
\hline 15 & 7,6 & $-68,0$ & $-0,7$ & $-94,3$ & $-98,3$ & $-86,7$ & $-90,0$ & $-94,2$ & $-84,3$ & $-44,2$ & $-38,9$ & $-62,5$ & $-83,5$ & $-49,0$ & $-17,0$ & $-52,2$ & $-67,6$ & $-60,7$ & $-21,3$ & $-79,2$ & 59,0 & $-73,5$ & $-53,6$ & $-54,9$ & 0,6 \\
\hline 16 & 49,8 & & 71,3 & 95,8 & 64,8 & 77,9 & 81,7 & 72,2 & 89,3 & 74,7 & 69,2 & 72,4 & 88,7 & 88,6 & 84,8 & 86,8 & 76,9 & 90,0 & 86,8 & 81,8 & 88,4 & 79,5 & 73,6 & 79,9 & 80,2 \\
\hline 17 & 88 & 91 , & 56,4 & 47 & 43 & 44,7 & 53,8 & 47 , & 33,5 & 21,3 & 12,7 & 58,9 & 41,1 & & 55,6 & 55,0 & 55,1 & 71,5 & 62,9 & 55,9 & 34,5 & 6,0 & 13,7 & 22,8 & 39,9 \\
\hline 18 & 9 & 98,9 & 89,5 & & & & & 79,1 & 57,9 & 44,9 & 30,0 & 7,0 & 1,1 & & 61,4 & 57 , & 50,3 & 70,7 & $-28,3$ & $-59,5$ & $-77,5$ & $-74,8$ & $-60,7$ & $-53,3$ & $-21,9$ \\
\hline 19 & 4,2 & 98,6 & 98,5 & & & & 68,4 & 84,2 & 75,7 & 55,8 & 59,7 & 62,5 & 65,8 & 65,3 & 67,4 & 68,7 & 75,1 & 71,6 & 76,9 & 70,9 & 52,6 & 38,9 & 59,4 & 57,3 & 39,7 \\
\hline 20 & & & 96,0 & & & 94,1 & 92,2 & 91 & 84,4 & 76,8 & 71,6 & 72,3 & 77,7 & & 85,7 & 83,6 & 87,5 & 87,5 & 79,9 & 77,1 & 77,8 & 77,4 & 77,8 & 74,3 & 67,3 \\
\hline 21 & & & 67,7 & & & & & & 36,9 & 2,5 & $-18,4$ & $-0,2$ & $-45,0$ & -45 & $-3,4$ & 7, & 17,5 & 16,2 & 26,4 & 22,5 & 23 & 19,6 & 1,9 & 8,0 & 22,5 \\
\hline 22 & 94,8 & 96,0 & 79,9 & 78,1 & 55,4 & 62,9 & 53,3 & 47,0 & 50,5 & 75,4 & 69,3 & 64,2 & 63,4 & 56,8 & 46,0 & 73,9 & 25,8 & 4,5 & $-19,6$ & $-23,5$ & $-32,8$ & $-20,3$ & $-38,0$ & $-35,3$ & $-62,4$ \\
\hline 23 & $-95,7$ & $-88,6$ & $-37,0$ & $-19,9$ & $-51,4$ & $-92,7$ & $-78,5$ & $-90,9$ & $-55,2$ & $-51,0$ & $-50,4$ & $-42,0$ & $-36,8$ & $-17,6$ & 14,3 & 40,6 & 30,6 & 31,8 & $-6,1$ & $-44,9$ & $-25,1$ & $-31,7$ & $-66,7$ & $-68,5$ & $-73,6$ \\
\hline 24 & 2,9 & & 46,9 & & -37, & 83,3 & 30,5 & 21, & 20,2 & 79,2 & 87,5 & 96,7 & 50,8 & $-12,4$ & 36,1 & $-64,9$ & $-54,5$ & $-75,3$ & $-76,0$ & $-85,0$ & $-81,8$ & $-77,1$ & $-83,4$ & $-88,3$ & $-82,4$ \\
\hline 25 & 84,0 & 87,4 & 90,5 & & 90,7 & 82,9 & 90,4 & 91 & 80,8 & 72,0 & 72,2 & 62,3 & 60,3 & 64,8 & 73,1 & 81,8 & 70,7 & 59,3 & 30,5 & 23,9 & 38,4 & 40,9 & 32,7 & 32,0 & 38,4 \\
\hline 26 & 1,9 & & 54,7 & & $-4,2$ & $-48,9$ & 33,7 & 56 & 6,6 & $-6,3$ & $-2,8$ & 31,4 & $-35,8$ & $-45,9$ & $-77,6$ & $-74,5$ & $-87,5$ & $-72,2$ & $-91,5$ & $-90,9$ & $-94,2$ & $-93,9$ & $-89,7$ & $-90,8$ & $-89,8$ \\
\hline 27 & & & 1,0 & & & & 46,2 & & 39,3 & 86,2 & 64,3 & 65,7 & 57,7 & 66 & 78,3 & 72,0 & 41,8 & 66,1 & $-24,8$ & $-45,3$ & $-69,6$ & $-77,2$ & \begin{tabular}{|l|l}
$-75,8$ \\
\end{tabular} & $-59,2$ & $-63,3$ \\
\hline 28 & & & 71,2 & & & & & & 73 & 61,6 & 64,2 & 56 , & 51,9 & & 27,8 & 21,0 & 18,5 & 25,8 & 1,3 & $-4,7$ & 32,2 & 14,6 & 25,8 & 27,7 & 17,4 \\
\hline 29 & $-29,2$ & $-8,3$ & 4,4 & & 17 & 28,6 & 39,6 & 42,0 & 34,6 & 18,9 & 30,6 & 15,7 & 1,9 & $-1,2$ & 16,6 & 25,3 & 17,2 & 42,4 & 25,5 & 23,4 & 25,4 & 34,7 & 38,3 & 49,2 & 47,1 \\
\hline 30 & 41,9 & & & & & & 52,4 & 49 & 60 & 61, & 28,0 & 7,3 & 15,5 & 21,9 & 25,5 & & 8,2 & 25,1 & 22,1 & & $-4,9$ & $-6,6$ & $-11,7$ & $-17,3$ & $-21,9$ \\
\hline 31 & 100,0 & & $-99,9$ & 0 & -99 & 8 & $-99,9$ & -99 & $-99,8$ & $-98,3$ & $-87,8$ & $-98,7$ & $-75,1$ & $-68,6$ & $-87,5$ & -62 & 41,8 & 34,5 & $-13,1$ &, 2 & 7,6 & 43,5 & 31,1 & 71,5 & 72,6 \\
\hline 32 & 13,2 & & 20,7 & & 31,4 & 29,8 & 33,5 & 45,4 & 34,6 & 19,4 & 1,0 & 10,8 & 13,3 & 21,1 & 23,0 & 15,0 & 12,1 & 5,3 & $-8,4$ & $-32,9$ & $-42,4$ & $-6,8$ & 6,6 & 9,1 & 15,4 \\
\hline 33 & 55,9 & 3,0 & 51,9 & 45 & 68 & 57,1 & 47,1 & 72,8 & 66,2 & 58,0 & 65,1 & 63,0 & 56,5 & 55,2 & 52,2 & 51,0 & 53,4 & 54,1 & 49,6 & 53,0 & 54,0 & 57,5 & 45,3 & 47,5 & 47,7 \\
\hline 34 & & & 40,0 & & & & 72,0 & 75 & 72,6 & 67,3 & 65,1 & 60,5 & 50,8 & 48,0 & 37,8 & 16,8 & 10,0 & $-2,7$ & 0,5 & $-0,2$ & $-17,1$ & $-11,0$ & $-22,0$ & $-18,5$ & $-12,3$ \\
\hline 35 & & & & & & & $-47,4$ & -36 & & -44 & & -35 & $-28,4$ & -17 & 3,6 & & 14,5 & 19,0 & 17,0 & & 14,2 & & 7,0 & & 14,2 \\
\hline 36 & & 98 & 97,8 & 97,8 & 96 & 97,1 & 98,9 & 95,6 & 96,8 & 94,0 & 97,9 & 97,2 & 98,4 & 96,5 & 96,4 & 94,3 & 87,5 & 82,6 & 76,5 & 70,3 & 72,3 & 67,0 & 56,5 & 59,1 & 63,4 \\
\hline 37 & 44,6 & 0,6 & $-51,0$ & 8,7 & 41, & $-0,5$ & 7,8 & $-29,0$ & $-57,7$ & $-35,6$ & $-52,9$ & $-72,9$ & $-49,2$ & 8,7 & 4,4 & $-28,1$ & $-70,3$ & $-79,2$ & $-89,5$ & $-85,5$ & $-87,2$ & $-89,3$ & $-85,9$ & $-88,2$ & $-88,2$ \\
\hline 38 & $-54,8$ & $-37,5$ & $-45,6$ & $-26,1$ & -45 & $-29,7$ & $-31,3$ & $-32,0$ & $-38,2$ & $-37,1$ & $-36,2$ & $-33,5$ & $-15,6$ & $-35,9$ & $-23,0$ & $-20,5$ & $-33,4$ & $-25,9$ & $-32,6$ & $-30,5$ & $-15,5$ & $-21,2$ & $-33,8$ & $-36,1$ & $-23,1$ \\
\hline 39 & & 58,7 & 71,0 & & & & 66,2 & 67, & 67,9 & 63,3 & 61,5 & 61,3 & 58,6 & 52,9 & 53,1 & 50,6 & 43,4 & 43,7 & 32,9 & 36,9 & 39,4 & 47,4 & 49,2 & 49,2 & 51,7 \\
\hline 40 & 29,4 & 61,3 & 78,8 & 80,1 & 81,7 & 82,6 & 85,5 & 89,6 & 89,1 & 80,6 & 73,3 & 76,7 & 69,7 & 73,1 & 71,9 & 72,0 & 71,3 & 69,2 & 64,2 & 59,5 & 62,6 & 66,0 & 71,2 & 75,1 & 75,1 \\
\hline
\end{tabular}




\begin{tabular}{|c|c|c|c|c|c|c|c|c|c|c|c|c|c|c|c|c|c|c|c|c|c|c|c|c|c|}
\hline 41 & 4,8 & $-50,1$ & $-73,6$ & $-86,2$ & $-90,4$ & $-96,6$ & $-97,3$ & $-96,8$ & $-98,8$ & $-98,0$ & $-98,4$ & $-93,2$ & $-85,9$ & $-82,4$ & $-85,3$ & $-89,6$ & $-91,4$ & $-92,8$ & $-94,9$ & $-95,3$ & $-96,8$ & $-96,3$ & $-97,0$ & $-97,1$ & $-96,1$ \\
\hline 42 & 99,8 & 99,9 & 99,7 & 99,7 & 99,8 & 99,8 & 99,7 & 99,8 & 99,7 & 99,6 & 99,4 & 99,7 & 99,7 & 99,7 & 99,7 & 99,7 & 99,5 & 99,5 & 99,1 & 99,5 & 99,5 & 99,5 & 99,4 & 99,2 & 98,6 \\
\hline 43 & 96,6 & 85,0 & 90,6 & 90,0 & 86,8 & 85,9 & 83,0 & 86,9 & 93,6 & 88,1 & 89,3 & 87,8 & 80,5 & 63,7 & 57,3 & 49,8 & 42,9 & $-18,5$ & $-16,7$ & $-26,6$ & $-16,3$ & $-19,9$ & $-39,4$ & 16,4 & $-9,6$ \\
\hline 44 & & $-6,2$ & 23,6 & 54,5 & 79,4 & 79,8 & 77,9 & 84,6 & 84,5 & 80,0 & 74,0 & 68,1 & 69,6 & 69,4 & 69,6 & 72,1 & 71,5 & 71,9 & 64,3 & 45,0 & 23,0 & 36,0 & 21,8 & 20,7 & 35,6 \\
\hline 45 & 0,3 & 80,3 & 17,0 & $-5,7$ & $-23,1$ & $-21,9$ & 16,2 & $-61,3$ & 16,9 & 50,1 & 29,3 & 45,1 & 68,0 & 85,8 & 90,6 & 83,2 & 77,8 & 81,0 & 76,7 & 75,6 & 82,4 & 89,4 & 79,5 & 87,7 & 94,0 \\
\hline 46 & 00,0 & 98,6 & 99,8 & 99,7 & 100,0 & 99,4 & 99,7 & 99,9 & 99,8 & 100,0 & 99,9 & 99,4 & 99,5 & 99,0 & 98,3 & 96,9 & 97,3 & 99,5 & 99,3 & 99,5 & 99,7 & 99,2 & 99,4 & 99,9 & 99,9 \\
\hline 47 & 99,9 & 100,0 & $-99,9$ & $-100,0$ & $-99,9$ & $-100,0$ & $-99,4$ & $-97,9$ & $-99,5$ & $-99,8$ & $-99,7$ & $-99,7$ & $-99,6$ & $-99,6$ & $-99,6$ & $-99,6$ & $-99,2$ & $-98,7$ & $-99,5$ & $-99,5$ & $-98,9$ & $-99,7$ & $-99,7$ & $-99,7$ & $-99,9$ \\
\hline 48 & 5,4 & $-4,2$ & 11,6 & 21,4 & 29,7 & 7,1 & 12,4 & 12,4 & 20,2 & 26,3 & 35,6 & 37,3 & 45,1 & 49,3 & 56,7 & 63,6 & 62,9 & 64,0 & 61,6 & 62,0 & 54,3 & 58,5 & 57,5 & 58,3 & 62,7 \\
\hline 49 & 43,7 & 51,6 & 57,7 & 68,7 & 78,4 & 71,7 & 70,2 & 46,1 & 71,1 & 77,4 & 73,9 & 81,9 & 83,1 & 90,3 & 90,7 & 90,2 & 90,3 & 86,4 & 88,7 & 86,0 & 85,5 & 85,6 & 86,5 & 83,6 & 84,2 \\
\hline 50 & 98,9 & 99,2 & 99,4 & 99,1 & 97,8 & 98,7 & 99,5 & 99,6 & 99,4 & 97,3 & 86,8 & 91,5 & 79,9 & 81,6 & 82,2 & 91,2 & 87,7 & 94,9 & 96,9 & 96,8 & 96,7 & 97,9 & 97,9 & 98,4 & 97,4 \\
\hline 51 & 4,3 & $-18,6$ & 20,6 & 24,7 & $\begin{array}{l}-7,2 \\
\end{array}$ & 3,8 & 49,6 & 52,4 & 80,8 & 44,6 & 39,1 & 26,6 & $-22,6$ & 5,2 & 39,3 & 21,0 & 10,5 & 18,4 & 5,9 & 16,9 & 39,2 & 34,5 & 46,4 & 63,8 & 49,7 \\
\hline 52 & 8,0 & $-4,7$ & 94,7 & $-60,0$ & $-69,6$ & 72,0 & $-55,6$ & 0,4 & 80,3 & 57,0 & 51,6 & 11,5 & $-60,1$ & $-77,7$ & $-74,4$ & $-78,5$ & $-70,2$ & $-73,1$ & $-63,1$ & $-76,8$ & $-79,3$ & $-85,1$ & $-78,6$ & $-63,7$ & $-54,9$ \\
\hline 53 & 99,8 & 100,0 & 99,6 & 98,3 & 92,7 & 99,8 & 97,7 & 99,1 & 99,2 & 98,8 & 96,4 & 93,8 & 97,1 & 92,4 & 97,4 & 97,6 & 99,5 & 99,4 & 82,1 & 85,9 & 88,6 & 95,6 & 97,8 & 99,1 & 98,4 \\
\hline 54 & 6,8 & 2,5 & 41,1 & 1,0 & $-21,6$ & $-22,5$ & 33,4 & 18,1 & 1,1 & 12,7 & $-0,9$ & $-7,8$ & $-2,7$ & 18,7 & 53,0 & 42,0 & 54,8 & 57,5 & 65,4 & 50,9 & 58,9 & 61,8 & 58,7 & 62,6 & 69,4 \\
\hline 55 & 60,1 & 2,2 & $-40,9$ & $-52,8$ & $-65,2$ & $-55,9$ & $-21,0$ & $-7,7$ & $-15,5$ & $-14,0$ & $-27,8$ & $-18,7$ & $-15,0$ & $-28,4$ & $-5,3$ & 13,9 & 3,5 & 2,3 & $-18,3$ & $-11,9$ & $-8,7$ & $-7,4$ & $-6,5$ & $-1,7$ & 27,2 \\
\hline 56 & 9,2 & 36,3 & 52,4 & 49,7 & 61,7 & 42,1 & 44,2 & 46,3 & 53,4 & 49,6 & 45,0 & 10,2 & 8,8 & 16,1 & 19,0 & 1,3 & 7,3 & 6,5 & 18,9 & 26,9 & 30,0 & 36,3 & 43,3 & 49,9 & 63,3 \\
\hline 57 & 98,2 & 99,3 & 97,9 & 94,4 & 95,4 & 89,6 & 90,2 & 92,0 & 93,5 & 95,2 & 96,4 & 97,7 & 97,8 & 97,4 & 96,8 & 95,0 & 93,0 & 88,4 & 92,0 & 90,0 & 92,0 & 92,3 & 92,0 & 93,5 & 94,6 \\
\hline 58 & 77,9 & 79,2 & 78,0 & 84,4 & 86,5 & 93,8 & 94,7 & 92,4 & 90,2 & 80,2 & 83,4 & 69,0 & 73,8 & 68,4 & 74,3 & 82,8 & 88,8 & 89,2 & 90,2 & 91,1 & 91,9 & 91,9 & 93,8 & 91,5 & 93,8 \\
\hline 59 & 9,3 & 29,4 & $-29,8$ & 8,2 & 28,0 & $-19,6$ & $-29,6$ & $-0,6$ & $-35,1$ & $-16,1$ & 15,5 & 1,1 & 3,3 & 24,0 & 39,5 & 41,5 & 35 & 43,2 & 42,8 & 46,7 & 54,5 & 57,6 & 56,1 & 63,3 & 68,4 \\
\hline 60 & & & 77,3 & & $-19,3$ & $-1,6$ & 66,1 & 32,2 & $-3,5$ & $-0,2$ & $-23,4$ & 78,0 & 85,0 & 85,5 & 90,0 & 89,7 & & 87,7 & 91,6 & 91,8 & 93,4 & 94,5 & 94,5 & 94,0 & 93,6 \\
\hline 61 & 99,7 & 99,6 & 99,5 & 99,5 & 99,3 & 99,4 & 99,6 & 99,7 & 99,8 & 99,8 & 99,6 & 99,6 & 99,6 & 99,5 & 99,3 & 99,8 & 99,8 & 99,7 & 99,7 & 99,8 & 99,8 & 99,7 & 99,7 & 99,7 & 99,5 \\
\hline 62 & 99,9 & 100,0 & 99,8 & 99,8 & 99,8 & 99,9 & 99,8 & 99,8 & 99,8 & 99,8 & 98,8 & 99,4 & 99,8 & 99,7 & 99,8 & 99,8 & 99,8 & 99,8 & 99,8 & 99,9 & 99,8 & 99,6 & 99,7 & 99,6 & 99,6 \\
\hline 63 & 99,1 & 9 & 97,9 & 99,0 & 96,8 & 98,6 & 98,5 & 97,7 & 99,2 & 99,2 & 99,2 & 99,6 & 99,4 & 99,5 & 99,3 & 99,4 & 99,4 & 99,4 & 99,2 & 99,3 & 99,2 & 99,4 & 99,5 & 99,4 & 99,4 \\
\hline 64 & & & 99,8 & 99,7 & 99,7 & 99,7 & 99,4 & 99,3 & 99,1 & 99,1 & 99,1 & 99,3 & 99,3 & 99,5 & 99,4 & 99,2 & & 99,5 & 99,3 & 99,3 & 99,3 & 99,4 & 99,4 & 99,4 & 99,1 \\
\hline 65 & 0,0 & 3 & 99,9 & 99,8 & 99,9 & 99,9 & 99,9 & 99,7 & 99,9 & 00,0 & 99,6 & 99,8 & 99,9 & 99,7 & 99,8 & 99,8 & 99,8 & 99,7 & 99,8 & 99,7 & 99,8 & 99,7 & 99,5 & 99,4 & 99,4 \\
\hline 66 & 0,0 & 0,0 & 99,8 & 99, & 99, & 99,9 & 100,0 & 99,6 & 99,2 & 00,0 & 99,8 & 99,9 & 99,8 & 99,8 & 99,8 & 99,5 & 99,3 & 99,7 & 99,9 & 99,8 & 99,3 & 99,9 & 99,9 & 99,8 & 99,9 \\
\hline 67 & & 99,0 & 99,9 & $\overline{95}$ & 99,9 & 99,6 & 99,7 & 99,4 & 99,6 & 99,4 & 99,0 & 99,2 & $\begin{array}{l}98,9 \\
\end{array}$ & 99,2 & 99,2 & 99,0 & 99 & 98,2 & 98,9 & 99,0 & 99,2 & 99,2 & 98,2 & 98,9 & 99,3 \\
\hline 68 & & & & & & 84 & 88,7 & 91,2 & 93,1 & 89,5 & 91,1 & 91,1 & 90,6 & 85,7 & 86,5 & 86,6 & & 84,4 & 79,9 & 73,6 & 68,2 & 74,9 & 78,6 & 75,3 & 76,1 \\
\hline 69 & 90,9 & 94,1 & 97,6 & 965 & 92,2 & 94,5 & 95,7 & 97,4 & 94,0 & 92,4 & 90,3 & 93,6 & 93,2 & 93,5 & 95,7 & 95,6 & 95,1 & 95,3 & 96,8 & 93,8 & 92,8 & 95,1 & 94,9 & 93,2 & 93,5 \\
\hline 70 & 73,4 & 6 & 73,5 & 74,6 & 68, & 67,3 & 59,7 & 56,5 & 80, & 70,6 & 81,0 & 86,2 & 81,0 & 77,2 & 80,3 & 76,5 & 73,7 & 69,9 & 67,9 & 70,2 & 73,0 & 78,5 & 72,6 & 76,0 & 79,9 \\
\hline 71 & 8 & 8 & 75,4 & 81 & & 88,2 & 85,8 & 87,1 & 82,0 & 80,9 & 86,2 & 90,8 & 91,2 & 90,6 & 88,6 & 76,9 & 70 & 75,0 & 74,3 & 63,6 & 55,2 & 74,9 & 52,1 & 53,7 & 68,1 \\
\hline 72 & & & & 2 & & & & & & & $-36,6$ & $-29,9$ & $-64,1$ & 1 & $-8,5$ & 13,8 & & 9,0 & $-68,1$ & $-29,6$ & $-23,9$ & 2,2 & 8,3 & 45,8 & 38,1 \\
\hline 73 & 51,7 & 66,1 & 67,7 & 1,9 & 70,5 & 76,0 & 85,5 & 88,2 & 90,1 & 92,6 & 92,7 & 93,4 & 93,9 & 91,3 & 91,4 & 91,8 & 90,2 & 87,8 & 84,6 & 84,9 & 87,3 & 88,1 & 85,6 & 84,8 & 87,3 \\
\hline 74 & 38,4 & $-69,4$ & $-29,9$ & $-19,3$ & 45,8 & $-20,7$ & 6,0 & 8,2 & 17,3 & $-30,1$ & $-30,1$ & $-29,4$ & $-48,1$ & $-32,0$ & $-38,5$ & $-39,4$ & $-44,8$ & $-37,5$ & $-53,7$ & $-66,5$ & $-73,1$ & $-75,1$ & $-71,3$ & $-64,1$ & $-54,0$ \\
\hline 75 & 6,8 & & $-65,7$ & & -2 & & $-73,0$ & $-69,8$ & $-21,9$ & $-58,1$ & $-73,0$ & $-80,3$ & $-77,6$ & $-81,5$ & $-73,2$ & $-51,6$ & $-82,9$ & $-83,0$ & $-79,3$ & $-70,1$ & $-76,0$ & $-72,3$ & $-68,0$ & $-70,5$ & $-67,7$ \\
\hline 76 & & & $-27,5$ & & -42 & $-40,1$ & $-34,1$ & & & $-22,2$ & $-13,0$ & 18,8 & 19,7 & 22,4 & 18,4 & $-0,2$ & & \begin{tabular}{|l}
$-7,6$ \\
\end{tabular} & 2,7 & $-6,0$ & $-24,3$ & $-15,7$ & $-3,1$ & 11,9 & 31,3 \\
\hline 78 & $-77,0$ & $-17,2$ & 2,9 & 36,1 & 12,9 & 1,4 & 17,4 & 77,6 & 89,5 & 87,9 & 39,5 & $-3,6$ & $-70,8$ & 9,8 & 64,8 & 90,7 & 22,2 & $-1,5$ & $-40,1$ & $-0,7$ & 34,9 & 59,3 & 23,0 & 52,3 & 34,2 \\
\hline 79 & 72,3 & 93,7 & 93,7 & & 96,5 & 90,7 & 96,1 & 98,0 & 97,8 & 94,5 & 89,2 & 83,9 & 55,7 & 32,3 & 27,8 & 15,0 & 13 & 2,2 & 23,5 & 5,5 & 9,9 & 10,1 & 12,3 & $-14,1$ & 34,4 \\
\hline 8 & & & 95 & & & & 94,9 & 96,4 & 97,6 & 92,2 & 93, & 89,3 & 87,9 & 92,7 & 91,2 & 88,8 & & 90,7 & 90,9 & 85,3 & 92,0 & 4,1 & 94,5 & 96,6 & 85,2 \\
\hline 8 & & & & & & & & & & & 75 & & & 36,0 & $-39,0$ & $-40,3$ & & 31,0 & 30,7 & & 62,2 & 1,0 & 2,6 & 62,7 & 50,0 \\
\hline 82 & 88,2 &, 2 & 84,4 & 89,8 & 91 , & 86,3 & 92,9 & 92,6 & 93,9 & 92,0 & 89,4 & 84,9 & 93,5 & 92,7 & 91,2 & 90,9 & 89,7 & 88,1 & 87,9 & 85,8 & 84,5 & 87,6 & 88,5 & 88,4 & 90,4 \\
\hline 83 & 95,0 & 96,4 & 90,6 & 90,5 & 92,8 & 94,4 & 93,3 & 93,7 & 96,7 & 95,8 & 95,5 & 96,8 & 96,5 & 95,6 & 95,8 & 95,5 & 95 & 94,7 & 93,4 & 93,7 & 93,5 & 93,8 & 93,7 & 93,0 & 93,5 \\
\hline 84 & $-20,4$ & $-2,9$ & $-5,4$ & 12,5 & 26,7 & 33,6 & 42,9 & 48,8 & 61,1 & 60,3 & 55,8 & 67,4 & 74,0 & 75,9 & 79,1 & 78,6 & 76,4 & 74,7 & 76,9 & 76,7 & 77,7 & 79,7 & 78,8 & 79,3 & $\overline{79,4}$ \\
\hline
\end{tabular}




\begin{tabular}{|c|c|c|c|c|c|c|c|c|c|c|c|c|c|c|c|c|c|c|c|c|c|c|c|c|c|}
\hline 85 & 81,3 & $\begin{array}{l}77,0 \\
\end{array}$ & \begin{tabular}{|l|l|}
67,6 \\
\end{tabular} & 76,1 & 73,1 & 73,1 & $\begin{array}{l}75,6 \\
\end{array}$ & 76,6 & 77,7 & $\begin{array}{l}76,8 \\
\end{array}$ & 71,4 & 73,1 & 72,5 & 74,6 & 77,8 & 73,6 & 76,2 & 75,8 & 77,5 & 78,0 & 81,7 & 84,3 & 82,7 & 83,1 & 82,8 \\
\hline 86 & 9,3 & $-6,7$ & $-54,7$ & $-42,4$ & \begin{tabular}{|l|l}
54,8 \\
\end{tabular} & $\begin{array}{l}-8,3 \\
\end{array}$ & 45,9 & 47,7 & 73,2 & 83,1 & 39,1 & 66,6 & 63,9 & 53,3 & 56,0 & 30,8 & 60,8 & 28,9 & 7,2 & 19,3 & 75,0 & 67,5 & 68,2 & 81,3 & 89,0 \\
\hline 87 & 35,4 & $-14,0$ & $-41,0$ & 17,2 & 52,3 & 57,6 & 37,3 & 72,4 & 69,6 & 83,2 & 74,9 & 76,0 & 68,3 & 70,2 & 66,2 & 62,5 & 54,0 & 57,2 & 47,1 & 25,2 & 12,7 & 17,2 & 0,7 & $-4,2$ & 11,7 \\
\hline 88 & $-95,9$ & $-97,7$ & $-94,9$ & $-97,2$ & $-95,8$ & $-96,6$ & $-96,4$ & $-97,6$ & $-97,5$ & $-95,9$ & $-95,2$ & $-96,8$ & $-94,9$ & $-92,0$ & $-96,2$ & $-95,6$ & $-94,7$ & $-92,6$ & $-91,9$ & $-90,6$ & $-88,5$ & $-90,6$ & $-92,8$ & $-92,9$ & $-93,8$ \\
\hline 89 & 9,7 & $-42,8$ & $-64,3$ & $-27,4$ & 15,5 & $-0,7$ & 55,5 & 88,4 & 89,4 & 87,0 & 89,6 & 72,7 & 49,3 & 33,8 & 67,7 & 91,3 & 80,9 & 80,0 & 81,5 & 64,8 & 57,3 & 45,3 & 46,2 & 56,8 & 68,6 \\
\hline 90 & $-18,8$ & $-16,7$ & 4,6 & 32,6 & 49,1 & 53,0 & 53,0 & 54,4 & 50,3 & 56,5 & 39,2 & 39,1 & 36,0 & 31,2 & 28,7 & 26,0 & 27,2 & 26,3 & 18,6 & 16,6 & 17,1 & 12,5 & 12,2 & 17,1 & 17,7 \\
\hline 91 & 96,4 & 92,1 & $\begin{array}{l}98,6 \\
\end{array}$ & $\begin{array}{l}99,6 \\
\end{array}$ & $\begin{array}{l}99,6 \\
\end{array}$ & 99,5 & 99,3 & 99,6 & 99,5 & $\begin{array}{l}99,5 \\
\end{array}$ & $\begin{array}{l}98,8 \\
\end{array}$ & 98,4 & 99,2 & 99,3 & 99,1 & 99,1 & 98,6 & 98,8 & 98,7 & \begin{tabular}{|c|}
98,8 \\
\end{tabular} & 98,5 & 98,2 & 98,3 & 98,1 & 96,6 \\
\hline$\overline{92}$ & 97,3 & 98,8 & 99,2 & 99,5 & 98,6 & 99,3 & 99,6 & 98,8 & 99,4 & 98,9 & 98,6 & 98,0 & 97,3 & 97,4 & 96,9 & 96,7 & 95,2 & 94,4 & $\begin{array}{l}94,8 \\
\end{array}$ & 95,4 & 93,5 & 94,2 & 94,1 & 93,4 & 92,2 \\
\hline 93 & 82,1 & 88,0 & 95,5 & 97,9 & 67,4 & 36,1 & 6,2 & 87,5 & 96,2 & 83,3 & 85,8 & 98,2 & 99,0 & 84,5 & 96,2 & 98,7 & 97,7 & 99,2 & 99,0 & 98,9 & 98,7 & 99,3 & 98,3 & 98,9 & 98,4 \\
\hline 94 & 92,2 & 92,8 & 91,1 & 94,0 & 94,7 & 93,0 & 96,9 & 97,9 & 98,0 & 98,0 & 98,0 & 98,6 & 98,8 & 99,0 & 98,9 & 98,9 & 98,6 & 98,3 & 98,7 & 98,3 & 98,1 & 98,2 & 98,3 & 97,9 & 98,0 \\
\hline 95 & & 99,6 & 99,5 & 99,4 & 97,9 & 96,6 & 97,7 & 99,1 & 99,4 & 99,6 & 99,6 & 99,7 & 99,6 & 99,4 & 99,4 & 99,5 & 99,4 & 99,5 & 98,9 & 96,9 & 95,1 & 97,4 & 97,8 & 99,1 & 98,8 \\
\hline 96 & 98,2 & 99,0 & 98,5 & $\begin{array}{l}98,8 \\
\end{array}$ & $\begin{array}{l}97,8 \\
\end{array}$ & 97,5 & 98,3 & 97,9 & $\begin{array}{l}99,0 \\
\end{array}$ & 97,7 & 98,1 & 97,7 & 97,6 & 97,6 & 97,7 & 97,2 & 97,8 & 97,7 & 97,3 & 97,5 & 97,9 & 97,3 & 97,1 & 97,4 & 96,6 \\
\hline 97 & 93,6 & 94,5 & 96,5 & 91,6 & 94,1 & 95,7 & 43,8 & 97,3 & $\begin{array}{l}92,8 \\
\end{array}$ & 86,8 & 82,3 & 74,2 & 90,4 & 82,9 & 92,5 & 85,9 & 84,0 & 64,6 & 61,9 & 78,3 & 62,0 & 69,0 & 64,1 & 42,6 & 59,8 \\
\hline 99 & 56,7 & 70,3 & 49,5 & 49,6 & 43,9 & 46,0 & 56,8 & 57,4 & 64,2 & 68,0 & 71,0 & 72,2 & 74,5 & 74,4 & 76,3 & 75,7 & 75,6 & 72,5 & 73,0 & 50,4 & 65,1 & 68,5 & 65,8 & 64,1 & 67,2 \\
\hline TOTAL & 52,7 & 57,2 & 58,7 & 63,3 & 61,0 & 63,9 & 67,4 & 68,1 & 74,0 & 73,8 & 70,1 & 71,6 & 70,3 & 71,7 & 72,3 & 69,4 & 67,8 & 66,6 & 63,3 & 61,3 & 60,1 & 60,2 & 58,1 & 59,4 & 62,4 \\
\hline
\end{tabular}

Fuente. Elaboración propia según COMTRADE, Naciones Unidas, disponible en http://comtrade.un.org/data/fecha de consulta: 8/12/2016 
Tabla Anexo III.3. Ventajas Comparativas Reveladas de México en el comercio con Estados Unidos, 1991-2015

\begin{tabular}{|c|c|c|c|c|c|c|c|c|c|c|c|c|c|c|c|c|c|c|c|c|c|c|c|c|c|}
\hline & 1991 & 1992 & 1993 & 1994 & 1995 & 1996 & 1997 & 1998 & 1999 & 2000 & 2001 & 2002 & 2003 & 2004 & 2005 & 2006 & 2007 & 2008 & 2009 & 2010 & 2011 & \begin{tabular}{|l|l|}
2012 \\
\end{tabular} & 2013 & 2014 & \begin{tabular}{|l|l|}
2015 \\
\end{tabular} \\
\hline 1 & 32,5 & 27,6 & 60,2 & 40,8 & 89,4 & 21,9 & $-7,7$ & 19,6 & 48,5 & 54,2 & 47,8 & 37,0 & 73,9 & 77,9 & 76,6 & 78,3 & 68,1 & 41,1 & 62,8 & 66,6 & 70,9 & \begin{tabular}{|l|}
73,5 \\
\end{tabular} & 55,7 & 65,2 & $\begin{array}{l}74,5 \\
\end{array}$ \\
\hline 2 & $-99,1$ & $-99,4$ & $-98,6$ & $-99,0$ & $-96,4$ & $-96,5$ & $-97,7$ & $-98,1$ & $-97,6$ & $-97,8$ & $-97,4$ & $-97,1$ & $-95,7$ & $-94,4$ & $-93,5$ & $-91,2$ & $-88,6$ & $-91,6$ & $-87,1$ & $-81,9$ & $-77,0$ & $-65,9$ & $-66,9$ & $-62,3$ & $-47,1$ \\
\hline 3 & 77,6 & 65,7 & 72,6 & 72,4 & 86,1 & 85,4 & 85,6 & 84,8 & 86,3 & 84,0 & 80,8 & 77,3 & 73,9 & 80,5 & 80,1 & 81,4 & 85,5 & 83,8 & 88,3 & 87,5 & 89,7 & 90,2 & 90,8 & 91,3 & 92,4 \\
\hline 4 & $-94,1$ & $-96,8$ & $-97,3$ & $-95,2$ & $-90,9$ & $-77,8$ & $-84,7$ & $-89,0$ & $-90,0$ & $-88,6$ & $-88,7$ & $-69,3$ & $-68,0$ & $-77,6$ & $-78,6$ & $-74,4$ & $-85,2$ & $-84,6$ & $-80,8$ & $-81,8$ & $-86,1$ & $-84,6$ & $-87,1$ & $-87,2$ & $-84,1$ \\
\hline 5 & $-37,8$ & $-44,6$ & $-44,0$ & $-47,7$ & $-42,3$ & $-51,7$ & $-39,9$ & $-31,6$ & $-37,0$ & $-55,3$ & $-76,5$ & $-85,3$ & $-85,1$ & $-82,6$ & $-82,9$ & $-85,9$ & $-83,6$ & $-83,9$ & $-61,9$ & $-39,7$ & $-43,2$ & $-41,6$ & $-44,2$ & $-44,9$ & $-42,2$ \\
\hline 6 & 28,3 & 14,3 & 15,3 & 0,0 & 20,7 & 8,7 & 12,8 & 23,1 & 22,6 & 30,0 & 31,8 & 34,6 & 20,2 & 23,8 & 24,0 & 23,6 & 26,7 & 12,2 & 13,6 & 17,6 & $-4,3$ & $-8,8$ & $-11,3$ & $-8,0$ & $-10,3$ \\
\hline 7 & 87,8 & 84,0 & 88,0 & 84,0 & 93,8 & 84,7 & 86,7 & 81,3 & 86,5 & 86,3 & 86,5 & 87,2 & 89,7 & 90,0 & 89,7 & 86,2 & 86,8 & 84,1 & 81,7 & 86,3 & 89,2 & 85,0 & 88,6 & 89,4 & 90,9 \\
\hline 8 & 74,7 & 70,6 & 57,1 & 41,6 & 72,1 & 68,6 & 65,7 & 70,2 & & 49,0 & 47,7 & 52,4 & 57,7 & 62,6 & & & 63,6 & & & 68,8 & 66,7 & 63,3 & 64,5 & 70,3 & \\
\hline 9 & 94,7 & 93,2 & 93,6 & 92,5 & 97,7 & 98,0 & 92,4 & 88,5 & 93,3 & 94,6 & 82,7 & 87,6 & 86,1 & 84,1 & 87,1 & 92,7 & 93,0 & 92,1 & 94,1 & 83,0 & 90,2 & 90,2 & 86,7 & 82,3 & 74,4 \\
\hline 10 & $-99,8$ & $-99,9$ & $-99,8$ & $-99,9$ & $-99,7$ & $-99,8$ & $-99,4$ & $-99,0$ & $-98,8$ & $-99,2$ & $-98,9$ & $-99,5$ & $-98,9$ & $-98,7$ & $-99,1$ & $-98,6$ & $-97,0$ & $-98,0$ & $-98,7$ & $-99,1$ & $-99,3$ & $-98,3$ & $-98,9$ & $-98,3$ & $-98,0$ \\
\hline 11 & $-90,3$ & $-93,9$ & $-91,9$ & $-91,0$ & $-80,4$ & $-89,5$ & $-92,0$ & $-91,3$ & $-90,6$ & $-88,9$ & $-87,4$ & $-93,0$ & $-93,5$ & $-83,7$ & $-88,3$ & $-91,0$ & $-90,8$ & \begin{tabular}{|l}
$-73,7$ \\
\end{tabular} & $-78,0$ & $-75,4$ & $-74,3$ & \begin{tabular}{|l}
$-75,7$ \\
\end{tabular} & $-71,5$ & $-71,8$ & \begin{tabular}{|l}
$-69,9$ \\
\end{tabular} \\
\hline 12 & $-84,4$ & 8,0 & $-90,0$ & $-91,8$ & $-90,1$ & $-93,5$ & 2,3 & $-92,2$ & $-91,8$ & $-91,8$ & $\mid-94,0$ & $-95,3$ & $-95,9$ & $-93,0$ & $-93,5$ & $-93,7$ & $-94,5$ & $-95,1$ & 94,5 & $-94,5$ & $-93,8$ & $-93,5$ & $-91,2$ & $-91,4$ & \\
\hline 13 & $-41,0$ & $-20,8$ & $-37,7$ & $-54,1$ & $-39,4$ & $-25,7$ & $-17,2$ & $-40,9$ & $-33,8$ & $-29,1$ & $-25,1$ & 0,4 & 1,5 & 2,5 & 26,3 & 4,9 & 10,6 & $-2,8$ & $-16,0$ & $-19,7$ & $-18,2$ & $-33,7$ & $-1,8$ & 9,2 & 1,4 \\
\hline 14 & 83,1 & 68,7 & 83,8 & 77,5 & 62,8 & 71,5 & 71,8 & 89,6 & 95,2 & 73,1 & 95,8 & 78,7 & 70,0 & 66,3 & 87,3 & 90,7 & 93,8 & 94,6 & 94,3 & 95,6 & 96,6 & 92,8 & 92,2 & 93,6 & 95,4 \\
\hline 15 & $-65,3$ & $-74,1$ & $-75,4$ & $-73,2$ & $-75,5$ & $-69,3$ & $-84,7$ & $-81,3$ & $-78,9$ & $-82,3$ & $-81,3$ & $-89,9$ & $-79,1$ & $-82,5$ & $-78,6$ & $-74,9$ & $-76,7$ & $-80,2$ & $-79,5$ & $-82,6$ & $-79,8$ & $-75,4$ & $-71,9$ & $-67,8$ & 67,5 \\
\hline 16 & 1,9 & $-14,1$ & $-50,2$ & $-47,0$ & $-33,2$ & $-15,4$ & $-13,3$ & $-30,9$ & $-14,5$ & $-29,5$ & $-28,7$ & $-29,7$ & $-28,5$ & $-30,3$ & $-32,3$ & $-14,8$ & $-14,3$ & $-23,6$ & $-38,4$ & $-45,1$ & $-45,0$ & $-47,0$ & $-54,9$ & $-52,3$ & 50,4 \\
\hline 17 & $-52,9$ & $-32,4$ & $-22,9$ & $-9,6$ & 20,2 & 3,2 & 9,5 & 22,8 & 31,7 & 20,0 & 40,5 & 63,6 & 47,6 & 44,0 & 45,9 & 44,8 & 6,1 & 31,9 & 39,8 & 24,4 & 33,6 & 14,2 & 33,1 & 34,1 & 35,3 \\
\hline 18 & $-61,8$ & $-42,6$ & $-29,8$ & $-56,0$ & $-11,2$ & $-19,7$ & $-2,3$ & $-24,1$ & $-35,9$ & $-64,4$ & $-74,3$ & $-20,6$ & $-14,4$ & $-7,4$ & $-1,8$ & 4,3 & $-0,5$ & $-0,5$ & 9,8 & 38,5 & 37,9 & 31,9 & 22,8 & 23,7 & 0,7 \\
\hline 19 & 14,7 & $-13,5$ & $-16,6$ & $-6,4$ & 41,0 & 37, & 38,0 & 24,1 & 27,6 & 23,8 & 23,5 & 24,9 & 21,5 & 9 , & & 39,4 & 40,9 & & & 51 & 53,1 & 51,3 & 45,2 & 40,4 & \\
\hline 20 & 71,0 & 45,2 & 47,7 & 42,0 & 74,4 & 65,3 & 53,9 & 45,4 & 43,2 & 31,1 & 35,9 & 34,8 & 32,0 & 38,7 & 38,4 & 32,8 & 44,1 & 43 & 47,3 & 48,9 & 44,9 & 42,4 & 38,4 & 40,0 & \\
\hline & $-42,7$ & $-51,4$ & $-52,1$ & $-51,8$ & $-27,7$ & $-25,3$ & $-30,6$ & $-35,5$ & $-46,7$ & $-45,1$ & $-47,2$ & $-42,3$ & $-40,4$ & $-34,4$ & $-39,3$ & $-45,3$ & $-27,2$ & $-27,8$ & $-26,6$ & $-20,4$ & $-25,8$ & $-30,0$ & $-29,6$ & $-36,2$ & $-37,1$ \\
\hline 22 & 54,5 & 46,2 & 38,8 & 42,0 & 73,5 & 80,6 & 79,1 & 83,0 & 81,3 & 80,5 & 79,6 & 81,7 & 81,1 & 86,0 & 87,2 & 87,7 & 82,7 & 79, & 81,7 & 76,5 & 70,3 & 68,6 & 70,1 & 76,6 & 78,9 \\
\hline 23 & $-99,8$ & $-99,8$ & $-99,6$ & $-99,9$ & $-96,0$ & $-89,8$ & $-89,3$ & $-94,9$ & $-98,4$ & $-98,6$ & $\mid-97,2$ & $-92,6$ & $-93,0$ & $-96,3$ & $-96,5$ & $-93,6$ & $-95,3$ & $-95,9$ & $-96,3$ & $-96,7$ & $-95,6$ & $-94,5$ & $-93,6$ & $-96,3$ & $-96,9$ \\
\hline 24 & 69,3 & 38,0 & 10,0 & $-69,6$ & $-32,6$ & 3,0 & 42,3 & 57,2 & 41,7 & 41,0 & 17,5 & 24,0 & 28,3 & 12,4 & $-14,6$ & $-36,7$ & $-49,6$ & $-55,0$ & $-66,3$ & $-60,9$ & $-70,6$ & $-66,4$ & 32,9 & 40,1 & 30,6 \\
\hline & 1,4 & 51,9 & & 41,3 & 48,0 & & 34,0 & 20,6 & 29,6 & 28,8 & & 34,2 & 38,8 & & 48, & 44,5 & \begin{tabular}{|l|}
39,6 \\
\end{tabular} & \begin{tabular}{|l}
47 \\
\end{tabular} & 28,4 & 28,9 & 28,2 & 13,4 & 16,5 & 24,7 & \\
\hline 2 & 8,1 & 39,3 & 6 & 59,3 & 52,0 & & 47,1 & 43,0 & 6,6 & $-11,2$ & $-49,6$ & $-63,8$ & -33, & 14,9 & 29, & \begin{tabular}{|c|}
$-55,9$ \\
\end{tabular} & $-35,7$ & -74, & $-54,1$ & $-41,1$ & $-63,8$ & $-80,2$ & $-93,2$ & $-93,0$ & $-95,2$ \\
\hline 27 & 68,5 & 59,7 & 65,8 & 67,8 & 65,2 & 64,2 & 62,6 & 51,5 & 53,2 & 50,6 & 52,1 & 58,4 & 69,4 & 71,8 & 66,4 & 71,2 & 67,1 & 58,5 & 53,7 & 41,0 & 30,5 & 25,9 & 20,7 & 12,9 & $-14,2$ \\
\hline 28 & $-20,8$ & $-15,4$ & $-15,3$ & $-7,9$ & $-13,4$ & $-22,7$ & $-21,7$ & $-36,1$ & $-33,9$ & $-30,2$ & -32, & $-29,9$ & $-21,5$ & -19 , & -20, & $-21,4$ & $-22,2$ & -21 & $-32,0$ & -25 & $-27,9$ & $-27,6$ & $-33,4$ & $-32,8$ & $-35,8$ \\
\hline & $-47,3$ & $-46,8$ & $-59,0$ & $-56,2$ & $-49,7$ & $-53,9$ & $-56,9$ & $-59,1$ & $-60,4$ & $-68,0$ & -70 , & $-72,5$ & $-74,2$ & $-79,2$ & -79 & $-79,8$ & $-85,7$ & -86 , & $-86,6$ & $-84,3$ & $-85,8$ & $-87,2$ & $-85,4$ & $-83,0$ & \begin{tabular}{|l}
$-77,5$ \\
\end{tabular} \\
\hline 30 & $-83,3$ & $-78,5$ & $-79,3$ & $-87,2$ & $-78,6$ & $-72,1$ & $-73,7$ & $-74,7$ & $-66,2$ & $-76,1$ & $-52,9$ & $-35,6$ & $-26,8$ & $-9,9$ & $-29,1$ & $-35,4$ & $-55,4$ & $\mid-57,6$ & $-65,5$ & $-67,7$ & $-56,9$ & \begin{tabular}{|l|}
$-65,6$ \\
\end{tabular} & $-65,4$ & $-63,8$ & $-63,4$ \\
\hline 31 & $-52,5$ & $-69,0$ & $-76,5$ & $-52,7$ & 14,7 & $-23,2$ & $-60,5$ & $-67,8$ & $-76,6$ & $-88,4$ & $-88,3$ & $-88,6$ & $-88,8$ & $-89,0$ & $-89,4$ & $-92,6$ & $-84,7$ & $-77,3$ & $-85,2$ & $-75,1$ & $-74,9$ & \begin{tabular}{|l|}
$-73,3$ \\
\end{tabular} & $-69,3$ & $-56,5$ & $\mid-70,9$ \\
\hline 32 & $-58,1$ & $-67,5$ & $-68,7$ & $-77,9$ & $-72,9$ & $-72,5$ & $-72,0$ & $-73,4$ & $-68,5$ & $-66,8$ & $-66,6$ & $-59,6$ & $-61,0$ & $-58,7$ & $-58,4$ & $-63,7$ & \begin{tabular}{|l|}
$-60,4$ \\
\end{tabular} & $-64,9$ & $-67,5$ & \begin{tabular}{|l}
$-68,3$ \\
\end{tabular} & $-69,9$ & \begin{tabular}{|l|}
$-68,2$ \\
\end{tabular} & $-69,9$ & $-70,7$ & $-73,2$ \\
\hline 33 & $-72,7$ & $-73,5$ & $-76,9$ & $-78,1$ & $-54,1$ & $-50,8$ & $-52,8$ & $-46,5$ & $-58,8$ & $-66,8$ & $-71,9$ & $-65,3$ & $-46,3$ & $-49,1$ & $-46,1$ & $-34,4$ & $-18,6$ & $-28,1$ & \begin{tabular}{|l|l|} 
\\
\end{tabular} & $-2,1$ & $-0,7$ & 2,7 & 10,7 & 11,5 & 9,6 \\
\hline 34 & $-6,2$ & $-28,2$ & $-26,1$ & $-24,7$ & $-0,9$ & 4,0 & 8,5 & 5,3 & 9,9 & 12,0 & 8,3 & 10,1 & $-1,2$ & $-5,2$ & $-2,6$ & $-3,2$ & 9,5 & 5,3 & $-12,9$ & $-8,2$ & $-13,2$ & $-23,6$ & $-24,1$ & $-26,3$ & $-23,9$ \\
\hline 35 & $-91,4$ & $-91,1$ & $-91,4$ & $-86,9$ & $-76,1$ & $-81,5$ & $-89,1$ & $-86,6$ & $-84,8$ & $-88,2$ & $-87,0$ & $-86,2$ & $-84,7$ & $-84,5$ & $-84,6$ & $-83,4$ & $-83,5$ & $-80,5$ & $-76,9$ & $-78,4$ & $-79,9$ & $-82,9$ & $-75,9$ & $-79,2$ & $-81,5$ \\
\hline 36 & $-90,4$ & $-70,8$ & & $-2,6$ & 23,7 & & 1,8 & $\begin{array}{l}-6,9 \\
\end{array}$ & & $-45,6$ & & $-40,9$ & $-72,8$ & $-76,0$ & & & $-36,4$ & & -44, & $-47,7$ & $-40,8$ & $-49,8$ & $-41,1$ & $-42,6$ & \\
\hline 37 & $-24,2$ & $-19,6$ & $-30,8$ & $-38,1$ & $-33,9$ & $-36,5$ & $-46,2$ & $-28,8$ & $-19,5$ & $-26,1$ & $-37,1$ & $-51,2$ & $-62,3$ & $-41,0$ & $-54,6$ & -72 & $-67,3$ & $-69,3$ & $-66,7$ & $\begin{array}{l}-70,7 \\
\end{array}$ & $-72,4$ & $\mid-72,5$ & $-75,9$ & $-75,8$ & $\begin{array}{l}-74,7 \\
\end{array}$ \\
\hline 38 & $-66,1$ & $-65,4$ & $-69,6$ & $-74,4$ & $-74,0$ & $-70,9$ & $-59,0$ & $-63,3$ & $-59,4$ & $-65,1$ & $-53,4$ & $-61,2$ & $-59,4$ & $-60,7$ & $-60,5$ & $-58,2$ & $-58,8$ & $-67,2$ & $-74,2$ & $-70,8$ & $-70,6$ & $-70,3$ & $-71,2$ & $-70,0$ & $-71,0$ \\
\hline 39 & $-65,3$ & $-69,4$ & $-69,2$ & $-69,7$ & $-61,4$ & $-65,9$ & $-67,6$ & $-67,8$ & $-69,2$ & $-71,3$ & $-68,0$ & $-66,2$ & $-65,1$ & $-59,9$ & $-58,2$ & $-58,7$ & $-58,3$ & $-58,0$ & $-57,1$ & $-57,5$ & $-56,2$ & $-56,9$ & $-57,5$ & $-55,8$ & $-55,2$ \\
\hline 40 & $-60,5$ & $-57,8$ & $-51,6$ & $-47,4$ & $-36,2$ & $-44,5$ & $-50,0$ & $-49,4$ & $-39,0$ & $-38,3$ & $-38,7$ & $-30,0$ & $-24,9$ & $-23,6$ & $-23,4$ & $-27,6$ & $-20,1$ & $-18,2$ & $-26,4$ & $-21,3$ & $-20,5$ & $-22,0$ & $-23,0$ & $-26,5$ & $-21,4$ \\
\hline
\end{tabular}




\begin{tabular}{|c|c|c|c|c|c|c|c|c|c|c|c|c|c|c|c|c|c|c|c|c|c|c|c|c|c|}
\hline 41 & $-74,4$ & $-71,8$ & $-64,1$ & 77,4 & $-38,3$ & $-63,4$ & $-67,6$ & $-67,6$ & $-71,2$ & $-73,9$ & $-68,0$ & $-73,7$ & $-67,6$ & $-82,0$ & $-78,4$ & $-77,5$ & $-78,5$ & $-69,3$ & $-61,9$ & $-58,9$ & $-59,0$ & $-53,2$ & $-59,6$ & $-56,0$ & $-53,5$ \\
\hline 42 & 32,6 & 30,7 & 33,5 & 36,1 & 48,4 & 63,7 & 64,7 & 53,6 & 44,8 & 25,5 & 39,6 & 35,8 & 25,9 & $-0,2$ & $-36,1$ & $-42,0$ & $-17,2$ & $-29,7$ & $-16,1$ & $-30,3$ & $-17,9$ & $-10,4$ & $-12,2$ & $\begin{array}{c}-0,6 \\
\end{array}$ & $-4,6$ \\
\hline 43 & $-79,2$ & $-94,5$ & $-94,6$ & $-78,7$ & $-10,4$ & $-14,3$ & $-8,6$ & $-7,7$ & $-17,6$ & $-18,2$ & $-23,8$ & $-44,1$ & $-59,7$ & $-29,7$ & $-74,2$ & $-66,2$ & $-47,8$ & $-67,1$ & $-56,2$ & $-59,5$ & $-39,5$ & $-42,2$ & $-28,0$ & $-17,3$ & $-49,5$ \\
\hline 44 & $-21,3$ & $-26,8$ & 9,1 & $-14,9$ & 11,6 & 23,6 & 21,3 & 6,3 & 3,0 & $-10,4$ & & $-15,9$ & $-23,4$ & & $-22,7$ & & $-30,4$ & $-34,5$ & $-38,9$ & $-45,0$ & $-46,8$ & $-46,8$ & $-42,0$ & $-43,5$ & $-41,2$ \\
\hline 45 & $-93,1$ & $-64,1$ & $-61,1$ & $-91,4$ & $-98,2$ & $-44,6$ & $-1,7$ & $-0,4$ & $-29,6$ & $-66,3$ & $-33,7$ & $-57,0$ & $-66,1$ & $-53,2$ & $-78,8$ & $-68,8$ & $-74,6$ & $-86,0$ & $-81,4$ & $-90,6$ & $-90,8$ & $-87,9$ & $-68,4$ & $-52,2$ & $-46,4$ \\
\hline 46 & 52,3 & 38,2 & 34,6 & 44,8 & 83,2 & 56,7 & 40,2 & $-25,2$ & $-69,1$ & $-68,0$ & $-44,3$ & 15,6 & $-22,1$ & $-10,1$ & 3,1 & 69,3 & 66,1 & 40,1 & 47,3 & 50,7 & 74,6 & 80,0 & 81,7 & 85,7 & 85,8 \\
\hline 47 & $-99,0$ & $-96,6$ & $-98,6$ & $-98,7$ & $-98,1$ & $-93,3$ & $-97,3$ & $-96,6$ & $-97,9$ & $-97,7$ & $-98,0$ & $-97,9$ & $-97,8$ & $-98,2$ & $-98,7$ & $-98,7$ & $-97,9$ & $-98,3$ & $-98,7$ & $-98,3$ & $-97,8$ & $-97,5$ & $-96,6$ & $-95,9$ & $-97,5$ \\
\hline 48 & $-73,3$ & $-75,9$ & $-79,1$ & $-78,4$ & $-56,9$ & $-65,1$ & $-62,9$ & $-61,7$ & $-62,8$ & $-65,3$ & $-62,9$ & $-56,0$ & $-53,6$ & $-50,0$ & $-51,0$ & $-49,8$ & $-48,7$ & $-53,8$ & $-57,1$ & $-56,4$ & $-54,8$ & $-62,5$ & $-61,6$ & $-59,3$ & $-59,3$ \\
\hline 49 & $-46,8$ & $-47,3$ & $-59,6$ & $-53,9$ & $-30,5$ & $-33,2$ & $-21,9$ & $-25,2$ & $-27,7$ & $-36,6$ & $-34,8$ & $-26,2$ & $-28,2$ & $-21,3$ & $-18,2$ & $-9,1$ & $-6,0$ & $-12,5$ & $-23,9$ & $-23,5$ & $-18,8$ & $-20,6$ & $-16,9$ & $-12,2$ & $-11,2$ \\
\hline 50 & $-100,0$ & $-100,0$ & $-99,5$ & $-82,3$ & $-90,4$ & $-95,6$ & $-88,2$ & $-89,9$ & $-97,2$ & $-99,5$ & $-99,3$ & $-99,5$ & $-99,2$ & $-99,2$ & $-96,6$ & $-100,0$ & $-99,9$ & $-99,4$ & $-100,0$ & $-99,7$ & $-45,2$ & $-84,5$ & $-97,3$ & $-99,9$ & $-98,5$ \\
\hline 51 & 7,9 & 42,6 & 55,5 & 38,3 & $-21,3$ & $-21,1$ & $-4,6$ & $-5,5$ & 8,4 & 23,0 & 19,6 & 21,0 & 21,4 & 6,2 & 12,9 & $-5,6$ & 36,9 & 35,9 & $-10,0$ & 0,6 & 24,1 & $-10,2$ & $-22,5$ & $-13,7$ & $-5,0$ \\
\hline 52 & $-27,0$ & $-61,4$ & $-74,5$ & $-78,8$ & $-44,5$ & $-43,5$ & $-44,2$ & $-58,7$ & $-59,3$ & $-71,9$ & $-75,2$ & $-69,7$ & $-75,1$ & $-76,4$ & $-77,5$ & $-85,9$ & $-84,3$ & $-88,8$ & $-88,2$ & $-88,2$ & $-89,2$ & $-87,7$ & $-88,2$ & $\begin{array}{l}-89,1 \\
\end{array}$ & $-87,7$ \\
\hline 53 & $-31,2$ & $-9,4$ & 7,3 & 16,4 & 32,0 & 31,8 & 40,1 & 35,3 & $-51,5$ & $-37,9$ & $-31,1$ & $-23,3$ & 9,7 & $-32,2$ & $-24,3$ & $-5,9$ & $-48,8$ & $-92,8$ & $-81,4$ & $-82,0$ & $-63,0$ & $-86,7$ & $-66,7$ & $-78,3$ & $-65,0$ \\
\hline 54 & $-51,5$ & $-64,3$ & $-54,6$ & $-57,6$ & $-35,9$ & $-44,0$ & $-48,9$ & $-52,9$ & $-61,3$ & $-64,1$ & $-53,6$ & $-47,3$ & $-34,8$ & $-32,4$ & $-25,3$ & $-24,3$ & $-20,4$ & $-21,8$ & $-24,0$ & $-28,9$ & $-25,1$ & $-31,7$ & $-33,9$ & $-50,5$ & $-55,2$ \\
\hline 55 & $-38,9$ & $-42,6$ & $-28,4$ & $-6,0$ & 26,1 & 0,8 & $-11,9$ & $-34,8$ & $-49,3$ & $-45,5$ & $-38,3$ & $-30,6$ & $-41,7$ & $-56,0$ & $-59,1$ & $-71,5$ & $-66,0$ & $-74,6$ & $-75,1$ & $-77,6$ & $-76,7$ & $-80,3$ & $-83,8$ & $-74,2$ & $-69,1$ \\
\hline 56 & $-74,7$ & $-74,0$ & $-71,5$ & $-69,6$ & $-62,8$ & $-41,9$ & $-31,4$ & $-45,4$ & $-33,0$ & $-37,3$ & $-31,0$ & $-38,3$ & $-47,2$ & $-40,9$ & $-40,4$ & $-42,6$ & $-40,0$ & $-39,9$ & $-50,6$ & $-43,4$ & $-47,7$ & $-59,0$ & $-61,0$ & $-63,9$ & $-67,6$ \\
\hline 57 & $-65,7$ & $-73,0$ & $-87,2$ & $-76,4$ & $-64,0$ & $-39,2$ & $-45,8$ & $-67,8$ & $-66,9$ & $-80,3$ & $-71,6$ & $-71,1$ & $-75,9$ & $-79,1$ & $-80,7$ & $-76,8$ & $-64,8$ & $-73,0$ & $-77,8$ & $-78,2$ & $-79,0$ & $-76,3$ & $-76,1$ & \begin{tabular}{|l|} 
\\
\end{tabular} & $-68,4$ \\
\hline 58 & $-83,8$ & $-80,9$ & $-82,7$ & $-80,4$ & $-72,4$ & $-65,6$ & $-62,2$ & $-74,2$ & $-85,1$ & $-81,2$ & $-74,8$ & $-70,2$ & $-65,5$ & $-65,8$ & $-69,1$ & $-73,5$ & $-67,8$ & $-68,4$ & $-69,0$ & $-63,7$ & $-63,2$ & $-62,4$ & $-63,2$ & $-63,7$ & $-66,1$ \\
\hline 59 & $-51,8$ & $-70,8$ & $-55,0$ & $-55,4$ & $-49,2$ & $-46,8$ & $-64,1$ & $-71,9$ & $-73,8$ & $-70,9$ & $-80,3$ & $-73,0$ & $-75,8$ & $-70,2$ & $-65,7$ & $-55,6$ & $-50,2$ & $-47,8$ & $-36,1$ & $-46,7$ & $-52,1$ & $-56,8$ & $-58,2$ & $-58,0$ & $-61,0$ \\
\hline 60 & $-51,3$ & $-64,3$ & $-53,0$ & $-66,0$ & $-50,1$ & $-32,1$ & $-31,3$ & $-38,9$ & $-42,5$ & $-59,7$ & $-61,8$ & $-60,1$ & $-65,0$ & $-75,0$ & $-77,6$ & $-74,1$ & $-79,4$ & $-83,6$ & $-85,1$ & $-89,9$ & $-89,8$ & $-92,1$ & $-92,0$ & $-90,9$ & $-90,1$ \\
\hline 61 & 8,7 & 6,4 & 11,5 & 9,7 & 29,5 & 35,3 & 37,6 & 39,7 & 43,1 & 46,8 & 48,2 & 50,5 & 51,9 & 58,8 & 60,1 & 58,7 & 63,7 & 60,6 & 50,4 & 47,8 & 47,2 & 43,3 & 39,8 & 38,0 & 35,5 \\
\hline 62 & 30,8 & 28,1 & 29,7 & 32,0 & 39,7 & 41,7 & 44,6 & 48,6 & 58,4 & 64,7 & 71,0 & 70,2 & 72,2 & 76,7 & 78,2 & 79,2 & 82,8 & 81,2 & 80,0 & 80,6 & 78,7 & 78,4 & $\begin{array}{l}79,2 \\
\end{array}$ & 76,5 & 71,3 \\
\hline 63 & 37,9 & 36,3 & 21,4 & 30,7 & 59,0 & 45,7 & 48,5 & 54,1 & $\begin{array}{l}54,9 \\
\end{array}$ & 53,1 & 68,2 & 74,7 & 78,2 & 76,6 & 69,4 & 64,5 & 59,2 & 49,6 & 52,3 & 52,0 & 38,6 & 42,1 & 36,3 & 33,6 & 30,6 \\
\hline 64 & 3,0 & 39,7 & 33,8 & 34,0 & 53,7 & 61,0 & 57,7 & 55,4 & 53,1 & 37,6 & 41,9 & 45,2 & 49,5 & 59,1 & 65,6 & 61,1 & 54,5 & 38,0 & $\begin{array}{l}52,9 \\
\end{array}$ & 49,5 & 56,0 & 67,3 & 64,1 & 61,4 & 57,7 \\
\hline 65 & 49,4 & 62,5 & 68,1 & 64,6 & 74,0 & 69,5 & 63,5 & 63,4 & 66,0 & 61,0 & 62,4 & 65,1 & 71,3 & 69,4 & 64,7 & 64,7 & 58,1 & 49,2 & 43,8 & 32,1 & 27,9 & 31,9 & 37,1 & 35,3 & 39,2 \\
\hline 66 & $-32,2$ & $-62,7$ & $-63,6$ & $-50,8$ & $-20,8$ & $-28,3$ & $-55,4$ & $-41,9$ & $-66,3$ & $-30,5$ & $-27,9$ & 5,6 & 15,7 & $-5,2$ & $-38,8$ & $-49,7$ & $-52,5$ & $-67,9$ & $-56,7$ & $-51,3$ & $-56,2$ & $-38,9$ & $-13,0$ & $-15,6$ & $-38,8$ \\
\hline 67 & $-55,6$ & $-30,6$ & $-31,2$ & $-49,9$ & $-12,3$ & $-9,7$ & $-14,5$ & $-12,4$ & $-48,2$ & $-61,8$ & $-66,1$ & $-66,1$ & $-58,9$ & $-42,5$ & $-48,3$ & $-41,6$ & $-51,0$ & $-43,3$ & $-36,7$ & $-26,9$ & $-31,6$ & $-52,1$ & $-53,2$ & $-41,5$ & $-57,0$ \\
\hline & 17,6 & 24,7 & 30,6 & 16,4 & 40,7 & 36,1 & 30,0 & 30,9 & 27,4 & 28,7 & 36,2 & 39,4 & 39,0 & 39,7 & 42,4 & 43,4 & 39,9 & 30,7 & 28,8 & 27,6 & 22,6 & 25,9 & 26,0 & 22,6 & 25,2 \\
\hline 69 & 39,4 & 53,2 & 55,4 & 55,2 & 60,5 & 57,6 & 63,1 & 56,2 & 55,0 & 46,9 & 47,5 & 47,7 & 64,6 & 64,9 & 65,9 & 65,4 & 58,1 & 62,0 & 59,5 & 53,9 & 47,3 & 48,4 & 56,8 & 55,7 & 59,0 \\
\hline 70 & 30,5 & 17,5 & 10,6 & 15,6 & 26,0 & 29,2 & 25,7 & 30,6 & 31,4 & 24,2 & 26,4 & 22,7 & 23,6 & 32,1 & 41,6 & 41,9 & 37,9 & 37,0 & 32,1 & 32,1 & 31,6 & 26,4 & 28,6 & 26,3 & 25,2 \\
\hline 71 & 24,6 & 5,6 & 16,1 & 10,3 & 65,9 & 66,4 & 35,1 & 24,2 & \begin{tabular}{|l|} 
\\
\end{tabular} & $-12,5$ & $-1,7$ & 10,3 & 20,5 & 26,5 & 46,7 & 57,8 & 55,7 & 66,8 & 73,1 & 77,0 & 79,2 & 79,7 & 79,6 & 76,5 & 73,6 \\
\hline 72 & $-54,2$ & $-57,4$ & $-30,6$ & $-3,2$ & 12,0 & 8,1 & 7,2 & 5,5 & 7,0 & $-0,8$ & $-17,6$ & 2,6 & $-3,1$ & 19,2 & 12, & 3,6 & 1,4 & $-6,1$ & $-31,5$ & $-18,4$ & $-25,8$ & $-38,5$ & $-34,2$ & $-30,6$ & $-46,4$ \\
\hline 73 & $-20,6$ & $-25,5$ & $-18,0$ & $-28,5$ & $-21,9$ & $-30,4$ & $-19,4$ & $-18,3$ & $-17,6$ & $-23,9$ & $-10,8$ & $\begin{array}{l}-0,5 \\
\end{array}$ & $\begin{array}{l}-0,1 \\
\end{array}$ & 1,0 & $-0,5$ & $\begin{array}{l}-4,3 \\
\end{array}$ & $-2,1$ & 1,8 & $-4,4$ & $-6,0$ & $-4,0$ & $-8,7$ & $-14,5$ & $-11,5$ & $-10,6$ \\
\hline 74 & $-11,4$ & $-2,8$ & $-0,2$ & $-3,0$ & 43,2 & 12,2 & 6,0 & 17,2 & 6,4 & $-4,2$ & 9,9 & $-17,3$ & $-28,6$ & $-29,4$ & $-17,7$ & $-23,7$ & $-11,8$ & $-22,2$ & $-27,7$ & $-39,8$ & $-13,5$ & $-22,9$ & $-38,3$ & $-31,1$ & $-33,7$ \\
\hline 75 & $-89,8$ & $-86,1$ & $-90,5$ & $-94,4$ & $-90,9$ & $-88,7$ & $-93,7$ & $-90,8$ & $-90,8$ & $-89,3$ & $-83,4$ & $-79,5$ & $-36,1$ & $-62,0$ & $-77,2$ & $-88,9$ & $-78,4$ & $-85,8$ & $-87,5$ & $-79,7$ & $-76,3$ & $-76,6$ & $-75,5$ & $-69,6$ & $-53,4$ \\
\hline 76 & $-57,4$ & $-58,4$ & $-58,9$ & $-55,3$ & $-38,8$ & $-48,3$ & $-46,8$ & $-51,8$ & $-51,1$ & $-55,9$ & $-51,7$ & $-49,7$ & $-46,1$ & $-45,4$ & $-46,9$ & $-52,2$ & $-51,7$ & -52 & $-53,5$ & $-60,3$ & $-59,2$ & $-54,3$ & $-64,3$ & $-63,9$ & $-64,7$ \\
\hline 78 & 32,3 & 63,1 & 59,2 & 37,9 & 65,4 & 4,7 & 35,3 & $-21,3$ & $-67,9$ & $-78,3$ & $-52,4$ & $-61,3$ & $-69,6$ & $-62,0$ & $-50,7$ & $-50,3$ & 12,3 & 10,3 & 1,8 & $-8,4$ & 34,9 & 37,1 & 48,3 & 51,4 & 58,8 \\
\hline 79 & 70,9 & 71,8 & 80,1 & 78,3 & 80,9 & 77,8 & 81,5 & 71,9 & 71,0 & 66,4 & 72,4 & 62,7 & 67,2 & 64,9 & 76,8 & 82,4 & 79,0 & 55,0 & 59,0 & 56,7 & 46,2 & 39,7 & 36,2 & 37,5 & 31,3 \\
\hline 80 & $-6,6$ & $-73,6$ & $-33,0$ & $-79,7$ & $-89,9$ & $-77,9$ & $-77,2$ & $-80,7$ & $-81,7$ & $-74,6$ & $-75,5$ & $-66,9$ & $-75,5$ & $-86,6$ & $-91,4$ & $-53,8$ & $-41,5$ & $-25,9$ & $-27,4$ & $-34,9$ & $-42,1$ & $-49,4$ & $-56,8$ & $-43,5$ & $-59,3$ \\
\hline 8 & $-2,8$ & 5,3 & 9,2 & $-13,0$ & $-4,7$ & $-14,4$ & $-25,1$ & $-27,8$ & $-56,2$ & $-66,7$ & $-72,4$ & $-81,5$ & $-60,9$ & $-57,0$ & $-60,4$ & $-64,8$ & $-62,6$ & $-76,2$ & $-85,7$ & $-79,6$ & $-80,4$ & $-81,3$ & $-84,2$ & $-82,3$ & $-71,4$ \\
\hline 82 & $-35,5$ & $-36,4$ & $-42,0$ & $-35,1$ & $-25,3$ & $-21,0$ & $-30,1$ & $-32,9$ & $-40,1$ & $-28,5$ & $-14,8$ & $-15,1$ & $-24,9$ & $-24,1$ & $-20,1$ & $-19,6$ & $-15,3$ & $-22,1$ & $-24,2$ & $-22,3$ & $-14,2$ & $-21,3$ & $-24,5$ & $-22,7$ & $-29,2$ \\
\hline 83 & $-43,3$ & $-44,9$ & $-43,6$ & $-38,0$ & $-30,0$ & $-12,1$ & $-13,4$ & $-7,0$ & 2,1 & $-9,7$ & $-1,4$ & 7,6 & 14,2 & 11,5 & 18,7 & 15,6 & 17,1 & 10,7 & 12,8 & 15,3 & 14,4 & 13,4 & 14,8 & 7,4 & 10,3 \\
\hline 84 & $-31,1$ & $-31,4$ & $-24,1$ & $-16,6$ & 1,0 & 3,3 & $-1,3$ & 2,2 & 6,6 & 4,8 & 11,2 & 9,3 & 4,4 & 2,9 & 3,5 & 5,2 & 9,9 & 5,1 & 3,8 & 15,5 & 10,5 & 8,3 & 5,4 & 2,4 & 7,6 \\
\hline
\end{tabular}




\begin{tabular}{|c|c|c|c|c|c|c|c|c|c|c|c|c|c|c|c|c|c|c|c|c|c|c|c|c|c|}
\hline 85 & 13,1 & 11,5 & 13,1 & 16,8 & 20,1 & 16,2 & 11,6 & 15,9 & 13,3 & \begin{tabular}{|l|}
9,8 \\
\end{tabular} & 14,9 & 20,0 & 22,5 & 24,0 & 25,9 & 28,3 & 37,6 & 36,5 & 31,9 & 26,2 & 25,5 & 25,4 & 22,3 & 20,7 & 21,0 \\
\hline 86 & $-67,9$ & \begin{tabular}{|l|}
$-7,5$ \\
\end{tabular} & 29,5 & $-6,5$ & $-2,5$ & 49,7 & 26,1 & 22,9 & 33,5 & 33,5 & 6,6 & $-24,2$ & $-28,6$ & $-32,6$ & $-35,1$ & $-40,7$ & $-58,7$ & 3,4 & $-2,8$ & $-48,7$ & $-62,9$ & $-69,6$ & $-63,5$ & $-71,8$ & $-72,8$ \\
\hline 87 & 6,5 & 7,4 & 13,9 & 12,6 & 39,8 & 44,2 & 33,7 & 36,0 & 42,0 & 39,2 & 41,0 & 42,5 & 45,4 & 41,8 & 40,9 & 46,4 & 43,6 & 39,7 & 45,5 & 47,1 & 44,0 & 45,3 & 47,0 & 52,5 & 53,9 \\
\hline 88 & $-91,5$ & $-96,1$ & $-92,8$ & $-93,1$ & $-65,8$ & $-70,4$ & $-71,5$ & $-84,8$ & $-65,7$ & $-71,1$ & $-85,8$ & $-34,9$ & $-81,8$ & $-93,0$ & $-92,2$ & $-94,1$ & $-77,7$ & $-70,9$ & $-75,7$ & $-67,7$ & $-56,1$ & $-52,9$ & $-59,2$ & $-43,9$ & $-57,9$ \\
\hline 89 & $-86,5$ & $-90,7$ & $-91,1$ & $-97,1$ & $-91,1$ & $-92,4$ & $-75,9$ & $-93,3$ & $-97,4$ & $-87,4$ & $-93,3$ & $-73,4$ & $-39,3$ & $-25,0$ & $-7,6$ & $-20,3$ & 8,5 & $-18,3$ & $-68,2$ & $-23,0$ & $-7,4$ & $-29,0$ & $-23,2$ & $-21,7$ & 4,8 \\
\hline 90 & $-24,0$ & $-21,3$ & $-13,2$ & 0,0 & 21,6 & 23,0 & 11,4 & 19,1 & 23,1 & 19,6 & 19,0 & 21,8 & 25,2 & 21,9 & 25,8 & 28,3 & 33,0 & 25,5 & 22,9 & 33,4 & 33,7 & 31,3 & 30,2 & 29,1 & 28,9 \\
\hline 91 & $-51,6$ & $-30,0$ & $-12,8$ & $-25,7$ & $-22,8$ & $-31,8$ & $-22,6$ & 22,7 & 26,1 & 10,9 & $-7,4$ & 18,2 & 31,1 & 36,8 & 42,1 & 40,3 & 35,1 & 17,4 & 34,3 & 26,2 & 1,9 & $-5,7$ & 2,0 & 4,4 & 5,3 \\
\hline 92 & 21,5 & 25,4 & 22,5 & 33,9 & 42,2 & 44,8 & 46,6 & 46,6 & 33,9 & 47,6 & 53,0 & 22,3 & 16,8 & 19,2 & 27,1 & 35,5 & 50,7 & 46,8 & 50,5 & 33,8 & 30,8 & 42,7 & 44,2 & 50,2 & 55,1 \\
\hline 93 & 21,3 & 0,8 & $-29,3$ & $-40,2$ & 25,4 & 6,8 & 12,1 & 11,8 & 54,2 & $-14,1$ & 71,7 & 70,3 & 50,2 & 45,5 & 29,6 & 38,5 & 21,4 & 27,9 & $-16,7$ & $-10,8$ & 6,0 & 20,3 & 35,7 & 28,0 & 19,2 \\
\hline 94 & 8,8 & 9,1 & 11,7 & 16,6 & 34,3 & 44,9 & 41,7 & 42,1 & 56,5 & 53,4 & 55,5 & 61,5 & 67,3 & 68,6 & 68,7 & 69,4 & 72,2 & 66,2 & 65,8 & 67,8 & 65,7 & 66,3 & 63,8 & 61,5 & 62,9 \\
\hline 95 & 7,4 & 4,0 & 20,9 & 12,9 & 47,2 & 47,0 & 34,4 & 41,6 & 34,1 & 28,6 & 42,6 & 63,1 & 45,9 & 39,2 & 29,5 & $\begin{array}{l}-6,2 \\
\end{array}$ & $-44,3$ & $-47,9$ & $-44,6$ & $-23,3$ & $-11,7$ & 5,1 & 10,9 & 7,5 & 14,2 \\
\hline 96 & 12,8 & \begin{tabular}{|l|}
$-6,8$ \\
\end{tabular} & \begin{tabular}{|c|}
$-4,9$ \\
\end{tabular} & 6,3 & 18,9 & 8,9 & $-11,2$ & $-8,9$ & $-9,4$ & \begin{tabular}{|l|}
$-3,3$ \\
\end{tabular} & 22,3 & 22,6 & 25,0 & 35,4 & 35,5 & 33,1 & 28,0 & 22,9 & 25,4 & 22,7 & 21,0 & 38,3 & 32,4 & 34,5 & 35,6 \\
\hline 97 & $-18,0$ & $-22,9$ & 5,7 & $-13,4$ & 69,2 & $-22,3$ & $-10,8$ & $-6,3$ & 28,9 & \begin{tabular}{|l|l|}
67,8 \\
\end{tabular} & 44,6 & $-1,4$ & 4,2 & 54,0 & $-0,6$ & $-8,6$ & 14,8 & $-12,9$ & $-35,9$ & 29,0 & $-22,5$ & $-34,7$ & 28,4 & $-1,0$ & 25,0 \\
\hline 99 & $-7,3$ & $-5,3$ & 0,3 & $-2,8$ & 14,2 & 10,8 & 6,4 & 7,1 & 11,0 & 11,6 & 18,0 & 21,3 & 24,3 & 26,2 & 24,3 & 23,5 & 24,1 & 20,6 & 26,1 & 14,8 & 5,2 & 5,0 & 3,9 & 6,3 & 9,0 \\
\hline TOTAL & $-2,2$ & $-6,1$ & $-1,1$ & $-0,5$ & 15,1 & 13,3 & 9,95 & 9,75 & 12,1 & 10,3 & 13,3 & 16,5 & 17,8 & 17,5 & 17,9 & 19,8 & 21,9 & 18 & 16 & 17,3 & 14,4 & 12,9 & 11,2 & 10,5 & 11,4 \\
\hline
\end{tabular}

Fuente. Elaboración propia según COMTRADE, Naciones Unidas, disponible en http://comtrade.un.org/data/, fecha de consulta: 8/12/2016 


\section{Tabla Anexo III.4. Índices de Contribución al Saldo de China en el comercio con Estados Unidos, 1991-2015}

\begin{tabular}{|c|c|c|c|c|c|c|c|c|c|c|c|c|c|c|c|c|c|c|c|c|c|c|c|c|c|}
\hline & 1991 & 1992 & 1993 & 1994 & 1995 & 1996 & 1997 & 1998 & 1999 & 2000 & 2001 & 2002 & 2003 & 2004 & 2005 & 2006 & 2007 & 2008 & 2009 & 2010 & 2011 & 2012 & 2013 & 2014 & 2015 \\
\hline 1 & $-0,02$ & $-0,02$ & $-0,01$ & $-0,01$ & $-0,01$ & $-0,01$ & $-0,01$ & $-0,01$ & $-0,01$ & $-0,01$ & 0,00 & $-0,01$ & $-0,01$ & 0,00 & 0,00 & 0,00 & 0,00 & $-0,01$ & $-0,01$ & 0,00 & $-0,01$ & $-0,01$ & $-0,01$ & 0,00 & 0,00 \\
\hline 2 & $-0,01$ &, 01 & $-0,04$ & 0,04 & 0,05 &, 08 & 07 & $-0,05$ & $-0,05$ & $-0,05$ & $-0,05$ & $-0,04$ & $-0,06$ & $-0,02$ & $-0,06$ & $-0,09$ & $-0,15$ & $-0,19$ & $-0,16$ & $-0,05$ & & $-0,14$ & $-0,14$ & $-0,09$ & $-0,04$ \\
\hline 3 & 0,22 & 0,22 & 0,10 & 0,02 & 0,00 & $-0,02$ & $-0,06$ & $-0,01$ & $-0,03$ & $-0,04$ & $-0,01$ & 0,00 & 0,00 & $-0,03$ & $-0,05$ & $-0,04$ & $-0,04$ & $-0,04$ & $-0,05$ & $-0,05$ & $-0,09$ & $-0,09$ & $-0,07$ & $-0,08$ & $-0,07$ \\
\hline 4 & 0,01 & 0,01 & 0,01 & 0,01 & 0,00 & 0,01 & 0,00 & $-0,01$ & $-0,01$ & $-0,01$ & $-0,01$ & $-0,01$ & $-0,01$ & $-0,01$ & $-0,01$ & $-0,02$ & $-0,02$ & $-0,03$ & $-0,02$ & $-0,03$ & $-0,04$ & $-0,04$ & $-0,07$ & $-0,07$ & $-0,04$ \\
\hline 5 & 0,04 & 0,03 & 0,01 & & & & 0,00 & & $-0,01$ & & & & & & & 0,00 & & & & & & & & & \\
\hline 6 & 0,00 & 0,00 & 0,00 & 0,00 & 0,00 & 0,00 & 0,00 & 0,00 & 0,00 & 0,00 & 0,00 & 0,00 & 0,00 & 0,00 & 0,00 & 0,00 & 0,00 & 0,00 & 0,00 & 0,00 & 0,00 & 0,00 & 0,00 & 0,00 & 0,00 \\
\hline 7 & 0,03 & 0,02 & 0,03 & 0,02 & 0,01 & 0,01 & 0,01 & 0,01 & 0,00 & 0,00 & 0,00 & 0,01 & 0,00 & 0,01 & 0,01 & 0,01 & 0,01 & 0,01 & 0,01 & 0,01 & 0,01 & 0,01 & 0,01 & 0,01 & 0,01 \\
\hline 8 & 0,00 & 0,00 & 0,00 & 0,00 & 0,00 & 0,00 & 0,00 & $-0,01$ & 0,00 & $-0,02$ & $-0,02$ & $-0,02$ & $-0,02$ & $-0,02$ & $-0,03$ & $-0,02$ & $-0,02$ & $-0,02$ & $-0,04$ & $-0,04$ & $-0,05$ & $-0,07$ & $-0,06$ & $-0,04$ & $-0,04$ \\
\hline 9 & 0,03 & 0,02 & 0,02 & 0,02 & 0,01 & & 0,01 & 0,01 & & 0,00 & 0,01 & & & & 0,00 & 0,00 & 0,00 & 0,00 & 0,00 & 0,01 & & 0,01 & 0,01 & & \\
\hline 10 & $-1,04$ & $-0,61$ & $-0,51$ & $-0,27$ & $-1,53$ & $-0,54$ & $-0,05$ & $-0,09$ & $-0,04$ & $-0,02$ & $-0,01$ & $-0,02$ & $-0,01$ & $-0,17$ & $-0,02$ & $-0,01$ & 0,00 & 0,00 & $-0,03$ & $-0,06$ & $-0,15$ & $-0,22$ & $-0,32$ & $-0,23$ & $-0,32$ \\
\hline 11 & 0,00 & 0,00 & 0,00 & 0,00 & 0,00 & 0,00 & 0,00 & 0,00 & 0,00 & 0,00 & 0,00 & 0,00 & 0,00 & 0,00 & 0,00 & 0,00 & 0,00 & 0,00 & 0,00 & 0,00 & 0,00 & 0,00 & 0,00 & 0,00 & 0,00 \\
\hline 12 & 0,04 & $-0,05$ & $-0,03$ & 0,00 & $-0,06$ & $-0,51$ & $-0,44$ & $-0,27$ & $-0,31$ & $-0,72$ & $-0,67$ & $-0,50$ & $-1,27$ & $-0,82$ & $-0,65$ & $-0,60$ & $-0,86$ & $-1,43$ & $-2,00$ & $-1,87$ & $-1,64$ & $-2,17$ & $-1,85$ & $-1,94$ & $-1,45$ \\
\hline 13 & 0,00 & 0,01 & 0,01 & 0,00 & 0,01 & 0,01 & 0,01 & 0,01 & 0,00 & 0,00 & 0,00 & 0,00 & 0,00 & 0,00 & 0,00 & 0,00 & 0,00 & 0,00 & 0,00 & 0,00 & 0,00 & 0,00 & 0,00 & 0,00 & 0,00 \\
\hline 14 & 0,01 & 0,00 & 0,00 & 0,00 & $-0,01$ & 0,00 & $-0,01$ & $-0,01$ & 0,00 & $-0,01$ & 0,00 & 0,00 & 0,00 & 0,00 & 0,00 & 0,00 & 0,00 & 0,00 & $-0,01$ & $-0,03$ & $-0,01$ & 0,00 & 0,00 & 0,00 & 0,00 \\
\hline 15 & $-0,01$ & $-0,02$ & $-0,01$ & $-0,22$ & $-0,53$ & $-0,14$ & $-0,18$ & $-0,30$ & $-0,06$ & $-0,01$ & $-0,01$ & $-0,02$ & $-0,05$ & $-0,01$ & $-0,01$ & $-0,02$ & $-0,03$ & $-0,03$ & $-0,01$ & $-0,07$ & $-0,03$ & $-0,05$ & $-0,02$ & $-0,02$ & $-0,01$ \\
\hline 16 & 0,00 & 0,00 & 0,00 & 0,00 & 0,00 & 0,00 & 0,00 & 0,00 & 0,01 & 0,00 & 0,00 & 0,00 & 0,01 & 0,01 & 0,01 & 0,01 & 0,01 & 0,01 & 0,02 & 0,01 & 0,02 & 0,01 & 0,01 & 0,01 & 0,01 \\
\hline 17 & 0,00 & 0,00 & 0,00 & 0,00 & 0,00 & 0,00 & 0,00 & 0,00 & $-0,01$ & $-0,01$ & $-0,01$ & 0,00 & $-0,01$ & $-0,01$ & 0,00 & 0,00 & 0,00 & 0 & 0,00 & 0,00 & $-0,01$ & $-0,01$ & $-0,01$ & $-0,01$ & $\overline{0,00}$ \\
\hline 18 & 0,01 & 0,01 & 0,01 & 0,00 & 0,00 & 0,01 & 0,00 & 0,00 & 0,00 & 0,00 & 0,00 & 0,00 & 0,00 & 0,00 & 0,00 & 0,00 & 0,00 & 0,00 & 0,00 & 0,00 & $-0,01$ & $-0,01$ & $-0,01$ & 0,00 & 0,00 \\
\hline 19 & 0,01 & 0,01 & 0,01 & 0,01 & 0,01 & 0,00 & 0,00 & 0,00 & 0,00 & 0,00 & 0,00 & 0,00 & 0,00 & 0,00 & 0,00 & 0,00 & 0,00 & 0,00 & 0,00 & 0,00 & 0,00 & 0,00 & 0,00 & 0,00 & $-0,01$ \\
\hline 20 & 0,06 & 0,05 & 0,03 & 0,03 & 0,04 & 0,04 & 0,03 & 0,02 & 0,01 & 0,00 & 0,00 & 0,00 & 0,01 & 0,01 & 0,01 & 0,01 & 0,03 & 0,04 & 0,02 & 0,02 & 0,03 & 0,03 & 0,03 & 0,02 & 0,01 \\
\hline 21 & $-0,01$ & 0,00 & 0,00 & 0,00 & 0,00 & $-0,01$ & $-0,01$ & $-0,01$ & $-0,01$ & $-0,02$ & $-0,04$ & $-0,02$ & $-0,06$ & $-0,06$ & $-0,02$ & $-0,02$ & $-0,01$ & $-0,02$ & $-0,01$ & $-0,01$ & $-0,01$ & $-0,01$ & $-0,02$ & $-0,02$ & $-0,01$ \\
\hline 22 & 0,01 & 0,01 & 0,00 & 0,00 & 0,00 & 0,00 & 0,00 & 0,00 & 0,00 & 0,00 & 0,00 & 0,00 & 0,00 & 0,00 & 0,00 & 0,00 & 0,00 & $-0,01$ & $-0,01$ & $-0,01$ & $-0,01$ & $-0,01$ & $-0,01$ & $-0,01$ & $-0,03$ \\
\hline 23 & $-0,01$ & $-0,01$ & $-0,01$ & $-0,01$ & $-0,02$ & $-0,17$ & $-0,12$ & $-0,18$ & $-0,03$ & $-0,05$ & $-0,04$ & $-0,04$ & $-0,03$ & $-0,02$ & $-0,02$ & $-0,01$ & $-0,01$ & $-0,01$ & $-0,05$ & $-0,13$ & $-0,08$ & $-0,12$ & $-0,23$ & $-0,21$ & $-0,26$ \\
\hline 24 & $-0,02$ & $-0,01$ & $-0,01$ & $-0,01$ & $-0,01$ & 0,00 & 0,00 & $-0,01$ & 0,00 & 0,00 & 0,00 & 0,00 & 0,00 & $-0,01$ & 0,00 & $-0,01$ & $-0,01$ & $-0,02$ & $-0,03$ & $-0,03$ & $-0,02$ & $-0,02$ & $-0,02$ & $-0,03$ & $-0,03$ \\
\hline 25 & 0,05 & 0 , & 0,04 & 0,03 & 0,05 & & 0,05 & 0,05 & 0,0 & 0,00 & 0,00 & $-0,01$ & $-0,01$ & -0 , & 0,00 & 0,02 & 0 & -0, & $-0,02$ & & & 01 & & $-0,02$ & $-0,01$ \\
\hline 26 & $-0,07$ & $-0,05$ & 0,00 & 0,01 & $-0,03$ & $-0,08$ & $-0,01$ & 0,00 & $-0,01$ & $-0,02$ & $-0,02$ & 0,00 & $-0,02$ & $-0,05$ & $-0,12$ & $-0,11$ & $-0,19$ & $-0,14$ & $-0,15$ & $-0,21$ & $-0,24$ & $-0,25$ & $-0,20$ & $-0,19$ & $-0,13$ \\
\hline 27 & 0,41 & $-0,10$ & $-0,34$ & 0,05 & 0,12 & 0,07 & $-0,12$ & $-0,04$ & $-0,07$ & 0,04 & $-0,01$ & $-0,01$ & $-0,02$ & $-0,01$ & 0,01 & 0,01 & $-0,03$ & 0,00 & $-0,10$ & $-0,21$ & $-0,30$ & $-0,34$ & $-0,37$ & $-0,22$ & $-0,28$ \\
\hline 28 & 0,00 & 0,01 & 0,03 & 0,01 & 0,02 & 0,03 & 0,00 & 0,02 & 0,00 & $-0,02$ & $-0,01$ & $-0,04$ & $-0,04$ & $-0,08$ & $-0,10$ & $-0,12$ & $-0,11$ & $-0,12$ & $-0,16$ & $-0,20$ & $-0,10$ & $-0,12$ & $-0,07$ & $-0,07$ & $-0,08$ \\
\hline 29 & $-0,65$ & $-0,37$ & $-0,28$ & $-0,27$ & $-0,23$ & $-0,1$ & $-0,13$ & $-0,11$ & $-0,19$ & $-0,27$ & $-0,1$ & $-0,2$ & $-0,40$ & -0, & $-0,33$ & $-0,23$ & -0 , & $-0,2$ & $-0,32$ & $-0,31$ & -0, & $-0,23$ & $-0,17$ & $-0,08$ & $-0,12$ \\
\hline 30 & $-0,01$ & $-0,01$ & $-0,02$ & 01 & $-0,03$ & $-0,03$ & $-0,01$ & $-0,02$ & $-0,01$ & $-0,01$ & $-0,02$ & $-0,04$ & $-0,03$ & $-0,03$ & $-0,04$ & $-0,04$ & $-0,06$ & $-0,0$ & $-0,07$ & $-0,07$ & $-0,12$ & $-0,12$ & $-0,13$ & $-0,17$ & $-0,22$ \\
\hline 31 & $-2,81$ & $-1,42$ & $-0,55$ & $-1,52$ & $-1,61$ & $-1,10$ & $-1,12$ & $-1,00$ & $-0,80$ & $-0,47$ & $-0,27$ & $-0,37$ & $-0,20$ & $-0,11$ & $-0,10$ & $-0,05$ & $-0,01$ & $-0,02$ & $-0,02$ & 0,00 & $-0,02$ & 0,00 & $-0,01$ & 0,01 & 0,01 \\
\hline 32 & $-0,04$ & $-0,08$ & $-0,03$ & $-0,03$ & $-0,02$ & $-0,03$ & $-0,03$ & $-0,02$ & $-0,04$ & $-0,04$ & $-0,07$ & $-0,05$ & $-0,04$ & $-0,03$ & $-0,04$ & $-0,04$ & $-0,04$ & $-0,05$ & $-0,06$ & $-0,11$ & $-0,15$ & $-0,07$ & $-0,05$ & $-0,04$ & $-0,04$ \\
\hline \begin{tabular}{|l|}
33 \\
\end{tabular} & 0,00 & 0,00 & 0,00 & $-0,01$ & 0,00 & 0,00 & $-0,01$ & 0,00 & 0,00 & $-0,01$ & 0,00 & $-0,01$ & $-0,01$ & $-0,0$ & $-0,02$ & $-0,02$ & $-0,01$ & $-0,0$ & $-0,01$ & $-0,01$ & $-0,0$ & 0,00 & $-0,01$ & $-0,01$ & $-0,02$ \\
\hline 34 & $-0,01$ & $-0,01$ & $-0,01$ & 0,00 & 0,01 & 0,01 & 0,00 & 0,01 & 0,00 & $-0,01$ & 0,00 & $-0,01$ & $-0,02$ & $-0,02$ & $-0,03$ & $-0,03$ & $-0,04$ & $-0,0$ & $-0,05$ & $-0,05$ & $-0,06$ & $-0,05$ & $-0,06$ & $-0,07$ & $-0,06$ \\
\hline 35 & 0,00 & 0,00 & $-0,01$ & $-0,01$ & 0,00 & $-0,01$ & $-0,01$ & $-0,01$ & $-0,01$ & $-0,02$ & $-0,03$ & $-0,02$ & $-0,03$ & $-0,03$ & $-0,02$ & $-0,02$ & $-0,01$ & $-0,02$ & $-0,02$ & $-0,02$ & $-0,02$ & $-0,02$ & $-0,02$ & $-0,02$ & $-0,02$ \\
\hline 36 & 0,05 & 0,05 & 0,04 & 0,03 & 0,03 & 0,03 & 0,02 & 0,02 & 0,02 & 0,01 & 0,02 & 0,01 & 0,02 & 0,01 & 0,01 & 0,01 & 0,01 & 0,00 & 0,01 & 0,00 & 0,00 & 0,00 & 0,00 & 0,00 & 0,00 \\
\hline 37 & $\begin{array}{l}-0,01 \\
\end{array}$ & & $-0,01$ & & 0,00 & & $-0,01$ & $-0,02$ & $-0,03$ & $-0,04$ & & $-0,05$ & $-0,06$ & & $-0,04$ & & $-0,03$ & $-0,0$ & $-0,07$ & $-0,07$ & $-0,07$ & $-0,07$ & $-0,08$ & $-0,08$ & \\
\hline 38 & $-0,12$ & $-0,08$ & $-0,08$ & $-0,06$ & $-0,13$ & $-0,09$ & $-0,11$ & $-0,11$ & $-0,13$ & $-0,14$ & $-0,14$ & $-0,13$ & $-0,12$ & $-0,15$ & $-0,12$ & $-0,14$ & $-0,17$ & $-0,19$ & $-0,19$ & $-0,20$ & $-0,19$ & $-0,20$ & $-0,24$ & $-0,25$ & $-0,21$ \\
\hline 39 & $-0,37$ & 0,02 & 0,20 & 0,23 & 0,10 & 0,01 & $-0,02$ & 0,00 & $-0,10$ & $-0,17$ & $-0,15$ & $-0,17$ & $-0,18$ & $-0,29$ & $-0,31$ & $-0,29$ & $-0,38$ & $-0,36$ & $-0,52$ & $-0,39$ & $-0,33$ & $-0,21$ & $-0,14$ & $-0,17$ & $-0,18$ \\
\hline 40 & $-0,01$ & 0,00 & 0,02 & 0,02 & 0,03 & 0,03 & 0,03 & 0,04 & 0,03 & 0,02 & 0,01 & 0,01 & 0,00 & 0,00 & 0,00 & 0,01 & 0,02 & 0,01 & 0,00 & $-0,01$ & 0,01 & 0,03 & 0,07 & 0,09 & 0,06 \\
\hline
\end{tabular}




\begin{tabular}{|c|c|c|c|c|c|c|c|c|c|c|c|c|c|c|c|c|c|c|c|c|c|c|c|c|c|}
\hline 41 & $-0,03$ & $-0,03$ & $-0,04$ & $-0,09$ & $-0,15$ & $-0,14$ & $-0,14$ & $-0,15$ & $-0,11$ & $-0,19$ & $-0,29$ & $-0,24$ & $-0,23$ & $-0,20$ & $-0,19$ & $-0,20$ & $-0,20$ & $-0,18$ & $-0,15$ & $-0,18$ & $-0,20$ & $-0,21$ & $-0,24$ & $-0,24$ & $-0,19$ \\
\hline 42 & 1,11 & 1,02 & 1,00 & 0,95 & 0,86 & 0,75 & 0,64 & 0,55 & 0,41 & 0,43 & 0,48 & 0,43 & 0,42 & 0,35 & 0,31 & 0,31 & 0,30 & 0,30 & 0,30 & 0,32 & 0,32 & 0,32 & 0,32 & 0,29 & 0,27 \\
\hline 43 & 0,01 & 0,01 & 0,01 & 0,01 & 0,01 & 0,01 & 0,01 & 0,01 & 0,00 & 0,00 & 0,01 & 0,01 & 0,00 & 0,00 & $-0,01$ & $-0,01$ & $-0,01$ & $-0,02$ & $-0,02$ & $-0,02$ & $-0,02$ & $-0,02$ & $-0,02$ & $-0,01$ & $-0,01$ \\
\hline 44 & $-0,42$ & $-0,23$ & $-0,11$ & $-0,02$ & 0,04 & 0,04 & 0,03 & 0,05 & 0,04 & 0,02 & 0,02 & $-0,02$ & 0,00 & $-0,01$ & $-0,01$ & 0,01 & 0,02 & 0,02 & 0,00 & $-0,07$ & $-0,18$ & $-0,11$ & $-0,19$ & $-0,21$ & $-0,14$ \\
\hline 45 & 0,00 & 0,00 & 0,00 & 0,00 & 0,00 & 0,00 & 0,00 & 0,00 & 0,00 & 0,00 & 0,00 & 0,00 & 0,00 & 0,00 & 0,00 & 0,00 & 0,00 & 0,00 & 0,00 & 0,00 & 0,00 & 0,00 & 0,00 & 0,00 & 0,00 \\
\hline 46 & 0,12 & 0,10 & 0,09 & 0,07 & 0,07 & 0,06 & 0,04 & 0,04 & 0,03 & 0,03 & 0,03 & 0,03 & 0,03 & 0,02 & 0,02 & 0,02 & 0,01 & 0,01 & 0,01 & 0,01 & 0,01 & 0,01 & 0,01 & 0,01 & 0,01 \\
\hline 47 & $-0,19$ & $-0,14$ & $-0,09$ & $-0,17$ & $-0,25$ & $-0,23$ & $-0,16$ & $-0,15$ & $-0,17$ & $-0,19$ & $-0,22$ & $-0,23$ & $-0,27$ & $-0,26$ & $-0,28$ & $-0,35$ & $-0,42$ & $-0,44$ & $-0,54$ & & $-0,61$ & $-0,55$ & & $-0,44$ & \\
\hline 48 & $-0,38$ & $-0,19$ & $-0,14$ & $-0,13$ & $-0,10$ & $-0,23$ & $-0,21$ & $-0,24$ & $-0,23$ & $-0,21$ & $-0,14$ & $-0,14$ & $-0,11$ & $-0,09$ & $-0,06$ & $-0,02$ & $-0,02$ & $-0,01$ & $-0,01$ & 0,00 & $-0,02$ & $-0,01$ & 0,00 & 0,00 & 0,00 \\
\hline 49 & 0,00 & 0,00 & 0,00 & 0,00 & 0,01 & 0,01 & 0,00 & $-0,03$ & 0,00 & 0,01 & 0,01 & 0,02 & 0,03 & 0,04 & 0,04 & 0,05 & 0,05 & 0,05 & 0,06 & 0,05 & 0,05 & 0,05 & 0,05 & 0,04 & 0,04 \\
\hline 50 & 0,03 & 0,02 & 0,02 & 0,01 & 0,01 & 0,02 & 0,02 & 0,02 & 0,01 & 0,01 & 0,00 & 0,00 & 0,00 & 0,00 & 0,00 & 0,00 & 0,00 & 0,00 & 0,00 & 0,00 & 0,00 & 0,00 & 0,00 & 0,00 & 0,00 \\
\hline 51 & $-0,04$ & $-0,02$ & $-0,01$ & $-0,01$ & $-0,02$ & $-0,01$ & 0,00 & 0,00 & 0,00 & 0,00 & 0,00 & 0,00 & 0,00 & 0,00 & & 0,00 & 0,00 & 0,00 & 0,00 & & 0,00 & 0,00 & & 0,00 & \\
\hline 52 & $-0,77$ & $-0,34$ & 0,09 & $-0,99$ & $-1,07$ & $-0,87$ & $-0,58$ & $-0,09$ & 0,01 & $-0,02$ & $-0,02$ & $-0,07$ & $-0,33$ & $-0,49$ & $-0,39$ & $-0,48$ & $-0,30$ & $-0,31$ & $-0,17$ & $-0,35$ & $-0,39$ & $-0,50$ & $-0,31$ & $-0,15$ & $-0,12$ \\
\hline 53 & 0,01 & 0,01 & 0,01 & 0,01 & 0,01 & 0,01 & 0,01 & 0,00 & 0,00 & 0,00 & 0,00 & 0,00 & 0,00 & 0,00 & 0,00 & 0,00 & 0,00 & 0,01 & 0,00 & 0,00 & 0,00 & 0,00 & 0,00 & 0,00 & 0,00 \\
\hline 54 & $-0,01$ & $-0,01$ & 0,00 & $-0,01$ & $-0,01$ & $-0,01$ & $-0,01$ & $-0,01$ & $-0,01$ & $-0,02$ & $-0,02$ & $-0,02$ & $-0,02$ & $-0,01$ & $-0,01$ & $-0,01$ & 0,00 & 0,00 & 0,00 & 0,00 & 0,00 & 0,00 & 0,00 & 0,00 & 0,00 \\
\hline 55 & $-0,36$ & $-0,18$ & $-0,13$ & $-0,16$ & $-0,24$ & $-0,17$ & $-0,09$ & $-0,05$ & $-0,06$ & $-0,06$ &, 07 & $-0,07$ & $-0,06$ & $-0,07$ & $-0,06$ & $-0,04$ & $-0,05$ & $-0,06$ & $-0,07$ & $-0,06$ & $-0,07$ & $-0,06$ & $-0,06$ & $-0,05$ & $-0,02$ \\
\hline 56 & 0,00 & 0,00 & 0,00 & 0,00 & 0,00 & 0,00 & 0,00 & 0,00 & 0,00 & 0,00 & $-0,01$ & $-0,02$ & $-0,03$ & $-0,02$ & $-0,03$ & $-0,04$ & $-0,04$ & $-0,04$ & $-0,03$ & $-0,02$ & $-0,02$ & $-0,01$ & $-0,01$ & $-0,01$ & 0,00 \\
\hline 57 & 0,10 & 0,11 & 0,08 & 0,05 & 0,06 & 0,03 & 0,03 & 0,03 & 0,02 & 0,02 & 0,02 & 0,02 & 0,02 & 0,02 & 0,01 & 0,01 & 0,01 & 0,01 & 0,01 & 0,01 & 0,02 & 0,02 & 0,02 & 0,02 & 0,02 \\
\hline 58 & 0,01 & 0,01 & 0,01 & 0,01 & 0,01 & 0,01 & 0,01 & 0,01 & 0,00 & 0,00 & 0,00 & 0,00 & 0,00 & 0,00 & 0,00 & 0,01 & 0,01 & 0,01 & 0,01 & 0,01 & 0,01 & 0,01 & 0,01 & 0,01 & 0,01 \\
\hline 59 & $-0,07$ & $-0,01$ & $-0,01$ & $-0,01$ & $-0,01$ & $-0,01$ & $-0,01$ & $-0,01$ & $-0,01$ & $-0,01$ & $-0,01$ & $-0,02$ & $-0,02$ & $-0,02$ & $-0,01$ & $-0,01$ & $-0,01$ & $-0,01$ & $-0,01$ & 0,00 & 0,00 & 0,00 & 0,00 & 0,00 & 0,00 \\
\hline 60 & 0,00 & 0,00 & 0,00 & 0,00 & 0,00 & 0,00 & 0,00 & 0,00 & $-0,01$ & 0,00 & $-0,01$ & 0,00 & 0,00 & 0,00 & 0,00 & 0,00 & 0,00 & 0,00 & 0,01 & 0,01 & 0,01 & 0,01 & 0,02 & 0,01 & 0,01 \\
\hline 61 & 1,07 & 0,90 & 0,78 & 0,60 & 0,46 & 0,43 & 0,39 & 0,34 & 0,27 & 0,23 & 0,27 & 0,25 & 0,26 & 0,25 & 0,31 & 0,36 & 0,44 & 0,43 & 0,57 & 0,60 & 0,60 & 0,56 & 0,58 & 0,55 & 0,51 \\
\hline 62 & 2,18 & 2,00 & 1,94 & 1,34 & 1,11 & 1,00 & 0,90 & 0,71 & 0,50 & 0,46 & 0,49 & 0,42 & 0,44 & 0,40 & 0,50 & 0,53 & 0,56 & 0,54 & 0,65 & 0,63 & 0,59 & 0,54 & 0,56 & 0,49 & 0,46 \\
\hline 63 & 0,32 & 0,28 & 0,25 & 0,22 & 0,21 & 0,16 & 0,15 & 0,14 & 0,13 & 0,12 & 0,15 & 0,16 & 0,19 & 0,19 & 0,19 & 0,21 & 0,22 & 0,21 & 0,24 & 0,25 & 0,25 & 0,24 & 0,26 & 0,25 & 0,24 \\
\hline 64 & 2,38 & 2,20 & 2,32 & 2,00 & 1,98 & 1,81 & 1,58 & 1,46 & 1,1 & 1,00 & 1,16 & 0,96 & 0,85 & 0,68 & 0,6 & 0,61 & 0,58 & 0,59 & 0,66 & 0,67 & 0,66 & 0,63 & 0,63 & 0,58 & 0,53 \\
\hline 65 & 0,08 & 0,10 & 0,10 & 0,08 & 0,06 & 0,06 & 0,05 & 0,05 & 0,04 & 0,04 & 0,04 & 0,0 & 0,05 & 0,05 & 0,04 & 0,05 & 0,04 & 0,04 & 0,05 & 0,05 & 0,05 & 0,05 & 0,05 & 0,05 & 0,05 \\
\hline 66 & 0,07 & 0,06 & 0,06 & 0,04 & 0,04 & 0,04 & 0,04 & 0,03 & 0,02 & 0,02 & 0,03 & 0,02 & 0,02 & 0,02 & 0,02 & 0,02 & 0,02 & 0,02 & 0,02 & 0,02 & 0,02 & 0,02 & 0,02 & 0,02 & 0,02 \\
\hline 67 & 0,29 & & 0,25 & 0,22 & 0,23 & 0,17 & & 0,15 & & & & & & 0,07 & & 0,05 & & 0,05 & & & 0,06 & 0,06 & 0,05 & 0,05 & 0,05 \\
\hline 68 & 0,00 & 0,01 & 0,01 & 0,03 & 0,03 & 0,03 & 0,04 & 0,05 & 0,05 & 0,05 & 0,06 & 0,05 & 0,05 & 0,03 & 0,03 & 0,04 & 0,04 & 0,03 & 0,02 & 0,02 & 0,01 & 0,02 & 0,03 & 0,02 & 0,02 \\
\hline 69 & 0,15 & 0,16 & 0,18 & 0,16 & 0,17 & 0,16 & 0,14 & 0,14 & 0,09 & 0,08 & 0,09 & 0,09 & 0,08 & 0,07 & 0,06 & 0,07 & 0,07 & 0,07 & 0,07 & 0,08 & 0,08 & 0,08 & 0,08 & 0,08 & 0,07 \\
\hline 70 & 0,02 & 0,01 & 0,01 & 0,01 & 0,01 & 0,01 & $-0,01$ & $-0,02$ & 0,01 & $-0,01$ & 0,03 & 0,03 & 0,02 & 0,01 & 0,02 & 0,02 & 0,01 & 0,01 & 0,01 & 0,02 & 0,03 & 0,04 & 0,03 & 0,04 & 0,05 \\
\hline 71 & 0,07 & & & 0,04 & & & & 0,05 & & & & & & & & & & 0,0 & & 0,01 & $-0,02$ & 0,06 & $-0,02$ & $-0,02$ & 0,02 \\
\hline 72 & $-0,01$ &, 10 & $-0,19$ & $-0,10$ & $-0,12$ & $-0,03$ & $-0,03$ & $-0,04$ & $-0,09$ & $-0,14$ & $-0,28$ & $-0,25$ & $-0,47$ & $-0,32$ & $-0,38$ & $-0,32$ & $-0,37$ & $-0,36$ & $-0,59$ & $-0,30$ & $-0,33$ & $-0,17$ & $-0,13$ & $-0,04$ & $-0,06$ \\
\hline 73 & $-0,01$ & 0,05 & 0,05 & 0,10 & 0,06 & 0,08 & 0,12 & 0,15 & 0,13 & 0,17 & 0,22 & 0,20 & 0,23 & 0,22 & 0,23 & 0,30 & 0,31 & 0,35 & 0,25 & 0,22 & 0,26 & 0,27 & 0,25 & 0,24 & 0,24 \\
\hline 74 & $-0,11$ & $-0,36$ & $-0,11$ & $-0,11$ & $-0,17$ & $-0,12$ & $-0,06$ & $-0,06$ & $-0,06$ & $-0,19$ & $-0,17$ & $-0,16$ & $-0,27$ & $-0,22$ & $-0,25$ & $-0,38$ & $-0,41$ & $-0,36$ & $-0,35$ & $-0,47$ & $-0,56$ & $-0,55$ & $-0,45$ & $-0,36$ & $-0,23$ \\
\hline 75 & $-0,01$ & & 01 & $-0,01$ & $-0,01$ & & & $-0,01$ & $-0,01$ & & $-0,01$ & $-0,01$ & $-0,01$ & $-0,02$ & & $-0,02$ & $-0,03$ & $-0,04$ & $-0,04$ & $-0,03$ & $-0,03$ & $-0,04$ & $-0,03$ & $-0,03$ & $-0,03$ \\
\hline 76 & $-0,15$ & $-0,12$ & $-0,09$ & $-0,11$ & $-0,18$ & $-0,20$ & $-0,19$ & $-0,11$ & $-0,13$ & $-0,20$ & $-0,17$ & $-0,11$ & $-0,11$ & $-0,13$ & $-0,20$ & $-0,33$ & $-0,30$ & $-0,34$ & $-0,26$ & $-0,31$ & $-0,40$ & $-0,33$ & $-0,27$ & $-0,19$ & $-0,12$ \\
\hline 78 & $-0,01$ & 0,00 & 0,00 & 0,00 & 0,00 & 0,00 & 0,00 & 0,00 & 0,00 & 0,00 & $-0,01$ & $-0,01$ & $-0,01$ & 0,00 & 0,00 & 0,00 & 0,00 & 0,00 & 0,00 & 0,00 & 0,00 & 0,00 & 0,00 & 0,00 & 0,00 \\
\hline 79 & 0,00 & 0,00 & 0,00 & 0,00 & 0,01 & 0,00 & $\overline{0,0}$ & 0,02 & 0,0 & 0,01 & 0,01 & 0,00 & 0,00 & $-0,01$ & $-0,01$ & $-0,02$ & $-0,02$ & $-0,02$ & \begin{tabular}{|l}
$-0,01$ \\
\end{tabular} & $-0,01$ & $-0,01$ & $-0,01$ & $-0,01$ & $-0,02$ & 0,00 \\
\hline 80 & 0,03 & & 0,01 & 0,01 & & 0,01 & & 0,01 & & & & & 0,00 & 0,00 & & 0,00 & 0,00 & 0,00 & 0,00 & 0,00 & 0,00 & 0,00 & 0,00 & 0,00 & 0,00 \\
\hline 81 & 0,03 & 0,01 & 0,02 & 0,02 & 0,01 & 0,01 & 0,00 & 0,01 & 0,01 & 0,00 & 0,00 & $-0,01$ & $-0,02$ & $-0,02$ & $-0,13$ & $-0,15$ & $-0,04$ & $-0,04$ & $-0,02$ & $-0,01$ & 0,00 & 0,00 & 0,00 & 0,00 & $-0,01$ \\
\hline 82 & 0,12 & 0,11 & 0,09 & 0,09 & 0,10 & 0,08 & 0,09 & 0,09 & 0,08 & 0,08 & 0,08 & 0,06 & 0,10 & 0,08 & 0,07 & 0,07 & 0,07 & 0,07 & 0,08 & 0,08 & 0,08 & 0,09 & 0,10 & 0,09 & 0,09 \\
\hline 83 & 0,10 & 0,10 & 0,09 & 0,08 & 0,10 & 0,10 & 0,08 & 0,09 & 0,09 & 0,09 & 0,11 & 0,11 & 0,11 & 0,10 & 0,10 & 0,12 & 0,13 & 0,12 & 0,12 & 0,13 & 0,13 & 0,13 & 0,14 & 0,13 & 0,13 \\
\hline 84 & $-2,42$ & $-1,97$ & $-2,61$ & $-2,20$ & $-1,70$ & $-1,58$ & $-1,35$ & $-1,15$ & $-0,84$ & $-0,95$ & $-1,02$ & $-0,35$ & 0,34 & 0,44 & 0,69 & 0,92 & 0,79 & 0,73 & 1,30 & 1,56 & 1,87 & 2,00 & 2,06 & 1,96 & 1,63 \\
\hline
\end{tabular}


\begin{tabular}{|l|l|l|l|l|l|l|l|l|l|l|l|l|l|l|l|l|l|l|l|l|l|l|l|l|l|}
\hline 85 & 1,59 & 1,14 & 0,58 & 0,97 & 0,95 & 0,74 & 0,65 & 0,71 & 0,32 & 0,28 & 0,12 & 0,14 & 0,20 & 0,29 & 0,57 & 0,45 & 0,93 & 1,01 & 1,58 & 1,84 & 2,31 & 2,67 & 2,78 & 2,74 & 2,45 \\
\hline 86 & 0,00 & 0,0 & $-0,02$ & 0,03 & 0,00 & $-0,01$ & 0,00 & 0,01 & 0,00 & 0,0 & $-0,0$ & 0,00 & 0,00 & 0,01 & $-0,0$ & $-0,03$ & 0,00 & $-0,03$ & $-0,03$ & $-0,03$ & 0,01 & 0,00 & 0,01 & 0,02 & 0,03 \\
\hline
\end{tabular}

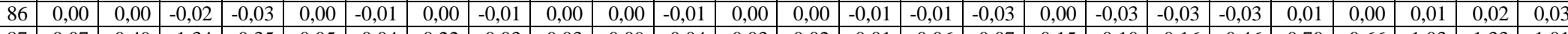

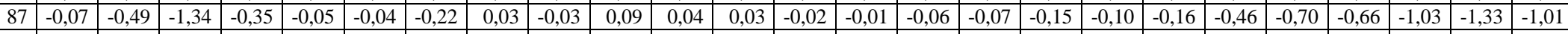

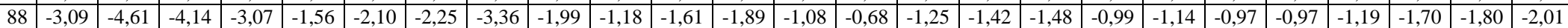

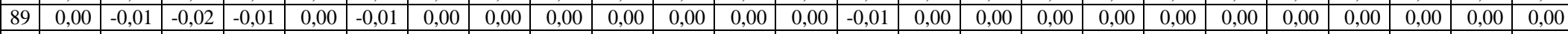

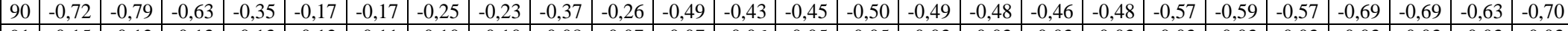

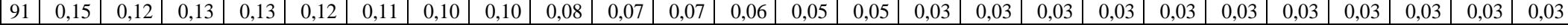

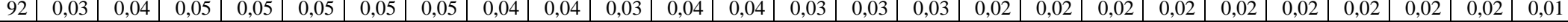
\begin{tabular}{|l|l|l|l|l|l|l|l|l|l|l|l|l|l|l|l|l|l|l|l|l|l|l|l|l|l|l}
\hline 93 & 0,01 & 0,02 & 0,05 & 0,02 & 0,00 & 0,00 & 0,00 & 0,00 & 0,00 & 0,00 & 0,00 & 0,00 & 0,00 & 0,00 & 0,00 & 0,01 & 0,00 & 0,00 & 0,01 & 0,01 & 0,01 & 0,01 & 0,01 & 0,01 & 0,01 \\
\hline
\end{tabular} \begin{tabular}{|l|l|l|l|l|l|l|l|l|l|l|l|l|l|l|l|l|l|l|l|l|l|l|l|l|l|l}
\hline 94 & 0,38 & 0,40 & 0,49 & 0,55 & 0,63 & 0,59 & 0,62 & 0,73 & 0,76 & 0,82 & 0,94 & 0,98 & 1,02 & 0,94 & 0,87 & 0,91 & 0,88 & 0,82 & 0,83 & 0,88 & 0,84 & 0,86 & 0,93 & 0,89 & 0,89 \\
\hline
\end{tabular}

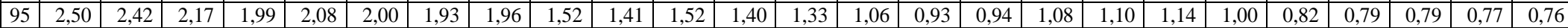

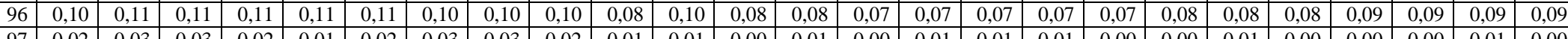

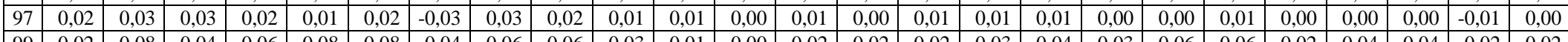

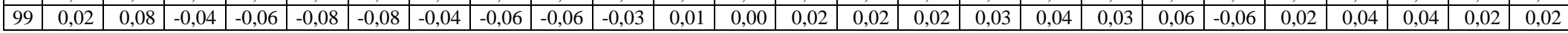

Fuente. Elaboración propia según COMTRADE, Naciones Unidas, disponible en http://comtrade.un.org/data/, fecha de consulta: 8/12/2016 


\section{Tabla Anexo III.5. Índices de Contribución al Saldo de México en el comercio con Estados Unidos, 1991-2015}

\begin{tabular}{|c|c|c|c|c|c|c|c|c|c|c|c|c|c|c|c|c|c|c|c|c|c|c|c|c|c|}
\hline & 1991 & 1992 & 1993 & 1994 & 1995 & 1996 & 1997 & 1998 & 1999 & 2000 & 2001 & 2002 & 2003 & 2004 & 2005 & 2006 & 2007 & 2008 & 2009 & 2010 & 2011 & 2012 & 2013 & 2014 & 2015 \\
\hline 1 & 0,15 & 0,12 & 0,20 & 0,10 & 0,20 & 0,01 & $-0,02$ & 0,01 & 0,04 & 0,05 & 0,04 & 0,02 & 0,06 & 0,07 & 0,06 & 0,05 & 0,04 & 0,01 & 0,04 & 0,04 & 0,04 & 0,05 & 0,03 & 0,05 & 0,06 \\
\hline 2 & $-0,35$ & 0,33 & $-0,27$ & 31 & $-0,18$ & $-0,21$ & $-0,24$ & $-0,26$ & $-0,24$ & $-0,25$ & $-0,29$ & $-0,28$ & $-0,31$ & $-0,27$ & $-0,31$ & $-0,31$ & $-0,29$ & $-0,33$ & $-0,35$ & $-0,32$ & $-0,30$ & $-0,27$ & $-0,28$ & $-0,31$ & $-0,23$ \\
\hline 3 & 0,17 & 0,12 & 0,14 & 0,14 & 0,15 & 0,13 & 0,12 & 0,11 & 0,10 & 0,08 & 0,07 & 0,05 & 0,05 & 0,05 & 0,05 & 0,04 & 0,05 & 0,05 & 0,06 & 0,03 & 0,04 & 0,04 & 0,04 & 0,04 & 0,04 \\
\hline 4 & $-0,08$ & $-0,09$ & $-0,13$ & $-0,08$ & $-0,06$ & $-0,04$ & $-0,05$ & $-0,05$ & $-0,04$ & $-0,04$ & $-0,05$ & $-0,04$ & $-0,05$ & $-0,06$ & $-0,07$ & $-0,06$ & $-0,12$ & $-0,12$ & $-0,10$ & $-0,11$ & $-0,13$ & $-0,12$ & $-0,15$ & $-0,16$ & $-0,13$ \\
\hline 5 & $-0,02$ & $-0,02$ & $-0,01$ & $-0,01$ & $-0,01$ & 0,01 & $-0,01$ & $-0,01$ & & & & $-0,06$ & $-0,06$ & & $-0,06$ & & & & & & & & & & $-0,02$ \\
\hline 6 & 0,01 & 0,00 & 0,00 & 0,00 & 0,00 & 0,00 & 0,00 & 0,00 & 0,00 & 0,00 & 0,00 & 0,00 & 0,00 & 0,00 & 0,00 & 0,00 & 0,00 & 0,00 & 0,00 & 0,00 & 0,00 & 0,00 & 0,00 & 0,00 & 0,00 \\
\hline 7 & 0,65 & 0,50 & 0,59 & 0,49 & 0,48 & 0,44 & 0,37 & 0,39 & 0,32 & 0,27 & 0,32 & 0,31 & 0,36 & 0,36 & 0,35 & 0,31 & 0,32 & 0,33 & 0,39 & 0,39 & 0,40 & 0,37 & 0,42 & 0,42 & 0,43 \\
\hline 8 & 0,31 & 0,32 & 0,22 & 0,14 & 0,18 & 0,15 & 0,14 & 0,16 & 0,15 & 0,08 & 0,08 & 0,08 & 0,10 & 0,12 & 0,14 & 0,10 & 0,15 & 0,14 & 0,24 & 0,22 & 0,21 & 0,22 & 0,25 & 0,31 & 0,36 \\
\hline 9 & 0,28 & 0,19 & 0,16 & & 0,23 & & 0,18 & 0,12 & & & & & & & 0,02 & & & & & 0,03 & & & 0,03 & & 0,02 \\
\hline 10 & $-0,47$ & $-0,53$ & $-0,40$ & $-0,47$ & $-0,48$ & $-0,80$ & $-0,31$ & $-0,41$ & $-0,36$ & $-0,30$ & $-0,37$ & $-0,40$ & $-0,39$ & $-0,39$ & $-0,33$ & $-0,37$ & $-0,48$ & $-0,65$ & $-0,51$ & $-0,43$ & $-0,59$ & $-0,51$ & $-0,37$ & $-0,37$ & $-0,35$ \\
\hline 11 & $-0,03$ & $-0,04$ & $-0,04$ & $-0,03$ & $-0,02$ & $-0,03$ & $-0,03$ & $-0,03$ & $-0,02$ & $-0,02$ & $-0,03$ & $-0,07$ & $-0,09$ & $-0,07$ & $-0,08$ & $-0,09$ & $-0,12$ & $-0,05$ & $-0,06$ & $-0,04$ & $-0,03$ & $-0,04$ & $-0,03$ & $-0,03$ & $-0,03$ \\
\hline 12 & $-0,31$ & $-0,32$ & $-0,30$ & $-0,32$ & $-0,30$ & $-0,42$ & $-0,36$ & $-0,28$ & $-0,22$ & $-0,19$ & $-0,22$ & $-0,27$ & $-0,30$ & $-0,24$ & $-0,25$ & $-0,23$ & $-0,28$ & $-0,38$ & $-0,35$ & $-0,30$ & $-0,27$ & $-0,29$ & $-0,25$ & $-0,24$ & $-0,19$ \\
\hline 13 & $-0,01$ & 0,00 & $-0,01$ & $-0,01$ & $-0,01$ & $-0,01$ & 0,00 & $-0,01$ & $-0,01$ & 0,00 & $-0,01$ & 0,00 & 0,00 & 0,00 & 0,00 & 0,00 & 0,00 & 0,00 & $-0,01$ & 0,00 & 0,00 & $-0,01$ & 0,00 & 0,00 & 0,00 \\
\hline 14 & 0,02 & 0,02 & 0,02 & 0,02 & 0,01 & 0,01 & 0,01 & 0,01 & 0,00 & 0,00 & 0,00 & 0,00 & 0,00 & 0,00 & 0,00 & 0,00 & 0,00 & 0,00 & 0,00 & 0,00 & 0,00 & 0,00 & 0,00 & 0,00 & 0,00 \\
\hline 15 & $-0,10$ & $-0,10$ & $-0,12$ & $-0,11$ & $-0,18$ & $-0,12$ & $-0,12$ & $-0,13$ & $-0,09$ & $-0,06$ & $-0,06$ & $-0,11$ & $-0,09$ & $-0,10$ & $-0,08$ & $-0,06$ & $-0,09$ & $-0,13$ & $-0,11$ & $-0,11$ & $-0,11$ & $-0,09$ & $-0,07$ & 0,06 & $-0,06$ \\
\hline 16 & 0,00 & $-0,01$ & $-0,03$ & $-0,03$ & $-0,01$ & $-0,01$ & $-0,01$ & $-0,01$ & $-0,01$ & $-0,01$ & $-0,01$ & $-0,01$ & $-0,01$ & $-0,02$ & $-0,02$ & $-0,01$ & $-0,01$ & $-0,01$ & $-0,02$ & $-0,02$ & $-0,02$ & $-0,02$ & $-0,02$ & 0,02 & $-0,02$ \\
\hline 17 & $-0,06$ & $-0,02$ & $-0,01$ & $-0,01$ & 0,00 & $-0,01$ & 0,00 & 0,01 & 0,01 & 0,01 & 0,02 & 0,04 & 0,02 & 0,02 & 0,03 & 0,04 & $-0,02$ & 0,0 & 0,05 & 0,02 & 0,0 & 0,00 & 0,06 & 0,05 & 0,05 \\
\hline 18 & $-0,03$ & $-0,02$ & $-0,01$ & $-0,02$ & $-0,01$ & $-0,01$ & 0,00 & $-0,01$ & $-0,01$ & $-0,03$ & $-0,06$ & $-0,01$ & $-0,01$ & $-0,01$ & $-0,01$ & $-0,01$ & $-0,01$ & -0, & 0,01 & 0,02 & & 0,02 & 0,01 & 51 & 0,01 \\
\hline 19 & 0,01 & $-0,01$ & $-0,01$ & $-0,01$ & 0,02 & 0,02 & 0,02 & 0,01 & 0,01 & 0,01 & 0,01 & 0,01 & 0,00 & $-0,01$ & $-0,01$ & 0,02 & 0,02 & 0,03 & 0,05 & 0,04 & 0,05 & 0,05 & 0,04 & 0,04 & 0,04 \\
\hline 20 & 0,11 & 0,06 & 0,06 & 0,06 & 0,07 & 0,05 & 0,04 & 0,04 & 0,03 & 0,02 & 0,02 & 0,02 & 0,01 & 0,02 & 0,03 & 0,02 & 0,03 & 0,03 & 0,05 & 0,04 & 0,04 & 0,04 & 0,04 & 0,04 & 0,04 \\
\hline 21 & $-0,03$ & $-0,04$ & $-0,05$ & $-0,06$ & $-0,03$ & $-0,03$ & $-0,03$ & $-0,04$ & $-0,06$ & $-0,05$ & $-0,07$ & $-0,08$ & $-0,09$ & $-0,08$ & $-0,10$ & $-0,13$ & $-0,08$ & $-0,07$ & $-0,08$ & $-0,06$ & $-0,06$ & $-0,06$ & $-0,06$ & 0,07 & $-0,07$ \\
\hline 22 & 0,14 & 0,13 & 0,11 & 0,10 & 0,13 & 0,15 & 0,17 & 0,20 & 0,20 & 0,21 & 0,23 & 0,26 & 0,27 & 0,26 & 0,27 & 0,28 & 0,25 & 0,24 & 0,29 & 0,23 & 0,20 & 0,20 & 0,21 & 0,28 & 0,30 \\
\hline 23 & $-0,12$ & $-0,16$ & $-0,13$ & $-0,13$ & $-0,11$ & $-0,10$ & $-0,07$ & $-0,08$ & $-0,07$ & $-0,07$ & $-0,12$ & $-0,07$ & $-0,09$ & $-0,10$ & $-0,10$ & $-0,11$ & $-0,12$ & $-0,15$ & $-0,17$ & $-0,13$ & $-0,13$ & $-0,12$ & $-0,12$ & $-0,14$ & $-0,14$ \\
\hline 24 & 0,01 & 0,01 & 0,00 & $-0,02$ & $-0,01$ & 0,00 & 0,01 & 0,01 & 0,00 & 0,00 & 0,00 & 0,00 & 0,00 & 0,00 & 0,00 & 0,00 & $-0,01$ & $-0,01$ & $-0,02$ & $-0,02$ & $-0,02$ & $-0,01$ & 0,01 & 0,01 & 0,00 \\
\hline 25 & 0,16 & 12 & 0,07 & 0,06 & 0,04 & & 0,02 & 0,01 & 0,0 & 0,01 & & & & 0,0 & 0,02 & & & & & & & 00 & 0,00 & & 0,00 \\
\hline 26 & 0,05 & 0,04 & 0,02 & 0,03 & 0,04 & 0,03 & 0,02 & 0,02 & 0,00 & 0,00 & $-0,02$ & $-0,03$ & $-0,0$ & 0,00 & 0,01 & $-0,05$ & $-0,03$ & $-0,11$ & $-0,04$ & $-0,03$ & $-0,11$ & $-0,13$ & $-0,20$ & $-0,25$ & $-0,27$ \\
\hline 27 & 3,14 & 2,64 & 2,49 & 2,13 & 1,69 & 1,66 & 1,79 & 0,87 & 1,01 & 1,41 & 1,14 & 1,42 & 2,05 & 2,40 & 2,65 & 3,05 & 2,67 & 2,94 & 2,04 & 1,45 & 1,18 & 0,84 & 0,54 & 0,12 & $-0,78$ \\
\hline 28 & $-0,07$ & $-0,03$ & $-0,04$ & $-0,02$ & $-0,08$ & $-0,09$ & $-0,08$ & $-0,10$ & $-0,08$ & $-0,06$ & $-0,07$ & $-0,07$ & $-0,05$ & $-0,06$ & $-0,06$ & $-0,07$ & $-0,09$ & $-0,09$ & $-0,09$ & $-0,07$ & $-0,07$ & $-0,07$ & $-0,08$ & $-0,08$ & $-0,09$ \\
\hline 29 & $-0,35$ & 31 & $-0,40$ & 38 & $-0,45$ & $-0,40$ & $-0,41$ & $-0,35$ & $-0,3$ & $-0,38$ & $-0,3$ & $-0,43$ & $-0,5$ & $-0,67$ & $-0,69$ & $-0,69$ & $-0,80$ & $-0,7$ & $-0,79$ & $-0,70$ & -0 , & $-0,76$ & $-0,69$ & & $-0,45$ \\
\hline 30 & $-0,05$ & $-0,04$ & $-0,05$ & $-0,06$ & $-0,05$ & $-0,05$ & $-0,05$ & $-0,05$ & $-0,05$ & $-0,06$ & $-0,07$ & $-0,06$ & $-0,06$ & $-0,05$ & $-0,08$ & $-0,09$ & $-0,09$ & -0, & $-0,18$ & $-0,17$ & $-0,13$ & $-0,16$ & $-0,13$ & $-0,14$ & $-0,14$ \\
\hline 31 & $-0,03$ & $-0,04$ & $-0,06$ & $-0,05$ & 0,00 & $-0,03$ & $-0,04$ & $-0,04$ & $-0,04$ & $-0,03$ & $-0,04$ & $-0,05$ & $-0,05$ & $-0,06$ & $-0,06$ & $-0,07$ & $-0,07$ & $-0,07$ & $-0,05$ & $-0,04$ & $-0,04$ & $-0,04$ & $-0,03$ & $-0,03$ & $-0,03$ \\
\hline 32 & $-0,06$ & $-0,08$ & $-0,08$ & $-0,10$ & $-0,10$ & $-0,10$ & $-0,10$ & $-0,12$ & $-0,12$ & $-0,11$ & $-0,11$ & $-0,10$ & $-0,11$ & $-0,11$ & $-0,11$ & $-0,11$ & $-0,10$ & $-0,10$ & $-0,12$ & $-0,11$ & $-0,11$ & $-0,11$ & $-0,11$ & $-0,12$ & $-0,12$ \\
\hline 33 & $-0,06$ & $-0,06$ & $-0,08$ & $-0,09$ & $-0,06$ & $-0,05$ & $-0,05$ & $-0,05$ & $-0,07$ & $-0,06$ & $-0,09$ & $-0,08$ & $-0,0$ & $-0,07$ & $-0,07$ & $-0,06$ & $-0,05$ & $-0,06$ & $-0,04$ & $-0,03$ & -0, & $-0,02$ & 0,00 & 0,00 & 0,00 \\
\hline 34 & 0,00 & $-0,02$ & $-0,03$ & 02 & $-0,01$ & $-0,01$ & 0,00 & 0,00 & 0,00 & 0,00 & 0,00 & $-0,01$ & $-0,02$ & $-0,02$ & $-0,02$ & $-0,02$ & $-0,01$ & $-0,01$ & $-0,03$ & $-0,02$ & $-0,02$ & $-0,03$ & $-0,03$ & $-0,04$ & $-0,04$ \\
\hline 35 & $-0,03$ & $-0,03$ & $-0,04$ & $-0,04$ & $-0,04$ & $-0,05$ & $-0,04$ & $-0,04$ & $-0,04$ & $-0,04$ & $-0,04$ & $-0,04$ & $-0,05$ & $-0,05$ & $-0,05$ & $-0,05$ & $-0,07$ & $-0,06$ & $-0,06$ & $-0,05$ & $-0,04$ & $-0,05$ & $-0,05$ & $-0,05$ & $-0,05$ \\
\hline 36 & $-0,01$ & $-0,01$ & 0,00 & 0,00 & 0,00 & 0,00 & 0,00 & 0,00 & 0,00 & $-0,01$ & 0,00 & $-0,01$ & $-0,03$ & $-0,03$ & $-0,03$ & $-0,03$ & $-0,03$ & $-0,02$ & $-0,02$ & $-0,02$ & $-0,02$ & $-0,02$ & $-0,01$ & $-0,01$ & $-0,01$ \\
\hline 37 & $-0,02$ & $-0,01$ & $-0,03$ & $-0,04$ & $-0,05$ & $-0,05$ & $-0,06$ & & $-0,05$ & $-0,06$ & & & & $-0,08$ & $-0,06$ & & $-0,09$ & $-0,07$ & $-0,07$ & & $-0,04$ & $-0,04$ & $-0,04$ & $-0,03$ & $-0,03$ \\
\hline 38 & $-0,15$ & $-0,12$ & $-0,15$ & $-0,18$ & $-0,19$ & $-0,21$ & $-0,18$ & $-0,18$ & $-0,16$ & $-0,15$ & $-0,14$ & $-0,16$ & $-0,16$ & $-0,17$ & $-0,19$ & $-0,20$ & $-0,19$ & $-0,23$ & $-0,27$ & $-0,24$ & $-0,22$ & $-0,23$ & $-0,25$ & $-0,26$ & $-0,26$ \\
\hline 39 & $-0,85$ & $-0,94$ & $-1,03$ & $-1,15$ & $-1,22$ & $-1,29$ & $-1,27$ & $-1,31$ & $-1,38$ & $-1,38$ & $-1,37$ & $-1,43$ & $-1,49$ & $-1,45$ & $-1,54$ & $-1,53$ & $-1,52$ & $-1,39$ & $-1,42$ & $-1,37$ & $-1,24$ & $-1,25$ & $-1,31$ & $-1,30$ & $-1,33$ \\
\hline 40 & $-0,22$ & $-0,19$ & $-0,18$ & $-0,17$ & $-0,19$ & $-0,23$ & $-0,27$ & $-0,27$ & $-0,21$ & $-0,19$ & $-0,20$ & $-0,18$ & $-0,17$ & $-0,17$ & $-0,18$ & $-0,19$ & $-0,17$ & $-0,15$ & $-0,18$ & $-0,17$ & $-0,16$ & $-0,18$ & $-0,17$ & $-0,19$ & $-0,18$ \\
\hline
\end{tabular}




\begin{tabular}{|c|c|c|c|c|c|c|c|c|c|c|c|c|c|c|c|c|c|c|c|c|c|c|c|c|c|}
\hline 41 & $-0,11$ & $-0,09$ & $-0,08$ & $-0,05$ & $-0,06$ & $-0,10$ & $-0,10$ & $-0,10$ & $-0,09$ & $-0,08$ & $-0,07$ & $-0,09$ & $-0,08$ & $-0,13$ & $-0,10$ & $-0,07$ & $-0,07$ & $-0,04$ & $-0,03$ & $-0,03$ & $-0,03$ & $-0,03$ & $-0,03$ & $-0,03$ & $-0,03$ \\
\hline 42 & 0,04 & 0,04 & 0,04 & 0,04 & 0,03 & 0,05 & 0,04 & 0,04 & 0,03 & 0,01 & 0,01 & 0,01 & 0,00 & $-0,01$ & $-0,03$ & $-0,03$ & $-0,01$ & $-0,02$ & $-0,01$ & $-0,01$ & $-0,01$ & $-0,01$ & $-0,01$ & 0,00 & $-0,01$ \\
\hline 43 & 0,00 & 0,00 & 0,00 & 0,00 & 0,00 & 0,00 & 0,00 & 0,00 & 0,00 & 0,00 & 0,00 & 0,00 & 0,00 & 0,00 & 0,00 & 0,00 & 0,00 & 0,00 & 0,00 & 0,00 & 0,00 & 0,00 & 0,00 & 0,00 & 0,00 \\
\hline 44 & $-0,09$ & $-0,11$ & $-0,09$ & $-0,05$ & $-0,01$ & 0,03 & 0,03 & $-0,01$ & $-0,02$ & $-0,04$ & $-0,04$ & $-0,05$ & $-0,06$ & $-0,06$ & $-0,06$ & $-0,07$ & $-0,07$ & $-0,06$ & $-0,06$ & $-0,06$ & $-0,05$ & $-0,05$ & $-0,05$ & $-0,05$ & $-0,05$ \\
\hline 45 & 0,00 & 0,00 & 0,00 & 0,00 & 0,00 & 0,00 & 0,00 & 0,00 & 0,00 & 0,00 & 0,00 & 0,00 & 0,00 & 0,00 & 0,00 & 0,00 & 0,00 & 0,00 & 0,00 & 0,00 & 0,00 & 0,00 & 0,00 & 0,00 & 0,00 \\
\hline 46 & 0,00 & 0,00 & 0,00 & 0,00 & 0,00 & 0,00 & 0,00 & 0,00 & 0,00 & 0,00 & 0,00 & 0,00 & 0,00 & 0,00 & 0,00 & & 0,00 & 0,00 & 0,00 & 0,00 & 0,00 & & 0,00 & & \\
\hline 47 & $-0,22$ & $-0,18$ & $-0,17$ & $-0,19$ & $-0,31$ & $-0,14$ & $-0,13$ & $-0,12$ & $-0,11$ & $-0,11$ & $-0,10$ & $-0,12$ & $-0,12$ & $-0,12$ & $-0,12$ & $-0,12$ & $-0,13$ & $-0,17$ & $-0,12$ & $-0,14$ & $-0,11$ & $-0,09$ & $-0,09$ & $-0,08$ & $-0,08$ \\
\hline 48 & $-0,51$ & $-0,53$ & $-0,59$ & $-0,59$ & $-0,55$ & $-0,53$ & $-0,46$ & $-0,47$ & $-0,48$ & $-0,45$ & $-0,46$ & $-0,41$ & $-0,42$ & $-0,39$ & $-0,38$ & $-0,38$ & $-0,38$ & $-0,38$ & $-0,44$ & $-0,39$ & $-0,33$ & $-0,34$ & $-0,34$ & $-0,32$ & $-0,33$ \\
\hline 49 & $-0,06$ & $-0,07$ & $-0,10$ & $-0,10$ & $-0,06$ & $-0,06$ & $-0,04$ & $-0,04$ & $-0,05$ & $-0,05$ & $-0,05$ & $-0,04$ & $-0,05$ & $-0,04$ & $-0,04$ & $-0,03$ & $-0,03$ & $-0,03$ & $-0,04$ & $-0,03$ & $-0,02$ & $-0,02$ & $-0,02$ & $-0,02$ & $-0,02$ \\
\hline 50 & 0,00 & 0,00 & 0,00 & 0,00 & 0,00 & 0,00 & 0,00 & 0,00 & 0,00 & 0,00 & 0,00 & 0,00 & 0,00 & 0,00 & 0,00 & 0,00 & 0,00 & 0,00 & 0,00 & 0,00 & 0,00 & 0,00 & 0,00 & 0,00 & \\
\hline 51 & 0,00 & 0,00 & 0,00 & 0,00 & 0,00 & 0,00 & 0,00 & 0,00 & 0,00 & 0,00 & 0,00 & 0,00 & 0,00 & 0,00 & 0,00 & 0,00 & 0,00 & 0,00 & 0,00 & 0,00 & 0,00 & 0,00 & 0,00 & 0,00 & 0,00 \\
\hline 52 & $-0,03$ & $-0,07$ & $-0,12$ & $-0,13$ & $-0,12$ & $-0,14$ & $-0,14$ & $-0,23$ & $-0,22$ & $-0,28$ & $-0,26$ & $-0,23$ & $-0,24$ & $-0,24$ & $-0,19$ & $-0,16$ & $-0,13$ & $-0,13$ & $-0,14$ & $-0,14$ & $-0,16$ & $-0,10$ & \begin{tabular}{|l|}
$-0,09$ \\
\end{tabular} & $-0,09$ & $-0,08$ \\
\hline 53 & 0,00 & 0,00 & 0,00 & 0,00 & 0,00 & 0,00 & 0,00 & 0,00 & 0,00 & 0,00 & 0,00 & 0,00 & 0,00 & 0,00 & 0,00 & 0,00 & 0,00 & 0,00 & 0,00 & 0,00 & 0,00 & 0,00 & 0,00 & 0,00 & 0,00 \\
\hline 54 & $-0,05$ & $-0,07$ & $-0,08$ & $-0,08$ & $-0,08$ & $-0,10$ & $-0,10$ & $-0,10$ & $-0,15$ & $-0,18$ & $-0,14$ & $-0,13$ & $-0,09$ & $-0,08$ & $-0,06$ & $-0,05$ & $-0,04$ & $-0,03$ & $-0,03$ & $-0,03$ & $-0,02$ & $-0,03$ & $-0,03$ & $-0,04$ & $-0,04$ \\
\hline 55 & $-0,03$ & $-0,03$ & $-0,02$ & $-0,01$ & 0,01 & $-0,01$ & $-0,02$ & $-0,04$ & $-0,06$ & $-0,05$ & $-0,05$ & $-0,05$ & $-0,06$ & $-0,06$ & $-0,07$ & $-0,07$ & $-0,06$ & $-0,06$ & $-0,05$ & $-0,05$ & $-0,05$ & $-0,05$ & $-0,05$ & $-0,04$ & $-0,04$ \\
\hline 56 & $-0,09$ & $-0,08$ & $-0,09$ & $-0,08$ & $-0,08$ & $-0,05$ & $-0,04$ & $-0,06$ & $-0,04$ & $-0,04$ & $-0,04$ & $-0,05$ & $-0,06$ & $-0,05$ & $-0,05$ & $-0,05$ & $-0,05$ & $-0,04$ & $-0,05$ & $-0,05$ & $-0,04$ & $-0,05$ & $-0,05$ & $-0,05$ & $-0,06$ \\
\hline 57 & $-0,03$ & $-0,03$ & $-0,04$ & $-0,03$ & $-0,02$ & $-0,02$ & $-0,02$ & $-0,02$ & $-0,02$ & $-0,02$ & $-0,02$ & $-0,02$ & $-0,02$ & $-0,02$ & $-0,02$ & $-0,01$ & $-0,01$ & $-0,01$ & $-0,01$ & $-0,01$ & $-0,01$ & $-0,01$ & $-0,01$ & $-0,01$ & $-0,01$ \\
\hline 58 & $-0,04$ & $-0,03$ & $-0,04$ & $-0,04$ & $-0,06$ & $-0,05$ & $-0,05$ & $-0,06$ & $-0,10$ & $-0,08$ & $-0,06$ & $-0,06$ & $-0,06$ & $-0,06$ & $-0,07$ & $-0,06$ & $-0,05$ & $-0,03$ & $-0,03$ & $-0,03$ & $-0,02$ & $-0,02$ & $-0,02$ & $-0,02$ & $-0,02$ \\
\hline 59 & $-0,02$ & $-0,04$ & $-0,03$ & $-0,03$ & $-0,03$ & $-0,03$ & $-0,04$ & $-0,06$ & $-0,06$ & $-0,05$ & $-0,10$ & $-0,10$ & $-0,14$ & $-0,11$ & $-0,10$ & $-0,08$ & $-0,09$ & $-0,07$ & $-0,06$ & $-0,07$ & $-0,07$ & $-0,08$ & $-0,09$ & $-0,09$ & $-0,10$ \\
\hline 60 & $-0,01$ & $-0,01$ & $-0,01$ & $-0,01$ & $-0,01$ & $-0,02$ & $-0,02$ & $-0,02$ & $-0,03$ & $-0,06$ & $-0,07$ & $-0,07$ & $-0,08$ & $-0,11$ & $-0,11$ & $-0,10$ & $-0,10$ & $-0,08$ & $-0,07$ & $-0,06$ & $-0,05$ & $-0,04$ & $-0,04$ & $-0,04$ & $-0,04$ \\
\hline 61 & 0,02 & 0,03 & 0,04 & 0,05 & 0,10 & 0,18 & 0,28 & 0,35 & 0,36 & 0,35 & 0,34 & 0,31 & 0,28 & 0,27 & 0,22 & 0,16 & 0,13 & 0,12 & 0,10 & 0,07 & 0,07 & 0,06 & 0,05 & 0,05 & 0,04 \\
\hline 62 & 0,28 & 0,33 & 0,29 & 0,31 & 0,29 & 0,35 & 0,47 & 0,58 & 0,66 & 0,68 & 0,68 & 0,61 & 0,56 & 0,52 & 0,45 & 0,32 & 0,27 & 0,24 & 0,26 & 0,21 & 0,20 & 0,19 & 0,19 & 0,18 & 0,16 \\
\hline 63 & 0,08 & 0,09 & 0,05 & 0,06 & 0,09 & 0,06 & 0,08 & 0,09 & 0,08 & 0,08 & 0,09 & 0,11 & 0,10 & 0,09 & 0,08 & 0,06 & 0,05 & 0,03 & 0,05 & 0,04 & 0,03 & 0,03 & 0,03 & 0,03 & 0,02 \\
\hline 64 & 0,08 & 0,09 & 0,07 & 0,05 & 0,06 & 0,07 & 0,08 & 0,06 & 0,05 & 0,03 & 0,03 & 0,02 & 0,02 & 0,02 & 0,02 & 0,02 & 0,02 & 0,01 & 0,02 & 0,02 & 0,02 & 0,03 & 0,04 & 0,03 & 0,03 \\
\hline 65 & 0,01 & 0,02 & 0,02 & 0,02 & 0,02 & 0,01 & 0,01 & 0,01 & 0,01 & 0,01 & 0,01 & 0,01 & 0,01 & 0,01 & 0,00 & 0,00 & 0,00 & 0,00 & 0,00 & 0,00 & 0,00 & 0,00 & 0,00 & 0,00 & 0,00 \\
\hline 66 & 0,00 & 0,00 & 0,00 & 0,00 & 0,00 & 0,00 & 0,00 & 0,00 & 0,0 & 0,00 & 0,00 & 0,00 & 0,00 & 0,00 & 0,00 & 0,00 & 0,00 & 0,00 & 0,00 & 0,00 & 0,00 & 0,00 & 0,00 & 0,00 & 0,00 \\
\hline 67 & 0,00 & 0,00 & 0,00 & 0,00 & 0,00 & 0,00 & 0,00 & 0,00 & 0,00 & 0,00 & 0,00 & 0,00 & 0,00 & 0,00 & 0,00 & 0,00 & 0,00 & 0,00 & 0,00 & 0,00 & 0,00 & 0,00 & 0,00 & 0,00 & $\overline{0,00}$ \\
\hline 68 & 0,02 & 0,02 & 0,03 & 0,02 & 0,02 & 0,02 & 0,02 & 0,02 & 0,01 & 0,02 & 0,02 & 0,02 & 0,02 & 0,02 & 0,03 & 0,03 & 0,02 & 0,01 & 0,01 & 0,01 & 0,01 & 0,01 & 0,01 & 0,01 & 0,01 \\
\hline 69 & 0,05 & 0,08 & 0,08 & 0,08 & 0,06 & 0,07 & 0,07 & 0,07 & 0,06 & 0,05 & 0,05 & 0,04 & 0,06 & 0,06 & 0,07 & 0,06 & 0,05 & 0,06 & 0,05 & 0,04 & 0,04 & 0,04 & 0,06 & 0,06 & 0,06 \\
\hline 70 & 0,11 & 0,07 & 0,03 & & 0,03 & 0,0 & 0,04 & 0,06 & & 0,04 & 0,03 & 0, & 0,02 & 0, & 0,06 & 0,05 & 0,04 & 0,04 & 0,04 & 0,03 & 03 & 02 & 0,03 & 0,03 & 0,03 \\
\hline 71 & 0,07 & 0,04 & 0,04 & 0,03 & 0,11 & 0,12 & 0,05 & 0,04 & $-0,04$ & $-0,05$ & $-0,03$ & $-0,02$ & 0,01 & 0,03 & 0,10 & 0,18 & 0,15 & 0,24 & 0,49 & 0,56 & 0,76 & 0,72 & 0,53 & 0,40 & 0,34 \\
\hline 72 & $-0,41$ & $-0,38$ & $-0,18$ & $-0,02$ & $-0,02$ & $-0,04$ & $-0,02$ & $-0,03$ & $-0,03$ & $-0,05$ & $-0,14$ & $-0,07$ & $-0,10$ & 0,01 & $-0,04$ & $-0,10$ & $-0,13$ & $-0,19$ & $-0,24$ & $-0,21$ & $-0,26$ & $-0,31$ & $-0,27$ & $-0,26$ & $-0,31$ \\
\hline 73 & $-0,13$ & $-0,15$ & $-0,13$ & $-0,24$ & $-0,32$ & $-0,44$ & $-0,25$ & $-0,24$ & $-0,25$ & $-0,29$ & $-0,18$ & $-0,13$ & $-0,13$ & $-0,13$ & $-0,15$ & $-0,20$ & $-0,20$ & $-0,14$ & $-0,16$ & $-0,17$ & $-0,14$ & $-0,18$ & $-0,22$ & $-0,20$ & $-0,20$ \\
\hline 74 & $-0,02$ & 0,01 & 0,00 & $-0,01$ & 0,11 & 0,00 & $-0,01$ & 0,02 & $-0,01$ & $-0,04$ & $-0,01$ & $-0,07$ & $-0,09$ & $-0,13$ & $-0,12$ & $-0,18$ & $-0,15$ & $-0,14$ & $-0,12$ & $-0,18$ & $-0,11$ & $-0,12$ & $-0,16$ & $-0,13$ & $-0,14$ \\
\hline 75 & $-0,01$ & $-0,01$ & $-0,01$ & 0,00 & 0,00 & 0,00 & $-0,01$ & $-0,01$ & $-0,01$ & $-0,01$ & $-0,01$ & $-0,02$ & $-0,01$ & $-0,02$ & $-0,02$ & $-0,03$ & $-0,03$ & $-0,03$ & $-0,03$ & $-0,02$ & $-0,02$ & $-0,02$ & $-0,02$ & $-0,02$ & $-0,01$ \\
\hline 76 & $-0,21$ & $-0,20$ & $-0,21$ & $-0,21$ & $-0,23$ & $-0,24$ & $-0,21$ & $-0,24$ & $-0,23$ & $-0,21$ & $-0,19$ & $-0,21$ & $-0,19$ & $-0,22$ & $-0,27$ & $-0,34$ & $-0,35$ & $-0,32$ & $-0,29$ & $-0,33$ & $-0,31$ & $-0,29$ & $-0,32$ & $-0,32$ & $-0,33$ \\
\hline 78 & 0,01 & 0,02 & 0,01 & 0,01 & 0,01 & 0,00 & 0,01 & $-0,01$ & $-0,02$ & $-0,02$ & 0,00 & 0,00 & $-0,01$ & $-0,01$ & $-0,01$ & $-0,01$ & 0,00 & 0,00 & 0,00 & 0,00 & 0,00 & 0,00 & 0,01 & 0,01 & 0,01 \\
\hline 79 & 0,04 & 03 & 0,06 & & 0,04 & 0,03 & 0,04 & 0,03 & 0,03 & 0,02 & 0,03 & 0,02 & 0,02 & 0,02 & 0,03 & 0,05 & 0,04 & 0,01 & 0,01 & 0,01 & 0,01 & 0,01 & 0,01 & 0,01 & 001 \\
\hline 80 & 0,00 & $-0,01$ & 0,00 & 0,00 & $-0,01$ & $-0,01$ & $-0,01$ & $-0,01$ & $-0,01$ & 0,00 & 0,00 & 0,00 & 0,00 & $-0,01$ & $-0,01$ & $-0,01$ & $-0,01$ & $-0,01$ & 0,00 & $-0,01$ & $-0,01$ & $-0,01$ & $-0,01$ & 0,00 & 0,00 \\
\hline 81 & 0,00 & 0,00 & 0,00 & 0,00 & 0,00 & 0,00 & 0,00 & 0,00 & 0,00 & $-0,01$ & $-0,01$ & $-0,02$ & $-0,01$ & $-0,01$ & $-0,01$ & $-0,01$ & $-0,02$ & $-0,03$ & $-0,03$ & $-0,03$ & $-0,03$ & $-0,02$ & $-0,03$ & $-0,03$ & $-0,02$ \\
\hline 82 & $-0,04$ & 0,04 & $-0,05$ &, 05 & 0,05 & $-0,04$ & $-0,05$ & $-0,05$ & $-0,07$ & $-0,05$ & $-0,03$ & $-0,03$ & $-0,04$ & $-0,04$ & $-0,04$ & $-0,04$ & $-0,04$ & $-0,04$ & $-0,04$ & $-0,04$ & $-0,03$ & $-0,04$ & $-0,04$ & $-0,04$ & $-0,05$ \\
\hline 83 & $-0,18$ & $-0,17$ & $-0,18$ & $-0,15$ & $-0,16$ & $-0,08$ & $-0,07$ & $-0,05$ & $-0,03$ & $-0,07$ & $-0,05$ & $-0,03$ & $-0,01$ & $-0,02$ & 0,00 & $-0,02$ & $-0,02$ & $-0,02$ & $-0,01$ & $-0,01$ & 0,00 & 0,00 & 0,01 & $-0,01$ & 0,00 \\
\hline 84 & $-1,64$ & $-1,53$ & $-1,35$ & $-1,04$ & $-0,82$ & $-0,59$ & $-0,73$ & $-0,50$ & $-0,38$ & $-0,36$ & $-0,15$ & $-0,51$ & $\begin{array}{c}-0,94 \\
\end{array}$ & $-1,07$ & $-1,03$ & $-0,98$ & $-0,78$ & $-0,83$ & $-0,85$ & $-0,13$ & $-0,29$ & $-0,36$ & $-0,47$ & $-0,67$ & $-0,33$ \\
\hline
\end{tabular}


\begin{tabular}{|l|l|l|l|l|l|l|l|l|l|l|l|l|l|l|l|l|l|l|l|l|l|l|l|l|l|}
\hline 85 & 1,72 & 1,99 & 1,70 & 2,11 & 0,64 & 0,36 & 0,20 & 0,78 & 0,15 & $-0,07$ & 0,19 & 0,40 & 0,53 & 0,74 & 0,87 & 0,94 & 1,80 & 1,97 & 1,81 & 0,96 & 1,04 & 1,15 & 1,02 & 0,92 & 0,93 \\
\hline 86 & $-0,09$ & 0,0 & 0,02 & 0,0 & $-0,01$ & 0,02 & 0,0 & 0,02 & 0,05 & 0,04 & $-0,0$ & $-0,02$ & $-0,03$ & $-0,03$ & $-0,04$ & $-0,05$ & $-0,09$ & $-0,01$ & $-0,01$ & $-0,04$ & $-0,08$ & $-0,10$ & $-0,08$ & $-0,12$ & $-0,15$ \\
\hline
\end{tabular}

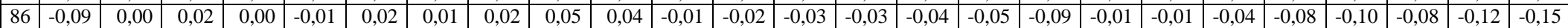

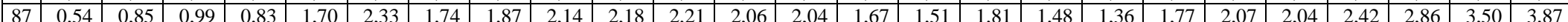

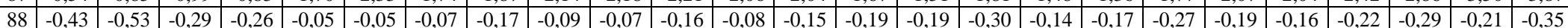

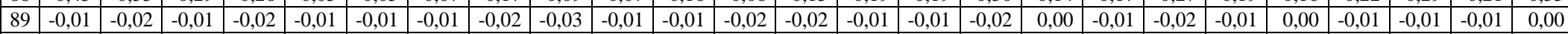

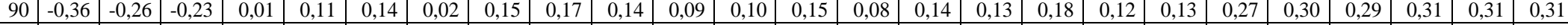

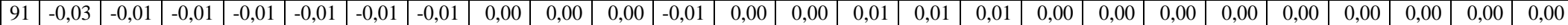

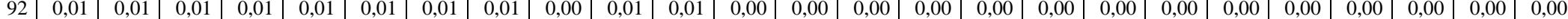

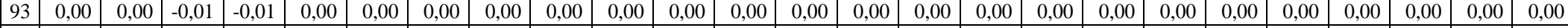

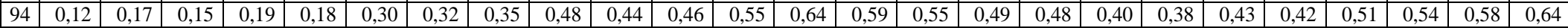

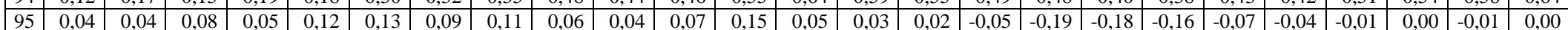

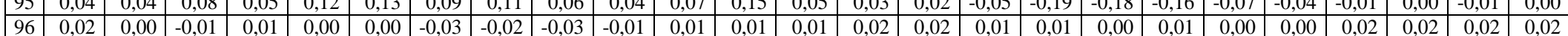

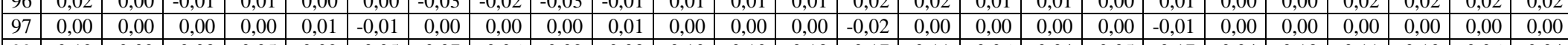

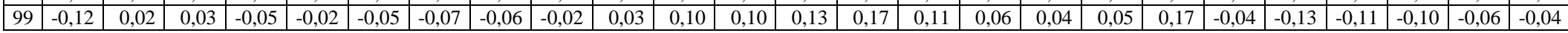

Fuente. Elaboración propia según COMTRADE, Naciones Unidas, disponible en http://comtrade.un.org/data/, fecha de consulta: 8/12/2016 


\section{Tabla Anexo III.6. CII en el comercio de China con Estados Unidos, por Secciones, 1991-2015}

\begin{tabular}{|c|c|c|c|c|c|c|c|c|c|c|c|c|c|c|c|c|c|c|c|c|c|c|c|c|c|}
\hline Sección & 1991 & 1992 & 1993 & 1994 & 1995 & 1996 & 1997 & 1998 & 1999 & 2000 & 2001 & 2002 & 2003 & 2004 & 2005 & 2006 & 2007 & 2008 & 2009 & 2010 & 2011 & 2012 & 2013 & 2014 & 2015 \\
\hline I & 9,0 & 8,8 & 15,4 & 20,9 & 16,4 & 23,7 & 24,9 & 19,9 & 28,7 & 27,0 & 23,0 & 21,2 & 20,5 & 24,2 & 23,5 & 23,4 & 17,9 & 19,9 & 23,8 & 26,0 & 28,4 & 22,9 & 20,8 & 22,0 & 24,1 \\
\hline II & 1,0 & 3,6 & & 5 & 1 & 2 & 6 & 5 & 10,2 & 8,0 & 7,5 & 10,1 & 5,7 & 5,1 & 9,0 & 10,3 & 7,9 & 6,4 & 5,2 & 4,9 & 4,5 & 4,3 & 5,1 & 4,5 & 5,6 \\
\hline III & 4,2 & 14,8 & 1,9 & 0,8 & 0,6 & 3,9 & 0,5 & 0,4 & 5,8 & 29,9 & 50,6 & 27,5 & 13,7 & 25,9 & 26,2 & 18,2 & 7,9 & 14,9 & 28,2 & 7,9 & 23,8 & 17,7 & 22,9 & 14,2 & 25,4 \\
\hline IV & 7,6 & 12,6 & 9,0 & 10,7 & 17,1 & 10,7 & 14,8 & 16,5 & 20,0 & 22,6 & 24,7 & 23,0 & 18,8 & 15,7 & 15,2 & 15,5 & 17,6 & 18,0 & 22,5 & 17,8 & 22,8 & 19,1 & 16,8 & 19,5 & 19,7 \\
\hline V & 12,0 & 10,2 & 2,2 & 4 & 1,6 & 5,4 & 21,8 & 16,8 & 28,8 & 8,2 & 19,4 & 14,4 & 14,9 & 13,8 & 10,4 & 11,6 & 13,7 & 6,9 & 10,4 & 5,8 & 4,8 & 4,4 & 9,8 & 16,8 & 17,8 \\
\hline VI & 9,6 & 13,6 & 17,5 & 13,5 & 13,3 & 16,9 & 17,1 & 17,4 & 20,0 & 29,3 & 30,4 & 35,6 & 37,0 & 36,4 & 38,0 & 36,7 & 35,5 & 35,5 & 36,4 & 36,0 & 36,7 & 37,7 & 35,6 & 36,1 & 36,6 \\
\hline VII & 3,5 & 2,9 & 3,7 & 5,1 & 6,4 & 6,1 & 7,2 & 7,9 & 7,6 & 9,2 & 9,4 & 9,7 & 10,0 & 11,1 & 13,3 & 14,8 & 13,0 & 15,2 & 14,6 & 16,8 & 18,9 & 17,1 & 17,1 & 17,6 & 17,8 \\
\hline VIII & 0,6 & 0,4 & 0,5 & 0,5 & 0,5 & 0,4 & 0,5 & 0,4 & 0,3 & 0,5 & 0,6 & 0,6 & 1,1 & 13 & 0,9 & 1,0 & 1,0 & 0,9 & 1,0 & 0,6 & 0,6 & 0,6 & 0,8 & 0,9 & 1,4 \\
\hline IX & 0,2 & 1,4 & 1,9 & 1,7 & 2,7 & 4,2 & 4,3 & 3,3 & 3,2 & 2,6 & 2,5 & 2,7 & 4,2 & 3,7 & 5,1 & 7,0 & 6,6 & 5,9 & 5,1 & 3,9 & 4,1 & 4,0 & 5,3 & 3,7 & 3,2 \\
\hline$X$ & 5,5 & 7,4 & 7,2 & 8,9 & 8,7 & 7,2 & 14,6 & 11,6 & 11,8 & 11,4 & 12,3 & 14,8 & 16,2 & 13,4 & 15,6 & 13,2 & 12,5 & 13,0 & 12,6 & 11,9 & 10,3 & 11,9 & 12,2 & 12,6 & 11,7 \\
\hline XI & 0,9 & 1,0 & 1,0 & 0,9 & 1,5 & 1,3 & & & & 2,1 & 2,4 & 2,4 & 2,0 & & 2,4 & 2,2 & 2,2 & 2,4 & 2,1 & 2,3 & 2,4 & 2,5 & 2,9 & 2,8 & 2,4 \\
\hline XII & 0,1 & 0,3 & 0,2 & 0,3 & 0,3 & 0,3 & 0,5 & 0,7 & 0,8 & 0,8 & 0,9 & 0,6 & 0,7 & 0,5 & 0,6 & 0,8 & 0,5 & 0,6 & 0,6 & 0,7 & 0,7 & 0,6 & 0,6 & 0,6 & 0,8 \\
\hline XIII & 4,4 & 4,8 & 4,0 & 4,2 & 6,3 & 5,9 & 5,7 & 6,4 & 5,4 & 8,6 & 7,7 & 5,7 & 7,1 & 06 & 9,6 & 9,7 & 10,9 & 12,5 & 13,4 & 15,2 & 13,9 & 11,1 & 11,9 & 13,2 & 12,3 \\
\hline XV & 7,7 & 5,4 & 11,6 & 7,3 & 14,9 & 14,1 & 10,5 & 10,1 & 8,1 & 7,3 & 7,7 & 7,6 & 6,3 & 8,4 & 9,4 & 8,3 & 9,4 & 11,3 & 12,1 & 11,5 & 11,1 & 11,0 & 11,9 & 12,4 & 11,8 \\
\hline XVI & 20,7 & 23,4 & 27,4 & 22,6 & 22,4 & 23,4 & 21,5 & 24,1 & 21,5 & 24,1 & 26,9 & 20,7 & 17,7 & 16,5 & 16,3 & 16,2 & 15,9 & 16,5 & 16,4 & 15,9 & 15,9 & 15,2 & 16,0 & 15,2 & 15,1 \\
\hline XVII & 8,8 & 6,2 & 7,3 & & 7,9 & 9,2 & & & & 8,5 & 10,8 & 9,6 & 15,6 & & 15,0 & 14,7 & 16,6 & 14,1 & 18,3 & 14,4 & 11,5 & 12,2 & 15,7 & 15,8 & 15,0 \\
\hline XVIII & 16,0 & 15,2 & 15,6 & 15,2 & 14,6 & 17,6 & 17,2 & 15,0 & 19,3 & 22,4 & 28,1 & 30,3 & 33,0 & 38,1 & 39,5 & 40,7 & 47,3 & 49,9 & 50,0 & 52,0 & 54,0 & 52,9 & 53,6 & 54,8 & 54,4 \\
\hline $\mathrm{XX}$ & 0,5 & 0,7 & 0 , & 0 , & 1,9 & 2,9 & & 1 , & & 1,1 & 1,0 & 0,8 & 0,8 & & 0,9 & 0,9 & 1,0 & 1,0 & 1,3 & 2,5 & 3,4 & 2,2 & 2,0 & 1,6 & 1,7 \\
\hline XXI & 6,4 & 5,4 & 3,5 & 8,2 & 2,8 & 2,6 & 16,7 & 2,7 & 7,2 & 13,2 & 17,7 & 25,8 & 9,6 & 17,1 & 7,4 & 14,1 & 16,0 & 35,4 & 37,3 & 21,7 & 37,1 & 30,3 & 32,4 & 57,3 & 40,1 \\
\hline
\end{tabular}

Fuente. Elaboración propia según COMTRADE, Naciones Unidas, disponible en http://comtrade.un.org/data/, fecha de consulta: 8/12/2016 


\section{Tabla Anexo III.7. CII en el comercio de México con Estados Unidos, por Secciones, 1991-2015}

\begin{tabular}{|c|c|c|c|c|c|c|c|c|c|c|c|c|c|c|c|c|c|c|c|c|c|c|c|c|c|}
\hline Sección & 1991 & 992 & 1993 & 1994 & 1995 & 1996 & 1997 & 1998 & 1999 & 2000 & 2001 & 2002 & 2003 & 2004 & 2005 & 2006 & 2007 & 2008 & 2009 & 2010 & 2011 & 2012 & 2013 & 2014 & 2015 \\
\hline I & 25,6 & 28,3 & 16,7 & 20,1 & 10,5 & 19,4 & 23,1 & 18,2 & 14,1 & 14,9 & 15,3 & 13,9 & 10,8 & 9,3 & 9,6 & 10,5 & 11,6 & 12,5 & 14,5 & 17,1 & 18,3 & 23,5 & 24,3 & 26,6 & 26,3 \\
\hline II & 7,2 & & & & & & & & 7,4 & 8,7 & & 8,4 & 8,0 & & 8,3 & 05 & 8,4 & 8,9 & 7,7 & 7,8 & 6,9 & 7,6 & 8,2 & 8,5 & 8,4 \\
\hline III & 16,6 & 24,5 & 19,6 & 20,4 & 21,0 & 27,5 & 14,8 & 17,6 & 19,9 & 16,8 & 16,6 & 7,0 & 14,5 & 16,9 & 8,9 & 16,9 & 8,7 & 10,9 & 19,1 & 15,7 & 18,1 & 21,6 & 24,4 & 24,7 & 23,0 \\
\hline IV & 271 & 310 & 343 & 29,4 & 24,2 & 22,7 & 25,4 & 24,6 & 25,5 & 26,8 & 24,0 & 27,1 & 29,4 & 27,8 & 27,7 & 28,2 & 31,3 & 31,6 & 28,9 & 29,8 & 29,6 & 30,5 & 31,6 & 28,7 & 26,2 \\
\hline $\mathrm{V}$ & 13,4 & 14,1 & 22,0 & 15,1 & 11,8 & 11,5 & 7,1 & 9,5 & 10,0 & 10,1 & 10,9 & 9,6 & 12,1 & 5,2 & 16,9 & 5,4 & 17,5 & 18,3 & 19,0 & 17,3 & 13,6 & 8,8 & 10,0 & 9,6 & 7,5 \\
\hline VI & 308 & 301 & 33,3 & 32,4 & 35,5 & 34,7 & 36,5 & 36,3 & 37,1 & 32,1 & 34,0 & 34,6 & 35,5 & 36,9 & 33,2 & 32,6 & 27,4 & 26,0 & 26,7 & 26,8 & 26,9 & 25,3 & 26,6 & 28,3 & 28,2 \\
\hline VIII & 40,2 & 41,2 & 46,9 & 55,9 & 55,2 & 35,4 & 32,9 & 35,3 & 33,0 & 32,5 & 34,9 & 37,5 & 40,2 & 23,0 & 25,6 & 30,5 & 33,5 & 40,3 & 48,4 & 41,0 & 47,4 & 45,4 & 43,8 & 47,9 & 51,8 \\
\hline IX & $30, J$ & & & & & & & & & & & & & & & 33,4 & 32,8 & 33,4 & 29,7 & 26,6 & 26,4 & 25,1 & 26,7 & 27,0 & 29,3 \\
\hline $\mathrm{X}$ & 22,7 & 21,7 & 17,2 & 17,7 & 25,4 & 25,5 & 24,3 & 25,3 & 22,8 & 22,9 & 26,1 & 25,7 & 25,7 & 6,2 & 27,3 & 8,1 & 29,8 & 26,8 & 26,4 & 25,9 & 28,3 & 30,1 & 31,5 & 1,6 & 33,9 \\
\hline XI & 512 & 520 & 51,5 & 53,3 & 49,5 & 49,8 & 48,6 & 44,7 & 40,6 & 35,4 & 32,9 & 31,8 & 30,1 & 27,5 & 27,9 & 29,8 & 28,4 & 28,7 & 30,7 & 30,2 & 30,6 & 32,6 & 33,6 & 34,2 & 34,0 \\
\hline XII & & & & & 39,6 & 35,6 & & 43,7 & 42,2 & 49,2 & 40,3 & 34,9 & 25,8 & & & 30,3 & 33,4 & 36,2 & 36,1 & 43,9 & 2,3 & 33,0 & 34,4 & 6,3 & 32,1 \\
\hline XIII & 37,2 & 43,6 & 43,8 & 40,7 & 35,6 & 35,6 & & 37,5 & 35,0 & 38,9 & 38,6 & 35,3 & 39,3 & & 34,1 & 35,7 & 38,1 & 39,7 & 41,9 & 41,0 & 42,1 & 49,2 & 50,2 & 51,4 & 50,6 \\
\hline $\mathrm{XV}$ & 40,8 & 36,2 & 36,9 & 36,1 & 38,3 & 42,2 & 45,4 & 46,3 & 47,5 & 47,9 & 48,4 & 50,7 & 49,7 & 49,1 & 50,5 & 48,7 & 47,7 & 47,6 & 50,2 & 49,4 & 48,6 & 50,8 & 19,0 & 47,6 & 45,6 \\
\hline XVI & & & 62,8 & & 7,4 & 55,8 & & 55,0 & 54,4 & & 54,6 & 51,7 & 49,6 & & & & 46,8 & 48,6 & 49,0 & 50,9 & 53,2 & 53,6 & 53,6 & 53,9 & 54,1 \\
\hline XVII & & 41,6 & 44,6 & & 36,8 & 39,8 & & 46,8 & 45,4 & & 46,6 & 50,4 & 51,6 & & & 51,3 & 55,1 & 58,6 & 53,6 & 52,2 & 54,7 & 53,3 & 52,1 & 46,2 & 44,4 \\
\hline XVIII & 65,6 & 69,4 & 70,6 & 67,2 & 56,5 & 53,0 & 56,5 & 58,2 & 55,2 & 57,7 & 54,7 & 53,2 & 51,1 & & 52,5 & 53,7 & 50,4 & 53,1 & 52,1 & 53,7 & 52,6 & 54,4 & 57,1 & 58,5 & 59,4 \\
\hline $\mathrm{XX}$ & 82,1 & 81,5 & 79,4 & 75,6 & 60,9 & 53,3 & 57,3 & 56,0 & 46,3 & 49,1 & 45,3 & 37,5 & 35,3 & 33,8 & & 31,5 & 27,7 & 32,0 & 32,4 & 32,7 & 35,0 & 34,5 & 36,9 & 38,5 & 37,6 \\
\hline XXI & 82,0 & 75,4 & 93,2 & 77,3 & 30,8 & 74,3 & 84,0 & 86,0 & 67,2 & 30,6 & 55,4 & 56,2 & 73,9 & 34,7 & 81,8 & 79,4 & 85,2 & 78,2 & 51,6 & 68,8 & 70,1 & 61,5 & 63,7 & 83,6 & 69,7 \\
\hline
\end{tabular}

Fuente. Elaboración propia según COMTRADE, Naciones Unidas, disponible en http://comtrade.un.org/data/, fecha de consulta: 8/12/2016 


\section{Tabla Anexo III.8. CII en el comercio de China con Estados Unidos, Capítulo 61, 1991-2015}

\begin{tabular}{|c|c|c|c|c|c|c|c|c|c|c|c|c|c|c|c|c|c|c|c|c|c|c|c|c|c|}
\hline & 1991 & 1992 & 1993 & 1994 & 1995 & 1996 & 1997 & 1998 & 1999 & 2000 & 2001 & 2002 & 2003 & 2004 & 2005 & 2006 & 2007 & 2008 & 2009 & 2010 & 2011 & 2012 & 2013 & 2014 & 2015 \\
\hline 6101 & 0,0 & 0,0 & 3,4 & 0,0 & 0,0 & 8,3 & 0,7 & \begin{tabular}{|l|}
0,2 \\
\end{tabular} & 0,6 & 0,0 & \begin{tabular}{|l|} 
\\
\end{tabular} & 0,6 & 0,8 & 1,2 & 0,0 & 0,0 & 0,1 & 0,2 & 0,1 & \begin{tabular}{|l|} 
\\
\end{tabular} & 0,2 & 0,3 & 0,2 & 0,3 & 0,5 \\
\hline 6102 & 0,0 & 0,0 & 0,0 & 0,2 & 1,3 & 0,0 & 0,0 & 0,6 & 0,2 & 0,2 & 0,4 & 0,1 & 1,6 & 0,2 & 0,2 & 0,1 & 0,3 & 0,9 & 0,5 & 0,2 & 0,2 & 0,1 & 0,2 & 0,2 & 0,2 \\
\hline 6103 & 0,5 & 0,0 & 0,5 & 0,1 & 1,6 & 0,1 & 1,2 & 1,6 & 6,7 & 0,1 & 1,0 & 1,0 & 1,5 & 4,4 & 1,4 & 0,1 & 1,9 & 1,8 & 1,0 & 0,3 & 0,2 & 0,6 & 0,2 & 0,3 & 0,3 \\
\hline 6104 & 0,1 & 0,6 & 0,4 & 0,2 & 0,8 & 0,2 & 0,5 & 0,9 & 0,1 & 0,1 & 2,5 & 1,5 & 1,0 & 7,3 & 3,1 & 1,4 & 0,5 & 0,3 & 0,5 & 0,4 & 0,4 & 0,4 & 0,5 & 0,6 & 0,9 \\
\hline 6105 & 0,5 & 0,0 & 0,0 & 0,0 & 0,3 & 0,0 & 0,3 & 0,2 & 0,2 & 0,5 & 0,2 & 1,5 & 0,2 & 0,6 & 0,8 & 0,2 & 0,1 & 0,3 & 0,3 & 0,1 & 0,3 & 0,9 & 0,9 & 1,4 & 2,7 \\
\hline 6106 & 0,0 & 0,0 & 0,0 & 0,0 & 1,0 & 0,5 & 0,2 & 0,1 & 0,0 & 0,0 & 0,7 & 1,3 & 2,8 & 0,2 & 0,3 & 0,1 & 0,5 & 0,6 & 0,0 & 0,2 & 0,3 & 0,2 & 0,1 & 0,6 & 0,6 \\
\hline 6107 & 0,4 & 3,7 & 0,2 & 0,0 & 0,0 & 0,1 & 0,0 & 0,0 & 3,7 & 0,4 & 0,0 & 0,2 & 0,1 & 0,0 & 0,7 & 0,0 & 0,0 & 0,7 & 0,0 & 0,0 & 0,0 & 0,2 & 0,1 & 0,1 & 0,5 \\
\hline 6108 & 0,0 & 1,1 & 0,3 & 0,0 & 0,0 & 0,0 & 0,0 & 0,0 & 0,1 & 0,2 & 0,0 & 0,0 & 0,4 & 0,6 & 0,1 & 0,0 & 0,1 & 0,0 & 0,0 & 0,1 & 0,1 & 0,0 & 0,0 & 0,1 & 0,2 \\
\hline 6109 & 0,6 & 0,0 & 0,7 & 0,2 & 1,0 & 0,8 & 1,5 & 0,8 & 0,2 & 0,6 & 1,4 & 1,8 & 1,4 & 1,0 & 1,4 & 0,4 & 1,5 & 1,5 & 2,7 & 1,6 & 1,8 & 1,2 & 1,8 & 1,5 & 1,8 \\
\hline 6110 & 0,1 & 0,0 & 0,1 & 0,0 & 0,1 & 0,1 & 0,1 & 0,1 & 0,0 & 0,1 & 0,2 & 0,2 & 0,2 & 0,2 & 0,2 & 0,1 & 0,1 & 0,1 & 0,1 & 0,0 & 0,1 & 0,1 & 0,1 & 0,1 & 0,2 \\
\hline 6111 & 0,0 & 1,1 & 0,0 & 0,1 & 0,1 & 0,2 & 0,1 & 0,0 & 0,0 & 0,0 & 1,0 & 0,2 & 0,0 & 0,0 & 0,1 & 0,0 & 0,0 & 0,0 & 0,1 & 0,1 & 0,1 & 0,1 & 0,1 & 0,1 & 0,2 \\
\hline 6112 & 0,0 & 0,0 & 0,0 & 0,0 & 0,5 & 0,0 & 0,0 & 0,0 & 0,0 & 0,1 & 0,1 & 0,1 & 0,3 & 0,2 & 0,0 & 0,2 & 0,0 & 0,2 & 0,1 & 0,0 & 0,1 & 0,0 & 0,3 & 0,5 & 0,0 \\
\hline 6113 & 0,0 & 0,0 & 0,0 & 0,0 & 0,0 & 13,1 & 0,1 & 0,0 & 0,3 & 0,0 & 0,7 & 0,2 & 0,5 & 1,3 & 0,6 & 2,1 & 3,8 & 0,6 & 0,6 & 1,4 & 0,8 & 0,2 & 0,8 & 4,1 & 2,3 \\
\hline 6114 & 0,0 & 0,1 & 0,0 & 0,0 & 1,1 & 0,5 & 1,1 & 0,4 & 0,3 & 0,3 & 3,5 & 3,2 & 2,3 & 4,7 & 2,5 & 2,5 & 1,1 & 2,5 & 0,2 & 0,1 & 0,4 & 0,7 & 0,4 & 0,2 & 0,5 \\
\hline 6115 & 0,0 & 1,7 & 0,2 & 2,5 & 14,9 & 9,4 & 4,0 & 1,8 & 4,2 & 1,7 & 1,9 & 0,2 & 0,5 & 0,3 & 5,3 & 0,3 & 0,1 & 0,2 & 0,1 & 0,1 & 0,1 & 0,1 & 0,1 & 0,2 & 0,3 \\
\hline 6116 & 5,8 & 11,6 & 15,5 & 12,6 & 9,9 & 7,6 & 5,6 & 1,3 & 1,3 & 0,4 & 0,1 & 0,2 & 0,1 & 0,2 & 0,3 & 0,4 & 0,7 & 0,5 & 0,3 & 0,6 & 0,9 & 1,1 & 0,4 & 0,5 & 0,4 \\
\hline 6117 & 0,0 & 3,3 & 0,4 & 4,6 & 6,1 & 0,3 & 1,2 & 5,1 & 1,5 & 0,3 & 0,2 & 0,1 & 0,2 & 0,3 & 1,0 & 0,6 & 0,1 & 0,3 & 1,1 & 0,1 & 0,2 & 0,4 & 0,1 & 0,1 & 0,1 \\
\hline
\end{tabular}

Fuente. Elaboración propia según COMTRADE, Naciones Unidas, disponible en http://comtrade.un.org/data/, fecha de consulta: 8/12/2016 


\section{Tabla Anexo III.9. CII en el comercio de México con Estados Unidos, Capítulo 61, 1991-2015}

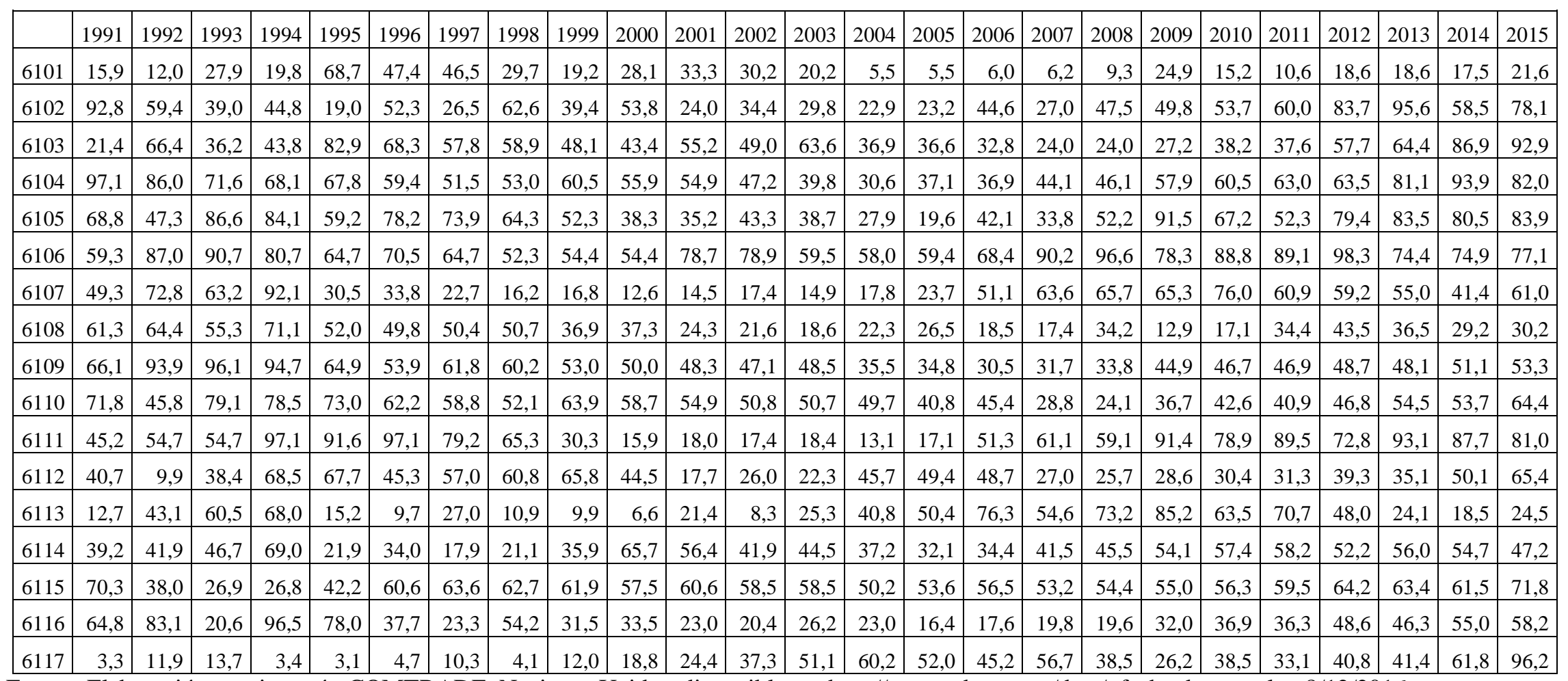

Fuente. Elaboración propia según COMTRADE, Naciones Unidas, disponible en http://comtrade.un.org/data/, fecha de consulta: 8/12/2016. 


\section{Tabla Anexo III.10. CII en el comercio de China con Estados Unidos, Capítulo 87, 1991-2015}

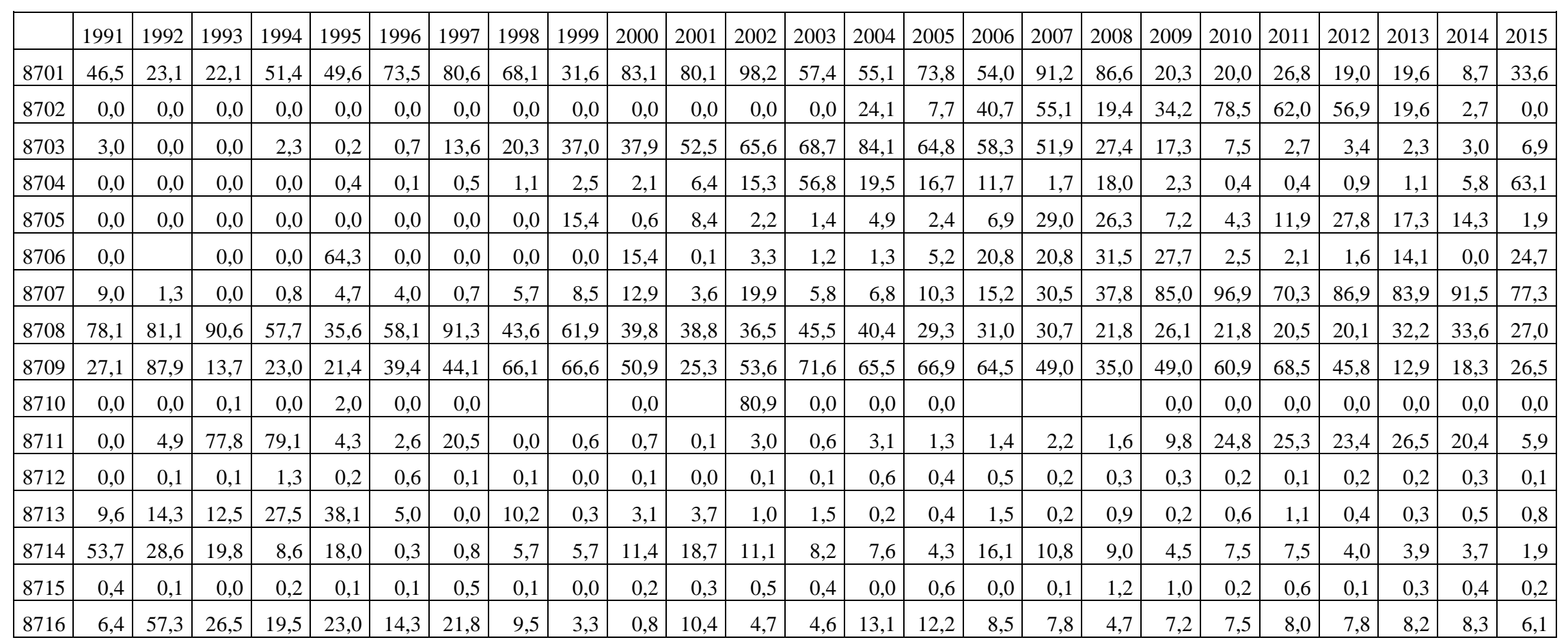

Fuente. Elaboración propia según COMTRADE, Naciones Unidas, disponible en http://comtrade.un.org/data/, fecha de consulta: 9/12/2016. 


\section{Tabla Anexo III.11. CII en el comercio de México con Estados Unidos, Capítulo 87, 1991-2015}

\begin{tabular}{|c|c|c|c|c|c|c|c|c|c|c|c|c|c|c|c|c|c|c|c|c|c|c|c|c|c|}
\hline & 91 & 92 & 93 & 94 & 95 & 96 & 97 & 998 & 999 & 000 & 001 & 002 & 003 & 004 & 005 & 2006 & 2007 & 2008 & 2009 & 2010 & 2011 & 2012 & 2013 & 2014 & 2015 \\
\hline & & & & & & & & & & & & & & & & & & & & & & & & & \\
\hline & & & & & & & & & & & & & & & & & & & & 9,2 & & & 7,0 & & 83,8 \\
\hline & & & & & & & & & & & & & & & & & & & 32,3 & & & & & 9,8 & 23,0 \\
\hline 8 & & & & & & & & & & & & & & & & & & & & & & & & & 68 \\
\hline & & & & & & & & & & & & & & & & & & & 65 & , & & 1,0 & 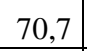 & $2, J$ & 3,4 \\
\hline 8706 & & & & & & & & & & & & & & & & & & & 79,6 & 0,8 & & & 0,6 & 4,8 & 38,0 \\
\hline 8707 & & & & & & & & & & & & & & & & & & & & & & & & & 1,0 \\
\hline 870 & 60,3 &, 2 & & & & & & & & 183 & & & & 970 & & & &, 4 & 95,8 & 4,6 & & & 5,7 & 9,3 & 89,8 \\
\hline 8709 & & & & & & & & & & & 50 & h & 20 & 0 & 7 & 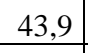 & 640 & 52 & 541 & 42,5 & & 8,6 & 1,5 & 1,8 & 23,7 \\
\hline & & & & & & & & & & & & & & & & & & & & & & & & 6,1 & 0,2 \\
\hline 871 & & 0 & 06 & 70,7 & 6,2 & 7,6 & 97,4 & 88 & 67 & 83,6 & 26 & & 02 & 367 & & & & م & ח 0 & 20 & & & 0 & 0,0 & 01 \\
\hline & & & & & & & & & & & & & & & & & & & 0,1 & & & & & & 13,0 \\
\hline & & & & & & & & & & & & & & & & & & & & & & & 7,4 & 6,1 & 8 \\
\hline 8714 & & & & & 99,9 & 9,1 & & & & & & & & & & & & & 49,0 & & & & 8,2 & 1,2 & $1 J, L$ \\
\hline & & & & & & & & & & & & & & & & & & & 3,7 & & & & 5,8 & 3,4 & 58,9 \\
\hline 8716 & נינ, & 70,5 & 97,4 & 89,2 & 57,8 & 67,3 & 51,5 & 66,7 & 49,4 & 74,7 & 80,0 & 99,0 & 70,8 & 66,7 & 66,1 & 68,5 & 70,3 & 87,3 & 89,3 & 74,7 & 63,1 & 65,0 & 75,3 & 62,1 & 55, \\
\hline
\end{tabular}

Fuente. Elaboración propia según COMTRADE, Naciones Unidas, disponible en http://comtrade.un.org/data/, fecha de consulta: 9/12/2016 


\section{Capítulo IV}

La política industrial como instrumento para atraer la inversión extranjera directa en México 


\section{IV-0. Introducción}

Se inicia este capítulo con el análisis de las políticas de atracción de la inversión extranjera directa (IED) en México desde tres diferentes niveles: el nacional, el estatal y el municipal. Para analizar el nivel nacional, se examinan tres políticas: primero, el Programa de la Maquiladora y el Programa para la Industria Manufacturera, Maquiladora y de Servicios de Exportación (IMMEX); segundo, la Ley de Inversión Extranjera (el cambio de las participaciones de los capitales extranjeros); y tercero, las políticas focalizadas en las pequeñas y medianas empresas (PYMES). Posteriormente, para el nivel estatal, se estudian las políticas fiscales utilizadas para la atracción de IED. Por último, se examina la política industrial de la ciudad de Tijuana, Baja California, como estudio de caso para analizar las políticas en el nivel municipal.

Después del estudio de las políticas industriales en los tres niveles indicados, analizamos las políticas de formación de México. La mayor parte de las empresas extranjeras que hacen IED en México pertenecen a la industria manufacturera. Por eso, la formación de ingenieros es una vía para aumentar la IED en esta industria. Asimismo, para la actividad de estas empresas, también se requieren "especialistas en papeleos", como abogados, contables y asesores. Además, todos los niveles de la política industrial (nacional, estatal y municipal) necesitan de las políticas de formación. Por ello, en este capítulo se analiza cómo funcionan dichas políticas en los tres niveles mencionados.

Tras ello, se examina la industria de los centros de llamadas (los call-center) como un ejemplo de las políticas industriales adoptadas para atraer la IED. Por último, para cerrar el capítulo, se exponen las conclusiones del mismo. 


\section{IV-1. Políticas industriales en el nivel nacional}

\section{IV-1. 1. Políticas industriales en la zona franca de exportación: Programa de la} Maquiladora y Programa para la Industria Manufacturera, Maquiladora y de Servicios de Exportación (IMMEX)

El establecimiento de una zona especial para el procesamiento de la exportación es una vía muy utilizada para atraer IED (RAMOS MARTÍNEZ et al., 2012; JIMÉNEZ y PODESTÁ, 2009). En el caso de México, este tipo de zonas existen desde 1965, cuando se creó el Programa de la Maquiladora. Desde la década de 1980, el gobierno de México consideró que la maquiladora es una vía importante para su desarrollo económico (GAMBRILL, 2008, p. 315). En la actualidad, este programa se ha convertido en el Programa para la Industria Manufacturera, Maquiladora y de Servicios de Exportación (IMMEX) (GAMBRILL, 2008, pp. 316-317). Aunque hay algunos cambios en los programas, la principal vía para atraer IED a México no se ha cambiado desde el Programa de la Maquiladora. El gobierno de México ha promovido siempre estas tres cosas: las importaciones de aparatos o ingredientes de productos, la fabricación de los productos finales en México y la exportación de los productos a países terceros (principalmente, a Estados Unidos). Generalmente, los programas mexicanos para atraer IED han facilitado estas tres etapas a las empresas extranjeras.

Sin embargo, en la primera etapa del programa de la Maquiladora, el gobierno mexicano no daba importancia a la exportación, porque el principal objetivo del gobierno en dicho programa era reducir el desempleo en la frontera norte (GÓMEZ VEGA, 2004). Como se ha analizado en el capítulo anterior, en los años sesenta el programa de industrialización de México se basaba en la política de sustitución de importaciones, en la que se daba una limitada relevancia a la fabricación de productos para ser exportados a otros países. Además, a causa de la finalización del Programa Bracero, ${ }^{1}$ hubo trabajadores mexicanos que se quedaron sin empleo en la frontera norte de México. Debido a ello, el primer objetivo del programa de la Maquiladora fue resolver el problema del desempleo. En este contexto, hasta los años ochenta, este programa no tuvo

\footnotetext{
${ }^{1}$ El Programa Bracero era un programa de trabajadores temporales basado en un acuerdo bilateral que enfocaba la migración temporal como tipo ideal y que mejoró las condiciones laborales y salariales de los mexicanos en EE.UU. Según DURAND. (2007). "El programa bracero (1942-1964). Un balance crítico". Migración y desarrollo, 9(9), pp.27-43.
} 
influencias destacadas en la economía mexicana. Hay varias razones que explican esta situación.

La primera razón de la baja importancia del programa de la Maquiladora en la economía mexicana era que hasta 1983 el gobierno de México había mantenido a este programa separado del resto de la industria manufacturera, porque el gobierno quería evitar que las importaciones temporales pudieran filtrarse de la industria maquiladora a la manufacturera (CARRILLO, HUALDE ALFARO y RAMIREZ, 2005). Esta estrategia estaba muy vinculada con la política imperante de sustitución de importaciones. En ese momento, la prioridad del gobierno en la política industrial era la fabricación de productos para satisfacer la demanda interna. Las exportaciones no tenían una alta prioridad en esta estrategia (MANDIOLA, 1999).

La segunda razón era la localización de las empresas extranjeras en México. En esa década, las empresas extranjeras, incluyendo las japonesas, no establecieron sus filiales en la zona de maquiladora, porque el programa de Maquiladora no permitía a las empresas extranjeras exportar a otros países debido a la política de la industrialización sustitutiva de importaciones (BUITELAAR, URRUTIA y PADILLA, 1990). La prioridad de la localización de la IED era vender sus productos, por eso, las empresas extranjeras querían instalar sus filiales en la zona del país con mayor consumo, que en el caso de México, era cerca de su capital (CARRILLO y GOMIS, 2014, p. 400). La diferente localización de las filiales era otro motivo de la baja influencia de dicho programa en la economía mexicana.

La tercera razón era la situación de la economía mundial y la nacionalidad de las empresas extranjeras en el programa de la Maquiladora. En ese tiempo, la mayor parte de las empresas que invirtieron en México eran estadounidenses. Sin embargo, tras la crisis del petróleo en los años 1970 y la pérdida de competitividad, las empresas estadounidenses redujeron sus inversiones en México y vendieron sus fábricas y filiales a otras empresas extranjeras, especialmente, japonesas y europeas. (GAMBRILL, 2008, p. 320)

En este contexto, el programa de la Maquiladora no funcionó bien antes de 1983. Por ello, el gobierno de México cambió su orientación y convirtió la zona maquiladora en un lugar para fabricar los productos finales y exportarlos (GÓMEZ VEGA, 2004, pp. 60-61). El motivo de este cambio de estrategia era la adhesión al Consenso de Washington, 
tras la crisis de la deuda externa. El gobierno tenía que aumentar sus exportaciones. Sin embargo, el fracaso de la política de industrialización sustitutiva de importaciones llevó a que las empresas mexicanas no tuvieran capacidad para exportar. Para revertir esta situación y aumentar las exportaciones, el gobierno mexicano necesitaba depender de las empresas extranjeras instaladas en el país (MANDIOLA, 1999, pp. 8-12).

Desde los años ochenta, la zona de maquiladora empezó a cambiar su forma. La Ley para Promover la Inversión Mexicana y Regular la Inversión Extranjera fue modificada y ampliada en esa década. En 1984, la Comisión Nacional de Inversión Extranjera estipuló que: a) no se necesitaba autorización para la inversión extranjera menor al 49\% del capital de las respectivas empresas, con excepción de las actividades señaladas por la Ley; b) se permitirían y se fomentarían las inversiones extranjeras, incluso con una participación superior al 50\% del capital de las empresas en actividades importantes para el desarrollo tecnológico, exportador, de generación empleo y/o de sustitución (DUSSEL PETERS, 2000, pp. 13-22). Con este cambio legislativo, el gobierno de México intentó aumentar las inversiones extranjeras lo más rápido posible. Además, como se verá después, este cambio en el porcentaje de las participaciones de los capitales extranjeros tendría influencia en el Programa de la Maquiladora.

Después de establecer la Industria de Maquiladora para la exportación dentro de la zona geográfica de la frontera norte -donde había zonas de libre comercio en Tamaulipas, Baja California, Baja California Sur y Parcial de Sonora-, el Programa Maquiladora se basó en una figura aduanera denominada "importaciones temporales," la cual condicionada la libre importación de maquinaria, equipos, materias primas, componentes, envases y combustibles a su posterior re-exportación (GAMBRILL, 2008, p. 318). Esto significa que este tipo de sistemas aduaneros eran una excepción al sistema de tributación nacional de México. Por eso, como hemos visto antes, hasta antes de la crisis de 1983, el gobierno había mantenido a la Maquiladora separada del resto de la industria manufacturera. Sin embargo, después de 1983, el gobierno cambió la estrategia de la Maquiladora, para aprovechar estas zonas como un lugar de atracción de la IED y establecer en ellas una plataforma de re-exportaciones a Estados Unidos.

En general, este cambio del programa de la Maquiladora ha funcionado bien. Como se ha analizado en el capítulo anterior, las exportaciones desde México a Estados Unidos y la IED aumentaron. Por ejemplo, en los años de 1990, México fue el primer exportador de televisores a Estados Unidos. Además, las ganancias procedentes de las exportaciones 
desde la zona de Maquiladora tuvieron una alta participación en las ganancias totales originadas por las exportaciones globales de México.

Aunque el programa de la Maquiladora tuvo efectos positivos en la economía mexicana, esta situación empezó a cambiar a partir de los años noventa, debido a la mayor competencia -especialmente, china- en el mercado estadounidense (CARRILLO y GOMIS, 2005). Desde la segunda mitad de la década de 1990, las empresas chinas aumentaron sus exportaciones a Estados Unidos. Sus productos exportados a este país eran casi los mismos productos que México exportaba. Es decir, en el mercado de Estados Unidos, México tenía ahora a un rival directo. Por otro lado, en la misma década, la recesión en la economía japonesa no permitió aumentar la IED japonesa en otros países (KOYAMA, 2013). Esto obligó a que las empresas japonesas tuvieran que reconsiderar sus planes y reducir su IED en México. Estas nuevas situaciones de los años 1990 obligaron a modificar las condiciones del Programa de la Maquiladora.

Además, como otro motivo, hay un decrecimiento de la zona de la maquiladora en la década de 2000. CARRILLO (2003, pp. 18-20) indica que la falta de apoyos crediticios, las carencias en la capacidad de avance de la tecnología y los problemas de educación y formación fueron los motivos de este descenso de la actividad en la maquiladora.

Como hemos visto, a través de sus políticas industriales para la atracción de IED, el gobierno de México desarrolló una estrategia para convertir al país en una plataforma de exportaciones a Estados Unidos. En 1990, el gobierno estableció el Programa de Importación Temporal para Producir Artículos de Exportación (PITEX) (CONTRERAS y MUNGUÍA, 2007). El PITEX permitía a los productores de mercancías destinadas a la exportación, importar temporalmente diversos bienes para ser utilizados en la elaboración de productos de exportación, sin cubrir el pago del impuesto general de importación, del impuesto al valor agregado y de las cuotas compensatorias, si fueran aplicables. ${ }^{2}$ En gran medida, el Programa de Operación de Maquila es bastante similar al PITEX, ya que es "un instrumento mediante el cual se permite importar temporalmente los bienes necesarios para ser utilizados en la transformación, elaboración o reparación de mercancías destinadas a la exportación, sin cubrir el pago del Impuesto General de

\footnotetext{
${ }^{2}$ Servicio de Administración Tributaria, Secretaría de Hacienda y Crédito Público, Gobierno de México, disponible en http://www.aduanas.gob.mx/aduana_mexico/A_Preguntas_Frecuentes_Otros.htm, fecha de consulta: 13/03/2015.
} 
Importación, del Impuesto al Valor Agregado y de las cuotas compensatorias, en su caso. Asimismo, para realizar aquellas actividades de servicios a mercancías destinadas a la exportación." 3

Sin embargo, una diferencia entre el PITEX y el Programa de Operación de Maquila es la localización de las empresas a las que se permiten importaciones temporales sin pagar derechos aduaneros. En el Programa de Operación de Maquila, sólo a las empresas que están localizadas en la zona de Maquiladora se les permite la importación temporal. En cambio, en el PITEX, todas las empresas que estén instaladas en México pueden beneficiarse del Programa. En el PITEX se estipula que "para los efectos de este Decreto, se entenderá por: exportador, a la persona moral residente en territorio nacional, productora de bienes no petroleros y que los destine al exterior mediante pedimento de exportación."4

Desde el punto de la vista de las empresas extranjeras, esta diferencia significa que, para recibir el beneficio de la eliminación de los derechos aduaneros para las "importaciones temporales," no es necesario localizar las filiales en la frontera norte. Ahora cuando instalen sus filiales en cualquier lugar dentro del territorio de México, se podrán acoger a este beneficio. A pesar de esto, el problema de los costes de transportes a Estados Unidos es muy importante para la mayor parte de las empresas extranjeras que exportan sus productos. Por eso, seguir ubicando sus filiales y fábricas en la zona de frontera norte de México es algo natural para poder reducir dichos costes.

Como se ha analizado hasta ahora, se puede entender que el gobierno de México ha intentado que el país sea un lugar para la re-exportación a otros países. Para alcanzar este objetivo, primero se estableció la zona de Maquiladora en el norte del país para otorgar la exención del pago de los derechos aduaneros sobre las importaciones temporales y así, promover la IED. Luego, dicha política se extendió a todos los territorios de México. Estos movimientos son de los años 1980 y 1990. Es decir, durante estas dos décadas, el Programa de la Maquiladora y el PITEX fueron las políticas más importantes para atraer

\footnotetext{
${ }^{3}$ Servicio Administración Tributaria, Secretaría de Hacienda y Crédito Público, Gobierno de México, disponible en http://www.aduanas.gob.mx/aduana_mexico/A_Preguntas_Frecuentes_Otros.htm, fecha de consulta: 13/03/2015.

${ }^{4}$ Decreto que establece el Programa de Importación Temporal para Producir Artículos de Exportación (Publicado en el Diario Oficial de la Federación el 3 de mayo de 1990); disponible en www.economia.gob.mx/files/transparencia/D26.pdf, fecha de consulta: 13/03/2015.
} 
IED en México. Además, ambos programas eran muy importantes para la economía mexicana. Así, por ejemplo, ambos programas aportaron más del $60 \%$ del total de los trabajadores en la industria manufacturera mexicana (DE LA CRUZ, KOOPMAN y WEI, 2011). Asimismo, como muestra el Gráfico IV-1, en el período 1993-2001 aumentaron las exportaciones totales de México y especialmente, las que tuvieron lugar bajo la modalidad de "temporales y maquila". También, el empleo en esta última modalidad aumentó a lo largo del período indicado.

Gráfico IV-1. 1. México: Estructura de las exportaciones según programas, 1993-2001 (En millones de dólares)

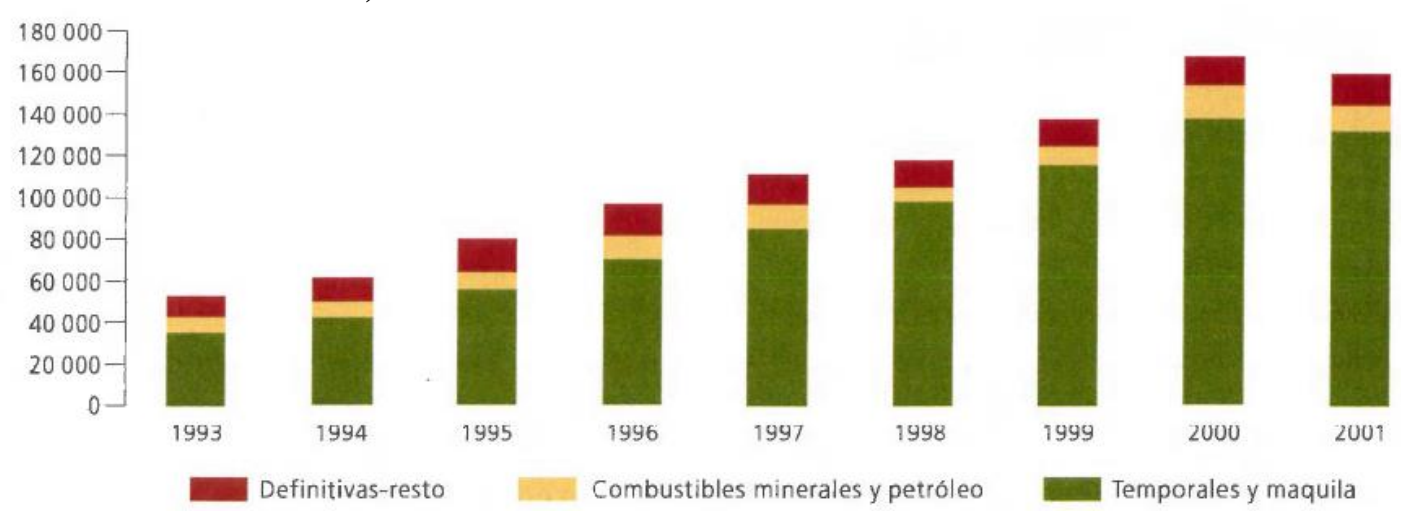

Fuente. Tomado desde DUSSEL PETERS. (2003). "Ser Maquila o No Ser Maquila, ¿Es Ésa la Pregunta?", Comercio Exterior, 53(4), p. 334, disponible en http://revistas.bancomext.gob.mx/rce/magazines/19/4/RCE.pdf, fecha de consulta: 17/7/2015

En 1994 el Tratado de Libre Comercio de América del Norte (TLCAN) entró en vigor. Como consecuencia de ello, el Tratado se convirtió en un importante estímulo para aumentar las exportaciones en la forma de "Temporales y Maquila." Como hemos visto en el capítulo anterior, las empresas japonesas -así como la de otros países-invirtieron e instalaron sus fábricas en México. Desde el punto de la vista del fomento de las exportaciones desde México, el Programa de la Maquiladora y el PITEX hicieron una importante contribución a la economía mexicana. Sin embargo, tras este éxito, México tendría que enfrentar nuevos problemas.

En el comienzo del nuevo siglo, la coyuntura internacional cambió, afectando a la economía mexicana. El avance de la economía china en ese momento fue mucho más importante que en los años noventa. Más problemático para la economía mexicana fue la recesión de la economía estadounidense al principio del nuevo milenio tras el pinchazo de la burbuja tecnológica en 2001. Como hemos visto en el capítulo anterior, la recesión de Estados Unidos indujo directamente la reducción de las exportaciones mexicanas. Esta 
reducción conllevó a su vez la disminución de las inversiones extranjeras. Estos cambios obligaron al gobierno de México a adoptar nuevas medidas para captar más IED. Así, en noviembre de 2006, el gobierno estableció un nuevo plan: el Programa de Fomento de la Industria Manufacturera, Maquiladora y de Servicios de Exportación (IMMEX) (MARTÍNEZ, 2016).

Antes del IMMEX, como un instrumento de sustitución del Programa de Maquiladora, el gobierno mexicano lanzó el Programa de Promoción Sectorial (PROSEC). Su beneficio era que las empresas podrían importar con el arancel ad-valorem preferencial especificado en el artículo 5 del mencionado decreto, diversos bienes para ser incorporados y utilizados en el proceso productivo de las mercancías señaladas ${ }^{5}$. Es decir, las empresas en el PROSEC podían recibir el beneficio de un bajo arancel cuando importaban. Sin embargo, los productos en los que se podía acceder a bajos aranceles eran muy limitados. Este factor fue un desincentivo para las empresas extranjeras, incluyendo las japonesas (NISIJIMA, 2003). Por eso, el PROSEC no fue tan favorable para la actividad de las empresas extranjeras en México.

El IMMEX, por su parte, es un instrumento integrado en el Programa para el Fomento y Operación de la Industria Maquiladora de Exportación (Maquila) y el PITEX, programas que conjuntamente cubrían el $85 \%$ de las exportaciones manufactureras de México. ${ }^{6}$ Esto significa que el objetivo del IMMEX es aumentar las exportaciones mexicanas por medio de la eliminación de los aranceles a las importaciones temporales de los productos que van a elaborar, transformar o reparar para exportar. En el IMMEX, las "importaciones temporales" se clasifican en tres tipos:"

a) Materias primas, partes y componentes que se vayan a destinar totalmente a integrar mercancías de exportación; combustibles, lubricantes y otros materiales que se vayan a consumir durante el proceso productivo de la mercancía de exportación; envases y empaques; etiquetas y folletos.

b) Contenedores y cajas de tráileres.

\footnotetext{
${ }^{5}$ Véase PROSEC. http://www.2006-2012.economia.gob.mx/comunidad-negocios/industria-ycomercio/instrumentos-de-comercio-exterior/prosec, fecha de consulta: 21/2/2017.

${ }^{6}$ Secretaría de Economía, Gobierno de México, disponible en http://www.economia.gob.mx/comunidadnegocios/industria-y-comercio/instrumentos-de-comercio-exterior/immex, fecha de consulta: 3/1/2015.

${ }^{7}$ Secretaría de Economía, Gobierno de México disponible en http://www.economia.gob.mx/comunidadnegocios/industria-y-comercio/instrumentos-de-comercio-exterior/immex, fecha de consulta: 3/1/2014
} 
c) Maquinaria, equipo, herramientas, instrumentos, moldes y refacciones destinadas al proceso productivo; equipos y aparatos para el control de la contaminación; para la investigación o capacitación, de seguridad industrial, de telecomunicación y cómputo, de laboratorio, de medición, de prueba de productos y control de calidad; así como aquéllos que intervengan en el manejo de materiales relacionados directamente con los bienes de exportación y otros vinculados con el proceso productivo; equipo para el desarrollo administrativo.

Además, las modalidades del IMMEX están clasificadas en cinco tipos como los siguientes: ${ }^{7}$

a) Programa IMMEX Controladora de Empresas, cuando en un mismo programa se integren las operaciones de manufactura de una empresa certificada denominada controladora y una o más sociedades controladas;

b) Programa IMMEX Industrial, cuando se realice un proceso industrial de elaboración o transformación de mercancías destinadas a la exportación;

c) Programa IMMEX Servicios, cuando se realicen servicios a mercancías de exportación o se presten servicios de exportación, únicamente para el desarrollo de las actividades que la Secretaría determine, previa opinión de la Secretaría de Hacienda y Crédito Público;

d) Programa IMMEX Albergue, cuando una o varias empresas extranjeras le faciliten la tecnología y el material productivo, sin que estas últimas operen directamente el Programa, y

e) Programa IMMEX Tercerización, cuando una empresa certificada que no cuente con instalaciones para realizar procesos productivos, realice las operaciones de manufactura a través de terceros que registre en su Programa.

Estas cinco categorías de modalidades del IMMEX son más amplias que el Programa de Operación de Maquila y el PITEX. En otras palabras, el IMMEX es más comprehensivo que los otros dos Programas. Comparado con ellos, el IMMEX tiene las siguientes características ${ }^{8}$.

\footnotetext{
${ }^{7}$ Secretaría de Economía, Gobierno de México, disponible en http://www.economia.gob.mx/comunidadnegocios/industria-y-comercio/instrumentos-de-comercio-exterior/immex, fecha de consulta 15/03/2016.

${ }^{8}$ Secretaría de Economía, Gobierno de México, disponible en http://www.gob.mx/cms/uploads/attachment/file/6227/IMMEX.pdf, fecha de consulta:15/03/2016.
} 
a) Simplificación de los requisitos de la solicitud de autorización y ampliación.

b) Adicionar el esquema de "tercerización" como modalidad.

c) Reducir el compromiso administrativo de exportación.

d) Simplificación del reporte anual de operaciones.

e) Modernización informática de la relación Empresa - Gobierno Federal.

f) Medidas de protección al esquema y certidumbre jurídica.

g) Por su gravedad se adiciona la causa de cancelación de programa.

h) Control de inventarios mínimo.

i) Medidas de facilitación para empresas que operen con mercancías sensibles.

j) Simplificación de trámites cuando se tengan varios programas.

k) Se sujetan a la misma operación aduanera.

1) Tienen las mismas obligaciones en materia de impuestos al comercio exterior regulados por los Tratados de Libre Comercio firmados por México.

m) Se reduce el número de trámites de 29 a 16 para simplificar operaciones.

Además, otra característica del IMMEX es que las empresas que aprovechan este programa tienen unas limitaciones de venta en el territorio de México (HERNÁNDEZ, 2014). Es decir, las empresas en este programa no pueden hacer mucha venta de sus productos en México. Si quieren vender sus productos en México, tienen que establecer otra forma de empresa en México. Desde esta perspectiva, se aprecia que el IMMEX es un programa para fortalecer las exportaciones desde México. O sea, es un programa para asegurar la promoción de actividades para elaborar y transformar las importaciones temporales con objeto de generar productos destinados a la exportación.

\section{IV-1. 2. Participaciones de los capitales extranjeros desde el $49 \%$ hasta el $100 \%$ : cambio de la Ley de Inversión Extranjera}

Como se ha analizado en el marco teórico de la IED, las empresas que quieren hacer IED en otros países tienen que mantener su propiedad, especialmente, los conocimientos y las capacidades para fabricar y generar valores añadidos en los productos. Para mantener esta capacidad, las empresas quieren mantener su internalización, Por eso, prefieren hacer IED, más que licencias y joint-venture (RUGMAN, 1985, pp. 570-575) 
Los porcentajes de las participaciones de las capitales extranjeras en los países de destino son un punto muy importante, al decidir los destinos de la IED. Especialmente, en las industrias manufactureras japonesas, sus experiencias y conocimientos se acumulan dentro de su cadena de producción (SASANAMI, 1997). Llevar estas cosas a otras empresas es muy costoso para las empresas japonesas. Además, las relaciones japonesas entre las empresas patronales y sus subcontrataciones son muy fuertes (YONEKURA, 1997). En este contexto, al decidir los destinos de la IED, las empresas japonesas prefieren invertir en los países que permiten el 100\% de las participaciones de los capitales extranjeros.

En el caso de México, durante mucho tiempo, no se habían permitido el 100\% de participaciones de los capitales extranjeros. En la Ley de Inversión Extranjera de 1993 se empezó a permitir el 100\% de participación de los capitales extranjeros en México. En dicha Ley se establece en su artículo 4 que "la inversión extranjera podrá participar en cualquier proporción en el capital social de sociedades mexicanas, adquirir activos fijos, ingresar nuevos campos de actividad económica o fabricar nuevas líneas de productos, abrir o establecer nuevos establecimientos, ampliar y relocalizar los ya existentes, salvo por lo dispuesto en esta ley",.

Sin embargo, a pesar del cambio que supuso la Ley de 1993, no se permitió el $100 \%$ de participaciones de los capitales extranjeros en todas las industrias. Hay industrias donde no se permiten ningún capital extranjero, son las denominadas “industrias reservadas.” Además, había varias industrias que tenían limitación máxima a las entradas de los capitales extranjeros. Sin embargo, aunque hay algunas diferencias, dependiendo de las industrias, de 1995 hasta 2004, se ha permitido la entrada gradual del 100\% de los capitales extranjeros en algunas industrias, por ejemplo, en (CUENCA, 2003):

a) transporte terrestre internacional de pasajeros, turismo y de carga entre puntos del territorio de México y el servicio de administración de centrales camioneras de pasajeros y servicios auxiliares, actualmente reservadas a mexicanos, la IED podrá participar a partir del 18 de diciembre de 1995 al 49\%; a partir del 1 de

\footnotetext{
${ }^{9}$ Ley de Inversión Extranjera de 1993, disponible en http://www.diputados.gob.mx/LeyesBiblio/ref/lie/LIE_orig_27dic93_ima.pdf, fecha de consulta 16/03/2015.
} 
enero de 2001 hasta con el 51\%, y del 10 de enero de 2004 al 100\% sin aprobación de la Comisión Nacional de Inversiones Extranjeras (CNIE)

b) fabricación y ensamble de partes, equipo y accesorios para la industria automotriz, con un nivel de participación del 49\%, modificado hasta el 100\% a partir del 1 de enero de 1999 sin aprobación de la CNIE

c) prestación de servicios de videotexto y conmutación en paquete, del nivel del $49 \%$ al 100\% partir del 1 de Julio de 1995

d) edificación, construcción e instalación de obras, con participación del 49\%, y aprobación de la CNIE para una participación mayor, liberada al 100\% a partir del 1 de enero de 1999 sin aprobación. La industria de fabricación y ensamble de partes, equipo y accesorios para la industria automotriz modificado hasta el 100\% a partir del 1 de enero de 1999 sin aprobación de la CNIE.

Basado en estas situaciones, se observa que a los capitales extranjeros se les permitió gradualmente entrar en el mercado de México desde la década de 1990. Desde el punto de vista de las empresas japonesas, en la década de 1990 las IED japonesas aumentaron rápidamente, especialmente después de la entrada en vigor del TLCAN. En esta situación, se puede decir que las empresas japonesas en México pudieron recibir los beneficios del IMMEX.

Ahora, se analizan las condiciones de las participaciones de los capitales extranjeros en México antes de 1993. Históricamente, en la Constitución de México, había algunos artículos que restringían el acceso de los capitales extranjeros. Por ejemplo, en la Constitución de 1917, se indicaba que sólo las personas físicas y morales mexicanas eran las únicas con derecho de adquirir dominio sobre las tierras y aguas y sus accesiones u obtener concesiones de explotación de minas y aguas. En el Diario Oficial de la Federación de 21 de enero y 29 de marzo de 1926, hay restricciones de las zonas en que se prohibía a los extranjeros el dominio de tierras y aguas en una franja de 100 kilómetros a lo largo de las fronteras y de 50 kilómetros en las playas (HERRERA IZAGUIRRE, VÁZQUEZ RANGEL y ESCOBEDO CARREÓN, 2014).

En 1973, se estableció la primera Ley para Promover la Inversión Mexicana y Regular la Inversión Extranjera. En esta Ley, el gobierno de México estableció la Comisión Nacional de Inversiones Extranjeras (CNIE) y todos los capitales extranjeros 
que entraban a México, necesitaban permiso de la CNIE. Además, en esta primera Ley, se establecieron estas industrias reservadas mexicanas (MORENO-BRID, 1999):

a) De participación exclusiva del Estado: extracción de petróleo y gas natural, petroquímico básico, extracción y explotación de minerales radioactivos, ciertas actividades mineras, generación de electricidad, transporte por ferrocarril, telégrafo y radiocomunicación;

b) De participación exclusiva de nacionales: radio y televisión, transportación automotora urbana, interurbana y por carreteras federales, el transporte aéreo, terrestre o marítimo, explotación de recursos forestales, distribución de gas;

c) De participación limitada al capital extranjero: Con un tope máximo de 34\%: explotación de minerales como carbón, hierro, roca fosfórica y azufre. Hasta 40\%, en las empresas dedicadas a la producción de petroquímicos secundarios y en la industria de autopartes, y en la minería sujeta a un régimen de concesiones a otorgar por parte del Estado;

d) En el resto de actividades se fijó un tope máximo de $49 \%$ a la participación extranjera en el capital de las empresas.

Se puede notar que las empresas extranjeras no pudieron obtener la mayor parte de las participaciones de los capitales en sus filiales en México. En ese tiempo, bajo la política de la industrialización sustitutiva de importaciones, el gobierno mexicano quería aumentar la productividad de las empresas mexicanas y por eso, no admitieron la presencia mayoritaria de los capitales extranjeros.

Sin embargo, tuvieron que cambiar esta estrategia después de la crisis de la deuda externa. El gobierno de México decidió aumentar las posibilidades de las actividades de los capitales extranjeros en México. Así, en 1989, hubo modificaciones a la Ley para Promover la Inversión Mexicana y Regular la Inversión Extranjera y se creó la Ley de la Inversión Extranjera. El objetivo principal de esta nueva Ley era la regulación de las inversiones directas y en cartera (HERRERA IZAGUIRRE, VÁZQUEZ RANGEL y ESCOBEDO CARREÓN, 2014, p. 690). Además, los requisitos para las empresas extranjeras que querían establecer sus filiales en México eran los siguientes (CUENCA, 2003, p. 247): 
a) Ubicarse físicamente fuera de las zonas de mayor concentración industrial (concretamente, fuera de la Ciudad de México, Guadalajara y Monterrey) (DUSSEL PETERS, 2000, p. 17).

b) Mantener un saldo equilibrado de divisas.

c) Generar empleos permanentes.

d) Realizar programas de capacitación y desarrollo personal de los trabajadores.

e) Coadyuvar al logro de los objetivos con apego a la política de desarrollo nacional.

f) Considerarse como nacionales, respecto de la adquisición de dichos bienes y no invocar la protección de su gobierno por lo que se refiere a aquellos, bajo la pena, en caso contrario, de perder en beneficio de la Nación, los bienes que hubieren adquirido.

Según estas características, hubo una limitación geográfica de ubicación de establecimiento de las empresas extranjeras. En ese año, aunque ya estaba vigente el programa de la maquiladora, el gobierno de México intentó con la nueva Ley incidir en la ubicación de las empresas extranjeras. Como se ha comentado en la primera parte de esta sección, esta Ley se modificó en 1993. Entre las modificaciones en la Ley de Inversiones extranjeras, las más importantes tuvieron que ver con las localizaciones de las filiales extranjeras y las industrias reservadas (esto es, las que no estaban abiertas a las empresas extranjeras).

\section{IV-1. 3. Políticas para las PYMES mexicanas}

En las políticas industriales, las políticas sobre PYMES son muy importantes porque en la mayor parte de los países, hay más PYMES que empresas grandes y hay más trabajadores en las PYMES que en las empresas grandes. Por eso, aumentar las capacidades de las PYMES induce aumentar los beneficios sociales y los empleos en un país.

Uno de los principales problemas de las PYMES en México es su capacidad de innovación tecnológica (ESTRADA BÁRCENAS, GARCIA PÉREZ DE LEMA y SANCHEZ TREJO, 2009). Desde el punto de vista de la IED, este problema es serio, porque la principal industria en la que invierten las empresas extranjeras en México es la manufacturera. En México, el 11,7\% de las unidades económicas son PYMES en la 
industria manufacturera (PAVÓN, 2010). Las PYMES mexicanas necesitan tecnologías para ser capaces de incorporar sus cadenas de producción a sus cadenas de valor. Es decir, las empresas extranjeras esperan que las PYMES mexicanas actúen como sus empresas subcontratadas (ALONSO, CARILLO y CONTRERAS, 2000, pp. 31-34). Sin embargo, las PYMES en México pierden esta oportunidad por falta de capacidad de innovación.

El segundo problema para las PYMES mexicanas es la falta de información y las asimetrías de información para entrar en las cadenas de producción (PAVÓN, 2010, pp.24-25). Es decir, como las empresas extranjeras no tienen suficiente información sobre las PYMES mexicanas, éstas no pueden entrar en sus cadenas de producción.

El tercer problema es que solo el $21 \%$ de las PYMES en la industria manufacturera se vinculan a actividades exportadoras (DUSSEL PETERS, 2004). Como hemos visto en los capítulos anteriores, en la economía mexicana, el papel de la exportación es muy importante. Sin embargo, las PYMES mexicanas no han aprovechado bien esta oportunidad.

Por eso, se puede decir que los principales problemas que las políticas para las PYMES en México tienen que resolver son el desarrollo de las tecnologías y la promoción de la información sobre y para las PYMES mexicanas. Por esta razón, a continuación, se analiza la promoción de informaciones para PYMES mexicanas. Como se mostrará, en México hay dos tipos de sistemas para encontrar las ofertas de PYMES mexicanas y las demandas de empresas extranjeras: el Sistema para la Subcontratación Industrial y el Programa de Empresas Integradoras

\section{IV-1. 3. 1. Sistema para la Subcontratación Industrial (SSI).}

En 1995, se creó el Consejo Nacional de las Micro, Pequeñas y Medianas Empresas con el objetivo de establecer políticas e instrumentos para promover el incremento de su eficiencia y la calidad, y fortalecer las cadenas productivas para vincular a las pequeñas empresas con la de mayor tamaño (GARCÍA y PAREDES, 2001). Además, en 1997, con el propósito de enlazar la oferta y la demanda de procesos de las empresas del país, se estableció el Sistema para la Subcontratación Industrial (SSI). Éste es un medio para facilitar las vinculaciones con las empresas grandes que tienen demanda de 
los productos y piezas y del ajuste de sus procesos industriales con las potenciales ofertas (GARCÍA y PAREDES, 2001, p. 17).

Actualmente, el SSI es un sistema de matching en internet de "oferentes y demandantes de productos y procesos industriales y conforma una red de información, verificada y actualizada por consultores especializados, para divulgar y consultar las capacidades productivas de los oferentes de procesos productivos, detallando además la maquinaria y equipo con que cuentan las empresas manufacturera oferentes. ${ }^{10}$ " El número de las empresas subcontratadas mexicanas que están inscritas en el SSI es de 1.900 empresas. $^{11}$

Ahora se analizan las informaciones sobre las PYMES mexicanas para subcontratar. Sus localizaciones en los estados en México se presentan en la Tabla IV-1.1. En 2015 hay empresas registradas en el SSI en 29 estados. Se observa que, dependiendo del estado, hay diferencias en el número de empresas registradas. En Nuevo León es donde hay más empresas registradas (49,7\%). Luego le siguen Hidalgo, D.F., Estado de México y Querétaro. Como hemos visto en el capítulo anterior, estos estados, con la excepción de Nuevo León, coinciden con aquellos estados en los que ha aumentado la IED en la última década. Además, otro aspecto interesante es que los estados de la frontera norte de México en los que hay zona de maquiladora (Baja California, Sinaloa y Sonora) no hay tantas empresas que usan el sistema de SSI. Solo 73 empresas en estos tres estados del noroeste están registradas en el SSI, representando solo el 3,8\% de total de todas empresas registradas.

\footnotetext{
${ }^{10}$ Página Web de la operación del Sistema para Subcontratación Industrial (SSI), disponible en http://www.contactopyme.gob.mx/ssi/Infogral/Definicion.asp?Lenguaje=0 , cita de consulta: 31/3/2015. ${ }_{11}$ Página Web de la operación del Sistema para Subcontratación Industrial (SSI), disponible en http://www.contactopyme.gob.mx/ssi/Infogral/Definicion.asp?Lenguaje=0 , cita de consulta: 31/3/2015.
} 
Tabla IV-1. 1. Localizaciones: empresas mexicanas registradas para subcontratar en el SSI, 2015.

\begin{tabular}{|l|r|l|r|}
\hline AGUASCALIENTES & 17 & OAXACA & 4 \\
\hline BAJA CALIFORNIA & 1 & PUEBLA & 15 \\
\hline CHIAPAS & 3 & QUERETARO & 117 \\
\hline CHIHUAHUA & 19 & QUINTANA ROO & 2 \\
\hline COAHUILA & 14 & SAN LUIS POTOSÍ & 16 \\
\hline COLIMA & 5 & SINALOA & 51 \\
\hline DISTRITO FEDERAL & 190 & SONORA & 21 \\
\hline DURANGO & 44 & TABASCO & 15 \\
\hline ESTADO DE MÉXICO & 111 & TAMAULIPAS & 25 \\
\hline GUANAJUATO & 3 & TLAXCALA & 5 \\
\hline GUERRERO & 1 & VERACRUZ & 33 \\
\hline HIDALGO & 169 & YUCATAN & 2 \\
\hline JALISCO & 52 & ZACATECAS & 1 \\
\hline MICHOACÁN & 15 & Total & $\mathbf{1 9 0 0}$ \\
\hline MORELOS & 4 & & \\
\hline NUEVO LEÓN & 945 & & \\
\hline
\end{tabular}

Fuente. Elaboración propia a partir de la Secretaría de Economía, Subsecretaría para la Pequeña y Mediana Empresa, Dirección General de Desarrollo Empresarial y Oportunidades de Negocio y Dirección de Desarrollo de Proveedores y Oportunidades de Negocio, disponible en http://www.contactopyme.gob.mx/ssi/Infogral/Reporte2.asp?Lenguaje=0, fecha de consulta: $31 / 03 / 2015$.

Por otra parte, la Tabla IV-1. 2 recoge las actividades de las empresas registradas en el SSI. Se observa que hay varias industrias, pero la mayor parte de ellas pertenecen a la industria manufacturera, concretamente a la fabricación de metalmecánica y plásticos.

Tabla IV-1. 2. Actividades de las empresas registradas en el SSI, 2015.

\begin{tabular}{|l|r|}
\hline ALIMENTOS & 79 \\
\hline ARTES GRÁFICAS & 8 \\
\hline CALZADO & 19 \\
\hline CONFECCIÓN & 122 \\
\hline CONSTRUCCIÓN & 78 \\
\hline ELÉCTRICO & 56 \\
\hline ELECTRÓNICO & 45 \\
\hline FARMOQUÍMICOS & 7 \\
\hline METALMECÁNICO & 1023 \\
\hline MUEBLES DE MADERA & 119 \\
\hline PLÁSTICO & 307 \\
\hline QUÍMICO & 165 \\
\hline TEXTIL & 45 \\
\hline TOTAL DE ACTIVIDADES ECONÓMICAS & $\mathbf{2 0 7 3}$ \\
\hline
\end{tabular}

Fuente. Elaboración propia a partir de la Secretaría de Economía, Subsecretaría para la Pequeña y Mediana Empresa, Dirección General de Desarrollo Empresarial y Oportunidades de Negocio y Dirección de Desarrollo de Proveedores y Oportunidades de Negocio, disponible en http://www.contactopyme.gob.mx/ssi/Infogral/Reporte2.asp?Lenguaje=0, fecha de consulta: 31/03/2015. 
Especialmente, la industria de plásticos en México se ha desarrollado muy rápidamente en los últimos años. De hecho, las exportaciones de plásticos mexicanos aumentaron un promedio anual del 9,67\% durante el periodo de 2003-2013 (GÓNGORA PÉREZ, 2014, p. 8; GANADO, 2008).

Según se muestra en la Tabla IV-1.3, el 50\% de las empresas mexicanas que se registran en el SSI son microempresas y el $25 \%$ son pequeñas empresas.

Tabla IV-1. 3. Tamaño de las empresas registradas en el SSI, 2015

\begin{tabular}{|l|c|}
\hline EMPRESAS (número de trabajadores) & Números de Empresas \\
\hline Micro Empresa (0-30) & 994 \\
\hline Pequeña Empresa (31-100) & 560 \\
\hline Mediana Empresa (101-500) & 306 \\
\hline Grandes Empresas (más de 500) & 39 \\
\hline TOTAL DE EMPRESAS & 1899 \\
\hline
\end{tabular}

Fuente. Elaboración propia a partir de la Secretaría de Economía, Subsecretaría para la Pequeña y Mediana Empresa, Dirección General de Desarrollo Empresarial y Oportunidades de Negocio y Dirección de Desarrollo de Proveedores y Oportunidades de Negocio, disponible en http://www.contactopyme.gob.mx/ssi/Infogral/Reporte2.asp?Lenguaje=0, fecha de consulta: 31/03/2015.

Ahora, con la tabla de IV-1.4 se analiza la información sobre las localizaciones de las empresas demandantes, que en el SSI se llaman empresas consultoras. En 27 estados, hay 172 empresas consultoras en el SSI. Los estados que tienen mayor número de consultoras son: D.F., Aguascalientes, Coahuila y Querétaro. Al comparar con el caso de las empresas registradas mexicanas, hay menos coincidencias sobre la localización entre ofertas y demandas. Sin embargo, lo más importante son las diferencias en los números entre las empresas consultoras y las empresas registradas mexicanas. Solucionar estas diferencias es una de las tareas del SSI.

A continuación, se analizan los casos de éxito en el SSI, es decir, los casos en los que las consultoras han encontrado a sus empresas subcontratadas mexicanas. La Tabla IV-1. 5 recoge estos casos de éxito. Se nota que la mayor parte de estos casos son entre el contratista mexicano y la subcontratista mexicana. Sin embargo, hay algunos casos en los que hay contratos entre las contratistas extranjeras y la subcontratista mexicana. Asimismo, se observa que las industrias en las que hay contrato son muy variadas: no son solo las industrias manufactureras metalmecánicas, sino también las industrias de 
alimentación, artesanía y plásticos. Esta variedad de las industrias se puede considerar como uno de los méritos del SSI.

Tabla IV-1. 4. Localizaciones de las empresas consultoras en el SSI, 2015

\begin{tabular}{|l|r|l|r|}
\hline AGUASCALIENTES & 15 & NAYARIT & 1 \\
\hline BAJA CALIFORNIA & 2 & NUEVO LEÓN & 8 \\
\hline BAJA CALIFORNIA SUR & 1 & PUEBLA & 7 \\
\hline CHIAPAS & 2 & QUERÉTARO & 13 \\
\hline CHIHUAHUA & 7 & QUINTANA ROO & 1 \\
\hline COAHUILA & 15 & SAN LUIS POTOSÍ & 9 \\
\hline COLIMA & 2 & SINALOA & 2 \\
\hline DISTRITO FEDERAL & 34 & SONORA & 5 \\
\hline DURANGO & 3 & TABASCO & 1 \\
\hline ESTADO DE MÉXICO & 4 & TAMAULIPAS & 2 \\
\hline GUANAJUATO & 3 & TLAXCALA & 6 \\
\hline HIDALGO & 3 & VERACRUZ & 5 \\
\hline JALISCO & 9 & YUCATÁN & 9 \\
\hline MICHOACÁN & 3 & Total de Consultoras & 172 \\
\hline
\end{tabular}

Fuente. Elaboración propia a partir de la Secretaría de Economía, Subsecretaría para la Pequeña y Mediana Empresa, Dirección General de Desarrollo Empresarial y Oportunidades de Negocio y Dirección de Desarrollo de Proveedores y Oportunidades de Negocio, disponible en http://www.contactopyme.gob.mx/ssi/Infogral/Reporte2.asp?Lenguaje=0, fecha de consulta: $31 / 03 / 2015$.

Tabla IV-1. 5. Los casos de éxito en el SSI hasta 2015.

\begin{tabular}{|c|c|c|c|}
\hline \multirow{7}{*}{$\begin{array}{l}\text { Textil y } \\
\text { Confección }\end{array}$} & CONTRATISTA & SUBCONTRATISTA & ACTIVIDADES \\
\hline & Cobertores y Tejidos & Creaciones Angélica & Conjuntos para bebé \\
\hline & Cobertores y Tejidos & Pequeños Pupi & Conjuntos para bebé \\
\hline & Centro Comercial Californiano & Pequeños Pupi & Ropa para bebé \\
\hline & El Famoso 333 & Gilberto Pluma García & Suéteres escolares \\
\hline & Cimaco & Grupo Emmanuelle & Ropa de vestir para dama \\
\hline & Terramar Mármol, S.A. & Torres Hermanos & Trapo limpio de algodón \\
\hline \multirow{2}{*}{ Artesanías } & Regalos Import & Oaxaca Import & Artesanías \\
\hline & Littana International, Inc. & Oaxaca Export & Artesanías \\
\hline Conservas & Sr. Francisco Torres A. & La Imperial, S.A. & Dulces en General \\
\hline \multirow{2}{*}{ Plástico } & Grupo Modelo, S.A. & Relojes Gary, S.A. & Promocionales \\
\hline & Pedro Lizana G. (CHILE) & Relojes Gary, S.A. & Relojes publicitarios \\
\hline
\end{tabular}

Fuente. Elaboración propia a partir de la Secretaría de Economía, Subsecretaría para la Pequeña y Mediana Empresa, Dirección General de Desarrollo Empresarial y Oportunidades de Negocio y Dirección de Desarrollo de Proveedores y Oportunidades de Negocio, disponible en $\mathrm{http} / / / \mathrm{www}$. contactopyme.gob.mx/ssi/Infogral/Reporte2.asp?Lenguaje=0, fecha de consulta: $31 / 03 / 2015$. 
Aunque hay algunos resultados positivos, no se puede decir que el SSI haya funcionado bien como un instrumento para vincular a los subcontratados mexicanos. El número de subcontratados que pudieron lograr vinculaciones con otras empresas ha sido muy pequeño. Además, según las entrevistas realizadas con las empresas japonesas en Tijuana, éstas no consideraban la necesidad de encontrar subcontratados mexicanos, por problemas, entre otros, en las calidades de sus productos ${ }^{12}$. Esta tendencia a la desconfianza hacia los subcontratados mexicanos sería un obstáculo para promover este tipo de sistema. Otro problema del SSI es la falta de participación de las empresas multinacionales. Para poder aumentar la vinculación de la cadena de producción de los subcontratados mexicanos, es muy importante lograr la participación de las empresas multinacionales.

\section{IV-1. 3. 2. Empresas Integradoras (EI).}

Generalmente, para las PYMES, aprovechar las economías de escala es muy complicado porque sus volúmenes de producción son pequeños y el número de sus consumidores es también pequeño. Por eso, una manera muy efectiva para aumentar los beneficios de las PYMES, es agrupar algunas PYMES para aprovechar los resultados de las economías de escala.

Basado en estas condiciones, en el caso de México, el programa de Empresas Integradoras (EI) se estableció en 1993 y se modificó en 1995. Este programa está basado en la historia de desarrollo de las PYMES en otros países, especialmente, en el caso de Italia (GARCIA y PAREDES, 2001, p. 3). Sus principales objetivos son proporcionar más eficiencia en el proceso de producción, sobre la base de la integración horizontal de pequeñas empresas, para obtener bienes y servicios de calidad y precios competitivos (GARCIA y PAREDES, 2001, p. 17).

La idea principal de las EI es inducir la especialización de las unidades productivas en alguna de las diferentes etapas del ciclo de fabricación; por ejemplo, investigación y desarrollo, diseño, ensamblaje, subcontratación de productos y procesos industriales y servicios especializados, que den como resultado un producto altamente diferenciado por

\footnotetext{
${ }^{12}$ Las entrevistas de la doctoranda en Tijuana tuvieron lugar en junio de 2015
} 
calidad, precio y oportunidad de entrega. ${ }^{13}$ Es decir, el principal objetivo de este programa es establecer una cadena de producción de las PYMES al integrar empresas que tienen capacidades diferentes.

Una característica de las EI es que se definen como empresas de servicios especializados que asocian personas físicas y jurídicas de escala micro, pequeña y mediana, y su objetivo fundamental es organizarse para competir en los diferentes mercados. ${ }^{14}$ Concretamente, hay tres tipos de apoyos en las EI (ALBA VEGA, 2001):

a) Fiscales: las EI se pueden acoger a los beneficios de un régimen fiscal preferencial, el Régimen Simplificado de las Personas Morales que establece el título II -A de la Ley del Impuesto sobre la Renta, por un período de cinco años.

b) Financieros: la banca de desarrollo elaboró programas especiales de apoyo para las EI. Nafin (Nacional Financiera, Banco de Desarrollo de México) está obligada, por el Decreto del 7 de mayo de 1993, a apoyar a los socios, otorgándoles créditos por medio de intermediarios financieros (banca comercial, uniones de crédito o entidades de fomento, como los fondos de los gobiernos de los estados) para que efectúen sus aportaciones al capital social de la EI. Además, debe otorgar a los intermediarios financieros garantías complementarias a las ofrecidas por las propias EI y por sus socios.

c) Administrativos: Nafin, por medio del Programa de Desarrollo Empresarial (Prodem), cuenta con diversos mecanismos para fortalecer el perfil gerencial del empresario mexicano mediante la capacitación, la asistencia técnica y el asociacionismo. Los cursos son de dos tipos: el primero es el relativo a temas gerenciales para la micro, pequeña y mediana empresa, que está organizado en 28 módulos agrupados en 6 paquetes (producción, administración, mercadotecnia, contabilidad, recursos humanos y finanzas), con una duración total de 286 horas. Estos cursos los imparte el Instituto Tecnológico Autónomo de México (ITAM), según un convenio firmado con Nafin; el segundo, de Proceso de Mejoramiento

\footnotetext{
${ }^{13}$ Secretaría de Economía, Subsecretaría para la Pequeña y Mediana Empresa Dirección General de Desarrollo Empresarial y Oportunidades de Negocio, Guía para la formación de una empresa integradora Secretaría de Economía, disponible en Internet http://www.contactopyme.gob.mx/integradoras/h_guias.html, fecha de consulta 3/4/2015.

${ }^{14}$ Secretaría de Economía, Subsecretaría para la Pequeña y Mediana Empresa, Dirección General de Desarrollo Empresarial y Oportunidades de Negocio y Dirección de Desarrollo de Proveedores y Oportunidades de Negocio, disponible en http://www.contactopyme.gob.mx/integradoras/antecedentes.asp, fecha de consulta:2/4/2015
} 
Continuo (calidad total), que busca desarrollar los conocimientos, las habilidades y las actitudes de los empresarios para implantar procesos de mejoramiento continuo de la calidad y de la productividad de sus negocios; consta de 17 módulos secuenciales, agrupados en cinco paquetes, con duración de 68 horas. Los cursos los imparte el Instituto Tecnológico y de Estudios Superiores de Monterrey (ITESM), por convenio con Nafin.

Lo más interesante de estos apoyos es que hay cursos para la administración de las empresas. Generalmente, para aumentar la competitividad de las empresas, se enfoca la formación hacia los ingenieros de alta calidad, mientras que se olvida la formación de los especialistas de administración, por ejemplo, abogados, contables y asesores. Sin embargo, al considerar el establecimiento de una cadena de producción con las empresas extranjeras, los trabajos de los especialistas en administración son muy importantes. Ellos tienen que interpretar las leyes y regulaciones de México para las empresas extranjeras. Por eso, la formación de administradores, también, es muy importante, para aumentar la competitividad de las empresas mexicanas.

Ahora, se analiza una parte de los resultados del programa de la EI. Veamos la Tabla IV-1.6 en la que se recoge el número de socios de las EI durante el periodo 19932000 por cada uno de los estados. En la lista, D.F. tiene el mayor número de empresas y el segundo número de socios. Al ver el número de empresas que están registradas en EI, los cinco primeros estados son: D.F., Sinaloa, Jalisco, Baja California y Chihuahua. En cuanto al número de socios, los cinco primeros estados son: Tamaulipas, D.F, Baja California, San Luis Potosí y Sinaloa. Además, en la tabla se recoge la relación "Número de Socios/ Número de empresas", esto es, cuántos socios tiene en sus redes una empresa de grupo. En este caso, los cinco primeros estados son: Tamaulipas, San Luis Potosí, Baja California, D.F, y Veracruz.

El objetivo principal de EI es "proporcionar más eficiencia en el proceso de producción, sobre la base de la integración horizontal de pequeñas empresas, para obtener bienes y servicios de calidad y precios competitivos." Es decir, el objetivo principal es aprovechar las economías de escala. Basado en estas condiciones, se puede decir que los estados con una ratio de "Número de socios/ Numero de empresa" alto, pueden aprovecharse mejor de este sistema. Según la Tabla IV-1.6, esos estados son los de Tamaulipas, San Luis Potosí y Baja California y, por lo tanto, son los que potencialmente 
se pueden beneficiar más de este sistema. Para hacer las redes de producción, se necesitan empresas que ya hayan tenido capacidades para fabricar algunos productos. La industrialización de la zona de la maquiladora es más alta que en otros estados y por eso, en los estados del Norte, hay una mayor concentración de socios de EI.

Tabla IV-1. 6. Empresas Integradoras y Números de Socios en los Estados, 1993-2000

\begin{tabular}{|l|c|c|c|}
\hline \multicolumn{1}{|c|}{ ESTADOS } & $\begin{array}{c}\text { Número de } \\
\text { Empresas }\end{array}$ & $\begin{array}{c}\text { Número de } \\
\text { Socios }\end{array}$ & $\begin{array}{c}\text { Número de } \\
\text { Socios/ Número } \\
\text { de empresas }\end{array}$ \\
\hline Baja California & 26 & 1414 & 55 \\
\hline Chihuahua & 20 & 435 & 22 \\
\hline D.F. & 43 & 1569 & 36 \\
\hline Jalisco & 28 & 652 & 23 \\
\hline Michoacán & 11 & 256 & 23 \\
\hline San Luis Potosí & 12 & 1025 & 85 \\
\hline Sinaloa & 31 & 843 & 27 \\
\hline Sonora & 15 & 294 & 20 \\
\hline Tamaulipas & 18 & 1994 & 110 \\
\hline Veracruz & 14 & 456 & 33 \\
\hline Otros & 105 & 4051 & 39 \\
\hline TOTAL & $\mathbf{3 2 3}$ & $\mathbf{1 2 9 8 9}$ & (promedio) 40 \\
\hline
\end{tabular}

Fuente. GARCÍA y PAREDES. (2001). Programas de apoyo a las micro, pequeñas y medianas empresas en México, 1995-2000. Serie Desarrollo Productivo 115. Santiago de Chile: CEPAL, p. 19. Disponible en http://repositorio.cepal.org/bitstream/handle/11362/4500/S0111988.pdf?sequence=1, fecha de consulta: 1/4/2015.

Además, hay una diferencia entre SSI y EI. SSI es un sistema para buscar proveedores y en él, las empresas patronales y sus proveedores están principalmente en la misma industria. Sin embargo, en el caso de EI, se puede tener "los socios" en otra industria: por ejemplo, las empresas manufactureras pueden tener un socio de la industria de la publicidad para anunciar sus productos. Teniendo en cuenta esto, los estados que han mostrado un alto número de socios de EI serían los estados con cierta variedad en sus industrias.

Hay algunos ejemplos de alianzas de empresas que han aprovechado exitosamente el programa de las EI. El primer caso éxito es el de la empresa Integradora Chamarras y Confecciones Xoxtla, S.A. de C.V., que en 1993 reunió a 52 de los 200 fabricantes de chamarras de San Miguel Xoxtla, Puebla (ALBA VEGA, 1996). Hubo dos ventajas de esta alianza empresarial: primero, fue la compra conjunta de materias primas; y segundo, fue el financiamiento: al vender al por mayor en las cadenas comerciales, éstas les pagaban hasta los $30 \mathrm{y}$, a veces, hasta los 90 días y los pequeños productores no podían 
financiar estos créditos obligados; su asociación en una EI les permitía conseguir este financiamiento (ALBA VEGA, 1996, p. 70). Después de formar la Asociación de Talleres Familiares de Xoxtla (ATAFAX), para exponer sus productos todos los domingos directamente ante el consumidor, invirtió en publicidad para anunciar sus productos. Esta actividad ayudó a aumentar sus ventas de productos. Otro caso fue el de la Promotora Ucressin, S.A. de C. V. (Unión de Crédito Agroindustrial, Pesquera y de Servicios del Sur de Sinaloa) que era una alianza más amplia. Dentro de esta empresa, se abarcaba la compra, venta, importación y exportación de productos primarios, pescados y bienes de capital para los diferentes sectores productivos asociados a la Ucressin y ofrecía los servicios de administración y contratación de seguros (ALBA VEGA, 1996, p. 68). La mayor parte de casos de éxitos en las EI eran empresas de vestidos y productos artesanos. También había casos de empresas de pescadores e industrias de diseños gráficos.

Ahora, se analiza la misma condición, pero en el período 2000-2014. Ello se puede observar en la tabla IV-1.7. Se nota que, primero, todos los estados tienen empresas registradas en este EI. Al comparar con los datos hasta el año 2000, se aprecia que aumentó tanto el número de empresas registradas como el número de socios.

Mientras los estados de Veracruz, Sinaloa y Distrito Federal son los tres primeros estados en cuanto al número de empresas registradas, los estados de San Luis Potosí, Veracruz, Sinaloa y Michoacán son los cuatro primeros respecto al número de socios. En Veracruz y Sinaloa, han aumentado ambos números, tanto el de empresas registradas como el de sus socios. Otra cosa que se puede apreciar en la Tabla IV-1.7 es el número promedio, es decir, el promedio de socios que tiene una empresa registrada en EI. El promedio del período 2000-2014 es de 20,1, mientras que la misma cifra para el período 1993-2000 fue de 40. Esta diferencia significa que, en los años 2000, el número de socios que tenía una empresa registrada en EI se ha reducido. Esta tendencia puede indicar que han existido dificultades para aprovechar las economías de escala. En la realidad, aunque el número de empresas registradas aumente, la mayor parte de ellas sólo tienen 4 o 5 socios. Bajo estas condiciones, sería difícil aprovechar la ventaja de las economías de escala. Además, dependiendo de la industria, hay dos o tres empresas integradas en la misma industria.

Actualmente, es necesario reflexionar sobre cómo puede funcionar ese sistema de EI para atraer la IED. EI es un sistema establecido dentro de la relación de las empresas mexicanas y por eso, no produce vinculaciones con las empresas extranjeras. Sin embargo, 
si este sistema pudiera ofrecer informaciones de sus socios a las empresas extranjeras, este sistema de EI funcionaría mejor.

Tabla IV-1. 7. Empresas Integradoras y Números de Socios en los Estados, 2000-2014.

\begin{tabular}{|c|c|c|c|}
\hline Estados & $\begin{array}{l}\text { Números de } \\
\text { Empresas }\end{array}$ & Números de socios & Socios/Empresas \\
\hline Aguascalientes & 26 & 220 & 8,5 \\
\hline Baja California & 32 & 234 & 7,3 \\
\hline Baja California Sur & 11 & 92 & 8,3 \\
\hline Campeche & 13 & 522 & 40,2 \\
\hline Coahuila & 26 & 337 & 13 \\
\hline Colima & 5 & 58 & 11,6 \\
\hline Chiapas & 32 & 389 & 12,2 \\
\hline Chihuahua & 21 & 165 & 7,9 \\
\hline Distrito Federal & 63 & 344 & 5,5 \\
\hline Durango & 23 & 908 & 39,5 \\
\hline Guanajuato & 43 & 414 & 9,6 \\
\hline Guerrero & 22 & 212 & 9,6 \\
\hline Hidalgo & 16 & 528 & 33 \\
\hline Jalisco & 47 & 458 & 9,7 \\
\hline Mexico & 15 & 122 & 8,1 \\
\hline Michoacán & 30 & 1074 & 35,8 \\
\hline Morelos & 9 & 168 & 18,7 \\
\hline Nayarit & 27 & 725 & 26,9 \\
\hline Nuevo León & 36 & 330 & 9,17 \\
\hline Oaxaca & 72 & 732 & 10,2 \\
\hline Puebla & 28 & 398 & 14,2 \\
\hline Querétaro & 11 & 247 & 22,5 \\
\hline Quintana Roo & 10 & 139 & 13,9 \\
\hline San Luis Potosí & 12 & 4098 & 341,5 \\
\hline Sinaloa & 103 & 1782 & 17,3 \\
\hline Sonora & 25 & 829 & 33,2 \\
\hline Tabasco & 14 & 168 & 12 \\
\hline Tamaulipas & 13 & 129 & 9,9 \\
\hline Tlaxcala & 8 & 226 & 28,3 \\
\hline Veracruz & 143 & 3190 & 22,3 \\
\hline Yucatán & 19 & 131 & 6,9 \\
\hline Zacatecas & 20 & 221 & 11 \\
\hline Total & 975 & 19590 & (Promedio)20,1 \\
\hline
\end{tabular}

Fuente. Elaboración propia a partir de

http://www.contactopyme.gob.mx/integradoras/directorio.asp , fecha de consulta: 1/4/2015.

Los sistemas de SSI y EI no están funcionando como formas efectivas de atracción de IED. Para aumentar las vinculaciones entre las PYMES mexicanas y las empresas extranjeras, se necesita mejorar las capacidades de las fabricaciones de las empresas mexicanas y a al mismo tiempo, mejorar el acceso de las informaciones de PYMES mexicanas a las empresas extranjeras. A la hora de mejorar esta segunda condición, SSI y EI pueden contribuir eficazmente a ello. 


\section{IV-2. Políticas industriales en el nivel de los estados}

En México, cada estado y cada municipio tienen derecho a establecer algunas políticas fiscales para atraer la IED. Es decir, dependiendo de los estados y municipios, sus políticas de incentivos son diferentes. En este epígrafe, basado en la base de datos de ProMéxico, analizamos las tendencias de las políticas fiscales de los estados de México. Los datos de este capítulo están actualizados hasta el año 2013.

ProMéxico clasifica en 22 categorías las políticas fiscales de los estados. Veamos primero estas categorías de las políticas fiscales: ${ }^{15}$

1) Exención temporal de impuestos y derechos estatales

2) Extensión temporal de ISN (Impuesto Sobre la Nómina) para empresas de nueva creación

3) Extensión de derechos del Registro Público de la Propiedad y el Comercio

4) Extensión del pago de licencia de Uso de Suelo

5) Extensión del pago de licencia de Construcción

6) Extensión del impuesto sobre tenencia o uso de vehículos de motor usados

7) Extensión de derechos de conexión de agua potable y drenaje

8) Reducción de impuestos y derechos estatales

9) Reducción en los derechos se generen en Registro Público de la Propiedad y el Comercio

10) Reducción en costes de avalúo de bienes inmuebles

11) Reducción del impuesto de traslado de dominio

12) Reducción del impuesto sobre registro y expedición de placas, calcomanía y tarjeta de circulación de vehículo estatal

13) Reducción en los derechos que se generen con motivo de la revisión de planos

14) Reducción del ISN para empresas que generen nuevos empleos

15) Reducción temporal del ISN

16) Reducción de Impuesto Predial

17) Reducción de Impuesto sobre Adquisición de inmuebles.

18) Reducción del pago de derechos por expedición de licencias de construcción

19) Reducción del pago de derechos por conexión a la red de agua potable y alcantarillado

20) Incentivos especiales para proyectos de investigación y desarrollo de tecnología

21) Incentivos especiales para proyectos fuera del área metropolitana

22) Reducción temporal de derecho de alumbrado público

Basándose en estas categorías, se analizan las tendencias de las políticas fiscales de los estados en México. En la Tabla IV-2.1 se analizan las políticas fiscales implementadas en cada estado en México.

\footnotetext{
15 Tomado de ProMéxico Disponible en http://mim.promexico.gob.mx/wb/mim/seleccion_de_indicadoresProMéxico, fecha de consulta:12/8/2015.
} 
Tablas IV-2. 1a. Clasificaciones de las políticas fiscales en cada estado de México: Parte 1

\begin{tabular}{|c|c|c|c|c|c|c|c|c|c|c|c|c|c|c|c|c|c|c|c|c|c|c|}
\hline & 1 & 2 & 3 & 4 & 5 & 6 & 7 & 8 & 9 & 10 & 11 & 12 & 13 & 14 & 15 & 16 & 17 & 18 & 19 & 20 & 21 & 22 \\
\hline Aguascalientes & & $\bullet$ & $\bullet$ & $\bullet$ & $\bullet$ & & $\bullet$ & $\bullet$ & & & & & & $\bullet$ & $\bullet$ & $\bullet$ & $\bullet$ & $\bullet$ & $\bullet$ & & $\bullet$ & \\
\hline Baja California & $\bullet$ & $\bullet$ & & $\bullet$ & $\bullet$ & $\bullet$ & $\bullet$ & $\bullet$ & $\bullet$ & & & & & $\bullet$ & $\bullet$ & $\bullet$ & $\bullet$ & $\bullet$ & $\bullet$ & $\bullet$ & $\bullet$ & $\bullet$ \\
\hline \multicolumn{23}{|l|}{$\begin{array}{l}\text { Baja California } \\
\text { Sur }\end{array}$} \\
\hline Campeche & $\bullet$ & $\bullet$ & $\bullet$ & & & $\bullet$ & & $\bullet$ & $\bullet$ & & & & & $\bullet$ & $\bullet$ & & $\bullet$ & & & $\bullet$ & $\bullet$ & \\
\hline Coahuila & ○ & ○ & ○ & & & & & & & & & & & ○ & ○ & ○ & ○ & O & ○ & ० & ○ & O \\
\hline Colima & $\bullet$ & $\bullet$ & & & & $\bullet$ & & $\bullet$ & $\bullet$ & & & $\bullet$ & & $\bullet$ & & & & & $\bullet$ & & & \\
\hline Chiapas & $\bullet$ & & $\bullet$ & & & & & $\bullet$ & $\bullet$ & $\bullet$ & & & & & & & & & & $\bullet$ & $\bullet$ & \\
\hline Chihuahua & $\bullet$ & $\bullet$ & $\bullet$ & $\bullet$ & $\bullet$ & $\bullet$ & & $\bullet$ & $\bullet$ & & $\bullet$ & & & $\bullet$ & $\bullet$ & $\bullet$ & $\bullet$ & $\bullet$ & & $\bullet$ & $\bullet$ & \\
\hline Distrito Federal & & & & & & & & & O & & & & & O & & ○ & O & ○ & & ○ & & \\
\hline Durango & $\bullet$ & $\bullet$ & $\bullet$ & $\bullet$ & $\bullet$ & & & $\bullet$ & $\bullet$ & & $\bullet$ & & & $\bullet$ & $\bullet$ & $\bullet$ & & $\bullet$ & & $\bullet$ & $\bullet$ & $\bullet$ \\
\hline Guanajuato & $\bullet$ & $\bullet$ & & & $\bullet$ & & & $\bullet$ & $\bullet$ & & & & & $\bullet$ & & & & $\bullet$ & $\bullet$ & $\bullet$ & $\bullet$ & \\
\hline Guerrero & & & & ○ & & & & $\bullet$ & $\bullet$ & & & & & $\bullet$ & $\bullet$ & $\bullet$ & $\bullet$ & $\bullet$ & & $\bullet$ & & \\
\hline Hidalgo & $\bullet$ & $\bullet$ & $\bullet$ & $\bullet$ & O & & ○ & O & $\bullet$ & O & $\bullet$ & & & $\bullet$ & $\bullet$ & O & $\bullet$ & $\bullet$ & ० & $\bullet$ & $\bullet$ & \\
\hline Jalisco & $\bullet$ & $\bullet$ & & & & & & $\bullet$ & $\bullet$ & $\bullet$ & $\bullet$ & & & $\bullet$ & $\bullet$ & $\bullet$ & $\bullet$ & $\bullet$ & & $\bullet$ & $\bullet$ & \\
\hline México & $\bullet$ & ० & & & & 0 & & $\bullet$ & & & & & & ○ & O & & & & & $\bullet$ & $\bullet$ & \\
\hline Michoacán & & & $\bullet$ & & $\bullet$ & & & & $\bullet$ & & & & & & & & & $\bullet$ & & & & \\
\hline Morelos & $\bullet$ & $\bullet$ & $\bullet$ & & & & & $\bullet$ & $\bullet$ & & & & & $\bullet$ & & & & & & $\bullet$ & ० & \\
\hline
\end{tabular}

Fuente. Tomado de ProMéxico, disponible en http://mim.promexico.gob.mx/wb/mim/seleccion_de_indicadores, fecha de consulta:13/8/2015. 
Tablas IV-2. 1b. Clasificaciones de las políticas fiscales en cada estado de México: Parte 2

\begin{tabular}{|c|c|c|c|c|c|c|c|c|c|c|c|c|c|c|c|c|c|c|c|c|c|c|}
\hline & $\mathbf{1}$ & 2 & 3 & 4 & 5 & 6 & 7 & 8 & 9 & 10 & 11 & 12 & 13 & 14 & 15 & 16 & 17 & 18 & 19 & 20 & 21 & 22 \\
\hline Nayarit & $\bullet$ & & $\bullet$ & $\bullet$ & $\bullet$ & & & $\bullet$ & $\bullet$ & & $\bullet$ & & & & & $\bullet$ & $\bullet$ & $\bullet$ & & $\bullet$ & & \\
\hline Nuevo León & $\bullet$ & $\bullet$ & $\bullet$ & $\bullet$ & $\bullet$ & & $\bullet$ & $\bullet$ & $\bullet$ & $\bullet$ & $\bullet$ & & $\bullet$ & $\bullet$ & $\bullet$ & $\bullet$ & $\bullet$ & $\bullet$ & $\bullet$ & $\bullet$ & $\bullet$ & \\
\hline Oaxaca & $\bullet$ & & & & & & & $\bullet$ & & & & & $\bullet$ & & & & & & & $\bullet$ & & $\bullet$ \\
\hline Puebla & $\bullet$ & ○ & & ○ & ○ & $\bullet$ & & $\bullet$ & & $\bullet$ & & & O & & & ○ & O & O & & $\bullet$ & $\bullet$ & O \\
\hline Querétaro & & & & & & & & & & & o & & & & & & & & & & & \\
\hline Quintana Roo & $\bullet$ & & & & & & & $\bullet$ & $\bullet$ & & $\bullet$ & $\bullet$ & & $\bullet$ & $\bullet$ & & $\bullet$ & $\bullet$ & & $\bullet$ & $\bullet$ & \\
\hline San Luis Potosí & & $\bullet$ & & & & & & & & & $\bullet$ & & & - & & $\bullet$ & $\bullet$ & $\bullet$ & & $\bullet$ & $\bullet$ & \\
\hline Sinaloa & & $\bullet$ & $\bullet$ & & $\bullet$ & & $\bullet$ & $\bullet$ & $\bullet$ & & & & & $\bullet$ & $\bullet$ & $\bullet$ & $\bullet$ & $\bullet$ & $\bullet$ & & $\bullet$ & \\
\hline Sonora & $\bullet$ & $\bullet$ & $\bullet$ & $\bullet$ & $\bullet$ & & $\bullet$ & $\bullet$ & $\bullet$ & $\bullet$ & $\bullet$ & $\bullet$ & $\bullet$ & $\bullet$ & $\bullet$ & - & $\bullet$ & - & $\bullet$ & $\bullet$ & $\bullet$ & $\bullet$ \\
\hline Tabasco & $\bullet$ & $\bullet$ & $\bullet$ & & & & & $\bullet$ & $\bullet$ & & $\bullet$ & & & - & $\bullet$ & & $\bullet$ & & & & & \\
\hline Tamaulipas & $\bullet$ & $\bullet$ & & & & & & $\bullet$ & & & & & & $\bullet$ & & & & & $\bullet$ & $\bullet$ & $\bullet$ & \\
\hline Tlaxcala & $\bullet$ & $\bullet$ & $\bullet$ & $\bullet$ & $\bullet$ & $\bullet$ & & • & $\bullet$ & $\bullet$ & $\bullet$ & & & $\bullet$ & - & $\bullet$ & & $\bullet$ & & $\bullet$ & & \\
\hline Veracruz & & & & & & & & - & $\bullet$ & & & & $\bullet$ & $\bullet$ & $\bullet$ & $\bullet$ & & $\bullet$ & - & $\bullet$ & & \\
\hline Yucatán & $\bullet$ & $\bullet$ & $\bullet$ & $\bullet$ & $\bullet$ & $\bullet$ & $\bullet$ & $\bullet$ & $\bullet$ & & & - & & $\bullet$ & $\bullet$ & $\bullet$ & & - & - & $\bullet$ & $\bullet$ & \\
\hline Zacatecas & & ○ & & & & & & & & & & & & O & & & & & & & & \\
\hline
\end{tabular}

- Sí o Hay algunas condiciones

Fuente. Tomado de ProMéxico, disponible en http://mim.promexico.gob.mx/wb/mim/seleccion_de_indicadores, fecha de consulta:13/8/2015. 
En estas tablas, se pueden identificar algunas características. Primero, hay políticas que son comunes a la mayor parte de los estados. Segundo, hay algunos estados que no tienen políticas especiales para atraer IED. Además, hay estados que tienen las políticas con algunas condiciones para atraer las IED.

Al resumir la Tabla IV-2.1 en la Tabla IV-2. 2, se aprecian los cinco primeros Estados según el número de ámbitos en los que trabajan sus políticas fiscales. Primero se analiza los estados: los que tiene más y menos políticas fiscales.

La Tabla IV-2. 2 pone de manifiesto que en la lista de los estados que tienen más ámbitos de las políticas fiscales, se encuentran los estados del norte. Al contrario, los estados que tienen menos ámbitos de las políticas físcales son los estados del sur o cerca de sur. Además, por ejemplo, las inversiones japonesas avanzan hacia los estados que ofrecen más beneficios a las empresas.

Tabla IV-2. 2. Los TOP 5 estados. Números de ámbitos de políticas fiscales

\begin{tabular}{|c|c|c|}
\hline & Mas ámbitos & Menos ámbitos \\
\hline $\mathbf{1}$ & Sonora & Baja California Sur \\
\hline $\mathbf{2}$ & Nuevo León & Querétaro \\
\hline $\mathbf{3}$ & Hidalgo & Zacatecas \\
\hline $\mathbf{4}$ & Yucatán / Baja California & Michoacán \\
\hline $\mathbf{5}$ & Chihuahua & Oaxaca \\
\hline
\end{tabular}

Fuente. Tomado de ProMéxico, disponible en http://mim.promexico.gob.mx/wb/mim/seleccion_de_indicadores, fecha de consulta:13/8/2015.

Ahora, se analiza sobre los ámbitos de estas políticas fiscales. Es decir, se analiza qué tipos de ámbitos son más comunes y menos comunes, entre los estados de México. Veamos en la Tabla IV-2. 3, los 10 ámbitos más habituales de las políticas fiscales y en la Tabla VI-2. 4, los 5 ámbitos menos comunes de las políticas filicales. 
Tabla IV-2. 3. Los 10 ámbitos más comunes de las políticas fiscales.

\begin{tabular}{|l|l|}
\hline 1. Reducción de impuestos y derechos estatales & $\begin{array}{l}\text { 6. Exención temporal del ISN para empresas de } \\
\text { nueva creación }\end{array}$ \\
\hline $\begin{array}{l}\text { 2. Incentivos especiales para proyectos de } \\
\text { investigación y desarrollo de tecnología }\end{array}$ & $\begin{array}{l}\text { 7. Reducción en el pago de derechos por } \\
\text { expedición de licencias de construcción }\end{array}$ \\
\hline $\begin{array}{l}\text { 3. Reducción del ISN para empresas que generen } \\
\text { nuevos empleos }\end{array}$ & $\begin{array}{l}\text { 8. Incentivos especiales para proyectos fuera del } \\
\text { área metropolitana }\end{array}$ \\
$\begin{array}{l}\text { 4. Reducción en los derechos que se generen del } \\
\text { Registro Público de la Propiedad y el Comercio }\end{array}$ & 9. Reducción temporal del ISN \\
\hline $\begin{array}{l}\text { 5. Exención temporal de impuestos y derechos } \\
\text { estatales }\end{array}$ & $\mathbf{1 0 .}$ Reducción de Impuesto Predial \\
\hline
\end{tabular}

Fuente. Tomado de ProMéxico, disponible en http://mim.promexico.gob.mx/wb/mim/seleccion_de_indicadores, fecha de consulta:13/8/2015.

Tabla IV-2. 4. Los 5 ámbitos menos comunes de las políticas filicales

\begin{tabular}{|l|l|}
\hline $\begin{array}{l}\text { 1. Reducción del impuesto sobre registro y } \\
\text { expedición de placas, calcomanía y tarjeta de } \\
\text { circulación de vehículo estatal }\end{array}$ & $\begin{array}{l}\text { 4. Reducción del impuesto de traslado de } \\
\text { dominio }\end{array}$ \\
\hline $\begin{array}{l}\text { 2. Reducción en los derechos que se generen con } \\
\text { motivo de la revisión de planos }\end{array}$ & $\begin{array}{l}\text { 5. Exención de derechos de conexión de agua } \\
\text { potable y drenaje }\end{array}$ \\
\hline $\begin{array}{l}\text { 3. Reducción temporal del derecho de alumbrado } \\
\text { público }\end{array}$ & \\
\hline
\end{tabular}

Fuente. Tomado de ProMéxico, disponible en http://mim.promexico.gob.mx/wb/mim/seleccion_de_indicadores, fecha de consulta: 13/8/2015.

Al analizar la Tablas IV-2.3, se nota que "Reducción de impuestos y derechos estatales" es la política fiscal más común: 25 estados tienen esta política. Es decir, la mayor parte de los estados de México tienen este artículo. Además, el artículo de "Incentivos especiales para proyectos de investigación y desarrollo de tecnología" es, también, bastante común: 24 estados lo tienen. Los artículos sobre ISN, también son comunes. Al contrario, se nota que el artículo de "Reducción del impuesto sobre registro y expedición de placas, calcomanía y tarjeta de circulación de vehículo estatal" es menos común: solo 4 estados lo tienen. Además, el artículo "Exención del impuesto sobre tenencia o uso de vehículos de motor usados" lo tienen solo 8 estados. Se puede decir que los artículos sobre automóviles de las políticas fiscales no son tan comunes en México. Basándose en el análisis de JIMENÉZ y PODESTÁ (2009, pp. 6-8), en México la "reducción de tasas" y los "créditos fiscales" son las más populares como políticas fiscales en el nivel de los estados. 
A partir de aquí, se desarrolla un análisis sobre qué tipo de artículos o ámbitos de las políticas fiscales son más comunes en función de las zonas de México: Noroeste (Baja California, Baja California Sur, Sinaloa y Sonora), Noreste (Coahuila, Chihuahua, Durango, Nuevo León y Tamaulipas), Central Occidente (Aguascalientes, Colima, Guanajuato, Jalisco, Michoacán, Nayarit, San Luis Potosí y Zacatecas), Centrales (Distrito Federal, Hidalgo, México, Morelos, Puebla, Querétaro y Tlaxcala) y Sur (Campeche, Chiapas, Guerrero, Oaxaca, Quintana Roo, Tabasco, Veracruz y Yucatán). Además, para decidir los artículos más comunes, se usa el porcentaje de los estados que tienen los mismos artículos. Se considera que los artículos "más comunes" son los que están presentes en más del $80 \%$ de los estados en cada zona.

\section{IV-2. 1. Los estados de Noroeste.}

Se empiezan a analizar los estados de Noroeste en México: Baja California, Baja California Sur, Sinaloa y Sonora. En esta región, aunque hay solo 4 estados, es una región muy importante como destino de la IED. En la Tabla IV-2.5, se nota que 9 artículos de las políticas fiscales son comunes en esta región. Además, hay varios artículos sobre “incentivos especiales para proyectos fuera del área metropolitana" que son comunes en esta región. Esta región recibe beneficios del programa de Maquiladora, pero hay diferencias económicas entre dentro y fuera de la maquiladora. Para solucionar este problema, los estados de Noroeste quieren aprovechar la IED. Además, hay dos artículos comunes que se trata creación de "Nuevos" empleos y empresas, como se ha analizado en los epígrafes anteriores ("Exención temporal del ISN para empresas de nueva creación" y "Reducción del ISN para empresas que generen nuevos empleos"). Esto significa que, para estos estados, lo importante es aumentar el empleo en esta zona. Además, Otra cuestión interesante es, que el artículo más común en la Tabla IV-2. 5 (el de "Reducción de impuestos y derechos estatales”) no es artículo común en esta zona.

Además, como otra característica de los artículos de las políticas fiscales en los estados de Noroeste es que hay varios artículos comunes entre los estados en esta región y sus políticas fiscales que se enfocan hacia la creación de filiales y empleos en esta zona. Es decir, en la Frontera norte se requiere una estrategia de desarrollo en el marco del capitalismo tecnocognitivo, liderada por el empuje de las manufacturas (SÁNCHEZJUÁREZ y GARCÍA ALMADA, 2014). Por eso, se necesita políticas fiscales que promuevan el establecimiento de más fábricas nuevas y más trabajadores en las fábricas 
en esta zona. Por eso, sus artículos de incentivo en las políticas fiscales se incluyen sobre el ISN y sobre la condición para construir fábricas.

Esta zona de maquiladora tiene otra tendencia en sus políticas fiscales. En esta zona hay varias empresas extranjeras. Para ellas, las informaciones sobre impuestos y tributaciones son muy importantes, pero muy complicadas de obtener y entender. Por eso, la manera de difundir las informaciones sobre incentivos fiscales a las empresas (nacionales e internacionales) es otro problema que aparece en esta zona.

Tabla IV-2. 5. Los Estados de Noroeste. Políticas más comunes

\begin{tabular}{|l|l|}
\hline \multicolumn{2}{|c|}{ Políticas más comunes } \\
\hline $\begin{array}{l}\text { Exención temporal del ISN para } \\
\text { empresas de nueva creación }\end{array}$ & $\begin{array}{l}\text { Reducción del ISN para empresas que } \\
\text { generen nuevos empleos }\end{array}$ \\
\hline $\begin{array}{l}\text { Exención del pago de licencia de } \\
\text { Construcción }\end{array}$ & Reducción temporal del ISN \\
\hline $\begin{array}{l}\text { Exención de derechos de conexión de } \\
\text { agua potable y drenaje }\end{array}$ & Reducción de Impuesto Predial \\
\hline $\begin{array}{l}\text { Reducción de impuestos y derechos } \\
\text { estatales }\end{array}$ & $\begin{array}{l}\text { Incentivos especiales para proyectos } \\
\text { fuera del área metropolitana }\end{array}$ \\
\hline $\begin{array}{l}\text { Reducción en los derechos que se } \\
\text { generen del Registro Público de la } \\
\text { Propiedad y el Comercio }\end{array}$ & \\
\hline
\end{tabular}

Fuente. Tomado de ProMéxico, disponible en

http://mim.promexico.gob.mx/wb/mim/seleccion_de_indicadores, fecha de consulta:14/8/2015.

\section{IV-2. 2. Los estados de Noreste}

Ahora, se analiza el caso de los estados de Noreste en México: Coahuila, Chihuahua, Durango, Nuevo León y Tamaulipas. En esta parte, analizamos los artículos más comunes.

Veamos la Tabla IV-2. 6. Una característica de esta zona es que hay 5 artículos que todos los estados en esta región tienen. Además, dentro de estos, hay "Incentivos especiales para proyectos de investigación y desarrollo de tecnología" e "Incentivos especiales para proyectos fuera del área metropolitana."

En estos dos artículos, no se mencionan específicamente qué es lo que los estados hacen, pero muestran sus objetivos. Por eso, los estados del noreste querían recibir 
beneficios de los proyectos de investigación y desarrollo de tecnología y los proyectos fuera del área metropolitana. Además, los artículos sobre ISN son comunes y el primer artículo de la lista común "Exención temporal de impuestos y derechos estatales" está también en esta lista. En esta zona, generalmente, los gobiernos se centran en el aumento de fábricas para los trabajadores locales que trabajan allí.

Además, desde el punto de vista de las empresas que quieran invertir y establecer sus filiales en esta zona, estas políticas fiscales serían una ventaja: sería más fácil de construir sus filiales o fábricas que en otros estados. Es decir, es más fácil establecer las cadenas de producción en esta zona de los estados de Noreste.

Tabla IV-2. 6. Los Estados de Noreste. Políticas más comunes

\begin{tabular}{|l|}
\hline \multicolumn{1}{|c|}{ Políticas más comunes (100\%) } \\
\hline Exención temporal de impuestos y derechos estatales \\
\hline Exención temporal del ISN para empresas de nueva creación \\
\hline Reducción del ISN para empresas que generen nuevos empleos \\
\hline $\begin{array}{l}\text { Incentivos especiales para proyectos de investigación y desarrollo de } \\
\text { tecnología }\end{array}$ \\
\hline Incentivos especiales para proyectos fuera del área metropolitana \\
\hline
\end{tabular}

Fuente. Tomado de ProMéxico, disponible en

http://mim.promexico.gob.mx/wb/mim/seleccion_de_indicadores, fecha de consulta:14/8/2015

\section{IV-2. 3. Los estados de la zona Central Occidente.}

Ahora, se analiza los artículos de los estados de Central Occidente en México: Aguascalientes, Colima, Guanajuato, Jalisco, Michoacán, Nayarit, San Luis Potosí y Zacatecas. Veamos la Tabla IV-2. 7. Según esta tabla, primero, se nota que hay pocos artículos que cumplen la condición "más común." Esto significa que las estrategias de las políticas fiscales son distintas dependiendo de los estados. No es como los estados del Noreste. Además, en la lista de los artículos "más comunes", no está el artículo de "Exención temporal de impuestos y derechos estatales". Como se ha analiza en el Capítulo II, la IED ha aumentado en esta zona, en los últimos años. Por eso, como en el caso de los estados del noreste, la difusión de las informaciones a las empresas extranjeras es importante en esta zona. 
Tabla IV-2. 7. Los Estados de la zona Central Occidente. Políticas más comunes.

\begin{tabular}{|l|}
\hline \multicolumn{1}{|c|}{ Politices más comunes. $(>\mathbf{8 0 \%})$} \\
\hline Exención temporal del ISN para empresas de nueva creación \\
\hline Reducción del ISN para empresas que generen nuevos empleos \\
\hline Reducción en el pago de derechos por expedición de licencias de construcción \\
\hline
\end{tabular}

Fuente. Tomado de ProMéxico, disponible en

http://mim.promexico.gob.mx/wb/mim/seleccion_de_indicadores, fecha de consulta:14/8/2015

\section{IV-2. 4. Los Estados Centrales.}

Se analiza el caso de los estados centrales: Distrito Federal, Hidalgo, México, Morelos, Puebla, Querétaro y Tlaxcala, en la Tabla IV-2. 8. En esta zona, hay incentivos altos para las investigaciones y desarrollo de tecnología, porque hay concentraciones de universidades y centros de estudios. Para estos estados, promover las actividades de investigación y desarrollo tiene más posibilidades de inducir un alto rendimiento de las universidades. Por ejemplo, en todo México hay 36 centros de infraestructuras públicas en biotecnología: 13 de ellos están situados en los estados centrales de México (AMAROROSALES y VILLAVICENCIO-CARBAJAL, 2015). Por eso, los estados tienen motivos para incentivar estas actividades para producir recursos humanos de alta calidad.

En la lista de los artículos "más comunes," se puede clasificar dos tipos de incentivos: sobre ISN e impuestos y derechos estatales. Esto significa que, en esta zona, hay mucha población en México. Por eso, las empresas extranjeras invierten en esta zona no solo para fabricar, sino para vender sus productos en esta zona. Para aumentar estos dos tipos de actividades económiaos, los estados centrales tienen que establecer los artículos de la política fiscal más adecuados para fabricantes y vendedores (por ejemplo, el artículo de "Incentivos especiales para proyectos de investigación y desarrollo de tecnología" va a dar más beneficios a la industria manufacturera que a la industria de servicios). Para dar ayuda a las empresas que fabrican y venden, es más fácil que las políticas fiscales se enfoquen a las reducciones de impuestos que a sus beneficios. Por eso, en los estados centrales se establecen las políticas fiscales más generalizadas para todas las industrias. 
Además, en el caso de México D.F, todos los artículos tienen algunas excepciones.: por ejemplo, en "Reducción en los derechos que se generen del Registro Público de la Propiedad y el Comercio" es :" $30 \%$ a industrias maquiladoras de exportación que adquieran espacios industriales; $70 \%$ por restauración o rehabilitación de inmueble, monumentos históricos o artísticos; $60 \%$ por nuevos proyectos inmobiliarios o restauración o rehabilitación en los perímetros A y B del Centro Histórico; $30 \%$ a entidades públicas y promotores privados que construyan espacios comerciales o rehabiliten y adapten. ${ }^{~} 16$ En el caso de México D.F, este tipo de condiciones se establecen de manera muy detallada.

Tabla IV-2. 8. Los estados centrales. Políticas más comunes.

\begin{tabular}{|l|}
\hline \multicolumn{1}{|c|}{ Políticas más comunes $(\mathbf{8 0 \% )}$} \\
\hline Incentivos especiales para proyectos de investigación y desarrollo de tecnología \\
\hline Reducción del ISN para empresas que generen nuevos empleos \\
\hline Reducción de impuestos y derechos estatales \\
\hline Exención temporal del ISN para empresas de nueva creación \\
\hline Exención temporal de impuestos y derechos estatales \\
\hline
\end{tabular}

Fuente. Tomado de Proméxico, disponible en

http://mim.promexico.gob.mx/wb/mim/seleccion_de_indicadores, fecha de consulta:14/8/2015

\section{IV-2. 5. Los estados del Sur.}

Al final, se analiza los artículos de los estados del sur: Campeche, Chiapas, Guerrero, Oaxaca, Quintana Roo, Tabasco, Veracruz y Yucatán. Veamos la Tabla IV-2. 9. Como los artículos de los estados centrales occidentales, se nota que hay pocos artículos "más comunes". Esta zona sur tiene 8 estados. Este es el máximo número de miembros de los grupos de Estados. Es muy normal que sea más difícil encontrar artículos comunes cuando hay mayor número de miembros. Además, en esta zona, hay diferencias muy grandes entre el estado que recibe más IED y el que recibe menos IED. Por ejemplo, en 2014, en Veracruz hubo 290,3 millones de dólares de IED, mientras que en Campeche

\footnotetext{
16 Tomado de ProMéxico, disponible en http://mim.promexico.gob.mx/wb/mim/seleccion_de_indicadores, fecha de consulta: 29/ 09/2015.
} 
hubo -117 millones de dólares de IED, es decir, 117 millones de dólares salieron desde este estado en 2014. ${ }^{17}$ Esta diferencia puede provocar diferencias en las políticas fiscales para atraer IED, dependiendo de los estados considerados.

Tabla IV-2. 9. Los estados del Sur. Políticas más comunes

\begin{tabular}{|l|}
\hline \multicolumn{1}{|c|}{ Políticas más comunes. $(>\mathbf{8 0 \%})$} \\
\hline Reducción de impuestos y derechos estatales \\
\hline $\begin{array}{l}\text { Reducción en los derechos que se generen del Registro Público de la Propiedad y el } \\
\text { Comercio }\end{array}$ \\
\hline Incentivos especiales para proyectos de investigación y desarrollo de tecnología \\
\hline Exención temporal de impuestos y derechos estatales \\
\hline Reducción del ISN para empresas que generen nuevos empleos \\
\hline Reducción temporal del ISN \\
\hline
\end{tabular}

Fuente. Tomado de ProMéxico, disponible en

http://mim.promexico.gob.mx/wb/mim/seleccion_de_indicadores, fecha de consulta:14/8/2015

Especialmente, en los estados del Sur, hay varios problemas para atraer IED desde el punto de vista de las empresas extranjeras; por ejemplo, la falta de infraestructuras e informaciones locales (SÁNCHEZ-JUÁREZ y GARCÍA ALMADA, 2014, pp. 36-38). Especialmente, antes de mejorar las condiciones de infraestructuras, es complicado que las empresas empiezan a invertir. Por eso, los estados del sur de México tienen que considerar como una prioridad estas políticas.

Hasta esta parte, se ha analizado las condiciones de las políticas fiscales en los estados de México. Principalmente, en los estados de México se ofrecen la reducción y la exención de impuestos y derechos estatales, como las ventajas principales a las empresas extranjeras. Dependiendo de las industrias, los artículos o ámbitos de las políticas fiscales que desean las empresas extranjeras son distintos. Sin embargo, para atraer IED, lo que es importante es hacer llegar los beneficios a través de sus políticas fiscales a las empresas extranjeras. Además, en México, los municipios, como ciudades y pueblos, tienen

\footnotetext{
${ }^{17}$ Secretaria de Economía, el Gobierno de México, disponible en http://www.economia.gob.mx/comunidad-negocios/competitividad-normatividad/inversion-extranjeradirecta/estadistica-oficial-de-ied-en-mexico, fecha de consulta: 23/3/2015.
} 
derecho a establecer algunas reglas para atraer la IED. Es decir, para las empresas extranjeras, es muy complicado desarrollar una política fiscal en sus destinos de IED.

\section{IV-2. 6. Políticas fiscales de atracción de IED y problema de gastos tributarios en México}

Hasta la sección anterior, se han analizado las leyes de política fiscal de los estados en México. Sin embargo, para planear y poner un decreto en vigor, hay unos costes o gastos. A la hora de evaluar las políticas fiscales, se necesita considerar especialmente los "gastos tributarios"

La Organización para la Cooperación y el Desarrollo Económico (OCDE) define estos gastos tributarios como "una transferencia de recursos públicos llevada a cabo mediante la reducción de las obligaciones tributarias con respecto a un impuesto de referencia, más que por la vía del gasto directo” (VILLELA, LEMGRUBER y JORRATT, 2009).

Según de la definición de la Comisión Económica para América Latina y el Caribe (CEPAL), "la idea que está detrás de esta formulación es que lo que se deja de recaudar por extensión, podría ser recaudado y gastado en esa u otra opción. Entonces, para poder evaluar la oportunidad de esa extensión, debe calcularse lo que se deja de recaudar" (JIMÉNEZ y PODESTÁ, 2009, p. 5). También, se apunta a que "en los últimos años se ha usado el término gasto tributario como síntoma de incentivos por el lado de las exenciones impositivas y se ha ampliado su utilización a un mayor número de impuestos" (JIMÉNEZ y PODESTÁ, 2009, p. 8).

Sin embargo, el sistema tributario es una política que establece cada país. Por eso, en la realidad, cada país tiene sus propias definiciones del gasto tributario. En México, se define el gasto tributario como "aquella cantidad que se deja de recaudar por la existencia de tratamientos fiscales especiales, facilidades administrativas, deducciones autorizadas, ingresos exentos, tasas preferenciales, estímulos fiscales y resoluciones particulares" (JIMÉNEZ y PODESTÁ, 2009, p.23-24).

Según estas tres definiciones, se puede encontrar un elemento común: el gasto tributario es una cantidad de dinero que el gobierno no puede recaudar debido a políticas 
que reducen la recaudación. La Ilustración IV-2. 1 facilita la conceptualización del gasto tributario.

\section{Ilustración IV-2. 1. Concepto del gasto tributario.}

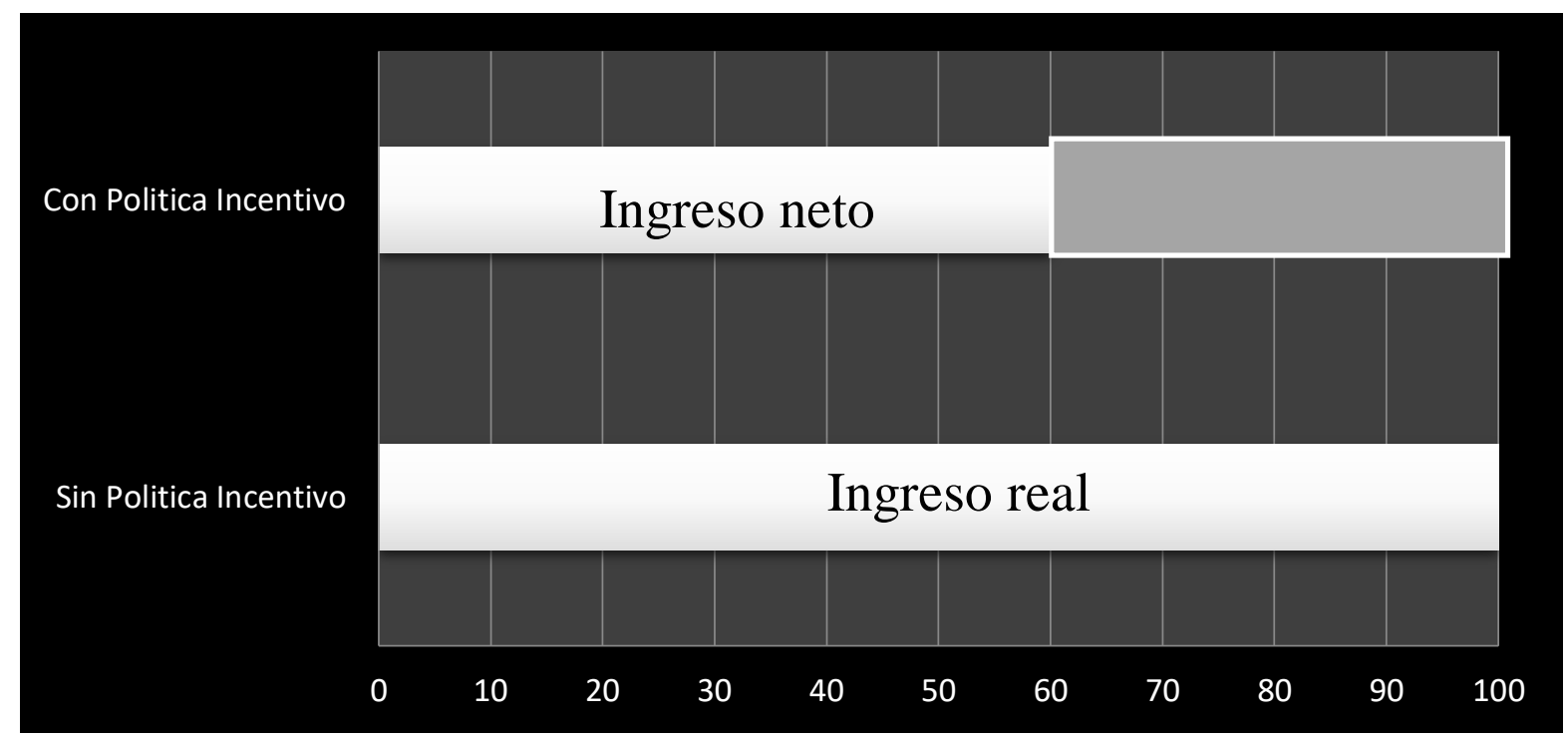

Fuente. Elaboración propia a partir de JIMÉNEZ y PODESTÁ. (2009). Inversión, incentivos fiscales y gastos tributarios en América Latina. Santiago de Chile: CEPAL. Disponible en http://www.andi.com.co/czf/Documents/Documentos\%20de\%20Interes/Microsoft\%20Word\%20-\% 20Inversi\%C3\%B3n,\%20Incentivos\%20fiscales\%20en\%20America\%20Latina\%20Cepal\%20Docu mento.pdf, fecha de consulta: 14/8/2015.

Para calcular los gastos tributarios, el gobierno tiene que entender qué puede recaudar sin las políticas de incentivos. Este tipo de cálculo es costoso y complicado para hacerlo solo en los gobiernos locales. En México, las políticas fiscales dependen de los gobiernos en el nivel estatal, pero necesita de la ayuda y el apoyo del gobierno central o federal.

Los gastos tributarios se originan en disposiciones tributarias como las siguientes (PECHO, 2014):

1. Exclusiones (hechos no gravados y inafectaciones)

2. Exenciones (exoneraciones)

3. Deducciones

4. Créditos

5. Alícuotas reducida

6. Diferimientos

7. Regímenes especiales o promocionales (como las zonas francas)

8. Reintegros (incluyendo algunas devoluciones)

En el caso de las políticas fiscales en cada estado en México, todos estos artículos menos el número 7, están bajo el control de cada estado. 
Si volvemos a la lista de ProMéxico en la que las políticas fiscales de los estados se clasifican en 22 categorías, éstas pueden ser ahora reagrupadas y clasificadas de acuerdo con las ocho disposiciones tributarias que se acaban de presentar:

1). Exclusiones (hechos no gravados e inafectaciones):

- Exención temporal de ISN (Impuesto Sobre la Nómina) para empresas de nueva creación.

- Exención de derechos del Registro Público de la Propiedad y el Comercio

- Exención del pago de licencia de Uso de Suelo

- Exención del pago de licencia de Construcción

- Exención del impuesto sobre tenencia o uso de vehículos de motor usados

- Exención de derechos de conexión de agua potable y drenaje

2). Exenciones (exoneraciones):

- Reducción de impuestos y derechos estatales

- Reducción en los derechos se generen en Registro Público de la Propiedad y el Comercio

- Reducción en costes de aval de bienes inmuebles

- Reducción del impuesto de traslado de dominio

- Reducción del impuesto sobre registro y expedición de placas, calcomanía y tarjeta de circulación de vehículo estatal

- Reducción de los derechos que se generen con motivo de la revisión de planes

- Reducción del ISN para empresas que generen nuevos empleos

- Reducción temporal del ISN

- Reducción de Impuesto Predial

- Reducción de Impuesto sobre Adquisición de inmuebles.

- Reducción del pago de derechos por expedición de licencias de construcción

- Reducción del pago de derechos por conexión a la red de agua potable y alcantarillado

3). Deducciones: Ninguno

4). Créditos:

- Incentivos especiales para proyectos de investigación y desarrollo de tecnología

- Incentivos especiales para proyectos fuera del área metropolitana

5). Alícuotas reducida: Ninguno

6). Diferimientos: Ninguno

7). Regímenes especiales o promocionales (como las zonas francas): Ninguno

8). Reintegros (incluyendo algunas devoluciones): Ninguno

Como hemos visto, la mayor parte de las políticas fiscales en cada estado de México son una forma de eliminar y/o reducir temporalmente la recaudación. Para los gobiernos locales de cada estado, esta situación conlleva la aceptación de la reducción de la recaudación tributaria que se hubiera ganado sin las políticas fiscales de atracción de la IED.

Se puede considerar que el gasto tributario es un tipo de coste para atraer la IED. Al ponerse en vigor la ley, siempre hay costes. Sin embargo, aunque haya algún gasto 
tributario al establecer las políticas fiscales de atracción de la IED, si se esperan más beneficios que costes (gastos tributarios), es muy probable que la política fiscal tenga más posibilidades de entrar en vigor.

En el caso de que haya gastos tributarios, es necesario establecer las políticas que puedan cubrir esos gastos tributarios. En la mayor parte de los estados de México, sus políticas fiscales para la atracción de IED suponen una reducción de algunas recaudaciones tributarias. Esto conlleva aceptar que no se pueden cubrir los gastos tributarios sólo con este tipo de políticas. Los gobiernos locales tienen que establecer otras políticas para cubrirlo.

Además, hay una pregunta esencial: ¿hasta qué punto las políticas incentivadoras de la IED tienen efectividad para aumentar la llegada de los flujos de IED? Según JAMES (2013), para atraer IED, el clima de inversiones es más importante que las políticas incentivadoras. Las políticas para mejorar el clima de inversiones sin reducir la recaudación son, por ejemplo, la mejora de las infraestructuras y el establecimiento de alguna oficina para ofrecer información. Por supuesto, también este tipo de políticas son costosas; pero, no provocan directamente la reducción de la recaudación tributaria. En el caso de las políticas que se usan para la reducción de la recaudación tienen posibilidad de enfrentar una doble pérdida de recursos económicos: el gasto tributario y el coste de las políticas. Comparados con el gobierno central o federal, la mayor parte de los gobiernos locales tienen menos recursos monetarios y humanos para promover la atracción de IED. Por eso, los gobiernos estatales tienen que plantear políticas adecuadas a cada situación y condición.

Asimismo, tenemos que considerar el costo de los gobiernos estatales en México para calcular y ejercer estas políticas. Como se ha dicho, depende de los estados, que no cuentan con suficientes recursos económicos y humanos.

Generalmente, la efectividad de las políticas para atraer la IED se tiene que analizar desde un punto de vista más amplio y a más largo plazo. Aunque se pueda logar el aumento de la IED a través de la reducción de la recaudación, si el gobierno local tiene problemas económicos, será imposible atraer la IED. Por eso, los gobiernos estatales en México tienen que tener objetivos más claros para atraer la IED. 


\section{IV-3. Políticas para atraer IED en el nivel municipal: el caso de Tijuana, Baja California.}

En esta parte, se analizan las políticas municipales para atraer la IED; es decir, qué han hecho las autoridades de una provincia para atraer IED en su nivel municipal. Como un ejemplo de este caso, se analiza el programa de desarrollo de la ciudad de Tijuana, Baja California.

Hay dos motivos para analizar las políticas de esta ciudad. Primero, por su proximidad al mercado de Estados Unidos: Tijuana tiene una larga historia como un destino de IED en México. Segundo, el municipio de Tijuana tiene este plan desde 1992, antes de entrar en vigor el TLCAN. Como se ha analizado en el Capítulo II, justo antes de entrar en vigor el TLCAN, la IED en México había aumentado muy rápidamente. Es muy normal que la ciudad de Tijuana intentara aprovechar esa IED para el desarrollo de su ciudad.

\section{IV-3. 1. Programa de desarrollo de la ciudad de Tijuana, Baja California.}

Hay varios motivos que inducen a los gobiernos locales a establecer sus planes de desarrollo; por ejemplo, para mejorar la competitividad de su territorio, para reducir los desequilibrios territoriales en una misma ciudad, para desarrollar los mercados de factores en el territorio, etc. (LLISTERRI, 2000; ELIZALDE HEVIA, 2003). En el caso de Tijuana, la clave ha sido su competitividad regional como una zona de maquiladora.

El Plan de Desarrollo de Tijuana planteaba el desarrollo de su base económica: se le dio peso específico a la capacidad de la ciudad para generar empleos, modernizar la base empresarial y atraer inversiones congruentes con el desarrollo de la ciudad (FUENTES y FUENTES, 2004). Además, otra característica de este plan fue que se planteó como un plan a medio-largo plazo (para un período de 3-5 años).

En el Plan de Desarrollo de 1992 el ayuntamiento de Tijuana estableció la creación del Consejo de Desarrollo Económico que se encargaría de promover las actividades económicas (FUENTES y FUENTES, 2004, p. 82). En 1993, este Consejo creó un comité en el que participaron los gobiernos del estado y el municipio, y se empezó la planeación estratégica. En octubre de 1995 este comité estableció el Plan Estratégico de 
Tijuana. ${ }^{18}$ Por eso, prácticamente, el plan desarrollo de 1995 fue el primer plan de desarrollo de la ciudad de Tijuana. El objetivo de este plan era crear una "ciudad más competitiva, desde el punto de vista económico y más habitable desde el punto de vista social" (Instituto Metropolitano de Planeación IMPLAN de Tijuana, 2008). Para lograr este objetivo, se identificaron seis temas críticos a atender, de los que se desprenderían los objetivos y proyectos estratégicos:

1. Inversión en recursos humanos

2. Revitalización de la articulación social

3. Esquemas de consolidación urbana

4. Promoción de la ciudad

5. Desarrollo de la base económica

6. Diseño e instrumentación de un modelo de gestión para la ciudad

Es decir, desde el primer paso de su plan estratégico, Tijuana se ha centrado en la importancia de la inversión de recursos humanos para el desarrollo de su territorio. Especialmente, en el caso de Tijuana, la educación y formación para ser técnicos e ingenieros es importante, debido a su localización en una zona de maquiladoras donde la mayor parte son empresas manufactureras. En la próxima sección, se analiza la formación y educación en las educaciones superiores y universidades de Tijuana. Especialmente, se concentra en la formación de técnicos ingenieros.

\section{IV-3. 2. Políticas de formación}

Para las empresas, los recursos humanos son factores importantes que deciden sus actividades. Algunas veces, para las empresas que buscan un lugar de destino para su IED, los recursos humanos en los países de destino son un factor importante que se tiene en cuenta en su decisión de invertir (DUNNING, 1995, p. 81).

Como se ha analizado anteriormente, para las empresas extranjeras que han invertido en México, su bajo coste de la mano de obra ha sido un factor principal a la hora de decidir su IED en México (GUZMÁN y TOLEDO, 2005). Las IED en Tijuana no eran una excepción de esta tendencia.

\footnotetext{
${ }^{18}$ Según información del Consejo de Desarrollo Económico en Tijuana, http://www.cdt.org.mx/historia.aspx, fecha de consulta 16/04/2015. Además, este Consejo tiene un modelo: Bilbao Metrópoli 30. Este proyecto bilbaíno era un motor para impulsar el Museo de Guggenheim, el Centro de Convenciones y la reubicación de la industria en Bilbao.
} 
Sin embargo, al mismo tiempo, para las empresas, la calidad de los recursos humanos es también un factor relevante al decidir sus destinos de IED. Para ellas, "la calidad" de los recursos humanos significa que los trabajadores puedan producir con alta rentabilidad dentro de su cadena de fabricación. Por eso, la formación de sus trabajadores es muy importante (VERACRUZ y DUTRÉNIT, 2004)

Desde el punto de vista de los países destinatarios de la IED, en este caso, México, estas preferencias de las empresas extranjeras dan otra oportunidad para planear otra estrategia de atracción de IED: las políticas de formación de recursos humanos. En el caso de México, la mayor parte de las empresas que invierten en este país son las empresas de las industrias manufactureras. Para estas empresas, contratar ingenieros que tengan buena calidad y capacidad es un factor fundamental para aumentar sus beneficios. Por eso, hay posibilidad de que elijan un lugar como destino de su IED en el que tenga una población con un alto porcentaje de buena formación como ingenieros y técnicos.

Para las actividades de las empresas en la industria de manufacturas, los ingenieros son un factor importante. Sin embargo, al mismo tiempo, no debemos olvidar que, para las actividades de las empresas, se necesitan también personas que no sean ingenieros y técnicos en empresas. Por ejemplo, uno de los objetivos de las actividades empresariales es aumentar los beneficios a través de la venta de sus productos y/o sus servicios. Por eso, se necesitarán empleados que conozcan cómo controlar los costes y beneficios desde el punto de la vista de las finanzas: éste sería el trabajo de los contables. Otro ejemplo: para comprar y vender los productos, las empresas tienen que contratar a sus vendedores o compradores. Para hacer y entender los contratos mercantiles, se necesitarán trabajadores que conozcan las leyes y regulaciones, porque los contratos fuera de las leyes y regulaciones no tienen efecto: éste sería el trabajo de los abogados o asesorías. Es decir, para las actividades empresariales, estos tipos de trabajos, que se suelen llaman "profesionales de papeleos", son también necesarios.

En este parte, se analizan las políticas de educación y formación para los ingenieros y técnicos en Tijuana, que es una de las ciudades principales en la actividad de las maquiladoras. 


\section{IV-3. 2. 1. Antecedentes históricos: Educación Superior y Formación en Tijuana.}

En el sistema educativo de México, cada municipio tiene derecho a planear y ejecutar sus planes de educación y formación. En este contexto, los programas educativos reflejan las condiciones de cada ente local. En el caso de la ciudad de Tijuana no es una excepción.

Tijuana es (y, también, era) una ciudad fronteriza y tiene kilómetros de costa marítima. Basado en esta condición, antes del programa de la Maquiladora, las licenciaturas existentes en Tijuana eran: Oceanología, Medicina Bilingüe, Agronomía, Veterinaria, especialización de maestros, Sociología, Economía, Derecho, Administración Pública, etc. (ABOITES, 2006). Generalmente, antes, se enseñaban en varios programas en institutos y las universidades de Tijuana.

Sin embargo, esta situación cambió a partir de los años 70. El Gobierno central empezó algunas reformas educativas. En la Ley Federal de 1973, la reforma de la enseñanza superior se orientó en dos direcciones principales. Una de ellas era implicar al sistema de Institutos Tecnológicos Regionales en su propagación en el territorio nacional, así como en la reforma de los planes de estudios y en la creación de nuevas carreras (RODRÍGUEZ-GÓMEZ, 1998). Debido a esta diversificación del sistema, el Instituto Tecnológico de Tijuana se creó en 1971 y el Instituto Tecnológico de Mexicali en 1982 (ESCALANTE VALDEZ, 2008). Es decir, desde la década de 1970, el gobierno de México ha intentado mejorar sus condiciones de la educación superior de carácter tecnológico.

En los años 1980, mientras México estaba sufriendo por la crisis económica, el gobierno central tuvo que reducir sus presupuestos para la educación. Sin embargo, al mismo tiempo, el gobierno hizo una inversión en dos lugares importantes. Primero en la enseñanza primaria y segundo en el desarrollo de modalidades de enseñanza media superior de carácter tecnológico (RODRIGUEZ-GOMEZ, 1998, p. 180). Es decir, debido a la limitación de recursos económicos, el gobierno de México concentró su política educativa. Además, en las ciudades de Tijuana y Ciudad Juárez se abrieron unas 50 nuevas plantas por año entre 1980 y 1992. Esto significa que en promedio se crearon unas 300 nuevas posiciones gerenciales cada año durante ese periodo (CONTRERAS, ESTRADA y KENNEY, 1997). Por eso, el gobierno central, estatal y municipal 
establecieron carreras para ser técnicos e ingenieros en las universidades y los institutos de estas zonas de la frontera norte.

Por lo tanto, en los años 1970 y 1980, el gobierno de México había promovido la mejora de la enseñanza superior de tecnología. Este movimiento se convirtió en un factor importante, especialmente en Tijuana en la década de 1990, cuando se empezó a negociar el TLCAN.

Tijuana es una de las ciudades que tiene más habitantes en la frontera norte de México. Además, en esta zona, ya había varias universidades desde 1970, como se analizó antes. Esta situación era muy favorable para formar técnicos e ingenieros para las maquiladoras. Cuando el gobierno central de México empezó a aprovechar la zona de Maquiladora para aumentar las exportaciones desde su país, el gobierno central también empezó a intervenir en el sistema educativo de Tijuana.

El objetivo del gobierno central en educación superior y formación para Tijuana era aumentar los recursos humanos de técnicos e ingenieros para trabajar en la maquiladora (ABOITES, 2006, p. 228). En este contexto, hubo un aumento de las instituciones y universidades para estudiar tecnologías e ingenierías, mientras que las facultades que no fueran de industriales, por ejemplo, medicina bilingüe, agronomía, sociología, economía, derecho, administración pública, se redujeron.

Teniendo en cuenta este punto de partida, en la siguiente sección se analiza la formación de ingenieros/técnicos.

\section{IV-3. 2. 2. Formación de técnicos e ingenieros en Tijuana}

\section{IV-3. 2. 2. 1. Formación de técnicos.}

Actualmente, en Tijuana hay 29 institutos tecnológicos. Esta cifra significa que más del $20 \%$ de todos los institutos de Tijuana son institutos tecnológicos. El Anexo IV1 muestra los institutos tecnológicos existentes en Tijuana.

Como se puede apreciar, hay tres tipos de institutos tecnológicos: el CECYTE, el CONALEP y el CBTIS (véase el Anexo IV-1). En primer lugar, se encuentra el Colegio de Estudios Científicos y Tecnológicos (CECYTE). En Tijuana, hay 20 institutos de esta categoría. En 1998, fue creado por el Ejecutivo Estatal como organismo público 
descentralizado del Gobierno del Estado, con personalidad jurídica y patrimonio propios, cuya cabeza de sector es la Secretaría de Educación y Bienestar Social. Su objetivo es contribuir, impulsar y consolidar los Programas de Educación Media Superior Tecnológica en la entidad. ${ }^{19}$ Según su página web, como motivos de la creación del CECYITE se identifican dos antecedentes importantes en Baja California desde los años 1980 y 1990: el aumento del número de entradas en la educación secundaria y la participación del sector productivo, en particular a través de los Comités de Vinculación de Mexicali y Tijuana, quienes avalaron la creación de nuevas instituciones de educación media superior de carácter tecnológico que permitieran formar recursos humanos cualificados para afrontar los retos de la globalización, la productividad y la competitividad. En agosto de 1998, empezaron a operar el Plantel Florido y el Plantel Pacífico con grupos de Electrónica y de Mantenimiento. ${ }^{20}$

En segundo lugar, está el Colegio de Estudios Científicos y Tecnológicos (CONALEP). Solo hay dos institutos de esta categoría en Tijuana. El origen de CONALEP es un poco antiguo: en 1978, fue creado por decreto presidencial, como un Organismo Público Descentralizado del Gobierno Federal. En 1993, uno de los objetivos del sistema educativo del CONALEP era "abrir las expectativas en materia de capacitación laboral, vinculación intersectorial, apoyo comunitario, asesoría y asistencia tecnológicas a las empresas ${ }^{21}$ ". Se nota que hay una característica del sistema educativo del CONALEP: hay varios cursos, que no son sólo para ser técnicos ${ }^{22}$.

Por último, está el Centro de Bachillerato Tecnológico Industrial y de Servicios (CBTIS). Hay 6 institutos de esta categoría en Tijuana. El CBTIS es una parte del sistema educativo de la Dirección General de Educación Tecnológica Industrial (DGETI). En 1971, la DGETI integró los centros de capacitación para el trabajo industrial, escuelas

\footnotetext{
${ }^{19}$ CECYTE Baja California. Disponible en http://www.cecytebc.edu.mx/cecyte/cecyte_historia.asp, fecha de consulta: 20/5/2015.

20 CECYTE Baja California. Disponible en http://www.cecytebc.edu.mx/cecyte/cecyte_historia.asp, fecha de consulta: 20/5/2015.

${ }^{21}$ CONALEP Baja California. Disponible en http://www.conalepbc.edu.mx/index.php/quienessomos/historia.html, fecha de consulta: 19/5/2015.

${ }^{22}$ En el caso de Tijuana, los primeros cursos técnicos o profesionales en el Instituto Tijuana I fueron "productividad y contabilidad fiscal" en 1980. Luego, hubo una carrera para ser técnicos: "combustión interna automotriz," "mecánico electricista", "electromecánica industrial" y "mantenimiento de microempresas." Ahora, en el Tijuana I, hay cursos de "contaduría," “electromecánica industrial," "mantenimiento de sistema de electrónicos," "mantenimiento de equipo de cómputo." En el Instituto Tijuana II los primeros cursos fueron "asistente ejecutivo" y "hostelería y gastronomía". Después se aumentaron con cursos como "comercio exterior" e "informática." Ahora, se ofrecen las carreras de "administración," "alimentos y bebidas" y "conservación del medio ambiente" y "informática."
} 
tecnológicas industriales, los centros de estudios tecnológicos en el Distrito Federal y los centros de estudios tecnológicos foráneos. En todo México, hay 168 CBTIS. ${ }^{23} \mathrm{Al}$ ver sus cursos, se nota que la mayor parte de ellos son para ser técnicos.

Estos tres centros educativos son los centros existentes en Tijuana para ser técnicos. Como se acaba de analizar, el origen del CBTIS y el CONALEP se remonta a 40 años atrás. Sin embargo, por necesidad de reformar los centros, éstos se convirtieron en centros de formación para técnicos industriales. Por el contrario, el CECYTE es muy nuevo, comparado con los otros dos centros. Además, según se muestra en el Anexo IV1, se observa que los institutos del CECYITE, comparados con los otros dos tipos de institutos, tienen más programas especializados en la tecnología electrónica. Por su parte, el CBTIS presenta una mayor variedad de programas.

Bajo este sistema, el 55,4\% de los jóvenes inscriptos en la educación media superior está en algún plantel técnico (ABOITES, 2006, p. 224). Desde el punto de vista de la formación técnica, se considera que los recursos humanos en Tijuana están bien preparados.

Además, el Consejo de Desarrollo de Tijuana (CDT) ha intentado establecer la vinculación entre los estudiantes en estos institutos tecnológicos y la actividad en las empresas japonesas. Los trabajadores de las empresas japonesas participan en actividades de $5 S^{24}$. El CDT decidió mandar algunos estudiantes del instituto a fábricas japonesas para practicar la actividad de 5S. Los estudiantes de estos institutos tecnológicos tenían experiencia de prácticas en las fábricas.

Basándose en estas actividades en el pasado, el Consejo de Desarrollo de Tijuana considera que es necesaria la formación de nuevos técnicos con más alto nivel. Este consejo tiene un plan para establecer un preparatorio de tecnología en Tijuana. ${ }^{25}$ En el sistema educativo en México, hay tres opciones después de graduarse de la educación secundaria: Bachillerato, Preparatorio y Técnicos. Los preparatorios son públicos y tienen

\footnotetext{
${ }^{23}$ Secretaría de Educación Pública, Subsecretaría de Educación Media Superior, Dirección General de Educación Tecnológica Industrial, del Gobierno de México. Disponible en http://www.dgeti.sep.gob.mx/index.php?option=com_content \&view=article\&id=61\&Itemid=476, fecha de consulta: 18/05/2015.

${ }^{24}$ La actividad de $5 \mathrm{~S}$ es una actividad para mejorar las condiciones laborales y la participación de los trabajadores. Se empezó en las fábricas japonesas en la década de 1980, según información de Nijon Bizup Kabusiki Gaisya. https://04510.jp/factory-times/305/, fecha de consulta: 19/07/2015.

${ }^{25}$ Información obtenida en la entrevista de la doctoranda con el Sr. Rafael Trujillo del Consejo de Desarrollo de Tijuana (CDT), realizada en Tijuana en junio de 2015.
} 
relación con las universidades públicas de México. Al contrario, los bachilleratos son privados y no tienen relación con las universidades.

Su plan del Preparatorio de Técnicos en Tijuana significa dos cosas. Primero, que existe la necesidad de formación de técnicos con más alta calidad y mayor especialización. Segundo, que busca una relación más fuerte entre la educación para técnicos y la educación universitaria. En cuanto a la primera motivación, se hace referencia a la necesidad de desarrollar la tecnología. Por ejemplo, ahora, en las empresas maquiladoras hacen falta técnicos que tengan capacidad de diseño de productos y procesos de fabricación. ${ }^{26}$ Para diseñar los procesos de fabricación, se necesitarán técnicos que conozcan todas las partes del proceso de fabricación.

Además, las maquinarias para las fabricaciones son ahora más complicadas de operar. Por eso, también los técnicos tienen que saber controlar estas maquinarias y de ahí, que se necesiten técnicos con un mayor nivel en las maquiladoras (CONTRERAS y HUALDE ALFARO, 2004). El primer objetivo del plan del Preparatorio de Técnicos es formar nuevos técnicos con conocimientos de últimas tecnologías. Sobre la relación entre la educación para técnicos y la educación universitaria, ésta supone intentar abrir una vía por la cual los técnicos pueden llegar a ser ingenieros. Es una manera de formar los técnicos requeridos con un mayor nivel de cualificación.

Hay otro motivo para que el gobierno de Tijuana esté promoviendo su plan del Preparatorio de Técnicos. El gobierno local busca cambios en el modelo de fabricación: en concreto, pasar de la fabricación de "más volumen y menos variedad" hacia la de “menos volumen y más variedad." 27 Para lograr este cambio en la manera de fabricación, se necesitará más técnicos que puedan adaptar varias tecnologías para las fabricaciones. Teniendo en cuenta todo esto, actualmente, en la ciudad de Tijuana se intenta aumentar el número de técnicos de alto nivel.

\footnotetext{
${ }^{26}$ Información obtenida en la entrevista de la doctoranda con el Sr. Sergio Langarica de la Cámara Nacional de la Industria Electrónica de Telecomunicaciones y Tecnologías de la Información (CANIETI), realizada en Tijuana en mayo de 2015.

${ }^{27}$ Información obtenida por la doctoranda en la entrevista con el Sr. Eduardo Gonzales de ProMéxico en Tijuana en junio de 2015.
} 


\section{IV-3. 2. 2. 2. Formación de ingenieros}

Desde la década de 1990, la ingeniería industrial es una de las veinte titulaciones más demandadas en la educación superior de México y la de mayor concentración de estudiantes en el área de la ingeniería. En 1995 representó el 5,1\% del total de alumnos mexicanos en educación superior y el 39\% de los alumnos matriculados en los Institutos Tecnológicos (VARGAS LEYVA, 1999).

Comparada con la formación de técnicos en la educación media y superior, la formación de ingenieros depende del gobierno local; es decir, la organización del plan de estudios en las universidades la puede decidir el gobierno local. En este sentido, las carreras en las universidades se diseñan de acuerdo a las condiciones y situaciones locales. Las carreras universitarias en Tijuana no son una excepción. Sin embargo, desde el fin de la década de 1980, la intervención del gobierno central en este ámbito fue más fuerte que antes (RUIZ-LARRAGUIVEL, 2011).

Actualmente, hay 6 universidades públicas y 24 universidades privadas en Tijuana. De las cuales, hay dos universidades públicas y una universidad privada que están especializadas en tecnología. No obstante, al ver el número de carreras, se nota que hay muchas posibilidades de formación de ingenieros en las universidades en Tijuana.

En los Anexos IV-2 y IV-3 se presentan las diferentes carreras impartidas en las Universidades de Tijuana en 2015. Se aprecia que el $27 \%$ de las carreras de las universidades públicas y el 12,6\% de las carreras de las universidades privadas son para la formación de ingenieros. Teniendo en cuenta estas cifras, se puede decir que las carreras para la formación de ingenieros en las universidades de Tijuana no son mayoritarias.

Existe una gran variedad de carreras universitarias en Tijuana, que viene explicada por varios motivos. Uno de ellos es el cambio de la política educativa. Antes, como se ha analizado anteriormente, el número de carreras en las universidades de Tijuana había aumentado porque las autoridades de México habían pensado que el aumento del número de ingenieros iba a ayudar a atraer a más empresas extranjeras en la maquiladora.

No obstante, tanto el gobierno central como el municipal han observado que hay más demanda de técnicos que de ingenieros para la maquiladora. Las empresas que tienen fábricas en la maquiladora buscan sus recursos humanos de ingenieros en todo México 
(HUALDE ALFARO, 2001). Trabajadores con el nivel de ingenieros, pueden encontrarse en Monterrey, DF y San Diego. Es decir, para buscar nuevos ingenieros, las empresas pueden buscarlos en todo México y por eso, no necesitan buscarlos solo en Tijuana. Además, en el caso en Tijuana, San Diego está al lado. Por eso, muchos estudiantes que desean ser ingenieros se van a las universidades de San Diego. Ante esta situación, las universidades de Tijuana empezaron a aumentar la oferta de titulaciones más allá de aquéllas dedicadas a la formación de ingenieros. ${ }^{28}$

En realidad, las personas que tienen el título de "ingenieros" no trabajan solo en el proceso de producción. Por ejemplo, en una empresa de productos médicos cuyo principal producto son los catéteres para el corazón, los ingenieros trabajan tanto en el proceso de producción como en el control de la calidad. ${ }^{29}$ Además, según VARGAS LEYVA (1999, p. 5), la práctica profesional de la ingeniería industrial y electrónica se caracteriza no solo por el dominio de los procesos industriales, sino también de otras facetas tales como el conocimiento de productos y la creación de nuevos diseños. En estas situaciones de trabajo, las cosas que se demandan de los "ingenieros" son más cuestiones relacionadas con el conocimiento amplio de la fabricación de los productos, desde cuestiones de logística hasta cuestiones de formación de los trabajadores.

Además, para ser gerentes en las fábricas de Tijuana, es casi obligatorio poseer el título de ingeniero. Según la investigación de CONTRERAS, ESTRADA y KENNEY (1997, p. 673), las carreras más comunes en la formación profesional de los gerentes son las ingenierías (71,4\% del total), con un claro predominio de la ingeniería industrial. Una proporción importante de estos profesionales $(39,1 \%)$ realizó sus estudios en las instituciones locales ubicadas en Tijuana y Ciudad Juárez.

Teniendo en cuenta esto, para la formación de los trabajadores en el nivel de "ingeniero" en las universidades, se necesita cursos amplios que se relacionen con la fabricación. Es decir, para formar buenos "ingenieros" se necesitan en las universidades, por ejemplo, buenos cursos de logística y de recursos humanos y formación de trabajadores. Además, estos cursos se deben basar en actividades reales y prácticas en las empresas.

\footnotetext{
${ }^{28}$ Información obtenida por la doctoranda en la entrevista con el Sr. Sergio Langarica de la Cámara Nacional de la Industria Electrónica de Telecomunicaciones y Tecnologías de la Información (CANIETI), realizada en Tijuana en mayo de 2015.

${ }^{29}$ Información obtenida por la doctoranda en la entrevista en MedToronic en Tijuana en junio de 2015.
} 
En el caso de Tijuana, hay un ejemplo de esta vinculación entre el mundo educativo y las empresas maquiladoras: los Comités de Vinculación. Estos Comités llevaron a cabo una labor positiva al reunir a las instituciones educativas y a los empresarios para realizar algunos eventos y efectuar sondeos acerca de las "necesidades de capacitación" (HUALDE ALFARO, 2001).

A pesar de esta experiencia positiva, lo cierto es que a las universidades de Tijuana les falta una mayor relación con las empresas de la maquiladora. Aunque hay algunos sistemas de prácticas en las empresas, la relación entre las universidades y las empresas maquiladoras no es muy activa. (HUALDE ALFARO, 2001, p. 17). De ahí que los ingenieros no acaben conociendo bien cuál es la situación real de las empresas y ello les dificulta la consecución de un puesto de trabajo. Esto también ha inducido a que haya una cierta limitación en el número de carreras de ingenieros en Tijuana.

En este contexto, Tijuana está actualmente intentando aumentar la formación de técnicos más que la de ingenieros. De hecho, el Consejo de Desarrollo de Tijuana está trabajando para establecer la Preparatoria de Técnicos. 


\section{IV-4. La relación entre las industrias y las políticas industriales para atraer IED en México: el caso de la industria de call-center (centro de llamadas)}

En esta sección se analizan las relaciones entre las industrias y las políticas industriales de México para atraer la IED. Para ello, se ha seleccionado la industria de call-center (centro de llamadas) como estudio de caso. Hay tres razones que justifican esta elección.

La primera razón por la que se analiza en esta parte es por la dependencia de esta industria del desarrollo de las tecnologías de la información y la comunicación (TICs). Cuando esta industria nació en Estados Unidos en la década de 1970 (MICHELI THRION, 2007), para su funcionamiento sólo se necesitaba el teléfono y sus correspondientes líneas, Sin embargo, últimamente, los teléfonos se conectan directamente a los ordenadores y estos ordenadores llaman automáticamente a sus clientes. Asimismo, a principios de los años setenta aparecieron los dispositivos de distribución de llamadas controlados por ordenador (Automatic Call Distributor, ACD) y en 1972 este sistema se aplicó por primera vez en el call-center de Continental Airlines. Por eso, para el desarrollo de esta industria, se necesita infraestructura para usar el ordenador y los datos electrónicos. (MICHELI THRION, 2007, p. 218).

La segunda razón es que, aunque esta industria necesita sistemas digitalizados, esta industria sigue dependiendo de los recursos humanos, o sea, requiere mano de obra. Históricamente, las industrias mexicanas que se han desarrollado en el país son aquellas industrias que necesitan un número importante de trabajadores con bajo costes. En este sentido, se puede decir que la industria de call-center es una industria típica de México.

Por último, la tercera razón es que las políticas industriales tienen un papel importante para el desarrollo de la industria de call-center. Estas políticas ayudan a establecer de un modo coordinado los principales componentes de los que depende su desarrollo.

\section{IV-4. 1. Industria de call-center: definición y principales características}

Según MICHELI THRION (2007, p. 221), “el call-center y sus proveedores tanto de tecnología como de recursos humanos, conforman una industria cuya producción final 
es la comunicación e información para las empresas. El espacio de flujos de interacción y la información que se recaba, almacena y transforma pueden verse como un telemercado que se va construyendo a partir de la intervención de los call-center en mercados originales de bienes y servicios." Es decir, el call-center es una forma de marketing directo a través del sistema telefónico. La industria de call-center es una manera de hacer marketing, esto es, de analizar las preferencias y opiniones de los consumidores.

Por otra parte, según GUADARRAMA, HUALDE ALFARO y LÓPEZ (2014) la industria de call-center tiene algunas características especiales relacionadas con sus recursos humanos. La primera característica es que los trabajadores en esta industria son jóvenes con altos niveles de educación. La otra característica es la alta rotación de trabajadores que se percibe en los call-centers a escala internacional. Aunque estas características son importantes para investigar esta industria, no debe olvidarse que estas dos características inducen otras características de la industria de call-center.

Las características mencionadas inducen una preferencia de localización: la industria tiende a concentrarse dentro de una zona urbana central, que tiene especialmente, población joven. También, cabe la posibilidad de que algunas empresas quieran tener sus centros de contacto cerca de las zonas universitarias. En suma, la localización de las empresas de call-center se suele concentrar allá donde haya población joven estudiante.

Además, la mayoría de los call-centers de 24 horas tiene horarios con turnos para sus trabajadores. Por ejemplo, hay horarios de trabajo desde las 09:00 a las 17:00, desde las 17:00 a las 22:00 y desde las 22:00 a las 09:00. Estos horarios con turnos permiten que los estudiantes puedan entrar en el mercado de trabajo de la industria de call-center. El problema de este tipo horario de trabajo es que induce precariedad laboral; es decir, el trabajo en el call-center es más inestable (GUADARRAMA, HUALDE ALFARO y LOPEZ, 2014, p. 123).

Otra característica de esta industria que no tiene que ver con los recursos humanos, es que sus actividades dependen de las actividades de otras industrias. La razón de ser de la industria de call-center es la venta. Sin embargo, esta industria no produce nada materialmente. Por eso, la relación con otras industrias es importante. Por ejemplo, en el caso de México, el sector financiero y el de telecomunicaciones son los que más han desarrollado este tipo de servicios, aunque en los últimos años se percibe una mayor diversificación (GUADARRAMA, HUALDE ALFARO y LOPEZ, 2014, p. 119). 
En definitiva, las singularidades de los trabajadores, el tipo de localización y la relación con otras industrias son tres características importantes de la industria de callcenter.

\section{IV-4. 2. Historia de la industria de call-center}

En México, se empezó a desarrollar la industria de call-center en la década de 1990. No obstante, desde la década de 1970, las empresas estadounidenses ya comenzaron a establecer sus call-centers por medio de subcontrataciones (MICHELI THRION, 2004). El primer call-center de estas características se estableció en México en 1973. El segundo y tercer call-center se establecieron en México en la década de 1980. En 1989, TELEMANTRA comenzó a desarrollar sus actividades en México y un año después, lo hizo la empresa MEGADIRECT.

TELEMANTRA - que posteriormente, se convirtió en Ticket Master-se dedicaba a vender entradas de conciertos de música, teatro y deportes. Una de las principales razones del establecimiento de esta empresa en la década de 1990 fue la celebración del Gran Premio de México de Fórmula I, ya que su primer trabajo fue la venta de las entradas para acudir a esta carrera de Fórmula I. ${ }^{30}$

Por lo que se refiere a MEGADIRECT, una característica de la actividad de este call-center era su tamaño: tenía 1.500 puestos. Hasta ese momento, ninguna empresa de call-center había tenido este tamaño.

Todo esto indica que, en México hasta casi la década de 1990, las empresas de call-center no habían iniciado plenamente sus actividades. Hay algunas razones que explican que el desarrollo de la industria de call-center en México tuviera que esperar hasta los años noventa. La primera razón se encuentra en la evolución de la tecnología de los centros de atención telefónica en Estados Unidos en la década de 1980, que llevó a la creación de instrumentos que permitieron la realización masiva de llamadas. (MICHELI THRION, 2007, p. 221). Gracias a esta evolución, se pudieron llamar y recibir varias

\footnotetext{
${ }^{30}$ Artículo de la entrevista a Roberto Kenny. Disponible en http://www.revistapantalla.com/telemundo/entrevistas/?id_nota=2923, fecha de consulta: 24/2/2008.
} 
llamadas desde distintos clientes al mismo tiempo. Esta evolución permitió a la industria de call-center expandir su tamaño y aumentar el número de trabajadores.

En este contexto, la industria de call-center necesitaba un mayor número de trabajadores para poder aumentar sus beneficios. Sin embargo, en la década de 1980, el coste de la mano de obra en Estados Unidos era bastante alto. Como en el caso de las empresas manufactureras estadounidenses, la industria de call-center también buscaba un mayor volumen de recursos humanos de bajo coste. Por eso, la necesidad de reducir el coste de la mano de obra fue uno de los principales motivos de la deslocalización de la industria de call-center hacia otros países. El desarrollo de la tecnología telefónica fue un primer factor que hizo posible el desarrollo de la industria de call-center en México y un segundo factor fue la necesidad de deslocalización para reducir los costes laborales, conocida como subcontratación fronteriza o nearshoring.

Además, al final de la década de los años ochenta, la economía estadounidense estaba sufriendo una recesión. Esta situación obligaba a las empresas a reestructurarse con objeto de reducir sus costes. Una manera de reducir costes era la subcontratación internacional (offshoring), esto es, las empresas llevaban el desarrollo de algunas de sus actividades hacia otros países (STACK y DOWNING, 2005). A través del traslado a otros países, por ejemplo, desde Estados Unidos a México, se podía reducir el coste de la mano de obra. Las actividades de las empresas como las de call-center se podían trasladar más fácilmente fuera de Estados Unidos: no se trataban de actividades que se tenían que hacer cara-a-cara directamente con sus clientes, y, además, allí donde había una línea de teléfono, se podía llevar a cabo estas actividades. Como se ha comentado anteriormente, el desarrollo de la tecnología telefónica en los años 1980 permitió los offshoring de los call-center. En este contexto, las empresas estadounidenses decidieron hacer offshoring de sus secciones de call-center, para poder acceder al beneficio del menor coste de la mano de obra mexicana. La recesión estadounidense y la consecuente necesidad de offshoring es el segundo factor de desarrollo de la industria de call-center en México

Otro factor de desarrollo de esta industria, se encuentra en el cambio demográfico vivido por Estados Unidos en las últimas décadas. Las empresas estadounidenses pudieron disfrutar de otra ventaja de la localización de sus call-centers en México: podían ofrecer un servicio bilingüe a sus clientes. Esta ventaja procede de los cambios demográficos acontecidos en Estados Unidos entre 1860 y 2014. Como muestran los 
Gráficos IV-4. 1. y IV-4. 2, la población de origen hispano en Estados Unidos ha aumentado sustancialmente en las últimas 4-5 décadas y se espera que continúe así en el futuro. Especialmente, desde la década de los noventa, el aumento de la población de origen hispano ha sido muy rápido. Esto significa que estos hispanos se convirtieron en importantes consumidores en Estados Unidos. Para ganar su confianza, las empresas estadounidenses prepararon su servicio de atención al cliente bilingüe inglés-español.

El Gráfico IV-4.3 pone en evidencia otra ventaja de la industria call-center en México, en concreto que aproximadamente el $60 \%$ de los hispanos en Estados Unidos tiene origen mexicano. Conocer la preferencia de estos hispanos es una ventaja para las empresas de la industria de call-center localizadas en México.

Gráfico IV-4. 1. Hispanos en Estados Unidos: nacidos dentro o fuera de Estados Unidos. 1960-2014

(En millones)

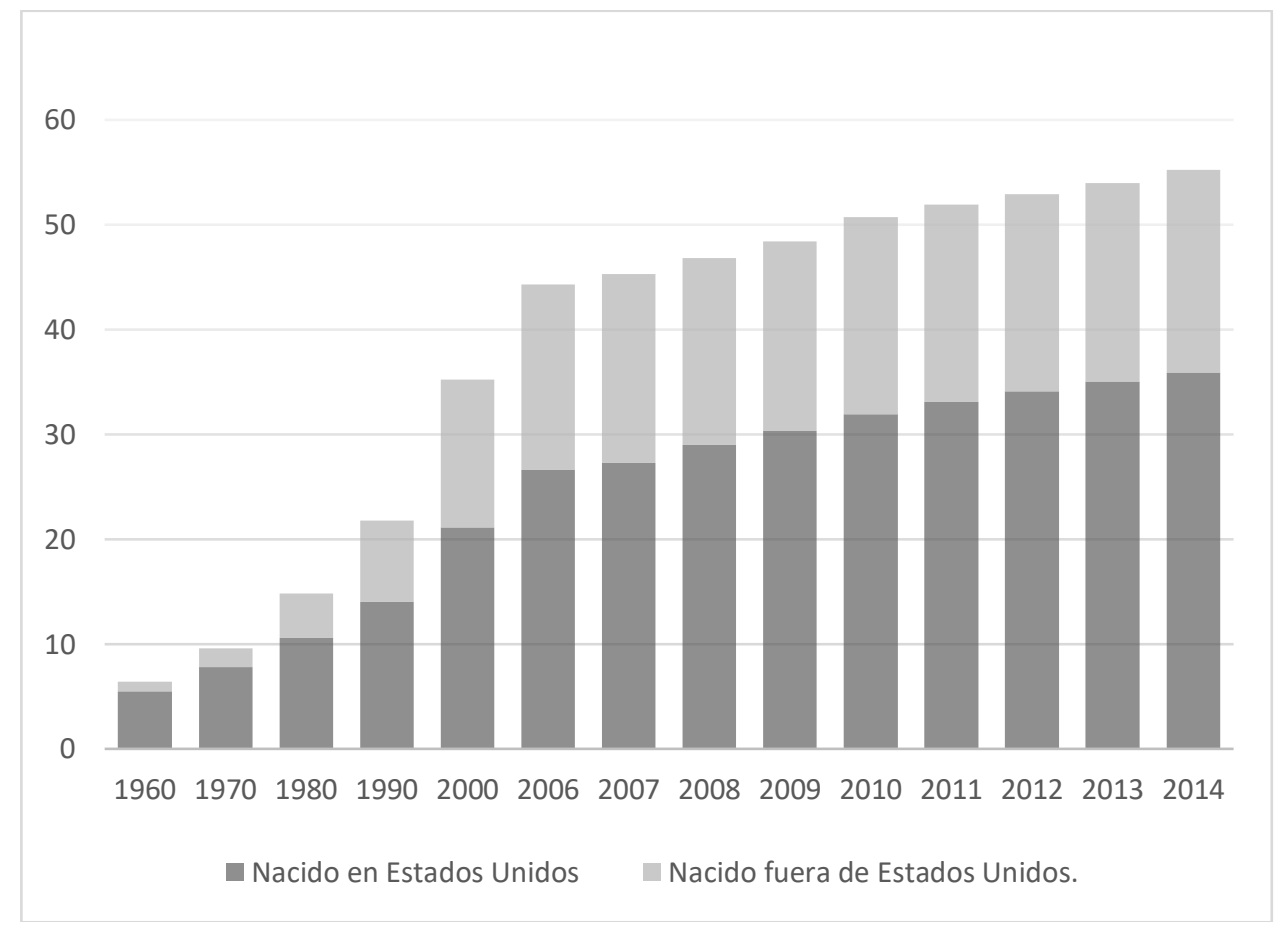

Fuente. Tomado de Pew Research Center, disponible en http://www.pewhispanic.org/2016/04/19/statistical-portrait-of-hispanics-in-the-united-states/, fecha de consulta: 15/1/2017. 
Gráfico IV-4. 2. Porcentaje de los hispanos en Estados Unidos. 1960-2014.

(En porcentajes)

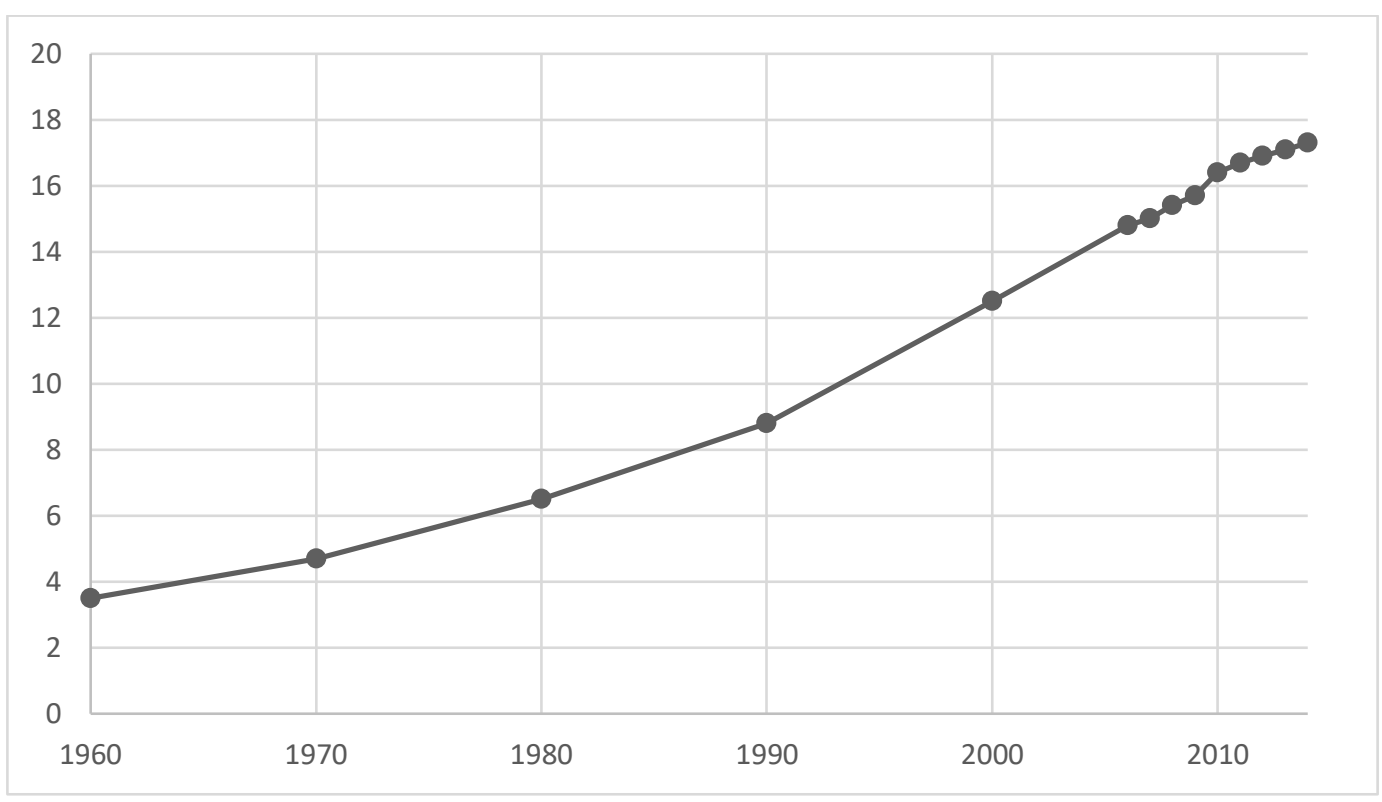

Fuente. Tomado de Pew Research Center, disponible en http://www.pewhispanic.org/2016/04/19/statistical-portrait-of-hispanics-in-the-united-states/ fecha de consulta: 15/1/2017.

Gráfico IV-4. 3. Porcentaje de los hispanos en Estados Unidos. Orígenes Mexicanos y nomexicanos. 1960-2014.

(En porcentajes)

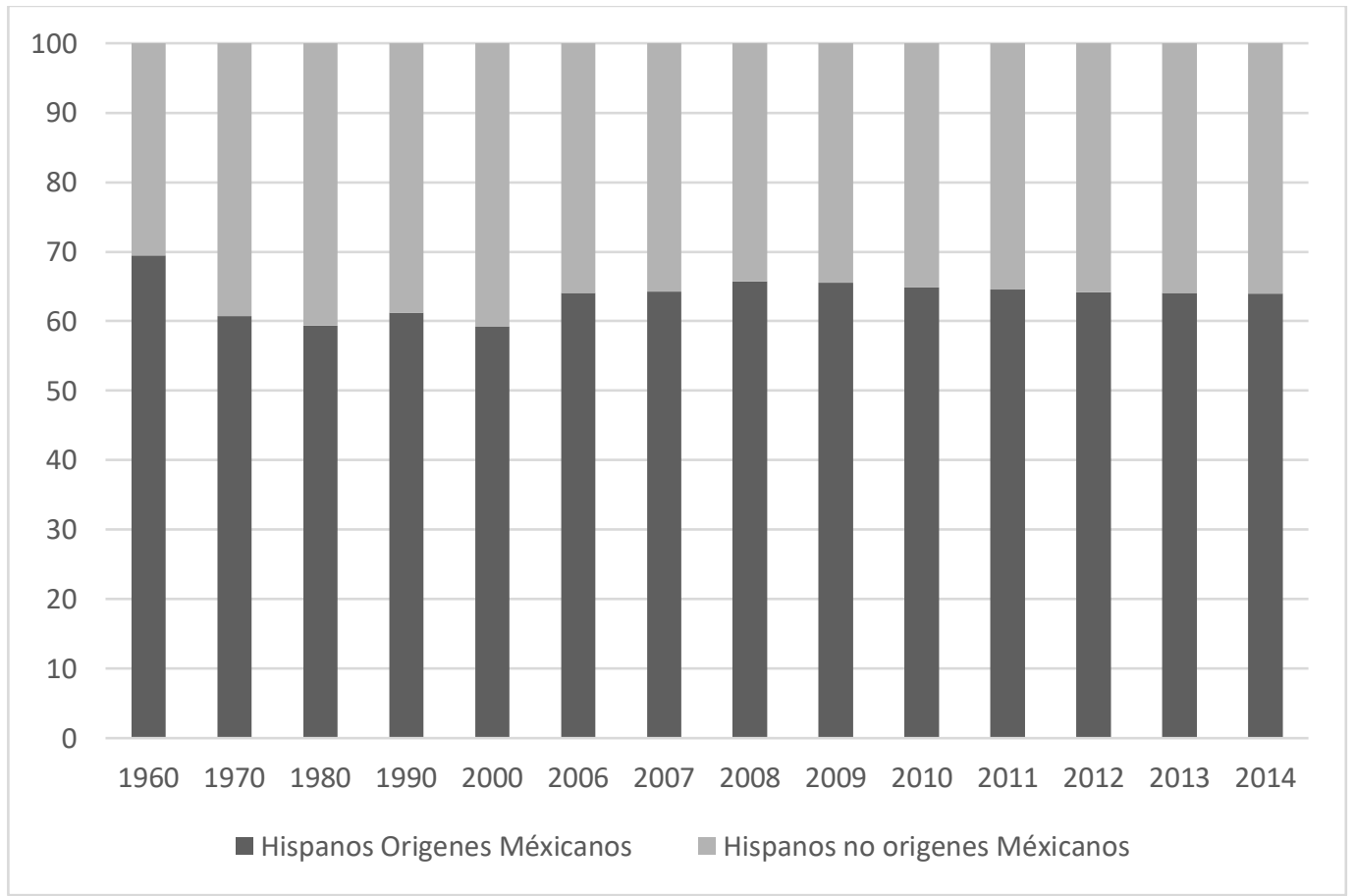

Fuente. Tomado de Pew Research Center, disponible en http://www.pewhispanic.org/2016/04/19/statistical-portrait-of-hispanics-in-the-united-states/ fecha de consulta: 15/1/2017. 
Para esta estrategia de marketing basada en las raíces mexicanas de los nuevos consumidores, la deslocalización de los call-center en México tenía una gran ventaja: se podía atender el aumento de la demanda de los emigrantes estadounidenses de origen mexicano, así como la de otros de origen latinoamericano. Era más fácil encontrar operadores que hablaran español y conocieran sus costumbres en sus países de origen que en Estados Unidos. Estos operadores tenían una mejor capacidad para vender sus productos a la comunidad latina. Es decir, emplear mexicanos era un factor importante para aumentar los beneficios de estas empresas.

Para las empresas de call-center estadounidenses, el traslado a México redujo el coste de sus operaciones y aumentó las posibilidades de expandir sus beneficios. En medio de la recesión de los años ochenta, las empresas estadounidenses se aprovecharon de las posibilidades que ofrecía México y la industria de call-center empezó a desarrollarse en México.

Desde el final de la década de 1980 y durante la década de 1990, la tecnología telefónica avanzó muy rápidamente (MICHELI THIRIÓN, 2007, p. 219). En el inicio de los años noventa, se vendieron los primeros teléfonos móviles en México. Asimismo, se fundaron empresas de móviles, como Iusacell, Telcel, Unefon y Pegaso. Simultáneamente, se establecieron proveedores de servicios de Internet (ISP), como Internet de México, Compuserve, Prodigy, Interplanet, entre otros. ${ }^{31}$ La popularidad de los teléfonos móviles hizo aumentar el número de usuarios de teléfonos en México. Para la industria de callcenter, este aumento era una gran oportunidad para su negocio. Esta situación significaba que, desde el punto de vista de la industria de call-center, México era un importante mercado para ampliar sus beneficios. Este factor fue otro incentivo para el desarrollo de esta industria en México en la década de los noventa.

Además, esta tendencia supuso también un movimiento hacia las subcontrataciones (out-sourcing) $)^{32}$, que se estaban acelerando en esa época (MICHELI

\footnotetext{
${ }^{31}$ Instituto Méxicano de Telemarketing, disponible en http://www.imt.com.mx/revistaCF/2014/02Marzo/files/assets/common/downloads/REVISTA58.pdf, fecha de consulta: 22/7/2017.

${ }^{32}$ La subcontratación (out-sourcing) es "una decisión estratégica que incluye contrataciones externas de determinantes actividades no estratégica o de procesos necesarios de negocios para fabricar bienes o servicios, a través de acuerdos o contratos con empresas que tiene más capacidad de estas actividades y procesos de negocio, con el objetivo de la mejorar las ventajas comparativas" (ESPINO-RODRÍGUEZ y PADRÓN-ROBAINA, 2006; TREJO FLORES y NAVARRETE, 2009, p.13).
} 
THIRIÓN, 2012). Estas subcontrataciones venían de la necesidad que tenían las empresas de reducir sus costes para aumentar su competitividad (TREJO FLORES y NAVARRETE, 2009, pp. 20-22; MONTARCÉ, 2009). Como se analizará posteriormente, este proceso de subcontrataciones fue uno de los motivos del desarrollo de la industria de call- center en Baja California.

La mayor parte de las empresas en la industria de call-center en México se fundaron en la década de 1990. En 1991, se fundó el Instituto Mexicano de Telemarketing, que posteriormente se convirtió en el actual Instituto Mexicano de Teleservicios. Este Instituto está formado por un grupo de empresas de call-center que buscaban promover el conocimiento de sus actividades. Como hemos analizado en la sección anterior, para las actividades de las empresas de call-center se necesitan de las relaciones con otras industrias. Este Instituto ha servido para dar a conocer las actividades que la industria de call-center puede ofrecer a otras industrias.

En la Tabla IV-4. 1. se recogen los call-centers establecidos en México entre 1973 y 2008. Se observa que en los call-centers creados en los años de 1990, el número de estaciones era muy alto. Como se muestra en el Gráfico IV-4. 4, el número de estaciones aumentó en el período indicado. Asimismo, se puede notar que las localizaciones de los call-centers eran muy variadas. En los años de 1970 y 1980, su principal localización era México D.F. Sin embargo, desde la década de 1990, sus localizaciones se expandieron desde Tijuana y Monterrey en el norte de México hasta el Estado de Tabasco, en el sur de México. El aumento del número de estaciones y de localizaciones de call-center son dos evidencias del desarrollo de la industria de call-center.

En la década de 2000, la tendencia del "gran call-center" empezó a desaparecer mientras que, al mismo tiempo, surgieron los clústeres de la industria de call-center en México. La creación de estos clústeres indujo la disminución en el número de estaciones de los call-centers. Una ventaja del clúster industrial era que hacía posible la reducción de los costes de operación, así como de los costes laborales. Esto significaba que la empresa no necesitaba gastar tanto dinero para desarrollar sus recursos humanos. Por eso, la aparición de los clústeres de la industria de call-center fue uno de los motivos que condujo a la desaparición del gran call-center. 
Tabla IV-4. 1. Call-centers en México, 1973-2008

\begin{tabular}{|c|c|c|c|}
\hline Años & Empresas & $\begin{array}{l}\text { Número de } \\
\text { estaciones }\end{array}$ & Localizaciones \\
\hline 1973 & PIONEX & 400 & D.F. y Ciudad Juárez \\
\hline 1985 & EDS-CENTROBE & 200 & D.F. y Ciudad Juárez \\
\hline 1986 & EDITORIA CIENTIFICA MEXICANA & 400 & D.F. \\
\hline 1989 & TELEMANTRA & & \\
\hline \multirow{2}{*}{1991} & TELESHOP MEXICO & 45 & D.F. \\
\hline & MEGADIRECT & 1500 & D.F. \\
\hline \multirow{3}{*}{1992} & AMERICALL & 90 & San Pedro, Garza Nuevo León \\
\hline & SEVINEXT & 823 & Puebla \\
\hline & SKYTEL & 200 & D.F, Guadalajara y Monterrey \\
\hline \multirow{3}{*}{1993} & ESCOBAR GONZALEZ Y ASOCIACIADOS & 25 & D.F. \\
\hline & LEGA XXI & 350 & Hermosillo, D.F, Guadalajara, \\
\hline & GCI (SITEL desde 1998) & 2400 & Monterrey y D.F. \\
\hline 1994 & Capta & 1360 & León y D.F. \\
\hline \multirow{2}{*}{1995} & CALL & 50 & D.F. \\
\hline & ISS DE MEXICO & 250 & D.F. \\
\hline \multirow{5}{*}{1996} & ATENCIÓN TELEFONICA & 900 & Chihuahua, León, Guadalajara, \\
\hline & AVANTEL & 860 & Monterrey \\
\hline & MERKAFON TELEPERFOMANCE & 4000 & D. F. y Monterrey \\
\hline & T\& BASE DE MÉXICO & 30 & D. F, Monterrey y Guadalajara \\
\hline & TELEMARK COPRATION & 450 & D. F. y Monterrey \\
\hline \multirow{5}{*}{1997} & COINSTA & 481 & Puebla \\
\hline & GRUPO TELEVISA & 4500 & Tijuana y D.F. \\
\hline & HIGH MARKETING AND TELEMARKETING & 120 & D. F. y Monterrey \\
\hline & MDY CONTACTO CENTER & 2100 & Monterrey, Tijuana y Mérida \\
\hline & TELETECH & 2300 & D.F. y León \\
\hline \multirow{2}{*}{1998} & GRUPO SITEL & 1428 & D. F. y Monterrey \\
\hline & TELECONTACT & 100 & D. F. y Monterrey \\
\hline \multirow{5}{*}{1999} & FAST & 215 & Querétaro \\
\hline & TKM CUSTOMER SOLITIONS & 420 & D.F. \\
\hline & GRUPO TPS & 1200 & D.F. y Santa Fe \\
\hline & CALL FAST & 700 & \\
\hline & CSI & 2200 & D. F. y Monterrey \\
\hline \multirow{3}{*}{2000} & TOPTEL & 750 & D. F. y Monterrey \\
\hline & VOICE SERVICE PROVIDER & 600 & \\
\hline & AMATEC & 780 & \\
\hline \multirow{6}{*}{2001} & ATENTO MÉXICO & 6166 & D. F. y Monterrey \\
\hline & CRM MEXICANA & 178 & D.F. \\
\hline & E-CONTACT & 40 & D.F. \\
\hline & TELEPHON SERVEYS & 50 & D.F. \\
\hline & X-SHOP & 120 & D.F. \\
\hline & MEGACALL & 1000 & Guadalajara \\
\hline \multirow[t]{2}{*}{2002} & IMPLUSE TELECOMONICATIONS DE & 552 & Querétaro \\
\hline & UNIFICA TELESERVICE & 75 & Monterrey \\
\hline 2003 & QUAFON & 1148 & D. F. y Monterrey \\
\hline \multirow{2}{*}{2004} & AVANTEL & 500 & Monterrey, Guadalajara, León, \\
\hline & COMERCIAL BOSS & 500 & \\
\hline 2005 & EFICASIA & 500 & \\
\hline 2006 & NEXT CONTACT & 800 & D.F, Hidalgo, Puebla, y Tabasco \\
\hline 2008 & GLOBAL CONTACT SERVICE & 200 & \\
\hline
\end{tabular}

Fuente. Elaboración propia a partir de INSTITUTO MEXICANO DE TELESERVICIOS (2014).

Revista de Contacto Fórum, 18(58) Pp.16-18. Disponible en

http://imt.com.mx/revistaCF/2014/02Marzo/, fecha de consulta: 9/12/2015. 
Gráfico IV-4. 4. Números de estaciones de los call-centers en México, 1973-2008.

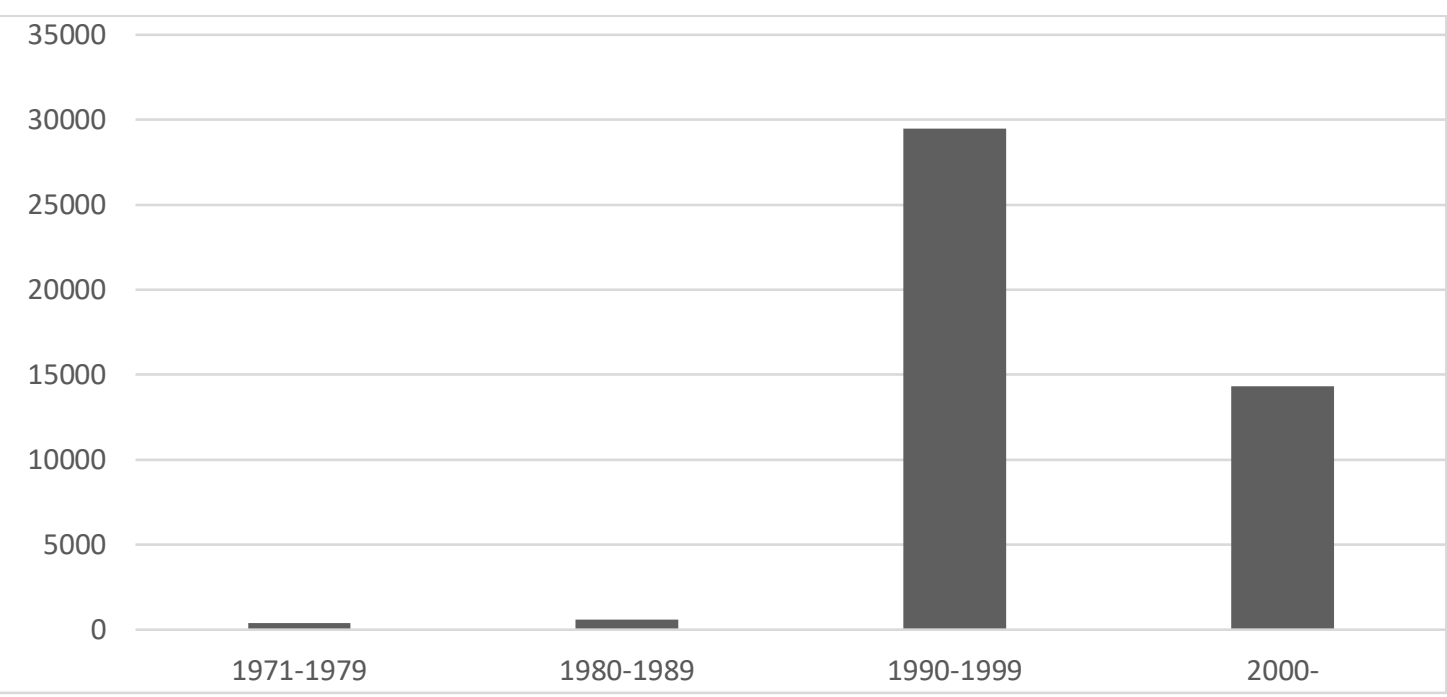

Fuente. Elaboración propia a partir de INSTITUTO MEXICANO DE TELESERVICIOS. (2014). Revista de Contacto Fórum, 18(58), pp. 16-18. Disponible en http://imt.com.mx/revistaCF/2014/02Marzo/, fecha de consulta: 9/12/2015.

Además, se puede encontrar un cambio de las funciones del call-center que induce a la desaparición del gran call-center: la especialización de sus clientes. Las empresas de call-centers tienen contratos con sus clientes (clientes directos) para llamar a los clientes de éstos (clientes indirectos). Por eso, los productos vendidos son los productos de los clientes que tienen contrato con el call-center.

Como se muestra en la Ilustración IV-4.1, los servicios y productos de la empresa de call-center dependen de sus clientes directos (cliente A). En la década de 1990, una empresa de call-center tenía contratos con empresas clientes de muy diversas industrias (de telecomunicaciones, de servicios financieros, de institutos gubernamentales, etc.). Sin embargo, desde 2000 esta condición cambió. Las empresas de call-centers empezaron a especializarse según el tipo de cliente e industria que contrataba sus servicios: así, por ejemplo, algunas empresas se encargaban del trabajo en la industria de las telecomunicaciones, mientras que otras se dedicaban a los trabajos en el sector financiero. Esta especialización de las empresas de call-centers en México indujo la desaparición del gran call-center (TSUSHIMA, 2009).

Al hablar del desarrollo de la industria de call-center, no se debe olvidar un factor importante de política económica: la liberalización de las líneas de teléfono de larga distancia e internacionales. En este mercado Telmex tenía un completo monopolio. Sin embargo, desde 1990 el gobierno mexicano promovió la liberalización de este mercado 
(DÍAZ, 2012). Después de la liberalización, varias empresas extranjeras y mexicanas de teléfonos entraron en el mercado de líneas de larga distancia e internacionales (TRUJILlO y CALDERÓN, 2013): AT\&T, ATSI, Avantel, Axtel, Bestel, BTel, Convergia de México, Global Crosing Landing, Grupo de Telecomunicaciones Mexicanas, Iusatel, International Van, Marcatel, Maxcom, Mexigult, Miditel, Presto Comunicaciones, Protel, Radio Movil Dipsa, Startel, Telecom Net, Telecomunicaciones del Pueblo, Telefónica Data México, Telmex, Teléfonos del Noroeste, Telereunión, Telmex, Unión Telefónica Nacional, Unefon, VPN de México, y W.L. Telecomunicaciones.

Ilustración IV-4. 1. Relaciones entre las empresas de call-centers y sus clientes

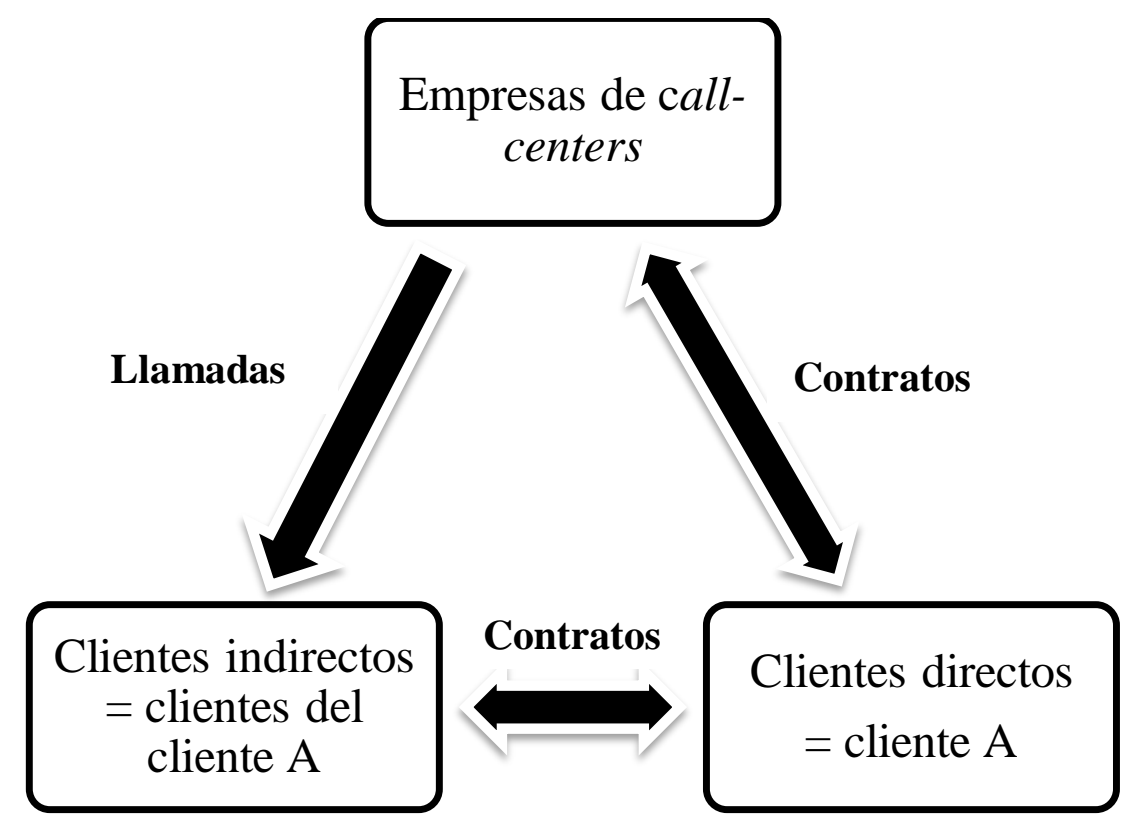

Fuente. Elaboración propia.

El hecho de que aumentara el número de empresas de telefonía -muchas de ellas extranjeras- indujo la reducción de las tarifas en las líneas de larga distancia e internacionales. Esta reducción de tarifas es un factor que contribuyó al desarrollo de la industria de call-center en México. Al establecerse un call-center, las líneas telefónicas, especialmente las de larga distancia son necesarias. Por eso, la reducción de las tarifas es otro factor del desarrollo de esta industria.

Actualmente, la industria de call-center se concentra en dos zonas principales: la zona de metropolitana de Ciudad de México y sus alrededores, y la zona de la frontera Norte de México, como Baja California. Estas zonas son los clústeres de la industria de 
call-center, teniendo cada una sus propias características. En la próxima sección, se analizan las características del clúster de call-center en Baja California.

\section{IV-4. 3. Desarrollo del clúster de call-center en Baja California}

La industria de call-center empezó sus actividades en Baja California en la década de 1990. Hay varias razones que explican que el inicio tuviera lugar en esa década.

En primer lugar, está la entrada en vigor del TLCAN (MICHELI THIRIÓN, 2012, pp. 145-146). Gracias a ello, el comercio en la zona fronteriza se activó más que antes. Este incremento del comercio indujo otro movimiento: la entrada de IED. Desde el punto de la vista de la industria de call-center, esta entrada de IED era un motor importante para su desarrollo porque la mayor parte de esta IED quería vender sus productos en Estados Unidos y la industria de call-center era una manera de hacer marketing para el mercado estadounidense. Al mismo tiempo, para las empresas de call-center de Baja California, las empresas extranjeras que venían a esta zona eran sus clientes potenciales. En este sentido, aumentó la IED en Baja California, y concretamente en Tijuana, lo que supuso otro motor del desarrollo de esta ciudad en la década de 1990.

En segundo lugar, está la tendencia a las subcontrataciones (out-sourcing), especialmente de empresas estadounidenses. Un motivo de ello estaba relacionado con el hecho de que las empresas necesitaban reducir sus costes para mantener (o mejorar) la competitividad de sus productos (TREJO FLORES y NAVARRETE, 2009, p. 26; MONTARCÉ, 2009, pp. 70-71). Gracias al desarrollo de la tecnología, era posible localizar el call-center en México y así, reducir costes (especialmente, los de la mano de obra).

Otro motivo del desarrollo de la industria, se puede encontrar en las iniciativas del Ayuntamiento de Tijuana para atraer IED. En junio de 1993 la firma de consultoría externa Andersen Consulting presentó al Ayuntamiento de Tijuana un ejemplo de la exitosa experiencia de España en la nueva planificación de sus ciudades para reordenarlas urbanística, económica y socialmente ante los requerimientos futuros. Con este precedente, en marzo de 1997 se constituyó oficialmente el Consejo de Desarrollo Económico de Tijuana, A.C. (CDT), iniciándose la preparación de la fase 2 del estudio estratégico, en el cual se generaron grupos de trabajo integrados por los consejeros del 
CDT y de las instituciones públicas para analizar los temas críticos que requerían una solución a corto plazo y para definir las principales acciones a poner en práctica, así como los tiempos en los que deberían realizarse para cumplir con los objetivos trazados para los primeros 10 años. $^{33}$

Finalmente, en 1998 el CDT estableció el Plan Estratégico de Desarrollo de Tijuana para "coordinar las iniciativas de los distintos agentes sociales en el diseño del futuro de la ciudad, mediante la identificación de tendencias urbanas y el

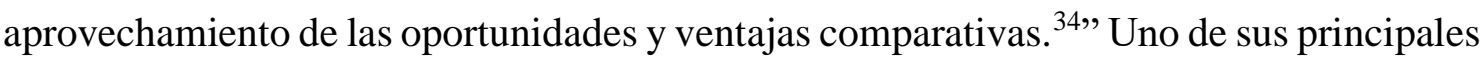
planes era establecer y/o fortalecer los clústeres industriales en Baja California, concretamente, en Tijuana. En 1998, las empresas extranjeras manufactureras ya tenían sus fábricas en la zona maquiladora. Por eso, en el plan, la mayor parte los clústeres industriales eran de las industrias manufactureras.

El Plan Estratégico Metropolitano de Tijuana cambia cada 5-6 años. Actualmente, se encuentra operativo el Plan Estratégico Metropolitano 2034. En este Plan, los clústeres industriales que se consideran muy importantes para el desarrollo económico de Tijuana son: automóviles, aeroespacial, productos médicos, turismo médico, tecnología informática, electrónicos y logísticos ${ }^{35}$.

Para la industria de call-center, este Plan Estratégico Metropolitano de Tijuana es importante, porque las empresas en estos clústeres tienen posibilidades de convertirse en sus clientes. Es decir, este Plan es como un mapa de sus clientes potenciales en el futuro cercano.

Asimismo, como una nueva estrategia de desarrollo de Tijuana, hay un plan para las maquiladoras en el que se contempla el aumento de las actividades de las industrias de servicios, especialmente las de subcontrataciones (out-sourcing). Las empresas pueden aprovecharse de la ventaja de la proximidad a Estados Unidos y de la mano de obra cualificada barata. Adicionalmente, gran parte de la población de la zona de Baja California habla inglés y esto, para las actividades de la industria de servicios, es muy importante ya que la diferencia de idiomas suele convertirse en un gran obstáculo para el

\footnotetext{
${ }^{33}$ CDT. http://www.cdt.org.mx/historia.aspx, fecha de consulta: 7/5/2015.

${ }^{34}$ CDT. http://www.cdt.org.mx/plan_estrategico_de_tijuana.aspx, fecha de consulta:7/5/2015.

${ }^{35}$ Véase el folleto informativo del Plan Estratégico Metropolitano 2034 de Tijuana, Consejo de

Desarrollo Económico de Tijuana (CDT).
} 
desarrollo de la industria. Sin embargo, en Tijuana, las empresas tienen menos posibilidades de sufrir este problema de idiomas. Estas condiciones son algunos de los factores que atraen a las empresas de out-sourcing que se instalan en Tijuana. Una de estas industrias es la de call-centers. Por eso, esta industria está incluida en el Plan Estratégico de Desarrollo de Tijuana.

\section{IV-4. 3. 1. Situación del cluster de call-centers: entrevista al presidente de la industria de call-center en Baja California}

En esta sección se analiza la situación de la industria de call-center en Baja California, a través de la entrevista realizada en 2015 al Señor Jorge Oros, presidente del cluster de call-center de Baja California y de la empresa de su propiedad Baja Callcenter. ${ }^{36}$ El objetivo de esta entrevista fue identificar las relaciones entre el desarrollo de la industria de call-center en Baja California y las políticas públicas para atraer la IED. Las preguntas de esta entrevista aparecen recopiladas en la Tabla IV-4.3.

El primer bloque de preguntas fue sobre la situación de la industria de call-center en México. En 2015, había 70.000 trabajadores en la industria de call-center en México. Las empresas en esta industria están concentradas en dos lugares de México: Ciudad de México y Frontera Norte. Hay una diferencia clara en las actividades desarrolladas por las empresas de call-center en estas dos localizaciones. Los servicios que ofrecen las empresas de call-center en la Ciudad de México son para dentro de México, mientras que las empresas en Baja California proporcionan servicios internacionales. Actualmente, el porcentaje de servicios internacionales en la industria de call-center en México representa sólo el $30 \%$ del beneficio total de la industria.

El segundo bloque de preguntas de la entrevista se centró en la industria de callcenter de Baja California. En 2015, había 55 empresas que ofrecían servicios de callcenter en Baja California y de ellas 5-10 empresas eran empresas estadounidenses. El número de trabajadores se situaba en 10.000-11.000 personas. Este número significa que el 14-16\% de los trabajadores de la industria de call-center de México trabajan en Baja California. La historia del desarrollo de la industria de call-cenetr en Baja California

\footnotetext{
${ }^{36}$ La doctoranda realizo esta entrevista el 12 de mayo de 2015, en el contexto de una estancia de investigación y de estudio de campo en Tijuana durante los meses de mayo y junio de 2015.
} 
empezó en la década de 1990, pero fue en la segunda década de 2000 cuando el desarrollo de esta industria fue especialmente importante: el beneficio de estas industrias en Baja California creció más de un $25 \%$.

Tabla IV-4. 2. Lista de preguntas al Sr. Jorge Oros, presidente del clúster de call-center en Baja California, 2015

\begin{tabular}{|l|}
\hline 1. Estructura de la industria de call-center en México \\
1-1. Número de trabajadores \\
1-2. Concentraciones de la industria \\
1-3. Diferencia de la industria call-center entre Ciudad de México y Tijuana \\
\hline 2. Estructura de la industria de call-center en Baja California \\
2-1. Número de empresas en Tijuana. \\
2-2. Número de trabajadores en Baja California \\
2-3. Historia de su desarrollo \\
2-4. Ventaja de la actividad en Baja California \\
3.Sobre su empresa Baja Callcenter \\
3-1. Número de trabajadores (porcentaje por género) \\
3-2. Sistema de formación y promoción de operadores. Problemas de rotación de los \\
3-3. Formación académica de los trabajadores \\
3-4. Productos de venta \\
\hline 4. Factores de desarrollo para la industria de call-center en Baja California \\
\hline 5. Problemas de la industria de call-center.
\end{tabular}

Fuente. Elaboración propia

El desarrollo de la industria de call-center en Baja California vino de tres factores principales. El primero fue el aumento de clientes. En la industria de call-center, "los clientes" son las empresas que contratan con las empresas de call-center y que piden tener contactos con sus consumidores. Es decir, el aumento del número de clientes contribuye directamente a aumentar el beneficio de estas empresas.

Un segundo factor fue que el aumento del número de clientes indujo el incremento del número de productos ofrecidos por la industria de call-center. Las empresas de callcenter en Baja California ofrecen servicios financieros (especialmente, de préstamos), de soporte técnico, de venta de hostelería, de seguros, etc. Especialmente, la venta de seguros médicos para el mercado de Estados Unidos ha aumentado mucho en los últimos años.

Por último, el tercer factor del desarrollo de la industria de call-center en Baja California fue la proximidad cultural a Estados Unidos. Como se ha analizado en la anterior sección, los servicios de call-center en Baja California son para el mercado de 
Estados Unidos. Se necesita que los productos tengan la calidad adecuada para satisfacer a los consumidores estadounidenses y que esa "calidad" incluya tanto calidad en el producto como calidad en la asistencia técnica de los operadores de la industria de callcenter. El $70 \%$ de los operadores de los call-centers de Baja California han tenido la experiencia de haber vivido antes en Estados Unidos y esta experiencia es un factor que facilita el aumento de la venta de los productos en Estados Unidos.

El tercer bloque de preguntas de la entrevista analizó la propia empresa del entrevistado (Baja Callcenter). En esta empresa hay 398 operadores. Todos son bilingües en español e inglés. Su porcentaje en cuanto a género es el siguiente: el $75 \%$ de los trabajadores son hombres y el $25 \%$ restante son mujeres. El sistema de formación y promoción para los operadores son distintos dependiendo del tipo de producto que vendan: como mínimo hay una semana de formación al inicio del trabajo, mientras que en el caso de las ventas de seguros, se necesitan dos meses de formación previa. Para vender los productos financieros y los seguros, los operadores necesitan aprender las características de estos productos, las leyes a las que están sujetos y la manera de transmitir eficazmente la información sobre estos productos. Por eso, su período de formación tiende a ser más largo. Sobre la promoción de los operadores, las respuestas dadas indican que depende de la capacidad de los operadores. No obstante, no es extraño que un operador se convierta en Super Visor ( $S V$ : supervisor o líder de operadores) en 3 o 4 meses. Las promociones son muy rápidas, pero también las rotaciones de operadores son altas.

Sobre la formación académica de los trabajadores, la mayor parte de ellos posee una licenciatura. Además, la empresa Baja Callcenter se relaciona con las universidades de Tijuana y recibe algunos estudiantes para hacer prácticas de 3 meses, trabajando a media jornada. La mayor parte de los estudiantes que participan en estas prácticas proceden de la Facultad de Administración de Empresas. Respecto a sus productos de venta, éstos son la venta de seguros, el soporte técnico y la venta de hostelería. El 85\% de sus beneficios procede de su call-center de Inbound y Outbound. El 15\% de sus beneficios provienen sólo de su call-center Inbound y el 5\% sólo del call-center de Outbound.

El cuarto bloque de preguntas de la entrevista se destinó a examinar los factores de desarrollo de la industria de call-center en Baja California. Se identificaron dos 
factores fundamentales. Primero es, como hemos visto antes, la proximidad a la cultura de Estados Unidos. Al vender productos a través del teléfono, la proximidad cultural ayuda a establecer cierta confianza entre los operadores y los consumidores. La proximidad geográfica es una ventaja para las empresas que operan en la zona de la frontera norte de México, pero en el caso de la industria de call-center, su proximidad a la cultura de Estados Unidos es una ventaja mayor para su negocio.

El segundo factor es la condición geográfica y demográfica de Tijuana. El mejor lugar para establecer un call-center es estar cerca o dentro de la ciudad, ya que eso facilita el transporte de los trabajadores y el acceso a las universidades en las que se encuentran los potenciales trabajadores. En Tijuana, hay aproximadamente 30 universidades. Los operadores del call-center tienen que conocer cómo manejar los ordenadores y en este sentido, los jóvenes tienden a conocer y manejar mejor las nuevas tecnologías. Gracias a las universidades de Tijuana, las empresas de call-center tienen facilidad para encontrar sus recursos humanos. Para los estudiantes universitarios que tienen que ganar dinero para seguir estudiando en la Universidad, el horario de trabajo por turnos en los call-centers es apropiado. Además, hay posibilidad de que ellos se conviertan en futuros trabajadores de estas empresas. Estas condiciones son un factor importante a la hora de tomar una decisión sobre la localización del call-center.

Sin embargo, la ubicación de un call-center dentro de la ciudad donde las condiciones de transporte son buenas, significa que el coste del alquiler de la oficina va a ser más caro que fuera de la ciudad. Por eso, aquí la empresa se enfrenta a un trade-off entre el coste del alquiler de la oficina y el beneficio de la localización dentro de la ciudad. Este trade-off es un problema que tienen que tener en cuenta las empresas de call-centers que deseen establecerse en Tijuana. También se puede encontrar este trade-off en México DF. Sin embargo, en este caso, la ciudad universitaria está al sur de la ciudad y no está dentro de la ciudad. Además, comparada con Tijuana, el sistema de transporte público es mejor. En este sentido, el trade-off no es tan fuerte en México DF. Además, sobre la relación entre el desarrollo de la industria de call-center y las privatizaciones de las empresas telefónicas de larga distancia e internacional en Baja California, las respuestas indicaron que la privatización de la telefonía en México no ha tenido influencia importante en el desarrollo de la industria. 
Por último, el quinto bloque de preguntas hizo referencia a los problemas de la industria de call-center en Baja California y México. De las respuestas, se identificaron tres problemas principales. En primer lugar, existe un cierto desconocimiento de la industria de call-center, en el sentido de que la economía mexicana no conoce plenamente la actividad y el potencial de la industria de call-center. Este desconocimiento es una desventaja para el desarrollo de la industria. Como se ha analizado en la anterior sección, la industria de call-center no produce nada materialmente, sino que vende productos a través del teléfono. En el caso de la industria de Baja California, el aumento de sus clientes es un factor esencial para el desarrollo de la industria. Con objeto de aumentar sus clientes, la industria de call-center tiene que anunciar sus actividades a las empresas que son sus potenciales clientes. Sin embargo, la industria de call-center en Tijuana tiene dificultades para hacer esto. Tijuana es un lugar importante en el programa de la Maquiladora. Este programa es para las empresas con negocios internacionales y para las empresas manufactureras. Las industrias terciarias, incluyendo la industria de call-center, no se han considerado como relevantes en el programa de la Maquiladora. En este contexto, es necesario hacer más visibles las actividades de la industria de call-center, especialmente en Baja California. El segundo problema para desarrollo de la industria de call-center es la atracción de las empresas extranjeras. Desde el punto de vista de la industria de callcenter, estas empresas pueden convertirse en sus clientes. Las empresas extranjeras necesitan algunas empresas para establecer la estrategia de marketing y ahí, podría desarrollarse más la industria de call-center en Baja California.

El tercer problema de la industria de call-center en Baja California es su relación con otras industrias. Como se ha recordado anteriormente, la industria de call-center no produce, sólo vende. Los productos que vende son los productos de las otras industrias. Es decir, esta industria necesita de la relación con otras industrias. Por ejemplo, el desarrollo de la industria financiera en Estados Unidos ayuda al desarrollo de la industria de call-centers en Tijuana. Por eso, esta industria necesita mantener y/o establecer buenas relaciones con las otras industrias. En Tijuana, el clúster de call-centers es un clúster que el gobierno de Baja California promueve. Por eso, la industria de call-centers en Baja California tiene una estrecha relación con otras industrias, por ejemplo, a través de la Cámara de Comercio y la Cámara Nacional de la Industria Electrónica de Telecomunicaciones y Tecnologías de la Información (CANIETI). 


\section{IV-5. Conclusiones}

En este capítulo, se ha analizado la política industrial destinada a la atracción de la IED, considerándola en los tres niveles relevantes de México: en el nivel nacional, estatal y municipal.

El gobierno central ha de establecer un marco general claro para las políticas de atracción de la IED, explicando simultáneamente el papel que espera que las empresas extranjeras desempeñen en la economía nacional. En el caso de México, el primer plan que impulsó el gobierno central -el Programa de la Maquiladora- tenía como objetivo promover la fabricación en México y la exportación a otros países. Esto revela claramente lo que el gobierno mexicano esperaba de la IED: ésta debía centrarse en fabricar y exportar. Posteriormente, en el programa de IMMEX, este papel esperado para las empresas extranjeras no cambió.

Para las inversiones japonesas, es decir, para las empresas japonesas en México, fue muy importante el cambio de la Ley de Inversiones Extranjeras. Como se ha mencionado en el capítulo, la mayor parte de las empresas japonesas que invierten en México son empresas manufactureras. Las grandes empresas japonesas que fabrican los productos terminados, necesitan de sus proveedores japoneses. Dentro de la jerarquía del Keiretsu $^{37}$ japonés, las empresas matrices controlan a sus proveedores para asegurarse la calidad de sus productos terminados. Por eso, las empresas manufactureras japonesas no tienen incentivos para invertir en los países donde haya alguna limitación al porcentaje de participación de los capitales extranjeros. En este contexto, el cambio de la Ley de Inversiones Extranjeras tuvo un efecto positivo para la atracción de inversiones japonesas en la industria manufacturera de México.

Al analizar las políticas en el nivel estatal, se ha puesto una especial atención a los sistemas de tributación que favorecen las actividades de las empresas extranjeras. Aunque estos sistemas son diferentes en cada estado, lo que se ha observado es que los estados de México que reducen los impuestos y derechos estatales atraen más inversiones.

Para atraer la IED, hay dos tipos de estrategias de tributación: una es la de reducir los impuestos y la otra es la de aumentar los incentivos. En el caso de los estados de México, la reducción de impuestos ha sido la mejor vía para la atracción de la IED.

\footnotetext{
${ }^{37}$ Keiretsu es una cadena de producción entre grandes empresas y sus proveedores.
} 
Además, se ha podido notar que la reducción del Impuesto sobre la Nómina (ISN) ha sido otra manera importante de atraer a la IED. Estas dos maneras de tributación tienen un punto en común: buscan la reducción de los costes de las empresas extranjeras.

Para las empresas extranjeras ubicadas en México, el principal objetivo de sus inversiones es la reducción de su coste. Este "coste" no es solo el coste de la producción, sino también el coste de la aceptación de las condiciones tributarias del país destino de la inversión. Por eso, las dos mencionadas reducciones de impuestos tienen un importante efecto positivo sobre la atracción de la IED.

Actualmente, las dos principales zonas que se están industrializando (o se han industrializado) en México son la zona Noroeste (Baja California, Baja California Sur, Sinaloa y Sonora) y la zona Central Occidental (Aguascalientes, Colima, Guanajuato, Jalisco, Michoacán, Nayarit, San Luis Potosí y Zacatecas). En ambas zonas se han adoptado modalidades tributarias que incluyen la reducción de impuestos como una vía efectiva de atracción de la IED.

Sin embargo, al considerar el gasto tributario, los gobiernos estatales corren el riesgo de perder ingresos tributarios con sus medidas reductoras de impuestos para la atracción de la IED. Por ello, es importante adoptar medidas tributarias equilibradas y contar con especialistas tributarios que puedan calcular el alcance del gasto tributario en cada estado.

En el nivel municipal, este capítulo ha puesto especial atención a la política de formación en Tijuana. Como hemos visto, el sistema de formación de ingenieros y técnicos en Tijuana se ha cambiado debido al plan del gobierno central. Sin embargo, últimamente, Tijuana intenta por sí misma cambiar el sistema de formación para formar más técnicos que ingenieros, que puedan trabajar en las empresas de la Maquiladora. Se ha adoptado un plan para establecer la preparatoria de técnicos con una fuerte vinculación con las universidades. Asimismo, para la formación de técnicos se requiere dar clases que permitan conocer las tecnologías más avanzadas que se usan en las empresas actuales y esto significa que se precisa de una estrecha colaboración con las empresas.

En los casos de las colaboraciones con las empresas de la Maquiladora, hay algunos ejemplos en Tijuana. Por ejemplo, el Consejo de Desarrollo de Tijuana (CDT) ha 
organizado unos grupos de estudiantes de institutos tecnológicos. ${ }^{38}$ Este tipo de vinculación entre empresas en la Maquiladoras y el sistema educativo de Tijuana empezó en la década de 1990, tras la entrada en vigor del TLCAN. Estos estudiantes tienen la oportunidad de trabajar varias semanas en las empresas de la Maquiladora. Esto es una ventaja para los estudiantes, ya que pueden conocer las actuales situaciones de las empresas maquiladoras. ${ }^{39}$ Sin embargo, la mayor parte de los estudiantes que han aprovechado esta experiencia no han acabado trabajando en las empresas japonesas, sino en otras empresas en las que los salarios eran más altos.

Como se ha analizado en el capítulo, en el caso de Tijuana hay una experiencia de colaboración de cuatro empresas japonesas con un instituto tecnológico de Tijuana ${ }^{40} \mathrm{El}$ gobierno de Japón tenía una actividad en dicho instituto para enseñar la manera en la que se trabaja en Japón. Las empresas japonesas enseñaron el 5S como una actividad esencial del control de la calidad (Quality Control Activity, o Kaizen). Las 5S son 5 actividades que tienen que hacer para mejorar las condiciones donde trabajan las empresas japonesas. Concretamente, 5S consiste en: Seiri que es arreglar, Seiton que es ordenar, Seisou que es limpiar, Seiketsu que es mantener la limpieza y Shitsuke que es la disciplina. Estas 5S son las actividades que los trabajadores en las fábricas japonesas tienen que hacer. Para enseñar y practicar estas $5 \mathrm{~S}$, las cuatro empresas japonesas trabajaron con el instituto tecnológico de Tijuana durante tres años.

Las opiniones sobre los resultados de esta actividad están polarizadas dentro de la comunidad japonesa en Tijuana. Una parte de la comunidad japonesa cercana al gobierno de Japón valora muy positivamente esta actividad. Sin embargo, algunas de las empresas japonesas en Tijuana consideran que esta actividad no sirve para nada: una actividad en un solo instituto de Tijuana no ayuda a aumentar los trabajadores en las empresas japonesas. A pesar de las opiniones negativas y positivas, esta actividad de $5 \mathrm{~S}$ ha sido un primer acercamiento a las empresas japonesas para la mayor parte de los estudiantes de Tijuana.

\footnotetext{
${ }^{38}$ Información obtenida en la entrevista realizada por la doctoranda con el Sr. Trujillo del CDT.

${ }^{39}$ Según el Sr. Trujillo (CDT), la mayor parte de los estudiantes que participaron en este aprendizaje con las empresas, han buscado sus trabajos fuera de la maquiladora, como en la zona de Bajío. Desde este punto de vista, este programa no ha funcionado bien para aumentar el número de técnicos tijuanenses en la Maquiladora.

${ }^{40}$ Información obtenida en la entrevista realizada por la doctoranda con el Sr. Trujillo del CDT.
} 
Cuando entró en vigor el TLCAN, las principales industrias que exportaban desde la Maquiladora a Estados Unidos eran la industria de automóviles y de televisores. Para fabricar este tipo de productos, la mano de obra que necesitaban era muy cualificada. No era como el caso de la industria textil -que había sido la principal industria de la Maquiladora- donde lo importante era la mano de obra barata. El municipio de Tijuana notó este cambio del tipo de mano de obra requerida por las empresas en la Maquiladora. Se puede decir que esta capacidad de notar y aceptar rápidamente el cambio que necesitaban las empresas en la Maquiladora ha sido una fortaleza del municipio de Tijuana.

Cuando las empresas deciden sus destinos de la IED, eligen el lugar donde puedan maximizar los beneficios de sus negocios. Principalmente, hay dos maneras para aumentar al máximo esos beneficios: reducir los costes o aumentar el valor agregado. Por eso, los países, los estados y los municipios que quieran atraer IED, tienen que establecer las maneras más apropiadas para reducir los costes de las empresas o aumentar los valores agregados que las empresas producen.

Como se he explicado anteriormente, el objetivo principal del Programa de la Maquiladora era ofrecer opciones a las empresas que exportaran sus productos a Estados Unidos con bajos costes. Estos bajos costes pueden proceder de dos cosas: del bajo coste del transporte a Estados Unidos y del bajo coste de la mano de obra. Teniendo en cuenta esto y la experiencia del Programa de la Maquiladora, el gobierno central realizó algunos cambios para adaptarse a la nueva situación que quedaron plasmados en la Ley de Inversiones Extranjeras.

Ahora, se considera el caso del nivel de los estados. Principalmente, la manera para atraer la IED en el nivel de los estados en México es ofrecer a las empresas extranjeras la posibilidad de reducir sus costes de producción. Por eso, las IED están concentradas en los estados que tienen (o ha tenido) las políticas tributarias más favorables a la reducción de los impuestos a las empresas extranjeras.

Sin embargo, en el nivel municipal, esto es en el caso de Tijuana, esta tendencia cambia. El caso de Tijuana, especialmente su estrategia de educación y formación de técnicos en el más alto nivel ha sido una vía para atraer IED, ayudando a las empresas extranjeras a aumentar el valor agregado de sus productos. En este sentido, se puede decir que las políticas nacionales y de los estados para atraer IED han sido diferentes a la 
seguida en el nivel municipal de Tijuana. Esta diferencia induce insatisfacción de Tijuana con las políticas del gobierno central. A través de las entrevistas realizadas, se percibió una cierta visión crítica con el gobierno central en el sentido de que éste ha estado restando importancia a la relevancia que la Maquiladora tiene para la economía de Tijuana.

El caso de la historia del desarrollo de la industria de call-center nos indica que hay diferencias entre las políticas de desarrollo industrial del gobierno central y municipal. Mientras el gobierno central consideró que la liberalización de las líneas telefónicas fijas de larga distancia e internacional era un punto importante para el desarrollo de esta industria, el presidente del clúster de la industria de call-center en Tijuana no lo consideraba así. Desde el punto de vista del clúster de call-center en Tijuana, el desarrollo de su industria procedió de factores ligados a la dinámica económica de Estados Unidos, más que a factores mexicanos.

Estas diferencias en los puntos de vista pueden convertirse en un obstáculo para establecer las futuras políticas de atracción de la IED. Esto no es nada positivo, especialmente en un contexto normativo del comercio internacional más restrictivo tras la pretensión estadounidense de renegociar el TLCAN. No obstante, el mayor problema que se ha percibido en la investigación en este capítulo respecto a las políticas de atracción de la IED en México, se encuentra en la descoordinación entre tres niveles de acción de dichas políticas (el nacional, el estatal y el municipal). El caso de Tijuana es un claro ejemplo de ello. 
Anexos Capítulo IV 
Tabla Anexo IV-1. Los institutos tecnológicos en Tijuana, 2015

\begin{tabular}{|c|c|}
\hline \multicolumn{2}{|c|}{ CECYTE: Colegio de Estudios Científicos y Tecnológicos } \\
\hline Plantel Zona Río & $\begin{array}{l}\text { Mecatrónica. } \\
\text { Electrónica } \\
\text { Programador de Software. }\end{array}$ \\
\hline Playas de Tijuana & $\begin{array}{l}\text { Mecatrónica } \\
\text { Programador de Software. }\end{array}$ \\
\hline Plantel El Florido & $\begin{array}{l}\text { Programador de Software. } \\
\text { Mantenimiento. } \\
\text { Electrónica. } \\
\text { Mecatrónica }\end{array}$ \\
\hline Telesecundaria No.12 & Producción \\
\hline Plantel Villa del Sol & $\begin{array}{l}\text { Electrónica } \\
\text { Producción } \\
\text { Programador de Software }\end{array}$ \\
\hline Telesecundaria No.37 & $\begin{array}{l}\text { Electrónica } \\
\text { Producción }\end{array}$ \\
\hline El Dorado & $\begin{array}{l}\text { Electrónica. } \\
\text { Producción. }\end{array}$ \\
\hline Plantel Las Águilas & $\begin{array}{l}\text { Electrónica } \\
\text { Programador de Software }\end{array}$ \\
\hline Plantel el Pacífico & $\begin{array}{l}\text { Electrónica. } \\
\text { Mantenimiento. } \\
\text { Turismo. } \\
\end{array}$ \\
\hline Secundaria No.42 & Mantenimiento. \\
\hline Colinas del Sol, Secundaria No. 20 & Mantenimiento \\
\hline $\begin{array}{l}\text { Ejido Lázaro Cárdenas, Telesecundaria } \\
\text { No. } 24\end{array}$ & $\begin{array}{l}\text { Mantenimiento } \\
\text { Turismo }\end{array}$ \\
\hline Plantel Cachanilla & $\begin{array}{l}\text { Programador de Software } \\
\text { Electrónica. }\end{array}$ \\
\hline Plantel el Niño & $\begin{array}{l}\text { Mantenimiento } \\
\text { Electrónica } \\
\text { Mecatrónica. }\end{array}$ \\
\hline Telesecundaria No. 39 & $\begin{array}{l}\text { Mantenimiento } \\
\text { Electrónica } \\
\text { Mecatrónica. }\end{array}$ \\
\hline Altiplano & Mecatrónica \\
\hline $\begin{array}{l}\text { Planteles Particulares Incorporados al } \\
\text { CECYTE }\end{array}$ & Técnico Programador Software \\
\hline Colegio Unidad México 1 & Técnico Programador Software \\
\hline Centro Pre Universitario (Zona Centro) & Técnico Programador Software \\
\hline Centro Pre Universitario (Las Brisas) & Técnico Programador Software \\
\hline
\end{tabular}




\begin{tabular}{|c|c|}
\hline \multicolumn{2}{|c|}{ CONALEP: Colegio Nacional de Educación Profesional Técnica } \\
\hline Plantel Tijuana II & $\begin{array}{l}\text { Alimentos y bebidas } \\
\text { Administración } \\
\text { Control de Contaminación } \\
\text { Informática }\end{array}$ \\
\hline Plantel Tijuana I & $\begin{array}{l}\text { Electromecánica } \\
\text { Electrónica Industrial } \\
\text { Contaduría } \\
\text { Mantenimiento de Equipos de Cómputo y } \\
\text { Control Digital. }\end{array}$ \\
\hline \multicolumn{2}{|c|}{ CBTIS: Centro de Bachillerato Tecnológico Industrial y de Servicios } \\
\hline Plantel CETIS No. 58 & $\begin{array}{l}\text { Administración. } \\
\text { Informática. } \\
\text { Electrónica. }\end{array}$ \\
\hline Plantel CBTIS No. 116 & $\begin{array}{l}\text { Informática. } \\
\text { Construcción. } \\
\text { Contabilidad. }\end{array}$ \\
\hline Plantel CBTIS No. 146 & $\begin{array}{l}\text { Análisis y Tecnología de Alimentos. } \\
\text { Construcción. } \\
\text { Contabilidad. } \\
\text { Mantenimiento Automotriz }\end{array}$ \\
\hline Plantel CBTIS No. 155 & $\begin{array}{l}\text { Administración. } \\
\text { Informática. } \\
\text { Contabilidad. } \\
\text { Electricidad. } \\
\text { Laboratorio Clínico. }\end{array}$ \\
\hline Plantel CETIS No. 156 & $\begin{array}{l}\text { Informática. } \\
\text { Electrónica } \\
\text { Analista en sistemas computacionales. }\end{array}$ \\
\hline Plantel CBTIS No. 237 & $\begin{array}{l}\text { Administración. } \\
\text { Informática. } \\
\text { Electrónica. } \\
\text { Mecánica Industrial. }\end{array}$ \\
\hline
\end{tabular}

Fuente. Elaboración propia a partir del Sistema Educativo Estatal del Estado de Baja California, disponible en. http://www.educacionbc.edu.mx/departamentos/ems/tijuana.php, fecha de consulta: 20/4/2015 
Tabla Anexo IV-2. Carreras en las Universidades públicas de Tijuana, 2015 (Licenciaturas e Ingenierías)

\begin{tabular}{|l|l|}
\hline Universidad & Carreras \\
\hline Colegio de la Frontera Norte & Estudios Culturales \\
& Estudios de Administración Pública \\
& Estudios de Población \\
& Estudios Económicos \\
& Estudios Sociales \\
& Estudios Urbanos y Medio Ambiente \\
\hline Instituto Tecnológico de Tijuana & Ing. Industrial \\
& Ing. Electromecánica \\
& Ing. Química \\
& Ing. Bioquímica \\
& Ing. Sistemas Computacionales \\
& Ing. Tecnologías de la Información y las \\
& Comunicaciones \\
& Ing. ambiental \\
& Ing. Biomédica \\
lng. Civil \\
Ing. Electrónica \\
Ing. En Aeronáutica \\
Ing. En Diseño Industrial \\
Ing. Gestión Empresarial \\
Ing. Informática \\
Ing. En Logística \\
ling. Nanotecnológica \\
Ing. Mecánica \\
Lic. Administración \\
\hline Lic. en Ciencias Religiosas \\
Lic. en Filosofía \\
\hline
\end{tabular}


Autónoma de Baja California (UABC)

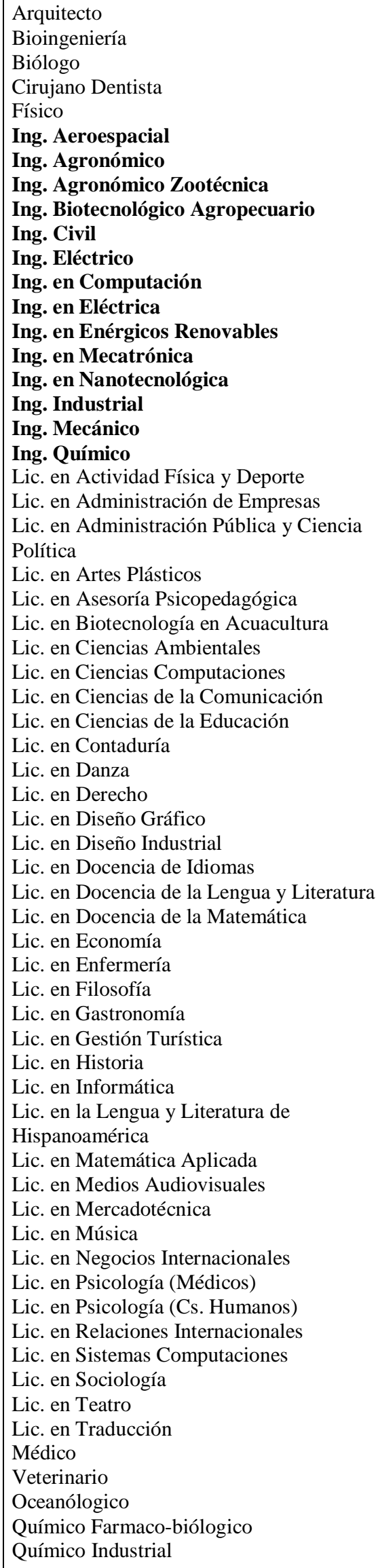




\begin{tabular}{|c|c|}
\hline Universidad Pedagógica Nacional (UPN) & $\begin{array}{l}\text { Lic. en Educación Preescolar } \\
\text { Lic. en Primaria para el Medio Indígena } \\
\text { Lic. en Educación }\end{array}$ \\
\hline Universidad Tecnológica de Tijuana & $\begin{array}{l}\text { 1). Técnico Superior Universitario } \\
\text { Contaduría } \\
\text { Mecatrónica } \\
\text { Energías Renovables } \\
\text { Tecnología Ambiental } \\
\text { Mantenimiento Industrial } \\
\text { Procesos Industriales - Administración } \\
\text { Industrial } \\
\text { Procesos Industriales - Administración Plásticos } \\
\text { Desarrollo de Negocios - Administración } \\
\text { Mercadotecnia } \\
\text { Clasificación Arancelaría y Despacho Aduanero } \\
\text { Tecnologías de la información y Comunicación } \\
\text { - Administración Sistemas Informáticos } \\
\text { Tecnologías de la información y Comunicación } \\
\text { - Administración Redes y telecomunicaciones } \\
\text { Tecnologías de la información y Comunicación } \\
\text { - Administración. Multimedia y comercio } \\
\text { electrónico } \\
\text { Administración del Autotransporte y Logística } \\
\text { 2). Licenciaturas } \\
\text { Lic. Profesional en Redes Inalámbricas y } \\
\text { Virtualización de Servidores } \\
\text { Lic. Profesional en Procesos de Manufactura de } \\
\text { Arneses para Aeronáutica } \\
\text { 3). Ingenierías } \\
\text { Ing. en Mecatrónica } \\
\text { Ing. en Financiera y Fiscal } \\
\text { Ing. en Tecnología Ambiental } \\
\text { Ing. en Electromecánica Industrial } \\
\text { Ing. en Procesos y Operaciones Industriales } \\
\text { Ing. en Desarrollo e Innovación Empresarial } \\
\text { Ing. en Tecnologías de la Información y } \\
\text { Comunicación }\end{array}$ \\
\hline
\end{tabular}

Fuente. Las páginas web de cada Universidad, fecha de consulta 15/08/2015 
Tabla Anexo IV-3. Carreras en las Universidades privadas de Tijuana 2015 (Licenciaturas e Ingenierías)

\begin{tabular}{|c|c|}
\hline Universidad & Carreras \\
\hline $\begin{array}{l}\text { Centro de Investigación para el Desarrollo Humano } \\
\text { (CIDH) }\end{array}$ & $\begin{array}{l}\text { Lic. en Administración en Mercadotecnia } \\
\text { Lic. en Derecho } \\
\text { Lic. en Hotelería, Negocios y Turismo } \\
\text { Lic. en Psicología Familiar }\end{array}$ \\
\hline Centro de Enseñanza Técnica y Superior (CETYS) & $\begin{array}{l}\text { Lic. en Administración de Mercadotecnia } \\
\text { Lic. en Negocios Internacionales } \\
\text { Lic. en Administración de Empresas } \\
\text { Lic. en Contador Público Internacional } \\
\text { Lic. en Administración de Negocios* } \\
\text { Lic. en Diseño Gráfico } \\
\text { Lic. en Derecho } \\
\text { Lic. en Psicología: } \\
\text { Ing. en Energías Renovables *Nueva } \\
\text { Ing. Industrial } \\
\text { Ing. en Cibernética Electrónica } \\
\text { Ing. Mecánica } \\
\text { Ing. en Ciencias Computacionales }\end{array}$ \\
\hline $\begin{array}{l}\text { Centro de Estudios Superiores del Noroeste } \\
\text { (Cuahutemoc) }\end{array}$ & $\begin{array}{l}\text { Lic. en Administración de Empresas } \\
\text { Lic. en Aduanas y Logística } \\
\text { Lic. en Contaduría Pública } \\
\text { Lic. en Mercadotecnia } \\
\text { Lic. en Negocios Internacionales } \\
\text { Lic. en Derecho } \\
\text { Lic. en Psicología } \\
\text { Lic. en Psicología Educativa } \\
\text { Ing. en Desarrollo de Software } \\
\text { Ing. en Multimedia } \\
\text { Lic. en Administración de Empresas (On-line) } \\
\text { Lic. en Aduanas y Logística (On-line) } \\
\text { Lic. en Contaduría Pública (On-line) } \\
\text { Lic. en Derecho (On-line) }\end{array}$ \\
\hline Centro Internacional de Estudios Superiores (CIES) & $\begin{array}{l}\text { Lic. en Administración de Empresas } \\
\text { Lic. en Contaduría Pública } \\
\text { Lic. en Mercadotecnia } \\
\text { Lic. en Psicología } \\
\text { Lic. en Comercio Exterior y Aduana } \\
\text { Lic. en Derecho } \\
\text { Lic. en Ciencias de la Educación }\end{array}$ \\
\hline Centro Universitario México Americano (CUMA) & $\begin{array}{l}\text { Lic. en Derecho } \\
\text { Lic. en Mercadotecnia } \\
\text { Lic. en Administración }\end{array}$ \\
\hline Escuela de Danza Gloria Campobello & $\begin{array}{l}\text { Técnico en Danza } \\
\text { Lic. en Danza }\end{array}$ \\
\hline Escuela Superior de Artes Visuales (ESAV) & $\begin{array}{l}\text { Lic. en Arquitectura de Interiores } \\
\text { Lic. en Artes Visuales }\end{array}$ \\
\hline Facultad de Ciencias de la Educación (FICED) & $\begin{array}{l}\text { Para ingresar al Doctorado en Ciencias de la } \\
\text { Educación }\end{array}$ \\
\hline Instituto de Estudios Especializados (IEE) & $\begin{array}{l}\text { Lic. en Derecho } \\
\text { Lic. en Administración de Empresas }\end{array}$ \\
\hline $\begin{array}{l}\text { Instituto de Estudios Superiores en Derecho Penal } \\
\text { (INDEPAC) }\end{array}$ & Lic. en Derecho \\
\hline Instituto para el Desarrollo Emprendedor (INPADE) & $\begin{array}{l}\text { Lic. en Mercadotecnia } \\
\text { Lic. en Comercio Exterior y Aduanas } \\
\text { Lic. en Contaduría Pública y Finanzas } \\
\text { Lic. en Administración de Empresas } \\
\text { Lic. en Derecho }\end{array}$ \\
\hline
\end{tabular}




\begin{tabular}{|c|c|}
\hline Universidad Xochicalco & $\begin{array}{l}\text { Lic. en Administración y Desarrollo Empresarial } \\
\text { Lic. en Arquitectura } \\
\text { Lic. en Ciencias de la Educación } \\
\text { Lic. en Comercio Internacional y Aduanas } \\
\text { Lic. en Comunicación } \\
\text { Lic. en Contaduría } \\
\text { Lic. en Criminalística } \\
\text { Lic. en Derecho } \\
\text { Lic. en Diseño Integral } \\
\text { Lic. en Medicina } \\
\text { Lic. en Mercadotecnia } \\
\text { Lic. en Nutrición } \\
\text { Lic. en Optométrica } \\
\text { Lic. en Psicología }\end{array}$ \\
\hline $\begin{array}{l}\text { Universidad Interamericana para el Desarrollo } \\
\text { (UNID·Tijuana) }\end{array}$ & $\begin{array}{l}\text { Lic. en Administración de Empresas } \\
\text { Lic. en Ciencias y Técnicas de la Comunicación } \\
\text { Lic. en Derecho } \\
\text { Lic. en Diseño e Industria de Vestido } \\
\text { Ing. en Sistemas de Información } \\
\text { Lic. en Mercadotecnia } \\
\text { Lic. en Psicología Organizacional } \\
\text { Lic. en Tecnología Educativa }\end{array}$ \\
\hline Universidad de Tijuana & $\begin{array}{l}\text { Lic. en Derecho } \\
\text { Lic. en Arquitectura } \\
\text { Lic. en Comercio Exterior y Legislación } \\
\text { Aduanera } \\
\text { Lic. en Administración } \\
\text { Lic. en Comunicación y Publicidad } \\
\text { Lic. en Contador Público } \\
\text { Lic. en Derecho } \\
\text { Lic. en Diseño Gráfico } \\
\text { Lic. en Informática Administrativa } \\
\text { Lic. en Psicología } \\
\text { Lic. en Ciencias de la Educación } \\
\text { Lic. en Mercadotecnia } \\
\text { Lic. en Relaciones Internacionales }\end{array}$ \\
\hline $\begin{array}{l}\text { Universidad del Desarrollo Profesional (UNIDEP. } \\
\text { Tijuana) }\end{array}$ & $\begin{array}{l}\text { Lic. en Administración de Empresas (On-line) } \\
\text { Lic. en Educación } \\
\text { Lic. en Enfermería } \\
\text { Lic. en Derecho } \\
\text { Lic. en Psicología Industrial } \\
\text { Ing. en Sistemas Computacionales } \\
\text { Lic. en Psicología Industrial } \\
\text { Lic. en Diseño y Decoración de Interiores } \\
\text { Lic. en Administración de Empresas }\end{array}$ \\
\hline Universidad UNIVER & $\begin{array}{l}\text { Lic. en Derecho } \\
\text { Lic. en Administración de Empresas } \\
\text { Lic. en Arquitectónica } \\
\text { Lic. en Ciencias de Comunicación } \\
\text { Lic. en Comercio Internacional y Aduanera } \\
\text { Lic. en Contaduría Pública } \\
\text { Lic. en Diseño de Modas } \\
\text { Ing. Industrial } \\
\text { Lic. en Pedagogía } \\
\text { Lic. en Psicología }\end{array}$ \\
\hline
\end{tabular}




\begin{tabular}{|c|c|}
\hline Universidad de las Californias (UDC) & $\begin{array}{l}\text { Lic. en Administración de Empresas } \\
\text { Lic. en Arquitectura } \\
\text { Lic. en Ciencias de Comunicación } \\
\text { Lic. en Ciencias de Educación } \\
\text { Lic. en Cinematográfica } \\
\text { Lic. en Comercio Internacional } \\
\text { Lic. en Contaduría Pública } \\
\text { Lic. en Derecho } \\
\text { Lic. en Diseño de Modas } \\
\text { Lic. en Diseño Gráfico Electrónico } \\
\text { Lic. en Informática Administrativa } \\
\text { Lic. en Ingeniería Civil } \\
\text { Lic. en Psicología }\end{array}$ \\
\hline Universidad Iberoamericana Tijuana (UIA) & $\begin{array}{l}\text { Lic. en Administración de Empresas } \\
\text { Lic. en Arquitectura } \\
\text { Lic. en Comunicación } \\
\text { Lic. en Derecho } \\
\text { Lic. en Diseño Gráfico Estratégico } \\
\text { Lic. en Enfermería } \\
\text { Lic. en Nutrición y Ciencias de los Alimentos } \\
\text { Lic. en Psicología } \\
\text { Ing. en Electrónica y Telecomunicaciones } \\
\text { Ing. Industrial } \\
\text { Ing. Mecánica y Electrónica } \\
\text { Ing. Mecatrónica Industrial }\end{array}$ \\
\hline Universidad Interamericana del Norte (UIN) & $\begin{array}{l}\text { Lic. en Derecho y Asuntos Internacionales } \\
\text { Lic. en Psicopedagogía } \\
\text { Lic. en Arte Culinario } \\
\text { Lic. en Nutrición } \\
\text { Lic. en Odontología } \\
\text { Lic. en Ciencias de Comunicación } \\
\text { Lic. en Comunicación Internacional } \\
\text { Lic. en Cinematográfica } \\
\text { Lic. en Diseño de Modas } \\
\text { Lic. en Diseño de Interiores } \\
\text { Lic. en Diseño Gráfico } \\
\text { Lic. en Músico } \\
\text { Lic. en Administración } \\
\text { Lic. en Administración Hotelería y Negocios } \\
\text { Turísticos } \\
\text { Lic. en Contaduría Pública y Auditor } \\
\text { Lic. en Mercadotecnia } \\
\text { Lic. en Computación Administrativa } \\
\text { Ing. Industrial de Administración Ambiental } \\
\text { Ing. Industrial de Sistemas de Calidad } \\
\text { Ing. Industrial de Mantenimiento } \\
\text { Ing. Industrial y de Sistemas }\end{array}$ \\
\hline Universidad Humanitas & $\begin{array}{l}\text { Lic. en Derecho } \\
\text { Lic. en Administración } \\
\text { Lic. en Contabilidad } \\
\text { Lic. en Psicología } \\
\text { Lic. en Ciencias Políticas y Administración } \\
\text { Pública } \\
\text { Lic. en Educación }\end{array}$ \\
\hline
\end{tabular}




\begin{tabular}{|c|c|}
\hline Tecnológico de Baja California (TBC) & $\begin{array}{l}\text { Ing. Computacionales } \\
\text { Ing. Computacionales y Telecomunicaciones } \\
\text { Ing. en Telecomunicaciones } \\
\text { Ing. Tecnologías de la Información } \\
\text { Ing. Industrial } \\
\text { Lic. en Administración de Mercadotécnica } \\
\text { Lic. en Administración y Dirección de Empresas } \\
\text { Lic. en Ciencias de la Educación } \\
\text { Lic. en Comercio Exterior y Aduanas } \\
\text { Lic. en Contaduría Físical Pública } \\
\text { Lic. en Derecho } \\
\text { Lic. en Estrategias Logísticos y Suministro Global } \\
\text { Lic. en Psicología } \\
\text { Lic. en Turismo, Hotelería y Restaurantes }\end{array}$ \\
\hline Centro de Estudios Universitarios "Benito Juárez G." & $\begin{array}{l}\text { Lic. en Administración de Empresas y Negocios } \\
\text { internacionales } \\
\text { Lic. en Ciencias computaciones } \\
\text { Lic. en Comercio exterior y Aduanas } \\
\text { Lic. en Derecho }\end{array}$ \\
\hline Centro de Estudios Superiores de la Frontera UNIFRONT & $\begin{array}{l}\text { Lic. en Criminología } \\
\text { Lic. en Diseño Grafico } \\
\text { Lic. en Psicología } \\
\text { Lic. en Psicopedagogía }\end{array}$ \\
\hline Centro de Estudios Superiores, Culinary Art School & Lic. en Arte Culinario \\
\hline
\end{tabular}

Fuente. Las páginas web de cada Universidad, fecha de consulta 15/08/2015. 
Conclusiones 
Los cuatro capítulos de esta tesis han permitido a la doctoranda obtener un conocimiento mucho más profundo sobre la IED recibida por México tanto desde Japón como desde otros países, examinar los flujos comerciales de este país hacia Estados Unidos en este mercado y arrojar luz sobre los efectos de las políticas públicas en el desarrollo de los flujos de IED. Por ello, esta doctoranda considera que se ha logrado el objetivo planteado de reconsiderar el papel de la IED en México desde tres puntos de vista complementarios. En efecto, la tesis ha permitido resituar el papel de Japón en la IED en México, analizar y comprender el crecimiento de las exportaciones mexicanas y la competencia con China en el mercado de Estados Unidos y el papel de las políticas públicas para potenciar primero la industria maquiladora mexicana $\mathrm{y}$, posteriormente, toda la industria manufacturera de exportaciones.

En particular, la tesis ha permitido contrastar las tres hipótesis que han guiado este trabajo. En el caso de la primera: "La evolución de la IED japonesa en México se ajusta a la teoría ecléctica de Dunning ya que en su evolución tienen importancia tanto las ventajas de las empresas japonesas (sus ventajas de propiedad), como las ventajas de localización de México y las necesidades de las empresas japonesas de internalizar estas ventajas", podemos decir que las ventajas de localización (la L del Paradigma OLI) son básicas en el caso mexicano.

En efecto, desde el punto de la vista de la IED, México es un país atípico en América Latina. La fuerte influencia económica de Estados Unidos es un factor muy importante a la hora de diseñar su política económica, pues una parte fundamental de su ventaja de localización es su proximidad, compartiendo frontera con Estados Unidos. Por ello, el objetivo más importante de la IED en México desde los años 80 ha sido la exportación de productos a Estados Unidos. Esta tendencia no ha cambiado hasta ahora. Por eso, esta IED depende más de la situación económica de Estados Unidos que de la situación económica de México. En el caso de la IED de empresas asiáticas -como las empresas de Japón y de Corea del Sur-, ésta también se ha visto influenciada por la situación relativa del tipo de cambio entre sus monedas y el dólar estadounidense y la situación de sus respectivas economías. Cuando sus monedas se han apreciado, las empresas asiáticas han tenido más dificultades para colocar sus exportaciones en Estados Unidos. En esos momentos, han dado más importancia a sus inversiones en México, para seguir exportando a Estados Unidos. 
Como hemos dicho, una ventaja fundamental de la IED en México es la proximidad geográfica al mercado estadounidense. Sin embargo, dependiendo de la industria, hay diferencias sobre lo que esta ventaja significa. Por ejemplo, para las empresas de la industria manufacturera, la proximidad significa un bajo coste de transporte, mientras que para las empresas de la industria de servicios, como las empresas de la industria de call-center, la proximidad significa la alta posibilidad de encontrar recursos humanos apropiados que conozcan la situación cotidiana de Estados Unidos. Esto indica que encontrar informaciones actuales sobre Estados Unidos es otra ventaja en la actividad inversora en México, especialmente para la industria de servicios.

La ventaja de la proximidad induce beneficios distintos dependiendo de las industrias. Enfocar adecuadamente este tema es muy importante para comprender la política industrial en México, porque hasta la década de 1990, la principal industria de exportación del país era la industria manufacturera intensiva en trabajo. Sin embargo, la situación está cambiando. En las últimas décadas, otras industrias como las de instrumentos médicos y aeroespaciales han aumentado su importancia en la economía mexicana. Estas industrias no son iguales que las industriales intensivas en trabajo del pasado. Ahora se necesitan inversiones más altas en recursos humanos. Además, la industria de servicios, como la industria de call-center, también está aumentando sus exportaciones a Estados Unidos. Estas nuevas industrias están confiriendo una nueva importancia al factor de la proximidad al mercado estadounidense. Tenemos que considerar que la ventaja de proximidad al mercado de Estados Unidos ofrece diferentes beneficios a la IED, dependiendo de la industria.

Además, una segunda ventaja de localización ha sido el aprovechamiento de su bajo coste de la mano de obra respecto al de Estados Unidos. Sin embargo, esta ventaja ya no es una realidad tan clara para México por dos razones. Primero, China ha surgido como un importante competidor en el mercado de Estados Unidos, con unos costes de mano de obra muy inferiores a los de México. No obstante, últimamente, la diferencia del coste de la mano de obra entre México y China se ha acercado, pero hace 15 años, el coste de la mano de obra china era mucho más barato que el de México. Esta situación significaba que la fabricación en México ya no podía depender únicamente de su bajo coste de mano de obra y hace necesaria la búsqueda de una mayor productividad 
Al hablar de IED en México, se tiende a poner el foco en las ventajas de localización de México, sin embargo, no se deben olvidar las ventajas de Propiedad (la O del Paradigma OLI) de las empresas japonesas. Las empresas japonesas que han invertido en México han tenido y siguen teniendo una alta capacidad de Investigación, Desarrollo e Innovación ( $\mathrm{I}+\mathrm{D}+\mathrm{i})$, con productos muy competitivos en el mercado internacional, y dentro de estas ventajas se pueden situar sus sistemas de producción como Just-In-Time. Estos elementos son decisivos para explicar sus inversiones en México.

La internalización también es clave para entender la IDE de las empresas japonesas. La I del Paradigma OLI nos ayuda a entender por qué las empresas de Japón eligen fabricar en México y no en Japón o Estados Unidos. Para las empresas mexicanas, no es fácil formar parte de las cadenas de fabricación de las empresas japonesas. Se ha mostrado que la relación en Japón entre empresas matrices y las empresas subcontratadas es muy fuerte. Para las PYMES en México es muy complicado conseguir los estándares de calidad que exigen las empresas japonesas y trabajar con ellas. Sin embargo, el gobierno en México (central y regional) intentan establecer sistemas para vincular las empresas extranjeras con las empresas locales. Esta ventaja de internalización se relaciona con la tercera hipótesis de esta tesis.

También, la tesis ha permitido contrastar la segunda hipótesis: "La evolución de las exportaciones de México a Estados Unidos es fruto de los flujos de IED recibidos por este país, pero se ha visto afectada por los cambios en las políticas comerciales de México y Estados Unidos y por los cambios en la regulación internacional del comercio". En efecto, en el capítulo I se ha analizado el marco institucional del comercio, destacando la firma del TLCAN y la incorporación de China a la OMC. El análisis de los flujos comerciales ha permitido observar la multiplicación de los mismos tras la firma del TLCAN. Se ha podido evidenciar que para México su mayor destino de exportación y su mayor origen de importación es Estados Unidos. Esta situación no ha cambiado desde hace 30 años. Por el contrario, en China el destino de su exportación y el origen de su importación son más variados, aunque con una participación muy importante de los países asiáticos. Esta mayor diversidad del comercio exterior de China ofrece más opciones de destinos de exportación a las empresas extranjeras localizadas en China. Por esta razón, el importante reto para México es aumentar el número de destinos de sus exportaciones y por ello se ha convertido en uno de los países que más tratados de libre comercio ha firmado. Aunque la mayor parte de las empresas extranjeras en México quiere exportar 
sus productos a Estados Unidos, sería deseable encontrar otros destinos para mantener sus actividades en México. Especialmente, México tiene la capacidad de convertir a otros países latinoamericanos en potenciales destinos para sus exportaciones y esta ventaja puede ser aprovechada por México.

La revisión de literatura teórica sobre el comercio realizada en el capítulo I se ha complementado en el capítulo III con un análisis aplicado. Respecto al comercio intraindustrial de México en el mercado de Estados Unidos, su valor no es tan elevado, aunque se sitúa en un nivel mucho más alto que el de China. En el caso de China su porcentaje de comercio intra-industrial es muy bajo, cercano a cero, ya que China importa muy poco desde Estados Unidos.

Por el contrario, en el caso de México, hay mucha importación desde Estados Unidos, aunque su porcentaje de comercio intra-industrial sea relativamente bajo. Un motivo fundamental de esto tiene que ver con los consumidores. Según Krugman, hay comercio intra-industrial, cuando hay variedad de preferencias de los consumidores (KRUGMAN, 1979, p. 471). Esto significa que para que se expanda el comercio intraindustrial, se necesita demanda de las diferentes variedades de los productos. En el caso de México y Estados Unidos, la diferencia de poder adquisitivo entre los consumidores de los dos países es muy grande, ya que solo una pequeña parte de los consumidores mexicanos tiene niveles de renta parecidos a los de Estados Unidos ${ }^{1}$. Esta diferencia de poder adquisitivo genera diferencias en las demandas entre México y Estados Unidos. Puede haber demanda de un producto en Estados Unidos, pero en México no existir dicha demanda, o existir en una proporción muy inferior, ya que solo los más ricos pueden demandar productos como los que se consumen en Estados Unidos. Las empresas pueden fabricar variedades de productos, a través de añadir una pequeña diferencia a sus productos originales. Pero si hay diferencias de demandas muy grandes sobre productos entre ambos países, las empresas no pueden corresponder a esas demandas porque no pueden aprovechar las economías de escala. Fabricar los dos tipos de productos totalmente distintos es muy costoso. En esta situación, hay menos posibilidades de

\footnotetext{
${ }^{1}$ En 2011, las ganancias nominales mensuales medias del empleo en México eran de 314 dólares (4.400 pesos mexicanos) mientras que en Estados Unidos eran de 3.276 dólares, según información de la Organización Internacional de Trabajo. Disponible en http://www.ilo.org/ilostat/faces/help_home/data_by_subject/subject-details/indicator-details-bysubject?indicator=EAR_MNEE_NOC_NB\&subject=EAR\&datasetCode $=$ GWR \&collectionCode $=$ GWR\& _adf.ctrl-state=me0490zxz_338\&_afrLoop=174095547903843\#!, fecha de consulta: 13/10/2016.
} 
desarrollar el comercio de intra-industrial. Si se lograra aumentar el poder adquisitivo de los consumidores mexicanos, habría más posibilidades de aumentar el comercio intraindustrial. Uno de motivo del bajo porcentaje de comercio intra-industrial en México procede de la diferencia de los poderes adquisitivos entre los consumidores de Estados Unidos y México.

Por otra parte, es necesario considerar la relación entre los "contenidos locales" y el comercio intra-industrial. En el TLCAN y el AAE entre México y Japón, hay artículos en los tratados sobre los "contenidos locales." Sin embargo, al observar los resultados del bajo porcentaje de comercio intra-industrial existente, se puede cuestionar la efectividad de estos artículos. Estos artículos de los "contenidos locales" tienen un problema, especialmente a la hora de establecer la manera de calcular los "contenidos locales" a partir del coste de fabricación o de los valores añadidos. Estas cifras no indican directamente si ha habido o no un aumento de la capacidad para generar alto valor añadido en los productos mexicanos. Para aumentar la capacidad de producir alto valor añadido en México, será necesario localizar en el país las fases más importantes de la fabricación de los productos. En otras palabras, altos "contenidos locales" no significan que directamente exista una alta capacidad de producción de valor añadido.

Además, el concepto de los “contenidos locales" está basado en la existencia del comercio intra-industrial vertical. En la actualidad, las exportaciones a Estados Unidos de instrumentos médicos, farmacéuticos y aeroespaciales han aumentado. En estas industrias es más fácil que se pueda promover el comercio intra-industrial horizontal con Estados Unidos. El desarrollo del comercio intra-industrial horizontal es difícil de medir y analizar a través de los "contenidos locales". En cualquier caso, para México será necesario establecer una estrategia para promover el comercio intra-industrial horizontal.

El análisis permite afirmar que el presidente Trump está cometiendo un error cuando compara el comercio de México con Estados Unidos con el de China. Cualquier política en contra de las importaciones de Estados Unidos desde México va a tener un efecto sobre el empleo en Estados Unidos porque México, aunque el nivel sea relativamente bajo, compra productos estadounidenses para producir. Del mismo modo, la producción en Estados Unidos aprovecha consumos intermedios producidos en México. Por el contrario, en el caso de China, el nivel de comercio intra-industrial es casi 0, por lo que las restricciones al comercio con China, aunque sí tendrán efectos sobre la 
eficiencia agregada del sistema y sobre los precios en Estados Unidos, no afectarán tan directamente al empleo en Estados Unidos.

Finalmente, la tesis ha permitido también responder a la tercera hipótesis: "Las políticas públicas tienen un papel clave para explicar la evolución de los flujos de IED en México, aunque otros factores externos, propios de los países de origen de la IED, de la evolución de la competencia internacional en el sector de las manufacturas y de la coyuntura económica y política del país de destino de las exportaciones que debe generar dicha IED son también relevantes".

Respecto a las políticas de atracción de la IED, se han analizado en tres niveles: el del gobierno central, el de los gobiernos de los estados, que es muy importante al ser México un país federal, y el municipal. El papel del gobierno central es diseñar el programa global de atracción de inversiones y mostrar su política de forma general a las empresas extranjeras. Así, las reformas de liberalización del comercio y las inversiones y, más concretamente, la Ley para Promover la Inversión Mexicana y Regular la Inversión Extranjera de 1993 fueron claves para el desarrollo de las inversiones japonesas en México, como también lo fue la firma del TLCAN en 1992 y la creación del programa IMMEX en 2006.

Por otro lado, los gobiernos de los estados y de los municipios tienen un papel destacado y tienen que conectar directamente con las empresas extranjeras. Por eso, en los gobiernos locales, se necesitan recursos humanos con alta capacidad para trabajar con empresas extranjeras. Por ejemplo, los gobiernos de los estados tienen el derecho de establecer las políticas tributarias de atracción de la IED. Esto significa que, los gobiernos provinciales deben conocer las situaciones y condiciones de las empresas extranjeras. Así, tienen que conocer qué tipo de políticas tributarias quieren las empresas y qué tipo de estrategias de inversiones tienen las empresas extranjeras. El desarrollo de una estrategia para aumentar los recursos humanos que puedan trabajar con las empresas extranjeras es necesario para que los gobiernos locales puedan ejercer su función adecuadamente. Si se puede aumentar este tipo de recursos humanos, tendrán la posibilidad de establecer una nueva relación más fructífera entre las empresas locales y las empresas extranjeras. Actualmente, las empresas extranjeras no tienen la oportunidad de conocer y tener una información completa de las empresas locales. Aunque el Gobierno de México tiene unos servicios de matching entre empresas extranjeras y empresas mexicanas, no se puede 
decir que funcionen bien. Para conocerse bien a ambos lados, es necesario contar con personal que conozca cómo se trabaja en las empresas extranjeras.

Además, el personal local que conoce bien a las empresas extranjeras puede también establecer una relación entre las empresas extranjeras y las instituciones académicas locales (por ejemplo, universidades, institutos, colegios y escuelas). Actualmente, la mayor parte de las empresas extranjeras instaladas en México no tienen una vinculación relevante con el sistema educativo de México. Esta vinculación sería de gran ayuda para incentivar un mayor interés entre los estudiantes para estudiar, por ejemplo, ciencias naturales o ingeniería. También, ayudaría a que los padres entendieran que ser un buen técnico e ingeniero es un buen futuro profesional para sus hijos. Por estas razones, el papel de los gobiernos locales en el desarrollo de los recursos humanos es muy importante para atraer más IED. Además, mejorar la condición de la inversión extranjera, por ejemplo, por medio de una mayor optimización de los transportes públicos (para ayudar a los trabajadores locales a trasladarse a las empresas extranjeras) también sería una vía útil y complementaria de apoyo a los recursos humanos.

La ventaja de México es la proximidad al mercado de Estados Unidos. En el futuro, para atraer más IED, México (no solo el gobierno central) tiene que dar una nueva perspectiva a su ventaja geográfica, en parte, mediante políticas públicas de consolidación de esta ventaja, por ejemplo, desarrollando nuevas infraestructuras que abaraten el transporte. En esta línea, el incremento de los recursos humanos adecuados que puedan trabajar con el personal de las empresas japonesas también será necesario. Un tema no menor en el caso de México es el de la violencia y la inseguridad, que se ha convertido en un problema global de México y que le está restando atractivo también como destino de la IED.

La situación actual, en la que la administración del presidente Trump quiere renegociar el TLCAN y poner impedimentos al comercio con México y con China está generando dudas sobre el futuro de las exportaciones de las empresas instaladas en México a Estados Unidos. En este momento es difícil saber todavía cuáles serán las políticas concretas que aplicará el presidente Trump y cuáles serán sus efectos sobre México, pero ya están quitando atractivo a México como destino de la IED y algunas empresas han cancelado inversiones previstas en México siguiendo los lineamientos 
propuestos por la nueva administración ${ }^{2}$. Sin embargo, debe tenerse en cuenta que obligar a reducir la producción en México de las empresas estadounidenses generará también un perjuicio a los consumidores de Estados Unidos, porque el precio será más caro si se produce en Estados Unidos.

\footnotetext{
${ }^{2}$ Véanse, por ejemplo, los efectos de la cancelación del plan de inversión de Ford en Aguascalientes. http://www.eleconomista.es/empresas-eAm-mexico/noticias/8062802/01/17/Que-pierde-Mexico-con-lacancelacion-de-la-inversion-de-Ford.html, fecha de consulta: 20/3/2017.
} 
Bibliografía 
ABOITES, Hugo. 2006. "Universidad y maquiladora en la frontera México-Estados Unidos: el experimento de la educación superior en la integración económica del libre comercio". En Vessuri Hebe (Editor), Universidad e Investigación Científica, Buenos Aires: Universidad de investigación científica. Pp. 221-236. http://biblioteca.clacso.edu.ar/gsdl/collect/clacso/index/assoc/D1106.dir/12Aboit es.pdf

AGUILAR-PÉREZ, Pedro y Lucila Patricia CRUZ-COVARRUBIAS. 2015. "Esquema de condicionantes en la relación proveedor-cliente en la industria automotriz. Caso sector autopartes en la Zona del Bajío", Dirección y Organización, (56), Pp. 57-67. http://www.revistadyo.org/index.php/dyo/article/download/474/496

AGUIRRE, Georgina, Ivette SALIM, Carolina TORRES y Mariana REINA. 2012. "EL TEOREMA HECKSCHER-OHLIN Y LA INDUSTRIA TEXTIL DE MÉXICO”, Comercio Exterior, 63 (6), Pp. 2-6. http://revistas.bancomext.gob.mx/rce/magazines/138/6/VOL._621_Comprobaci\%C3\%B3n.pdf

ALBA VEGA, Carlos. 1996. "Las empresas integradoras en México". En Oscar Muños (Editor), Estado, empresarios, instituciones: estrategias para la transformación productiva, Santiago de Chile: CEPAL/CIEPLAN, Pp. 61-77. http://repositorio.cepal.org/bitstream/handle/11362/1527/S33804M971.pdf?sequ ence $=1$

ALBA VEGA, Carlos. 2001. "Las empresas integradoras en México", Comercio exterior, 51(12), Pp. 1056-1062. http://revistas.bancomext.gob.mx/rce/magazines/29/3/RCE.pdf

ALONSO, Jorge, Jorge CARILLO y Oscar CONTRERAS. 2000. Trayectorias tecnológicas en empresas maquiladoras asiáticas y americanas en México. Serie Desarrollo Productivo 72. Santiago de Chile: CEPAL, http://repositorio.cepal.org/bitstream/handle/11362/4456/1/S00030189_es.pdf

ALONSO RODÍGUEZ, José Antonio. 1991. "Economía española: especialización comercial y factores de competitividad", en José Luis García Delgado, Andrés Pedreño Muñoz y Juan Velarde Fuertes (Coordinadores), Apertura e internacionalización de la economía española: España en una Europa sin fronteras : V Jornadas de Alicante sobre Economía Española, Madrid: Colegio de Economistas de Madrid.

ALPERSTAIN, Aída Lerman. 2008. "La Institución del Comercio Mundial: del GATT al OMC", Comercio Exterior, 58(2), Pp. 135-134. http://revistas.bancomext.gob.mx/rce/magazines/112/5/RCE5.pdf

AMANO Tomofumi y Kentei HAN.2003. "Nityuu Kaden Sangyo Hatten no Dinamizumu (jyo)- Kokusai Bungyou no Tenkai to Kyousou Yui no Henka”, Keiei-Ronsyuu, Universidad de Toyo, (58), Pp. 123-144. www.toyo.ac.jp/uploaded/attachment/2834.pdf

AMARO-ROSALES, Marcela y Daniel Hugo VILLAVICENCIO-CARBAJAL. 2015. "Incentivos a la innovación de la biotecnología agrícola-alimentaria en México", Estudios sociales (Hermosillo, Son.), 23(45). Pp. 33-45. http://www.scielo.org.mx/pdf/estsoc/v23n45/v23n45a2.pdf

ANELLI, José María. 2013. Política fiscal e inversión: un enfoque sistémico y de crecimiento inclusivo. Serie Macroeconomía del Desarrollo 127. Santiago de 
Chile: CEPAL.

http://repositorio.cepal.org/bitstream/handle/11362/5360/S1300900_es.pdf?sequ ence $=1 \&$ isAllowed $=\mathrm{y}$

APIR (ASIA PACIFIC INSTITUTE OF RESEARCH). 2014. APIR COMENTARY, Num. 28. 18 de febrero, 2014. http://www.apir.or.jp/ja/research/files/2014/02/APIR_Commentary_No28.pdf

BALASSA, Bela. 1963. "An empirical demonstration of classical comparative cost theory", The Review of Economics and Statistics, 45 (3), Pp. 231-238. http://www.jstor.org/stable/pdf/1923892.pdf

BALASSA, Bela. 1966. "Tariff reductions and trade in manufacturers among the industrial countries", The American Economic Review, 56(3), Pp. 466-473. http://www.jstor.org/stable/1823779?seq=1\#page_scan_tab_contents

BALASSA, Bela. 1986. "Comparative advantage in manufactured goods: a reappraisal", The Review of Economics and Statistics, 68(2), Pp. 315-319. http://documents.worldbank.org/curated/en/704931468739539459/pdf/multipage.pdf

BERGSTRAND, Jeffrey H. 1985. "The gravity equation in international trade: some microeconomic foundations and empirical evidence", The review of economics and statistics, 67(3), Pp. 474-481.

http://www.jstor.org/stable/1925976?seq=1\#page_scan_tab_contents

BERGSTRAND, Jeffrey H. 1989. "The Generalized Gravity Equation, Monopolistic Competition, and the Factor-Proportions Theory in International Trade", The Review of Economics and Statistics, 71(1), Pp. 143-153. http://www.jstor.org/stable/pdf/1928061.pdf

BRESNAHAN, Timothy y Valerie A RAMEY. 1993. "Segment shifts and capacity utilization in the US automobile industry", The American Economic Review, 83 (2), Pp. 213-218. http://www.jstor.org/stable/pdf/2117666.pdf

BUCKLEY, Peter J. 2006. "Stephen Hymer: Three phases, one approach?", International Business Review, 15(2), Pp. 140-147. http://ac.elscdn.com/S0969593105001216/1-s2.0-S0969593105001216main.pdf?_tid=26a31552-0b08-11e7-a40e00000aacb35f\&acdnat=1489751709_dc0a723282ab9fbc287748e36f124352

BUCKLY, Peter. J. 2011. "The theory of international business pre-Hymer", Journal of World Business, 46(1), Pp. 61-73.

http://s3.amazonaws.com/academia.edu.documents/44471057/The_theory_of_in ternational_business_pre20160406-7766ka9r5w.pdf?AWSAccessKeyId=AKIAJ56TQJRTWSMTNPEA\&Expires=1485 018142\&Signature $=$ YmZFwyWM5FSrK3bl2rXsSABEFHE\%3D\&responsecontentdisposition=inline \%3B\%20filename\%3DThe_theory_of_international_business _pre.pdf

BUENO, Carmen. Gonzalo SARAVÍ. 1997. "Relaciones de cooperación interempresariales: Lecciones de la experiencia mexicana.", Nueva Sociedad, (151), Pp. 102-121. http://nuso.org/media/articles/downloads/2627_1.pdf 
BUITELAAR, Rudolf y Ramón PADILLA. 1996. "El comercio intraindustria de México con sus principales socios comerciales", Estudios económicos, 11(1), Pp. 77-116. http://aleph.academica.mx/jspui/bitstream/56789/25480/1/11-0211996-0077.pdf

BUITELAAR, Rudolf, Ruth URRUTIA y Ramón PADILLA. 1990. Centroamérica, México y República Dominicana: maquila y transformación productiva. Cuadernos de la CEPAL, Núm. 85. México DF: CEPAL. http://repositorio.cepal.org/bitstream/handle/11362/27809/S9900500_es.pdf?seq uence $=1 \&$ isAllowed $=y$

BURTON, Fred y F. H. SAELENS. 1987. "Trade barriers and Japanese foreign direct investment in the colour television industry", Managerial and Decision Economics, 8(4), Pp. 285-293. http://onlinelibrary.wiley.com/doi/10.1002/mde.4090080404/epdf

Cabinet Office del Gobierno de Japón. 1981. Keizai-Hakusyo, Syowa 56nennd, Tokyo: Economic Planning Agency, Japan. http://www5.cao.go.jp/keizai3/keizaiwp/wp-je81/wp-je81-000i1.html

CARBAUGH, Robert J. 2004. Economía internacional, traducción de Pilar Mascaró Sacristán y Magda Elizabeth Treviño Rosales. México: Cengage Learning Editores. $12^{\circ}$ edición. http://s3.amazonaws.com/academia.edu.documents/35395178/EconomiaInternacional-Carbaugh12th_redacted1.pdf?AWSAccessKeyId=AKIAJ56TQJRTWSMTNPEA\&Expire $s=1485018239 \&$ Signature $=J$ fdPFMUKTxBOpNBn46IqJJlfUZE\%3D\&response -contentdisposition=inline\%3B\%20filename\%3DDecision_theory_in_expert_systems_a nd_ar.pdf

CARRILLO, Jorge. 2003. "Maquiladoras: Urge mayor inversión y recuperar competitividad", Ejecutivos de Finanzas, Pp.15-20. www.jorgecarrillo.info/index.php?r=publicaciones/ver_documento\&id=274\&u= MjEyLjEyOC4xNTUuMTI4

CARRILLO, Jorge. 2009. "Exportaciones mexicanas y el reto de China: la industria de la televsión. ¿Amenaza u oportunidad?" Globalización, Conocimiento y Desarrollo. La nueva economía global del conocimiento. Estructura y problemas, Tomo I. México D.F: UNAM. Pp. 371-381. http://www.jorgecarrillo.info/index.php?r=publicaciones\%2Ffiltra\&lang=es\&cat egoria $=117 \& q$

CARRILLO, Jorge. 2013. "Movement toward Regional Markets in Latin America".En Katsuo Yamazaki, Wooseok Juhn y Tetsuo Ado (Editores), Hybrid Factories in Latin America. Londores: Palgrave Macmillan. Pp. 44-70. http://www.jorgecarrillo.info/index.php?r=publicaciones/info\&id=400\&lang=es

CARRILLO, Jorge. 2015. "Escalamiento industrial, manufactura avanzada y sus límites. Las multinacionales en México". En Universidad Autónoma Metropolitana y Educación y Cultura Asesoría y Promoción S.C. (Editores), Manufactura Avanzada. Prioridades Socioeconómicas y Redes de Colaboración para el Desarrollo en su Proyección Local y Global al año 2024. México D.F: Universidad Autónoma Metropolitana. Pp. 53-65. http://www.jorgecarrillo.info/index.php?r=publicaciones/info\&id=437\&lang=es 
CARRILLO, Jorge y Graciela BENSUNSAN. 2012. "Corporaciones multinacionales y prácticas del empleo en México". En Enrique de la Garza Toledo (Coordinador), La situación de Trabajo en México 2012. El trabajo en la crisis, Pp. 731-751.

http://www.jorgecarrillo.info/index.php?r=publicaciones/info\&id=399\&lang=es

CARRILLO, Jorge y Oscar CONTRERAS. 2005. "Corporaciones transnacionales y redes de abastecimiento local en la industria del televisor en el norte de México" en Dussel Peters y Palacios Lara (Coordinadores), Condiciones y retos de la electrónica en México, México, D.F: Normalización y Certificación Electrónica A.C. Pp.277-302. http://www.colef.mx/jorgecarrillo/corporacionestransnacionales-y-redes-de-abastecimiento-local-en-la-industria-del-televisor-enel-norte-de-mexico/

CARRILLO, Jorge y Jim GERBER. 2006. "The Future of the Maquiladora: Between Industrial Upgrading and Competitive Decline", Forum Fronterizo, San Diego Dialogue, San Diego: University of California, 08 de marzo 2006. http://www.jorgecarrillo.info/index.php?r=publicaciones\%2Ffiltra\&lang=es\&cat egoria $=114 \& q$

CARRILLO, Jorge y Redi GOMIS. 2003. "Los retos de las maquiladoras ante la pérdida de competitividad", Comercio Exterior, 53(4), Pp. 318-327. http://www.colef.mx/jorgecarrillo/wp-content/uploads/2012/04/PU255.pdf

CARRILLO, Jorge y Redi GOMIS. 2005. "Integración Económica y maquiladoras en México: evolución y perspectivas frente al reto de China". En R. Partida y J. Carrillo (coordinadores), Integración Regional y Globalización: impactos económicos y sindicales, USAID-Fundación Friedrich Ebert, Pp. 31-47. http://www.colef.mx/jorgecarrillo/wp-content/uploads/2012/04/PU300.pdf

CARRILLO, Jorge y Redi GOMIS. 2014. "Empresas Innovadoras e inclusión en México", en Economías Latinoamericanas. Cómo avanzar más allá del ingreso medio, Santiago de Chile: Cieplan. pp.391-427.

CARRILLO, Jorge y Alfredo HUALDE ALFARO. 2000. "Desarrollo Regional y Maquiladora Fronteriza: Peculiaridades de un Cluster Electrónico en Tijuana", El Mercado de Valores, 60(10), pp.45-72. http://dusselpeters.com/05.pdf

CARRILLO, Jorge y Alfredo HUALDE ALFARO. 2013. “¿Una maquiladora diferente? competencias laborales profesionales en la industria aeroespacial en Baja California”. En Mónica Casalet (Editores), La industria aeroespacial: Complejidad productiva e institucional, México D.F: FLACSO. Pp. 163-197. http://www.jorgecarrillo.info/index.php?r=publicaciones/info\&id=402\&lang=es

CARRILLO, Jorge, Alfred HUALDE ALFARO y Cirila Quintero RAMIREZ. 2005. "Recorrido por la historia de las maquiladoras en México" Comercio Exterior, 55(1), Pp. 30-42. http://revistas.bancomext.gob.mx/rce/magazines/74/4/RCE.pdf

CARRILLO, Jorge, Michael MORTIMORE y Jorge Alonso ESTRADA. 1998. El Impacto de las empresas Transnacionales en la Reestructuración Industrial de México. El caso de las Industrias partes para vehículos y de Televisores, Desarrollo Productivo 50. Santiago de Chile: CEPAL. https://www.researchgate.net/profile/Jorge_Alonso_Estrada/publication/253954 590_El_impacto_de_las_empresas_transnacionales_en_la_reestructuracion_indu 
strial_de_Mexico_el_caso_de_las_industrias_de_partes_para_vehiculos_y_de_t elevisores/links/00b4951fb5fb9d094e000000.pdf

CARRILLO, Jorge e Ismael PLASCENCIA. 2010. "La presencia China en Baja California". En Enrique Dussel Peters y Yolanda Trápaga (Editores), Hacia un diálogo entre México y China. Dos y tres décadas de cambios socioeconómicos. Senado de la Republica, Centro de estudios China-México, CICIR, y Friedrich Ebert: México, Pp. 357-366. http://www.redalcchina.org/monitor/images/pdfs/Investigacion/35_Carrillo_2010.pdf

CARRILLO, Jorge, Ismael PLASCENCIA y Redi GOMIS. 2011. "Las Corporaciones Multinacionales en Mexico" en Martinez Villavicencio, D. y A. Lopez de Alba (Coordinadores), Estrategias, sectores, y regiones, Mexico Ed. Plaza y Valdez/CONCYTEG/UAM-Xochimilco, pp. 191-227. http://www.jorgecarrillo.info/index.php?r=publicaciones\%2Ffiltra\&lang=es\&cat egoria $=119 \& q$

CARRILLO, Jorge, Ismael PLASCENCIA y Roberto ZARÁTE. 2012. “La inversión directa extranjera y las corporaciones multinacionales en América Latina y México." En Jorge Carrillo (Editor), La importancia de las multinacionales en la sociedad global. Viejos y nuevos retos para México. Tijuana: El Colegio de la Frontera Norte. Pp. 73-104.

http://www.jorgecarrillo.info/index.php?r=publicaciones/info\&id=395\&lang=es

CARRILLO REGALADO, Salvador. 2016. “DETERMINANTES DE LA LOCALIZACIÓN REGIONAL DE LA INVERSIÓN EXTERNA DIRECTA MANUFACTURERA. EL CASO DE LA IED JAPONESA EN EL SECTOR AUTOMOTRIZ, 2006-2014", $1^{\circ}$ Encuentro Nacional sobre Desarrollo Regional en México, Mérida, Yucatán del 15 al 18 de noviembre de 2016.AMECIDERITM. http://ru.iiec.unam.mx/3292/1/200-Carrillo.pdf

CASTILLO, Víctor y Ramón RAMÍREZ. 1992. "La subcontratación en la industria maquiladora de Asia y México", Comercio exterior, 42(1). Pp. 33-41. http://revistas.bancomext.gob.mx/rce/magazines/254/4/RCE4.pdf

CEPAL, N. U. 2010. La República Popular China y América Latina y el Caribe: hacia una relación estratégica. Santiago de Chile: CEPAL. http://repositorio.cepal.org/bitstream/handle/11362/2956/RP_China_America_L atina_Caribe.pdf?sequence $=1$ \&isAllowed $=\mathrm{y}$

CEPAL, N. U. 2011. La República Popular China y América Latina y el Caribe: hacia una nueva fase en el vínculo económico y comercial. Santiago de Chile: CEPAL. http://repositorio.cepal.org/bitstream/handle/11362/2995/S2011010.pdf?sequenc $\mathrm{e}=1$

CHACHOLIADES, Miltiades. 1992. Economía internacional. México D.F: McGrawHill.

CHAKRABORTY, Suparna. 2009. "The boom and the bust of the Japanese economy: A quantitative look at the period 1980-2000", Japan and the World Economy, 21(1), Pp.116-131. http://ac.els-cdn.com/S0922142508000078/1-s2.0S0922142508000078-main.pdf?_tid=51c8b85a-fa8b-11e6-a36a00000aacb35e\&acdnat=1487938876_0bc737855681a01d4d145dc79028baa8

CHÁVEZ-MARTÍN DEL CAMPO, Juan Carlos y Katia GARCÍA LOREDO. 2015. Identificación de clusters regionales en la industria manufacturera mexicana. 
Working Papers, Banco de México. http://www.banxico.org.mx/publicacionesy-discursos/publicaciones/documentos-deinvestigacion/banxico/\%7BBCF9EC46-B8F1-2058-E05D97398AEDF3FC\%7D.pdf

COLLADO ARMENGOL, Albert. 2002. "La inversión directa en China: implicaciones derivadas de su entrada en la OMC", Información Comercial Española, ICE: Revista de economía, 2(797), Pp. 77-92. http://www.revistasice.info/cachepdf/ICE_797_7791_634C7E3DC84BA12C35EE5140CA192C92.pdf

CONTRERAS, Oscar, Jorge ESTRADA y Martin KENNEY. 1997. "Los gerentes de las maquiladoras como agentes de endogeneización de la industria”, Comercio exterior, 47(8). Pp. 670-679. http://revistas.bancomext.gob.mx/rce/magazines/338/8/RCE8.pdf

CONTRERAS, Óscar y Alfredo HUALDE ALFARO. 2004. "El aprendizaje y sus agentes. Los portadores del conocimiento en las maquiladoras del norte de México" Estudios sociológicos, 22(64), Pp. 79-122. http://www.estudiossociologicos.colmex.mx/index.php/es/article/download/597/ 597

CONTRERAS, Óscar F y Luis Felipe MUNGUÍA. 2007. "Evolución de las maquiladoras en México: Política industrial y aprendizaje tecnológico", Región y sociedad, 19(SPE), Pp. 71-87. http://www.scielo.org.mx/pdf/regsoc/v19nspe/v19nspea5.pdf

CUENCA, Sara Quiroz. 2003. "Competitividad e inversión extranjera directa en México", Análisis Económico, 18(37), Pp. 241-256. http://www.redalyc.org/pdf/413/41303712.pdf?sequence=1\&isAllowed=y

DE LA CRUZ, Justino, Roberto B KOOPMAN y Shang-Jin WEI. 2011. "Estimating Foreign Value added in México's Manufacturing Exports", Office of Economics Working Paper, U.S. International Trade Commission. https://www.usitc.gov/publications/332/EC201104A.pdf

DE LEON P. Guadalupe Garcia. 2010. "México y Japón: comercio bilateral en el marco del Acuerdo de Asociación Económica", Comercio Exterior, 60 (2), Pp. 116125.

http://revistas.bancomext.gob.mx/rce/magazines/135/2/116_GARCIA_mex_japo n.pdf

DELGADILLO ESCOBAR, Jessica Lorena y Jesús Salvador JIMÉNEZ RIVERA, 2008. "MITOS Y REALIDADES DEL TLCAN", Revista Digital Universitaria, 9(5), Pp. 1-23. http://www.revista.unam.mx/vol.9/num5/art30/art30.pdf

DELGADO SELLEY, Orlando. 2016. "La crisis económica global: respuestas de algunos bancos centrales (2007-2013)", Ola Financiera, 9 (24), pp. 65-89. http://revistas.unam.mx/index.php/ROF/article/viewFile/56460/50109

DÍAZ, Alfonso Anaya. 2012. "Industria telefónica en México. Monopolio y entrada en pequeña escala. Una Revisión”, Economía UNAM, 373, Pp.41-59. http://www.economia.unam.mx/publicaciones/econinforma/373/03alfonsoanaya. pdf. 
DING, Ke. 2015. "Nikkei tyuusyou supplyer no tyuugokusijyoukaitaku ni kansuru itikousatu-nihonteki seisansistemuno kaigaitenkai no sitenkara", Asia Keizai, 56(1), Pp.10-33. http://ir.ide.go.jp/dspace/bitstream/2344/1453/1/ZAJ201503_003.pdf

DUNNING, John H. 1980 "Toward an eclectic theory of international production: Some empirical tests", Journal of international business studies, 11 (1), Pp. 9-31. http://s3.amazonaws.com/academia.edu.documents/44054668/Dunning1980_To ward_an_Eclectic_Theory_of_International_Production_Some_Empirical_Tests. pdf?AWSAccessKeyId=AKIAJ56TQJRTWSMTNPEA\&Expires=1485019417 $\&$ Signature $=$ EGud\%2BzoGCvy0cT914DN1MqZu5Ng\%3D\&response-contentdisposition=inline\%3B\%20filename\%3DDunning1980_Toward_an_Eclectic_T heory_of.pdf

DUNNING, John H. 1995. Multinational Enterprises and the Global Economy, Wolkingham: Addison-Wesley.

DUNNING, John. H. 1998. "Location and the Multinational Enterprise: A Neglected Factor?” Journal of International Business Studies, 29(1), Pp. 45-66. http://link.springer.com/article/10.1057/palgrave.jibs.8490024

DUNNING, John. H. 2000. "The eclectic paradigm as an envelope for economic and business theories of MNE activity", International business review, 9(2), Pp. 163190. http://www.sciencedirect.com/science/article/pii/S0969593199000359

DUNNING, John. H y Sarianna M. LUNDAN. 2008. "Institutions and the OLI paradigm of the multinational enterprise", Asia Pacific Journal of Management, 25(4), Pp. 573-593. http://link.springer.com/article/10.1007\%2Fs10490-0079074-Z

DURAND, Jorge. 2007. "El programa bracero (1942-1964). Un balance crítico". Migración y desarrollo, 9(9), Pp.27-43.

http://repositorio.cualtos.udg.mx:8080/jspui/bitstream/123456789/64/5/El\%20Pr ograma\%20Bracero\%20(1942-

1964).\%20Un\%20balance\%20cr\%C3\%ADtico.pdf

DUSSEL PETERS, Enrique. 2000. La inversión Extranjera en México, Serie Desarrollo Productividad, Número 80, Santiago de Chile: CEPAL.

http://repositorio.cepal.org/bitstream/handle/11362/4462/S00080670.pdf?sequen $\mathrm{ce}=1)$

DUSSEL PETERS, Enrique. 2003. "Ser maquila o no ser maquila, ¿es ésa la pregunta?” Comercio exterior, 53(4), Pp. 328-336. http://revistas.bancomext.gob.mx/rce/magazines/19/4/RCE.pdf

DUSSEL PETERS, Enrique. 2004. "Pequeña y mediana empresa en México: condiciones, relevancia en la economía y retos de política", Economía UNAM, 1 (2), Pp. 64-84. http://www.scielo.org.mx/pdf/eunam/v1n2/v1n2a6.pdf

DUSSEL PETERS, Enrique. 2005. "The Implications of China's entry into the WTO for Mexico". Global Issue Papers, No. 24 (NOVEMBER), Berlin: Heinrich Böll Foundation. http://dusselpeters.com/24.pdf

DUSSEL PETERS, Enrique. 2012a. "The Auto Parts-Automotive Chain in Mexico and China. Co-Operation Potential?", The China Quarterly, 209, Pp. 82-110. http://www.dusselpeters.com/55.pdf 
DUSSEL PETERS, Enrique. 2012b. "Salarios en China", Reforma, el día 22 de febrero, 2012. http://www.dusselpeters.com/reforma2012-02.pdf

DUSSEL PETERS, Enrique. 2013a. "Are NAFTA and Export-Oriented Industrialization Passé for Mexico's Economy? Global Lessons". En Ashok Bardhan, Dwight M. Jaffee y Cynthia A. Ktoll (Editores), The Oxford Handbook of Offshoring and Global Employment. New York: Oxford University Press, Pp. 564-588. http://dusselpeters.com/110.pdf

DUSSEL PETERS, Enrique. 2013b. "La economía china desde la crisis internacional en 2008: estrategias, políticas y tendencias", Economía UNAM, 10 (28), Pp. 53-69. http://www.dusselpeters.com/60.pdf

DUSSEL PETERS, Enrique. 2014. "Las importaciones de la cadena autopartesautomotriz de Estados Unidos. Principales condiciones y características (19902012)". En Lourdes Álavez, Jorge Carrillo y María Luisa González (Editores), El auge de la industria automotriz en México en el siglo XXI. Reestrucutración catching up. México D.F: UNAM/COLEF, Pp. 133-146. http://dusselpeters.com/76.pdf

DUSSEL PETERS, Enrique. 2015a. "Una década de conocimiento de la economía china en México. Síntesis y retos". En Alicia Girón, Aurelia Vargas y Guillermo Pulido (Coordinadores), China y México. Un diálogo cultural desde las humanidades y las ciencias sociales. México D.F: UNAM, Pp. 313-322. http://dusselpeters.com/105.pdf

DUSSEL PETERS, Enrique. 2015b."EL rol cambiante de China en América Latina. ¿Favorable para todos?", Atlantic Council/Adrienne Arsht Latin America Center. http://www.dusselpeters.com/90.pdf

DUSSEL PETERS, Enrique. 2016a. "Mexico's new industrial organization since the 1980s: Glocal challenges from export-orientation and polarization". En John Weiss y Michael Tribe (Editores), Routledge Handbook of Industry and Development. Londres y Nueva York: Routledge International Handbooks, Pp. 320-334. http://dusselpeters.com/111.pdf

DUSSEL PETERS, Enrique. 2016b. "México-China 2016-2018: diagnóstico y propuestas en el ámbito económico (comercio e inversiones)", En Enrique Dussel Peters (Coordinador), La relación México-China. Desempeño y propuestas para 2016-2018. México D.F: Unión de Universidades de América Latina y el Caribe, Pp. 85-88. http://dusselpeters.com/101.pdf

DUSSEL PETERS, Enrique y Lorena CÁRDENAS CASTRO. 2007."México y China en la cadena hilo-textil-confección en el mercado de Estados Unidos", Comercio Exterior, 57(7), Pp. 530-545. http://dusselpeters.com/35.pdf

DUSSEL PETERS, Enrique y Lorena CARDENAS CASTRO. 2011. "El comercio intraindustrial en México: un comparativo entre China y Estados Unidos", Comercio Exterior, 61(4), Pp. 1-15. http://dusselpeters.com/49.pdf

DUSSEL PETERS, Enrique y Kevin GALLAGHER. 2013. "China's Economic Effects on the U.S.-Mexico Trade Relationship: Towards a New Triangular Relationship?". En Enrique Dussel Peters, Adrian H.Hearn y Harley Shakin (Editores), China and the New Triangular Relationships in the Americas. China and the Future of US-Mexico Relations. California y México D.F: University of 
California y Universidad Nacional Autónoma de México. Pp. 13-24.

http://www.dusselpeters.com/62.pdf

DUSSEL PETERS, Enrique y Kevin GALLAGHER. 2014. "El huésped no invitado del TLCAN: China y la desintegración del comercio en América del Norte", Boletín Informativo Techint, (343), Pp. 13-43. http://www.dusselpeters.com/97.pdf

DUSSEL PETERS, Enrique y Samuel ORTIZ VELAZQUEZ. 2016. "El Tratado de Libre Comercio de América del Norte, ¿contribuye China a su integración o desintegración?". En Enrique Dussel Peters (Coordinador), La nueva relación comercial de América Latina y el Caribe con China: ¿integración o desintegración regional? México D.F: Unión de Universidades de América Latina y el Caribe, Pp. 245-307. http://dusselpeters.com/100.pdf

ELIZALDE HEVIA, Antonio. 2003. Planificación estratégica territorial y políticas públicas para el desarrollo local. Serie Gestión Pública 29. Santiago de Chile: CEPAL http://repositorio.cepal.org/bitstream/handle/11362/7285/1/S03266_es.pdf

ESCALANTE VALDEZ, Julisa Angélica. 2008. Diseño de un plan de promoción de educación superior en Tijuana Baja California. Tesis de Master en la universidad Autónoma de Aguascalientes. http://bdigital.dgse.uaa.mx:8080/xmlui/bitstream/handle/123456789/511/311722 .pdf?sequence $=1 \&$ isAllowed $=\mathrm{y}$

ESPINO-RODRÍGUEZ, Tomás F y Víctor PADRÓN-ROBAINA. 2006. “A review of outsourcing from the resource-based view of the firm", International Journal of Management Reviews, 8 (1). Pp. 49-70. https://www.researchgate.net/profile/Tomas_EspinoRodriguez/publication/259396813_A_Review_of_Outsourcing_from_the_Resou rce-Based_View_of_the_Firm/links/0deec52b6bec610c3b000000.pdf

ESQUIVEL, Gerardo y Felipe LARRAÍN. 2001. “¿Cómo atraer inversión extranjera directa?" Trabajo preparado como parte del Proyecto Andino de la Universidad de Harvard y la Corporación Andina de Fomento (CAF). http://www.cid.harvard.edu/archive/andes/documents/workingpapers/fdi/esquive lylarrain.pdf

ESTRADA BÁRCENAS, Roberto, Domingo GARCIA PÉREZ de LEMA y Víctor Gabriel SANCHEZ TREJO. 2009. "Factores determinantes del éxito competitivo en la Pyme: Estudio Empírico en México", Revista Venezolana de Gerencia, 14(46), Pp.169-182. http://www.produccioncientificaluz.org/index.php/rvg/article/viewFile/10528/10 516

FALCK REYES, Melba. 2012. "La inversión extranjera directa japonesa en Méjico y el impacto de la crisis global", Globalización, Competitividad y Gobernabilidad de Georgetown/Universia, 6(1), Pp. 36-54. https://gcg.universia.net/article/viewFile/419/545

FALCK REYES, Melba y Vanila DE LA VEGA SHIOTA. 2014. "La inversión japonesa en México en el marco del Acuerdo para el Fortalecimiento de la Asociación Económica entre México y Japón. El caso del sector de equipo de transporte", Comercio Exterior, 64(6), Pp. 23-34. 
http://revistas.bancomext.gob.mx/rce/magazines/760/3/la_inversion_japonesa.pd $\mathrm{f}$

FALCK REYES, Melba y Agustina RODRÍGUEZ ALEGRIA. 2004. “Corea del Sur: un importante socio para México", México y la Cuenca del Pacífico, 7 (22), Pp. $65-$

78.http://s3.amazonaws.com/academia.edu.documents/35318426/Corea_del_Sur

$-$

_un_importante_socio_para_Mexico.pdf?AWSAccessKeyId=AKIAIWOWYYG Z2Y53UL3A\&Expires $=1488209211 \&$ Signature $=$ UkvZZgNlb2Y\%2BG\%2FOE 01ox3cLAitk\%3D\&response-content-

disposition=inline\%3B\%20filename\%3DMEXICO_Y_LA_CUENCA_DEL_PA CIFICO_Corea_de.pdf

FITZGERALD, Valpy, 1998. "La CEPAL y la teoría de la industrialización”, Revista de la CEPAL, 40, Pp.47-61.

http://www.cepal.org/publicaciones/xml/9/19229/valpy.htm

FRANKEL, Jeffrey A, Peter R. ORSZAG, 2002. American economic policy in the 1990s. Massachusetts: MIT Press.

https://www.researchgate.net/profile/Jeffrey_Frankel/publication/4895051_Ame rican_Economic_Policy_in_the_1990's/links/546fd9b10cf216f8cfa9e6fd.pdf

FUENTES, César M. y Noé Arón FUENTES. 2004. “Desarrollo económico en la Frontera Norte de México: de las políticas nacionales de fomento económico a las estrategias de desarrollo económico local", Revista Iberoamericana de Filosofía, Política y Humanidades, 6(11), Pp. 71-86. http://alojoptico.us.es/Araucaria/nro11/monogr11_2.pdf

FUKAO Kyoji y Dougun, EN. 2001. Nihonn no taigai tyokusetutoushi to kuudouka. RIETI Discction Paper. No.01-J. http://www.ier.hitu.ac.jp/ fukao/japanese/publication/paper/2001/2001-91.pdf

GAMBRILL, Mónica. 2008. "IMMEX: Convergencia de la maquiladora y la industria manufacturera de exportación”, Comercio Exterior, 58(4), Pp.315-322. http://revistas.bancomext.gob.mx/rce/magazines/114/8/RCE8.pdf

GANADO, Alfredo Salomón. 2008. "La industria del plástico en México", Comercio exterior, 58 (6), Pp. 486-492.

http://revistas.bancomext.gob.mx/rce/magazines/116/6/RCE6.pdf

GARCÉS-DÍAZ, Daniel Guíllermo. 2008. “Análisis de las funciones de importación y exportación de México (1980-2000)”, El Trimestre Económico, 75(297), Pp. 109-141. http://www.redalyc.org/html/313/31340954003/

GARCÍA, Juan González. 2014. “El Acuerdo de Asociación Económica México-Japón: ¿es posible un relanzamiento?", Comercio Exterior, 64(6), Pp. 2-8. http://revistas.bancomext.gob.mx/rce/magazines/760/2/el_acuerdo_de_asociacio n.pdf

GARCÍA, Gilberto y Víctor PAREDES. 2001. Programas de apoyo a las micro, pequeñas y medianas empresas en México, 1995-2000. Serie Desarrollo Productivo 115. Santiago de Chile: CEPAL. http://repositorio.cepal.org/bitstream/handle/11362/4500/S0111988.pdf?sequenc $\mathrm{e}=1$ 
GARCÍA, Juventino López, Fernando Padilla LOZANO y Pablo Gutiérrez CASTORENA. 2014. "Las Políticas Públicas del Desarrollo Regional de Aguascalientes, México 1980-2012”. Presentación del Congreso de II congreso de Estudios de Desarrollo (REEDES), en Huelva, 16-18 de junio, 2014. http://www.uhu.es/IICIED/pdf/6_4_poltica.pdf

GARNICA VERA, José Ricardo y Francisco Aníbal GANGA CONTRERAS. 2007. "Los clusters industriales: precisión conceptual y desarrollo teórico", Cuadernos de Administración, 20(33), Pp. 303-322.

http://www.javeriana.edu.co/Facultades/C_Econom_y_Admon/cuadernos_admo n/pdfs/12_33_clusters_industriales.pdf

GERBER, Jim y Jorge CARRILLO. 2006. "The future of the maquiladora: Between industrial upgrading and competitive decline", NAFTA and the maquiladora program: Rules, routines, and institutional legitimacy. El Paso: Texas Western Press. Forthcoming, A Forum Fronterizo, San Diego Dialogue, UCSD, La Jolla. http://www.colef.mx/jorgecarrillo/wp-content/uploads/2012/04/PU310.pdf

GIL LAMADRID, Patricia, Sergio MARTINEZ, Alonso SALAZAR, Francisco MARTINEZ y Homero NAÑEZ. 2012. "VENTAJACOMPARATIVA DEL SECTOR AUTOMOTOR DE MÉXICO”, Comercio Exterior, 63 (5), Pp. 43-54. http://revistas.bancomext.gob.mx/rce/magazines/143/7/Ventaja_corporativa_del _sector_automotor.pdf

GITLI, Eduardo y Randall ARCE. 2001. "El ingreso de China la OMC y su impacto sobre los países de la cuenca del Caribe", Revista de la CEPAL, 74, Pp. 87-107. http://www.cepal.org/publicaciones/xml/9/19309/lcg2135e_Gitli.pdf

GLIGO, Nicolo. 2007. Políticas efectivas para atraer inversión extranjera directa en América Latina y el Caribe. Serie Desarrollo Productivo 175. Santiago de Chile: CEPAL.

http://repositorio.cepal.org/bitstream/handle/11362/4572/S0700049_es.pdf?sequ ence $=1$

GÓMEZ VEGA, María Carmen. 2004. "El desarrollo de la industria de la maquila en México. Problemas del Desarrollo. Revista Latinoamericana de Economía", 35 (138), Pp. 57-83.

http://revistas.unam.mx/index.php/pde/article/viewFile/7540/7029

GÓNGORA PÉREZ, Juan Pablo. 2013. "Producción y Exportación en México", Comercio Exterior, 63 (2), Pp. 14-18. http://revistas.bancomext.gob.mx/rce/magazines/153/10/SKMBT_C5501402121 4580.pdf

GÓNGORA PÉREZ, Juan Pablo. 2014. "La industria del plástico en México y el mundo" Comercio exterior, 64(5), Pp.6-9.

http://revistas.bancomext.gob.mx/rce/magazines/761/3/la_industria_del_plastico .pdf

GONZÁLEZ, Isabel Suárez y Jesús Galende DEL CANTO. 1998. "Los factores determinantes de las inversiones empresariales en I+ D”, Economía Industrial, (319), Pp. 63-76. https://dialnet.unirioja.es/servlet/articulo?codigo=140014

GONZÁLEZ, Juan. 2000. "Estados Unidos: acuerdo bilateral con China para su acceso a la Organización Mundial del Comercio (OMC)", México y la Cuenca del Pacifico, 3(9), Pp. 53-60. 
http://148.202.18.157/sitios/publicacionesite/pperiod/pacifico/Revista9/10Juan.p df

GONZALEZ GARCIA, Juan y José Salvador MEZA ROLA. 2008. "La política industrial en el siglo XXI y la nueva economía institucional”, Comercio Exterior, 58(11), Pp. 769-779. http://revistas.bancomext.gob.mx/rce/magazines/120/2/RCE2.pdf

GRUBEL, H. G y P. J. LLOYD. 1975. Intra-Industry Trade: The Theory and Measurement of International Trade in Differentiated Products. Nueva York: JohnWiley\&Sons.

GUADARRAMA, Rocío, Alfredo HUALDE ALFARO y Silvia LÓPEZ. 2014. La precariedad laboral en México. Dimensiones, dinámicas y significados. Tijuana: El Colegio de la Frontera Norte.

GUILLÉN, Arturo. 2012. "México, ejemplo de las políticas anti-desarrollo del Consenso de Washington", Estudos Avançados, 26 (75). Pp. 57-76. http://www.scielo.br/pdf/ea/v26n75/05.pdf

GUTIÉRREZ-HACES, Teresa. 2004. "La inversión extranjera directa en el TLCAN", Economía UNAM, 21(3), Pp. 30-52. http://www.ejournal.unam.mx/ecu/ecunam3/ecunam0302.pdf

GUZMÁN, Alenka y Alejandro TOLEDO. 2005. "Competitividad manufacturera de México y China en el mercado estadounidense", Economía UNAM, 2(4), Pp. 94-137. http://www.scielo.org.mx/pdf/eunam/v2n4/v2n4a6.pdf

HELPMAN, Elhanan.1981. "International trade in the presence of product differentiation, economies of scale and monopolistic competition: A Chamberlin-Heckscher-Ohlin approach", Journal of international economics, 11(3), Pp. 305-340. http://www2.econ.iastate.edu/classes/econ655/lapan/Readings/IntlTradeinPresen ceProdDifferentiationEconScaleetcHELPMAN.pdf

HERNÁNDEZ, Bernardo, Armando ARREDONDO, Carlos CRUZ, Eugenia SÁNCHEZ, y Teresa DAMIÁN. 1993. "Empresas de aparatos médicos y su vinculación con centros de desarrollo tecnológico en México", Boletín Sanit Panama, 115(4), Pp. 317-327. http://iris.paho.org/xmlui/bitstream/handle/123456789/16301/v115n4p317.pdf?s equence $=1 \&$ isAllowed $=\mathrm{y}$

HERNANDEZ, José Paul. 2014. "Nuevo Régimen fiscal para maquiladoras", Fisco Actualidades, septiembre, (15), Pp. 3-12. http://imcp.org.mx/wpcontent/uploads/2014/09/Fisco-Septiembre-2014-15.pdf

HERNÁNDEZ, Roberto Hernández. 2006. "Las relaciones comerciales entre China y Estados Unidos y el comercio de bienes industriales y agrícolas; implicaciones para México", México y La Cuenca del Pacifico, 9(27), Pp. 25-39.

http://www.mexicoylacuencadelpacifico.cucsh.udg.mx/sites/default/files/Las\%2 Orelaciones $\% 20$ comerciales $\% 20$ entre $\% 20$ China $\% 20 \mathrm{y} \% 20$ Estados $\% 20$ Unidos $\%$ 20y\%20el\%20Comercio\%20de\%20bienes\%20industriales\%20y\%20agr\%C3\%A Dcolas.pdf

HERRERA IZAGUIRRE, Juan, Carlos Francisco VÁZQUEZ RANGEL y Ramiro Aurelio ESCOBEDO CARREÓN.2014. "Ley de la Inversión Extranjera: 
¿Instrumento para el desarrollo económico?” Boletín mexicano de derecho comparado, 47(140), Pp. 687-703.

http://www.scielo.org.mx/scielo.php?pid=S004186332014000200010\&script=sc i_arttext\&tlng=en

HUALDE ALFARO, Alfredo. 2001. "Del territorio a la empresa: conocimientos productivos entre los ingenieros del norte de México", Región y sociedad, 13(21). Pp. 03-45. http://www.scielo.org.mx/pdf/regsoc/v13n21/v13n21a1.pdf

HUALDE ALFARO, Alfred y Jorge CARRILLO. 2007. La industria aeroespacial en Baja California. Características productivas y competencias laborales y Profesionales. Tijuana: Colegio de la frontera Norte.

HYMER, Stephen. 1976. The international Operations of National Firms: A Study of Direct Foreign Investment. Cambridge, Massachusetts y Londres: The MIT Press. Thesis de PhD. http://gbatech.org/article/1095.pdf

HYMER, Stephen H y Luis R ROMERO. 1982. La compañía multinacional: un enfoque radical. Traducción de Luis Rodoríguez Romero, Madrid: Hermann Blume.

IIDA, Kenichi. 1981. "Kigyouno kaigaitoushi ni kansuru ichikousatu: Wagakunikigyou no kaigaitoushi to mondaiten", Chiba keiai keizaidaigaku kenkyuu-ronsyu. 19, Pp.119-147. http://ci.nii.ac.jp/els/40002362776.pdf?id=ART0000557129\&type=pdf\&lang=e n\&host=cinii\&order_no $=\& p p v \_t y p e=0 \& l a n g \_s w=\& n o=1487585929 \& \mathrm{cp}=$

IMPLAN (INSTITUTO METROPOLITANO de PLANEACIÓN de TIJUANA). 2008. Plan Estratégico Metropolitano 2012-2034. Tijuana-Tecate-Playas de Rosarito.http://cdet.com.mx/wp-content/uploads/2015/04/PlanEstrate\%CC\%81 gico-Metropolitano.pdf

INEGI (Instituto Nacional de Estadística y Geografía). 2016. "SE DIFUNDEN ESTADÍSTICAS DETALLADAS SOBRE LAS MICRO, PEQUEÑAS Y MEDIANAS EMPRESAS DEL PAÍS”, BOLETÍN DE PRENSA NÚM. 285/16, 13 DE JULIO DE 2016.

http://www.inegi.org.mx/saladeprensa/boletines/2016/especiales/especiales 2016 _07_02.pdf

INSTITUTO MEXICANO DE TELESERVICIOS. 2014. Revista de Contacto Fórum, 18(58), pp. 16-18. http://imt.com.mx/revistaCF/2014/02Marzo/

ISHII, Toru. 2013. "1990 nendi ikouno nijonkeizaiteimei no gennin ni tsuiteno ichikousatu”, Kenkyuukiyou, 19. Pp.1-20. http://ci.nii.ac.jp/els/110009659889.pdf?id=ART0010135059\&type=pdf\&lang= en $\&$ host $=$ cinii\&order_no $=\& p p v \_t y p e=0 \& l a n g \_s w=\& n o=1487587342 \& \mathrm{cp}=$

IWATA, Katsuo. 2013. “Gendai sekaikeizai to keizaigaku no kadai”, Tokyo-keizaidaigakushi, (277), Pp. 15-35. http://www.tku.ac.jp/kiyou/contents/economics/277/Katsuo_Iwata.pdf

JAMES, Sebastian. 2013. Tax and non-tax incentives and investments: evidence and policy implications, Investment Climate Advisory Service, The World Bank Group. http://www.estimacionestributarias.com/archivos/Effectiveness\%20of\%20Tax\% 
20and $\% 20$ NonTax $\% 20$ Incentives $\% 20$ and $\% 20 \% 20$ Investments. $\% 20$ Evidence $\% 2$ 0and\%20Policy\%20Implications.pdf

JIMÉNEZ, Juan Pablo y Andrea PODESTÁ. 2009. Inversión, incentivos fiscales y gastos tributarios en América Latina. Santiago de Chile: CEPAL. http://www.andi.com.co/czf/Documents/Documentos\%20de\%20Interes/Microso $\mathrm{ft} \% 20$ Word $\% 20-\% 20$ Inversi\%C3\%B3n,\%20Incentivos\%20fiscales $\% 20 \mathrm{en} \% 20 \mathrm{~A}$ merica\%20Latina\%20Cepal\%20Documento.pdf

KAKU, Shishi. 2010. "Gekihensuru global keizai no nakano nihonno kaigaotyokusetutoushi no tenkaini tuite", Teikyo-keizaigaku-kenkyu, 43(2), Pp.73-85. https://appsv.main.teikyo-u.ac.jp/tosho/keizaigaku43-2-06.pdf

KENNY, Martin y Richard FLORIDA. 1994. "Japanese Maquiladoras: Production Organization and Global Commodity Chains", World Development, 22(1), Pp. 27-44. http://citeseerx.ist.psu.edu/viewdoc/download?doi=10.1.1.457.825\&rep=rep1\&t ype=pdf

KIMINO, Satomi, David S. SAAL y Nigel DRIFFIELD. 2007. "Macro determinants of FDI inflows to Japan: an analysis of source country characteristics", The World Economy, 30 (3). Pp. 446-469.

https://www.researchgate.net/profile/David_Saal/publication/4921271_Macro_D eterminants_of_FDI_Inflows_to_Japan_An_Analysis_of_Source_Country_Char acteristics/links/09e41512372c5c7d77000000.pdf

KLEPPER, Steven y Kenneth L SIMONS. 2000. "Dominance by birthright: entry of prior radio producers and competitive ramifications in the US television receiver industry” Strategic Management Journal, 21(10), Pp. 997-1016. http://www.jstor.org/stable/pdf/3094424.pdf

KO, Kenrai. 2012. "1950nendai no beikokuno taihokutou asia seisaku to kankokukeizai no syomondai”, Asia kenkyu, 58 (12). Pp.33-55. https://www.jstage.jst.go.jp/article/asianstudies/58/1.2/58_33/_pdf

KOBAYASHI, Tomohiko. 2007. "Kokusaiseido toshiteno tiikikyoutei-nihonnno teiketushita keizairenkeikyoutei no seido kouzouno hikakubunsekiwo daizaitoshite", RIETI Discussion Paper: 07-J-037. http://www.rieti.go.jp/jp/publications/dp/07j037.pdf

KOJIMA, Kiyoshi. 1973. "A Macroeconomic Approach to Foreign Direct Investment," Hitotsubashi Journal of Economics, 14(1), Pp. 1-21. http://hermes-ir.lib.hitu.ac.jp/rs/bitstream/10086/8008/1/HJeco0140100010.pdf

KOSACOFF, Bernardo y Adrián RAMOS. 1997. "Consideraciones económicas sobre la política industrial”, Documento de trabajo 76. Buenos Aires: CEPAL. http://repositorio.cepal.org/bitstream/handle/11362/7368/LCbueL159_es.pdf

KOSACOFF, Bernardo y Adrián RAMOS. 1999. "El debate sobre política industrial", Revista de la CEPAL, (68), Pp. 35-60.

http://repositorio.cepal.org/bitstream/handle/11362/12176/068035060_es.pdf?se quence $=1$

KOYAMA, Daisuke, 2013. "Beityuu-sijyouni okeru nihonkigyouno kaigaijigyoukatudou", Ritsumeikan Kokusai Chiiki Kenkyuu, 37, Pp.75-93. http://www.ritsumei.ac.jp/acd/re/k-rsc/ras/04_publications/ria_ja/37_05.pdf 
KRUGMAN, Paul. 1979. "Increasing returns, monopolistic competition, and international trade", Journal of international Economics, 9(4), Pp. 469-479. http://www.sciencedirect.com/science/article/pii/0022199679900175

KRUGMAN, Paul. 1980. "Scale Economies, Product Differentiation, and the Pattern of Trade", The American Economic Review, 70(5), Pp. 950-959. http://web.econ.ku.dk/Nguyen/teaching/krugman\%201980.pdf

KRUGMAN, Paul. 1981. "Intraindustry specialization and the gains from trade", The Journal of Political Economy, 89 (5), Pp. 959-973. http://www2.econ.iastate.edu/classes/econ655/lapan/readings/intraindustry\%20s pecialization $\% 20$ and $\% 20$ the $\% 20$ gains $\% 20$ from $\% 20$ trade $\% 20 \mathrm{krugman}$.pdf

KRUGMAN, Paul. 1992. Geografía y Comercio, traducción de Alfons Méndez, Barcelona: Antoni Bosch Editor.

KRUGMAN, Paul y Maurice OBSTFELD. 2006. Economía internacional, traducción en Yago Moreno, Madrid: Pearson Educación. $7^{\text {a }}$ Edición.

KUWAYAMA, Mikio, y Osvaldo ROSALES. 2012. China y América Latina y el Caribe: Hacia una relación económica y comercial estratégica. Libros de CEPAL 114. CEPAL: Santiago de Chile. http://repositorio.cepal.org/bitstream/handle/11362/2598/S1100769_es.pdf?sequ ence $=1 \&$ isAllowed $=\mathrm{y}$ :

LARA, Edgar. 2002. Los países subdesarrollados en el marco de las negociaciones de la OMC. Alternativas para el Desarrollo, (75), Pp. 30-42. http://www.repo.funde.org/324/1/APD-75-III.pdf

LARRIVA, Juan José y Amado VEGA. 1982. "El comercio exterior de la industria automovilística en México. Evolución y perspectivas", Comercio exterior, 32(12), Pp.1358-1363. http://revistas.bancomext.gob.mx/rce/magazines/666/10/RCE10.pdf

LEE, Kiseok y Shawn NI. 2002. "On the dynamic effects of oil price shocks: a study using industry level data", Journal of Monetary Economics, 49 (4), Pp. 823-852. http://ac.els-cdn.com/S0304393202001149/1-s2.0-S0304393202001149main.pdf?_tid=f639b2ce-f83b-11e6-9e9d00000aacb362\&acdnat=1487684890_29fb056a70e2579f522273405f94eb86

LEWIS, Cleona. 1948. The United States and foreign investment problems. Nueva York: Brookings Institution.

LIAO, Wang-Ting. 2014. "Development and Characteristics of Direct Investments to China by Japanese Enterprises", Aichi-syukutokudagakugendaisyakaikenkyuuka- kiyo. (10), Pp. 105-118. http://askar.aasa.ac.jp/dspace/bitstream/10638/5496/1/0034-010-201405-105-117.pdf

LINCOLN, James R. y Masahiro SHIMOTANI. 2009. "Whither the Keiretsu, Japan's Business Networks? How Were They Structured? What Did They Do? Why Are They Gone?", Working Paper Series, Institute for Research on Labor and Employment. https://escholarship.org/uc/item/00m7d34g

LLISTERRI, Juan José. 2000. “Competitividad y desarrollo económico local nuevas oportunidades operativas”, DOCUMENTO DE DISCUSIÓN, Washington, DC: Banco Interamericano de Desarrollo. https://www.researchgate.net/profile/Juan_Llisterri/publication/266333205_Com 
petitividad_y_Desarrollo_Economico_Local_Nuevas_Oportunidades_Operativa s/links/54e4aed50cf22703d5bf14e1/Competitividad-y-Desarrollo-EconomicoLocal-Nuevas-Oportunidades-Operativas.pdf

LÓPEZ ARÉVALO, Jorge Alberto y Oscar RODIL MARZÁBAL. 2008. "Comercio intra-industrial e intra-firma en México en el contexto del proceso de integración de América del Norte (1993-2006)", Economía UNAM, 5(13), Pp. 86-112. http://www.scielo.org.mx/pdf/eunam/v5n13/v5n13a5.pdf

LÓPEZ ARÉVALO, Jorge Alberto, Oscar RODIL MARZÁBAL y Saúl VALDEZ. 2014. "La incursión de China en el Tratado de Libre Comercio de América del Norte (TLCAN) y sus efectos en el comercio intraindustrial", Revista CEPAL 114. Pp. 89-106. http://200.9.3.98/bitstream/handle/11362/37438/RVE114Lopezetal_es.pdf?sequ ence $=1 \&$ isAllowed $=\mathrm{y}$

LÓPEZ, Juan Torres y Alberto Montero SOLER. 1993. “¿Del fordismo al toyotismo?” Cuadernos de Ciencias Económicas y Empresariales, (24), Pp.47-59. http://cuadernos.uma.es/pdfs/pdf509.pdf

LOWE, Nichola y Martin KENNEY. 1999. "Foreign investment and the global geography of production: Why the Mexican consumer electronics industry failed", World Development, 27(8), Pp. 1427-1443. https://www.researchgate.net/profile/Nichola_Lowe/publication/4749737_Forei gn_Investment_and_the_Global_Geography_of_Production_Why_the_Mexican _Consumer_Electronics_Industry_Failed/links/55904efe08aed6ec4bf65cc6.pdf

LUNDAN, Sarianna. M. 2010. "What are Ownership Advantages?", Multinational Business Review, 18 (1), Pp. 51-70. https://www.researchgate.net/profile/Sarianna_Lundan/publication/228118954_ What_are_Ownership_Advantages/links/566835dd08ae34c89a05b521.pdf

MANDIOLA, Gerardo. 1999. México: empresas maquiladoras de exportación en los noventa. Serie Reformas Económicas 49. México DF: CEPAL http://repositorio.cepal.org/bitstream/handle/11362/7514/1/S9900618_es.pdf

MARTÍN, Joan y Vicente Orts RÍOS. 1996. "Naturaleza y causas del comercio intraindustrial”, Ekonomiaz: Revista vasca de economía, (36), Pp. 78-101. https://dialnet.unirioja.es/descarga/articulo/274415.pdf

MARTÍNEZ, María Fernanda Tanco. 2016. "EL IMPACTO DEL PROGRAMA IMMEX EN LA INDUSTRIA MAQUILADORA MEXICANA". Ponencia en el $1^{\circ}$ Congreso de Estudiantes Comercio Exterior, 17-18 de mayo en 2016, Universidad Autónoma del Estado de Hidalgo. https://www.uaeh.edu.mx/cexticea/memorias/mesas_de_trabajo/Globalizacion_ Retos_y_Estrategias_para_los_Negocios_Internacionales/Maria_Fernanda_Tanc o_Martinez/CNE040.pdf

MARTÍNEZ PIVA, Jorge Mario. 2015. Incentivos públicos de nueva generación para la atracción de inversión extranjera directa (IED) en Centroamérica. Serie Estudios y Perspectivas 134. México D.F: CEPAL. http://repositorio.cepal.org/bitstream/handle/11362/4915/S1500169_es.pdf?sequ ence $=4 \&$ is Allowed $=y$ 
MASUDA, Koutaro. 2015. "Jidai to tomoni shinkashita njonn no taigai tyokusetutoushi (kaiko to tenbou)", Kokusai boueki to toushi. 27(2), Pp.4-18. www.iti.or.jp/kikan101/101masuda.pdf

MCGUIRE, Jean y Sandra DOW. 2009. "Japanese keiretsu: Past, present, future. Asia Pacific Journal of Management”, 26(2), Pp. 333-351. http://link.springer.com/article/10.1007/s10490-008-9104-5

MEJÍA REYES, Pablo, Elías Eduardo GUTIÉRREZ ALVA y Claudia Adriana FARÍAS SILVA. 2006. "La sincronización de los ciclos económicos de México y Estados Unidos”, Investigación Económica,65(258), Pp. 15-45. http://ri.uaemex.mx/bitstream/handle/20.500.11799/39440/La\%20sincronizaci\% F3n\%20de\%20los\%20ciclos\%20econ\%F3micos20de\%20M\%E9xico\%20y\%20 Estados\%20Unidos.pdf?sequence $=2$

MICHELI THIRIÓN, Jordy. 2004. Memoria Virtual. http://www.cmsconsultores.com/wpcontent/uploads/2012/03/TELEMARKETING_Y_GLOBALIZACION_EN_LA _ECONOMIA_MEXICANA.doc, fecha de consulta 7/10/2013.

MICHELI THIRIÓN, Jordy. 2006. "El trabajo en la sociedad de la información. El caso ilustrativo del telemercadeo", Estudios Sociológicos, 24(70), Pp. 197-220. http://estudiossociologicos.colmex.mx/index.php/es/article/view/392/392

MICHELI THIRIÓN, Jordy. 2007. "Centros de atención telefónica y telemercadeo: paradigma de la economía de masas", Comercio exterior, 57(3), Pp. 218-231. http://revistas.bancomext.gob.mx/rce/magazines/101/4/RCE4.pdf

MICHELI THIRIÓN, Jordy. 2012. "El sector de call centers: Estructura y tendencias. Apuntes sobre la situación de México", Frontera norte,24 (47). Pp. 145-169. http://www.scielo.org.mx/pdf/fn/v24n47/v24n47a6.pdf

Ministerio de Economía del Gobierno de Japón. 1975. Wagakuni Kigyouno kaigai jigyou Katsudou, Tokyo.: Ministerio de Economía el gobierno de Japón.

Ministerio de Economía del Gobierno de Japón. 1978. Wagakuni Kigyouno kaigai jigyou Katsudou, Tokyo: Ministerio de Economía del Gobierno de Japón.

Ministerio de Economía del Gobierno de Japón. 1979. Wagakuni Kigyouno kaigai jigyou Katsudou, Tokyo: Ministerio de Economía del Gobierno.

Ministerio de Economía, Negocio e Industria del gobierno de Japón. 1981. Wagakuni Kigyouno Kaigai Jigyou Katsudou, Tokyo: Ministerio de Economía Negocio e Industria del gobierno de Japón.

Ministerio de Economía, Negocios e Industria del Gobierno de Japón. 1984. Kaden Sangyou no genjyou. Tokyo: Ministerio de Economía, Negocios e Industria del Gobierno de Japón.

Ministerio de Economía, Negocio e Industria del gobierno de Japón. 1985. Wagakuni Kigyouno Kaigai Jigyou Katsudou, Tokyo: Ministerio de Economía Negocio e Industria del gobierno de Japón.

Ministerio de Economía, Negocio e Industria del Gobierno de Japón. 1986. Kaden Sangyou no genjyou. Tokyo: Ministerio de Economía, Negocios e Industria del Gobierno de Japón. 
Ministerio de Economía, Negocio e Industria, del gobierno de Japón. 1997. Wagakuni Kigyouno kaigaikatudou houkoku, Tokyo: Ministerio de Economía.

Ministerio de Economía, Negocio e Industria del Gobierno de Japón. 1986. Situación Actual de la industria electrodoméstica. Tokyo : Ministerio de Economía, Negocios e Industria del Gobierno de Japón

Ministerio de Fianza del Gobierno de Japón. 1987. Zaisei Kinnyuu toukei geppou. (428), Pp. 2-6.

http://warp.da.ndl.go.jp/info:ndljp/pid/8379094/www.mof.go.jp/pri/publication/z aikin_geppo/hyou/g428/428_b.pdf

MIRANDA, Arturo Vicencio. 2007. "La industria automotriz en México: Antecedentes, situación actual y perspectivas", Contaduría y administración, (221), pp. 209246. http://www.scielo.org.mx/pdf/cya/n221/n221a10.pdf

MIYAKAWA, Yasuo. 1984. "Internationalization of Japanese Automobile Industry and International Industrial System of the Japanese Automobile Industry in the World", Journal of Geography (Chigaku Zasshi), 93(3), Pp. 133-155. https://www.jstage.jst.go.jp/article/jgeography1889/93/3/93_3_133/_pdf

MONROY-GÓMEZ-FRANCO, Luis Ángel 2014. "México: el contenido importado en los principales sectores exportadores", Comercio Exterior, 64(2), Pp. 2-5. http://revistas.bancomext.gob.mx/rce/magazines/756/1/mexico-el-contenido.pdf

MONTARCÉ, Inés. 2009. "Del otro lado del teléfono: identidad y acción colectiva en Call Centers de la ciudad de México". En Enrique de la Garza Toledo, Trabajo no clásico, organización y acción colectiva, vol. 2. México D-F: Universidad Autónoma Metropolitana-Iztapalapa y Plaza y Valdés, S.A. de C.V. Pp. 69-122. http://www.izt.uam.mx/sotraem/NovedadesEditoriales/TrabajonoclasicoII.pdf\#p age $=69$

MORALES TORONCOSO, Carlos. 2008. "El Comercio entre México y China: una colosal triangulación", Comercio Exterior, 58(12), Pp. 885-895. http://revistas.bancomext.gob.mx/rce/magazines/121/5/RCE5.pdf

MORENO-BRID, Juan Carlos. 1999. Reformas macroeconómicas e inversión manufacturera en México, Serie Reformas Económicas 47. México D.F.: CEPAL. http://repositorio.cepal.org/handle/11362/7510

MORENO-CODINA, Tonahtiuc. 2015. "Plan maestro del corredor logístico industrial automotriz del Bajío" Quivera, 17(1), Pp. 13-34. http://www.redalyc.org/jatsRepo/401/40140031002/40140031002_visor_jats.pdf

MORTIMORE, Michael, Sebastián VERGARA y Jorge KATZ. 2001. La competitividad internacional y el desarrollo nacional: implicancias para la política de Inversión Extranjera Directa (IED) en América Latina. Serie Desarrollo Productivo 107. CEPAL. http://repositorio.cepal.org/bitstream/handle/11362/4488/S01080635_es.pdf?seq uence $=1 \&$ isAllowed $=\mathrm{y}$

NAKAGAWA, Mitsuru. 2009. "Nihonkigyou no senryakuteki koudou:usugata terebi no jirei”, Economic Studies, 59 (2), Pp. 93-111. http://hdl.handle.net/2115/39324

NAMIMITSU, Iwao. 1992. "Kenkyu-note: Nichibei bouekimasatu mondai”, Kagawahougaku, 12(2), Pp.169-186. 
http://ci.nii.ac.jp/els/110000062323.pdf?id=ART0000405065\&type=pdf \&lang= en\&host=cinii\&order_no $=\& p p v \_t y p e=0 \& l a n g \_s w=\& n o=1487693562 \& \mathrm{cp}=$

NISHIJIMA, Syoji. 2003. "Latin América ni okeru jiyuubouekikyoutei no tenkainihonnheno ganni”, Sekai keizai hyoron, 47(12), Pp. 22-30. http://www.lib.kobeu.ac.jp/handle_kernel/90000071

NISHIJIMA, Shoji. 2009. "Desarrollo Económico y política industrial de Japón: Implicaciones para países en desarrollo", RIBE Discussion Paper Series 46, Instituto de Investigación para Economía y Administración (RIEB), Universidad de Kobe. http://www.paginaspersonales.unam.mx/files/165/JAPON2.pdf

OKABE, Taku. 2004. "Sinopsis del acuerdo de asociación económica entre México y Japón”, México y la Cuenca del Pacífico, 7(23), Pp. 103-123. http://148.202.18.157/sitios/publicacionesite/pperiod/pacifico/Revista23/08Taku .pdf

ONIZUKA, Yoshihiro. 2003. "Tyuugoku sinsyutu nikkei kigyu no syuuekiseisinsyutukigyuha riekiwo ageteiruka”, Kokusaiboueki to toshi, (54), Pp.87-102. http://www.iti.or.jp/kikan54/54onizuka.pdf

ONO, Hiroshi. 1995. "Sengono nihonnno jidousyasangyouhatten”, Economic Studies, Universidad de Hokkaido, 45(1), Pp. 68-76. http://hdl.handle.net/2115/31994

ONO, Isao. 1995. "Beikokuno boueki to nitibei bouekikankei: sono rekishitekikousatsu," Edogawa-jyosi-tankidaigaku-kiyo, 10, Pp. 76-88. http://ci.nii.ac.jp/els/110000468828.pdf?id=ART0000849461\&type=pdf\&lang= en $\&$ host $=$ cinii\&order_no $=\& p p v \_t y p e=0 \& l a n g \_s w=\& n o=1487604799 \& \mathrm{cp}=$

OOYANE, Satoshi. 1992. "Nitibei boueki masatsu to kanbei boueki masatsu", Asiakenkyu, 38(3), Pp. 33-72. https://www.jstage.jst.go.jp/article/asianstudies/38/3/38_33/_pdf

ORTIZ VELAZQUEZ, Samuel y Enrique DUSSEL PETERS. 2016. "La nueva relación comercial entre América Latina y el Caribe y China: ¿promueve la integración o desintegración comercial?". En Enrique Dussel Peters (Cooordinador), La nueva relación comercial de América Latina y el Caribe con China: ¿integración o desintegración regional? México D.F: Unión de Universidades de América Latina y el Caribe, Pp.13-58. http://dusselpeters.com/100.pdf

PALACIOS, Juan Manuel Sandoval. 2013. "EL PROGRAMA BRACERO Y LAS POLÍTICAS DE TRABAJADORES MIGRATORIOS TEMPORALES PARA UN MERCADO LABORAL REGIONAL DE AMÉRICA DEL NORTE”, Istor: revista de historia internacional, 13(52), Pp. 55-89.

http://s3.amazonaws.com/academia.edu.documents/33878862/El_Programa_Bra cero_y_el_Mercado_Laboral_Regional_de_America_del_Norte.pdf?AWSAcces sKeyId=AKIAJ56TQJRTWSMTNPEA\&Expires $=1485022292 \&$ Signature $=J L O$ GAib4CWuNucUVBAKAXbdmx3A\%3D\&response-contentdisposition=inline\%3B\%20filename\%3DEl_Programa_Bracero_y_el_Mercado_ Laboral.pdf

PAVÓN, Lilianne. 2010. Financiamiento a las microempresas y pymes en México (2000-2009), Serie Financiamiento al desarrollo 226. Santiago de Chile: CEPAL.http://repositorio.cepal.org/bitstream/handle/11362/5205/lcl3238e.pdf?s equence $=1$ 
PECHO, Miguel. 2014. “Gastos tributarios en América Latina: 2008-2012," Documento de Trabajo No 2-2014, Dirección de Estudios e Investigaciones Tributarias, Centro Interamericario Administraciones Tributarios. https://ciatorgpublic.sharepoint.com/Biblioteca/DocumentosdeTrabajo/2014/DT02_2014.pdf

PERES NUÑEZ, Wilson. 1993. “¿Dónde estamos en política industrial?” Revista de la CEPAL, (51), Pp. 37-49.

http://repositorio.cepal.org/bitstream/handle/11362/11920/051037049_es.pdf?se quence $=1 \&$ is Allowed $=\mathrm{y}$

PORTER, Michael. 2000. "Location, competition, and economic development: Local clusters in a global economy", Economic development quarterly, 14 (1), Pp. 1534. home.furb.br/wilhelm/COMPETIV/Porter_Cluster3.doc

PORTER, Michael. 2003. "The economic performance of regions" Regional studies, 2 37(6 y 7), Pp. 549-578. http://abclusters.org/wpcontent/uploads/2014/03/Porter2003The_Economic_Performance_of_Regions1.pdf

PORTER, Michael. 2004. “Cadena de valor”, Estr@tegia Magazine, 1(19), Pp. 1-3. http://www.estrategiamagazine.com/descargas/Cadena\%20de\%20Valor.pdf

PORTER, Michael. 2007. "La ventaja competitiva de las naciones", Harvard Business Review, 85(11), Pp. 69-95.

http://s3.amazonaws.com/academia.edu.documents/32370097/La_Ventaja_Com petitiva_de_las_Naciones.pdf?AWSAccessKeyId=AKIAIWOWYYGZ2Y53UL 3A\&Expires=1488149721\&Signature=uTEWVQYxXYY89\%2BLbwaex\%2Fif bOJU\%3D\&response-content-

disposition=inline\%3B\%20filename\%3DLa_Ventaja_Competitiva_de_las_Naci ones.pdf

POSADA, Héctor Mauricio y Juan Esteban VÉLEZ. 2009. “Comercio y Geografía Económica: una nota sobre la contribución de Krugman a la teoría económica”. Lecturas de Economía, 69(69), Pp. 299-311.

http://aprendeenlinea.udea.edu.co/revistas/index.php/lecturasdeeconomia/article/ view/748/644

PRASAD, Eswar y Thomas RUMBAUGH. 2003. “Más allá de la Gran Muralla: por qué algunos consideran la integración de China en el sistema de comercio mundial como una amenaza, mientras que a otros les parece positivo", Finanzas y desarrollo: publicación trimestral del Fondo Monetario Internacional y del Banco Mundial, 40(4), Pp. 46-49. http://www.imf.org/external/pubs/ft/fandd/spa/2003/12/pdf/prasad.pdf

RAMÍREZ BONILLA, Juan José. 2014. "La relación comercial México-Japón, diez años después de la firma del Acuerdo para el Fortalecimiento de Asociación Económica", Comercio Exterior, 64(6), Pp. 9-22. http://revistas.bancomext.gob.mx/rce/magazines/760/4/la_relacion_comercial.pd $\mathrm{f}$

RAMÍREZ DE LA O, Rogelio. 1981. “Las Empresas Transnacionales y el Comercio Exterior de México", Comercio Exterior, 31(10), Pp. 1150-1168. http://revistas.bancomext.gob.mx/rce/magazines/388/7/RCE7.pdf

RAMOS MARTÍNEZ, Alejandro, Romina GAYÁ, Rosario CAMPOS y Kathia MICHALCZEWSKY. 2012. Marcos teóricos para el análisis de las zonas de 
procesamiento de exportaciones en América Latina y el Caribe. Institute for the Integration of Latin America and the Caribbean, Washington D.C.: InterAmerican Development Bank: IDB-TN-432.

https://publications.iadb.org/bitstream/handle/11319/5496/Marcos\%20te\%C3\% B3ricos\%20para\%20el\%20an\%C3\%A1lisis\%20de\%20las\%20zonas\%20de $\% 20$ procesamiento $\% 20 \mathrm{de} \% 20$ exportaciones $\% 20 \mathrm{en} \% 20 \% 20 \mathrm{Am} \% \mathrm{C} 3 \% \mathrm{~A} 9 \mathrm{rica} \% 20 \mathrm{La}$ tina $\% 20 y \% 20 \mathrm{el} \% 20$ Caribe.pdf? sequence $=1$

RAPOSO, Núria Puig y Adoración Álvaro MOYA. 2004. "La guerra fría y los empresarios españoles: la articulación de los intereses económicos de Estados Unidos en España, 1950-1975”, Revista de Historia Económica/Journal of Iberian and Latin American Economic History (Second Series), 22(2), Pp. 387424. http://earchivo.uc3m.es/bitstream/handle/10016/2766/Puig\%20Raposo.pdf?sequence=1

RODRÍGUEZ-GÓMEZ, Roberto. 1998. "Expansión del sistema educativo superior en México 1970-1995”, En Magdalena Fresán (Editor), Tres Décadas de Políticas del Estado en la Educación Superior, México DF: ANUIES. Pp. 167-205. http://works.bepress.com/roberto_rodriguez/24/

ROS, Jaime. 1990. "ELDEBATE SOBRE INDUSTRIALIZACION: EL CASO DE MEXICO". En Ricardo French-Davis, Morris Teubal y Jaime Ros (Editores), ELEMENTOS PARA EL DISEÑO DE POLITICAS INDUSTRLVLES Y TECNOLOGICAS EN AMERICA LATINA, Santiago de Chile: CEPAL. Pp. 119170. http://repositorio.cepal.org/bitstream/handle/11362/2725/S9000500_es.pdf

ROS, Jaime. 2001. "Política industrial, ventajas comparativas y crecimiento", Revista de la CEPAL, (73), Pp. 129-149. http://repositorio.cepal.org/bitstream/handle/11362/10723/073129148_es.pdf?se quence $=1$

ROSALES, Osvaldo 1994. "Política industrial y fomento de la competitividad", Revista de la CEPAL, (53), Pp. 59-79. http://repositorio.cepal.org/bitstream/handle/11362/11950/053059079_es.pdf?se quence $=1$

RUGMAN, Alan M. 1980. "Internalization as a general theory of foreign direct investment: A re-appraisal of the literature", Review of World Economics, 116(2), Pp. 365-379. http://download.springer.com/static/pdf/137/art\%253A10.1007\%252FBF026968 64.pdf?originUrl=http $\% 3 \mathrm{~A} \% 2 \mathrm{~F} \% 2 \mathrm{Flink}$.springer.com $\% 2$ Farticle $\% 2 \mathrm{~F} 10.1007 \%$ 2FBF02696864\&token $2=\exp =1485170017 \sim$ acl $=\% 2 \mathrm{Fstatic} \% 2 \mathrm{Fpdf} \% 2 \mathrm{~F} 137 \% 2 \mathrm{~F}$ art\%25253A10.1007\%25252FBF02696864.pdf\%3ForiginUr1\%3Dhttp\%253A\% 252F\%252Flink.springer.com\%252Farticle\%252F10.1007\%252FBF02696864* $\sim$ hmac $=3401 \mathrm{a} 9 \mathrm{f} 7 \mathrm{c} 96 \mathrm{~b} 99 \mathrm{ad} 24 \mathrm{~d} 48 \mathrm{a} 2 \mathrm{f} 8689112 \mathrm{a} 9089 \mathrm{ac} 2 \mathrm{cfdb} 81 \mathrm{cb} 8 \mathrm{~b} 357186 \mathrm{a} 0 \mathrm{dbc}$ cb13

RUGMAN, Alan. M. 1985. "Internalization is still a general theory of foreign direct investment", Weltwirtschaftliches Archiv, 121(3), Pp. 570-575. http://download.springer.com/static/pdf/727/art\%253A10.1007\%252FBF027081 94.pdf?originUrl=http $\% 3 \mathrm{~A} \% 2 \mathrm{~F} \% 2 \mathrm{Flink}$.springer.com $\% 2$ Farticle $\% 2 \mathrm{~F} 10.1007 \%$ 2FBF02708194\&token $2=\exp =1485170079 \sim$ acl $=\% 2$ Fstatic $\% 2 F p d f \% 2 F 727 \% 2 \mathrm{~F}$ art\%25253A10.1007\%25252FBF02708194.pdf\%3ForiginUrl\%3Dhttp\%253A\% 252F\%252Flink.springer.com\%252Farticle\%252F10.1007\%252FBF02708194* 
$\sim \mathrm{hmac}=2 \mathrm{f} 15 \mathrm{ce} 45 \mathrm{a} 361 \mathrm{bdba} 90 \mathrm{~d} 1 \mathrm{~b} 93 \mathrm{ecc} 15 \mathrm{f} 1 \mathrm{f} 5479 \mathrm{~d} 30 \mathrm{e} 2 \mathrm{c} 8124 \mathrm{ff} 6 \mathrm{~b} 01 \mathrm{a} 47 \mathrm{~b} 556108$ 902

RUGMAN, Alan M y Alain VERBEKE. 2003. "Extending the theory of the multinational enterprise: Internalization and strategic management perspectives", Journal of International Business Studies, 34(2), Pp. 125- 137. http://www.jstor.org/stable/pdf/3557148.pdf?seq=1

RUIZ-LARRGUIVE, Estela. 2011. "La educación superior tecnológica en México", Revista Iberoamericana de Educación Superior, 2(3), Pp.35-52. http://ries.universia.net/index.php/ries/article/view/79

SAKAKIBARA, Sadao, Barbara B. FLYNN y Roger G. SCHROEDER. 1997. "The impact of just-in-time manufacturing and its infrastructure on manufacturing performance", Management Science, 43 (9). Pp. 1246-1257. http://pubsonline.informs.org/doi/abs/10.1287/mnsc.43.9.1246 https://www.jstor.org/stable/2634636?seq=1\#page_scan_tab_contents

SÁNCHEZ-JUÁREZ, Isaac Leobardo y Rosa Maria GARCÍA ALMADA, 2014. "Bajo crecimiento económico, política industrial y regiones en México". En Jorge Alberto Pérez Cruz, Guadalupe Isabel Ceballos Álvarez y Adolfo Rogelio Cogco Calderón (Coordinadores), Los retos de la política industrial ante la reconfiguración especial en México. Una perspectiva desde las externalidades pecuniarias y tecnológicas, Ciudad Victoria: Universidad autónoma de Tamaulipas, Pp.15-41. https://www.researchgate.net/profile/Isaac_SanchezJuarez/publication/259764128_Bajo_crecimiento_economico_politica_industrial _y_regiones_en_Mexico/links/0a85e537aa7000569d000000.pdf

SASANAMI, Yoko. 1997. "Kaigai tyokusetutoushi to boueki: Nijonno kigyounaiboueki ni tsuite", Mita Gakkai Zassi, 90(3), Pp. 469-485. https://koara.lib.keio.ac.jp/xoonips/modules/xoonips/download.php?koara_id=A N00234610-19971001-0001

SASANAMI, Yoko y Hiroki, KAWAI. 1998. "Ousyu-Asia-Hokubei niokeru nihonkigyouno kaigaitenkai," Keio Journal of economcs, 91(2), Pp. 18-30. http://koara.lib.keio.ac.jp/xoonips/modules/xoonips/detail.php?koara_id=AN002 34610-19980701

SATO, Sadayuki. 1994. "20 seikimatsu no amerika sihonsyugi”, Keio journal of economics, 87(2), Pp.199-213.

http://koara.lib.keio.ac.jp/xoonips/modules/xoonips/detail.php?koara_id=AN002 34610-19940701-0045

SEN, Amartya. 1998. "Las teorías del desarrollo a principios del siglo XXI", Cuadernos de economía, 17(29), Pp. 73-100. https://dialnet.unirioja.es/servlet/articulo?codigo $=4934951$

SME Support (Organization for Small \& Medium Enterprises and Regional Innovation, JAPAN).2003. Heisei 15 nendo tyousa houkokusyo. Tokyo: Organization for Small \& Medium Enterprises and Regional Innovation. http://www.smrj.go.jp/keiei/dbps_data/_material_/common/chushou/b_keiei/kei eikokusai/pdf/cy_h15jittaianso.pdf

SMITH, Adam. 1776. Wealth of Nations. London: Methuen \& Co., Ltd. (Version electronica: SMITH, Adam. 2015. Wealth of Nations. Chicago: University of Chicago Bookstore. https://dialnet.unirioja.es/servlet/articulo?codigo=4934951) 
STACK, Martin y Ricard DOWNING. 2005. "Another look at offshoring: Which jobs are at risk and why?" Business Horizons, 48(6), Pp. 513-523.

http://www.sciencedirect.com/science/article/pii/S0007681305000467

STIGLITZ, Joseph E. 1993. "The role of the state in financial markets", The World Bank Economic Review, 7(1), Pp. 19-52.

http://s3.amazonaws.com/academia.edu.documents/37930315/Role-of-

Government-in-Financial-

Market.pdf?AWSAccessKeyId=AKIAJ56TQJRTWSMTNPEA\&Expires $=14850$

23026\&Signature=zuKvLIscnntxFdQ1\%2BhfQL1QkNZ0\%3D\&response-

content-disposition=inline \%3B\%20filename\%3DFinance.pdf

STOLPER, Wolfgang F. y Paul A. SAMUELSON, 1941. "Protection and real wages", The Review of Economic Studies, 9(1), Pp. 58-73.

https://sites.duke.edu/econ206_01_s2011/files/2011/05/31a-Final-notes-Stolperand-Samuelson.pdf

STURGEON, Timothy J. 2002. "Modular production networks: a new American model of industrial organization", Industrial and corporate change, 11(3). Pp. 451-496. https://www.files.ethz.ch/isn/29533/2002-003.pdf

SUAVÉ, Pierre. 2008. "Normas sobre el comercio y las inversiones: perspectivas de América Latina". Revista de la CEPAL, (94), Pp. 29-42. http://www.cepal.org/publicaciones/xml/9/32719/94eSauve.pdf

SUGITANI, Shigeru. 1991. "Tyuukenn-tyuusyou seizougyou no kaigai tyokustu toushi”, Keizaigaku-ronkyu, 45(1), Pp. 1-34. http://ci.nii.ac.jp/els/110000405044.pdf?id=ART0000528374\&type=pdf\&lang= en $\&$ host $=$ cinii\&order_no $=\& p p v \_t y p e=0 \& l a n g \_s w=\& n o=1485019573 \& \mathrm{cp}=$

SUZUKI, Hideo. 2013. "1980 nendi nihon no bukka, boueki, baburu no kankei", Meijyo-ronso, 14(2), Pp. 19-32. http://wwwbiz.meijou.ac.jp/SEBM/ronso/no14_2/04_SUZUKI.pdf

TAI, Nihyo. 2014. “Tyuugoku ni okeru nikkeikigyou no rittisenryaku no henka to eikyou youin", AGI Working Paper Serize.

https://agi.repo.nii.ac.jp/?action=pages_view_main\&active_action=repository_vi ew_main_item_detail\&item_id=71\&item_no=1\&page_id=13\&block_id=21

TAKANAKA, Kimio. 2001. "Kenkyu-Note. Nihon no bouekikouzou ni okeru henka no houkousei”, Keiei-keiri-kenkyu, 67, Pp.45-58.

http://ci.nii.ac.jp/els/110000062886.pdf?id=ART0000406251\&type=pdf\&lang= en $\&$ host $=$ cinii\&order_no $=\& p p v \_t y p e=0 \& l a n g \_s w=\& n o=1487941346 \& \mathrm{cp}$

TAKEDA, Yasushi. 1983. "Nihonnno sizennkankyou to kokusaikeiei no siteki tokusitu (Parte 6): dainiji sekaitaisenngo niokeru nihonnkigyou no Kaigaisyunsyutu to sono Tokusei”, KOMADAI-KEIEI_KENKYU, 14(4), Pp. 39-59. http://ci.nii.ac.jp/els/110001190109.pdf?id=ART0001525053\&type=pdf\&lang= en\&host=cinii\&order_no $=\& p p v \_t y p e=0 \& l a n g \_s w=\& n o=1485019715 \& \mathrm{cp}=$

TAKII, Mitsuo. 2002. "NAFTA ikinai boueki no tenkai”, Kikan Kokusai boueki to tousi, Tokyo:Kokusaiboueki tousi kenkyuusyo.13(1), Pp. 95-105. http://www.iti.or.jp/kikan49/49takii.pdf 
TANAKA, Norihito. 2012. "Nihonkigyou no kokusaisenryaku-Monodukuri no keisyou to kadai”, kokusai-keiei forum, (23), Pp. 117-135.

https://www.jstage.jst.go.jp/article/jgeography1889/93/3/93_3_133/_pdf

TEECE, David J. 2006. "Reflections on the Hymer thesis and the multinational enterprise", International Business Review, 15(2), Pp. 124-139. http://www.sciencedirect.com/science/article/pii/S0969593105001204

TOKORO, Yasuhiro. 2006. "México y Japón: una perspectiva del Acuerdo de Asociación Económica”, Economía UNAM, 3(7). Pp. 47-68. http://www.scielo.org.mx/pdf/eunam/v3n7/v3n7a3.pdf

TREJO FLORES, Lidia y Carlos J NAVARRETE. 2009. "Factores que influyen la decisión de tercerización de tecnologías de información” Revista Latinoamericana Y Del Caribe De La Associacion De Sistemas De Informacion, 2 (2), Pp.11-41. http://aisel.aisnet.org/cgi/viewcontent.cgi?article=1008\&context=relcasi

TRUJILLO, Eva María Cruz y CALDERÓN, José Régulo Morales. 2013. "TENDENCIAS Y PERSPECTIVAS DEL SECTOR DE TELECOMUNICACIONES EN MÉXICO” Denarius, Revista de economía y administración. 27(2), Pp.125-150. http://148.206.53.234/revistasuam/denarius/include/getdoc.php?id=867\&article= $352 \&$ mode $=$ pdf

TSUSHIMA, Yukari. 2009. Comercio de Servicios y Desarrollo Económico: El Caso de la Industria de Call-center en México. Tesis que para la obtención del Título de Máster en Estudio Latinoamericanos. Instituto de Iberoamérica, Universidad de Salamanca.

UCHITA, Mitsuru. 2003. "Beikoku shijyou wo meguru mexico tyuugoku no kyougou", Kikan Kokusai boueki to tousi, (52), Pp. 32-40. http://www.iti.or.jp/kikan52/52uchida.pdf

UNCTAD (United Nations Conference on Trade and Development). 2015. World Investment Report 2015. Reforming International Investment Governance. Ginebra: UCTAD, ONU. http://unctad.org/en/PublicationsLibrary/wir2015_en.pdf

UNGER, Kurt y Roberto CHICO. 2004. "La industria automotriz en tres regiones de México. Un análisis de clusters”, El Trimestre Económico, 71(284), Pp. 909941. http://www.redalyc.org/pdf/313/31328406.pdf

UNGER, Kurt, Benjamín DETRAUX, Ariadna MARTÍNEZ y Michelle REVILLA. 2003. Los clústeres industriales en México: especializaciones regionales y la política industrial. Santiago de Chile: CEPAL. http://s3.amazonaws.com/academia.edu.documents/32532088/KurtUnger.pdf?A WSAccess KeyId=AKIAIWOWYYGZ2Y53UL3A\&Expires $=1488416319 \&$ Sign ature=A9tDaKQUTIZLQmzOp\%2F79AwUpw3Y\%3D\&response-contentdisposition=inline\%3B\%20filename\%3DLos_clusters_industriales_en_Mexico_ espe.pd

VALDENEBRO, Alex Covarrubias. 2017. "La geografía del auto en México. ¿Cuál es el rol de las instituciones locales? The geography of the car in Mexico. What is the role of local institutions?" Estudios Sociales. Revista de Alimentación 
Contemporánea y Desarrollo Regional, 27(49). Pp. 211-242.

http://www.ciad.mx/estudiosociales/index.php/es/article/viewFile/457/277

VALDERRAMA SANTIBÁÑEZ, Ana Lilia y Omar NEME CASTILLO. 2011. "Los determinantes del comercio intraindustrial, horizontal y vertical, en las industrias manufactureras de México", Estudios Económicos, 26(1), Pp. 35-68. http://estudioseconomicos.colmex.mx/archivo/EstudiosEconomicos2011/3568.pdf

VARGAS LEYVA, María Ruth. 1999. "INGENIERIA INDUSTRIAL. PRACTICA E IDENTIDAD PROFESIONAL EN LA INDUSTRIA MAQUILADORA ELECTRONICA EN LA CIUDAD DE TIJUANA", Revista Educación Superior, 28(110), Pp. 1-9.

VERACRUZ, Alexandre Oliveira y DUTRÉNIT, Gabriela. 2004. La IED y las capacidades de innovación y desarrollo locales: lecciones del estudio de los casos de la maquila automotriz y electrónica en ciudad de Juárez. México DF: CEPAL. http://repositorio.cepal.org/handle/11362/25668 http://resu.anuies.mx/archives/revistas/Revista110_S1A3ES.pdf

VERNON, Raymond. 1966. "International investment and international trade in the product cycle", The quarterly journal of economics, 80(2), Pp. 190-207. http://s3.amazonaws.com/academia.edu.documents/27784550/vernon.pdf?AWS AccessKeyId=AKIAJ56TQJRTWSMTNPEA\&Expires=1485023424\&Signature $=$ TwxaKyt55M3qysXVgpp5E7k9KoU\%3D\&response-contentdisposition=inline\%3B\%20filename\%3DInternational_investment_and_internati on.pdf

VIEYRA, Antonio. 2003. "El sector automotriz en el proceso de industrialización en México: aspectos histórico-económicos de su conformación territorial”, En José Luis García Ruiz (Coordinador), Sobre ruedas. Una historia crítica de la industria del automóvil en España. Madrid: Editorial Síntesis. Pp. 213-238. https://www.researchgate.net/profile/Antonio_Vieyra/publication/228732216_El _Sector_automotriz_y_el_proceso_de_industrializacion_en_Mexico_Aspectos_ historicoeconomicos_de_su_conformacion_territorial/links/55f9fe5308aeba1d9f269b75/ El-Sector-automotriz-y-el-proceso-de-industrializacion-en-Mexico-Aspectoshistorico-economicos-de-su-conformacion-territorial.pdf

VILLARREAL, René y Ramos DE VILLARREA. 2001. "La apertura de México y la paradoja de la competitividad: hacia un modelo de competitividad sistémica" Comercio Exterior, 51 (9). Pp.772-788. http://revistas.bancomext.gob.mx/rce/magazines/32/2/villa0901.pdf

VILLARREAL, Diana Rebeca y Marcela VILLEGAS. 2005. "Cambios en la localización de la industria automotriz en México 1994-2004”. México, Universidad Autónoma Metropolitana, http://csh.xoc.uam.mx/produccioneconomica/publicaciones/cambiosenlalocaliza ciondelaindustria.pdf

VILLELA, Luiz, Andrea LEMGRUBER. Michael JORRAT.2009. "Los presupuestos de gastos tributarios. Conceptos y desafíos de implementación", documento de trabajo No. IDB-WP-131, Banco Interamericano de Desarrollo. https://publications.iadb.org/bitstream/handle/11319/4302/Tax\%20Expenditure $\% 20$ Budgets.pdf?sequence $=2$ 
YONEKURA, Minoru. 1997. "Foreign Direct Investment and Location of management by Japanese Small and Medium-sized Suppliyer", Tyuugoku Tankidaigaku Kiyo, 28, Pp.51-73. https://curren.cjc.ac.jp/file/512/20100223093621/J28_051_073.pdf

YOSHIDA, Hideaki. 2008. "Handoutai 60nen to nihonnno handoutaisangyou," Keizaishi-kenkyuu, 11, Pp. 37-58. http://ci.nii.ac.jp/els/110009585485.pdf?id=ART0010039676\&type=pdf\&lang= en \&host=cinii\&order_no $=\& p p v \_t y p e=0 \& l a n g \_s w=\& n o=1487694513 \& \mathrm{cp}$

ZEPEDA BUSTOS, Carmen Silvia. 2012. "Privatizaciones realizadas durante el gobierno de Ernesto Zedillo”, El Cotidiano, 27(172), Pp. 32-39. http://www.redalyc.org/html/325/32523118004/

\section{Recursos desde internet}

AMPIP (La Asociación Mexicana de Parques Industriales). http://ampip.org.mx/es/acerca/

Atlas of Economic Complexity. http://atlas.cid.harvard.edu/

Banco Mundial. http://datos.bancomundial.org/

Banco de la Reserva Federal de San Luis https://fred.stlouisfed.org

Cabinet Office, Government of Japan. http://www5.cao.go.jp/

Cámara de diputados, México. http://www.diputados.gob.mx

CDT (Consejo de Desarrollo Económico en Tijuana). http://www.cdt.org.mx/historia.aspx

CECYTE Baja California. http://www.cecytebc.edu.mx/

COMTRADE, Naciones Unidas. http://comtrade.un.org/data/

CONALEP Baja California. http://www.conalepbc.edu.mx

Estadísticas de negocios de Japón, Ministerio de Hacienda, el gobierno de Japón. http://www.customs.go.jp/toukei

El Economista. http://eleconomista.com.mx/

El Gobierno de México. https://datos.gob.mx/busca/

FERROMEX. https://www.ferromex.com.mx. 
FMI (Fondo Monetario Internacional), World Economic Outlook, IMF Data Mapper. http://www.imf.org/external/datamapper

Gabinete de Innovación Europea. http://www.hispanialink.com

Honda México. http://www.honda.mx/corporativo/honda-de-mexico/

IMMEX (Industria Manufacturera, Maquiladora y de Servicios de Exportación) http://www.index.org.mx/IMMEX/antecedentes.php

INEGI (Instituto Nacional de Estadística y Geografía). http://www. inegi.org.mx/

Instituto Mexicano de Telemarketing. http://www.imt.com.mx

Inversión Celaya. http://www.investincelaya.com/

Japan Automobile Manufacture Association. http://www.jama.or.jp

Japan Customs. http://www.customs.go.jp

JETRO (Japan External Trade Organización). https://www.jetro.go.jp

México Xport. http://mexicoxport.com

Ministerio de Economía, Negocio E industria del Japón. http://www.meti.go.jp

Ministerio de Tierra, Infraestructura, Transporte y Turismo, Gobierno de Japón. http://www.mlit.go.jp/statistics

Miguel de la Madrid Hurtado, http://www.mmh.org.mx/showbookcambio.php?book=Segundo

Nijon Bizup Kabushiki Gaisya. https://04510.jp/factory-times/305/

Nissan Mexicana. http://www.nissan.com.mx/

OECD (Organizatión For Economic Coperation and Dvelopment). http://stats.oecd.org.

OMC (Organización Mundial de Comercio). https://www.wto.org/

Pew Research Center. Hispanic trends. http://www.pewhispanic.org/

Policy Research Institute, Minister of Finance, Government of Japan. http://warp.da.ndl.go.jp/info:ndljp/pid/8379094/www.mof.go.jp/pri/publication 
Poyry

http://www.poyry.com

Principal Global Indicaste.

http://www.principalglobalindicators.org/

Programa de Importación Temporal para Producir Artículos de Exportación. www.economia.gob.mx/files/transparencia/D26.pdf

Proméxico.

http://www.promexico.gob.mx

Promoción de inversión Celaya.

http://www.investincelaya.com/

PROCEC (Programas de Promoción Sectorial).

http://www.2006-2012.economia.gob.mx/comunidad-negocios/industria-ycomercio/instrumentos-de-comercio-exterior/prosec

Principal Global Indicaste.

http://www.principalglobalindicators.org/

Research Instituto of Economy, Trade and Industry, Japan. http://www.rieti.go.jp

Secretaria de Comunicaciones y transportes del Gobierno de México. http://nats.sct.gob.mx/

Secretaría de Economía, Gobierno de México. http://www.economia.gob.mx

Secretaría de Economía, Subsecretaría para la Pequeña y Mediana Empresa, Dirección General de Desarrollo Empresarial y Oportunidades de Negocio y Dirección de Desarrollo de Proveedores y Oportunidades de Negocio, México. http://www.contactopyme.gob.mx/

Secretaría de Educación Pública, Subsecretaría de Educación Media Superior, Dirección General de Educación Tecnológica Industrial, del Gobierno de México. http://www.dgeti.sep.gob.mx/index.php?option=com_content\&view=article\&id $=61 \&$ Itemid $=476$

Servicio de Administración Tributaria, Secretaría de Hacienda y Crédito Público, Gobierno de México. http://www.aduanas.gob.mx/aduana_mexico/

SICE (Sistema de Información Sobre Comercio Exterior). http://www.sice.oas.org/

Sony.

http://www.sony.co.jp.

SSI (La operación del Sistema para Subcontratación Industrial). http://www.contactopyme.gob.mx/ssi/

The Atlas of Economic Complexity. http://atlas.cid.harvard.edu/

United Satates Census Bureau, Estados Unidos.

http://www2.census.gov/

http://www.census.gov/ 
UNCTAD (United Nations Conference on Trade and Development) http://unctadstat.unctad.org

WCO (World Customs Organization). http://www.wcoomd.org.

World Economic Outlook, IMF Data Mapper.

http://www.imf.org/external/datamaper 
